\title{
Mercury in Sediment, Water, and Biota of Sinclair Inlet, Puget Sound, Washington, 1989-2007
}

Open-File Report 2009-1285 



\section{Mercury in Sediment, Water, and Biota of Sinclair Inlet, Puget Sound, Washington, 1989-2007}

By Anthony J. Paulson, Morgan E. Keys, and Kelly L. Scholting

Open-File Report 2009-1285 


\title{
U.S. Department of the Interior \\ KEN SALAZAR, Secretary
}

\section{U.S. Geological Survey \\ Marcia K. McNutt, Director}

\section{U.S. Geological Survey, Reston, Virginia: 2010}

\author{
For more information on the USGS — the Federal source for science about the Earth, its natural and living resources, \\ natural hazards, and the environment, visit http://www.usgs.gov or call 1-888-ASK-USGS \\ For an overview of USGS information products, including maps, imagery, and publications, \\ visit http://www.usgs.gov/pubprod \\ To order this and other USGS information products, visit http://store.usgs.gov
}

Any use of trade, product, or firm names is for descriptive purposes only and does not imply endorsement by the U.S. Government.

Although this report is in the public domain, permission must be secured from the individual copyright owners to reproduce any copyrighted materials contained within this report.

Suggested citation:

Paulson, A.J., Keys, M.E., and Scholting, K.L., 2010, Mercury in sediment, water, and biota of Sinclair Inlet, Puget Sound, Washington, 1989-2007: U.S. Geological Survey Open-File Report 2009-1285, 220 p. 


\section{Contents}

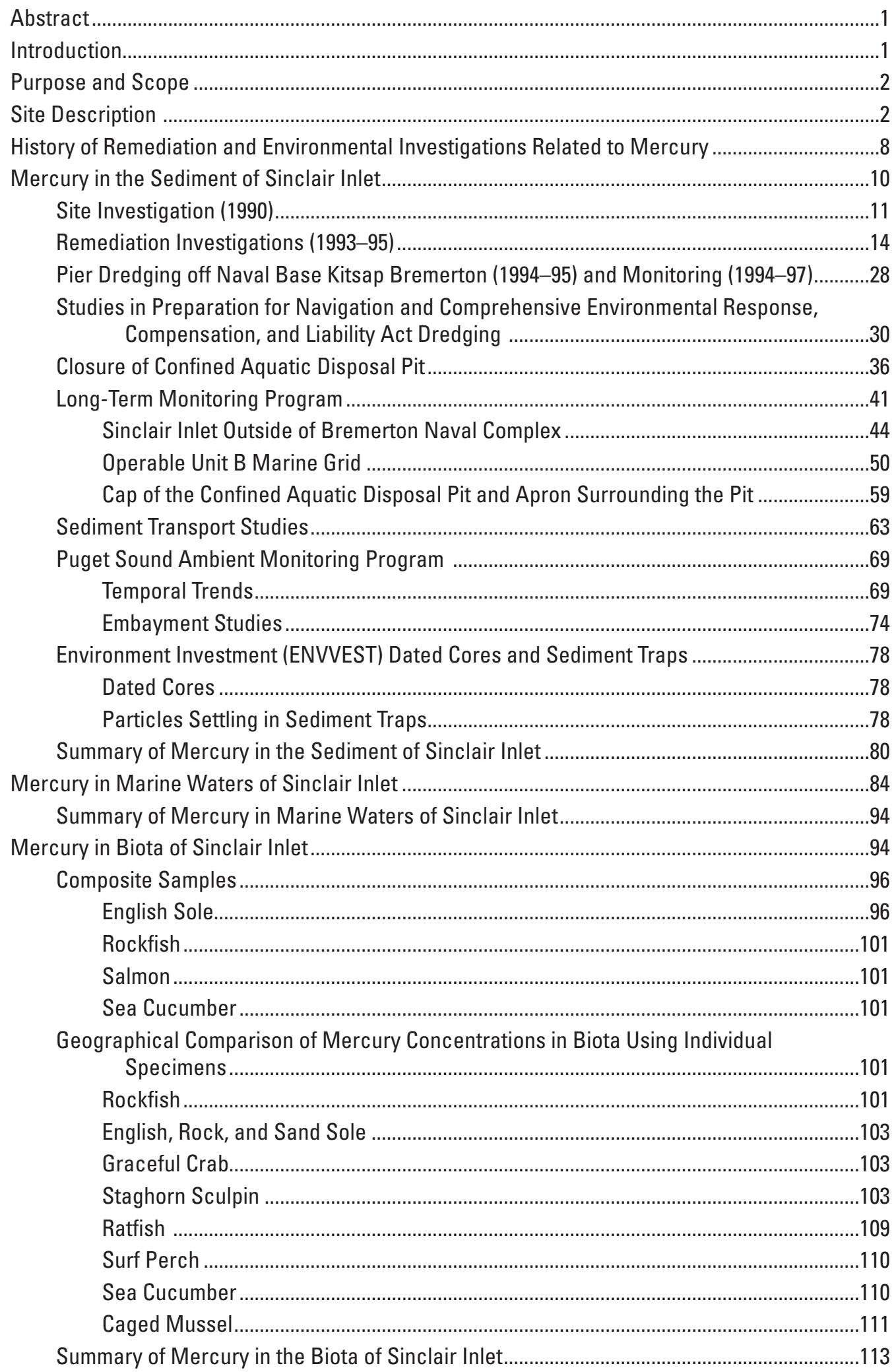




\section{Contents-Continued}

Observations to be Considered for Future Sampling Efforts ......................................................115

Sediment, Settling Particles, and Suspended Solids.........................................................115

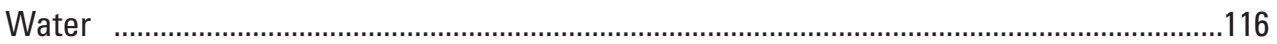

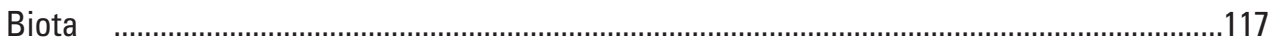

Summary

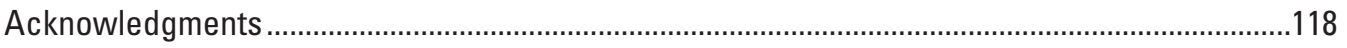

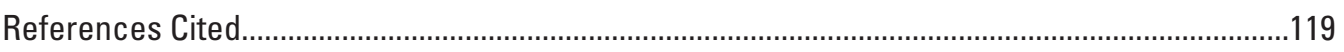

Appendix A. Evaluation of the Quality of Available Data for Marine Sediment, Marine

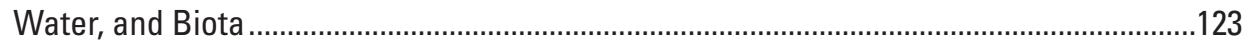

Appendix B. Listings of Sediment Data Examined .................................................................133

Appendix C. Relations Between Ancillary Sediment Parameters .................................................161

Appendix D. Core Profiles from the Operable Units A and B Remedial Investigation/Feasibility Studies from the Confined Aquatic Disposal Pit for the Long-Term Monitoring Program, from the Special Transport Study, and from the Environment Investment (Envvest) Project .177

Appendix E. Residuals for Long-Term Monitoring Program .......................................................201

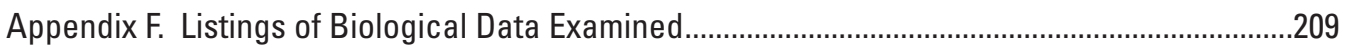

\section{Figures}

Figure 1. Maps showing locations of Sinclair Inlet, water bodies adjacent to Sinclair Inlet, and site locations outside the Bremerton naval complex boundary from previous studies, Puget Sound, Washington ................................

Figure 2. Map showing location of Operable Units A, B Marine, B Terrestrial, and NSC of the Bremerton naval complex along the northern shore of Sinclair Inlet, Puget Sound, Washington

Figure 3. Graph showing total mercury concentrations compared with total aluminum concentrations in surface sediment off Operable Unit A, off Operable Unit B Marine, and outside of the Bremerton naval complex, Washington, from the 1990 Site Investigation

Figure 4. Graph showing total mercury concentrations compared to total organic carbon in surface sediment from Operable Unit A, Operable Unit B Marine, and outside of the Bremerton naval complex, Washington, from the 1990 Site Investigation

Figure 5. Graph showing total mercury concentrations compared to total fines in surface sediment from Operable Unit A, Operable Unit B Marine, and outside of the Bremerton naval complex, Washington, from the 1990 Site Investigation ... 14

Figure 6. Graph showing mercury-toxicity characteristic leaching procedure concentrations compared to total organic carbon in surface sediment from Operable Unit A stationsand offshore site ST48 of the Bremerton naval complex, Washington, from the 1993 Remedial Investigation

Figure 7. Graph showing mercury-toxicity characteristic leaching procedure concentrations compared to total fines in surface sediment from Operable Unit A stations and offshore site ST48 of the Bremerton naval complex, Washington, from the 1993 Remedial Investigation 


\section{Figures-Continued}

Figure 8. Boxplot graphs showing vertical profiles of mercury-toxicity characteristic leaching procedure concentrations, percentages of sand, silt and clay, total organic carbon, and percentage of solids at MS219 of Operable Unit A of the Bremerton naval complex, Washington

Figure 9. Boxplot graphs showing vertical profiles of mercury-toxicity characteristic leaching procedure concentrations, percentages of sand, silt and clay, total organic carbon, and percentage of solids at MS222

Figure 10. Boxplot graphs showing vertical profiles of mercury-toxicity characteristic leaching procedure concentrations, percentages of sand, silt and clay, total organic carbon, and percentage of solids at ST48 off the Bremerton naval complex, Washington.

Figure 11. Graph showing total mercury concentration compared to total organic carbon in surface sediment from outside of the Bremerton naval complex, Washington, from the 1994 and 1995 Remedial Investigation

Figure 12. Graph showing total mercury concentration compared to total fines in surface sediment from outside of the Bremerton naval complex, Washington, from the 1994 and 1995 Remedial Investigation

Figure 13. Graph showing total mercury concentration compared to total aluminum in surface sediment from outside of the Bremerton naval complex, Washington, from the 1994 Remedial Investigation

Figure 14. Graph showing total mercury concentration compared to total organic carbon in surface sediment from Operable Unit B Marine of the Bremerton naval complex, Washington, from the 1994 Remedial Investigation

Figure 15. Graph showing total mercury concentration compared to total fines in surface sediment from Operable Unit B Marine of the Bremerton naval complex, Washington, from the 1994 Remedial Investigation

Figure 16. Graph showing total mercury concentration compared to total aluminum in surface sediment from Operable Unit B Marine from the 1994 Remedial Investigation

Figure 17. Boxplot graphs showing vertical distribution of total mercury concentrations and total finesat station SINC-MIDCH off the Bremerton naval complex, Washington

Figure 18. Graph showing total mercury concentration compared to total organic carbon off pier in Naval Base Kitsap Bremerton (site shown in inset of figure 2) in 1994-1995, 1996, and 1997

Figure 19. Graph showing total mercury concentration compared to total fines at pier in Naval Base Kitsap Bremerton (site shown in inset of figure 2) in inset of figure 2 in 1994-1995, 1996, and 1997

Figure 20. Map showing location of DM-SE surface samples collected in 2001 after the closure of the Confined Aquatic Disposal pit of the Bremerton naval complex, Washington, with the eight labeled "spokes" in relation to the CP cells of the Long-Term Monitoring Program

Figure 21. Graph showing total mercury concentration compared to total organic carbon for surface sediment samples in Operable Unit A and offshore of Operable Unit A, Bremerton naval complex, Washington that had not been capped as part of a remediation remedy or were not within the boundary of the Confined Aquatic Disposal site 


\section{Figures-Continued}

Figure 22. Graph showing total mercury concentration compared to total fines for surface sediment samples in Operable Unit A and offshore of Operable Unit A, Bremerton naval complex, Washington that had not been capped as part of a remediation remedy or were not within the boundary of the Confined Aquatic Disposal site

Figure 23. Graph showing total mercury concentration compared to total organic carbon for surface sediment samples collected from locations off Operable Unit B, Bremerton naval complex, Washington, that had not been dredged, 1990-94 and in Operable Unit B Marine, 1995 .....

Figure 24. Graph showing total mercury concentration compared to total fines for surface sediment samples from locations off Operable Unit B, Bremerton naval complex, Washington, that had not been dredged, 1990-94, and in Operable Unit B Marine, 1995

Figure 25. Graph showing total mercury concentration compared to total organic carbon in the surface sediment of spokes 1 to 4 collected in 2001

Figure 26. Graph showing total mercury concentration compared to total fines in the surface sediment of spokes 1 to 4 collected in 2001

Figure 27. Graph showing total mercury concentration compared to total organic carbon in the surface sediment of spokes 5 to 8 collected in 2001

Figure 28. Graph showing total mercury concentration compared to total fines in the surface sediment of spokes 5 to 8 collected in 2001

Figure 29. Graph showing total mercury concentration compared to total fines in the surface sediment from State-owned aquatic lands, Sinclair Inlet, Washington, collected in 2003

Figure 30. Map showing location of 1,500-ft grid cells in Sinclair Inlet outside of the Bremerton naval complex, Washington

Figure 31. Map showing location of $500-\mathrm{ft}$ grid cells in Operable Unit B Marine of the Bremerton naval complex, Washington

Figure 32. Graph showing total mercury concentration compared to total organic carbon in the surface sediment from Sinclair Inlet outside of the Bremerton naval complex, Washington, collected in 2003 with low and high outliers labeled

Figure 33. Graph showing total mercury concentration compared to total fines in the surface sediment from Sinclair Inlet outside of the Bremerton naval complex, Washington, collected in 2003 with low outliers labeled

Figure 34. Graph showing total mercury concentration compared to total organic carbon in the surface sediment from Sinclair Inlet outside of the Bremerton naval complex, Washington, collected in 2005 with the high outlier labeled

Figure 35. Graph showing total mercury concentration compared to total fines in the surface sediment from Sinclair Inlet outside of the Bremerton naval complex, Washington, collected in 2005 with the high outlier labeled

Figure 36. Graph showing total mercury concentration compared to total organic carbon in the surface sediment from Sinclair Inlet outside of the Bremerton naval complex, Washington, collected in 2007 with cell 21 labeled for comparison to 2003 and 2005

Figure 37. Graph showing total mercury concentration compared to total fines in the surface sediment from Sinclair Inlet outside of the Bremerton naval complex, Washington, collected in 2007with cell 1 (low outlier) and cell 21 for comparison to 2003 and 2005 labeled 


\section{Figures-Continued}

Figure 38. Graph showing total mercury concentration compared to total organic carbon in composite surface sediment from Operable Unit B Marine of the Bremerton naval complex, Washington, collected in 2003

Figure 39. Graph showing total mercury concentration compared to total fines in surface composite sediment rom Operable Unit B Marine of the Bremerton naval complex, Washington, collected in 2003

Figure 40. Graph showing total mercury concentration compared to total organic carbon in composite surface sediment from Operable Unit B Marine of the Bremerton naval complex, Washington, collected in 2003

Figure 41. Graph showing total mercury concentration compared to total fines in surface composite sediment from Operable Unit B Marine of the Bremerton naval complex, Washington, collected in 2005

Figure 42. Graph showing total mercury concentration compared to total organic carbon in composite surface sedimentfrom Operable Unit B Marine of the Bremerton naval complex, Washington, collected in 2003

Figure 43. Graph showing total mercury concentration compared to total fines in surface composite sediment from Operable Unit B Marine of the Bremerton naval complex, Washington, collected in 2007

Figure 44. Graph showing total mercury concentration compared to total organic carbon for surface and subsurface sediment core sections collected from the Confined Aquatic Disposal pit of the Bremerton naval complex, Washington, in 2003, 2005, and 2007

Figure 45. Graph showing total mercury concentration compared to total fines for surface and subsurface sediment core sections collected from the Confined Aquatic Disposal pit of the Bremerton naval complex, Washington, in 2003, 2005, and 2007

Figure 46. Graph showing total mercury concentration compared to total organic carbon for surface sediment collected from the Confined Aquatic Disposal pit apron of the Bremerton naval complex, Washington, in 2003 and 2005

Figure 47. Graph showing total mercury concentration compared to total fines for surface sediment collected from the Confined Aquatic Disposal pit apron of the Bremerton naval complex, Washington, in 2003 and 2005

Figure 48. Graph showing total mercury concentration compared to total organic carbon in the surface sediment and cores from the 500 -ft cell 35 that had undergone navigational dredging and in the surface sediment and cores from $500-\mathrm{ft}$ cell 56 that had undergone remedial dredging collected as part of the 2005 transport study

Figure 49. Graph showing total mercury concentration compared to total fines in the surface sediment and cores from 500 - $\mathrm{ft}$ cell 35 that had undergone navigational dredging and in the surface sediment and cores (RDC1 and $\mathrm{RDC2}$ ) from the $500-\mathrm{ft}$ cell 56 that had undergone remedial dredging collected as part of the 2005 transport study

Figure 50. Graph showing total mercury concentration compared to total fines in surface sediment in June 2005 and particles settling into sediment traps between June and August 2005 in 1,500-ft grid cells 13 and 21, and in 500-ft grid cells 35 and 5667 


\section{Figures-Continued}

Figure 51. Graph showing total mercury concentration compared to total organic carbon in surface sediment in June 2005 and particles settling into sediment traps between June and August 2005 in 1,500-ft grid cells 13 and 21, and in 500-ft grid cells 35 and 56

Figure 52. Graph showing total mercury concentrations in surface sediment at seven Long-Term Temporal Monitoring stations of the Puget Sound Ambient Monitoring Program of Washington, sampled between 1989 and 2005 arranged by their Puget Sound Partnership Area

Figure 53. Graph showing total mercury concentrations, total organic carbon, and total fines in surface sediment at the Sinclair Inlet Long-Term Temporal Monitoring station 34 of the Puget Sound Ambient Monitoring Program of Washington, sampled between 1989 and 2005

Figure 54. Graph showing total mercury concentrations compared to total organic carbon for surface sediment at the Sinclair Inlet Long-Term Temporal Monitoring station 34 of the Puget Sound Ambient Monitoring Program of Washington, sampled between 1989 and 2005

Figure 55. Graph showing total mercury concentrations compared to total fines for surface sediment at the Sinclair Inlet Long-Term Temporal Monitoring station 34 of the Puget Sound Ambient Monitoring Program of Washington, sampled between 1989 and 2005

Figure 56. Graph showing total mercury concentrations compared to total organic carbon in the surface sediment collected by the Puget Sound Ambient Monitoring Program embayment study in 1998 and the regression line for the 1994 Offshore Sinclair Inlet surface sediment from the Remedial Investigation/Feasibility Study and the 2003 offshore surface sediment from the Long-Term Monitoring Program 1,500-ft grid sampling

Figure 57. Graph showing total mercury concentrations compared to total organic carbon in the surface sediment collected by Puget Sound Ambient Monitoring Program embayment study in Washington State from Sinclair Inlet (1998), Elliott Bay off Seattle, and Bellingham Bay

Figure 58. Graph showing total mercury concentrations compared to total organic carbon in the surface sediment from Sinclair Inlet, Port Gardner off Everett, Liberty Bay off Poulsbo, Commencement Bay off Tacoma, and Budd Inlet off Olympia

Figure 59. Graph showing total mercury concentrations compared to total fines in the surface sediment from Sinclair Inlet, Bellingham Bay, Port Gardner off Everett, Elliott Bay off Seattle, Liberty Bay off Poulsbo, Commencement Bay off Tacoma, and Budd Inlet off Olympia

Figure 60. Graph showing total mercury concentrations compared to total aluminum concentrations for surface sediment in Sinclair Inlet, Washington and material collected by sediment traps by the ENVironmental InVESTment Project in 2002

Figure 61. Boxplot graph showing slopes calculated from the linear relations between total mercury concentrations and total organic carbon content in sediments from Sinclair Inlet and other Puget Sound embayments in Washington

Figure 62. Map showing categorization of cells in the 500-ft Operable Unit B Marine grid of the Bremerton naval complex, Washington, by the occurrence of tier 1 outliers and the frequency of tier 2 outliers from the 2003, 2005, and 2007 Long-Term Monitoring Program 


\section{Figures-Continued}

Figure 63. Graphs showing total mercury concentrations in unfiltered near-surface waters of Sinclair Inlet, Port Orchard Passage, and Rich Passage (Washington) between 2002 and 2005

Figure 64. Graph showing total mercury compared to total aluminum concentrations in unfiltered marine water at nearshore stations within the Bremerton naval complex of Washington, a nearshore station off Port Orchard and stations in central Sinclair Inlet in the wet season of 2004 ....

Figure 65. Graph showing total mercury concentrations compared to salinity for unfiltered marine water column samples collected in Puget Sound, Washington, September 13-14, 2005

Figure 66. Graphs showing water elevation in Puget Sound, Washington, compared to time and time of sampling at locations during the flooding tidal cycles of September 13 and 14, 2005

Figure 67. Graphs showing total mercury concentrations in waters of Puget Sound, Washington, compared to salinity for each of the subsets of unfiltered marine samples collected during the flooding tidal cycles of September 13 and 14,2005

Figure 68. Graphs showing concentrations of total mercury compared to total organic carbon concentrations for each of the unfiltered subsets of samples collected during the flooding tidal cycles of September 13 and 14, 2005 in Puget Sound, Washington

Figure 69. Graphs showing total mercury concentrations in water from Puget Sound, Washington, compared to total aluminum concentrations for each of the subsets of unfiltered samples collected during the flooding tidal cycles of September 13 and 14, 2005

Figure 70. Graph showing total mercury concentration of whole- body staghorn sculpin compared to fish length for individual specimens collected in 2005 from Sinclair Inlet, Washington, and near Vendovi Island

Figure 71. Graph showing mean total mercury concentrations in muscle tissue composites of English sole collected in Sinclair Inlet, Washington, by the U.S. Navy and the Puget Sound Ambient Monitoring Program between 1994 and 2007

Figure 72. Graph showing total mercury concentrations in muscle of individual English sole specimens collected from Sinclair Inlet, Washington, during 1996, 2003, and 2007 compared to fish length

Figure 73. Graph showing total mercury concentrations in muscle of individual English sole specimens collected from Sinclair Inlet, Commencement Bay, Duwamish Waterway, Elliott Bay, Eagle Harbor, Nisqually Delta, Hood Canal, off Vendovi Island, the Strait of Georgia, and Port Gardner between 2003 and 2007 compared to fish length

Figure 74. Graph showing total mercury concentrations in muscle of individual rock sole specimens individuals collected from Sinclair Inlet, Hood Canal, and off Vendovi Island between 2003 and 2007 compared to fish length

Figure 75. Graph showing total mercury concentrations in individual graceful crab specimen collected from Sinclair Inlet, off Vendovi Island, the Nisqually delta, and Hood Canal between 2002 and 2005 compared to crab length 


\section{Figures-Continued}

Figure 76. Graph showing total mercury concentrations in muscle of individual ratfish specimens collected from Sinclair Inlet, Commencement Bay, Eagle Harbor, Elliott Bay, the Nisqually Delta, Hood Canal, and the Strait of Georgia between 2003 and 2005 compared to fish length

Figure 77. Graph showing total mercury concentrations of individual specimens and composites of two surf perch of comparable size from Sinclair Inlet, off Vendovi Island, the Nisqually Delta, and Hood Canal compared to fish length collected in 2005 and 2007

Figure 78. Boxplot graph showing mean mercury concentrations of tissue from indigenous mussels and caged mussels deployed in Sinclair Inlet, Puget Sound, Washington, and nearby water bodies for 84 days during 2005

\section{Tables}

Table 1. Linear regression statistics of total mercury concentration (dry weight) compared to total organic carbon (dry weight), total fiines (dry weight), and total aluminum concentration (dry weight) in sediments collected from stations outside of Bremerton naval complex, Washington, as part of the 1994-95 Remedial Investigation Study, the Long-Term Monitoring Program (2003, 2005, and 2007), and the 1997-99 Puget Sound Ambient Monitoring Program Study of Washington

Table 2. Comparison of analysis of 500-foot grid composites with selected pier grab samples collected in 2003 from Operable Unit B Marine of the Bremerton naval complex, Washington

Table 3. Years and cell numbers for which total mercury sediment concentrations in 500 -foot grid cells within Operable Unit B Marine of the Bremerton naval complex, Washington, deviated from predicted values were based on the regression of mercury compared to total organic carbon for greater Sinclair Inlet sediments

Table 4. Mean mass settling rate of dry solids in sediment traps deployed in 2005 (U.S. Navy Special Transport Study) and in 2002 (ENVironmental inVESTment Study) in Sinclair Inlet, Washington

Table 5. Variability of total mercury concentrations in the top 10-cm of ENVironmental inVESTment cores, and the depth and the maximum total mercury concentration of total mercury peak in the sediment column of Sinclair Inlet, Washington

Table 6. Concentrations of total mercury and ancillary data from unfiltered marine water-column samples collected from Sinclair Inlet and other Puget Sound locations in Washington

Table 7. Total mercury concentrations in muscle tissue composites of English sole collected from Sinclair Inlet, Washington

Table 8. Mean total mercury concentration in composites of English sole muscle collected throughout Puget Sound, Washington, between 1989 and 1999

Table 9. Mean total mercury concentration in composites of English sole liver collected throughout Puget Sound, Washington, between 1989 and 1999

Table 10. Statistics of analysis of variance and analysis of covariance of total mercury concentrations in fish and invertebrate from Puget Sound, Washington, 


\section{Tables-Continued}

Table 11. Means and standard deviations of fish and invertebrate collected between 2003 and 2007 from Puget Sound, Washington, used in the analysis of covariance. 104

Table 12. Total mercury concentration of composites of mussels deployed in cages in Sinclair Inlet and Holmes Harbor, Puget Sound, Washington, 1994

Table 13. Summary of mercury in composites and individual specimens of various species and results of caged mussel experiments in Puget Sound, Washington

\section{Conversion Factors, Acronyms, and Abbreviations}

Inch/Pound to SI

\begin{tabular}{lll}
\hline \multicolumn{1}{c}{ Multiply } & \multicolumn{1}{c}{ By } & \multicolumn{1}{c}{ To obtain } \\
\hline foot $(\mathrm{ft})$ & 0.3048 & meter $(\mathrm{m})$ \\
mile $(\mathrm{mi})$ & 1.609 & kilometer $(\mathrm{km})$ \\
square mile $\left(\mathrm{mi}^{2}\right)$ & 2.590 & square kilometer $\left(\mathrm{km}^{2}\right)$ \\
cubic yard $\left(\mathrm{yd}^{3}\right)$ & 0.7646 & cubic meter $\left(\mathrm{m}^{3}\right)$ \\
\hline
\end{tabular}

SI to Inch/Pound

\begin{tabular}{lll}
\hline \multicolumn{1}{c}{ Multiply } & \multicolumn{1}{c}{ By } & \multicolumn{1}{c}{ To obtain } \\
\hline micrometer $(\mu \mathrm{m})$ & $3.967 \times 10^{-5}$ & inch \\
centimeter $(\mathrm{cm})$ & 0.3937 & inch (in.) \\
millimeter $(\mathrm{mm})$ & 0.03937 & inch (in.) \\
meter $(\mathrm{m})$ & 3.281 & foot (ft) \\
kilometer $(\mathrm{km})$ & 0.6214 & mile (mi) \\
milligram per kilogram $(\mathrm{mg} / \mathrm{kg})$ & $1.6 \times 10^{-5}$ & ounce per pound (oz/lb) \\
square centimeter $\left(\mathrm{cm}^{2}\right)$ & 0.1550 & square inch $\left(\mathrm{in}^{2}\right)$ \\
square meter $\left(\mathrm{m}^{2}\right)$ & 10.76 & square foot $\left(\mathrm{ft}^{2}\right)$ \\
cubic meter $\left(\mathrm{m}^{3}\right)$ & 1.308 & cubic yard $\left(\mathrm{yd}^{3}\right)$ \\
square kilometer $\left(\mathrm{km}^{2}\right)$ & 0.3861 & square mile $\left(\mathrm{mi}^{2}\right)$ \\
cubic meter per second $\left(\mathrm{m}^{3} / \mathrm{s}\right)$ & 70.07 & acre-foot per day (acre-ft/d) \\
centimeter per second $(\mathrm{cm} / \mathrm{s})$ & 0.3937 & inch per second (in $/ \mathrm{s})$ \\
gram per square centimeter per & 0.22757 & ounce per square inch per year \\
\multicolumn{1}{c}{ year $\left(\mathrm{g} / \mathrm{cm}^{2} / \mathrm{yr}\right)$} & & $\left(\right.$ oz $\left./ \mathrm{in}^{2} / \mathrm{yr}\right)$ \\
\hline
\end{tabular}

Concentrations of chemical constituents in water are given either in milligrams per liter $(\mathrm{mg} / \mathrm{L})$, micrograms per liter $(\mu \mathrm{g} / \mathrm{L})$, or nanograms per liter $(\mathrm{ng} / \mathrm{L})$.

\section{Datums}

Vertical coordinate information is referenced to the North American Vertical Datum of 1988 (NAVD 88).

Horizontal coordinate information is referenced to the North American Datum of 1983 (NAD 83).

Elevation, as used in this report, refers to distance above the vertical datum of the Puget Sound mean lower low water. 


\section{Conversion Factors, Acronyms, and Abbreviations-Continued}

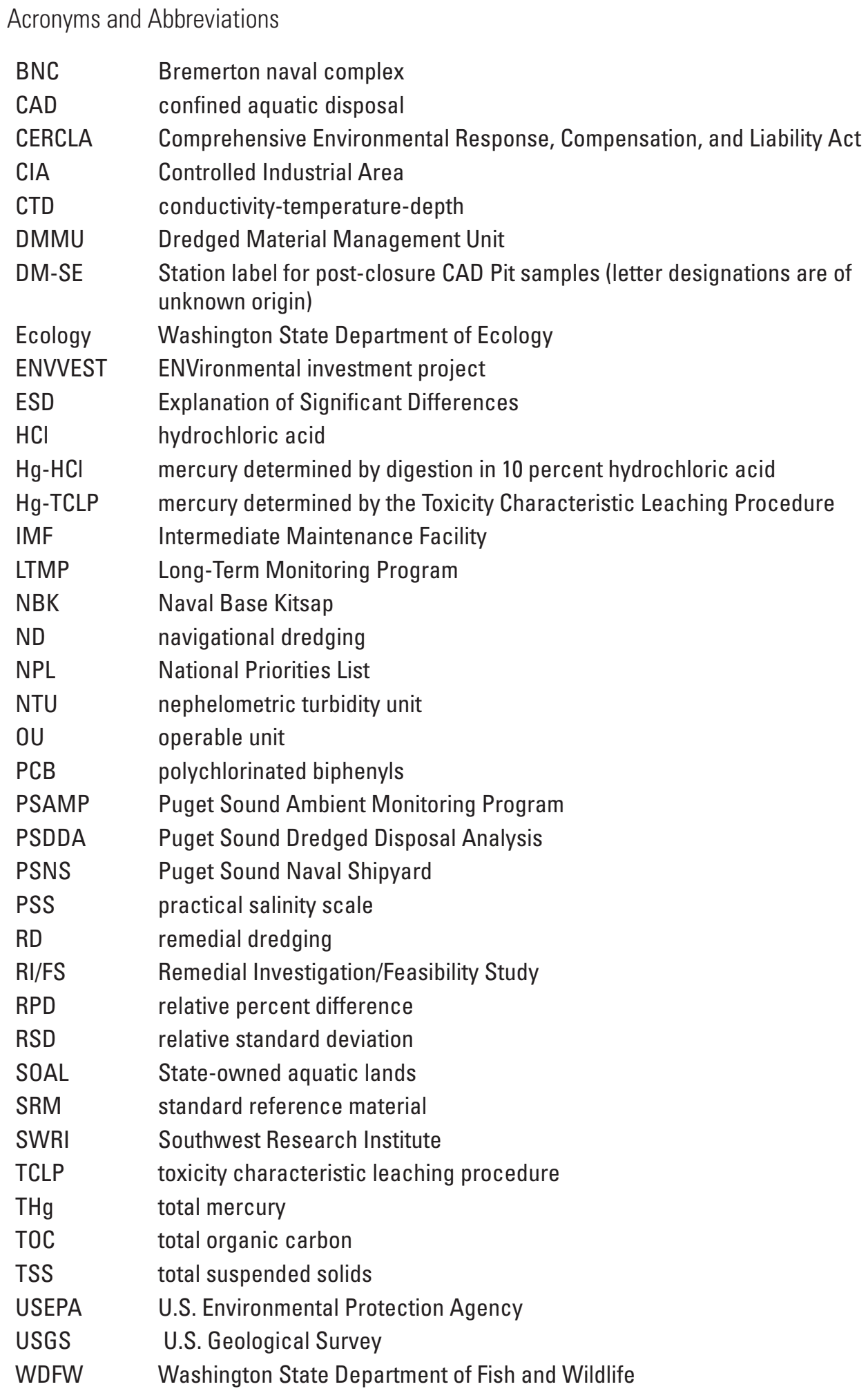




\title{
Mercury in Sediment, Water, and Biota of Sinclair Inlet, Puget Sound, Washington, 1989-2007
}

\author{
By Anthony J. Paulson, Morgan E. Keys, and Kelly L. Scholting
}

\section{Abstract}

Historical records of mercury contamination in dated sediment cores from Sinclair Inlet are coincidental with activities at the U.S. Navy Puget Sound Naval Shipyard; peak total mercury concentrations occurred around World War II. After World War II, better metallurgical management practices and environmental regulations reduced mercury contamination, but total mercury concentrations in surface sediment of Sinclair Inlet have decreased slowly because of the low rate of sedimentation relative to the vertical mixing within sediment. The slopes of linear regressions between the total mercury and total organic carbon concentrations of sediment offshore of Puget Sound urban areas was the best indicator of general mercury contamination above pre-industrial levels. Prior to the 2000-01 remediation, this indicator placed Sinclair Inlet in the tier of estuaries with the highest level of mercury contamination, along with Bellingham Bay in northern Puget Sound and Elliott Bay near Seattle. This indicator also suggests that the 2000/2001 remediation dredging had significant positive effect on Sinclair Inlet as a whole. In 2007, about 80 percent of the area of the Bremerton naval complex had sediment total mercury concentrations within about 0.5 milligrams per kilogram of the Sinclair Inlet regression. Three areas adjacent to the waterfront of the Bremerton naval complex have total mercury concentrations above this range and indicate a possible terrestrial source from waterfront areas of Bremerton naval complex. Total mercury concentrations in unfiltered Sinclair Inlet marine waters are about three times higher than those of central Puget Sound, but the small numbers of samples and complex physical and geochemical processes make it difficult to interpret the geographical distribution of mercury in marine waters from Sinclair Inlet.

Total mercury concentrations in various biota species were compared among geographical locations and included data of composite samples, individual specimens, and caged mussels. Total mercury concentrations in muscle and liver of English sole from Sinclair Inlet ranked in the upper quarter and third, respectively, of Puget Sound locations. For other species, concentrations from Sinclair Inlet were within the mid-range of locations (for example, Chinook salmon). Total mercury concentrations of the long-lived and higher trophic rockfish in composites and individual specimens from Sinclair Inlet tended to be the highest in Puget Sound. For a given size, sand sole, graceful crab, staghorn sculpin, surf perch, and sea cucumber individuals collected from Sinclair Inlet had higher total mercury concentrations than individuals collected from non-urban estuaries. Total mercury concentrations in individual English sole and ratfish were not significantly different than in individuals of various sizes collected from either urban or non-urban estuaries in Puget Sound. Total mercury concentrations in English sole collected from Sinclair Inlet after the 2000-2001 dredging appear to have lower total mercury concentrations than those collected before (1996) the dredging project. The highest total mercury concentrations of mussels caged in 2002 were not within the Bremerton naval complex, but within the Port Orchard Marina and inner Sinclair Inlet.

\section{Introduction}

As early as the 1980s, the sediment of Sinclair Inlet was known to have elevated concentrations of a number of elements and organic compounds (Malins and others, 1982). A remedial investigation of the marine waters off the Bremerton naval complex (BNC), Bremerton, Washington, was completed in 1996 (U.S. Navy, 2002) and the Record of Decision (U.S. Environmental Protection Agency, 2000) was issued as final in 2002. The remediation option included isolating a considerable volume of contaminated sediment from interactions with the benthic food web by capping and disposal of dredge spoils in a covered confined aquatic disposal pit in 2001. The primary objective of the marine sediment cleanup was to address the potential risk to humans, particularly those engaged in a subsistence lifestyle, from consumption of bottom-dwelling fish with polychlorinated biphenyls (PCBs) in their tissues (U.S. Navy, 2002). Three pathways were identified as having the capability to transport chemicals from terrestrial landscape of the BNC to the marine environment, and thus as having the potential to recontaminate the recently remediated marine sediment. The pathways included direct dry dock discharges, discharge of groundwater, and discharge of stormwater system facilities handling surface-water runoff. 
As lead agency for environmental cleanup of the BNC, the U.S. Navy has completed the second 5-year review of the remedial actions of the marine sediment within the boundary of the BNC (U.S. Navy, 2007a), pursuant to Section 121(c) of the Comprehensive Environmental Response, Compensation, and Liability Act (CERCLA) and the National Oil and Hazardous Substances Pollution Contingency Plan (40 Code of Federal Regulations Part 300). One of the issues highlighted in the second 5-year review was that "There is insufficient information to determine whether the remedial action taken at OU [Operable Unit] B Marine with respect to mercury in sediment is protective of ingestion of rockfish by subsistence finfishers" (U.S Navy, 2007a). Recommendations and follow-up actions in the 5-year review are as follows:

- Revisit Remedial Investigation/Feasibility Study (RI/FS) ground-water-to-surface-water transport evaluations in light of total mercury concentrations in two long-term monitoring wells,

- Perform trend analyses and assess functionality and protectiveness of remedy for marine sediment, and

- Collect additional information necessary to perform a risk evaluation and reach conclusions regarding the protectiveness of the remedy (U.S. Navy, 2002) with respect to total mercury concentrations in Sinclair Inlet sediment and fish tissue.

Since 2007, the U.S. Geological Survey (USGS) and the U.S. Navy have entered into several multi-year interagency agreements. The objectives of these studies are to (a) estimate the magnitudes of the different predominant sources of total mercury to Sinclair Inlet, including those from the BNC, (b) evaluate the transformation of mercury to a bioavailable form in Sinclair Inlet, and (c) assess the impact of the sources and transformation processes on the mercury burden in marine organisms and sediment.

\section{Purpose and Scope}

The first agreement with the U.S. Navy calls for USGS to (a) examine the present status of mercury in the sediment, water, and biota of Sinclair Inlet using available data, (b) examine the sources of mercury to Sinclair Inlet and generate new data to evaluate the mercury sources from dry dock discharges and groundwater flowing from the BNC into Sinclair Inlet, and (c) obtain the first measurements of methylmercury in the watershed of Sinclair Inlet.

Since 1982, a variety of mercury data have been collected in the marine waters, sediment, and biota of Sinclair Inlet. Examination of the more extensive data set collected since 1989 provides a historical perspective of the mercury conditions in Sinclair Inlet. In addition, mercury data obtained during large sampling events collected over a large geographical area can provide insights into the sources of mercury to Sinclair Inlet, as well as the processes that control mercury transport within Sinclair Inlet. This report summarizes present and past conditions of mercury in sediment, water, and biota based on available data.

\section{Site Description}

Sinclair Inlet is a shallow embayment (maximum depth of $20 \mathrm{~m}$ ) on the west side of the Puget Sound lowlands and within the north-central Puget Sound Action Area of the Puget Sound Partnership (fig. 1A). The Puget Sound lowland is a long, northward-trending structural depression between the Cascade Mountains on the east and the Olympic Mountains on the west. Most of the Puget Sound lowland physiographic province is mantled with thick glacial and postglacial deposits.

Sinclair Inlet is adjacent to another shallow embayment, Dyes Inlet (fig. 1B). The Sinclair Inlet-Dyes Inlet system is hydrologically complex not only because of the geometry of the Dyes Inlet-Sinclair Inlet connection, but because Bainbridge Island blocks the connection between the Dyes Inlet-Sinclair Inlet system and central Puget Sound. The Dyes Inlet-Sinclair Inlet system is connected to central Puget Sound through Port Madison/Agate Passage/Port Orchard Passage on the north side of Bainbridge Island and through Rich Passage on the south side of Bainbridge Island. Rich Passage shallows to $20 \mathrm{~m}$; the maximum depth in Agate Passage is $6 \mathrm{~m}$. The shallowing of these passages results in extensive vertical mixing of the incoming tidal water. Tides in Puget Sound are mixed diurnally and have a maximum tidal range of about $5 \mathrm{~m}$ relative to a maximum depth of about $20 \mathrm{~m}$ for Sinclair Inlet. The relative proportion of tidal volumes through Port Orchard Passage and Rich Passage is unknown. Because the tidal prism volume of Dyes Inlet is about three times that of Sinclair Inlet, tidal currents in Port Washington Narrows, which connects Dyes Inlet to Sinclair Inlet, often lag those of Sinclair Inlet (Wang and Richter, 1999).

Sinclair Inlet is an irregularly shaped triangular embayment about $1.9 \mathrm{~km}$ across and $6.4 \mathrm{~km}$ long (fig. 1C). The irregular shoreline was formed during glacial and postglacial periods. More than 20 small streams drain the Sinclair Inlet watershed and influence surface-water quality within the basin. The larger streams in the area include Gorst, Blackjack, Anderson, and Wright Creeks. The mean maximum monthly discharges (1993-2004) during the winter wet season for Gorst, Blackjack, Anderson and Annapolis Creeks were about $0.9,0.7,0.3$ and $0.05 \mathrm{~m}^{3} / \mathrm{s}$, respectively (Brandenberger and others, 2007). The outer boundary of Sinclair Inlet for this study is defined as the seaward side of a cable area that extends from the Bremerton dock of the Washington State Ferry System to the pointed shoreline near Annapolis Creek. This definition of the study area yields a surface area of $8.37 \mathrm{~km}^{2}$ and a cross-sectional area at its entrance of $27,050 \mathrm{~m}^{2}$. 


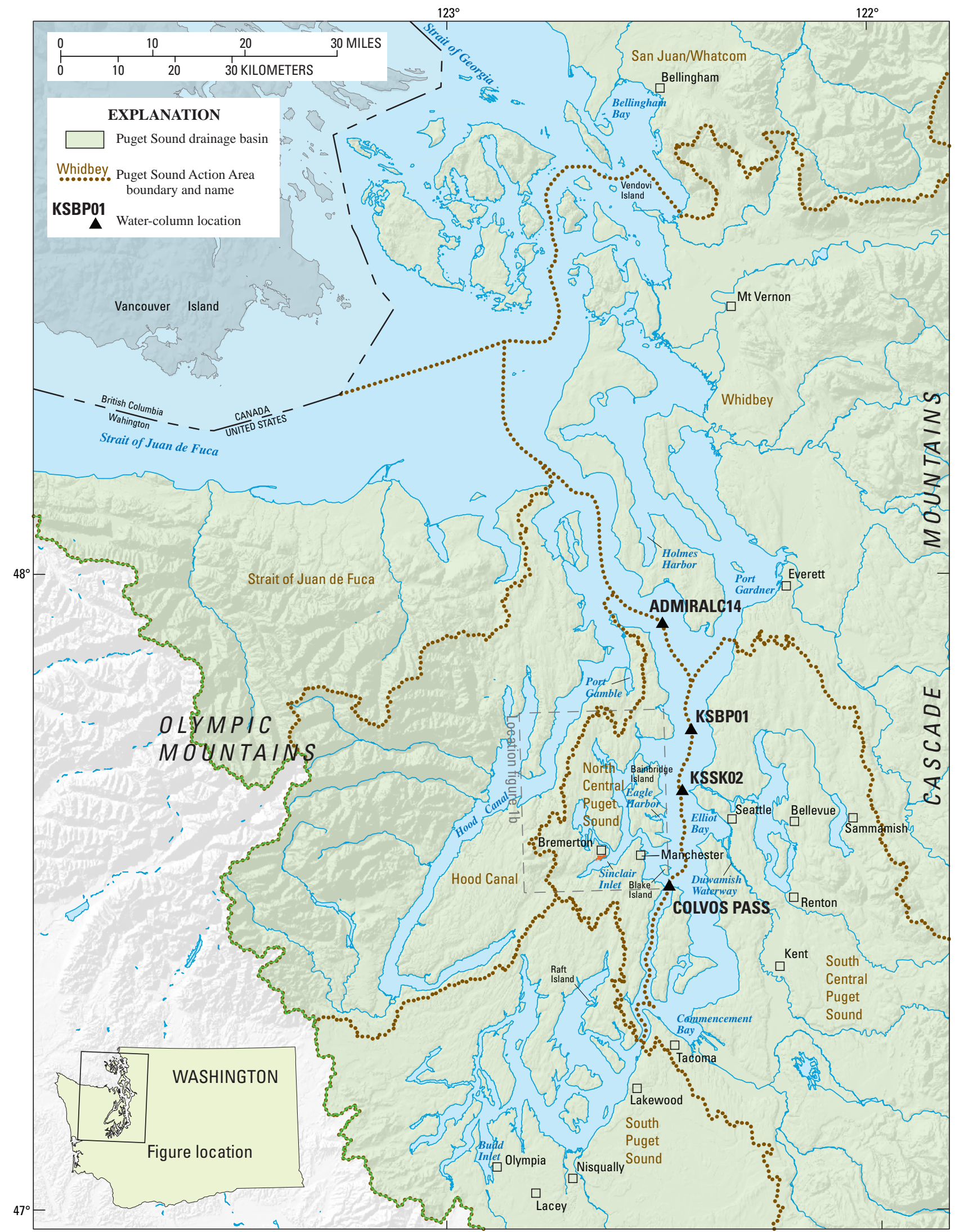

A.

Figure 1. Locations of $(A)$ Sinclair Inlet, $(B)$ water bodies adjacent to Sinclair Inlet, and $(C)$ site locations outside the Bremerton naval complex boundary from previous studies, Puget Sound, Washington. 


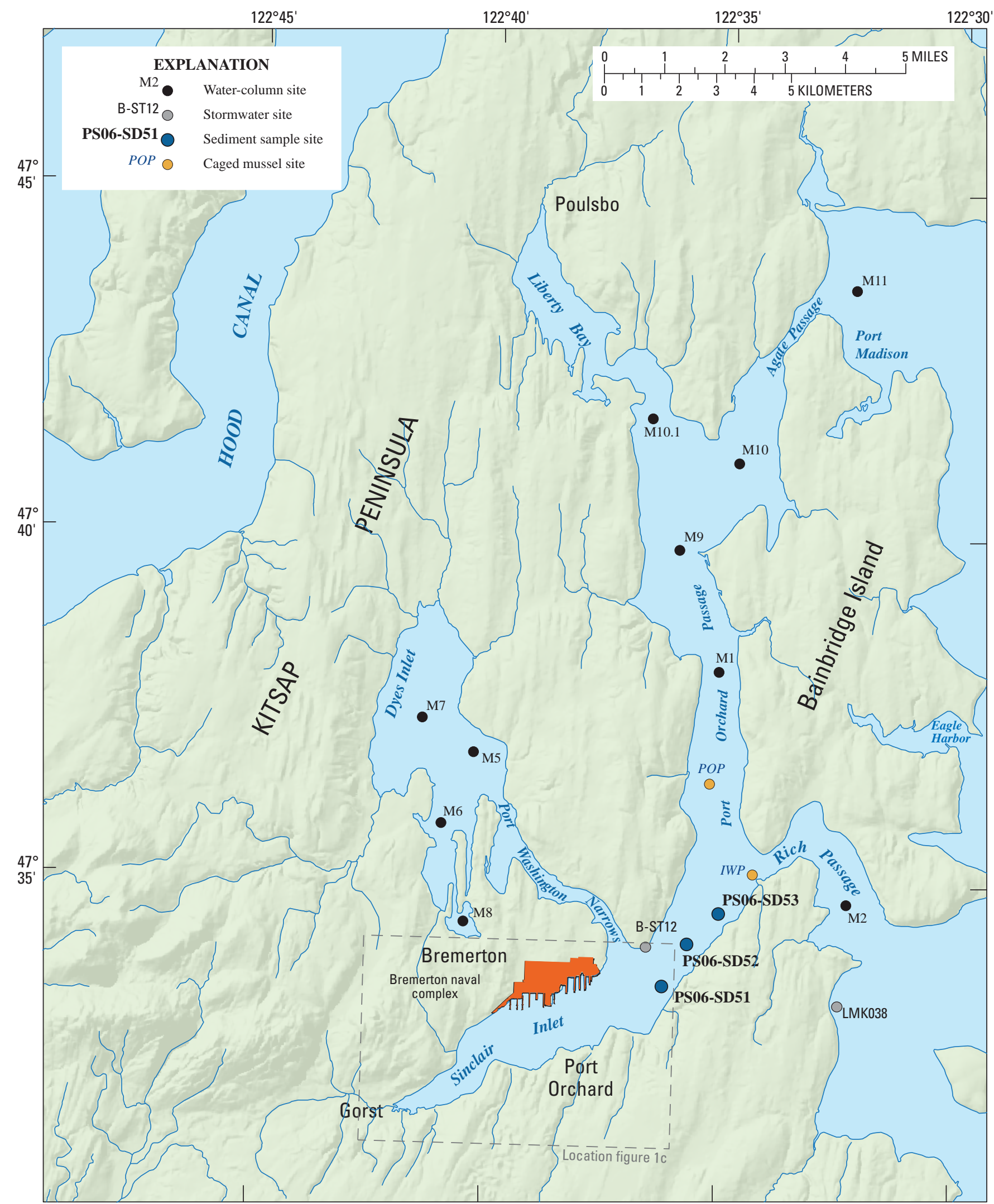

B.

Figure 1.-Continued. 


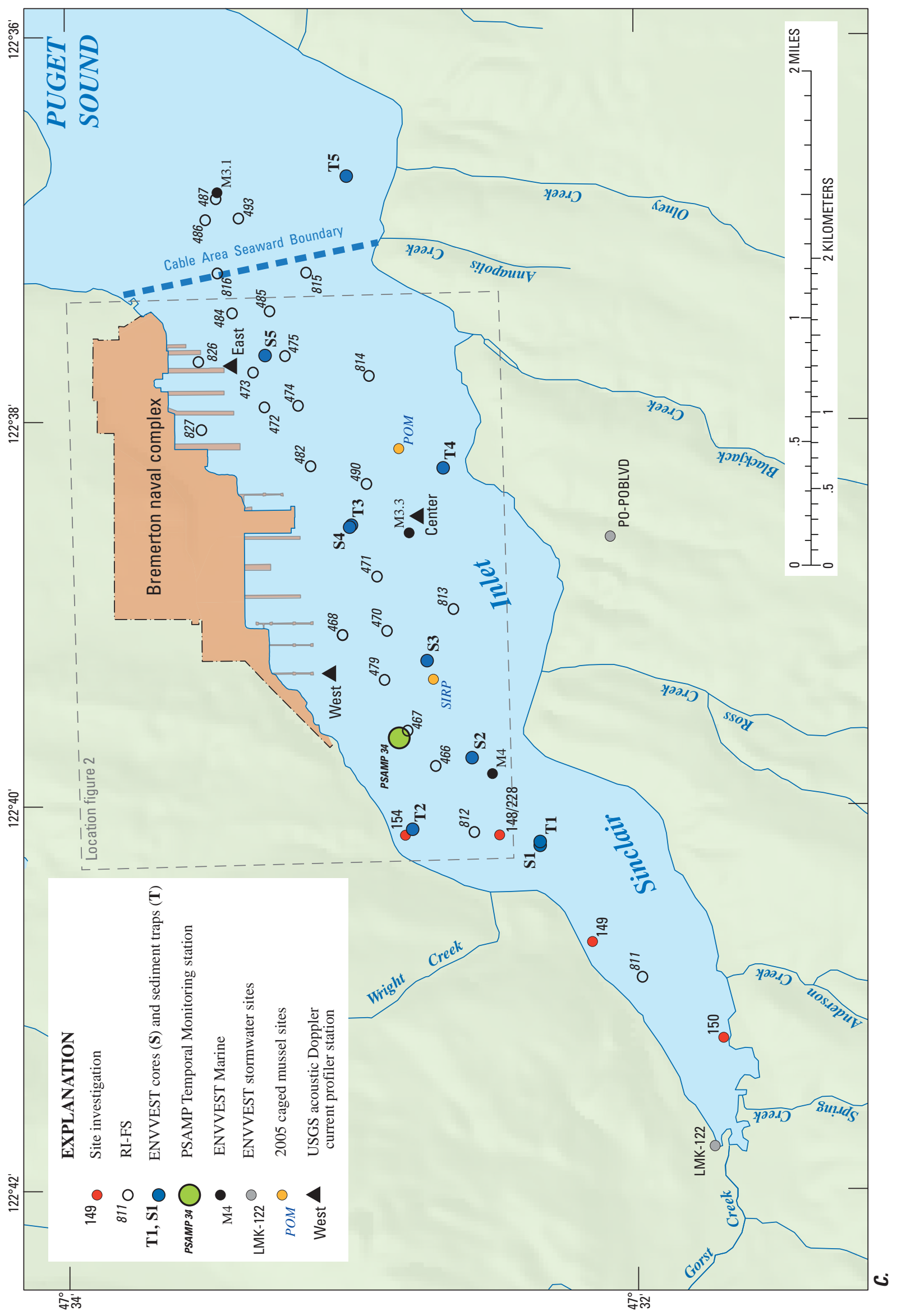

!. 
Vertical mixing in the Rich and Agate Passages, the shallowness (20 m) of Sinclair Inlet relative to the tidal range, and the relatively small flow of freshwater results in Sinclair Inlet being essentially "a tidally dominated, non-stratified, saline body of water" (U.S. Navy, 1992). The physical oceanographic study of Gartner and others (1998) also determined that Sinclair Inlet was non-stratified. In August of 1994, the water column of Sinclair Inlet was essentially isothermal. During the wet season in March 1994 when surface runoff would be near its maximum, the surface stratification was less than 1 salinity unit in 30 units. Gartner and others (1998) determined that typical current speeds were 5 to $10 \mathrm{~cm} / \mathrm{s}$. Wind forcing caused residual currents (time-averaged currents filtered with a 35-hour low-pass filter) in the bottom layer to flow in the opposite direction of the currents of the surface layer and the wind. Unlike systems dominated by estuarine circulation, low-pass filtered residual currents in Sinclair Inlet were similar in magnitude to the tidal currents.

The Bremerton naval complex is located on the north shore of Sinclair Inlet in Bremerton, Washington (fig.1C) and contains two separate Navy commands: Puget Sound Naval Shipyard and Intermediate Maintenance Facility (PSNS \& IMF), Bremerton site, and Naval Base Kitsap Bremerton (NBK Bremerton).

The primary role of NBK Bremerton is to serve as a deep-draft home port for aircraft carriers and supply ships. Facilities on the NBK Bremerton property include six piers and moorings, a steam plant, parking, housing, shopping, recreation, and dining facilities for military personnel and their families. NBK Bremerton also hosts several tenant commands including the Naval Inactive Ships Movement Office, which is responsible for providing long-term care of inactive naval vessels, and the Fleet and Industrial Supply Center, which provides material acquisition and warehouse services to west coast Navy commands. Naval Base Kitsap Bremerton occupies the western part of the naval complex and is a fenced, secure area.

The primary role of PSNS \& IMF is to provide overhaul, maintenance, conversion, refueling, defueling, and repair services to the naval fleet. PSNS \& IMF can dry dock and maintain all classes of Navy vessels and is the Nation's sole nuclear submarine and ship recycling facility. The PSNS \& IMF has six dry docks, eight piers and moorings, and numerous industrial shops to support its industrial operations. Like NBK Bremerton, PSNS \& IMF is host to many tenant commands. PSNS \& IMF occupies the eastern part of the naval complex and is a fenced high-security area.
For the purposes of environmental remediation, the BNC was divided into Operable Units (OU): OU A, OU B, OU C, OU D, and OU NSC (fig. 2). OU B was further divided into OU B Marine and OU B Terrestrial. OU C is an upland area and OU D is a waterfront parcel on the eastern side of the BNC that has been remediated and turned over to the City of Bremerton. Of the OUs, only data previously collected within the present OU B Marine will be addressed in this report. For the purposes of this document, greater Sinclair Inlet is defined as the area outside of OU B Marine of the BNC.

“Operable Unit A (OU A) consists of approximately $0.049 \mathrm{~km}^{2}$ of manmade land and the adjacent marine environment of Sinclair Inlet. It is located southwest of the main Puget Sound Naval Shipyard operations. The site is relatively level except for the riprap seawall, and most of its surface is paved. OU A is currently used as a parking lot for shipyard and deployed personnel and has been temporarily used as a staging area for dredge spoils. In the past, it was used as a helicopter pad and as a disposal area for industrial wastes associated with shipbuilding and decommissioning. Most of the land at OU A is composed of industrial fill to a depth of 2.1 to $10.7 \mathrm{~m}$ below the current ground surface. The fill increases in thickness toward the shore, where it is overlain with a layer of riprap stone. This industrial fill is composed of sandblast grit, scrap metal, brick, glass, wood, and other debris. Several shallow pits were established near the former helicopter pad and used for disposal of liquid wastes." (U.S. Navy, 1995a).

OU NSC formerly contained the Defense Reutilization Marketing Office, which recycled materials and contained an acid drain pit that was removed in 1995. Much of the western part of OU NSC consist of various former disposal sites and shoreline fill areas used for leveling and extending PSNS boundaries. The material used as fill varies with the location, but includes oily sludge, automobile scrap, construction debris, shipyard debris, spent abrasive grit, and other materials. Potential contaminants include PCBs, heavy metals, organics, and organotins (U.S. Navy, 1995b).

OU B Terrestrial contains the PSNS and the NBK Bremerton, excluding OU NSC. A number of waterfront areas in OU B Terrestrial served as former disposal sites and shoreline fill areas used for leveling and extending PSNS. These areas received fill material that included oily sludge, automobile scrap, construction debris, shipyard debris, spent abrasive grit, and other materials (U.S. Navy, 1992). A suspected fill area at the eastern boundary of PSNS is now covered with gravel and some asphalt pavement is used to store bulk materials. 


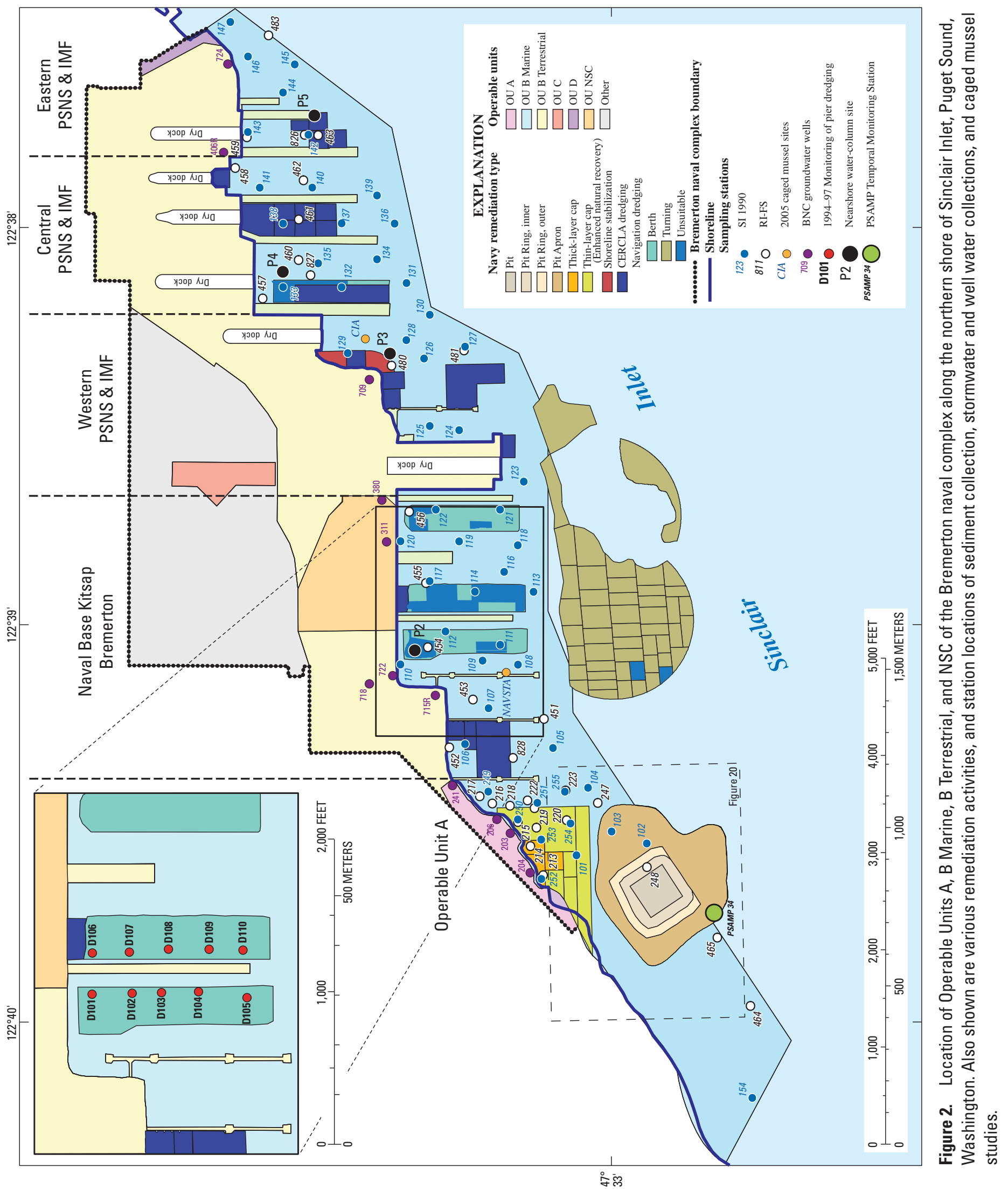


About $0.012 \mathrm{~km}^{2}$ in the central PSNS \& IMF in OU B Terrestrial (fig. 2) was used as a fill area from 1960 to 1974 and contains about $53,500 \mathrm{~m}^{3}$ of fill ranging in thickness from 11.3 to $15.2 \mathrm{~m}$. Fill materials included construction debris, rubble, spent abrasive grit ("blaster sand" and copper slag), and dredged sediment. In 1998, this area was paved and the Defense Reutilization Marketing Office was relocated from the OU NSC. As part of the remedial action for OU B Marine in 2000 and 2001, the shoreline perimeter was stabilized. This site also is part of the disposal site and shoreline fill area in central PSNS \& IMF. The primary concern at this site is oil from two tanks at the site of a power plant used for steam generation from 1910 to 1942, which was demolished in 1994.

The western part of OU B Terrestrial contains NBK Bremerton and includes two possible sources of contamination including the landfill for the former town of Charleston. About 4 acres, just west of the OU NSC, historically contained a number of wooden and concrete block structures including a garbage can cleaning facility, and a storage area for PCB waste and off-line transformers. In the 1980s, two darkstained soil spots were removed during a time-critical removal action. Subsequently, the buildings were demolished and a hazardous-and-flammable-materials warehouse and associated parking areas were constructed on the site from 1994 to 1996. Some soils contaminated with lead and other substances were removed during the construction of the hazardous-andflammable-materials warehouse.

Farther west in the NBK Bremerton area of OU B Terrestrial is a large former disposal site and shoreline fill area. A concrete tank used for the neutralization of acids, bases, and spent electroplating solutions was observed to be degrading to the extent that metal reinforcement bar was exposed. This observation prompted shipyard personnel to arrange alternative liquid-waste-disposal methods and to take the tank out of service in 1983.

\section{History of Remediation and Environmental Investigations Related to Mercury}

A synthesis of data on total mercury (THg)

concentrations in sediment throughout Puget Sound indicated that THg concentrations in sediment within OU B Marine in central PSNS \& IMF were higher than other urban areas of Puget Sound (Evans-Hamilton, Inc. and D.R. Systems, Inc., 1987). The level of THg contamination was of the same magnitude as reported in sediment from Bellingham Bay associated with the Georgia-Pacific chlor-alkali plant and in sediment from Commencement Bay associated with the
Asarco copper smelter. In 1989, the State of Washington Puget Sound Ambient Monitoring Program began monitoring the marine waters and sediment of Puget Sound. The sediment of Sinclair Inlet had the highest concentrations of THg and PCBs of all the long-term sediment monitoring sites in the first Puget Sound-wide sampling (Tetra Tech, Inc., 1990). The State of Washington continues long-term monitoring sediment at one site in Sinclair Inlet and one site in Dyes Inlet. In addition, between 1997 and 1999, marine sediment in various regions of Puget Sound were studied using high resolution spatial measurements; Sinclair Inlet was sampled in 1998 (Long and others, 2000).

An Initial Assessment Study (URS Consultants, Inc., 1991) in 1990 assessed if previous PCB cleanup efforts associated with the two dark spots at the PCB storage area on the NBK Bremerton were successful. The maximum PCB concentration measured in soil during the investigation was $1.94 \mathrm{mg} / \mathrm{kg}$, below the Model Toxics Control Act Method A industrial soil cleanup levels of $10 \mathrm{mg} / \mathrm{kg}$ for total PCBs. Soil samples analyzed for total metals showed the presence of lead and mercury. Soil borings analyzed for THg exceeded the Model Toxics Control Act Method A industrial soil cleanup level $(1 \mathrm{mg} / \mathrm{kg})$ at 17 locations. The results of the initial assessment study were included in the Final Remediation Report (U.S. Navy, 1995b).

In 1990, the URS Team began a Site Investigation of nine sites on the BNC under contract with the U.S. Navy (1992), and suggested that further evaluation was needed. The remedial investigation of OU A was initiated in 1992 and continued in two phases through 1994 (U.S. Navy, 1995a). OU A (fig. 2) is located on the western edge of the BNC site and contained a helicopter landing pad at one time. Presently, the majority of OU A is occupied by a paved parking lot outside of the security fence of the BNC.

Likewise, the remedial investigation of OU NSC, which contained an acid drain slab, was initiated in 1992 and continued in two phases through 1994 (U.S. Navy, 1995b). Project management plans for OU B were developed in 1994 to guide the Remedial Investigation process for OU B, which took place between 1994 and 1996 in two phases; the final report was issued in 2002 (U.S. Navy, 2002). The remediation investigation of OU B included most of the working waterfront, including the piers and dry docks of the Controlled Industrial Area (CIA) of the PSNS, and contained most sites sampled as part of the Site Investigation. The operable units were reorganized for the Feasibility Study and a new operable unit (OU B Marine) was established that included marine sediment within the former OUA and OU B. The investigations of OU A and OU B Terrestrial were devoted to the soils, groundwater, and surface water of their respective land areas. 
Due to increased mission requirements of the BNC, the Navy proposed dredging $80,360 \mathrm{~m}^{3}\left(105,100 \mathrm{yd}^{3}\right)$ of sediment on both sides of a pier off NBK Bremerton in 1991. The agencies of the Puget Sound Dredged Disposal Analyses issued a suitability determination in February 1994 for the unconfined open-water disposal of approximately $39,500 \mathrm{~m}^{3}$ $\left(51,700 \mathrm{yd}^{3)}\right.$ of material at a disposal site in Elliott Bay (fig. $1 A)$. The remaining $40,900 \mathrm{~m}^{3}\left(53,400 \mathrm{yd}^{3}\right)$ of material were designated for disposal at an upland disposal site. The dredging of the east side of the pier was completed in December 1994, and dredging of the west side of the pier was completed in March 1995. Annual monitoring of the dredged area occurred from 1995 through 1997 (U.S. Navy, 1998).

In June 1994, the U.S. Environmental Protection Agency (USEPA) designated the BNC for inclusion on the National Priorities List (NPL). A Feasibility Study was completed in 1998 to evaluate several alternatives for developing home port facilities for three NIMITZ-class aircraft carriers (U.S. Navy, 1999) in which dredging of 303,600 $\mathrm{m}^{3}\left(397,159 \mathrm{yd}^{3}\right)$ of sediment was proposed. Dredging off western and central PSNS \& IMF and off NBK Bremerton, as well as turning basins for berths at BNC, was proposed. Sediment sections from the surface to a depth of $122 \mathrm{~cm}$ were collected from 77 locations and subsurface sections (deeper than $122 \mathrm{~cm}$ ) from 7 locations were collected and analyzed (U.S. Navy, 1999). The composition of proposed dredged spoils was further studied (U.S. Navy, 2000) because of the large number of sediment sections that failed to meet the regional Puget Sound suitability guidelines for open-water disposal and because sediment chemistry concentrations of toxic constituents were poorly related with the occurrence of end points of toxicity tests (U.S. Navy, 1999).

As early as 1997, coordination began between planning efforts for clean-up of the marine sediment and construction activities designed to improve the homeport capabilities of the shipyard. With the need for navigational dredging of marine sediment within OU B Marine, plans for a confined aquatic disposal (CAD) site were developed in 1999. In the design of a CAD, a pit is dug in the sub-tidal sediment of an estuary and the contaminated sediment is placed in the pit. After dredging and dredge disposal is complete, the pit is covered with a thick cover of clean coarse sediment. Disposal of dredge spoils from the most contaminated sediment of the BNC also were to be confined in the CAD under CERCLA.

The Record of Decision for OU B Marine (U.S. Environmental Protection Agency, 2000) indicated that fish tissue contaminated with PCBs posed an unacceptable risk to subsistence seafood harvesters. Consumption of older rockfish with high THg concentrations also was identified as a possible human health risk. Since the marine area off OU A is not part of the working waterfront of the BNC, capping of this subtidal contaminated sediment with clean sediment was chosen as a remedy to isolate living marine resources from the contaminated sediment. A thick cap was placed over the most contaminated sediment near the shoreline and a thin cap was placed over most of the contaminated sediment off OU A. The assumption underlying the placement of a thin cap over the less contaminated sediment was that the thin cap would isolate living marine resources from contamination until such time that natural sedimentation of clean sediment (enhanced natural recovery) would permanently bury the contaminated sediment. Results of PCB analyses of sediment collected around the CAD Pit in 2001 and in state-owned aquatic lands (SOAL) in 2003 led to additional thin caps being placed on the periphery of the CAD pit (U.S. Navy, 2004).

The Record of Decision provides for post remediation monitoring to be used in reviews every five years to assess the effects of the initial and subsequent remedial actions. The Long-Term Monitoring Program (LTMP) examines the marine sediment and natural resources in Sinclair Inlet and in the groundwater resources of OU A, OU B, and OU NSC. Beginning in 2003, the LTMP examined the concentrations of PCBs and THg in sediment in 72 cells of a 500-ft sampling grid within the boundary of the BNC and 32 cells of a 1,500-ft sampling grid in Sinclair Inlet outside of the BNC boundary on a biennial basis. In addition, the cap of the CAD pit was examined in 2003 and 2005, as well as a ring of 15 cells of uncapped sediment around the CAD pit, called the CAD Pit Apron. In 2004, the boundary of OU B Marine was extended to include state-owned aquatic lands shown in fig. 2 (U.S. Navy, 2004).

The LTMP continues to monitor groundwater for THg, other dissolved metals, and organic contaminants in five wells installed during the Remedial Investigation and five new wells installed in 2004 within close proximity to the shoreline. The PCB and THg concentrations in composites of English sole were measured in 2003 and 2007 to assess impacts of contamination on human health. In the second 5-year review (U.S. Navy, 2007a), mercury contamination in marine sediment and groundwater continued to be a concern.

This report contains geographical systems for locating sites from the Site Investigation, the Remedial Investigation/ Feasibility Study, and the LTMP. To facilitate conversion among these systems, locations from earlier U.S. Navy programs are identified in this report within specific cells of the newer LTMP 500-ft grid or 1,500-ft grid. In addition, sites outside of Sinclair Inlet mentioned in this report are identified within a Puget Sound Partnership Action Area (accessed July 13, 2009, at http://www.psp.wa.gov/aa_action_areas.php).

The ENVironmental inVESTment (ENVVEST) project was developed between Federal, State and local partners to specifically address the development of Total Maximum Daily Loads for the Sinclair/Dyes Inlet Watershed adjacent to Puget Sound Naval Shipyard, and the Final Project Agreement was signed in September 2000 (Sinclair/Dyes Inlets Water Quality Improvement Project, accessed July 13, 2009, at http://www. ecy.wa.gov/programs/wq/tmdl/sinclair-dyes_inlets/). 
The ENVVEST project documented fecal coliform contamination (Cullinan and other, 2007), and also measured contaminants of concern, including THg, to Sinclair and Dyes Inlets.

In 2007, the U.S. Navy asked the U.S. Geological Survey (USGS) to evaluate the status of mercury in the sediment, water, and biota of Sinclair Inlet, and to evaluate the sources of mercury to Sinclair Inlet. Forty samples from 11 wells, two dry dock well discharge points, and the steam plant were collected between December 2007 and June 2008 to evaluate groundwater and point sources of mercury from the BNC. In addition, a survey of methylmercury concentrations in dry dock discharges, groundwater, five creeks, and two wastewater treatment facilities was completed in 2008. A tidal study of filtered THg in one LTMP well and the adjacent intertidal region was completed in June 2008. A survey of methylmercury concentration in the marine water column at six sites within Sinclair Inlet and three sites outside of Sinclair Inlet also was completed in 2008.

A comprehensive field study examining the biogeochemical processes that transfer inorganic THg in the sediment to methylmercury in zooplankton was conducted by USGS between August 2008 and August 2009. The overall objective of this study is to describe and quantify the biogeochemical processes that lead to methylation of mercury in sediments, the release of methylmercury and ionic mercury from sediments, and the bioaccumulation of methylmercury into the base of the pelagic food web. Specific goals are to (1) determine the spatial and temporal variability of methylmercury concentrations in zooplankton and, as feasible, phytoplankton in Sinclair Inlet relative to the spatial and temporal variability of dissolved and particulate concentrations of total mercury and methylmercury in the water column and other water-column constituents associated with organic matter, (2) assess the seasonal probability that THg in the sediments throughout Sinclair Inlet may be methylated, and (3) confirm the seasonal assessment by intensively examining the pore waters of Sinclair Inlet sediments at six sites and the releases of total mercury and methylmercury from Sinclair Inlet sediments using incubated sediment-core experiments. The results of these field studies will be published in 2010 .

\section{Mercury in the Sediment of Sinclair Inlet}

Similar to most elements, the distribution of mercury in sediment often is controlled by the physical characteristics of the sediment (grain size, organic content, and mineralogy). Because of the electronic configuration of the outer shell of the mercury atom, mercury has a tendency to associate with organic compounds. Therefore, the concentration of mercury in sediment generally is highly correlated with the organic carbon content of the sediment. These organic compounds often are adsorbed onto the surfaces of silt and clay particles. Because the amount of surface area available for adsorption of organic compounds per a given weight of particles increases with decreasing size of particles, higher organic carbon content generally is associated with small particles. Thus, total organic carbon (TOC) content often increases with increasing amounts of finer grained particles in a sediment sample. The grain-size distribution of sediment is characterized by the percentage of dry weight of gravels and boulders (larger than $2 \mathrm{~mm}$ ), sands (between $0.064 \mathrm{~mm}$ and $2 \mathrm{~mm}$ ), silts (between 0.008 and $0.064 \mathrm{~mm}$ ) and clays (smaller than $0.002 \mathrm{~mm}$ ). The distribution of many contaminants often is correlated with amounts of fine-grained material (called total fines), which is defined as the silt and clay fraction less than $0.064 \mathrm{~mm}$.

In addition to higher organic carbon content in finer grained material, the mineralogy of the sediment generally varies with grain size. The clay and silt fractions contain more aluminosilicate minerals compared to the sand fraction, which contains silica sands. Thus, the total aluminum content is a surrogate for the amount of fine-grained material in a sediment sample. The finer grained aluminosilicate mineral assemblages also contain higher amounts of iron and manganese oxide minerals, which strongly adsorb mercury. Aluminum content, total fines, and organic carbon content, therefore, are interrelated and represent a measure of the organic and mineral surfaces that have a strong ability to adsorb metals.

For each investigation of marine sediment in the following sections, THg concentrations in sediment of greater Sinclair Inlet outside of the BNC are regressed against TOC content, sediment total aluminum concentrations, and percentage of fines if sufficient data are available. A description of the quality of each data set is presented in appendix A and the environmental data are presented in tables in appendix B. For studies in which two or three of the sediment indicators were measured, the relations between sets of indicators are presented in appendix C.

The depth of the sediment column over which a sediment sample was collected is also an important parameter in assessing the THg concentration in sediment. In estuaries, suspended solids enter marine water from rivers and streams in the watershed, from point discharges, and from overland flows over impermeable surfaces of the developed watershed (that is, stormwater). These suspended solids are transported throughout the estuary by tidal dispersion and estuarine circulation and are deposited as marine sediment in a fairly consistent manner over time spans of years, if watershed land use or the climate has not changed dramatically. The rate at which solids are buried by newly deposited suspended solids is called the sedimentation rate. Sedimentation rates in Puget Sound usually vary between millimeters to 
centimeters per year. If physical processes were the only forces acting on the sediment, then the sediment would record the history of pollution in the annual varves with high temporal resolutions, similar to the annual growth of tree rings or record of ice cores. However, in uncontaminated sediment, benthic organisms (worms, mussels, and shellfish) thoroughly mix sediment down to a depth called the surface mixed zone or the biologically active zone. The degree of biological activity decreases with increasing depth, with the most intense mixing by shallow bioturbators occurring near the surface. These bioturbators are at lower densities at greater depths in the sediment. In toxicological studies, sediment often is collected from the sediment-water interface to a depth of $10 \mathrm{~cm}$ to encompass the biologically active zone. Thus, the sediment in a surface sediment sample represents sedimentation over some time period. For instance, a 10-cm surface sediment represents 20 years of sediment accumulation if the sedimentation rate is $0.5 \mathrm{~cm} / \mathrm{yr}$. If the depth interval of a $10-\mathrm{cm}$ sample includes the legacy pollution, the THg concentration will be higher than the THg concentration of sediment that is currently be deposited. Thus, the THg to organic carbon relation for a study in which sediment was sampled to a depth of $10 \mathrm{~cm}$ may look very different from the THg to organic carbon relation for a study in which sediment was sampled to a depth of $2 \mathrm{~cm}$. The depth to which sediment are collected often is dictated by the specific purpose of the study. In the studies examined herein, surface sediment was collected to depths from 2 to $10 \mathrm{~cm}$. Caution should be exercised when comparing the relations between THg and the above sediment indicators, as the various studies collected sediment to different depths.

The wet chemical method of assaying mercury in sediments also may influence results. In routine methods, the sediment is digested with strong inorganic acids that not only decompose organic matter and metal oxides associated with particle surfaces, but also digest some of the internal lattice of the mineral particles. The mercury concentrations measured by strong acid digestion often is called total mercury (THg). In a special study associated with the 1994 study of OU B Marine, four sediment samples were digested in 10 percent hydrochloric acid $(\mathrm{HCl})$ and designated as mercury- $\mathrm{HCl}$ (described in appendix A). The Toxicity Characteristic Leaching Procedure (TCLP; U.S. Environmental Protection Agency, 1990) used in the 1993 OU A study requires that sediment be extracted with a weak organic acid. This procedure extracts the organic carbon compounds associated with particle surfaces, but does not digest the clay mineral matrix of the sediment and the designation Hg-TCLP is used. The mercury concentrations measured by these three procedures only will be comparable if the majority of the mercury is absorbed to particle surfaces and not locked into the internal lattice of minerals. All sediment data for mercury, TOC, and total fines are reported on a dry weight basis.
In summary, caution must be exercised when examining mercury concentrations in sediment of Sinclair Inlet across the various studies described below. The extraction procedure used and the depth to which the surface sample was collected may result in different analytical results. Some of these methodological inconsistencies can be mitigated by examining mercury concentrations in relation to one or more of the three indicators of sediment physical characteristics described above (TOC content, percentage of fine-grained sediment less than $0.064 \mathrm{~mm}$, and total aluminum). However, the choice of indicators was not consistent among the studies described below.

\section{Site Investigation (1990)}

As part of the Site Investigation in 1990 (U.S. Navy, 1992) to investigate the contamination of marine sediment by storm drains from the BNC, marine surface sediment $(0-4 \mathrm{~cm})$ was collected from 53 stations within what is now OU B Marine and 6 sites outside the boundary of the BNC. THg and total aluminum concentrations were measured for all sites, TOC was determined in 14 samples, and total fines was determined for 13 of the 14 sites for which TOC was determined. The data generally were acceptable in that the relative percent difference (RPD) of two field duplicates averaged 23 percent, but samples collected off OU A were qualified (did not meet data quality objectives) for holding time exceedances (appendix A). The data used in this report are listed in tables B1 and B2.

When THg concentrations are plotted against total aluminum concentrations (fig. 3), the six samples collected outside of the OU B boundary fell into two groups: one group with low total aluminum and THg concentrations (about $8,000 \mathrm{mg} / \mathrm{kg}$ and less than the detection limit of about $0.13 \mathrm{mg} / \mathrm{kg}$, respectively) and the other with higher concentrations (22,000 mg/kg and about $1.2 \mathrm{mg} / \mathrm{kg}$, respectively). The dashed line (fig. 3 ) between these two groups illustrates the qualitative trend between THg and total aluminum in greater Sinclair Inlet in 1990. Although about one-half the samples from the present OU B Marine were either below or slightly above this qualitative trend line, a number of samples in OU A and OU B Marine were significantly above this line, indicating possible local sources. In particular, one surface sample collected off OU A had a THg concentration of $5.2 \mathrm{mg} / \mathrm{kg}$.

For the subset of samples for which total carbon content and total fines data were available (figs. 4 and 5), there were not significant linear relations $(p<0.05)$ between THg concentrations and total organic carbon and total fines. For the small subset of samples for which total aluminum, TOC, and total fines were measured (figs. $\mathrm{C} 1-\mathrm{C} 3$ ), the significances of the relation of total aluminum concentrations versus TOC $\left(\mathrm{R}^{2}=0.61, p=0.001\right)$ and the relation of TOC versus total fines $\left(\mathrm{R}^{2}=0.61, p=0.004\right)$ were similar. 


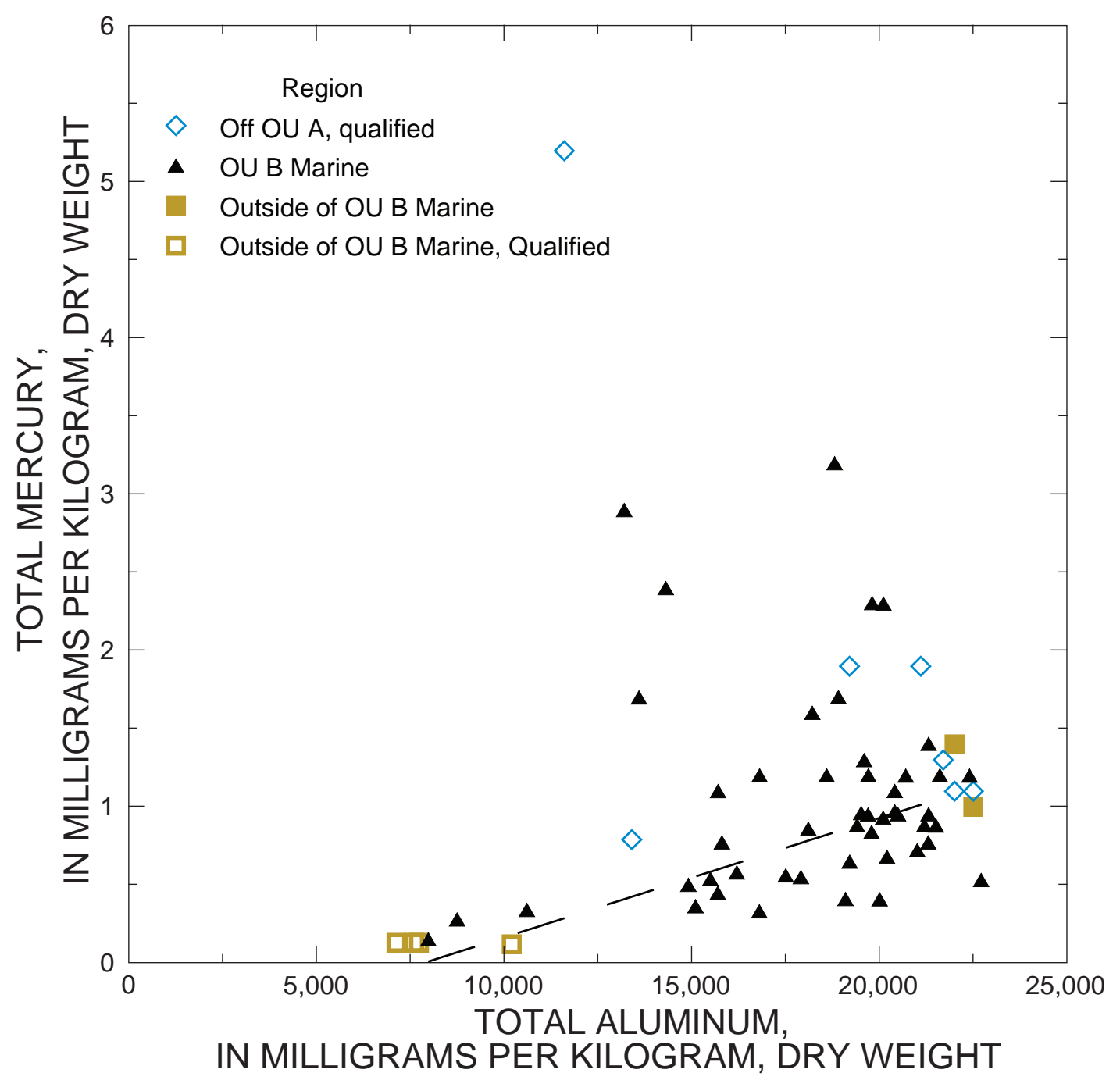

Figure 3. Total mercury concentrations compared with total aluminum concentrations in surface sediment $(0-4 \mathrm{~cm})$ off Operable Unit A, off Operable Unit B Marine, and outside of the Bremerton naval complex, Washington, from the 1990 Site Investigation (tables B1 and B2). Open symbols are qualified because mercury values are below reporting levels or because of holding time exceedances. Dashed line shows qualitative relation between the two groups of samples outside of Bremerton naval complex. 


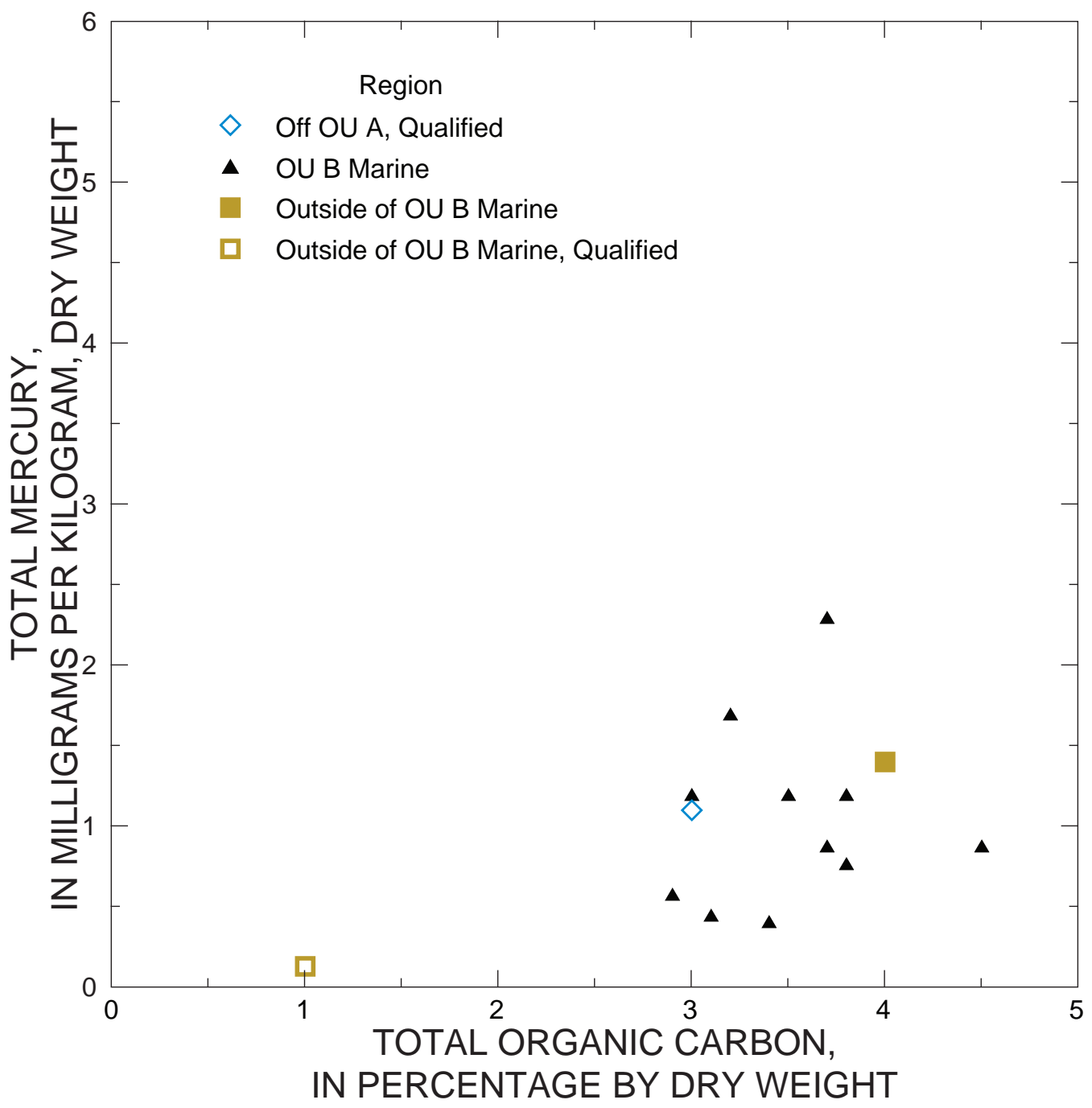

Figure 4. Total mercury concentrations compared to total organic carbon in surface sediment $(0-4 \mathrm{~cm})$ from Operable Unit A, Operable Unit B Marine, and outside of the Bremerton naval complex, Washington, from the 1990 Site Investigation (tables B1 and B2). Open symbols are qualified because mercury values are below reporting levels or because of holding time exceedance. 


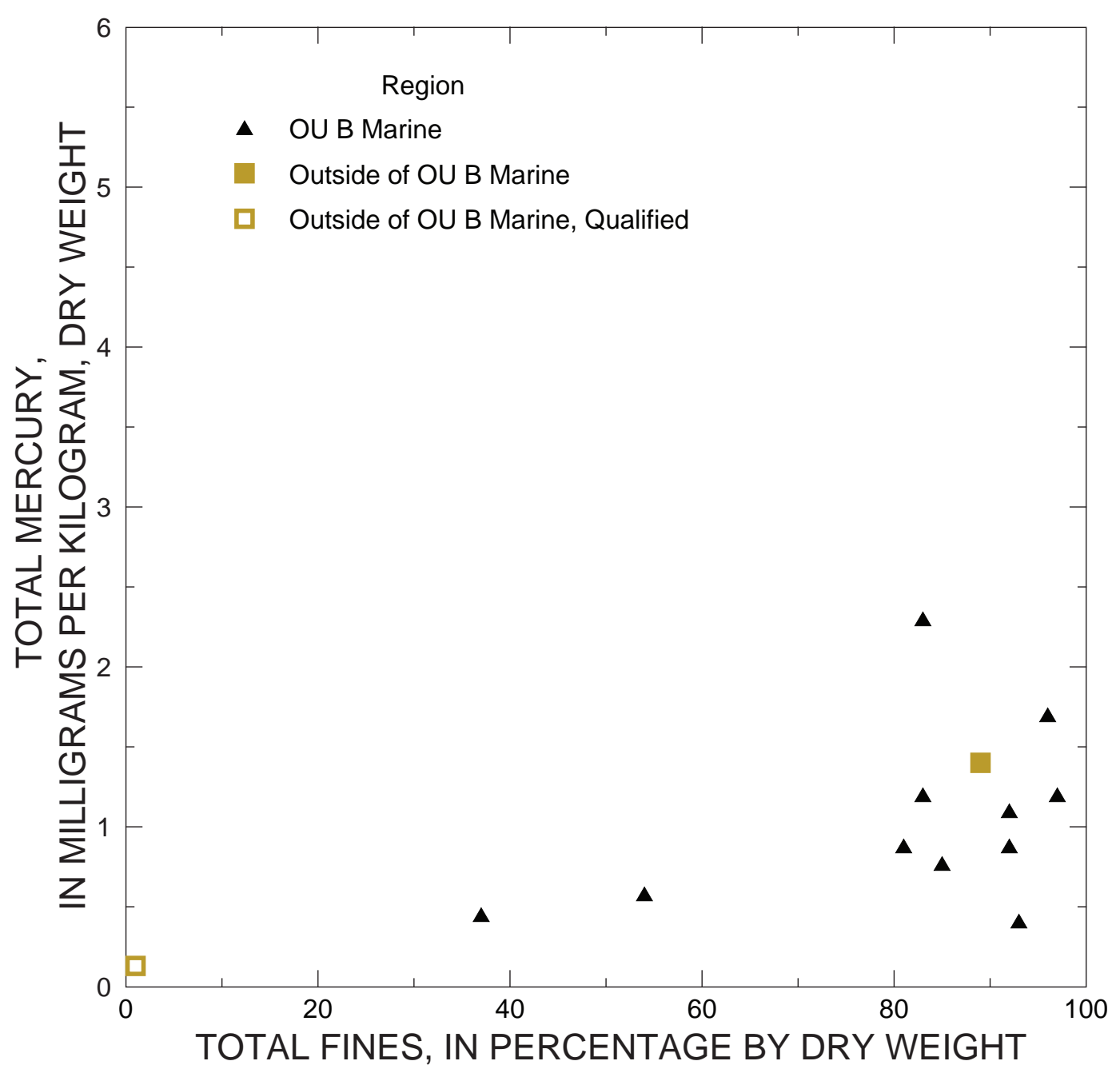

Figure 5. Total mercury concentrations compared to total fines in surface sediment $(0-4 \mathrm{~cm})$ from Operable Unit A, Operable Unit B Marine, and outside of the Bremerton naval complex, Washington, from the 1990 Site Investigation (table B2). Open symbol is qualified because mercury value is below the reporting level.

\section{Remediation Investigations (1993-95)}

The Installation Restoration Program investigates potential environmental contamination at Department of Defense facilities resulting from past operations and waste disposal practices (U.S. Navy, 1995a). The long-range objective of the Installation Restoration Program is to develop remedies consistent with the National Oil and Hazardous Substances Pollution Contingency Plan for sites that pose a threat to human health or the environment. In June 1993, marine sediment was collected at 11 sites (locations 213-223 in fig. 2) off OU A and one offshore site (ST48 at location $148 / 228)$ at two depths ( $0-5 \mathrm{~cm}$ and generally $5-25 \mathrm{~cm})$. In addition, sediment was collected at a third depth $(25-60 \mathrm{~cm})$ at five sites off OU A (219-223) and the one site offshore (table B3). After extracting the sediment using the weak organic acidic TCLP solution, the extract was analyzed for Hg-TCLP. The small amounts of aluminum extracted by this method indicated that the procedure did not dissolve the lattice structure of minerals. TOC and total fines also were measured. Although the RPD of three laboratory and one field duplicates were less than 4 percent, only 29 percent of the Hg-TCLP analyses were deemed acceptable due to low matrix spike recoveries and values below the reporting level (appendix A).

The Hg-TCLP concentrations in surface sediment $(0-5 \mathrm{~cm})$ at these 12 locations (table B3) ranged between 0.42 and $2.1 \mathrm{mg} / \mathrm{kg}$ (U.S. Navy, 1995a) and were weakly correlated $(p=0.096)$ with TOC and total fines (figs. 6 


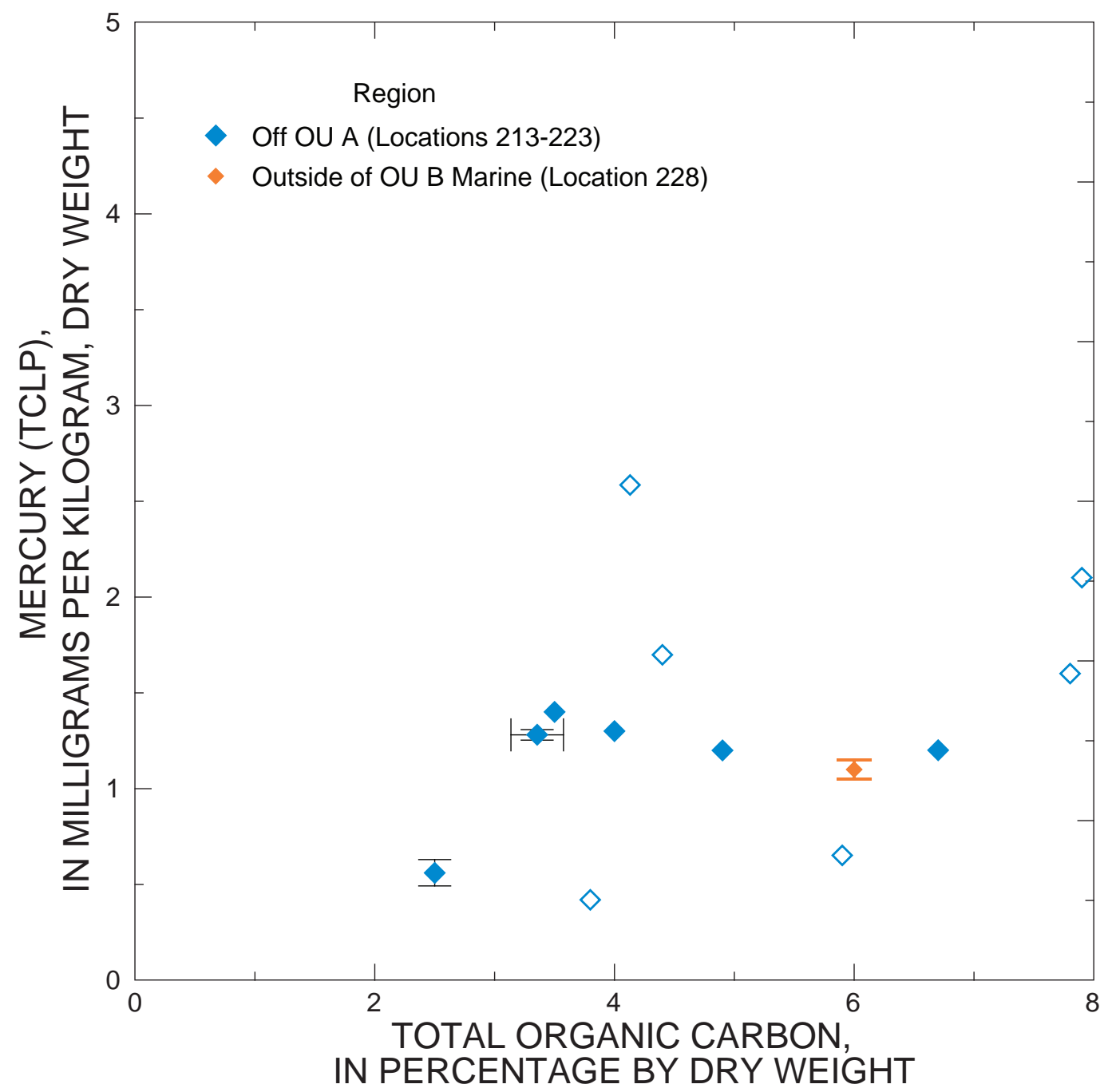

Figure 6. Mercury-toxicity characteristic leaching procedure (TCLP) concentrations compared to total organic carbon in surface sediment $(0-5 \mathrm{~cm})$ from Operable Unit A stations (locations 213-223) and offshore site ST48 (location 228) of the Bremerton naval complex, Washington, from the 1993 Remedial Investigation (table B3). Open symbols are qualified because mercury values are below reporting levels or because matrix spikes were outside acceptable limits. Vertical and horizontal error bars represent the ranges for duplicate analyses of mercury and total organic carbon, respectively.

and 7). Higher Hg-TCLP concentrations in OU A were generally nearshore at depths between $5 \mathrm{~cm}$ and $25 \mathrm{~cm}$ in the sediment column. This trend is illustrated by a concentration of $7.1 \mathrm{mg} / \mathrm{kg}$ in the $20-25 \mathrm{~cm}$ section of the vertical profile (fig. 8) from the nearshore station MS219 (location 219). Off the western side of NBK Bremerton, Hg-TCLP concentrations as high as $4.9 \mathrm{mg} / \mathrm{kg}$ were measured at depth (fig. 9). In contrast to nearshore locations, the Hg-TCLP concentration in the deepest section at offshore station 228 (fig. 10) decreased to concentrations less than the reporting level of $0.19 \mathrm{mg} / \mathrm{kg}$.
The vertical profiles for stations MS220, MS221, and MS223 (locations 220, 221 and 223 in fig. 2) are shown in figures D1-D3.

In 1994, sampling focused on surface sediment $(0-10 \mathrm{~cm})$ in OU B and included analysis of THg, total aluminum, TOC, and total fines (U.S. Navy, 2002). Much of the THg data obtained by strong acid digestion was qualified. Sampling in 1995 concentrated on defining the areal extent over which sediment needed to be dredged or capped and six samples collected off the BNC were analyzed for THg, TOC and total fines. 


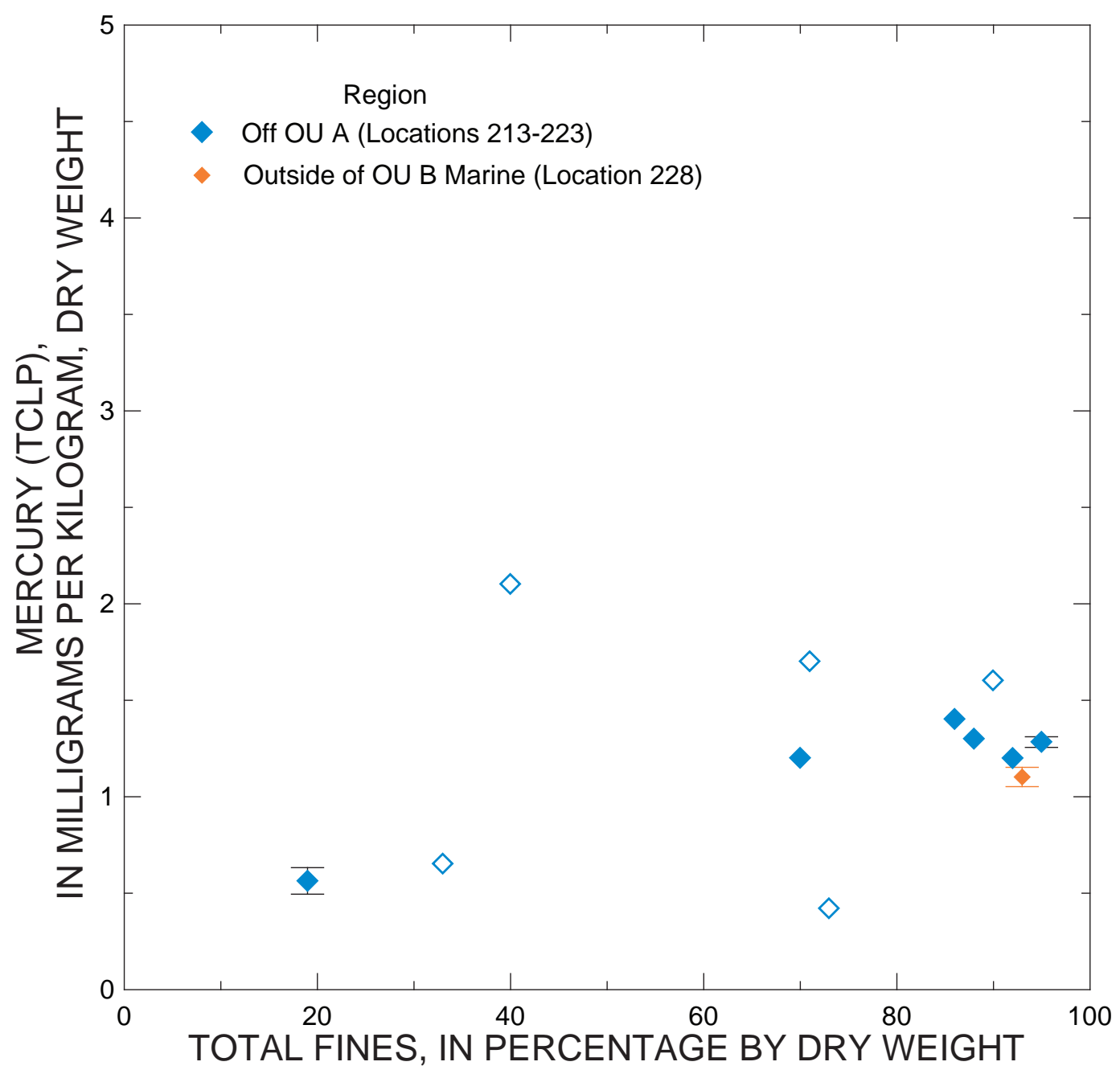

Figure 7. Mercury-toxicity characteristic leaching procedure (TCLP) concentrations compared to total fines in surface sediment $(0-5 \mathrm{~cm})$ from Operable Unit A stations (locations 213-223) and offshore site ST48 (location 228 of the Bremerton naval complex, Washington, from the 1993 Remedial Investigation (table B3). Open symbols are qualified because mercury values are below reporting levels or because matrix spikes were outside acceptable values. Vertical error bars represent the ranges for duplicate analyses. 

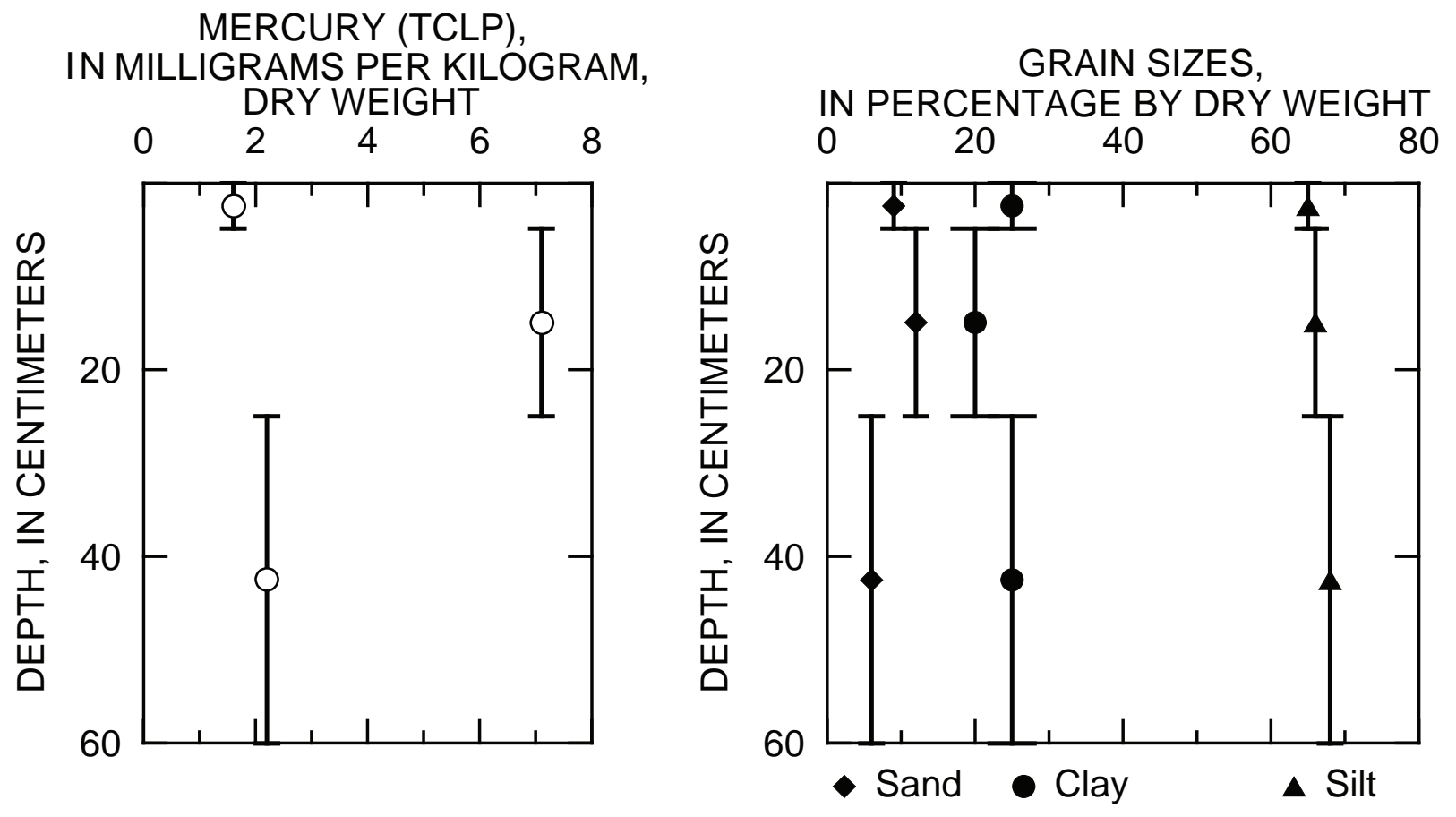

TOTAL ORGANIC CARBON, IN PERCENTAGE BY DRY WEIGHT
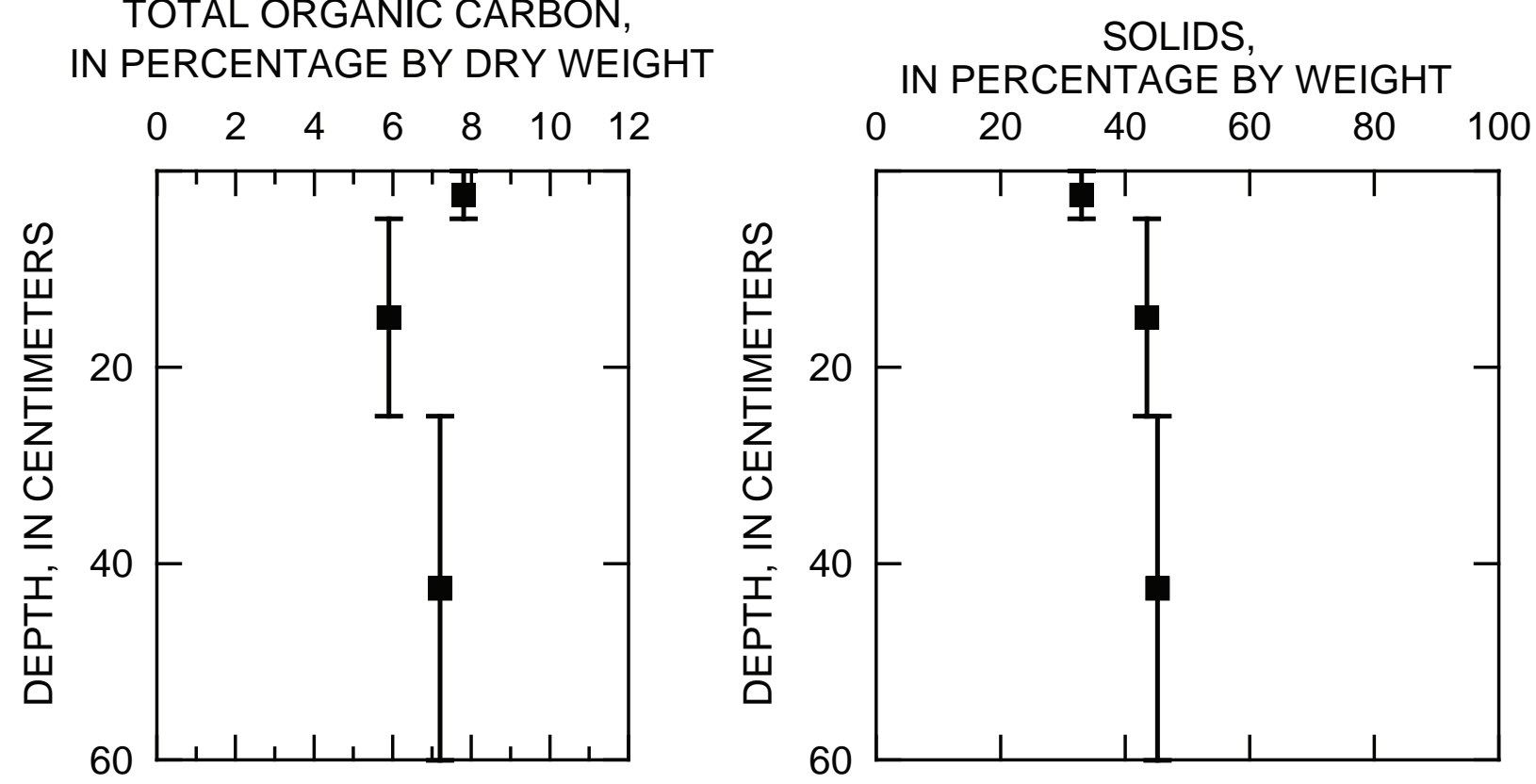

Figure 8. Vertical profiles of mercury-toxicity characteristic leaching procedure (TCLP) concentrations, percentages of sand, silt and clay, total organic carbon, and percentage of solids at MS219 (location 219) of Operable Unit A of the Bremerton naval complex, Washington. Open symbols are qualified because matrix spikes were outside acceptable limits. The vertical bars represent the depth interval of each core section (table B3). 

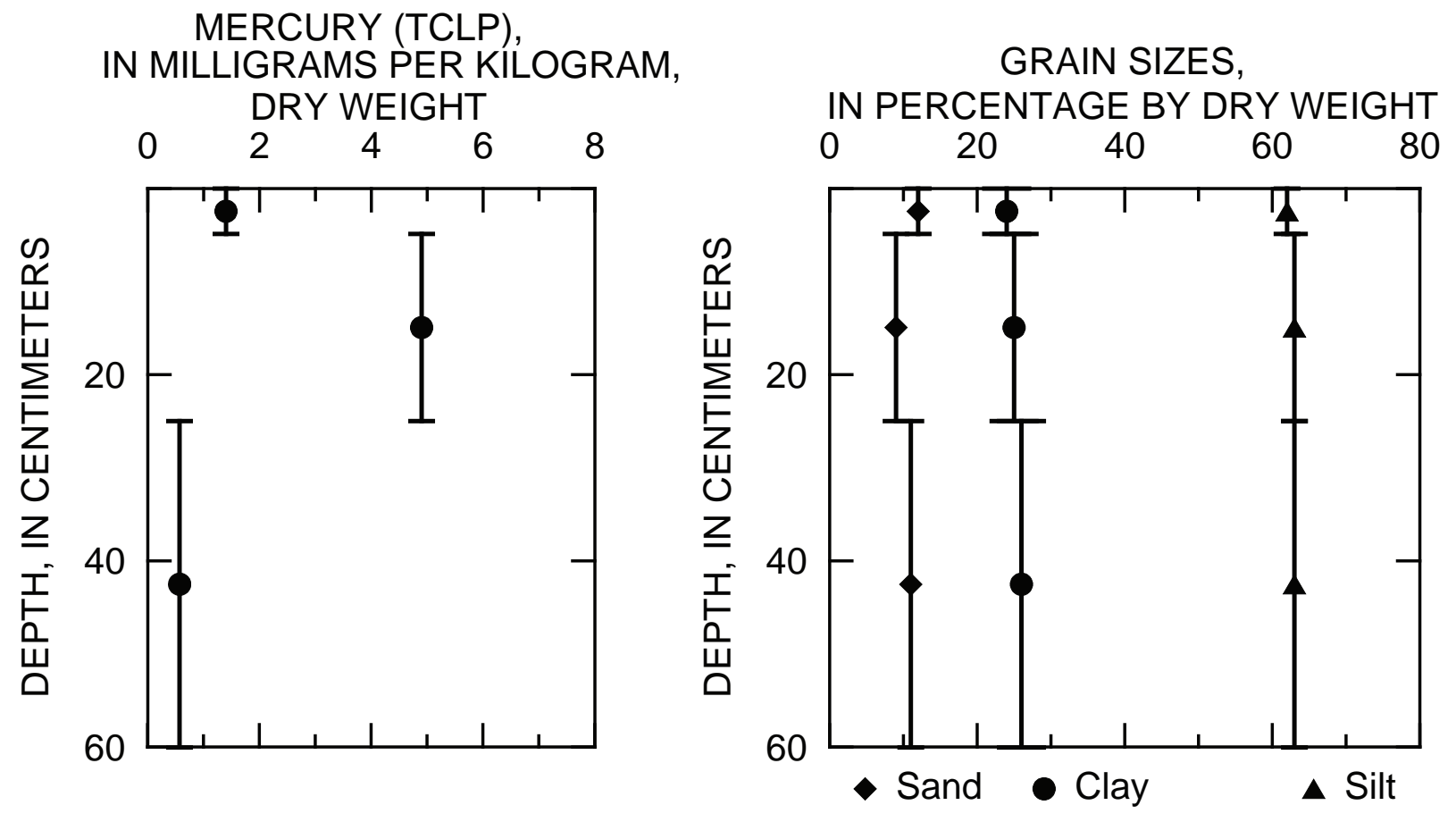

TOTAL ORGANIC CARBON, IN PERCENTAGE BY DRY WEIGHT
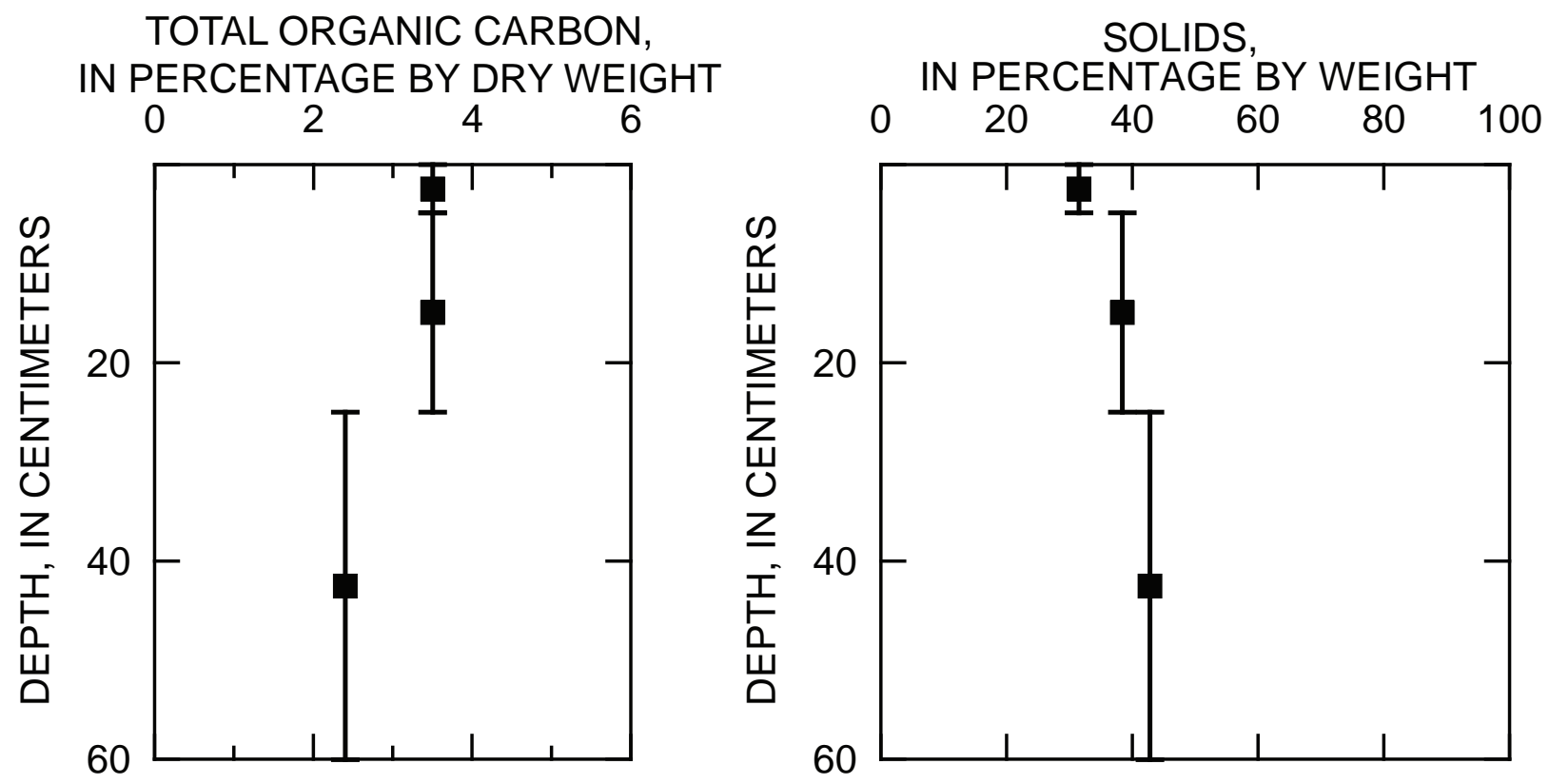

Figure 9. Vertical profiles of mercury-toxicity characteristic leaching procedure (TCLP) concentrations, percentages of sand, silt and clay, total organic carbon, and percentage of solids at MS222 (location 222). The vertical bars represent the depth interval of each core section (table B3). 

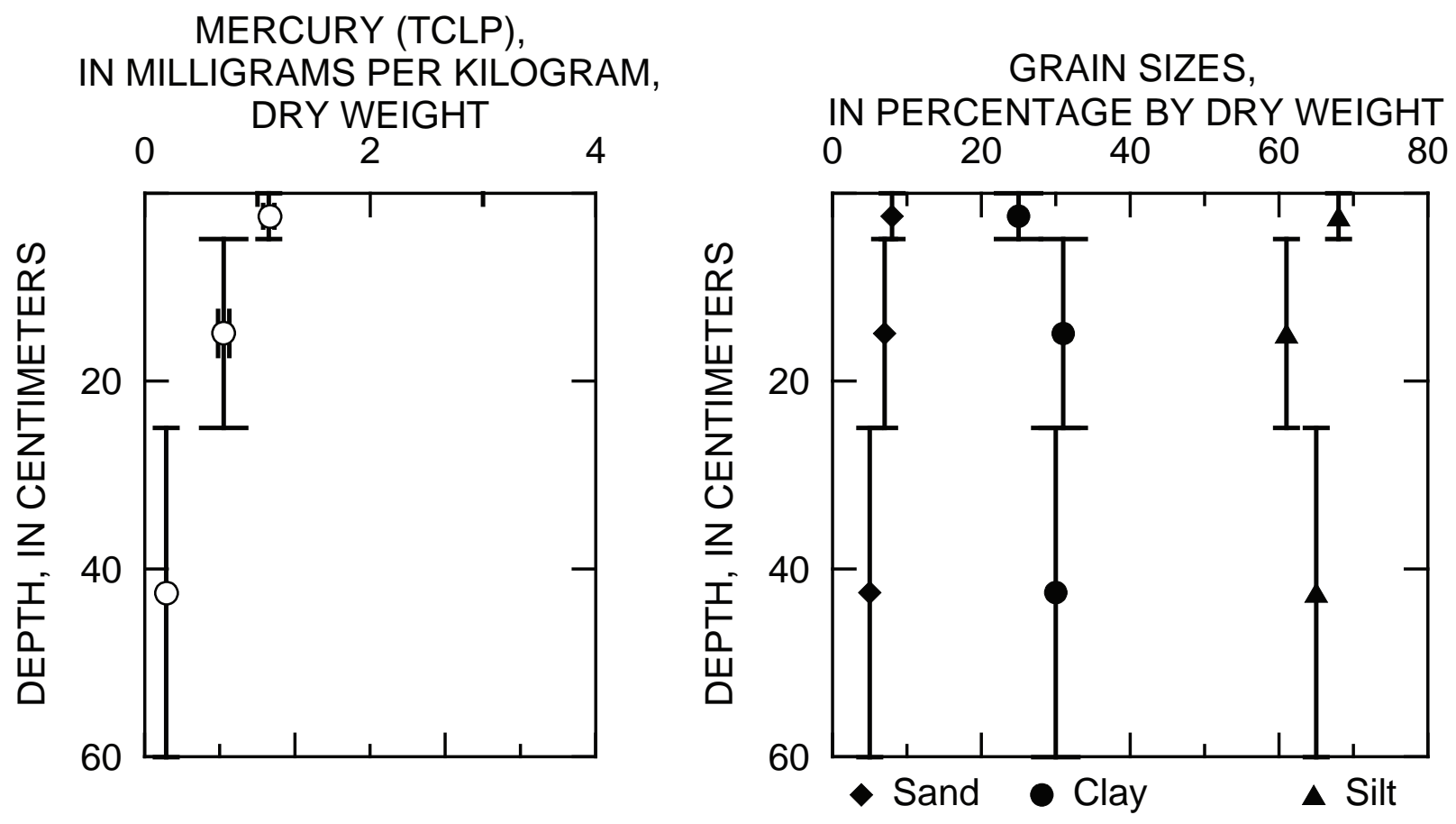

TOTAL ORGANIC CARBON, IN PERCENTAGE BY DRY WEIGHT
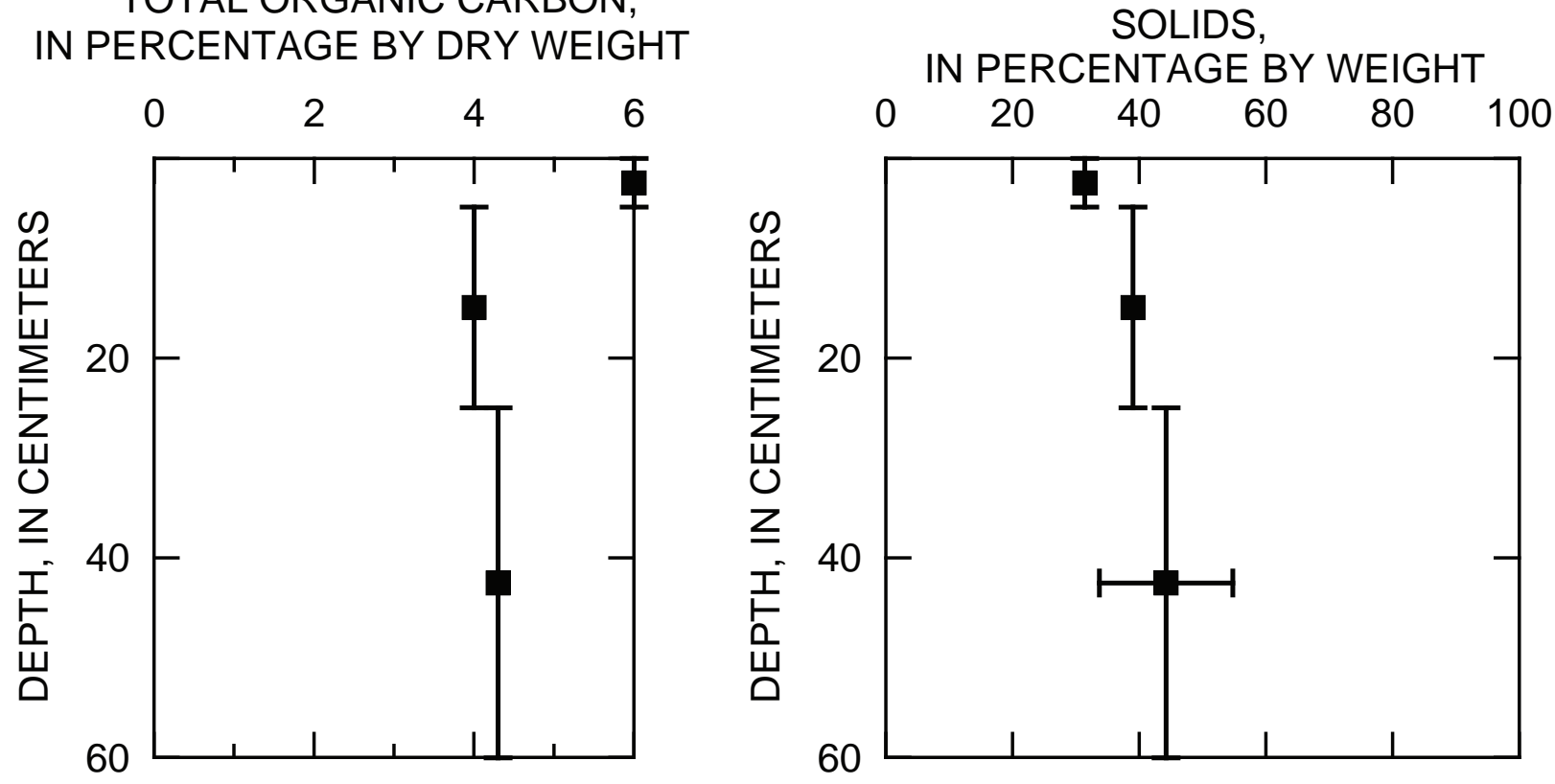

Figure 10. Vertical profiles of mercury-toxicity characteristic leaching procedure (TCLP) concentrations, percentages of sand, silt and clay, total organic carbon, and percentage of solids at ST48 (location 228) off the Bremerton naval complex, Washington. Open symbols are qualified because matrix spikes were outside acceptable limits. The vertical bars represent the depth interval of each core section (table B3). 
THg concentrations in surface sediment outside of OU B ranged between 0.14 and $1.7 \mathrm{mg} / \mathrm{kg}$ (excluding outlier location 472 in table B4). Quantitative analyses of the linear relations between $\mathrm{THg}$ and the ancillary parameters of TOC and total fines for greater Sinclair outside of OU B Marine were obtained using results from 17 samples collected in 1994 and 6 samples collected in 1995 from outside of BNC (figs. 11 and 12). For the regressions of THg compared to TOC and total fines, the probability that the slope of the regression was zero was less than 0.001 (table 1), indicating that THg was statistically correlated with TOC and total fines. Regression statistics of THg compared with TOC and total fines outside of the BNC are listed in table 1, after outliers were identified and removed from the data set. Total aluminum (fig. 13) was measured only in 1994 and $\mathrm{THg}$ was significantly correlated with total aluminum $(p=0.039)$.

Table 1. Linear regression statistics of total mercury concentration (dry weight) compared to total organic carbon (dry weight), total fiines (dry weight), and total aluminum concentration (dry weight) in sediments collected from stations outside of Bremerton naval complex, Washington, as part of the 1994-95 Remedial Investigation Study, the Long-Term Monitoring Program (2003, 2005, and 2007), and the 1997-99 Puget Sound Ambient Monitoring Program Study of Washington.

[Data sources: 1994-95 Sinclair Inlet, U.S. Navy 1995a, 2000; 2003 Sinclair Inlet, U.S. Navy, 2006a; 2005 Sinclair Inlet,U.S. Navy, $2006 b ; 2007$ Sinclair Inlet, U.S.Navy, 2008b; Bellingham Bay and Port Garder, Long and others, 1999; 1998 Sinclair, Liberty Bay, and Elliott Bay; Long and others, 2000; Commencement Bay and Budd Inlet, Long and others, 2002. Outliers for the U.S. Navy Sinclair Inlet dataset for 2003, 2005, 2007 were identified as having ratios of the residuals to the interquartile range greater than 3 and are shown in figure E1. The ratios of the residuals to the interquartile range is listed in parenthesis for each outlier. Abbreviations cm, centimeter; No., number; <, less than]

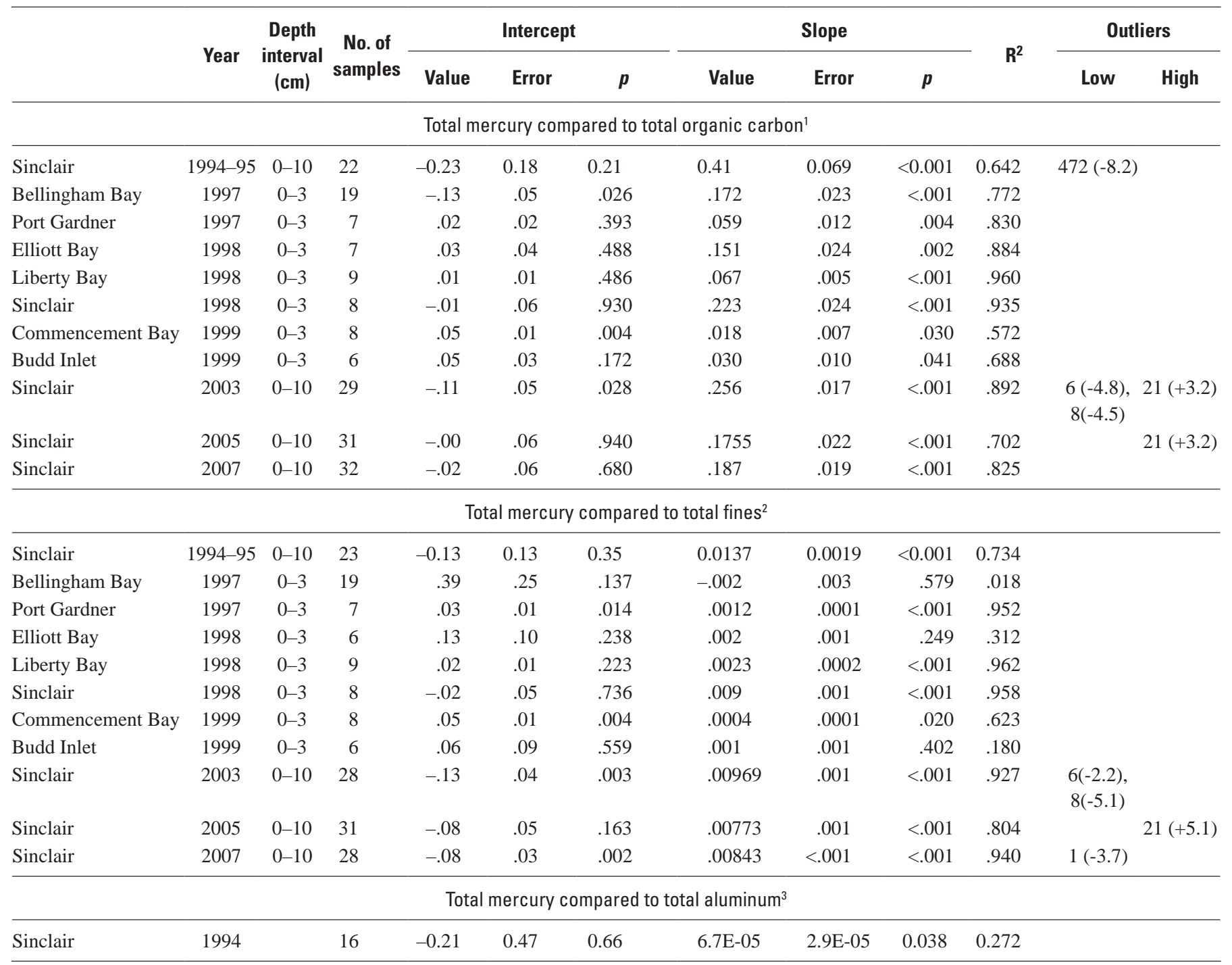

${ }^{1}$ Slope in units of milligrams per kilogram (dry weight) per percentage total organic carbon by dry weight.

${ }^{2}$ Slope in units of milligrams per kilogram (dry weight) per percentage of total fines by dry weight.

${ }^{3}$ Slope is a ratio in the same units and is unitless. 


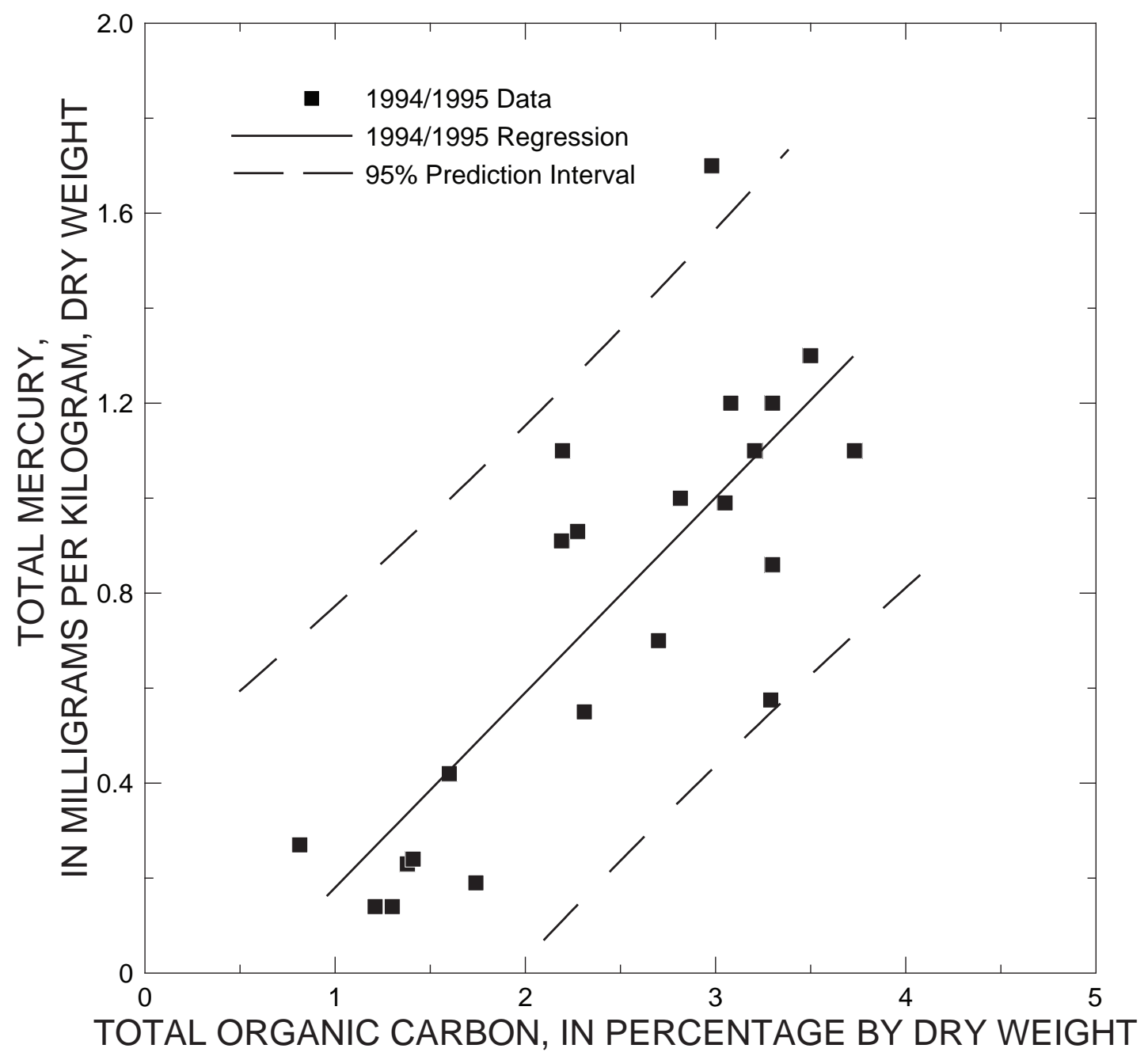

Figure 11. Total mercury concentration compared to total organic carbon in surface sediment $(0-10 \mathrm{~cm})$ from outside of the Bremerton naval complex, Washington, from the 1994 and 1995 Remedial Investigation (table B4). The solid line represents the statistically significant regression line (table 1) and the dashed lines represent the 95 percent prediction intervals. 


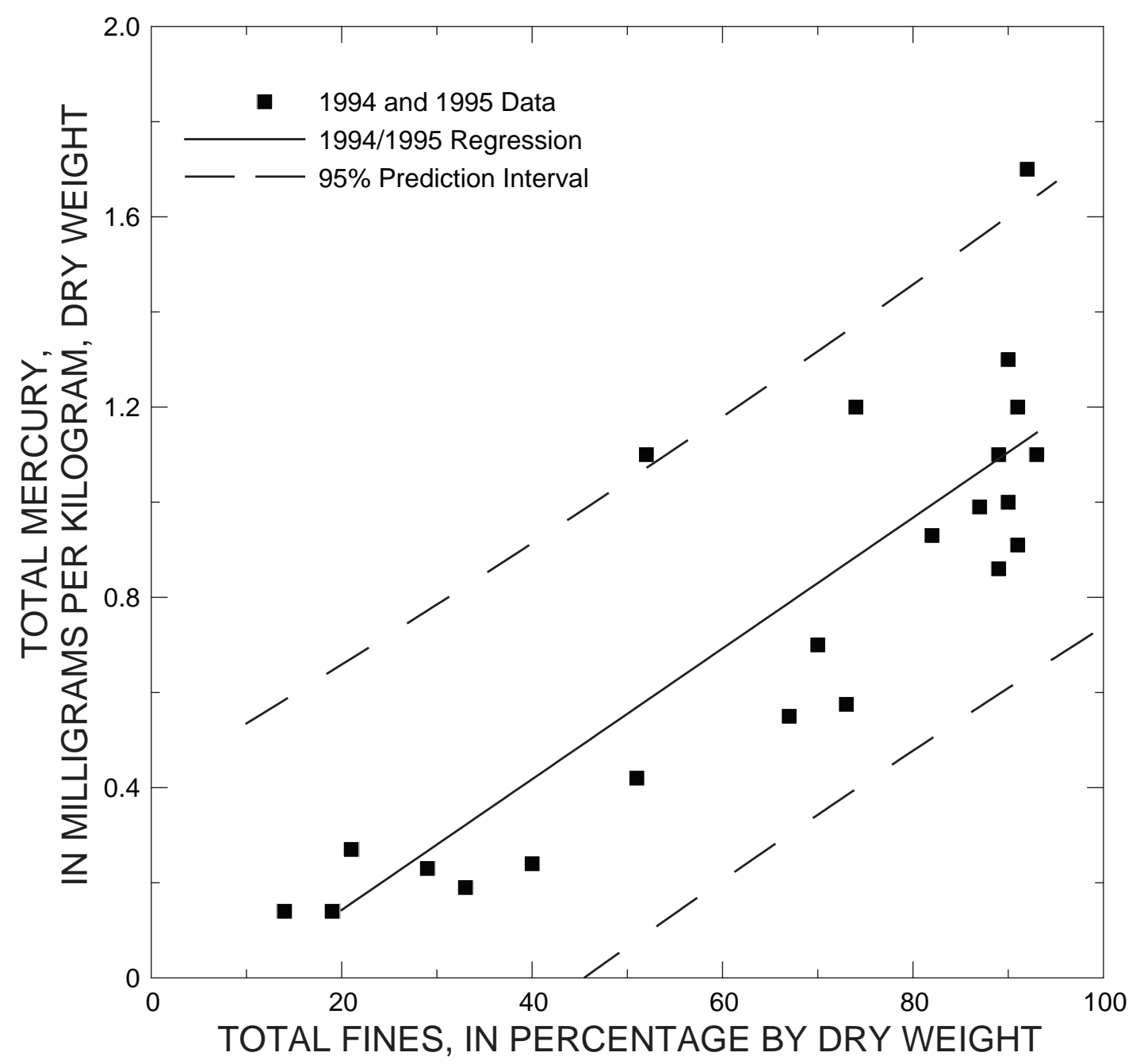

Figure 12. Total mercury concentration compared to total fines in surface sediment $(0-10 \mathrm{~cm})$ from outside of the Bremerton naval complex, Washington, from the 1994 and 1995 Remedial Investigation (table B4). The solid line represents the statistically significant regression line (table 1) and the dashed lines represent the 95 percent prediction intervals. 


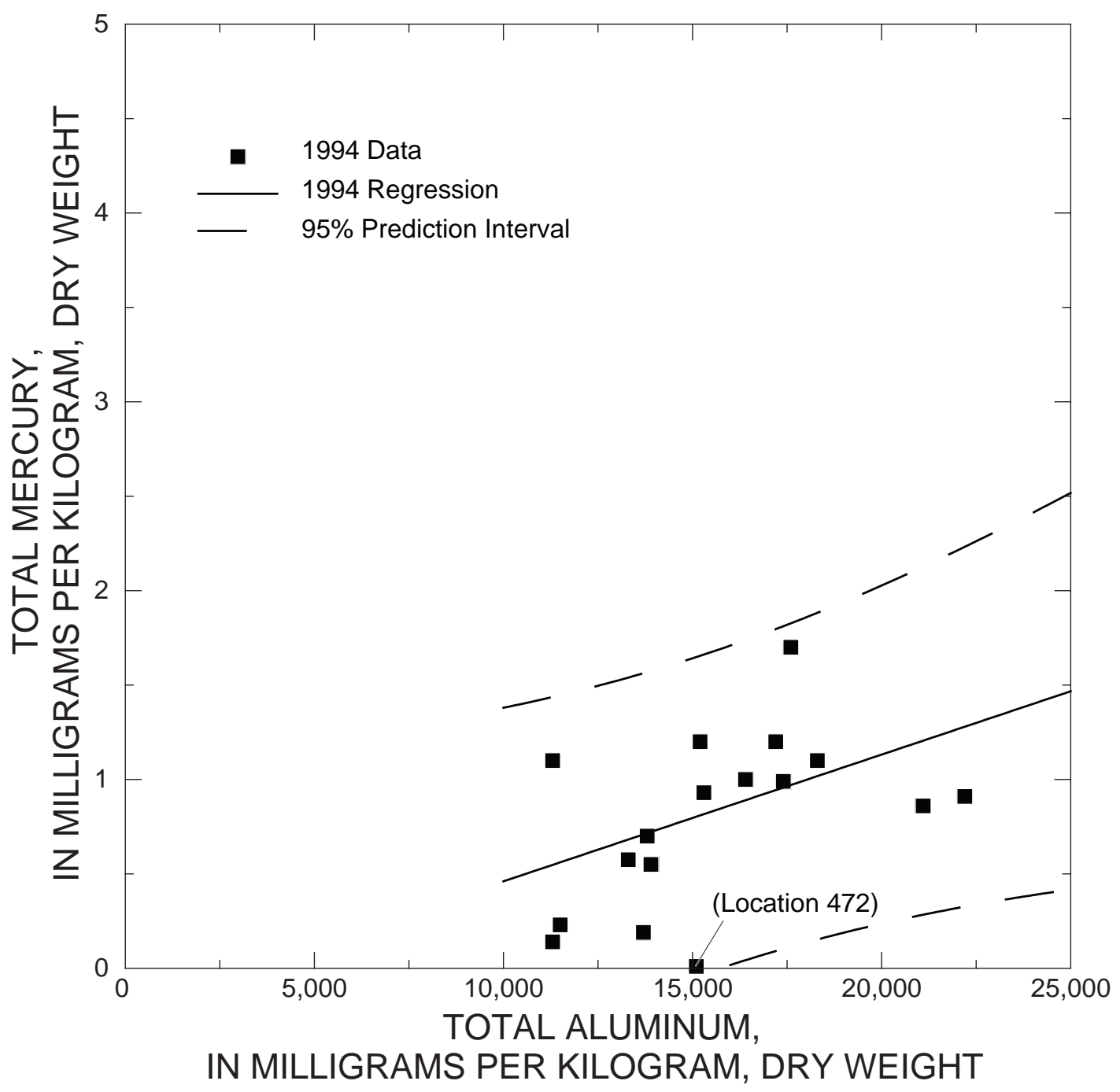

Figure 13. Total mercury concentration compared to total aluminum in surface sediment $(0-10 \mathrm{~cm})$ from outside of the Bremerton naval complex, Washington, from the 1994 Remedial Investigation (table B4). The solid line represents the statistically significant regression line (table 1) and the dashed lines represent the 95 percent prediction intervals. 
When THg concentrations in surface sediment $(0-10 \mathrm{~cm})$ from OU B Marine (table B5) are plotted against TOC (fig. 14), six of the samples are outside of the prediction interval for the regression line for sediment outside of the BNC. In particular, THg concentrations from sites 458-6E BIASED and 463-6E REP (sampled on May 19, 1994) were approximately $4 \mathrm{mg} / \mathrm{kg}$. In contrast, eight of the thirteen of the OU B Marine samples are above the prediction interval for regression line of $\mathrm{THg}$ compared to total fines for samples outside of the BNC (fig. 15). Total aluminum concentrations varied between about 15,000 to $25,000 \mathrm{mg} / \mathrm{kg}$ and $\mathrm{THg}$ concentrations varied by 7 -fold (fig. 16). The relations among total fines, TOC content, and aluminum concentrations are shown in appendix C (figures C4-C6 for samples outside of OU B Marina and in figures C7-C9 for samples within OU B Marina).

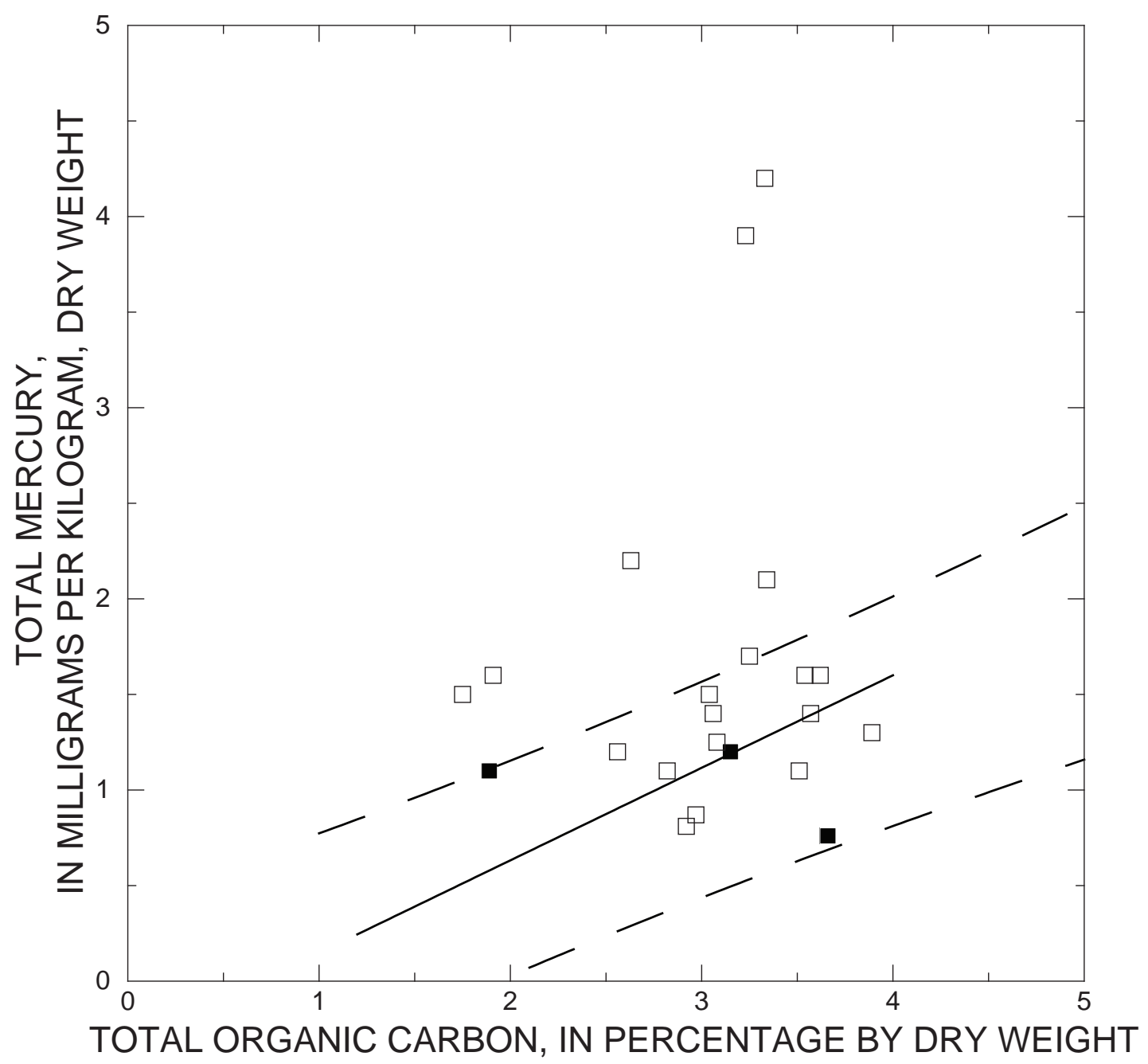

Figure 14. Total mercury concentration compared to total organic carbon in surface sediment $(0-10 \mathrm{~cm})$ from Operable Unit B Marine of the Bremerton naval complex, Washington, from the 1994 Remedial Investigation (table B5). Open symbols are qualified. The solid line represents the statistically significant 1994-95 regression between the variables for sediment outside of the Bremerton naval complex, Washington (fig. 11 and table 1) and the dashed lines represent the upper 95 percent prediction intervals. 


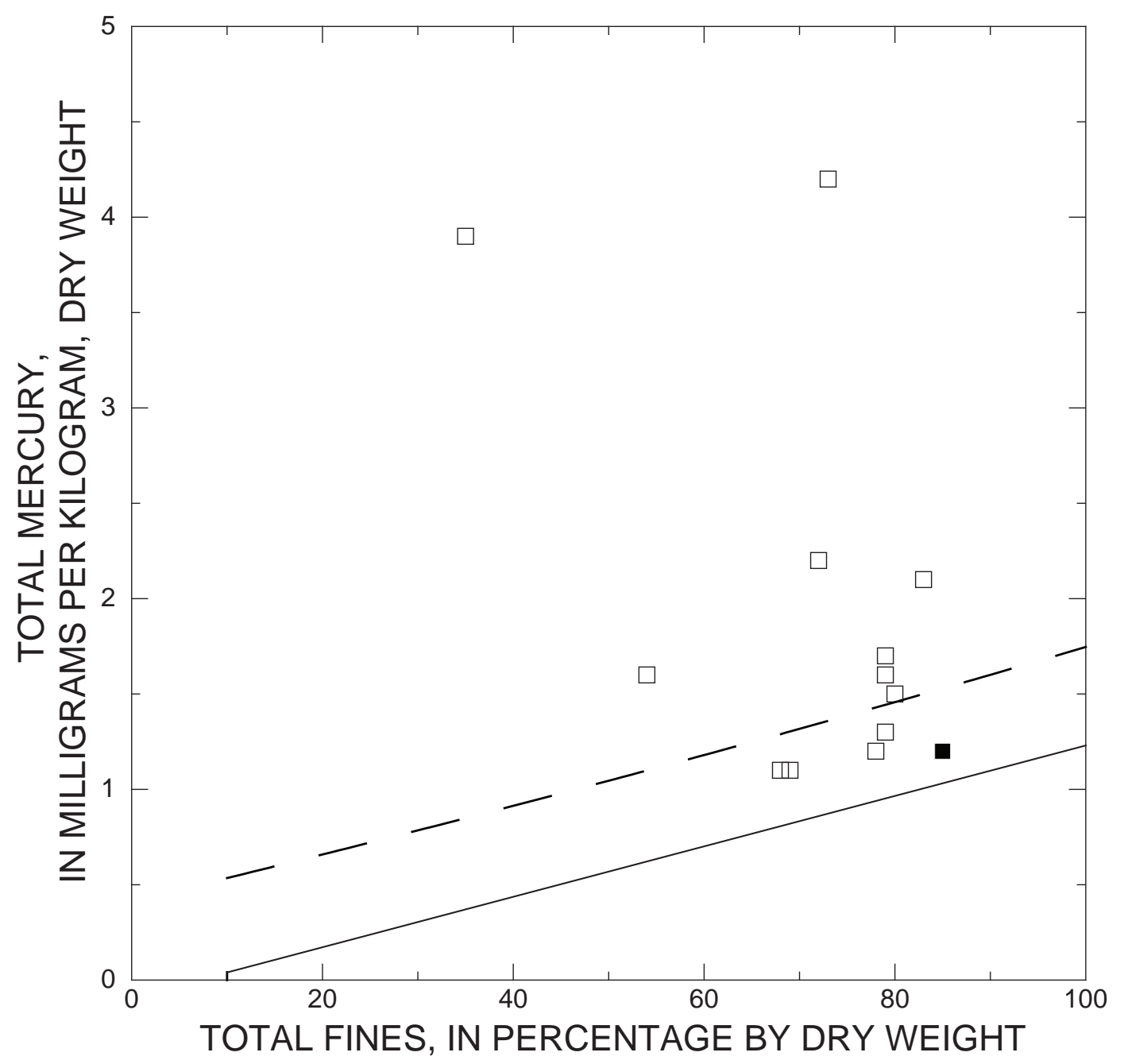

Figure 15. Total mercury concentration compared to total fines in surface sediment $(0-10 \mathrm{~cm}$ ) from Operable Unit B Marine of the Bremerton naval complex, Washington, from the 1994 Remedial Investigation (table B5). Open symbols are qualified. The solid line represents the statistically significant 1994-95 regression between the variables for sediment outside of the Bremerton naval complex, Washington, (fig. 12 and table 1) and the dashed line represents the upper 95 percent prediction interval. 


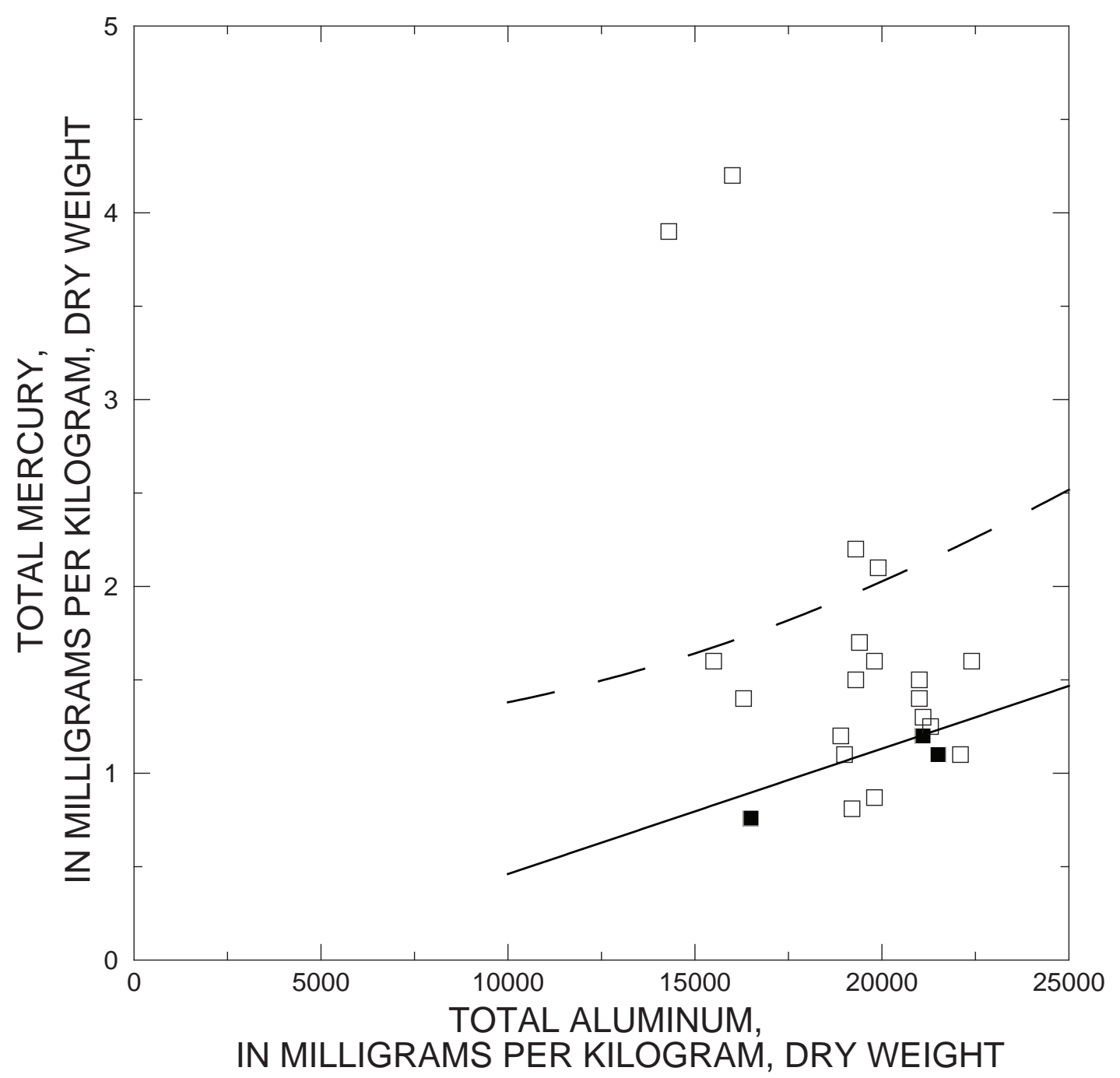

Figure 16. Total mercury concentration compared to total aluminum in surface sediment $(0-10 \mathrm{~cm})$ from Operable Unit B Marine from the 1994 Remedial Investigation (table B5). Open symbols are qualified. The solid line represents the statistically significant 1994-95 regression between the variables for sediment outside of the Bremerton naval complex, Washington, (fig. 13 and table 1) and the dashed line represents the upper 95 percent prediction interval. 
A core with high vertical resolution was collected in October of 1995 in greater Sinclair Inlet outside of the BNC boundary (location 490) and five sections in the top $30 \mathrm{~cm}$ were analyzed in triplicate (fig. 17). Mean THg concentrations increased with depth from a mean of $0.83 \mathrm{mg} / \mathrm{kg}$ in the top $2.5 \mathrm{~cm}$ to an mean of $1.5 \mathrm{mg} / \mathrm{kg}$ in the $20-30 \mathrm{~cm}$ section. Below $30 \mathrm{~cm}$ depth, THg concentrations were less than or equal to $0.23 \mathrm{mg} / \mathrm{kg}$. The $30-\mathrm{cm}$ discontinuity also was observed with total fines and may be related to previous disturbances in the area, such as dredging.
In October 1995, three cores (locations 826-828 in fig. 2) were taken off eastern PSNS \& IMF (location 826), off central PSNS \& IMF (location 827) and off NBK Bremerton (location 828). Surface $(0-61 \mathrm{~cm})$ and deeper subsurface $(61-122 \mathrm{~cm})$ core sections were collected at each site. THg concentrations were greatest in the surface core section and were $0.33,6.5$, and $1.2 \mathrm{mg} / \mathrm{kg}$, respectively (table B5). The profiles for these cores are shown in figures D4-D6.
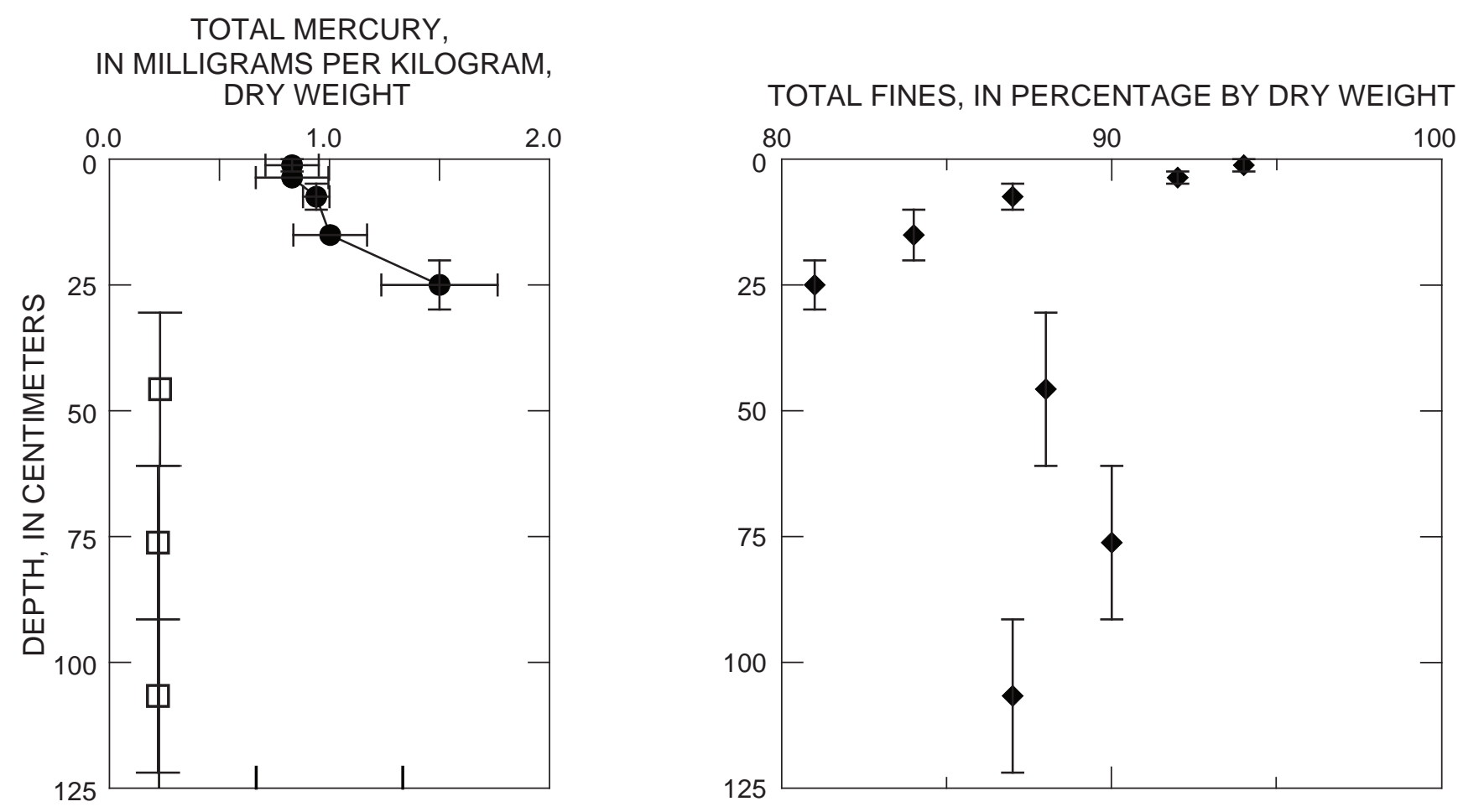

Figure 17. Vertical distribution of total mercury concentrations and total fines (table B4) at station SINC-MIDCH (location 490) off the Bremerton naval complex, Washington. The vertical error bars indicate the vertical interval of each core section and the horizontal error bars indicate one standard deviation of triplicate analyses. The open circles represent values below the method detection limit. 


\section{Pier Dredging off Naval Base Kitsap Bremerton (1994-95) and Monitoring (1994-97)}

Between December 1994 and March 1995, sediment on both sides of a pier off NBK Bremerton (shown in the inset of fig. 2) was dredged for navigational purposes and dredge spoils were disposed outside of Sinclair Inlet. Sampling of surface sediment (0-2 cm) occurred in December 1994 (east side of pier) and in March 1995 (west side of pier) immediately after dredging of the respective sides. To detect recontamination of the dredged area, post-dredging sampling occurred on both sides of the pier (11 sites) in May of 1996 and in September 1997 (table B6; U.S. Navy, 1998). In general, data of THg compared to TOC and total fines fall along the regressions lines for the 1994-95 sites outside of the BNC (figs. 18 and 19). However, higher THg concentrations were measured at the station nearest the shoreline (location D101) in 1995 and 1996. When sampled in 1997, the THg concentration at station D101 was below than the general scatter around the 1994-95 regression lines.

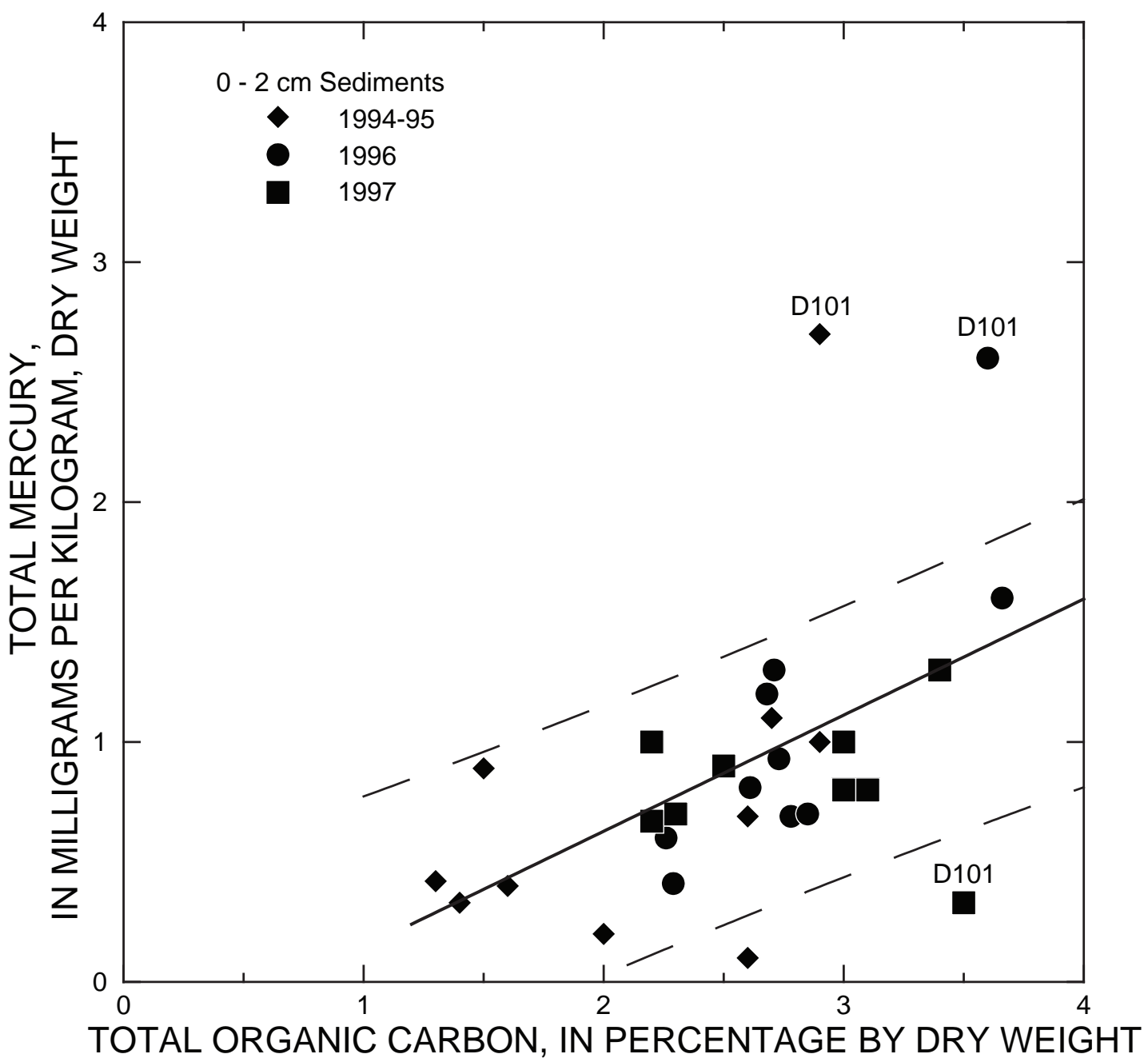

Figure 18. Total mercury concentration compared to total organic carbon off pier in Naval Base Kitsap Bremerton (site shown in inset of figure 2) in 1994-1995, 1996, and 1997 (table B6). The solid line represents the statistically significant 1994-95 regression between the variables for sediment outside of the Bremerton naval complex, Washington (fig. 11 and table 1) and the dashed lines represent the upper 95 percent prediction intervals. Location D101 for 1995, 1996, and 1997 data is labeled. 


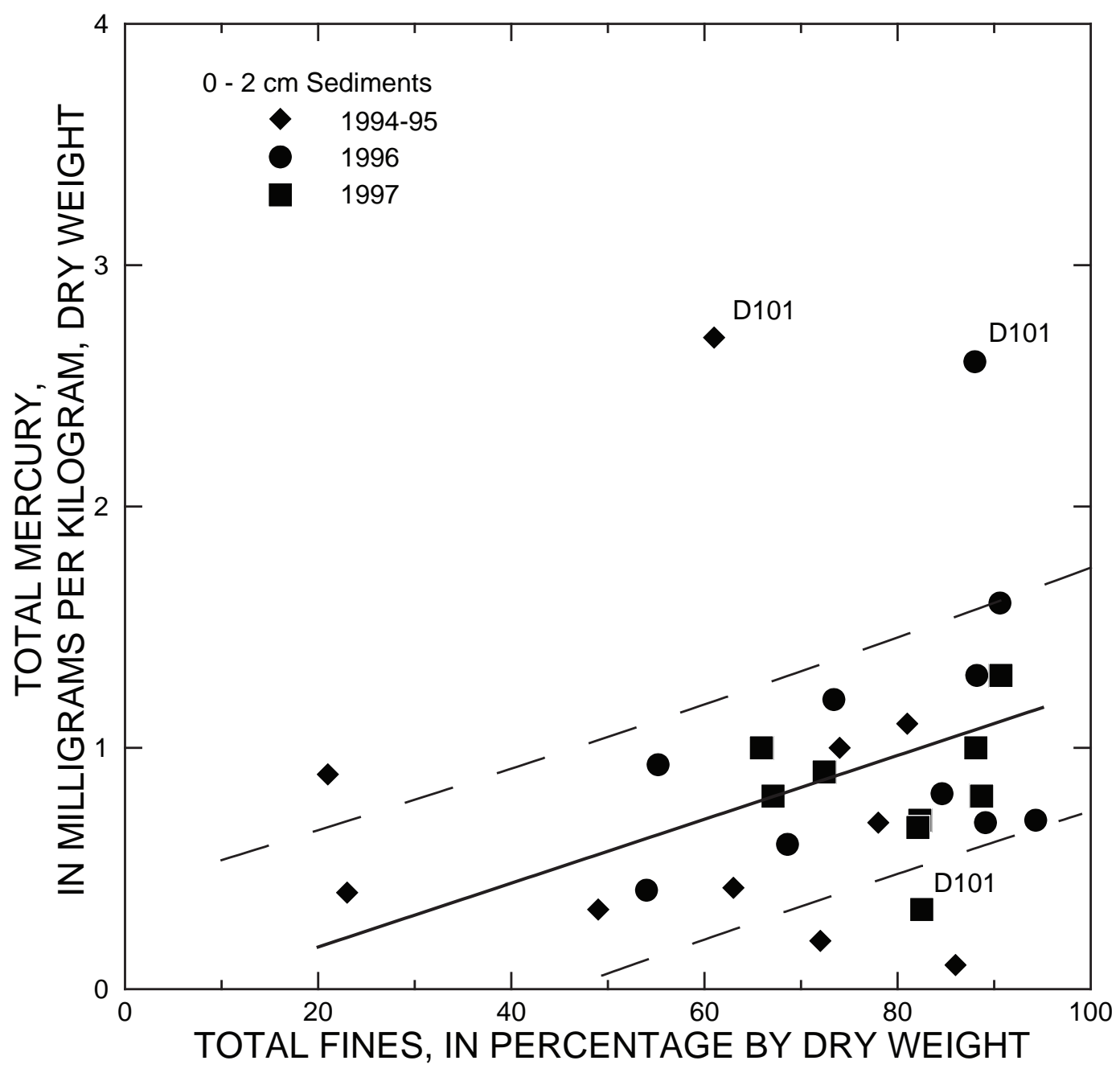

Figure 19. Total mercury concentration compared to total fines at pier in Naval Base Kitsap Bremerton (site shown in inset of figure 2) in inset of figure 2 in 1994-1995, 1996, and 1997 (table B6). The solid line represents the statistically significant 1994-95 regression between the variables for sediment outside of the Bremerton naval complex, Washington (fig. 12 and table 1) and the dashed lines represent the 95 percent prediction intervals. Location D101 for 1995, 1996, and 1997 data is labeled. 


\section{Studies in Preparation for Navigation and Comprehensive Environmental Response, Compensation, and Liability Act Dredging}

Because of the need for navigational dredging of marine sediment within OU B Marine to improve the shipyard's homeport capabilities for three NIMITZ-class aircraft carriers, plans were developed in 1999 for the construction of a confined aquatic disposal (CAD) site that would confine the dredge spoils. These plans were expanded to confine contaminated sediments from cleanup activities of OU B Marine. The level of PCB in tissues of bottom-dwelling fish consumed by subsistence fishers was the primary basis for marine sediment cleanup. A secondary consideration was elevated levels of THg measured in rockfish collected in Sinclair Inlet (West and O’Neill, 1998) and THg concentrations in marine sediment above the state cleanup screening level (U.S. Navy, 2002).

In 1999, two studies characterized the sediment to be dredged from the berths adjacent to western and central PSNS \& IMF and NBK Bremerton from the turning basins off the BNC (U.S. Navy, 1999, 2000). Sediment to be dredged was divided into 77 surface Dredged Material Management Units (DMMUs) and eight subsurface DMMUs. A composite sediment sample from a surface 122-cm core from each surface DMMU or a core from each subsurface DMMU was tested to determine suitability for open-water disposal in accordance with the sediment quality assessment procedures of the Dredged Material Management Program, formerly known as the Puget Sound Dredged Disposal Analysis (PSDDA). The chemical results were compared to the Screening Level, Bioaccumulation Trigger, and Maximum Level criteria set by the PSDDA program.

Composites from such a large vertical section provide little information on the vertical distribution of THg and the potential mercury for exposure to living resources. However, DMMUs in which THg concentrations exceed the PSDDA Screening Level $(0.41 \mathrm{mg} / \mathrm{kg})$ or PSDDA Bioaccumulation Trigger $(1.5 \mathrm{mg} / \mathrm{kg})$ indicate locations where mercury has been depositing over decades. Figure 2 shows the 25 of 77 DMMUs (dark blue regions in the CERCLA and Navigations areas) that were deemed "unsuitable" for open marine disposal because THg concentrations were above $0.41 \mathrm{mg} / \mathrm{kg}$ (U.S. Navy, 1999). Three DMMUs within the berthing areas off NBK Bremerton were above the bioaccumulation trigger of $1.5 \mathrm{mg} / \mathrm{kg}$. Dredged Material Management Units in which THg concentrations were greater than the screening level included: (1) berthing area in NBK Bremerton and (2) turning basin offshore of NBK Bremerton. In addition, a subsurface core from the berthing area off NBK Bremerton also exceeded the screening level. Sediment from nine DMMUs that did not exceed the screening level was retested later in 1999 (U.S. Navy, 2000). Of these nine DMMUs, sediment from two DMMU taken from the turning basin offshore of NBK Bremerton slightly exceeded the screening level in the retest.
In addition, one of three new DMMUs on the southern side of the turning basin off western PSNS \& IMF also slightly exceeded the screening level.

In June 2000 before the CAD was filled with dredge material (table B7), seven surface $(0-10 \mathrm{~cm})$ samples (DM-SE-1 to -11 in fig. 20) that formed a ring around the CAD were sampled (Grady May, U.S. Navy, written commun., 2007) and represent ambient conditions in the area. THg concentrations in the ring around the CAD ranged between 0.2 and $1.32 \mathrm{mg} / \mathrm{kg}$. During the time that dredge spoils were being placed in the CAD in January of 2001, two samples (DM-SE-29 and DM-SE-30/DM-SE-31 in table B7) in the dredged area at the entrance of the smallest dry dock in central PSNS \& IMF (dark blue area in fig. 2) had estimated THg concentrations of 1.39 and $7.54 \mathrm{mg} / \mathrm{kg}$, respectively, which led to the CERCLA dredging of the entrance to smallest dry dock in central PSNS \& IMF.

A considerable mass of mercury was removed from the surface layer of Sinclair Inlet during the 2000 navigational and CERCLA dredging. Before examining the post-remediation monitoring data, it is valuable to assess sediment conditions in OU B Marine after remediation by describing the sediment that was analyzed between 1990 (the Site Investigation) and 2000 (before filling and capping the CAD pit), but that had not been dredged. Assuming that THg concentrations of non-remediated sediment did not change dramatically between 1990 and 2000, the characteristics of these samples should reflect sediment conditions of non-dredged areas for the different units of BNC after the closure of the CAD pit.

The remediation of OU A (fig. 2) included placing a thick-layer cap over sediment containing THg concentrations of $5.2 \mathrm{mg} / \mathrm{kg}$ (table B2) at the surface of location 252 and Hg-TCLP concentrations of $12.3 \mathrm{mg} / \mathrm{kg}$ (table B3) in the subsurface section of MS213 (location 213). A thin-layer cap was used to cover surface sediment with THg concentrations ranging between 0.34 to $1.9 \mathrm{mg} / \mathrm{kg}$ (locations 101 and 253 in table B2, respectively). The thin-layer cap further isolated subsurface (> $4 \mathrm{~cm}$ deep) sediment containing Hg-TCLP concentrations as high as $7.1 \mathrm{mg} / \mathrm{kg}$ (station MS219, 5-25 $\mathrm{cm}$ in table B3). Surface sediment that was not remediated (locations 247, 255, 217, 218, 222, 223, 464, and 465) contained mercury concentrations between 0.95 (location 247 in table B5) and $1.4 \mathrm{mg} / \mathrm{kg}$ (location 222 in table B3). When combined with the ambient June 2000 samples (table B7), non-remediated ambient sediment (sediment not under the thin- or thick-layer caps) showed very little correlation with TOC ( $p=0.46)$ (fig. 21) and only moderately correlated with total fines $\left(p=0.027, R^{2}=0.55\right)$ fig. 22$)$. Polygons around the majority of the surface sediment samples collected between 1993 and 2000 in the plot of mercury compared to TOC (fig. 21) and $\mathrm{Hg}$ compared to total fines (fig. 22) represent general conditions in the area off OU A before remedial dredging and closure of the CAD site. Subsurface samples as high as $4.9 \mathrm{mg} / \mathrm{kg}$ (fig. 9) at station MS222 (location 222 in table B3) also were not remediated. 


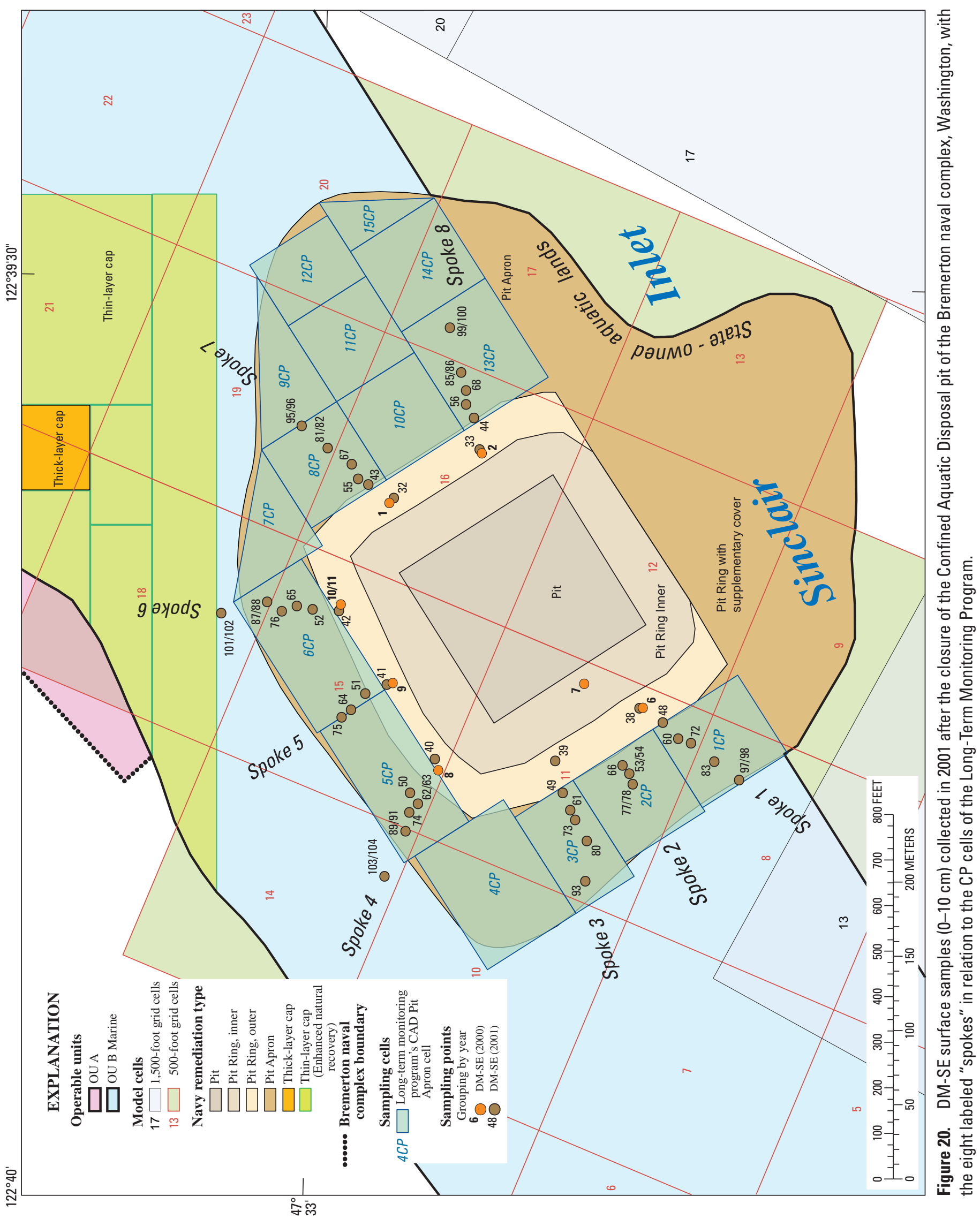




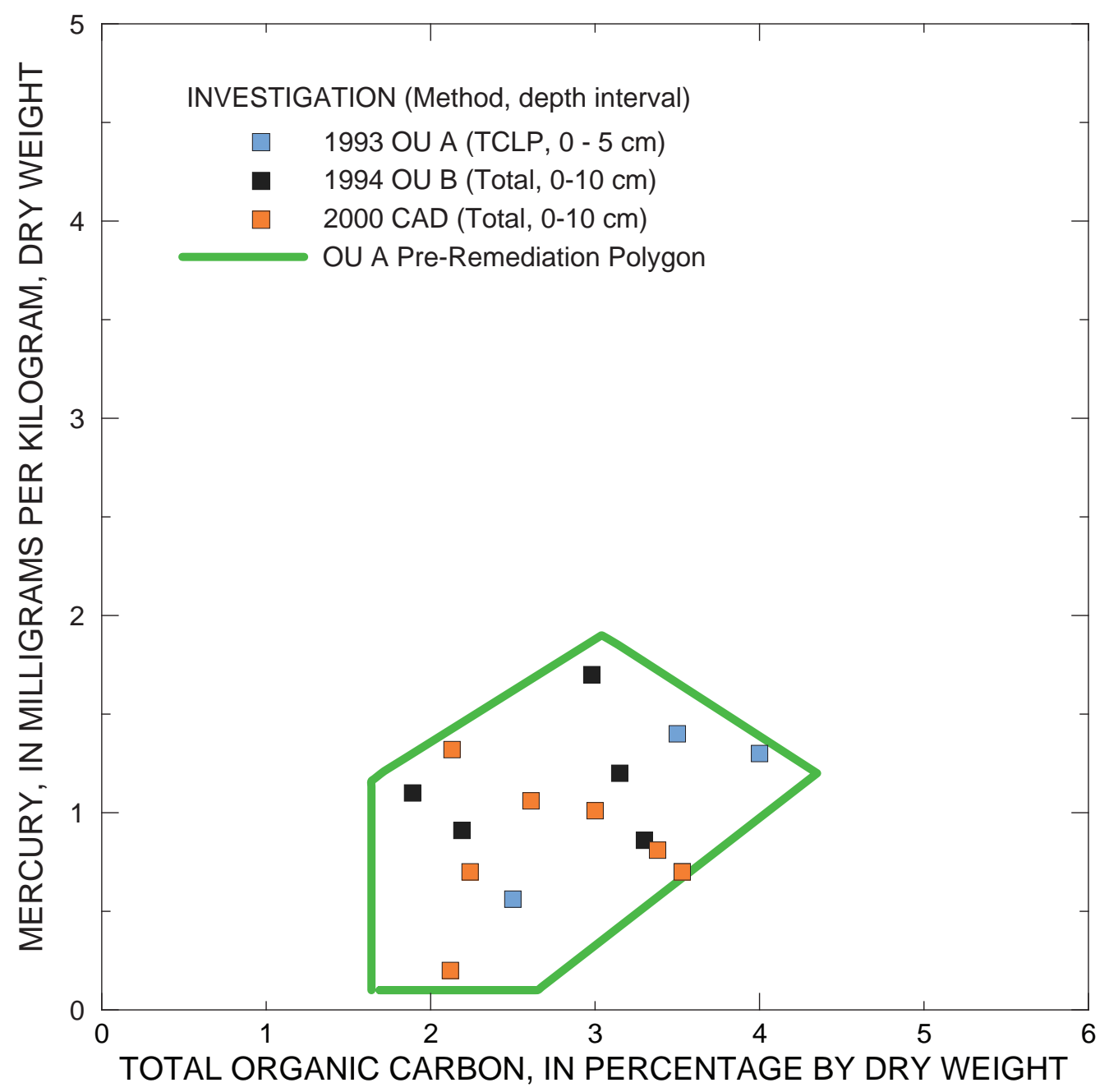

Figure 21. Total mercury concentration compared to total organic carbon for surface sediment samples in Operable Unit A (1993, table B3) and offshore of Operable Unit A, Bremerton naval complex, Washington (1994; table B5; 2000; table B7) that had not been capped as part of a remediation remedy or were not within the boundary of the Confined Aquatic Disposal site. Note that mercury assays included toxicity characteristic leaching procedure extraction $(1993)$ and total digestion $(1994,2000)$ and samples compositing over different vertical intervals: $0-5 \mathrm{~cm}(1993)$ and $0-10 \mathrm{~cm}(1994,2000)$. The pre-remediation polygon encompasses all surface sediment samples collected between 1993 and 2000 from locations that had not been dredged. 


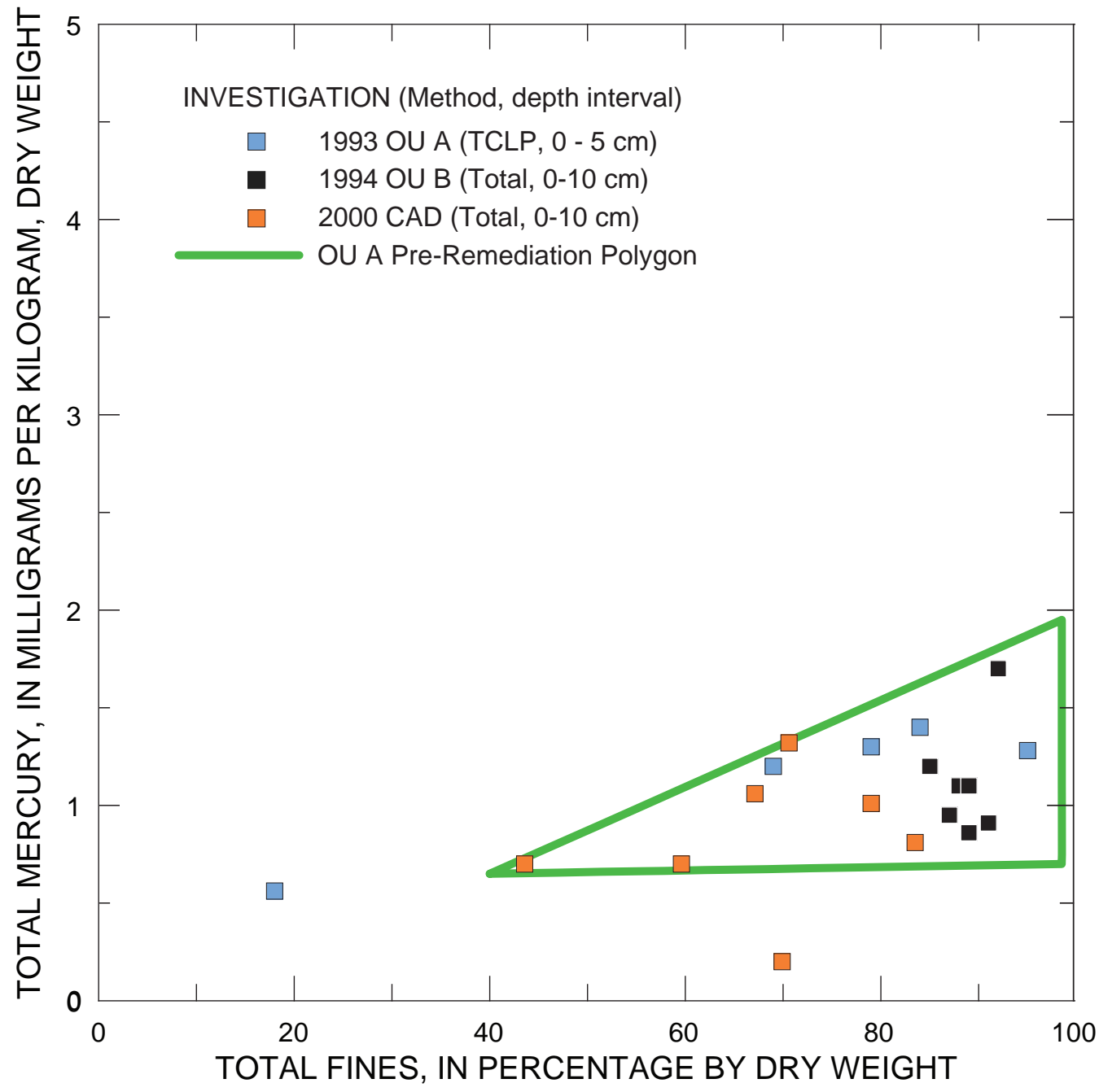

Figure 22. Total mercury concentration compared to total fines for surface sediment samples in Operable Unit A (1993; table B3) and offshore of Operable Unit A, Bremerton naval complex, Washington (1994; table B5; 2000; table B7) that had not been capped as part of a remediation remedy or were not within the boundary of the Confined Aquatic Disposal site. Note that mercury assays included toxicity characteristic leaching procedure extraction $(1993)$ and total digestion $(1994,2000)$ and samples compositing over different vertical intervals: $0-5 \mathrm{~cm}(1993)$ and $0-10 \mathrm{~cm}(1994,2000)$. The pre-remediation polygon encompasses most surface sediment samples collected between 1993 and 2000 from locations that had not been dredged. 
After navigational and CERCLA dredging in OU B (fig. 2) was completed in 2001, THg concentrations in surface sediment at locations that had not been dredged were not correlated with both TOC and total fines ( $p=0.63$ and 0.84 , respectively, in figs. 23 and 24). Only two sites that were sampled for surface sediment between 1990 and 1995 and had not been dredged contained THg concentrations greater than $2.5 \mathrm{mg} / \mathrm{kg}$ in surface sediment: (1) location 458 (table B5) to the east of the area dredged at the entrance to the smallest dry dock in central PSNS \& IMF, and (2) location 110 (table B2) off NBK Bremerton (note that this location is not plotted in figures 22 and 23 because no data on TOC or total fines are available). In addition, the top 61-cm core section at location 827 (table B5) between piers in central PSNS \& IMF contained a THg concentration of $6.5 \mathrm{mg} / \mathrm{kg}$.

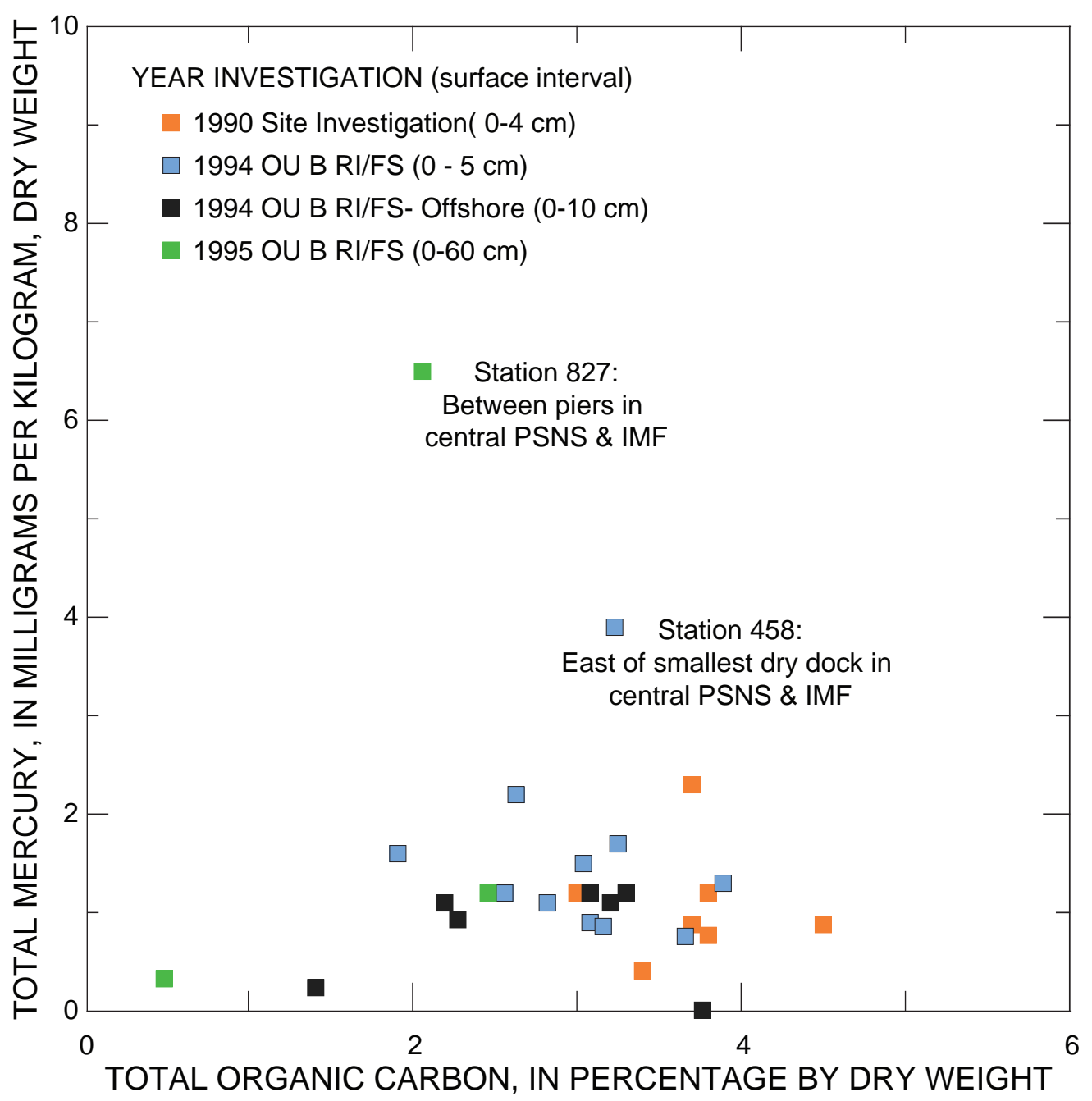

Figure 23. Total mercury concentration compared to total organic carbon for surface sediment samples collected from locations off Operable Unit B, Bremerton naval complex, Washington, that had not been dredged, 1990-94 (tables B2 and B5) and in Operable Unit B Marine, 1995 (table B5). Note that total mercury data is composited over different vertical intervals: 0-4 cm (1990), 0-5 cm and 0-10 cm (1994), and 0-60 cm (1995). 


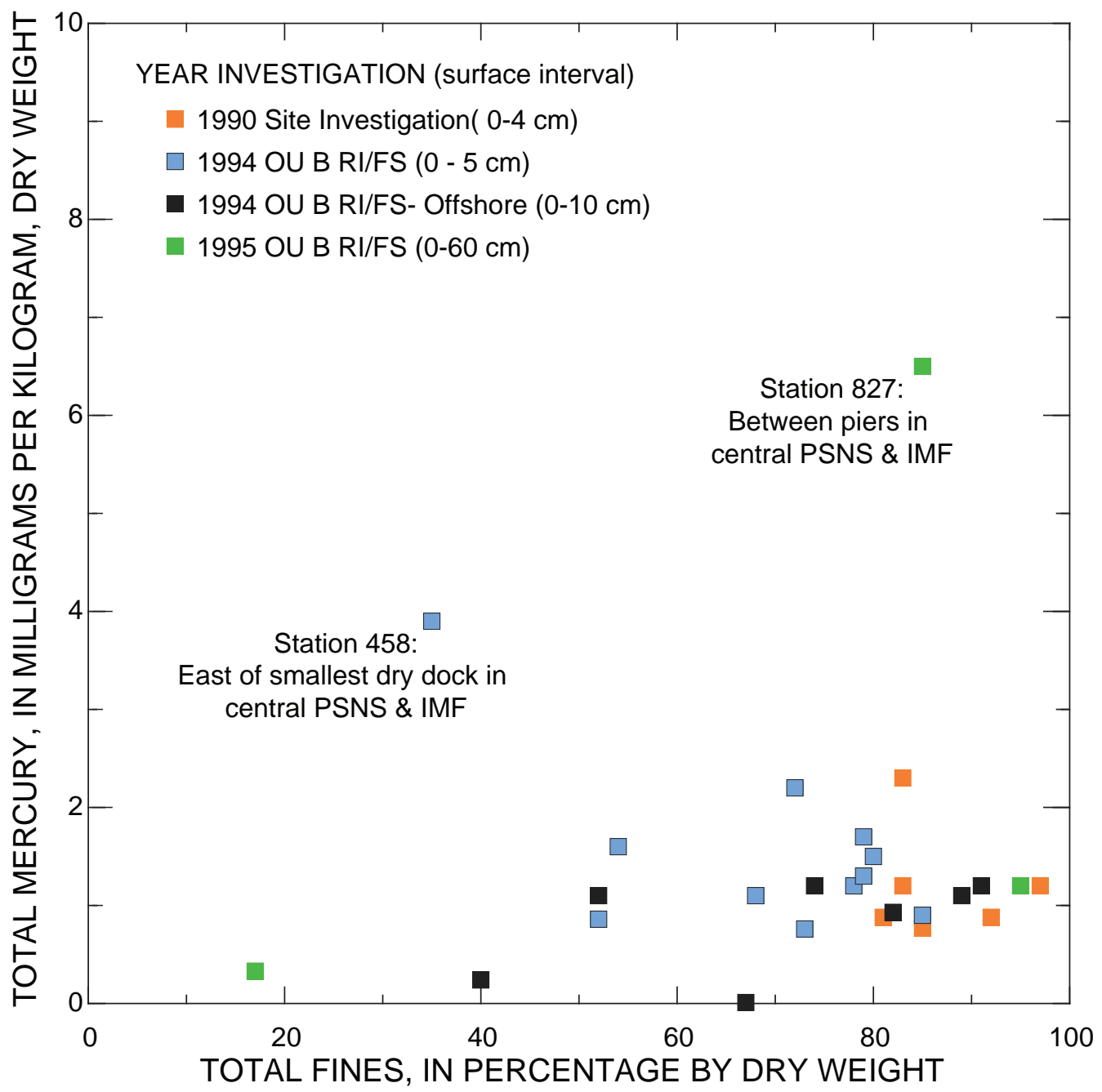

Figure 24. Total mercury concentration compared to total fines for surface sediment samples from locations off Operable Unit B, Bremerton naval complex, Washington, that had not been dredged, 1990-94 (table B2 and B5), and in Operable Unit B Marine, 1995 (table B5). Note that total mercury data composited is over different vertical intervals: 0-4 cm (1990), 0-5 cm and 0-10 cm (1994), and 0-60 cm (1995). 


\section{Closure of Confined Aquatic Disposal Pit}

After the Confined Aquatic Disposal (CAD) pit was covered, sediment samples around the perimeter of the pit were collected and PCB concentrations were reported in a closure report (U.S. Navy, 2004). This section presents unpublished THg concentrations in sediment near the CAD pit associated with its closure (Grady May, U.S. Navy, written commun., 2007). These THg concentrations in sediment collected after the closure of the CAD pit (August to November, 2001) were examined to assess changes in the general mercury conditions relative to conditions prior to the construction of the CAD pit (figs. 21 and 22). According to the U.S. Navy (2006a), "The confined aquatic disposal pit, or CAD pit, was constructed in the shape of a 615-by-600 foot rectangle, with a depth of 30 feet and side slopes of 3 horizontal to 1 vertical." The majority of contaminated sediment was placed in the CAD pit during October 2000 through January 2001, and disposal of the last dredged material to the CAD pit occurred on February 15, 2001.

"After being filled with contaminated sediment, the CAD pit was left undisturbed to allow for consolidation. After four months, when tests indicated that the sediment had consolidated enough to allow capping, a one-foot layer of clean sand was distributed across the CAD pit to form the initial cap layer (primary sand cap). After more than two months of additional consolidation, the cap over the CAD pit was completed. The final cap layer was made up of sediment from the turning basins in central Sinclair Inlet that had been demonstrated to meet requirements for open water disposal, together with clean sediment stockpiled from the CAD pit excavation. Based on measured volumes of sediment, the final sediment cap layer had an average thickness of more than six feet." (U.S. Navy, 2006a).

Sediment was resampled after the CAD pit was capped (table B7, Grady May, U.S. Navy, written commun., 2007) with a sampling design that included eight lines radiating out from the boundary of the CAD pit in a manner that resembled eight spokes (fig. 20). Three to eight samples were collected along the line of each spoke. Some of these spokes formed the basis for the cells of the apron of the CAD pit as part of the LTMP. Fifteen cells (labeled 1CP to 15CP in fig. 20) were created around the CAD pit and sampled in 2003 and 2005. Significant increases in mercury concentrations relative to pre-2000 conditions (polygons in figs. 21 and 22) were observed near the CAD pit boundary for spokes 1,3 , and 4 (locations 38, 39 and 40 in figs. 25 and 26) and spokes 5 and 7 (locations 32 and 41 in figs. 27 and 28). "The Navy elected, while the remedial contractor was still on site, to use stockpiled clean sediment to form a supplementary cover with an average thickness of 2 feet in an approximately 100-foot wide strip surrounding the three sides of the pit that are owned by the Navy." (U.S. Navy, 2006a). The supplementary material covered the five locations with high sediment THg concentrations in coarse material near the CAD pit boundary referred to above. In contrast to the locations near the CAD pit that contained coarser material, THg concentrations greater than $2 \mathrm{mg} / \mathrm{kg}$ in the outer ends of spokes 4, 5, 6 (cells 5CP and $6 \mathrm{CP}$ ) and spoke 8 (cell 13CP) were associated with finer sediment (figs. 26 and 28). Because the CAD pit boundary and the enhanced natural recovery area of OU A were not sampled as part of either the Site Investigation or Remedial Investigation, it is not known if elevated THg concentrations were present in this area prior to opening and closure of the CAD pit. This finer-grained material with higher THg concentrations could have been present before the CAD pit was opened or could have been deposited as fine-grained, slowly settling dredge material drifted from the CAD pit prior to closure by tidal currents.

According to the U.S. Navy (2006a),

"The area abutting the fourth side of the CAD Pit, being State-owned aquatic land (SOAL), was not addressed during the original remedial action because there was insufficient time while equipment was on site to obtain the required authorization. Instead, after discussion with the State, the Navy undertook a supplementary program to characterize the SOAL adjacent to the CAD pit as a basis for evaluating the need for further remediation in this area. This sediment characterization was performed in September 2003. Based on the findings of this field work, the Navy, EPA, and Ecology prepared an Explanation of Significant Differences (ESD) in early 2004, documenting a change in the OU B Marine boundary to incorporate the SOAL area and identifying action levels for a response action for the area."

The THg concentration data (Grady May, U.S. Navy, written commun., 2007) from the SOAL area (table B8) are plotted in comparison to TOC (fig. 29) against the background of the polygon representing samples collected from OU A between 1993 and 2000 from locations not remediated (fig. 21). Only 2 of 31 samples had higher total mercury concentrations than the polygon representing pre-CAD conditions. According to the U.S. Navy (2006a),

"Subsequent to publication of the ESD, in early 2004, after consultation with the State and [US]EPA, the Navy placed clean sediment from previouslycharacterized turning basin areas in central Sinclair Inlet with a thickness of 0.8 to 1.5 feet on the portion of the SOAL area that met the action level (U.S. Navy 2004).” 


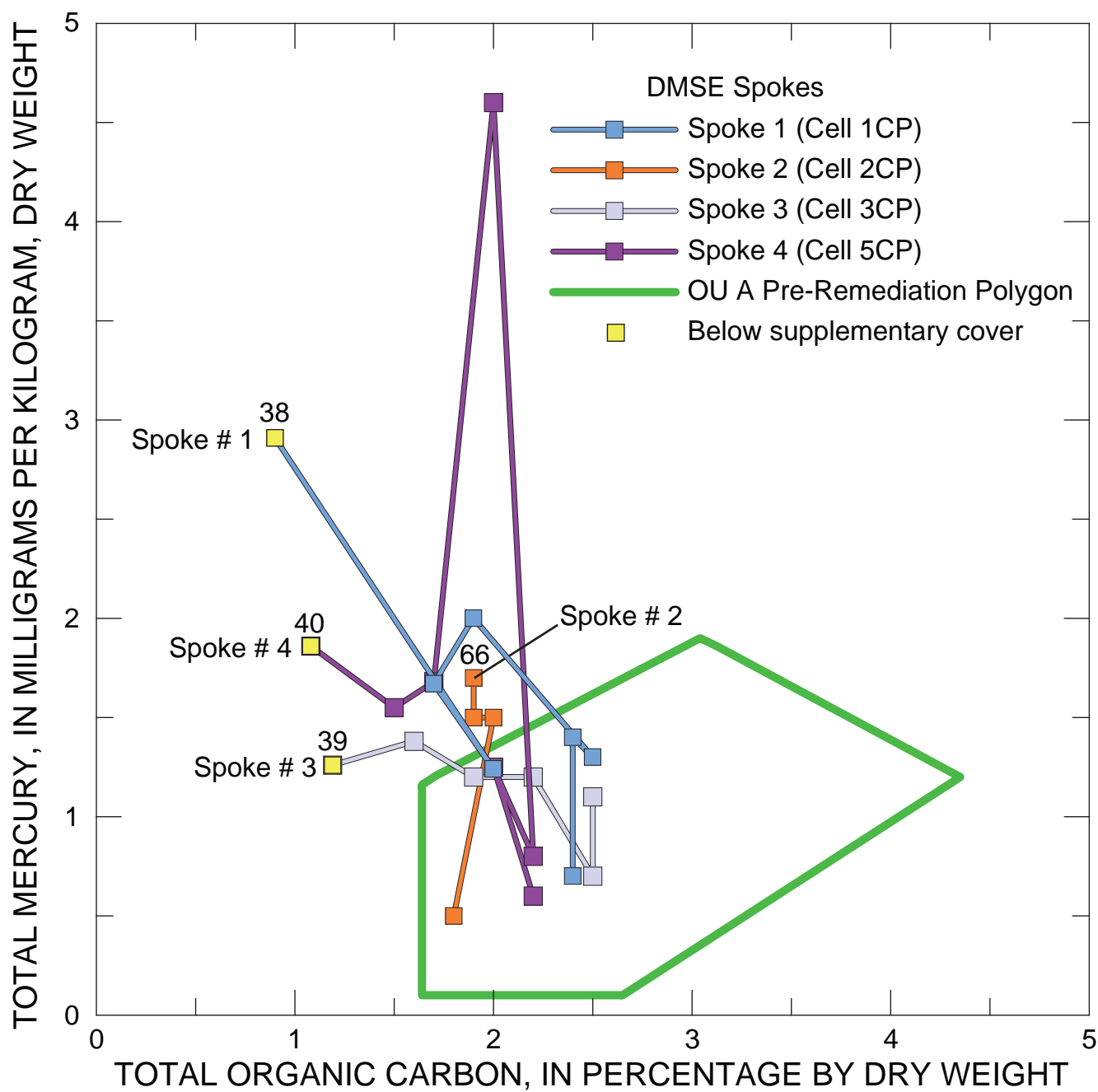

Figure 25. Total mercury concentration compared to total organic carbon in the surface sediment $(0-10 \mathrm{~cm})$ of spokes 1 to 4 collected in 2001 (table B7). Samples from each spoke are connected with lines and the spoke label is placed near the sample closest to the Confined Aquatic Disposal pit of the Bremerton naval complex, Washington (fig. 20). With the exception of spoke 2, the sample in each spoke nearest the pit was covered with the supplementary cover. The polygon encompasses all of the samples collected from Operable Unit A collected between 1993 and 2000 that were not remediated (fig. 21). 


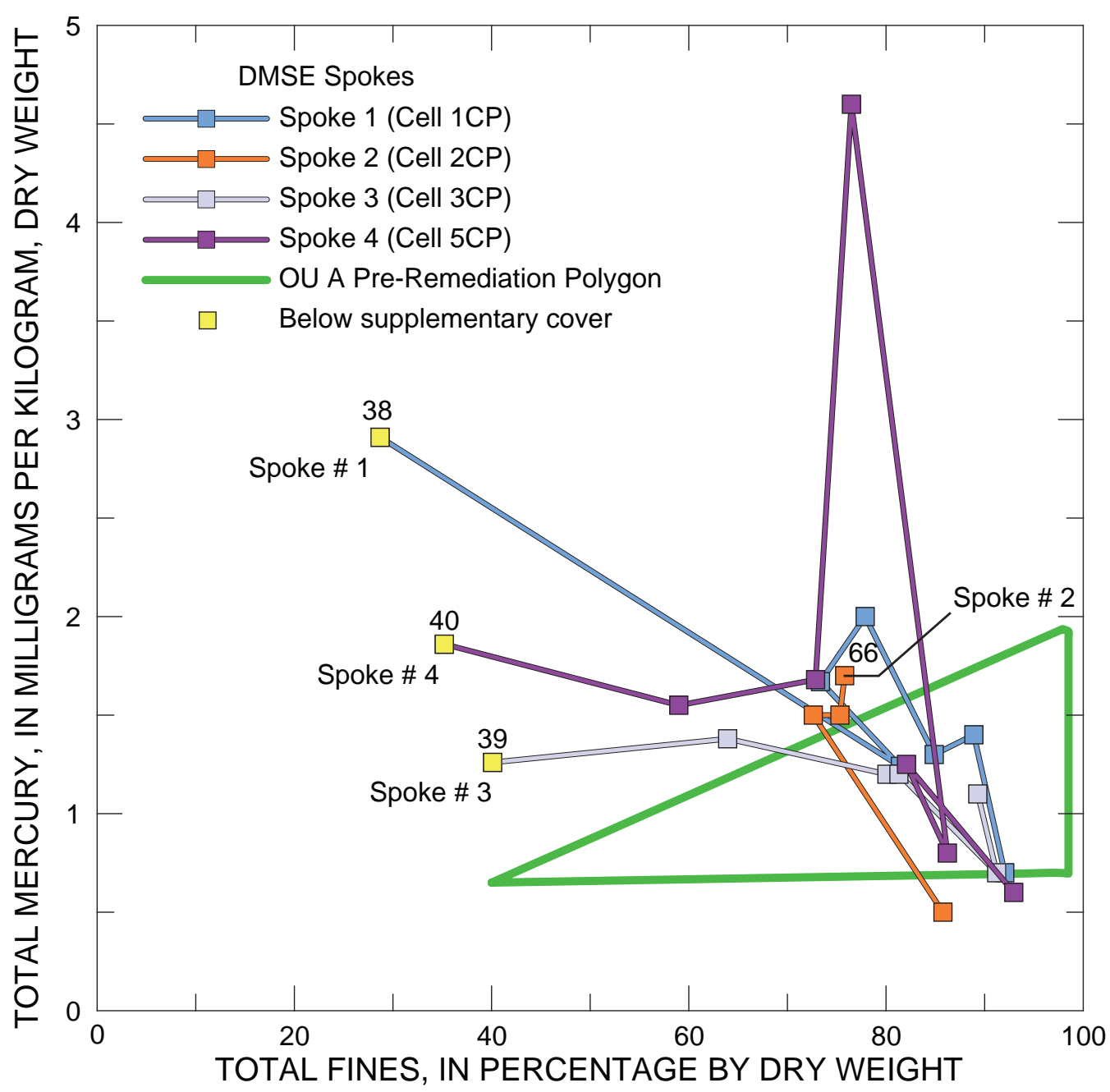

Figure 26. Total mercury concentration compared to total fines in the surface sediment $(0-10 \mathrm{~cm}$ ) of spokes 1 to 4 collected in 2001 (table B7). Samples from each spoke are connected with lines and the spoke label is placed near the sample closest to the Confined Aquatic Disposal pit of the Bremerton naval complex, Washington (fig. 20). With the exception of spoke 2, the sample in each spoke nearest the pit was covered with the supplementary cover. The polygon encompasses most of the samples collected from Operable Unit A collected between 1993 and 2000 that were not remediated (fig. 22). 


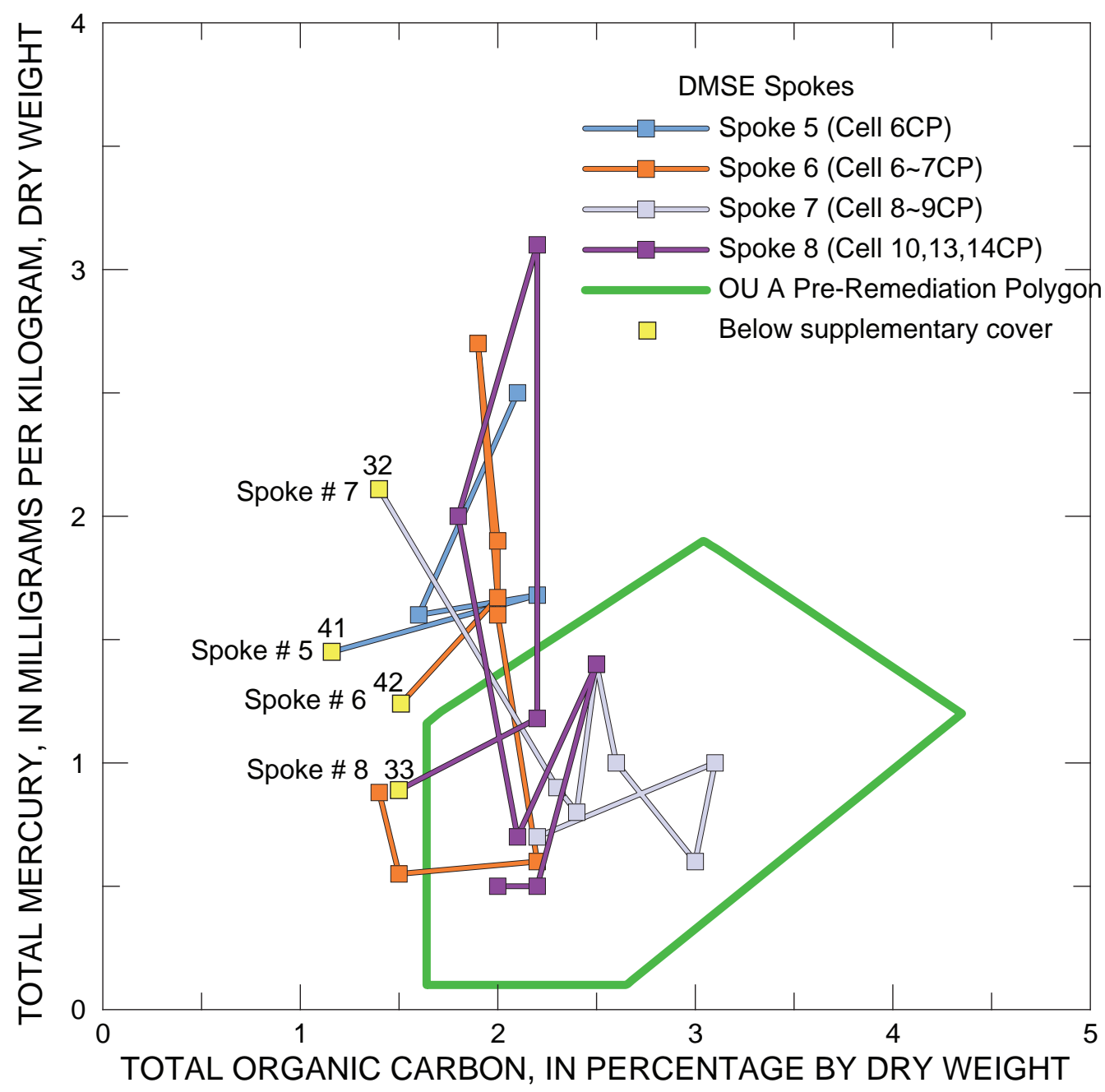

Figure 27. Total mercury concentration compared to total organic carbon in the surface sediment $(0-10 \mathrm{~cm})$ of spokes 5 to 8 collected in 2001 (table B7). Samples from each spoke are connected with lines and the spoke label is placed near the sample closest to the Confined Aquatic Disposal pit of the Bremerton naval complex, Washington (fig. 20). The sample in each spoke nearest the pit was covered with the supplementary cover. The polygon encompasses all of the samples collected from Operable Unit A collected between 1993 and 2000 that were not remediated (fig. 21). 


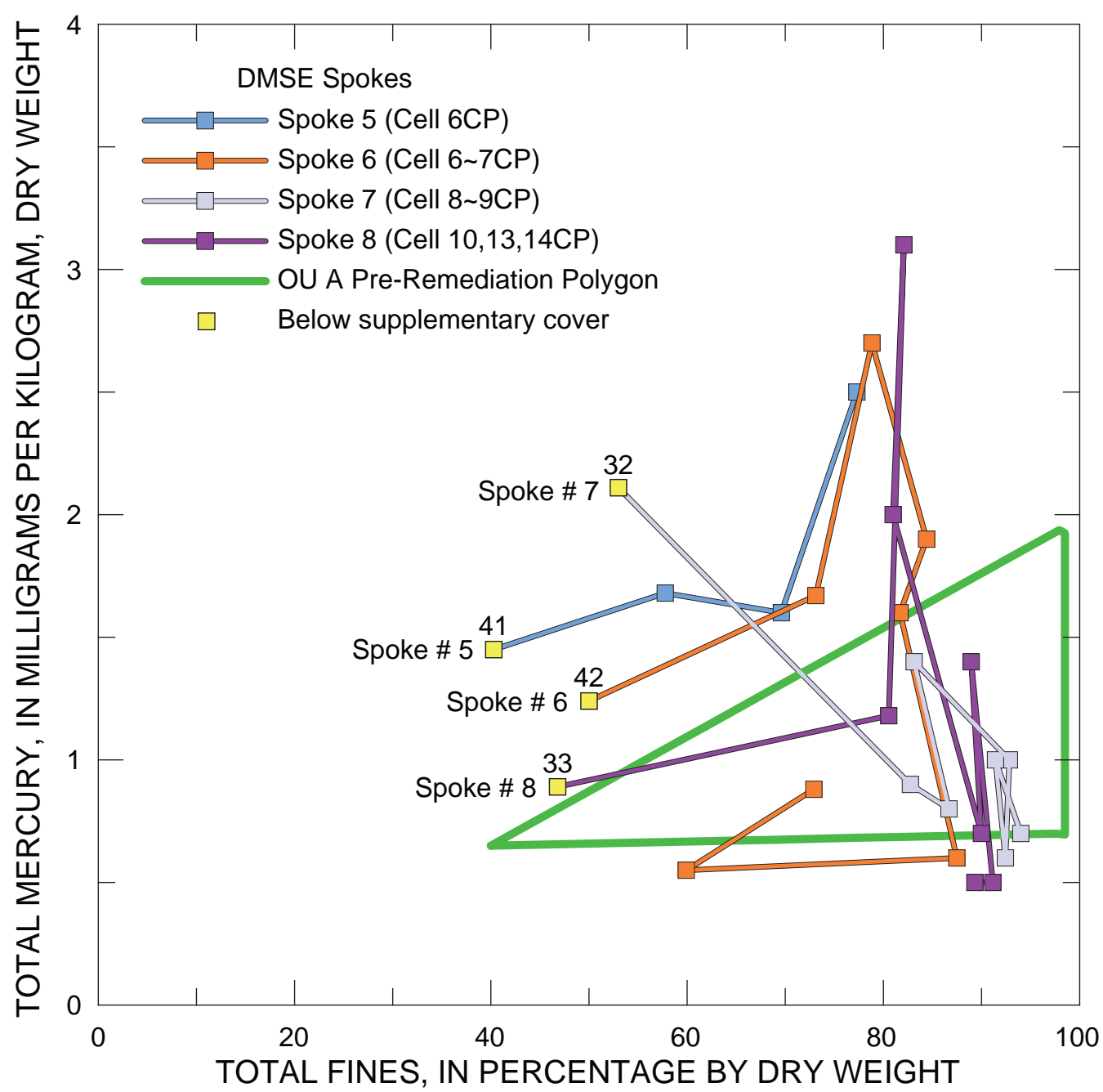

Figure 28. Total mercury concentration compared to total fines in the surface sediment $(0-10 \mathrm{~cm}$ ) of spokes 5 to 8 collected in 2001 (table B7). Samples from each spoke are connected with lines and the spoke label is placed near the sample closest to the Confined Aquatic Disposal pit of the Bremerton naval complex, Washington (fig. 20). The sample in each spoke nearest the pit was covered with the supplementary cover. The polygon encompasses most of the samples collected from Operable Unit A collected between 1993 and 2000 that were not remediated (fig. 22). 


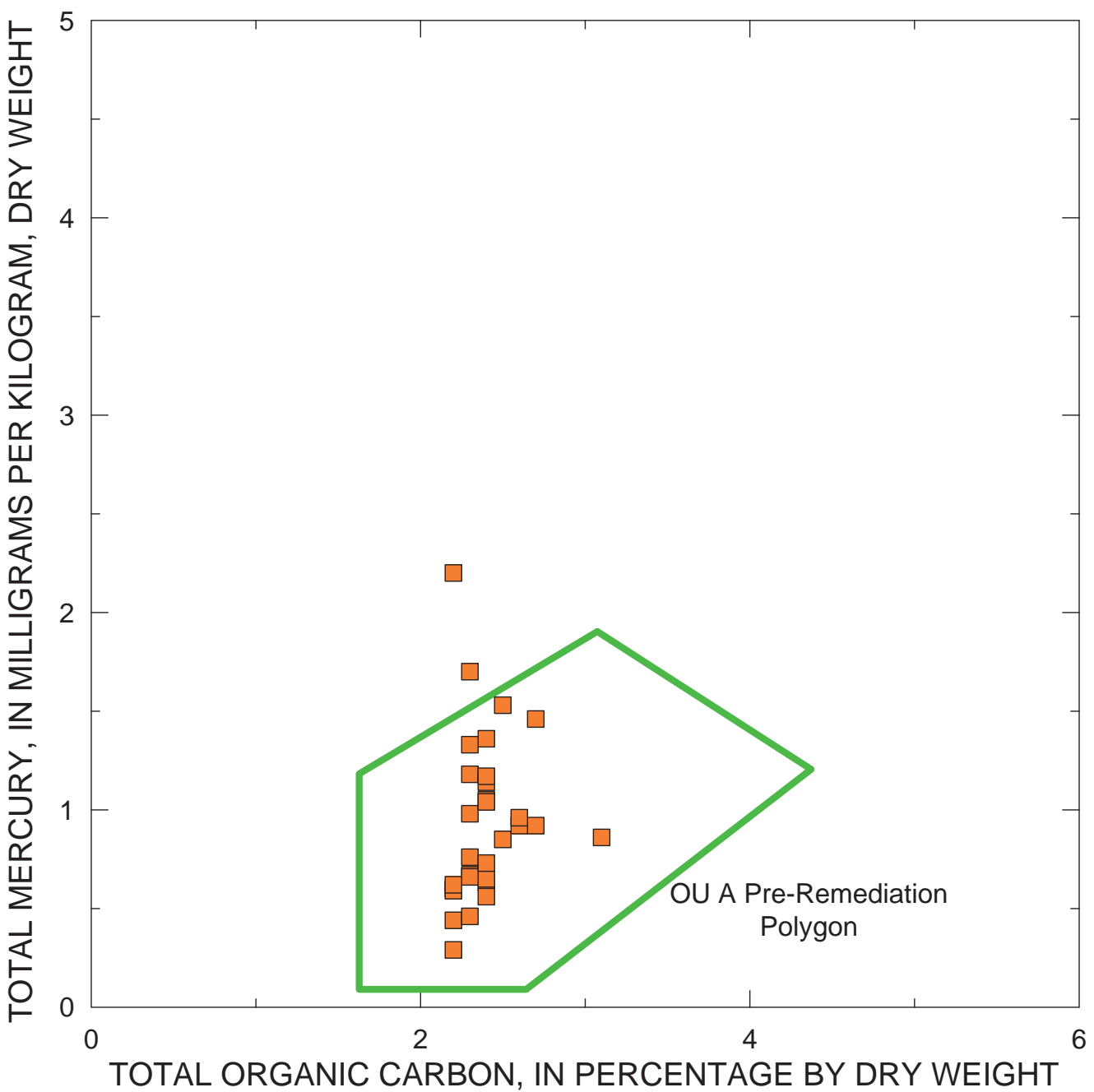

Figure 29. Total mercury concentration compared to total fines in the surface sediment $(0-10 \mathrm{~cm})$ from State-owned aquatic lands, Sinclair Inlet, Washington, collected in 2003 (table B8). The polygon encompassed all the samples from Operable Unit A collected between 1993 and 2000 that were not remediated (fig. 21).

\section{Long-Term Monitoring Program}

The LTMP was developed to provide information expected to help answer questions regarding the integrity of the remedy for OU B Marine and the quality of the marine environment in Sinclair Inlet. The LTMP sediment sampling associated with requirements of the Record of Decision began in 2003. The LTMP includes biennial random-stratified sampling of surface sediment $(0-10 \mathrm{~cm})$ in thirty-two $1,500-\mathrm{ft}$ grid cells in Sinclair Inlet that are outside of the BNC (fig. 30) and seventy-one 500-ft cells within the BNC (fig. 31). In each cell, three grab samples were composited for analyses of THg, TOC, and grain size. Monitoring focusing on the stability of the CAD pit and the dispersion of contaminants within the CAD apron also was part of the LTMP (U.S. Navy, 2006a, 2006b, and 2008b). 


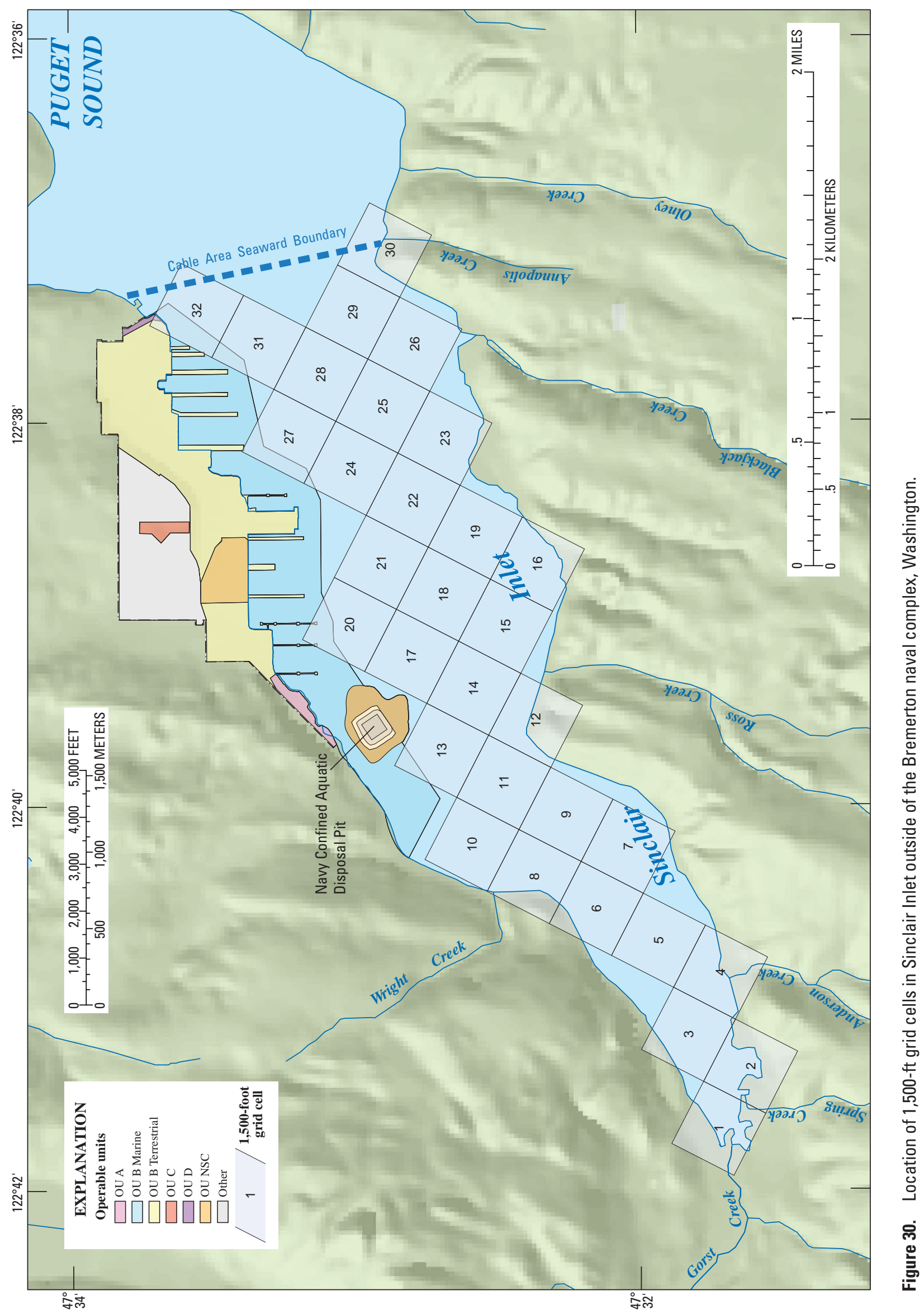




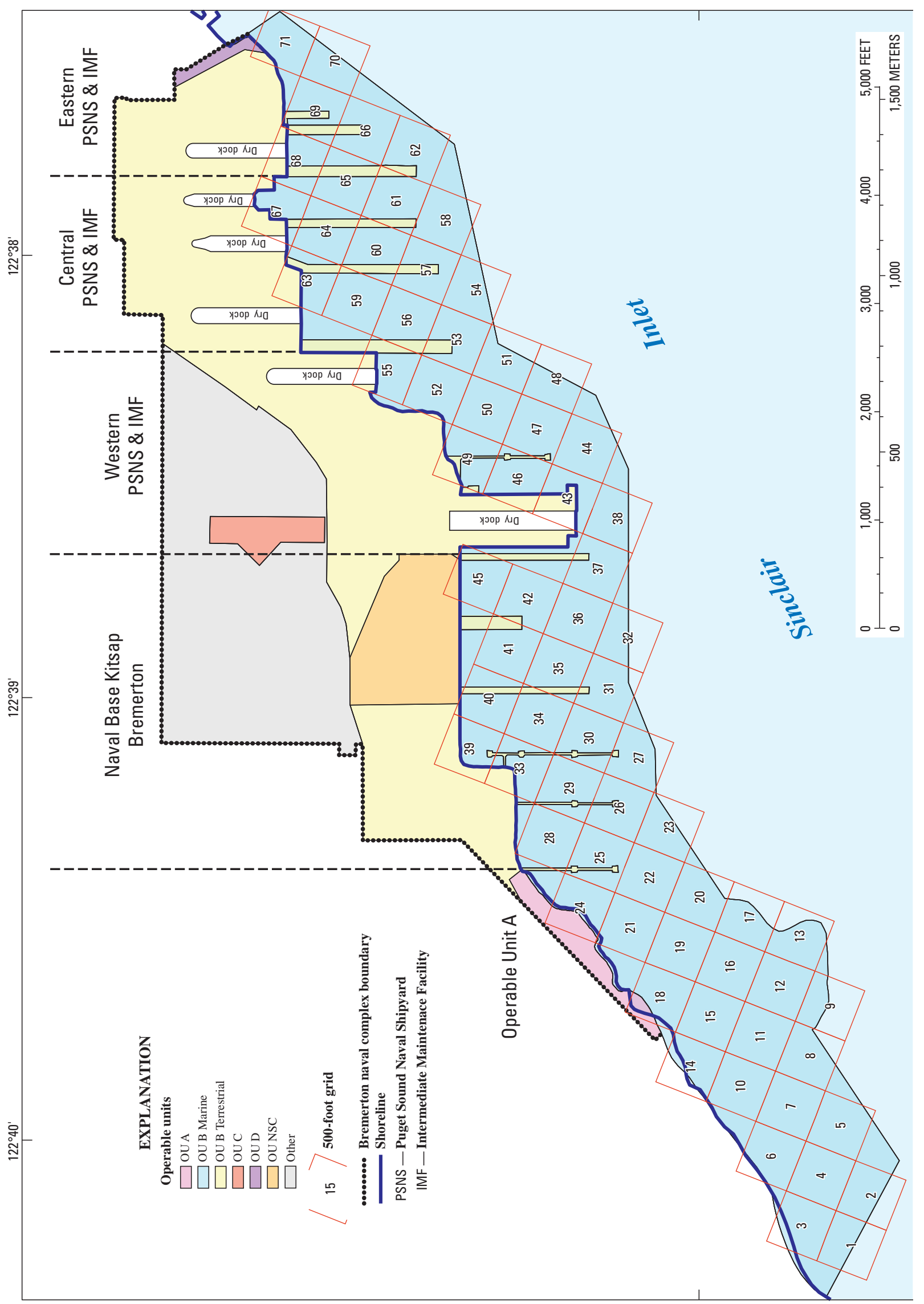

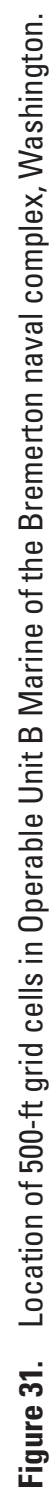




\section{Sinclair Inlet Outside of Bremerton Naval Complex}

In each of the biennial samplings (2003, 2005, 2007), the highest sediment THg concentrations outside of the BNC in Sinclair Inlet usually were measured in grid cell 21 (fig. 30), which is adjacent to the BNC, and ranged from $1.3 \mathrm{mg} / \mathrm{kg}$ in 2005 to $0.86 \mathrm{mg} / \mathrm{kg}$ in 2007 (table B9). THg sediment concentrations were related to both TOC and total fines (figs. 32-37). The relations between TOC and total fines are shown in figures $\mathrm{C} 10-\mathrm{C} 12$. The $\mathrm{THg}$ residuals (actual THg value minus the expected $\mathrm{THg}$ value from the regressions between $\mathrm{THg}$ and $\mathrm{TOC}$ and between $\mathrm{THg}$ and total fines) were computed and plotted (figs. E1- E2). Data from samples with low or high residuals were eliminated from the regression if the residual of a sample was greater than three times the interquartile range of the residuals. In 2003 grid cell 21 was identified as a high outlier and cells 6 and 8 near the northern shore line to the west of BNC were identified as low outliers in 2003. In 2005, grid cell 21 was identified as a high outlier. The regression statistics after elimination of outliers are shown in table 1 . For all three years, the slope of $\mathrm{THg}$ in comparison to TOC and total fines was significant $(p<0.001)$. The averaging process that occurred in compositing the three grab samples partially is responsible for these tight correlations. The strong relation among $\mathrm{THg}$ concentrations, TOC and total fines in Sinclair Inlet outside of the BNC suggests that the physical mixing processes of fine-grained, organic-rich particles generally are controlling THg concentrations in sediment. Throughout greater Sinclair Inlet, coarse solids with low THg concentrations are mixing with finer solids with higher TOC and THg concentrations.

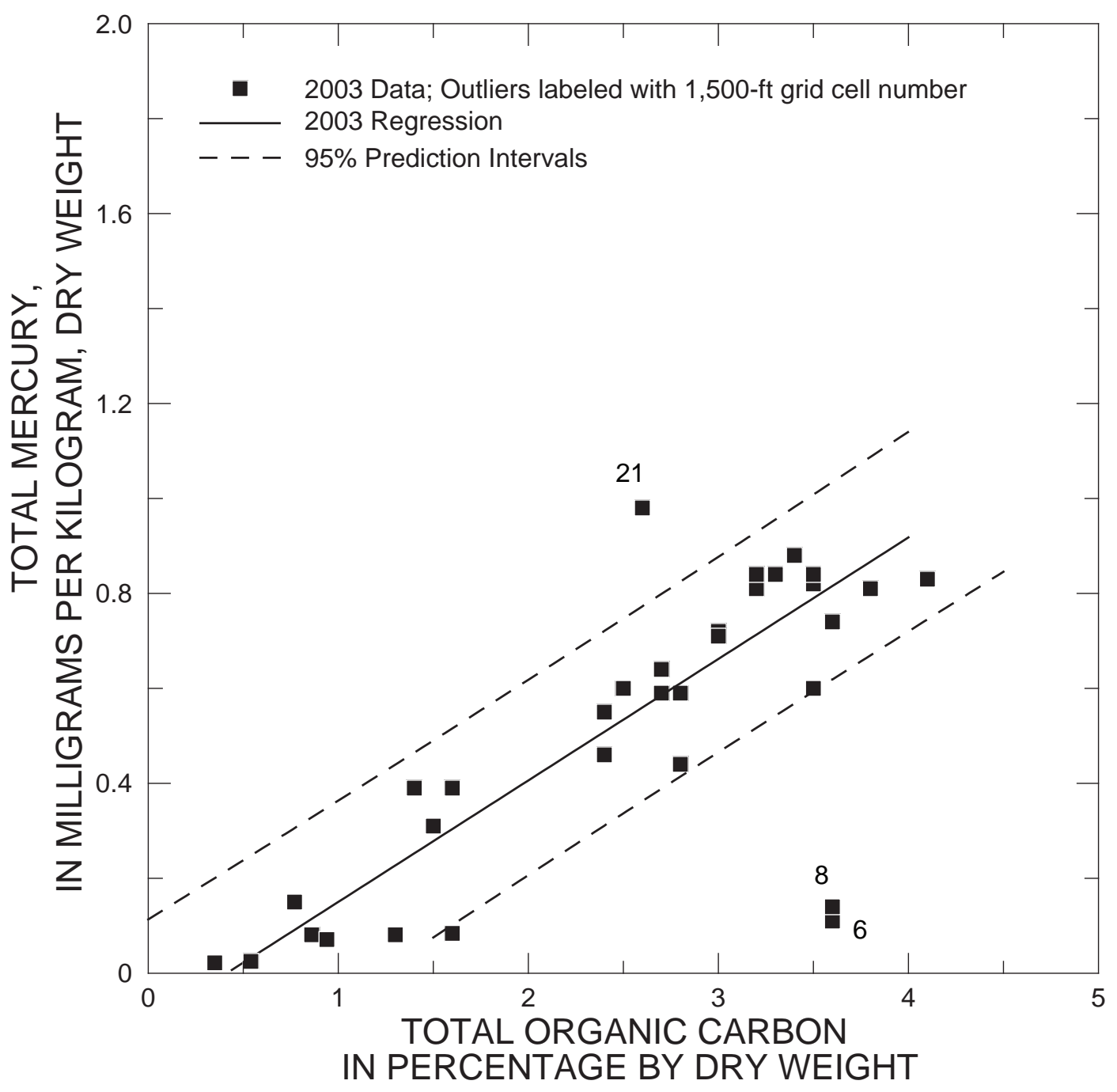

Figure 32. Total mercury concentration compared to total organic carbon in the surface sediment $(0-10 \mathrm{~cm})$ from Sinclair Inlet outside of the Bremerton naval complex, Washington, collected in 2003 (table B9) with low and high outliers labeled. 


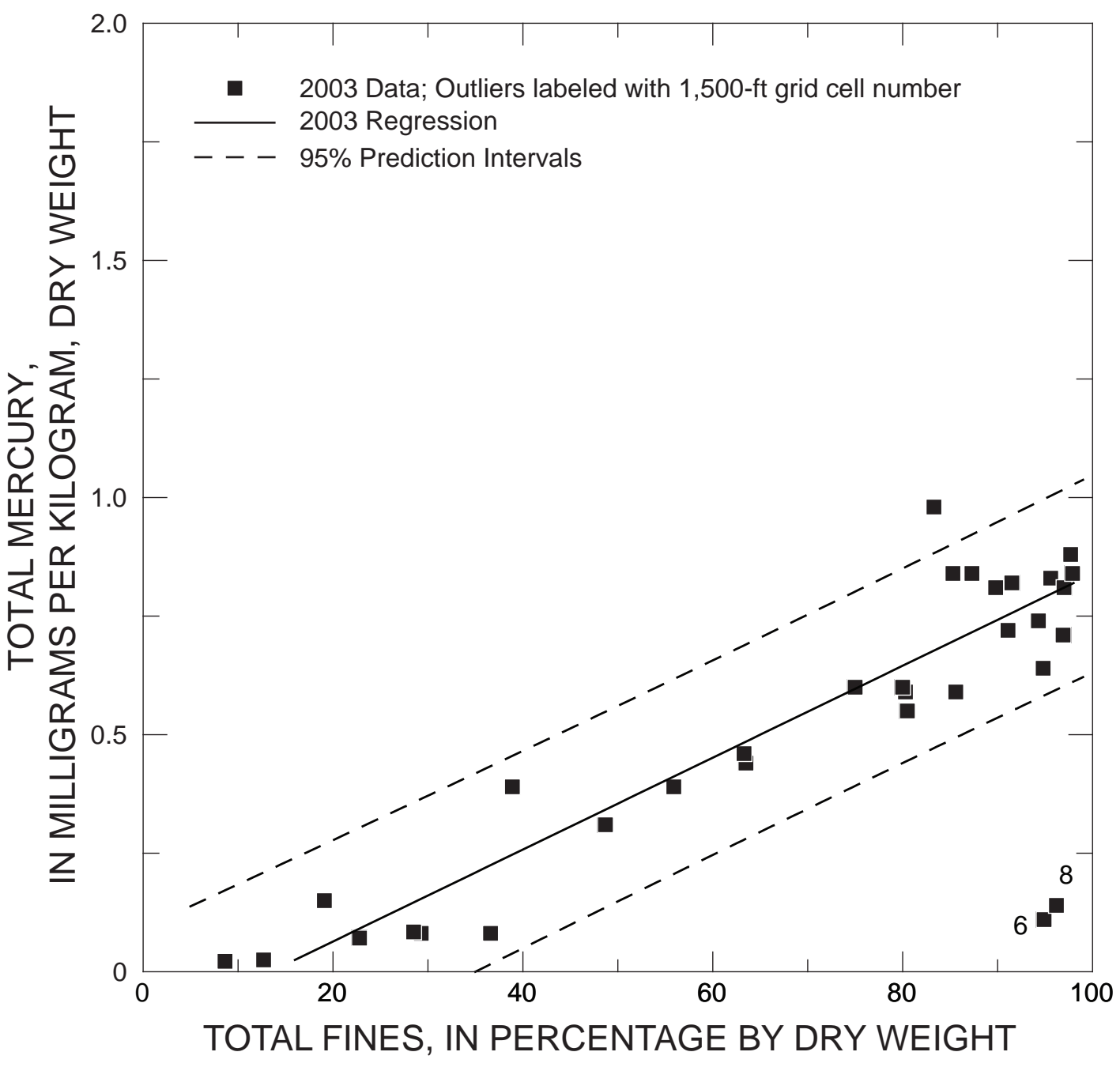

Figure 33. Total mercury concentration compared to total fines in the surface sediment $(0-10 \mathrm{~cm})$ from Sinclair Inlet outside of the Bremerton naval complex, Washington, collected in 2003 (table B9) with low outliers labeled. 


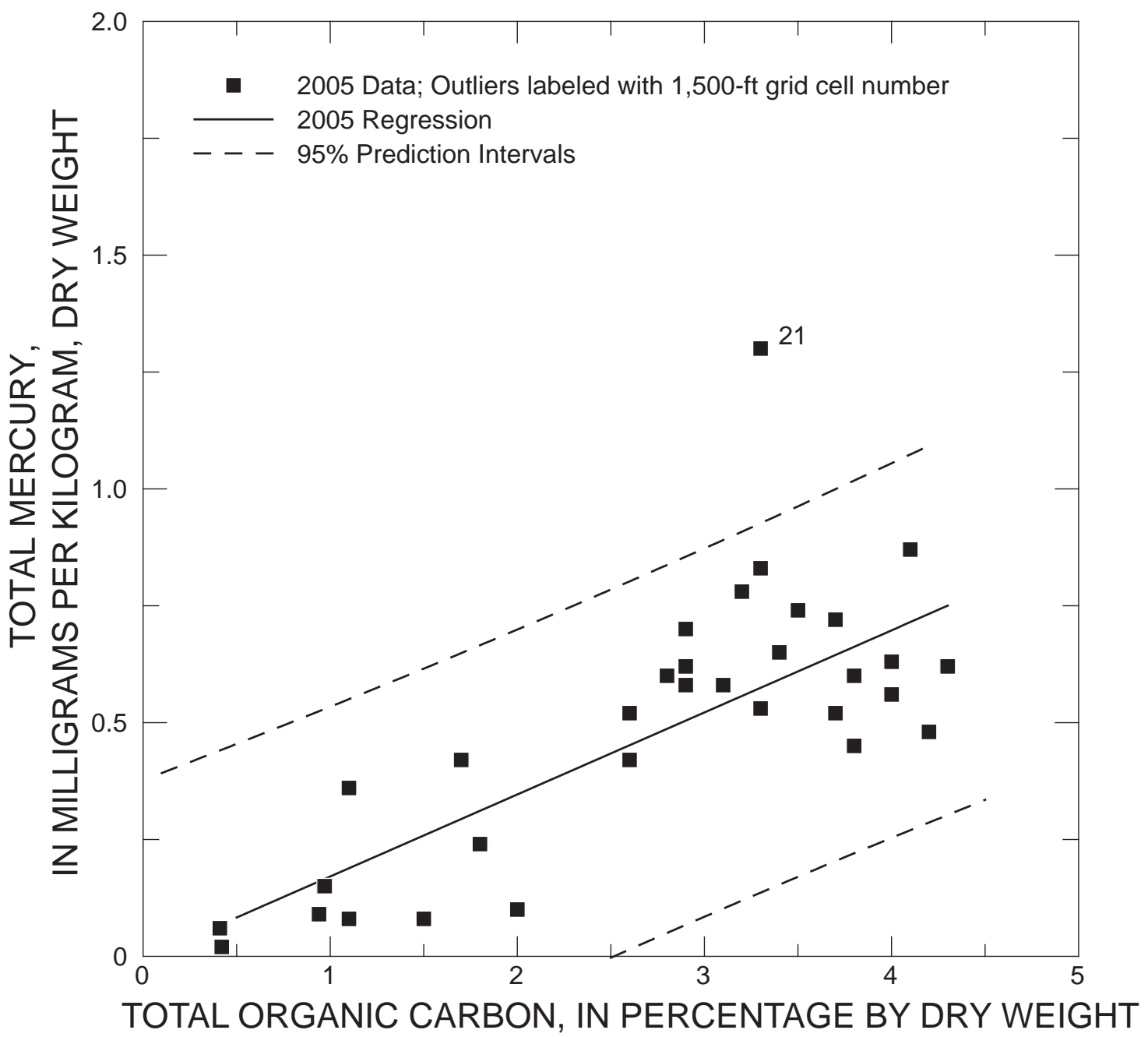

Figure 34. Total mercury concentration compared to total organic carbon in the surface sediment $(0-10 \mathrm{~cm})$ from Sinclair Inlet outside of the Bremerton naval complex, Washington, collected in 2005 (table B9) with the high outlier labeled. 


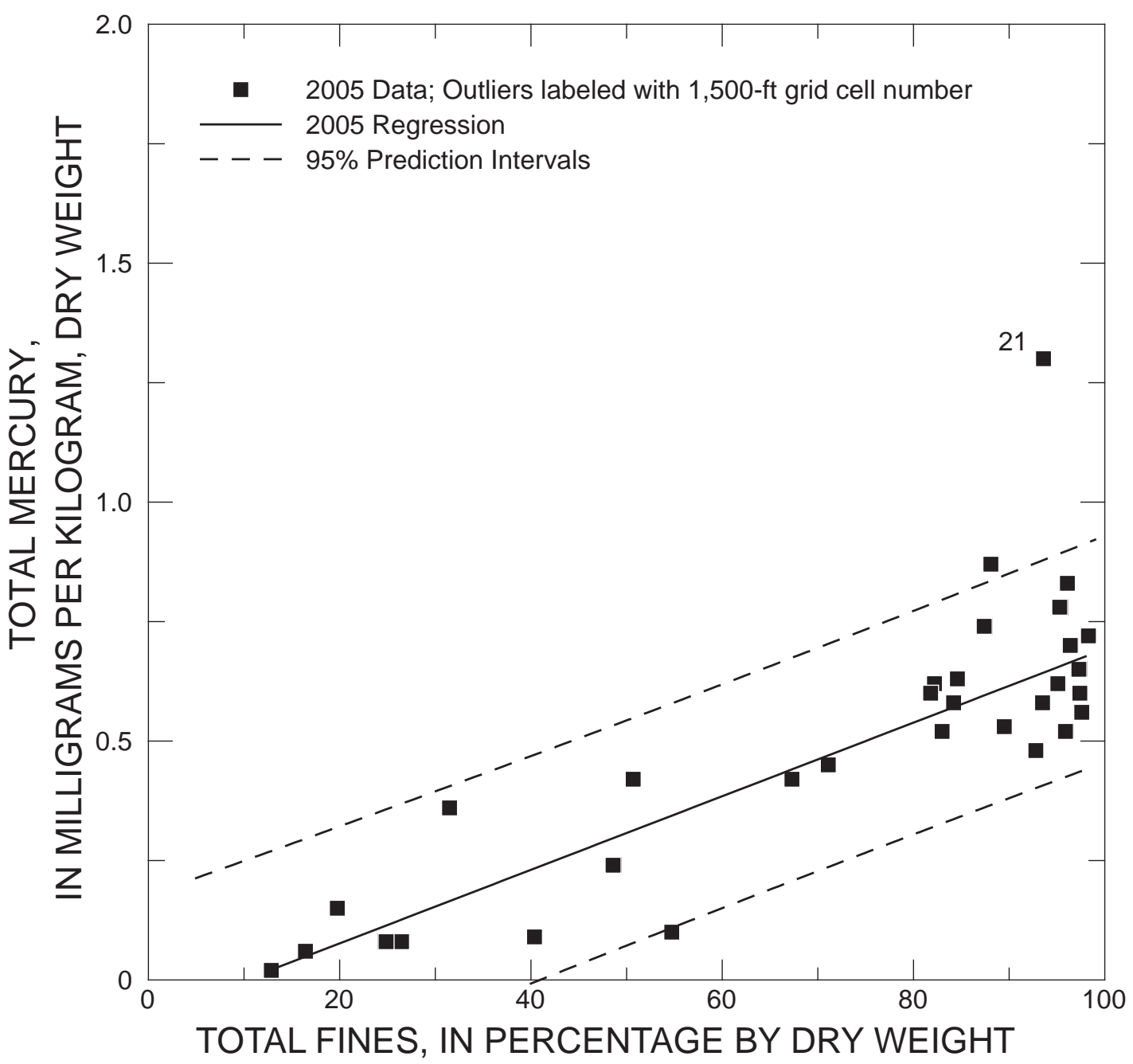

Figure 35. Total mercury concentration compared to total fines in the surface sediment $(0-10 \mathrm{~cm})$ from Sinclair Inlet outside of the Bremerton naval complex, Washington, collected in 2005 (table B9) with the high outlier labeled. 


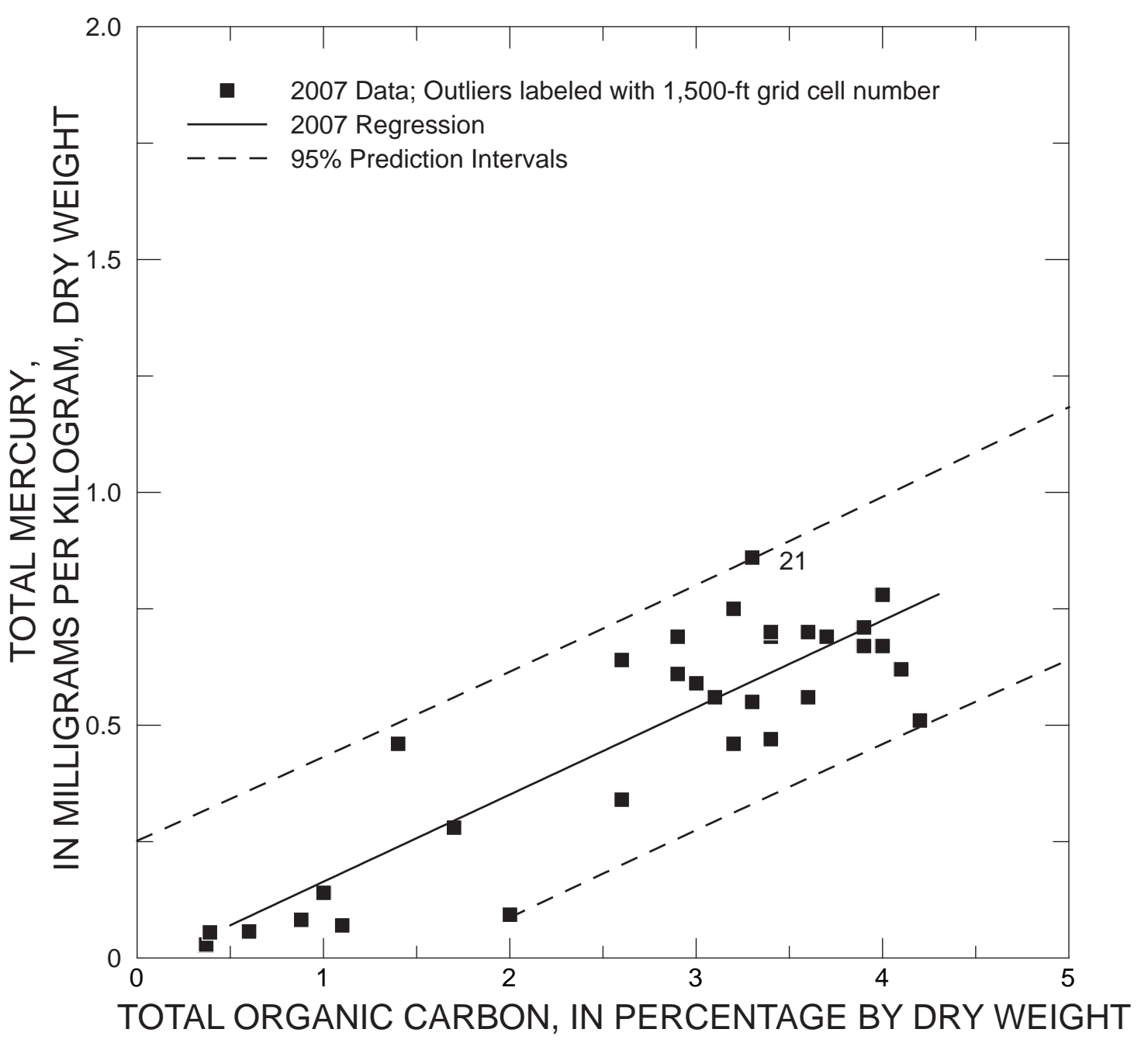

Figure 36. Total mercury concentration compared to total organic carbon in the surface sediment $(0-10 \mathrm{~cm})$ from Sinclair Inlet outside of the Bremerton naval complex, Washington, collected in 2007 (table B9) with cell 21 labeled for comparison to 2003 and 2005. 


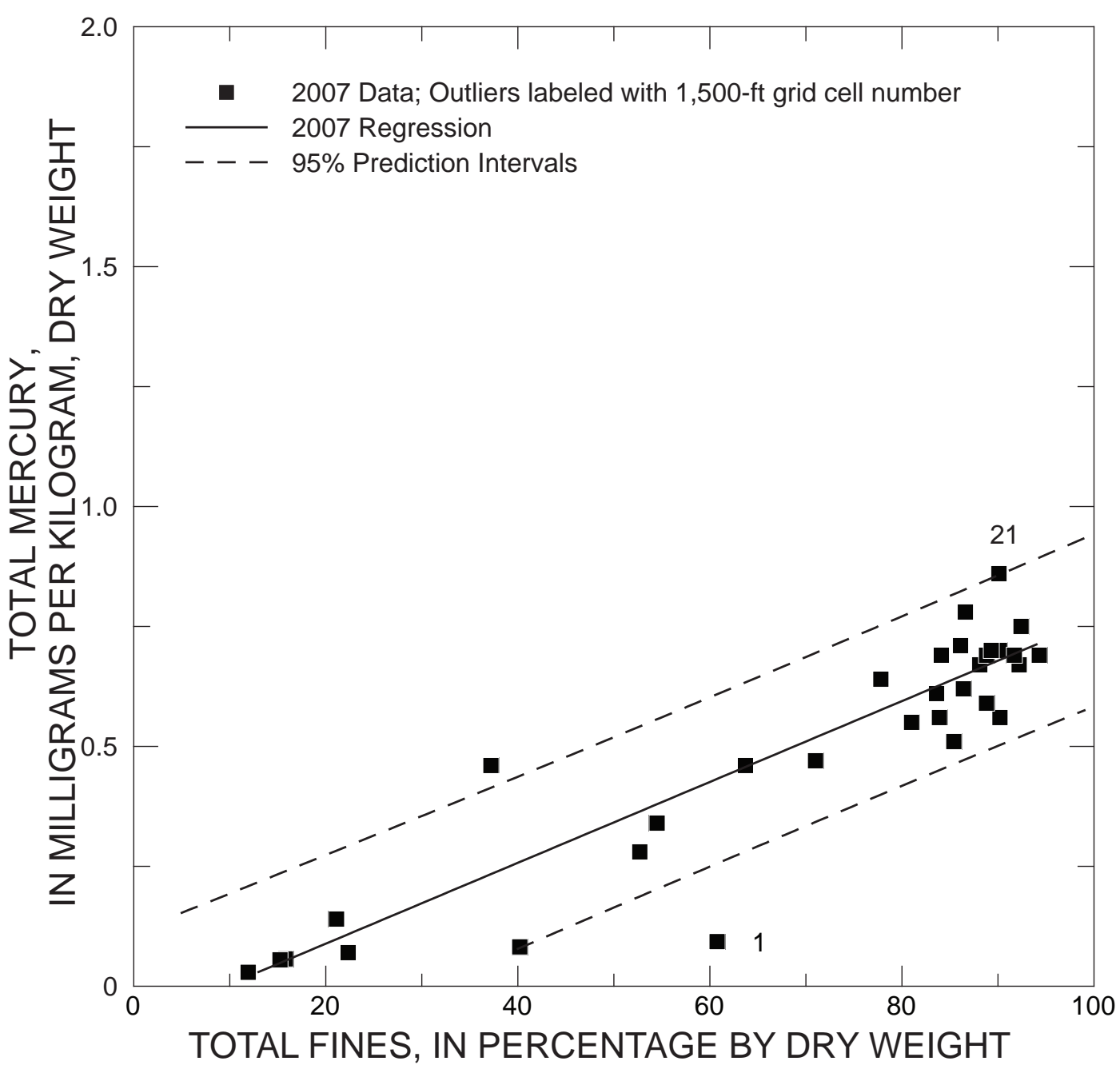

Figure 37. Total mercury concentration compared to total fines in the surface sediment $(0-10 \mathrm{~cm})$ from Sinclair Inlet outside of the Bremerton naval complex, Washington, collected in 2007 (table B9) with cell 1 (low outlier) and cell 21 for comparison to 2003 and 2005 labeled. 


\section{Operable Unit B Marine Grid}

Transport of sediments and sedimentary mercury in OU B Marine is controlled by the same physical mixing processes that control the relations among THg, TOC and total fines (figs. C13-C15) in greater Sinclair Inlet (outside of the BNC boundary). In the absence of localized sources, $\mathrm{THg}$ concentrations from OU B Marine could be expected to follow relations with ancillary parameters similar to those observed for greater Sinclair Inlet. To identify areas of recontamination by continuing sources of mercury from the BNC waterfront or historical sediment pollution that has not been remediated, deviations from the greater Sinclair Inlet relation of THg and TOC were evaluated. TOC concentrations from the sediment of OU B Marine are applied to the regression equation for greater Sinclair Inlet to calculate expected THg concentrations. Areas of concern for mercury contamination are identified when the actual THg concentrations exceeds the expected THg concentration by a prescribed concentration defined by the statistical analysis described below.

Assessing THg concentration from the analysis of composite samples in relation to TOC and total fines requires information on the representativeness of the composite samples. The representativeness of the individual samples composing the composite samples used to characterize twelve 500 -ft grid cells was examined by the U.S. Navy (2006a) in 2003 by the individual analyses of sub-samples of one to two of the three grab samples that contributed to the composite for the grid cell (table 2 with locations in figure 31 ). There were significant differences between the individual grab samples and the composites; differences for $\mathrm{THg}$ were greater than for TOC. For TOC, individual grab samples ranged from 53 percent lower than the respective composite (cell 67) to 78 percent higher than the composite (cell 61). For THg, individual grab samples ranged from 78 percent lower than the composite sample (cell 60) to 363 percent higher than the composite (cell 67 near the entrance to smallest dry dock in central PSNS \& IMF). In addition, the two individual grab samples (60-A and 60-C) analyzed from cell 60 had THg concentrations that were about 78 percent lower than the THg concentrations of the composite from grid cell 60 . Even though grab sample 60-B was not analyzed, the THg concentration of grab sample 60-B can be approximated from the mass balance of THg from equal masses of grabs 60-A, $60-\mathrm{B}$, and $60-\mathrm{C}$ in the composite sample. The calculated THg concentrations of grab sample $60-\mathrm{B}$ is $10.9 \mathrm{mg} / \mathrm{kg}$. A THg concentration this high is not unreasonable for cell 60 because the THg concentration in the composite from cell 60 collected in 2005 was $18.8 \mathrm{mg} / \mathrm{kg}$. These analyses of separate grab samples indicate that there is substantial horizontal heterogeneity of THg concentrations around the piers of PSNS \& IMF.
The 2003 sediment THg concentrations within the OU B Marine Boundary (cells with the 500-foot grid shown in fig. 31 and data in table B10) plotted against TOC (fig. 38) show most of the data points fall around the trend line for greater Sinclair Inlet. TOC concentrations and total fines from sediments of OU B Marine were applied to the regressions for the 1,500-ft grid to calculate the expected concentrations. Deviations of the actual values from the expected values (residuals) were then ordered by rank (figs. E3 and E4). Breaks in the rank order of residuals of the THg for the TOC regression were used to classify samples at two levels. Classification of 'tier 1 ' samples was visually based on the most obvious break and 'tier 2' samples were above and to the right of a more subtle break in the rank order of residuals. These two breaks in the distribution of ranked ordered residuals were used to classify eleven of seventy-one cell samples of the $500-\mathrm{ft}$. Samples from four tier 1 grid cells (11, 19, 60 and 63) easily can be recognized in figure 38; the sample from cell 63 had a $\mathrm{THg}$ concentration of $6.13 \mathrm{mg} / \mathrm{kg}$. Seven of the 71 samples (tier 2 samples) were offset by more than $0.64 \mathrm{mg} / \mathrm{kg}$ and less than $2.26 \mathrm{mg} / \mathrm{kg}$, a more subtle break in the rank order (fig. E3). These seven samples were above the upper 95 percent prediction interval of greater Sinclair Inlet. Note that there is also a group of samples near the mean of TOC (2.7 percentage by weight) that are at about the 95 percent prediction interval for the greater Sinclair Inlet, and are not classified as tier 2 samples because their residuals do not exceed the $0.64 \mathrm{mg} / \mathrm{kg}$ offset value. Tier 1 samples and tier 2 samples are listed in table 3. Similar deviations were observed when THg concentrations were plotted against total fines (fig. 39) and samples visually above the greater Sinclair Inlet trend line are labeled in figure 39.

In 2005, three sediment samples were classified as tier 1 by the most obvious break in the rank order of residuals (fig. E5). The sample from cell 60 located in central PSNS \& IMF (fig. 31) had far greater THg sediment concentrations $(18.8 \mathrm{mg} / \mathrm{kg})$ than any other sample collected over duration of the Long-Term Sampling Program (fig. 40). Eight other samples were classified as tier 2 samples with residuals above the break of $0.53 \mathrm{mg} / \mathrm{kg}$, but below $2.13 \mathrm{mg} / \mathrm{kg}$. In 2005, the 95 percent prediction interval from the greater Sinclair Inlet regression and the $0.53 \mathrm{mg} / \mathrm{kg}$ tier 2 offset were similar. The plot of THg compared to total fines shows a similar pattern (fig. 41 and fig. E6).

Cell 67 near the entrance to smallest dry dock in central PSNS \& IMF between piers in central PSNS \& IMF (fig. 31) contained sediment with the highest THg concentration in 2007 (fig. 42). Deviations of tier 1 samples from the trend line for the relation of THg with TOC for greater Sinclair Inlet in 2007 (fig. E7) were smaller than the deviations observed in 2003 and 2005 data (figs. E3 and E5). 
Table 2. Comparison of analysis of 500 -foot grid composites with selected pier grab samples collected in 2003 from Operable Unit B Marine of the Bremerton naval complex, Washington.

[Data source: U.S. Navy, 2006a. Composite is from grab samples A, B and C from each grid cell. Abbreviations TOC, total organic carbon; mg/kg, milligram per kilogram; <, less than]

\begin{tabular}{|c|c|c|c|c|c|}
\hline \multirow[b]{2}{*}{ Sample } & \multicolumn{2}{|c|}{ Values } & \multicolumn{2}{|c|}{ Percent difference } & \multirow[b]{2}{*}{ Description of individual grab samples } \\
\hline & $\begin{array}{c}\text { TOC } \\
\text { (percentage } \\
\text { by dry } \\
\text { weight) }\end{array}$ & $\begin{array}{c}\text { Total } \\
\text { mercury } \\
\text { (mg/kg, dry } \\
\text { weight) }\end{array}$ & TOC & $\begin{array}{l}\text { Total } \\
\text { mercury }\end{array}$ & \\
\hline Composite-29 & 3.4 & 1 & & & \\
\hline Composite-33 & 3.1 & 1.4 & & & \\
\hline Grab 33-B & 4.3 & 1.1 & 39 & -21 & Grab B appears to be a near-mooring sample. \\
\hline Composite-34 & 2.3 & 1.2 & & & \\
\hline Grab 34-C & 2.6 & 3.8 & 13 & 217 & $\begin{array}{l}\text { Grab C was collected outside cell } 34 \text { and in a nearshore area that is likely } \\
\text { rarely dredged. }\end{array}$ \\
\hline Composite-41 & 2.6 & 0.82 & & & \\
\hline Grab 41-B & 2.8 & 0.7 & 8 & -15 & $\begin{array}{l}\text { Grabs B and C appear to be near-pier samples; grab A (not analyzed) appears } \\
\text { to be from sideslope. }\end{array}$ \\
\hline Grab 41-C & 2.5 & 1.3 & -4 & 59 & \\
\hline Composite-45 & 3 & 0.61 & & & \\
\hline Grab 45-B & 3.2 & 0.33 & 7 & -46 & Grabs B and C are from near-pier locations. \\
\hline Grab 45-C & 2.8 & 0.9 & -7 & 48 & \\
\hline Composite-46 & 1.2 & 0.42 & & & \\
\hline Grab 46-B & 1 & 0.3 & -17 & -29 & $\begin{array}{l}\text { Grabs B and C are near-mooring samples from outside cell; grab A (not } \\
\text { analyzed) is effectively a nearshore sample. }\end{array}$ \\
\hline Grab 46-C & 1.2 & 0.4 & 0 & -5 & \\
\hline Grab 60-A & 3.3 & 0.95 & 6 & -78 & Grabs A and C are from near-pier locations, as is grab B. \\
\hline Grab 60-C & 3.1 & 1.1 & $<1$ & -74 & \\
\hline Grab 60-B & 3 & 10.9 & & & From mass balance of composite from equal mass of grabs A, B and C. \\
\hline Composite-61 & 1.8 & 0.35 & & & \\
\hline Grab 61-A & 3.2 & 0.43 & 78 & 23 & Grabs A and C are from near-pier locations, as is grab $\mathrm{B}$. \\
\hline Grab 61-C & 2.3 & 0.42 & 28 & 20 & \\
\hline Composite-67 & 4.5 & 1.9 & & & \\
\hline Grab 67-C & 2.1 & 8.8 & -53 & 363 & $\begin{array}{l}\text { Grab C is in partially dredged drydock mouth area; grab A (not analyzed) is on } \\
\text { near-pier sideslope. }\end{array}$ \\
\hline Minimum & & & -53 & -78 & \\
\hline Maximum & & & 78 & 363 & \\
\hline
\end{tabular}




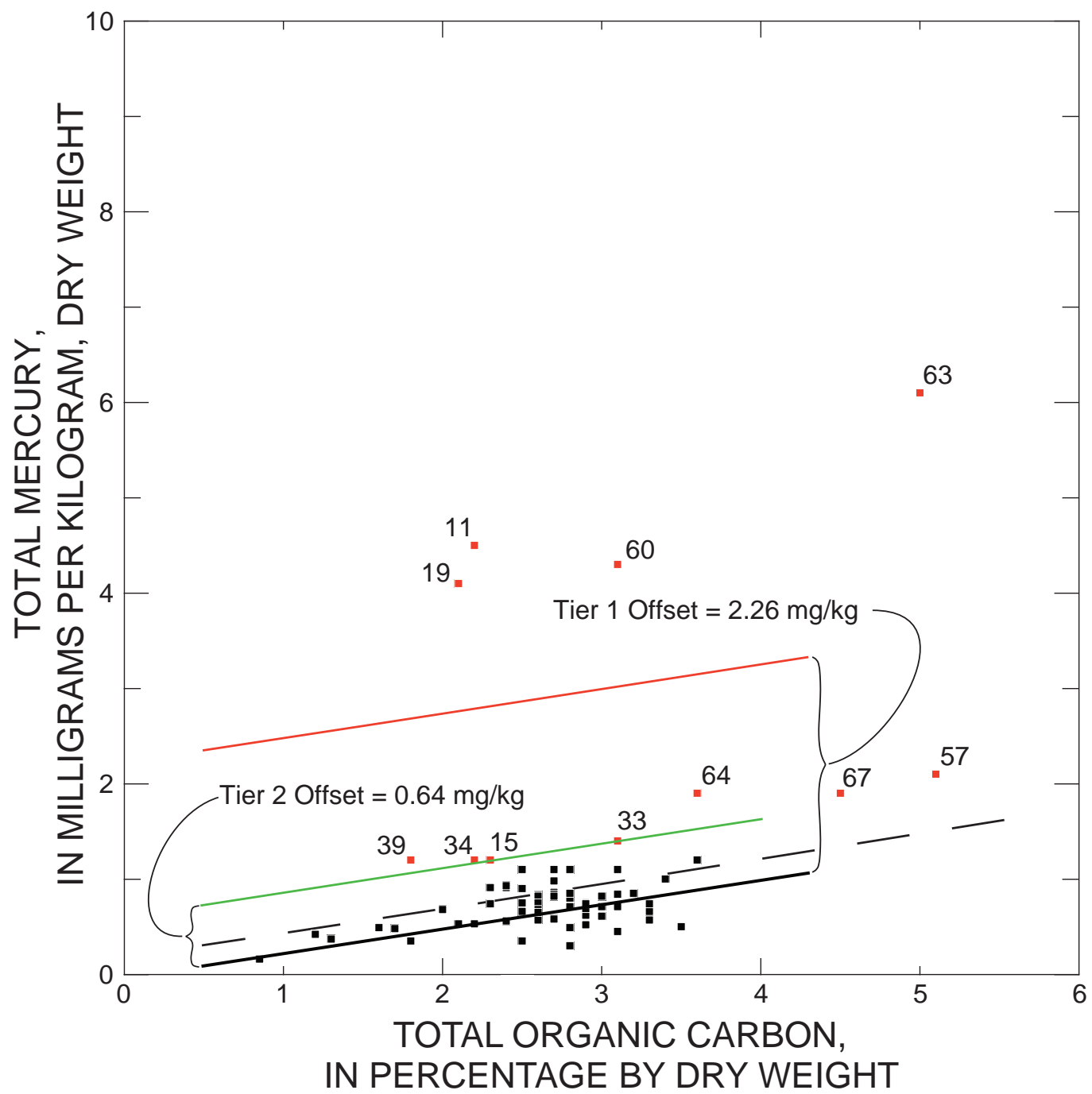

Figure 38. Total mercury concentration compared to total organic carbon in composite surface sediment $(0-10 \mathrm{~cm})$ from Operable Unit B Marine of the Bremerton naval complex, Washington, collected in 2003 (table B10). Tier 1 and 2 samples are labeled with their respective cell numbers of the $500-\mathrm{ft}$ grid. The black solid line represents the regression line for Sinclair Inlet samples collected in 2003 from outside of the Bremerton naval complex (fig. 32 and table 1) and the red and green solid lines are the offsets for tier 1 and tier 2 samples, respectively, identified by breaks in the rank-ordered residuals (fig. E3). The dashed black line is the upper 95 percent prediction interval for greater Sinclair Inlet shown in fig. 32. 
Table 3. Years and cell numbers for which total mercury sediment concentrations in 500 -foot grid cells within Operable Unit B Marine of the Bremerton naval complex, Washington, deviated from predicted values were based on the regression of mercury compared to total organic carbon for greater Sinclair Inlet sediments.

[Locations of grid cells are shown on figure 31; tier 1 and tier 2 samples are identified by breaks in the rank ordered of the residuals in figures E3, E5, and E7 and are shown as red squares in figures 38,40 , and 42 . Symbol: -, no tier assigned]

\begin{tabular}{|c|c|c|c|c|}
\hline \multirow{2}{*}{$\begin{array}{l}\text { Grid cell } \\
\text { number }\end{array}$} & \multirow{2}{*}{$\begin{array}{l}\text { Number of } \\
\text { times grid } \\
\text { cell was an } \\
\text { outlier }\end{array}$} & \multicolumn{3}{|c|}{$\begin{array}{c}\text { Tier to which grid cell sample } \\
\text { was assigned }\end{array}$} \\
\hline & & 2003 & 2005 & 2007 \\
\hline \multicolumn{5}{|c|}{ Remediated areas off Operable Unit A } \\
\hline 11 & 1 & 1 & - & - \\
\hline 15 & & 2 & - & - \\
\hline 18 & 1 & - & - & 2 \\
\hline 19 & 1 & 1 & - & - \\
\hline \multicolumn{5}{|c|}{ Naval Base Kitsap Bremerton } \\
\hline 39 & 3 & 2 & 2 & 1 \\
\hline 34 & 1 & 2 & - & - \\
\hline 31 & 1 & - & 2 & - \\
\hline 33 & 2 & 2 & 2 & - \\
\hline 35 & 1 & - & - & 2 \\
\hline 40 & 1 & - & - & 2 \\
\hline 42 & 1 & - & 2 & - \\
\hline \multicolumn{5}{|c|}{ Western PSNS \& IMF } \\
\hline 43 & 1 & - & 2 & - \\
\hline \multicolumn{5}{|c|}{ Central PSNS \& IMF } \\
\hline 60 & 3 & 1 & 1 & 1 \\
\hline 63 & 3 & 1 & 1 & 1 \\
\hline 67 & 3 & 2 & 1 & 1 \\
\hline 64 & 3 & 2 & 2 & 2 \\
\hline 57 & 2 & 2 & 2 & - \\
\hline 59 & 2 & - & 2 & 2 \\
\hline \multicolumn{5}{|c|}{ Eastern PSNS \& IMF } \\
\hline 68 & 1 & - & - & 2 \\
\hline 71 & 1 & - & - & 1 \\
\hline
\end{tabular}




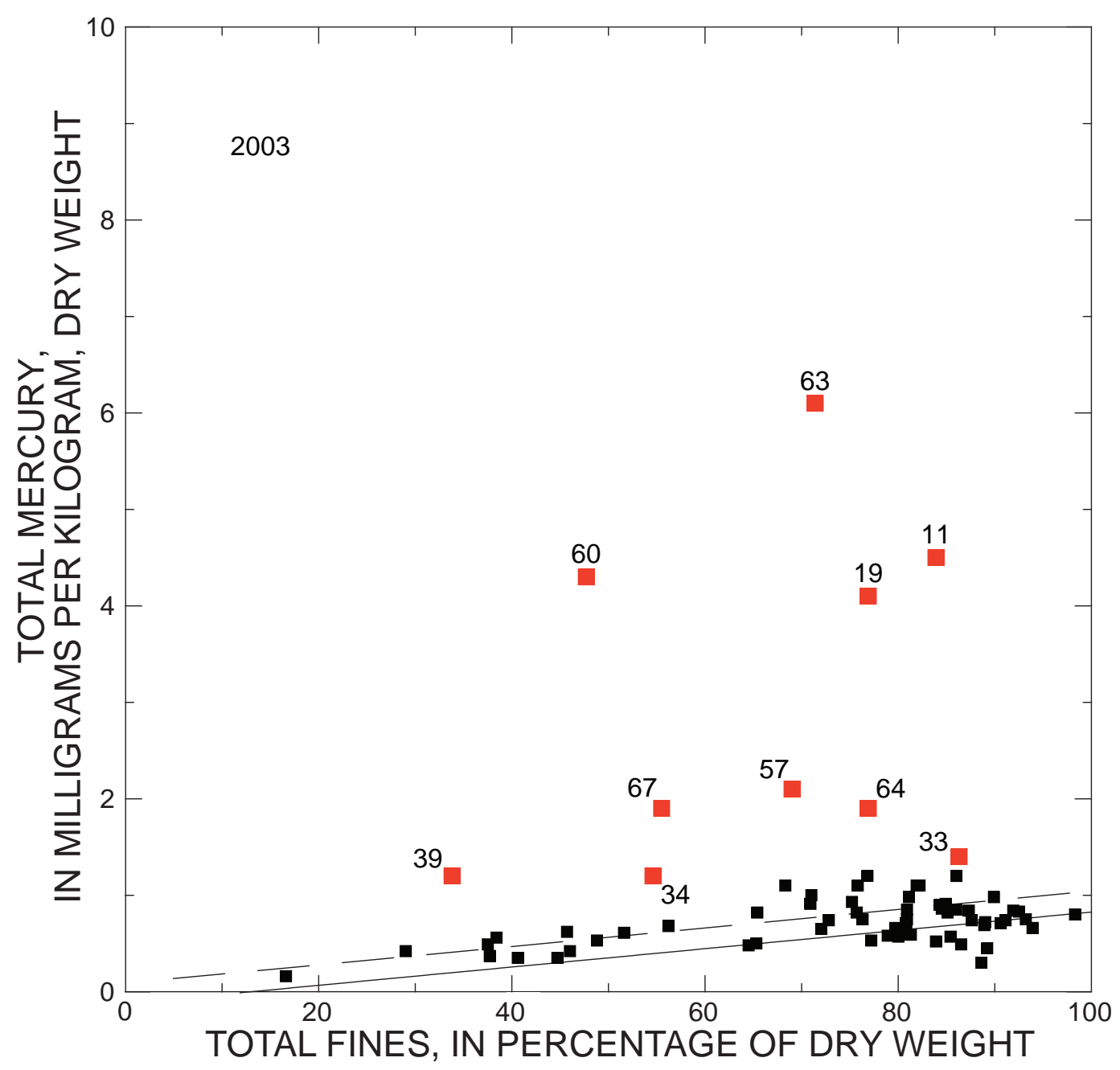

Figure 39. Total mercury concentration compared to total fines in surface composite sediment $(0-10 \mathrm{~cm})$ from Operable Unit B Marine of the Bremerton naval complex, Washington, collected in 2003 (table B10). Samples of interest are labeled with their respective cell numbers of the 500 -ft grid (fig. E4). The black solid and dashed lines represent the regression line and upper 95 percent prediction interval, respectively, for the Sinclair Inlet samples collected in 2003 outside of the Bremerton naval complex (fig. 33 and table 1). 


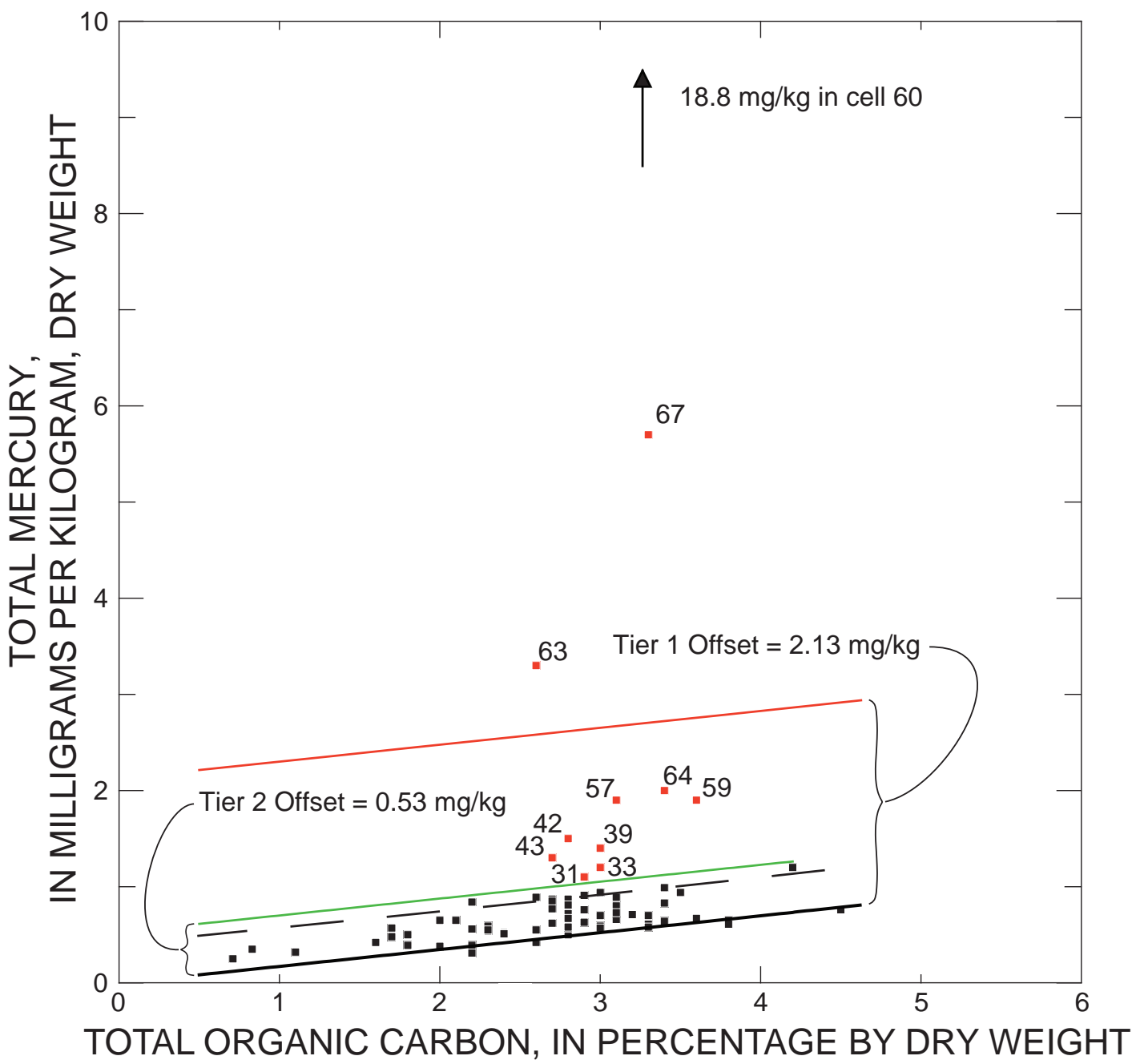

Figure 40. Total mercury concentration compared to total organic carbon in composite surface sediment $(0-10 \mathrm{~cm})$ from Operable Unit B Marine of the Bremerton naval complex, Washington, collected in 2003 (table B10). Tier 1 and 2 samples are labeled with their respective cell numbers of the $500-\mathrm{ft}$ grid. The black solid line represents the regression line for Sinclair Inlet samples collected in 2003 from outside of the Bremerton naval complex (fig. 32 and table 1) and the red and green solid lines are the offsets for tier 1 and tier 2 samples, respectively, identified by breaks in the rank-ordered residuals (fig. E5). The dashed black line is the upper 95 percent prediction interval for greater Sinclair Inlet shown in fig. 34. 


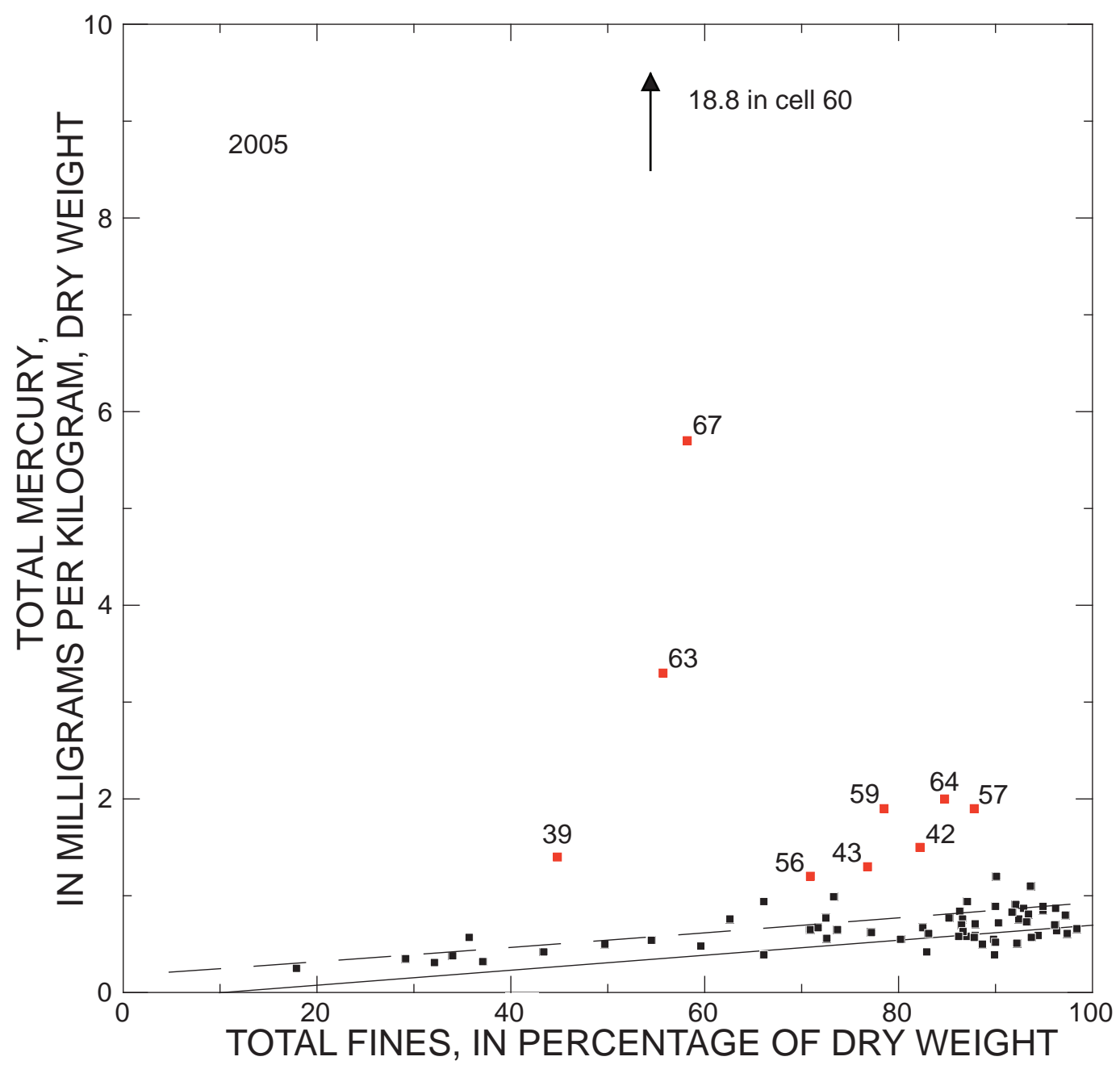

Figure 41. Total mercury concentration compared to total fines in surface composite sediment $(0-10 \mathrm{~cm})$ from Operable Unit B Marine of the Bremerton naval complex, Washington, collected in 2005 (table B10). Samples of interest are labeled with their respective cell numbers of the 500 - $\mathrm{ft}$ grid. The black solid line and dashed lines represent the regression line and upper 95 percent prediction interval, respectively, for the Sinclair Inlet samples collected in 2005 outside of the Bremerton naval complex, Washington (fig. 35 and table 1). 


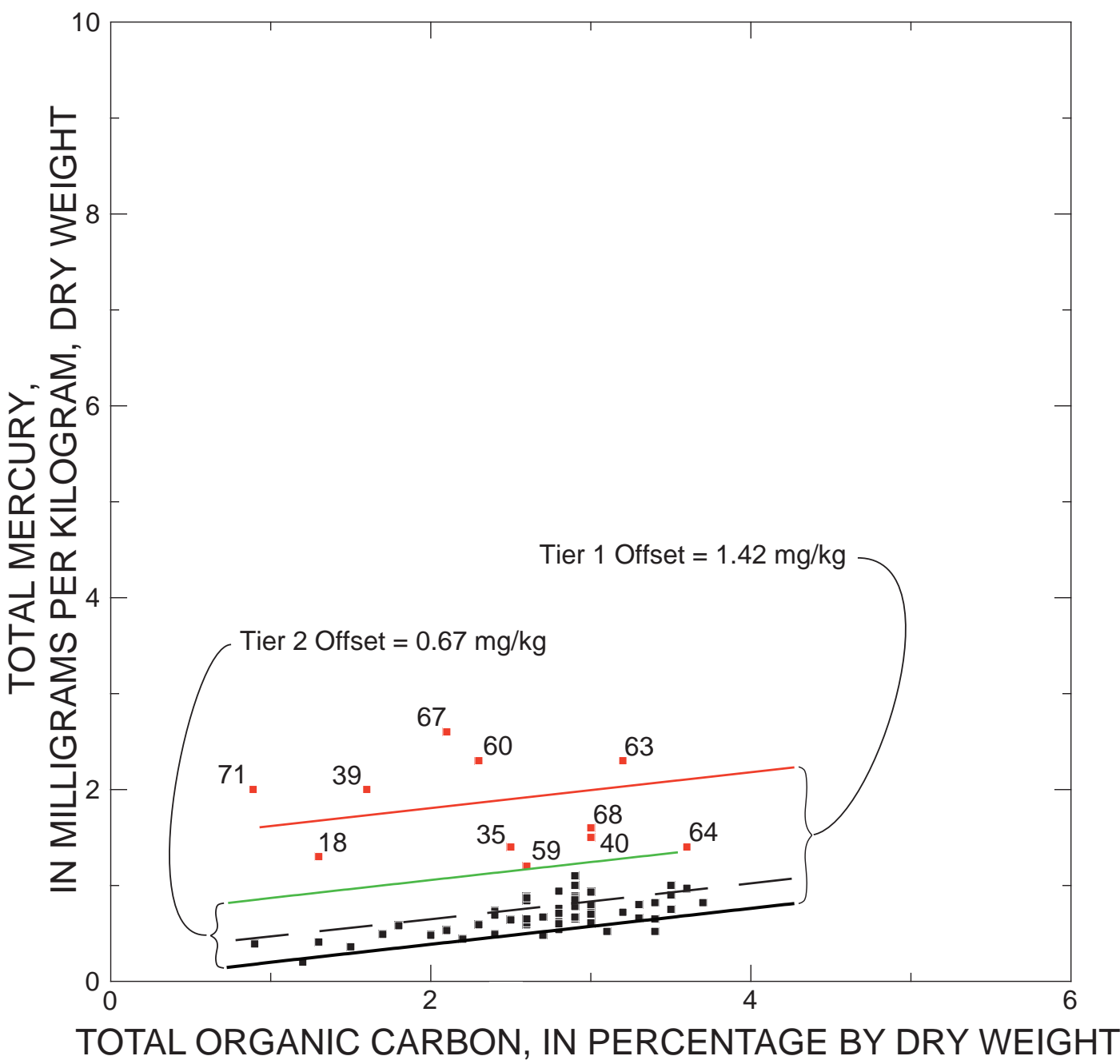

Figure 42. Total mercury concentration compared to total organic carbon in composite surface sediment $(0-10 \mathrm{~cm})$ from Operable Unit B Marine of the Bremerton naval complex, Washington, collected in 2003 (table B10). Tier 1 and 2 samples are labeled with their respective cell numbers of the 500 - $\mathrm{ft}$ grid. The black line represents the regression line for Sinclair Inlet samples collected in 2003 from outside of the Bremerton naval complex (fig. 32 and table 1) and the red and green solid lines are the offsets for tier 1 and tier 2 samples, respectively, identified by breaks in the rank-ordered residuals (fig. E7). The dashed black line is the upper 95 percent prediction interval for greater Sinclair Inlet shown in fig. 36 . 
More rigorous mixing of the composite samples in 2007 may have reduced heterogeneity of the 2007 composite samples. Seven other samples were classified as tier 2 samples with residuals greater than $0.67 \mathrm{mg} / \mathrm{kg}$. Similar to 2003, there is a group of samples near the mean of TOC that are about the 95 percent prediction interval for greater Sinclair Inlet, and are not classified as tier 2 samples because their residuals do not exceed the $0.67 \mathrm{mg} / \mathrm{kg}$ offset value. The regression of $\mathrm{THg}$ sediments concentrations compared to total fines for the 2007 data also showed fewer samples with large deviations (fig. 43 and fig. E8). In general, the 2007 LTMP data from OU B Marine exhibit tighter grouping of results around the general Sinclair Inlet trend line, and a smaller range of deviations around the trend line.

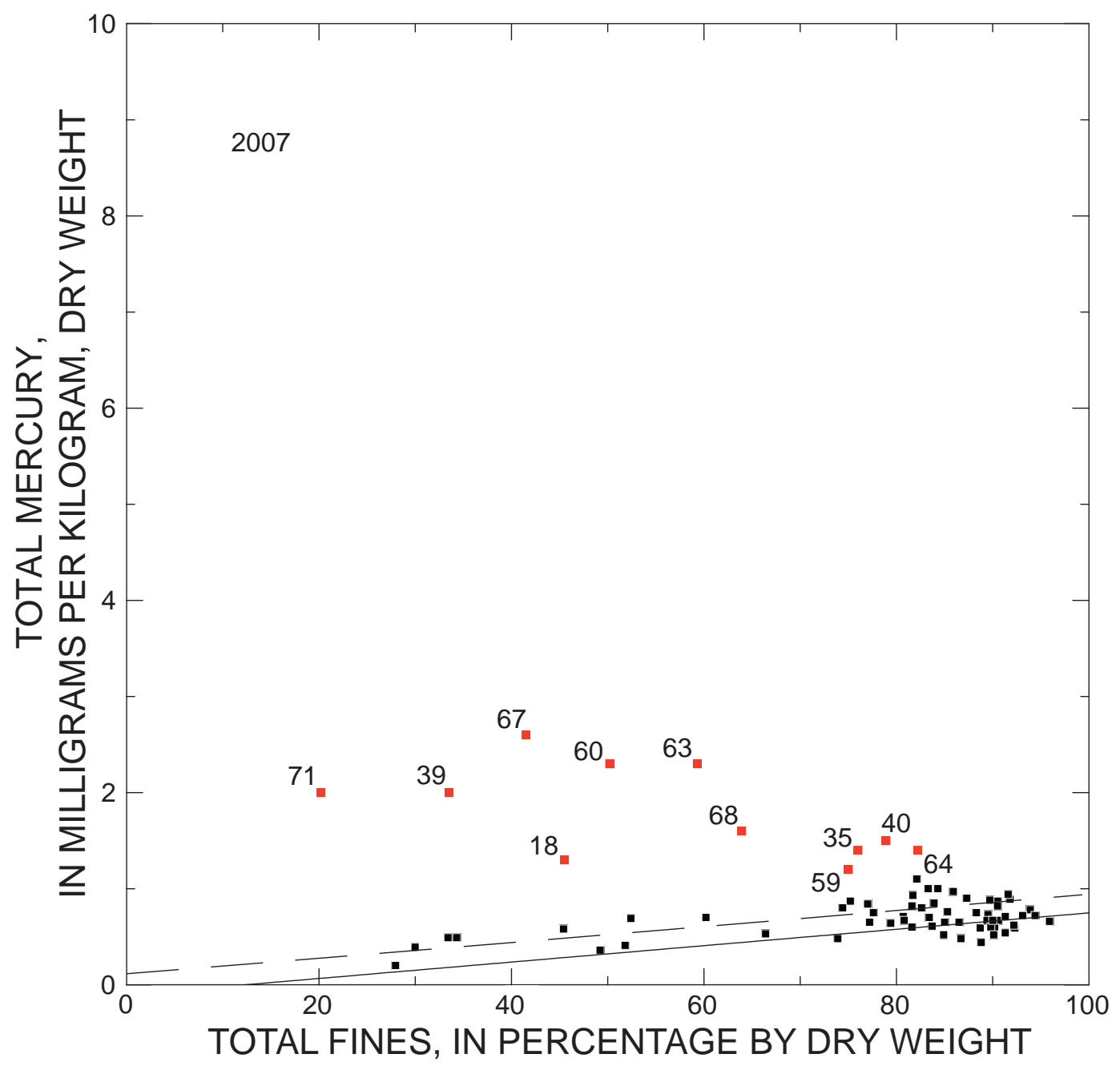

Figure 43. Total mercury concentration compared to total fines in surface composite sediment $(0-10 \mathrm{~cm})$ from Operable Unit B Marine of the Bremerton naval complex, Washington, collected in 2007 (table B10). Samples of interest are labeled with their respective cell numbers of the 500 -ft grid. The black solid line and dashed lines represent the regression line and upper 95 percent prediction interval, respectively, for the Sinclair Inlet samples collected in 2007 outside of the Bremerton naval complex, Washington (fig. 37 and table 1). 


\section{Cap of the Confined Aquatic Disposal Pit and Apron Surrounding the Pit}

One part of the LTMP included monitoring of the CAD pit to evaluate whether the CAD pit cover was continuing to prevent the release of contaminants from sediment disposed in the pit. Physical and chemical characteristics of the cap of the CAD pit and the CAD apron were monitored (U.S. Navy 2006a, 2006b, 2008a) and the bathymetric elevation of the CAD pit decreased $2 \mathrm{ft}$ between 2001 and 2003 and $4 \mathrm{ft}$ between 2001 and 2005. This settling has been attributed to consolidation of the dredge spoils and the cap material rather than erosion of the cap material (U.S. Navy, 2006a). The CAD pit apron sediment was monitored to evaluate whether PCB concentrations from the apron were sufficiently elevated to prevent meeting the area-wide average remedial goal for PCBs.
THg, TOC and total fines data from the cores collected during the 2003, 2005, and 2007 LTMP sampling are listed in table B11. Only one core (PIT-01) with two vertical sections was successfully collected and analyzed in 2003 (fig. D7). In 2005, four cores with three vertical sections were collected (figs. D8-D11). Clean sand cap seemed to be encountered in the 61-91 cm sections at cores PIT-02 and PIT-03 in 2005 (figs. D9-D10). A significant high anomaly in TOC was observed in the 30-61 cm section of core PIT-02 (fig. D9). In 2005 and 2007, the profiles of THg in cores PIT-1 (figs. D8 and D12) and PIT-02 (figs. D9 and D13) were uniform with depth, and THg concentrations decreased with depth in cores PIT-03 and PIT-04 in 2007 (figs D14-D15).

THg sediment concentrations from core sections plotted against TOC (fig. 44) show two of the four 2003 core segments with TOC greater than 1 percent were within the

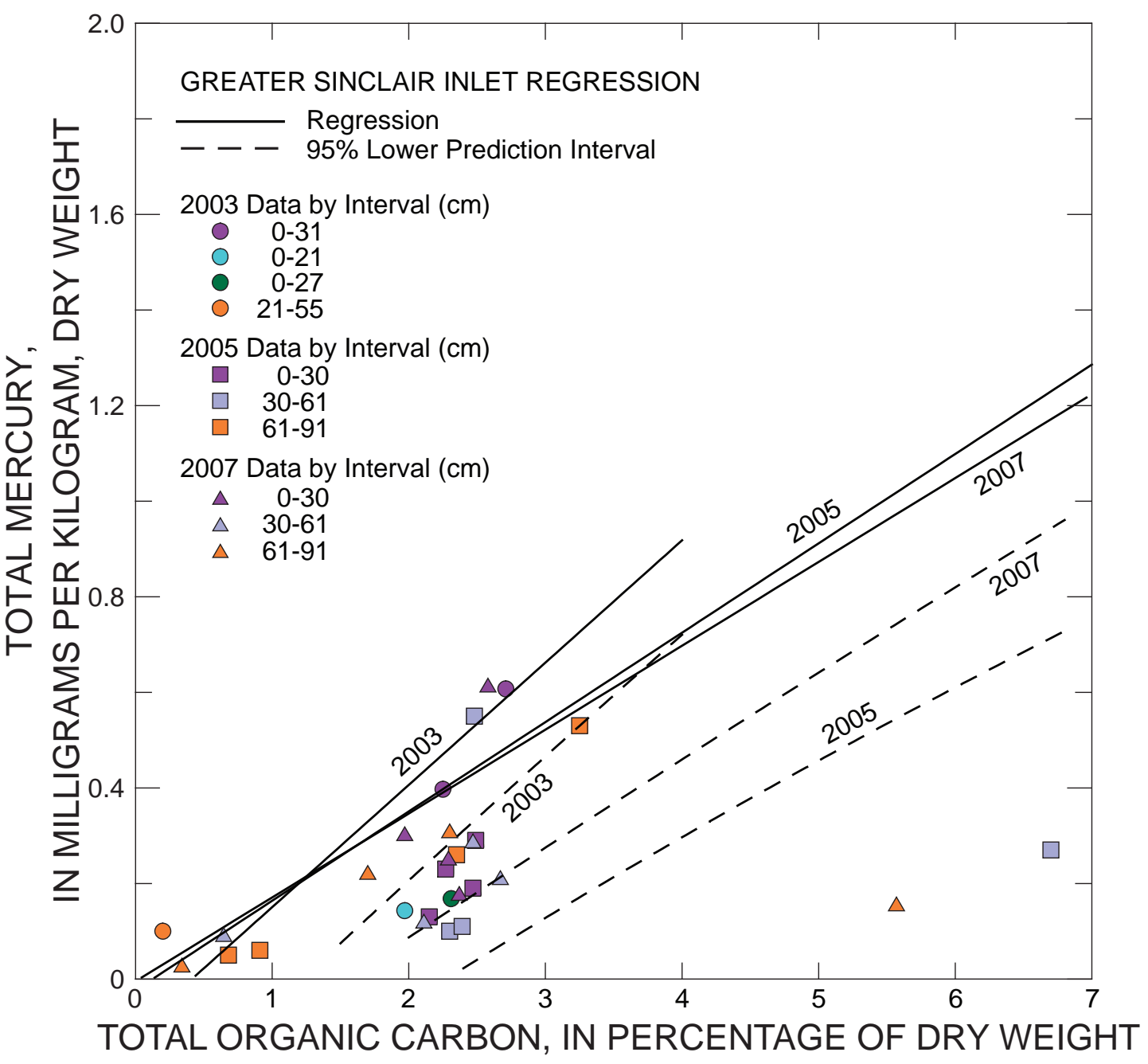

Figure 44. Total mercury concentration compared to total organic carbon for surface and subsurface sediment core sections collected from the Confined Aquatic Disposal pit of the Bremerton naval complex, Washington, in 2003, 2005, and 2007 (table B11). The solid and dashed lines represent the regression lines and 95 percent lower prediction intervals, respectively, for samples collected outside of the Bremerton naval complex, Washington, in 2003, 2005, and 2007 (figs. 32, 34, and 36; table 1). 
95 percent prediction interval of the greater Sinclair Inlet regression and the other two were below the 95 percent prediction interval. Because of the greater 95 percent prediction intervals for the 2005 and 2007 regressions, most of the 2005 and 2007 pit samples were within the prediction interval. THg sediment concentrations plotted against total fines (fig. 45) show most samples were below the lower 95 percent prediction intervals for greater Sinclair Inlet for the respective collection year.
Composite samples comprised of three surface sediment $(0-10 \mathrm{~cm})$ grab samples were collected in each of 15 cells (labeled CP) within the CAD pit apron on three sides of the CAD pit in 2003 and 2005 (fig. 20). The highest THg sediment concentrations in $2003(1.17 \mathrm{mg} / \mathrm{kg})$ and 2005 $(1.6 \mathrm{mg} / \mathrm{kg})$ were measured in cell 6CP (table B12), which is on the northwest side of the CAD pit. Cell 5CP, located to the west of cell 6CP, had the second highest THg concentration in both years. THg sediment concentrations from the fifteen CP cells plotted against TOC show that most of the samples

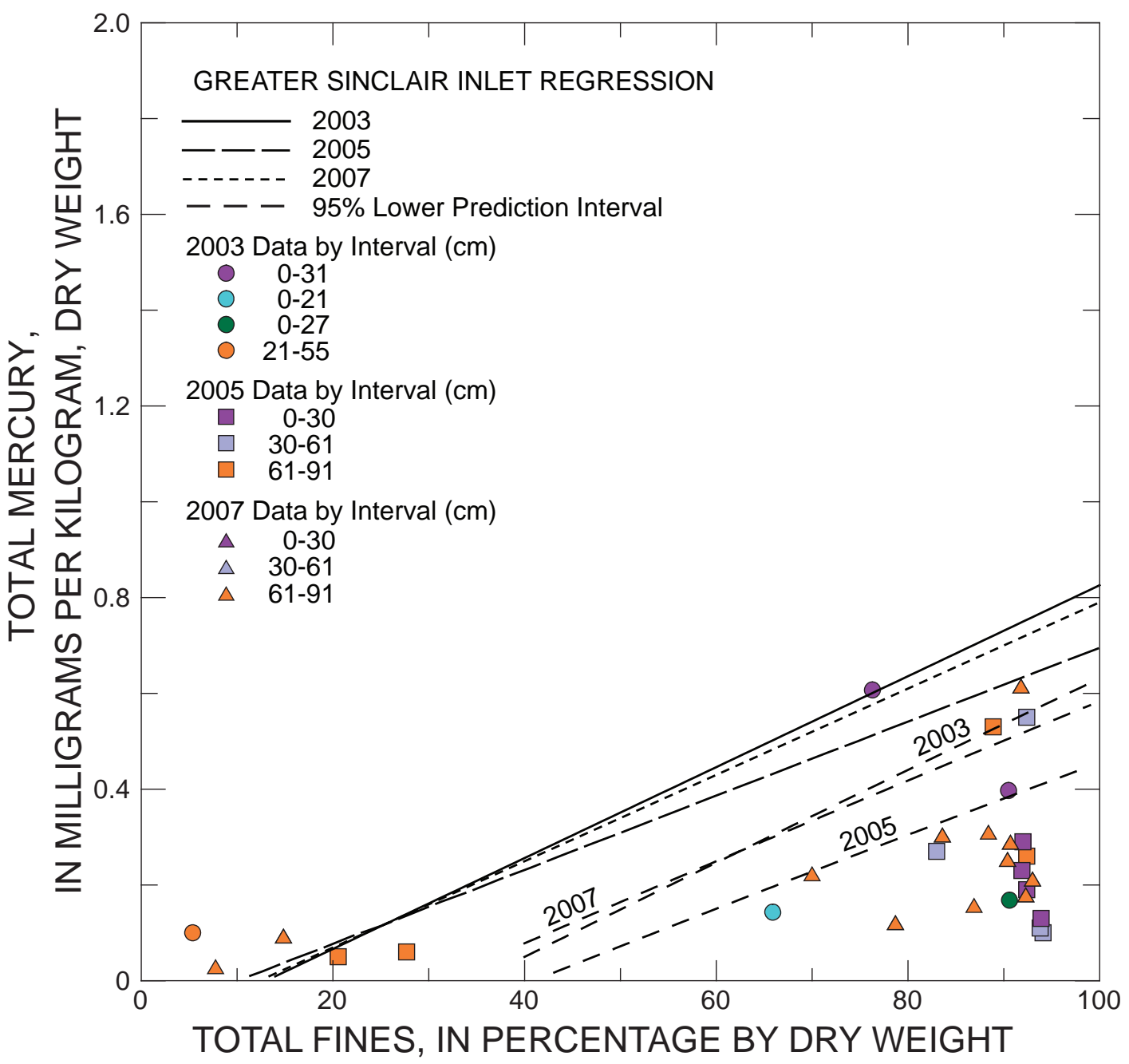

Figure 45. Total mercury concentration compared to total fines for surface and subsurface sediment core sections collected from the Confined Aquatic Disposal pit of the Bremerton naval complex, Washington, in 2003, 2005, and 2007 (table B11). The solid and dashed lines represent the regression lines and 95 percent lower prediction interval, respectively, for samples collected outside of the Bremerton naval complex, Washington, in 2003, 2005, and 2007 (figs. 33, 35, and 37; table 1). 
collected in 2003 and 2005 plot above the regression line of THg compared to TOC for the greater Sinclair Inlet samples (fig. 46). Only 5CP and 6CP samples were above the 95 percent confidence interval of greater Sinclair Inlet in both years. However, only the 2005 sample from cell 6CP was outside of the polygon representing locations in the vicinity of the CAD pit that were not remediated (not shown). THg sediment concentrations from the CP cells plotted against total fines show a similar pattern; the samples from 5CP and 6CP have higher THg concentrations than CAD pit apron samples and are higher than the upper 95 percent prediction interval (fig. 47). Similar to CAD pit apron sediment samples collected in 2001 after the CAD pit closure (spokes 4 and 5 in figs. 25-28), most samples are above the greater Sinclair Inlet regression lines but within the polygon representing locations in the area that were not remediated. These observations indicate that THg concentrations in the apron area are more a result of historical sediment conditions before the CAD pit was developed, rather than due the filling and closing of the CAD pit. Localized effects of the CAD pit operation seemed to be limited to the apron area on the northwest side of the pit (cells 5CP and 6CP).

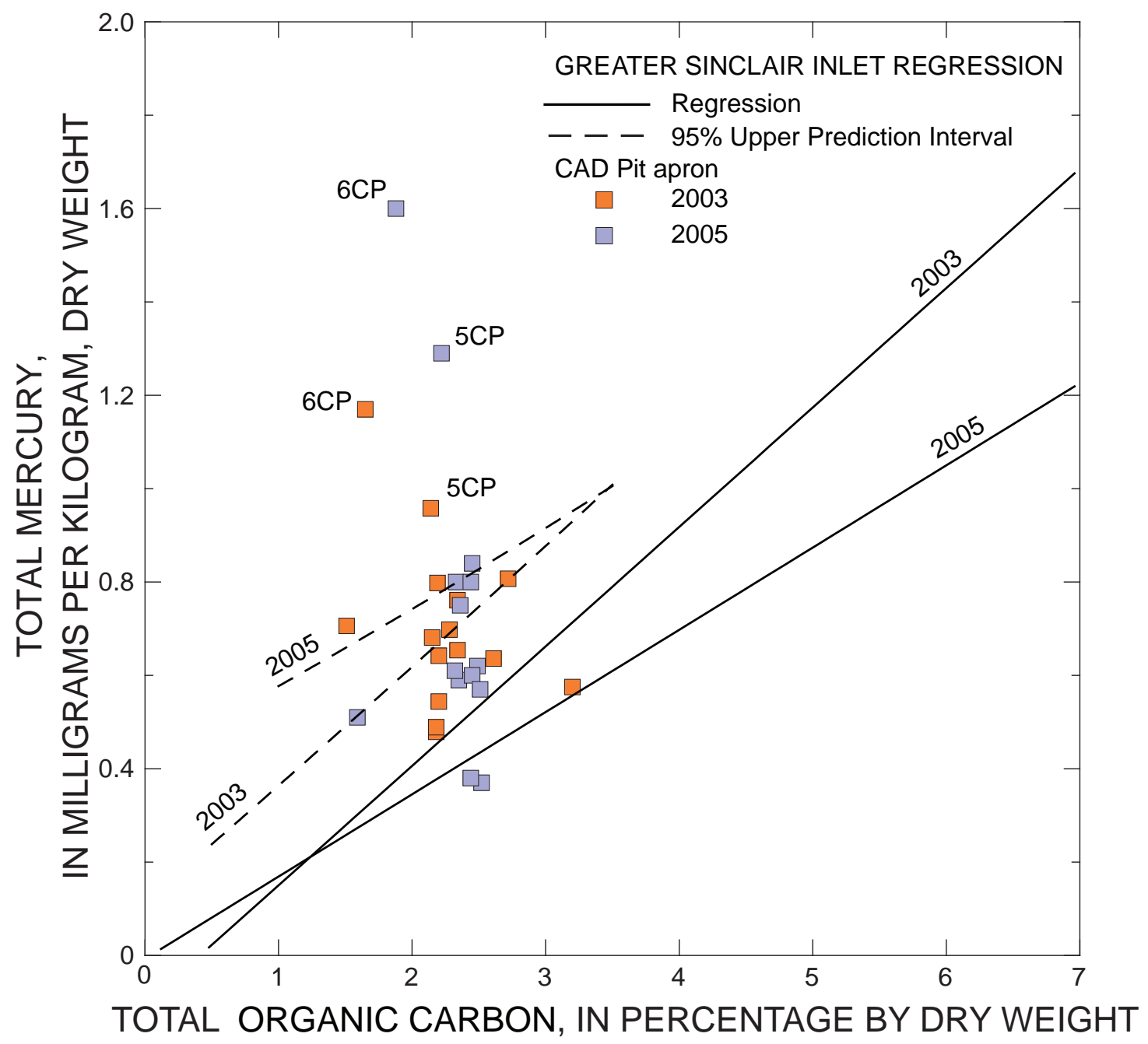

Figure 46. Total mercury concentration compared to total organic carbon for surface sediment $(0-10 \mathrm{~cm})$ collected from the Confined Aquatic Disposal pit apron of the Bremerton naval complex, Washington, in 2003 and 2005 (table B12). The sold and dashed lines represent the regression lines and upper 95 percent prediction intervals, respectively, for Sinclair Inlet samples collected in 2003 and 2005 outside of the Bremerton naval complex (figs. 32 and 34 , table 1). 


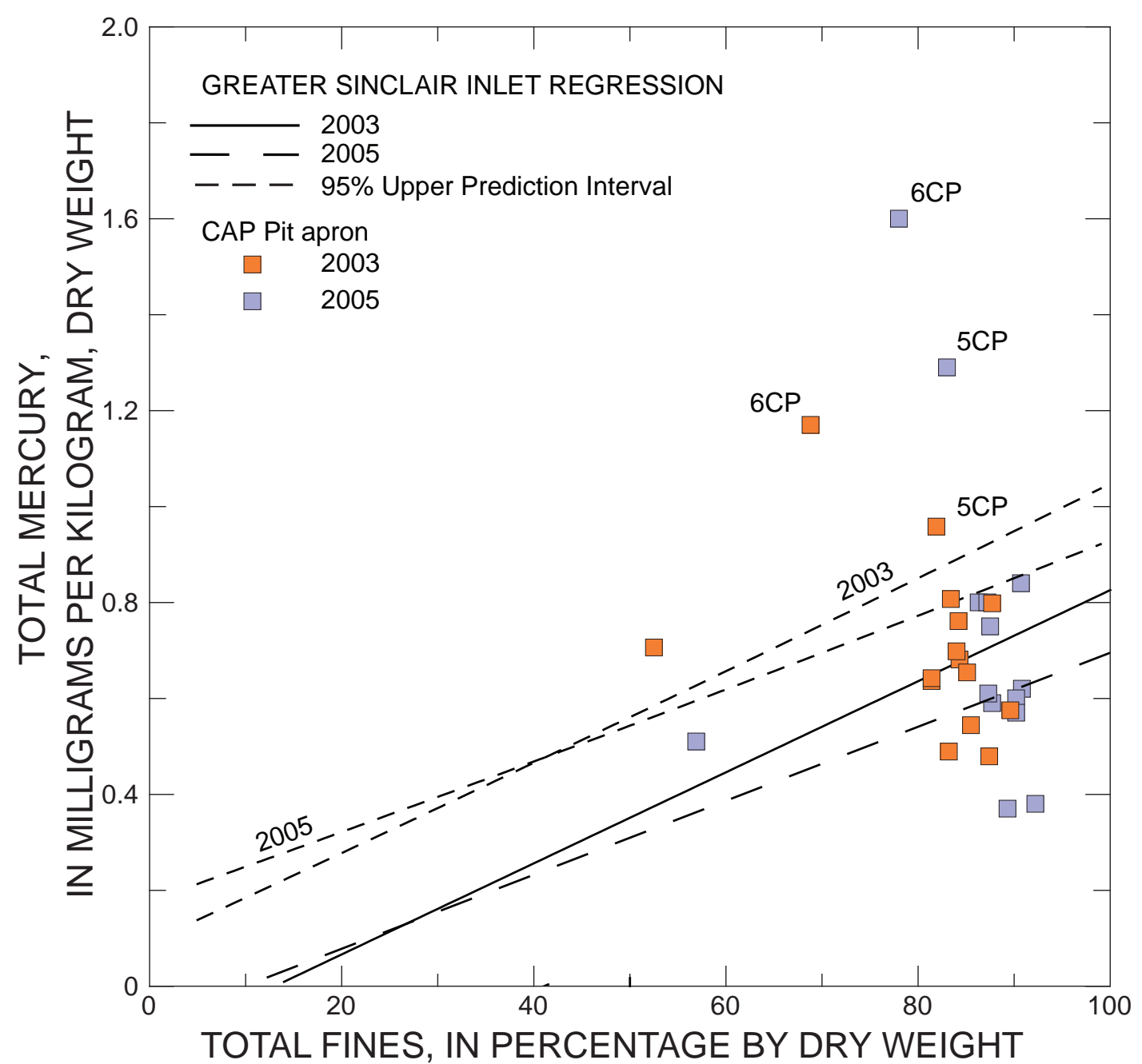

Figure 47. Total mercury concentration compared to total fines for surface sediment collected from the Confined Aquatic Disposal pit apron of the Bremerton naval complex, Washington, in 2003 and 2005 (table B12). The solid and dashed lines represent the regression lines and upper 95 percent prediction intervals, respectively, for Sinclair Inlet samples collected in 2003 and 2005 outside of the Bremerton naval complex (figs. 33 and 35 , table 1). 


\section{Sediment Transport Studies}

Four studies have examined resuspension of sediment into the water column and transport of suspended solids and resuspended sediments in Sinclair Inlet. In one study, an acoustic Doppler current profiler was deployed at three sites in Sinclair Inlet (fig. 1C) in February-March 1994 and July-August 1994. During periods of weak winds, tidal currents in Sinclair Inlet were determined to be weak with typical speeds of 5 to $10 \mathrm{~cm} / \mathrm{s}$ (Gartner and others, 1998). Tidal and residual currents were of the same magnitude and reversals of flow from the expected estuarine circulation were driven by wind events. On the station on the east side of Sinclair Inlet, a Geoprobe that contained a downward looking camera and transmissometers at different heights above the bed sediment also were deployed. The amplitudes of the fluctuations in the light transmissivity diminished away from the bed and suggest that material was resuspended from bottom sediment due to tidal stresses. The median total suspended solids concentrations in discrete water samples collected $0.5 \mathrm{~m}$ off the bottom ranged between 27 to $45 \mathrm{mg} / \mathrm{L}$ for the three sites. Although current-generated ripples were absent, the camera showed that small scale animal tracks about $1 \mathrm{~cm}$ in depth were erased during peak tidal currents. During the deployments, bottom sediment movement in Sinclair Inlet was minimal and critical shear velocities for resuspension only were achieved up to 1.5 hours per day.

The second study (U.S. Navy, 2007b) consisted of sampling of sediment and settling particles, deployment of current and turbidity meters, and Seaflume tests to assess sediment erosion rates and critical shear stress. In 2005, sediment (table B13) and settling particles (table 4) were sampled at specific locations within 500-ft cell 35 (fig. 31) that had undergone navigational dredging (labeled ND in table B13) and at specific locations within 500-ft cell 56 that had undergone remedial dredging (labeled RD in table B13) to determine if previously dredged areas were being recontaminated by the transport and deposition of sediment within the BNC. The definition of recontamination includes input from terrestrial sources and movement of nearby sediment that had not been dredged that contained legacy THg. Within each cell, two surface sediment samples $(0-10 \mathrm{~cm})$, and two sediment cores (RDC01 and -02 and NDC01 and -02 each with three 5-cm vertical sections) were collected. THg sediment concentrations and organic carbon content in the surface $0-5 \mathrm{~cm}$ sections were higher than the $10-15 \mathrm{~cm}$ sections in all four cores (figs. D16-D19). THg sediment concentrations plotted against TOC (fig. 48) show that the samples from cell 35 that had undergone navigational dredging were within the 95 percent prediction interval of the 2005 regression for samples collected from greater Sinclair Inlet during 2005 (fig. 34). In contrast, most of the samples from cell 56 that had undergone remedial dredging fall above the 95 percent prediction interval for greater Sinclair Inlet. A similar difference between cells 35 and 56 is observed for THg sediment concentrations plotted against total fines (fig. 49).
The elevated THg sediment concentrations at RD sites in cell 56 relative to the greater Sinclair Inlet 2005 trend line could have resulted from (1) conditions after the CERCLA dredging, (2) transport of organic-rich, fine-grained material from nearby regions of high THg concentrations due to tidal dispersion, (3) transport of nearby contaminated sediment during episodic events, such as propeller scour or wave action from extreme storms, or (4) recontamination from waterfront terrestrial stormwater discharges. The THg concentration of the subsurface DMMU within cell 56 (greater than $4 \mathrm{ft}$ below the sediment-water interface before dredging occurred) was $0.177 \mathrm{mg} / \mathrm{kg}$ (U.S. Navy, 1999), suggesting that clean material remained after CERCLA dredging.

As part of the 2005 Transport Study (U.S. Navy, 2007b), physical transport mechanisms were examined at sites within 1,500-ft cells 13 and 21 (site SI-01 and SI-02, respectively) and 500-ft cells 35 and 56 (sites SI-03 and SI-05, respectively) from June to August 2005 (figs. 30-31). Surface sediment $(0-10 \mathrm{~cm})$ was collected before the deployment of three sediment traps at each site (table 4). The sediment traps were recovered in August (deployment periods between 55 and 57 days). The total dry weight of settling particles of the individual traps at each site was measured and the contents of the three traps at each site were composited. TOC content, grain-size distributions, and THg concentration of solids of each composite were measured. When the THg sediment concentrations of settling solids are plotted against total fines (fig. 50), THg concentrations of both sediments and trap particles fall on or near the regression line for greater Sinclair Inlet surface sediment $(0-10 \mathrm{~cm})$ and within the 95 percent prediction interval for the regression of greater Sinclair Inlet sediments during 2005. Settling particles contained more organic carbon than sediment samples from the corresponding site (fig. 51). Both sediment and sediment trap material from the four sites were within the 95 percent prediction interval of the 2005 greater Sinclair Inlet regression of THg versus TOC.

For each site, the amounts of sediment settling into the three sediment traps were similar (standard deviations ranging from 4 percent at site SI-05 to 11 percent at site SI-01, table 4). When the amount of dry sediment collected by the traps was normalized by the duration of the deployment and the area over which sediment was collected $\left(182-\mathrm{cm}^{2}\right.$ opening), the mean mass rate of settling of dry solids at SI-01, SI-02 and SI-03 ranged between 3.38 and $3.77 \mathrm{~g} / \mathrm{cm}^{2} / \mathrm{yr}$. The mean mass settling rate at SI-05 was slightly higher at $5.50 \mathrm{~g} / \mathrm{cm}^{2} / \mathrm{yr}$.

Current meters and backscatter turbidity sensors were deployed in 1,500-ft cells 13 and 21 (site SI-01 and SI-02, respectively) and 500-ft cells 35 and 56 (site SI-03 and SI-05, respectively) from June to August 2005. Mean current speeds ranged between 3.3 and $4.3 \mathrm{~cm} / \mathrm{s}$, and maximum currents were $12.4,13.9,10.9$, and $12.1 \mathrm{~cm} / \mathrm{s}$, respectively. Biofouling of the optical backscatter sensors after 3 weeks in two sensors and malfunctioning data loggers limited the usefulness of the turbidity measurements. 
Table 4. Mean mass settling rate of dry solids in sediment traps deployed in 2005 (U.S. Navy Special Transport Study) and in 2002 (ENVironmental inVESTment Study) in Sinclair Inlet, Washington.

[Data: U.S. Navy program,U.S. Navy, 2007b; ENVVEST Program, http://www.ecy.wa.gov/programs/wq/tmdl/sinclair-dyes_inlets/sinclair_cd/DATA/2002_ Data/Sediment_Traps_2002/Metals/Sediment_Trap_Data_plots.pdf. Locations for ENVVEST traps are shown in figures $1 C$ and 2, and the locations of the 1,500-foot grid and 500-foot grid cells are shown in figures 30 and 31, respectively. Abbreviations ENVVEST, ENVironmental inVESTment; LTMP, LongTerm Monitoring Program; CERCLA, Comprehensive Environmental Response, Compensation, and Liability Act; PSNS, Puget Sound Naval Shipyard; mg/kg, milligram per kilogram; g/ $\mathrm{cm}^{2} / \mathrm{yr}$, gram per square centimeter per year; RPD, relative percent difference; RSD, relative standard deviation; NA, not applicable; -, no data]

\begin{tabular}{|c|c|c|c|c|c|c|c|c|c|c|c|c|c|c|}
\hline \multirow{2}{*}{ Program } & \multirow{2}{*}{$\begin{array}{c}\text { Sample } \\
\text { identifier }\end{array}$} & \multirow{2}{*}{$\begin{array}{c}\text { Sediment } \\
\text { trap } \\
\text { location }\end{array}$} & \multirow{2}{*}{$\begin{array}{l}\text { Start } \\
\text { date }\end{array}$} & \multirow{2}{*}{$\begin{array}{l}\text { End } \\
\text { date }\end{array}$} & \multirow{2}{*}{ Remediation } & \multirow{2}{*}{$\begin{array}{l}500- \\
\text { foot } \\
\text { grid } \\
\text { cell } \\
\text { no. }\end{array}$} & \multirow{2}{*}{$\begin{array}{c}1,500- \\
\text { foot } \\
\text { grid } \\
\text { cell } \\
\text { no. }\end{array}$} & \multirow{2}{*}{$\begin{array}{c}\text { Total } \\
\text { mercury } \\
\text { (mg/ } \\
\text { kg, dry } \\
\text { weight) }\end{array}$} & \multirow{2}{*}{$\begin{array}{c}\text { Total } \\
\text { aluminum } \\
\text { (mg/kg, } \\
\text { dry weight) }\end{array}$} & \multirow{2}{*}{$\begin{array}{c}\text { Total } \\
\text { organic } \\
\text { carbon } \\
\text { (percen- } \\
\text { tage by dry } \\
\text { weight) }\end{array}$} & \multirow{2}{*}{$\begin{array}{c}\text { Total } \\
\text { fines } \\
\text { (percen- } \\
\text { tage } \\
\text { by dry } \\
\text { weight) }\end{array}$} & \multicolumn{3}{|c|}{$\begin{array}{l}\text { Particle mass } \\
\text { settling rate }\end{array}$} \\
\hline & & & & & & & & & & & & $\begin{array}{c}\text { Mean } \\
\left(\mathbf{g} / \mathrm{cm}^{2} /\right. \\
\mathbf{y r})\end{array}$ & RPD & $\begin{array}{c}\text { RSD } \\
\text { (percent) }\end{array}$ \\
\hline \multicolumn{15}{|c|}{ Inside Bremerton naval complex } \\
\hline ENVVEST & Trap 2 & $\begin{array}{l}\text { Bremerton } \\
\text { wastewater } \\
\text { treatment } \\
\text { facility outfall }\end{array}$ & 04-15-02 & 06-13-02 & $\begin{array}{c}\text { Not } \\
\text { remediated }\end{array}$ & 1 & NA & 0.615 & 46,600 & - & - & 4.26 & 0.8 & \\
\hline $\begin{array}{l}\text { U.S. Navy, } \\
\text { LTMP }\end{array}$ & SI-03 & $\begin{array}{l}\text { 500-foot grid } \\
\text { cell } 35\end{array}$ & 06-08-05 & 08-04-05 & $\begin{array}{l}\text { CERCLA } \\
\text { dredging }\end{array}$ & 35 & NA & .71 & - & 5.18 & 95.7 & 3.58 & & 6 \\
\hline $\begin{array}{l}\text { U.S. Navy, } \\
\text { LTMP }\end{array}$ & SI-05 & $\begin{array}{l}\text { 500-foot grid } \\
\text { cell } 56\end{array}$ & 06-08-05 & 08-04-05 & $\begin{array}{l}\text { CERCLA } \\
\text { dredging }\end{array}$ & 56 & NA & .73 & - & 4.83 & 93.2 & 5.50 & & 4 \\
\hline \multicolumn{15}{|c|}{ Inside Sinclair Inlet study area of 1,500-foot grid } \\
\hline ENVVEST & Trap 1 & Gorst & $04-15-02$ & 06-11-02 & $\begin{array}{l}\text { Not } \\
\text { remediated }\end{array}$ & NA & 9 & 0.583 & 44,000 & - & - & 5.78 & 4.1 & \\
\hline ENVVEST & Trap 3 & $\begin{array}{l}\text { East Sinclair off } \\
\text { PSNS }\end{array}$ & $04-17-02$ & 06-13-02 & $\begin{array}{l}\text { Near } \\
\text { navigation } \\
\text { dredging }\end{array}$ & NA & ${ }^{1} 21$ & 0.705 & 60,500 & - & - & 7.45 & 0.1 & \\
\hline ENVVEST & Trap 4 & $\begin{array}{l}\text { Port Orchard } \\
\text { Marina }\end{array}$ & 04-18-02 & 06-13-02 & $\begin{array}{l}\text { Not } \\
\text { remediated }\end{array}$ & NA & 23 & 0.317 & 32,800 & - & - & 0.90 & 17.4 & \\
\hline $\begin{array}{l}\text { U.S. Navy, } \\
\text { LTMP }\end{array}$ & SI-01 & $\begin{array}{l}\text { 1,500-foot grid } \\
\text { cell } 13\end{array}$ & 06-07-05 & 08-04-05 & $\begin{array}{l}\text { Not } \\
\text { remediated }\end{array}$ & NA & 22 & 0.506 & - & 4.97 & 92.6 & 3.77 & & 11 \\
\hline $\begin{array}{l}\text { U.S. Navy, } \\
\text { LTMP }\end{array}$ & SI-02 & $\begin{array}{l}\text { 1,500-foot grid } \\
\text { cell }{ }^{1} 21\end{array}$ & 06-07-05 & 08-04-05 & $\begin{array}{l}\text { Not } \\
\text { remediated }\end{array}$ & NA & 13 & .61 & - & 4.88 & 90.1 & 3.38 & & 6 \\
\hline \multicolumn{15}{|c|}{ Outside of Sinclair Inlet study area of 1,500-foot grid } \\
\hline ENVVEST & Trap 5 & $\begin{array}{l}\text { Port Orchard } \\
\text { wastewater } \\
\text { treatment } \\
\text { facility outfall }\end{array}$ & 04-17-02 & 06-11-02 & $\begin{array}{l}\text { Not } \\
\text { remediated }\end{array}$ & NA & NA & 0.248 & 44,500 & - & - & 9.30 & 0.2 & \\
\hline
\end{tabular}

\footnotetext{
${ }^{1}$ Just outside of the northeastern facing border of 1,500-foot grid cell 21 and adjacent to several navigation dredging areas.
} 


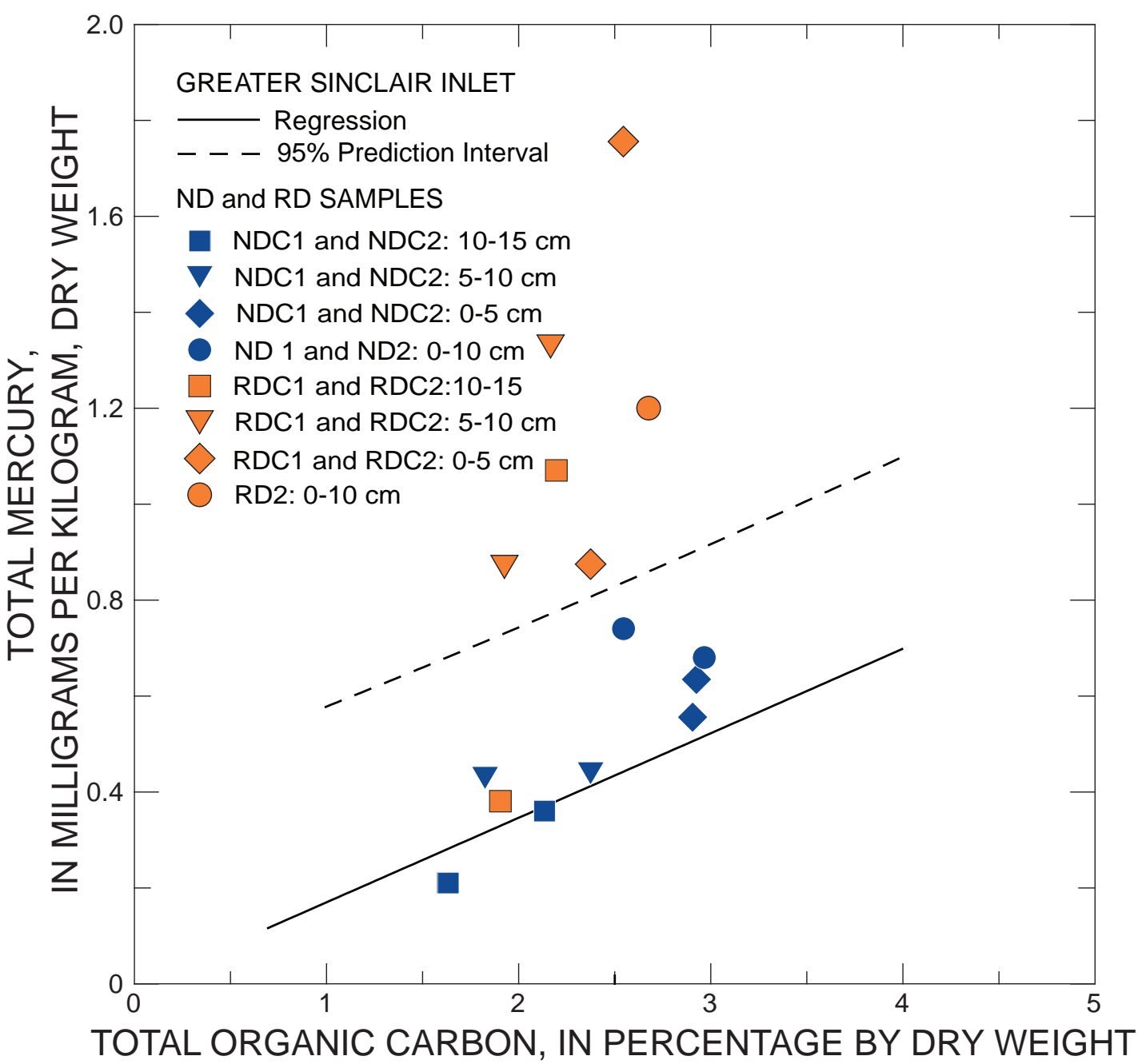

Figure 48. Total mercury concentration compared to total organic carbon in the surface sediment (0-10 cm; ND1 and ND2) and cores (NDC1 and NDC2) from the 500-ft cell 35 (fig. 31) that had undergone navigational dredging (ND) and in the surface sediment (0-10 cm; RD1 and RD2) and cores (RDC1 and RDC2) from 500-ft cell 56 that had undergone remedial dredging (RD) collected as part of the 2005 transport study (table B13). The solid and dashed lines represent the regression line and upper 95 percent prediction interval for greater Sinclair Inlet, Washington, samples collected in 2005 outside of the Bremerton naval complex (fig. 34 and table 1). 


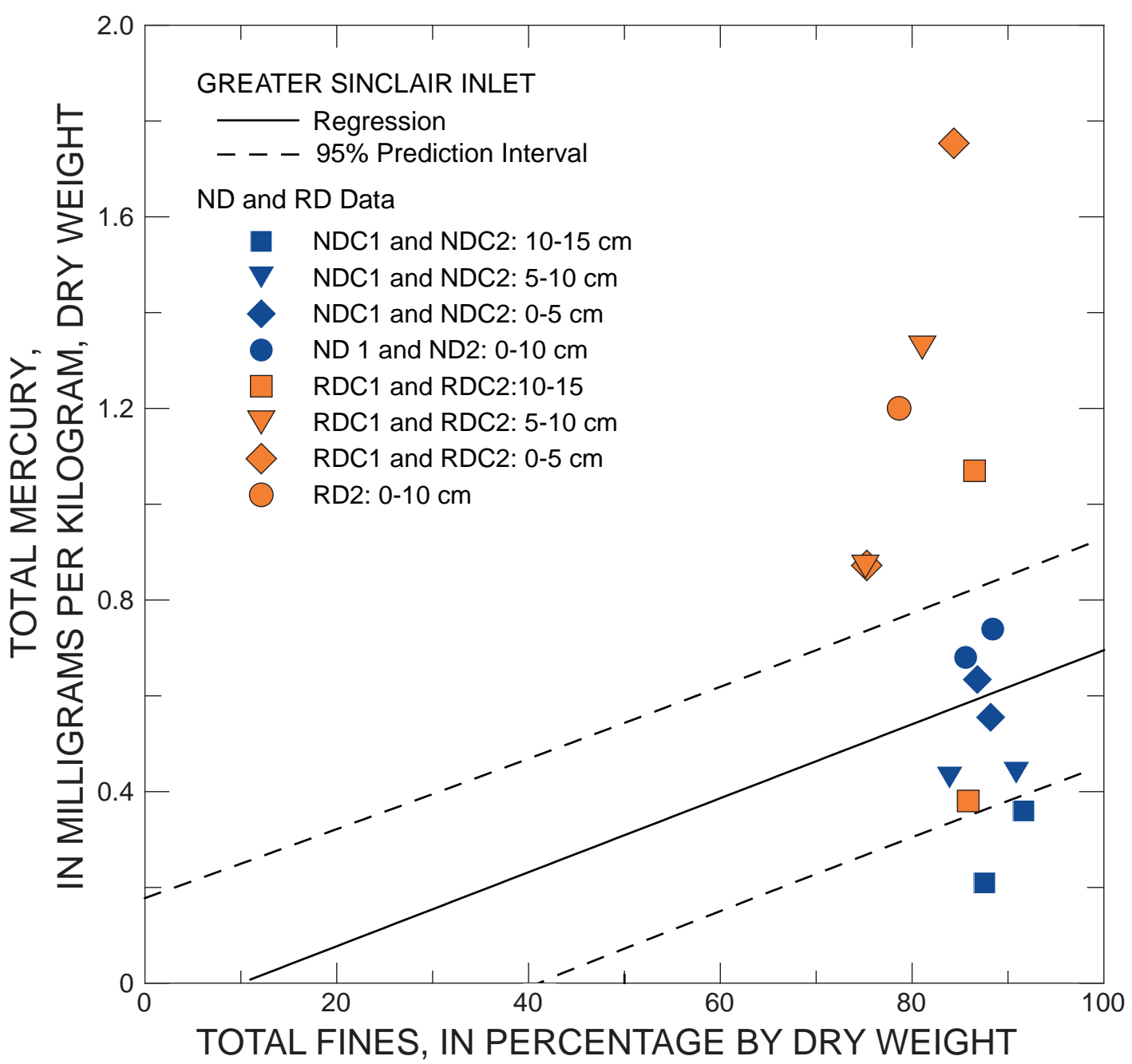

Figure 49. Total mercury concentration compared to total fines in the surface sediment (0-10 cm; ND-01 and ND-02) and cores (NDC1 and NDC2) from 500-ft cell 35 (fig. 31) that had undergone navigational dredging (ND) and in the surface sediment $(0-10 \mathrm{~cm}$; $\mathrm{RD}-01$ and RD-02) and cores (RDC1 and RDC2) from the 500-ft cell 56 that had undergone remedial dredging (RD) collected as part of the 2005 transport study (table B13). The solid and dashed lines represent the regression line and upper 95 percent prediction interval for greater Sinclair Inlet, Washington, samples collected in 2005 outside of the Bremerton naval complex (fig. 35 and table 1). 


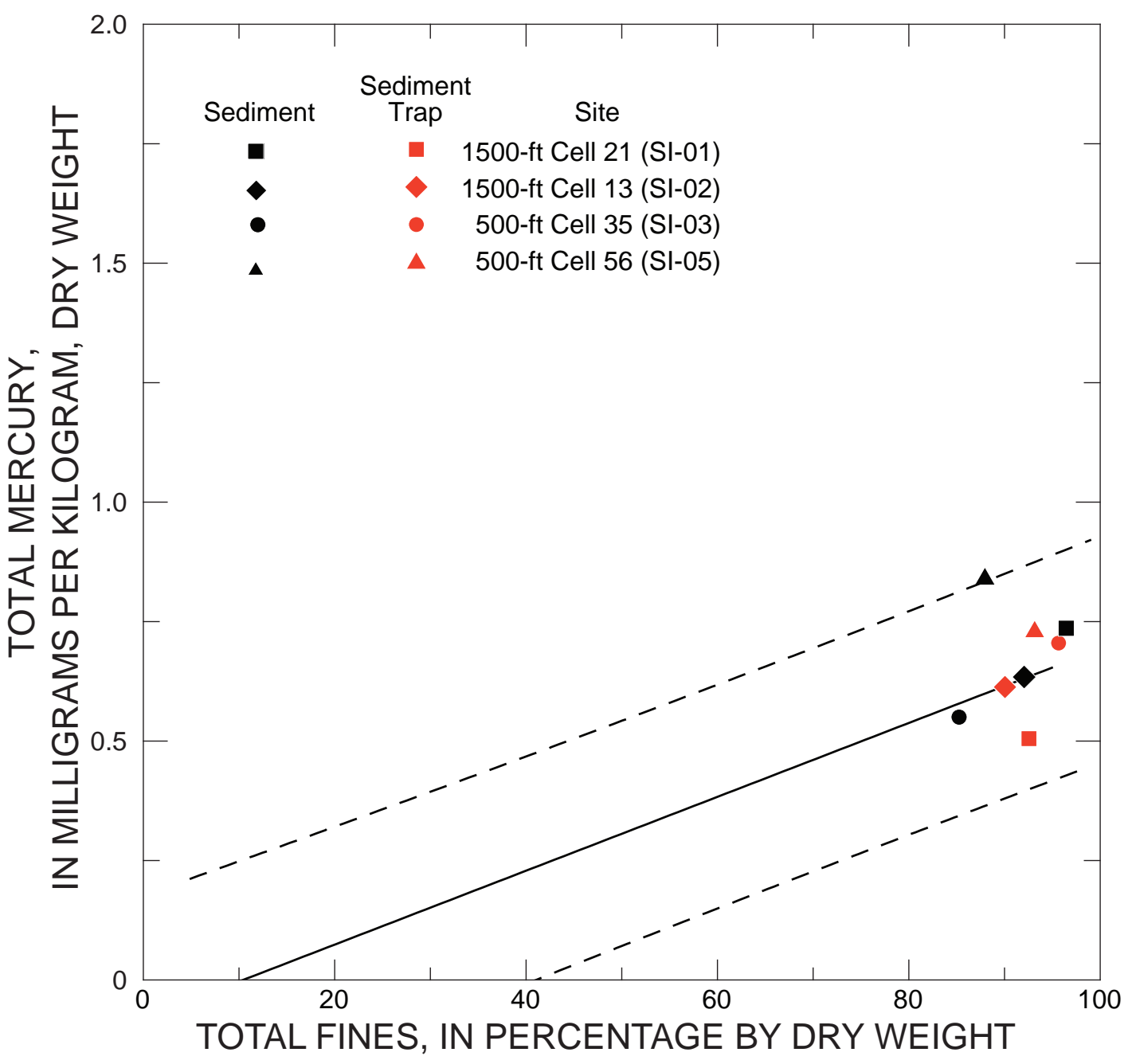

Figure 50. Total mercury concentration compared to total fines (tables 4 and B13) in surface sediment in June 2005 (black symbols) and particles settling into sediment traps between June and August 2005 (red symbols) in 1,500-ft grid cells 13 and 21 in figure 30 (SI-01 and SI-02, respectively), and in 500-ft grid cells 35 and 56 in figure 31 (SI-03 and SI-05, respectively). The solid and dashed lines represent the regression line and 95 percent prediction interval for greater Sinclair Inlet, Washington, samples collected in 2005 outside of the Bremerton naval complex (fig. 35 and table 1). 


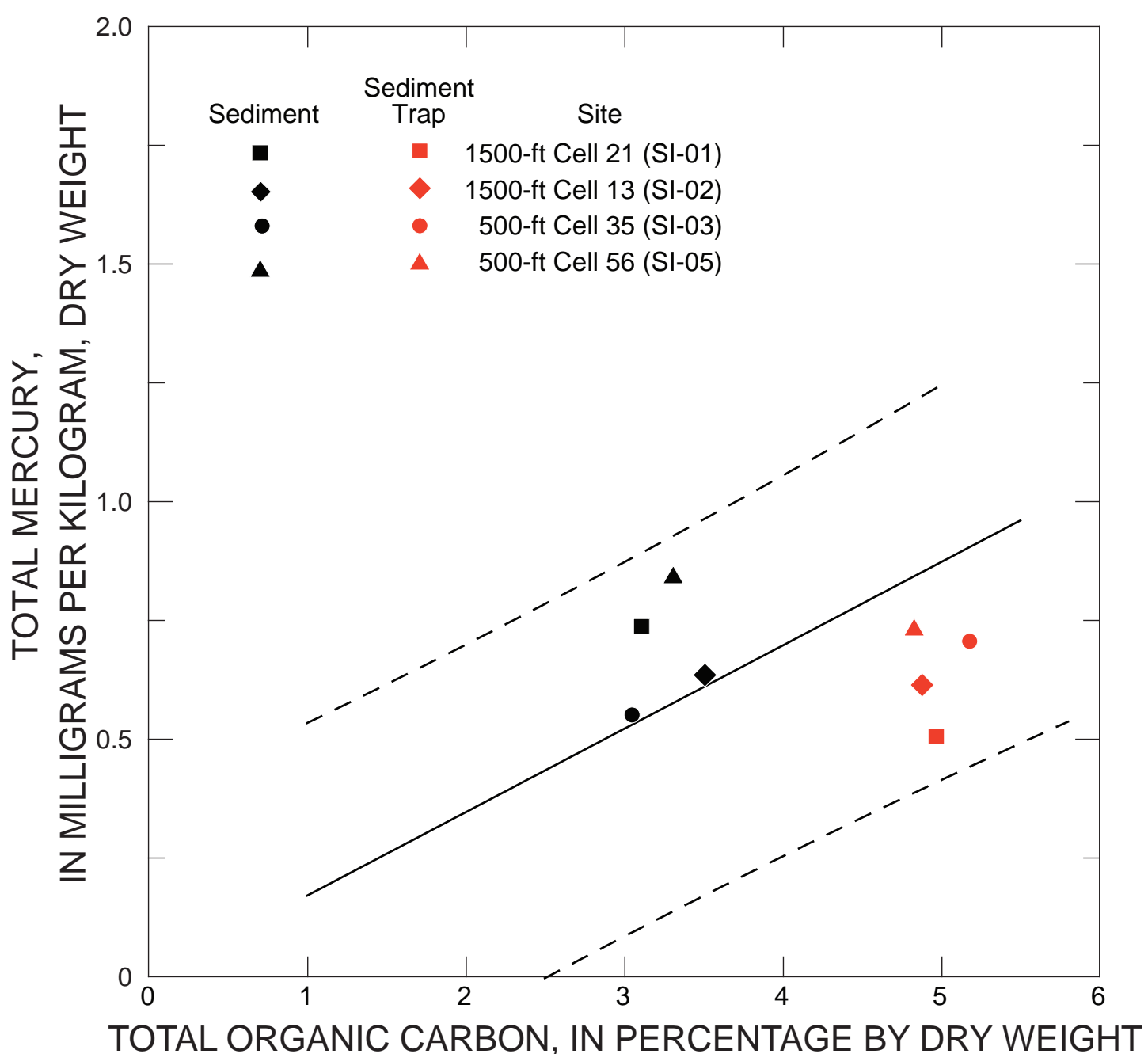

Figure 51. Total mercury concentration compared to total organic carbon (tables 4 and B13) in surface sediment in June 2005 and particles settling into sediment traps between June and August 2005 in 1,500-ft grid cells 13 and 21 in figure 30 (SI-01 and SI-02, respectively), and in 500-ft grid cells 35 and 56 in figure 31 (SI-03 and SI-05, respectively). The solid and dashed lines represent the regression line and 95 percent prediction interval for greater Sinclair Inlet, Washington, samples collected in 2005 outside of the Bremerton naval complex (fig. 34 and table 1. 
When sensors were judged to be operating properly, turbidity was generally below 10 nephelometric turbidity units (NTU), but several spikes in turbidity occurred in central Sinclair Inlet (1,500-ft grid cell 21$)$ that were unrelated to current speed. Similar to Gartner and others (1998), the U.S. Navy (2007b) concluded that sediment erosion and transport within the OU B Marine and Sinclair Inlet only occurs to a limited extent. In contrast, the critical shear stress measured by Seaflume tests were an order of magnitude higher than bed shear stresses inferred from Sinclair Inlet current meter measurements. The Seaflume tests seem to suggest that Sinclair Inlet sediments did not erode during conditions typical of the current meter deployments.

The third study focusing on bottom sediment scour by conventional propellers and cycloidal thrusters (U.S. Navy, 2008b) provides some insights into the mechanisms that transport sediments within BNC and possibly could be responsible for the recontamination of dredged areas observed in the 2005 Transport Study (U.S. Navy, 2007b). Bottom sediment scour lines observed by high resolution multibeam sonar ranged in depths from $6 \mathrm{~cm}$ to $24 \mathrm{~cm}$. Particles with a diameter of $25 \mu \mathrm{m}$ from the sediment of the scoured area were predicted to travel up to $3 \mathrm{~km}$ when suspended $12 \mathrm{~m}$ into the water column. Combined with the Seaflume sediment erosion tests, hydraulic modeling of the near-bottom currents (45-100 cm/s) from conventional propellers and the cycloidal thruster, used on water tractors operating within the BNC, predicted bottom sediment scour depths ranging from $0.3 \mathrm{~cm}$ to $18 \mathrm{~cm}$, respectively. This level of scour of bottom sediments and resuspension of bottom sediments readily can explain temporal trends in the sediment chemistry of BNC following the significant dredging that occurred in 1994 and 2000-01.

The fourth set of studies on sediment transport (McLaren, 2008) examined changes in the grain-size distribution between May 1998, October 2003, and May 2007 for about 100 pairs of sediment samples that were collected within $250 \mathrm{~m}$ of each other (McLaren, 2004). Between 1998 and 2003, the grainsize distribution in Sinclair Inlet changed significantly from medium silt to coarse silt (mean mean grain size decreased from 5.92 phi in May 1998 to 4.96 phi in October 2003). Remedial and navigational dredging during 2001, which removed fine-grained sediments and exposed underlying coarser glacial, is a possible cause of this coarsening of sediments throughout Sinclair Inlet (McLaren, 2004). The May 2007 sediments compared to nearby sediments collected in May 1998 showed less coarsening of the sediments (mean mean grain size decreased from 5.92 phi in May 1998 to 5.23 phi in May 2007) than sediments between May 1998 and October 2003. In greater Sinclair Inlet and the BNC, sediment coarser than very fine sand (phi of 4) was present to a lesser extent in May 2007 relative to October 2003, and more finer grained sediment near the peak of grain-size distribution (phi of about 6.5) was present in May 2007 relative to October 2003. Comparison between May 1998 and May 2007 clearly indicates coarsening of the sediment occurred during the interval that major dredging occurred (2000-2001).

Although recovery of Sinclair Inlet between October 2003 and May 2008 from prior dredging may be occurring (McLaren, 2008), the effects of seasonal effects between October and May sampling cannot be ruled out.

\section{Puget Sound Ambient Monitoring Program}

Puget Sound Assessment and Monitoring Program (PSAMP) of the Marine Sediment Monitoring Team of the Washington State Department of Ecology (Ecology) conducts monitoring of Puget Sound sediments to provide regional and ecosystem-wide information on Puget Sound sediment quality to environmental managers and decision-makers.

\section{Temporal Trends}

The Long-Term Temporal Monitoring Program was established as part of PSAMP to record sediment conditions for various habitats and geographic locations throughout Puget Sound and to identify if any significant changes in physical, chemical, and biological sediment parameters occurred over time. The results of the initial 1989 sampling of marine sediment in Sinclair Inlet by the PSAMP partially were responsible for initiating the 1990 Site Investigation. The Sinclair Inlet station for PSAMP's Long-Term Temporal Monitoring is located on the border of the BNC in the southwest corner of the CAD pit apron area (fig. 20). The 1989 data showed that THg sediment concentrations at the PSAMP Long-Term Temporal Monitoring station in Sinclair Inlet were more than five times the concentrations of other comparable industrial embayments (fig. 52). In general, THg concentrations at the Sinclair Inlet station ranged from 0.5 to $0.9 \mathrm{mg} / \mathrm{kg}$ and were at least three times larger than any other Long-Term Temporal Monitoring station in Puget Sound (Sediment Database (PSAMPSedComponentdatabase.zip) accessed at http://www.ecy.wa.gov/programs/eap/psamp/ index.htm). Although no temporal trends in THg sediment concentrations were detected (Dutch and others, 2005), the $2005 \mathrm{THg}$ concentrations were the highest of the 16-year sampling history at Sinclair Inlet Long-Term Temporal Monitoring station.

Because TOC and total fines previously have been shown to be important in controlling THg concentrations in Sinclair Inlet, the temporal relationships between THg concentrations and TOC and total fines are shown in figure 53. 


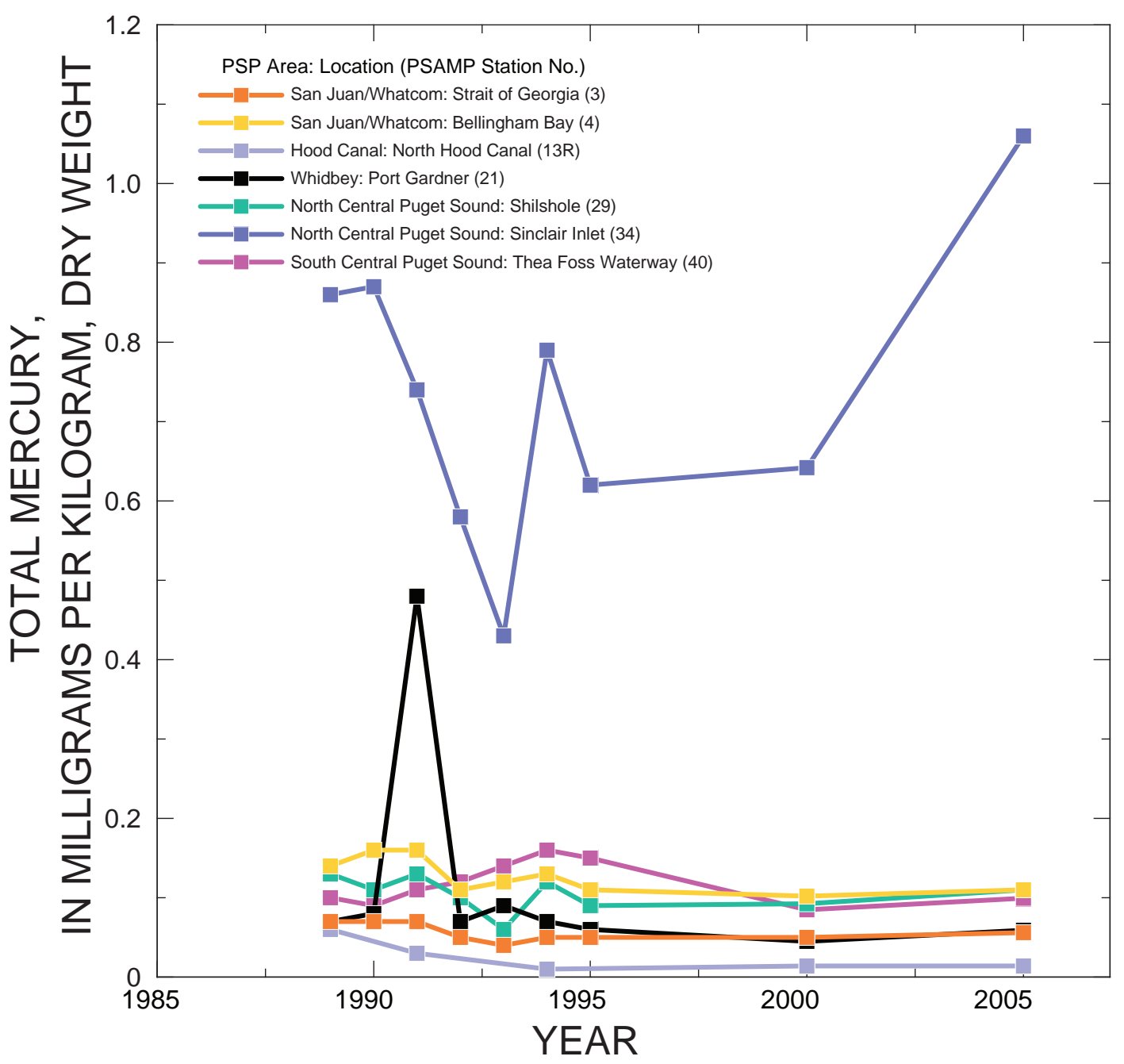

Figure 52. Total mercury concentrations in surface sediment $(0-3 \mathrm{~cm})$ at seven LongTerm Temporal Monitoring stations of the Puget Sound Ambient Monitoring Program of Washington, sampled between 1989 and 2005 arranged by their Puget Sound Partnership Area. The Sediment Database (PSAMPSedComponentdatabase.zip) was accessed at http://www.ecy.wa.gov/programs/eap/psamp/index.htm. 


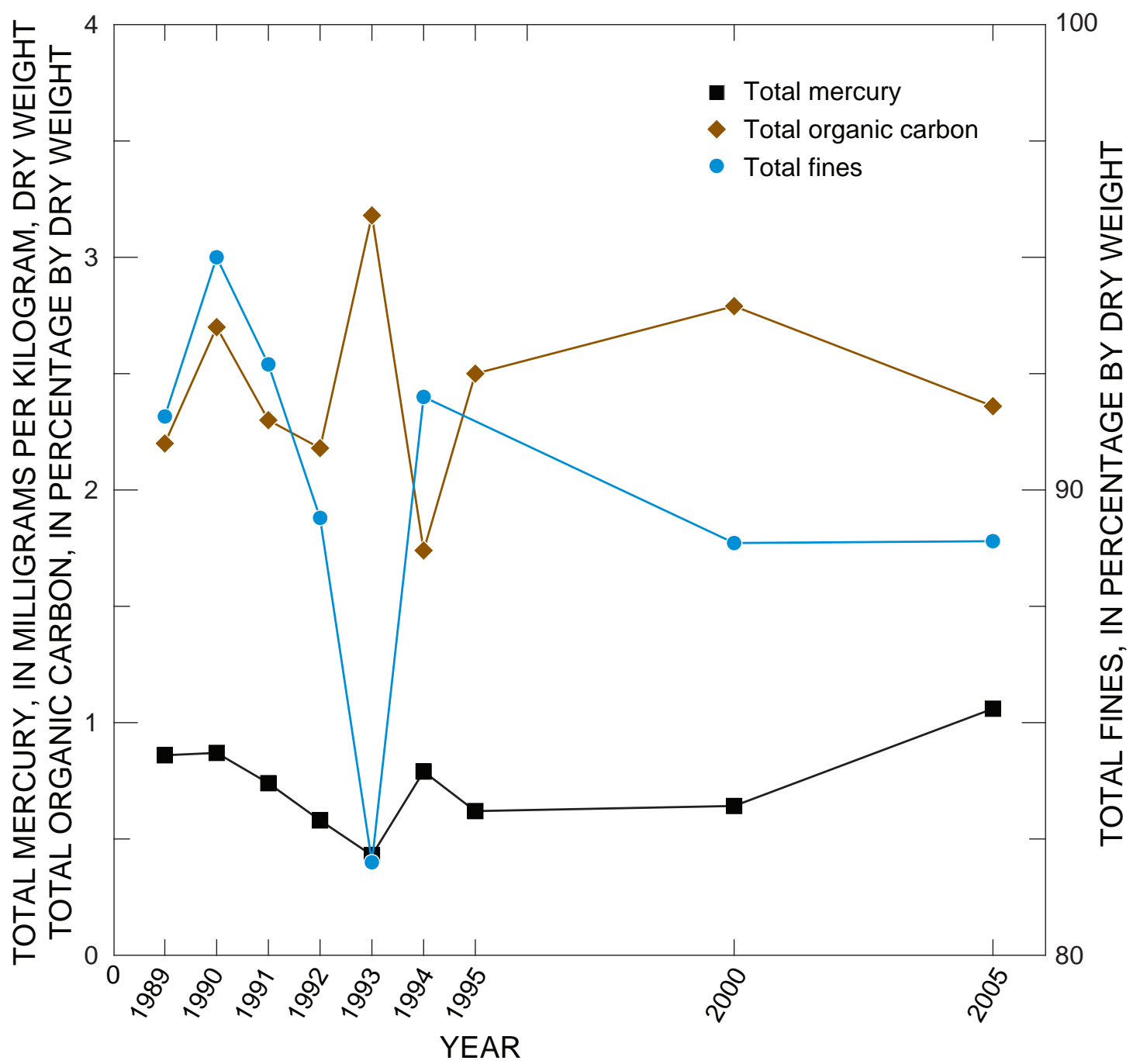

Figure 53. Total mercury concentrations, total organic carbon, and total fines in surface sediment $(0-3 \mathrm{~cm})$ at the Sinclair Inlet Long-Term Temporal Monitoring station 34 of the Puget Sound Ambient Monitoring Program of Washington, sampled between 1989 and 2005. The Sediment Database (PSAMPSedComponentdatabase.zip) was accessed at http://www.ecy.wa.gov/programs/eap/psamp/index.htm. 
The continuous decrease in THg concentrations between 1990 and 1993, and the increase between 1993 and 1994 seemed to be related to changes in grain-size distribution. However, the 2005 increase in THg sediment concentrations did not seem to be related to either TOC or total fines. Because the THg sediment concentrations in the area off OU A prior to remediation were variable and the Long-Term Temporal Monitoring Sinclair Inlet station is near the CAD pit, the entire Sinclair Inlet Long-Term Temporal Monitoring data set was compared to the sediment conditions in the area before remediation. The 1989 to 2005 PSAMP Sinclair Inlet THg sediment data plotted against TOC (fig. 54) show that all of the Long-Term Temporal Monitoring samples fall within the polygon that represents THg sediment data collected by the U.S. Navy between 1993 and 2000 at locations that were not remediated. When THg sediment data are plotted against total fines (fig. 55), some of the Long-Term Temporal Monitoring data fall below the polygon representing THg sediment data collected by the U.S. Navy between 1993 and 2000 at locations that were not remediated. Thus, it appears that much of the variability of the PSAMP THg data is due to the variability associated with sampling Long-Term Temporal Monitoring site and not due to general temporal trends. Ecology also concluded that there was no significant temporal trend in THg at the PSAMP Sinclair Inlet site.

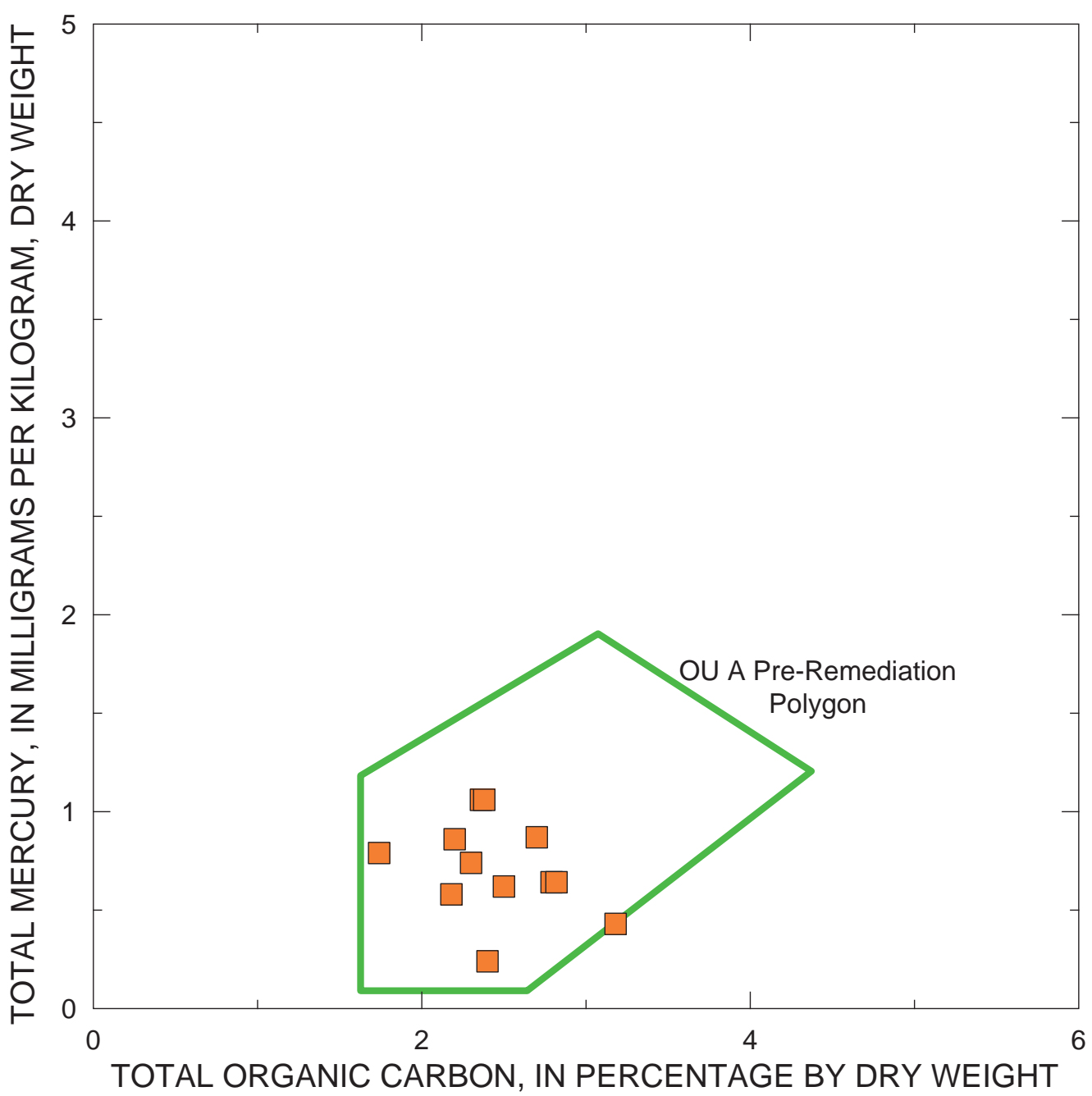

Figure 54. Total mercury concentrations compared to total organic carbon for surface sediment $(0-3 \mathrm{~cm})$ at the Sinclair Inlet Long-Term Temporal Monitoring station 34 of the Puget Sound Ambient Monitoring Program of Washington, sampled between 1989 and 2005. The Sediment Database (PSAMPSedComponentdatabase.zip) was accessed at http://www.ecy.wa.gov/programs/eap/psamp/index.htm. The polygon represents data from locations near the Confined Aquatic Disposal pit that were not remediated (fig. 21). 


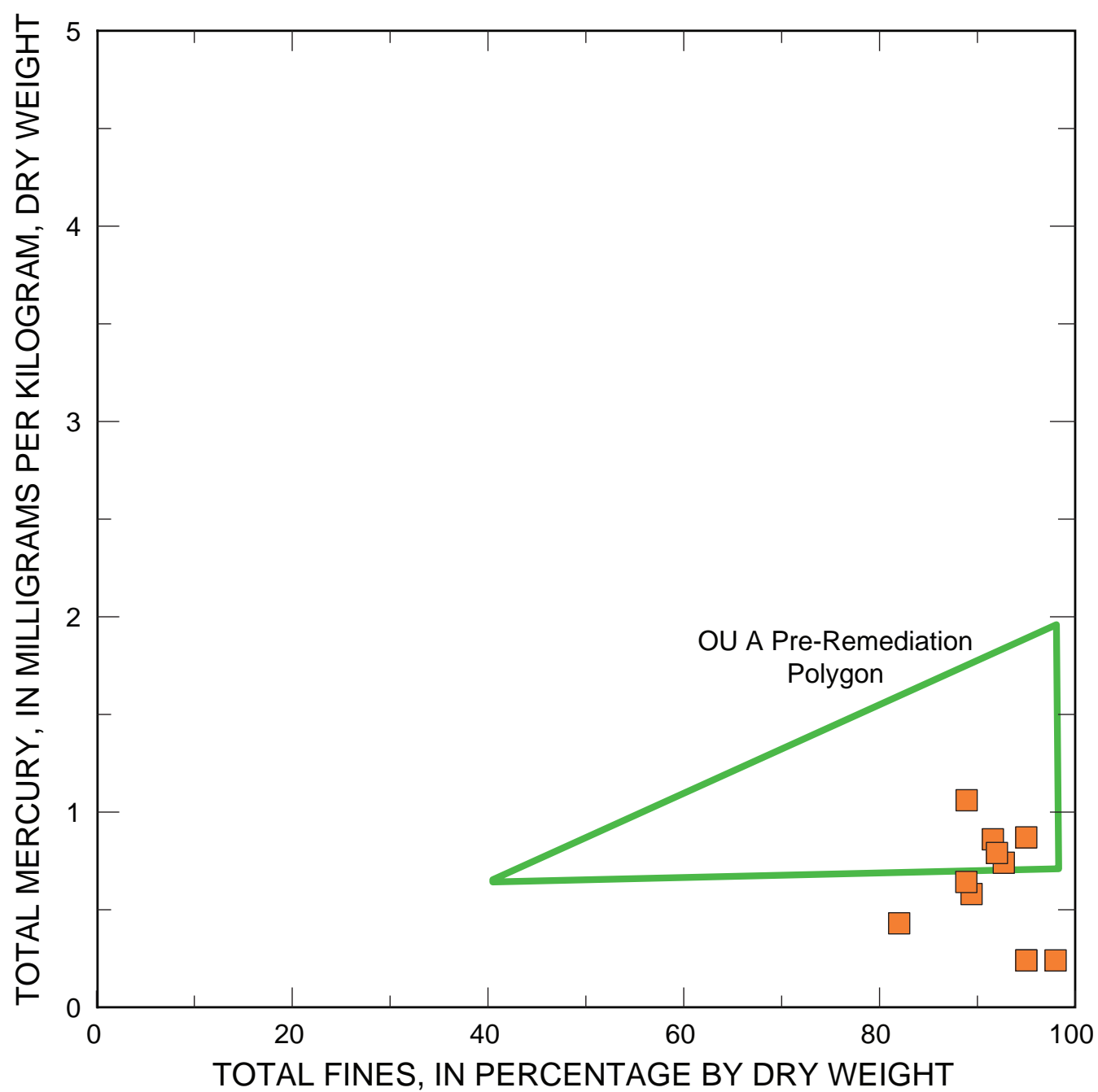

Figure 55. Total mercury concentrations compared to total fines for surface sediment $(0-3 \mathrm{~cm})$ at the Sinclair Inlet Long-Term Temporal Monitoring station 34 of the Puget Sound Ambient Monitoring Program of Washington, sampled between 1989 and 2005.

The Sediment Database (PSAMPSedComponentdatabase.zip) was accessed at http://www.ecy.wa.gov/programs/eap/psamp/index.htm. The polygon represents data from locations near the Confined Aquatic Disposal pit that were not remediated (fig. 22). 


\section{Embayment Studies}

Use of a single station for long-term monitoring within an embayment can make interpretation of the results difficult, especially if the one station representing the embayment is located near a pollution point source with inputs that vary with time, or if the station lies within an area with strong gradients for the constituent of interest. PSAMP completed three random stratified samplings between 1997 and 1999 that examined distribution of contaminants in surface sediment $(0-3 \mathrm{~cm})$ within the boundaries of numerous embayments and sub-regions of Puget Sound (Long and others, 1999, 2000, 2002). These studies allow direct comparisons of the offshore distribution of THg in sediment of Sinclair Inlet with the general distribution of THg in offshore stations (table B14) of several urban embayments within Puget Sound. The PSAMP data for Sinclair Inlet first is compared with the U.S. Navy data for Sinclair Inlet. The eight samples collected by PSAMP in 1998 from offshore regions of Sinclair Inlet fell into two distinct groups (fig. 56): one represented by four sites with low TOC ( $<0.05$ percent by weight) and one group represented by four sites with high TOC (3-4 percent by weight). The THg sediment concentration of the high TOC Sinclair Inlet group was in the top 10 percent of samples measured by PSAMP. The four high TOC samples collected in 1998 by PSAMP were between the regression lines of THg versus TOC represented by the 1994 Remediation Investigation data and the 2007 data from the offshore LTMP 1,500-ft grid sampling. Although the PSAMP and U.S. Navy samples were collected at different times and used different depth intervals for surface sediment, the data generally were comparable.

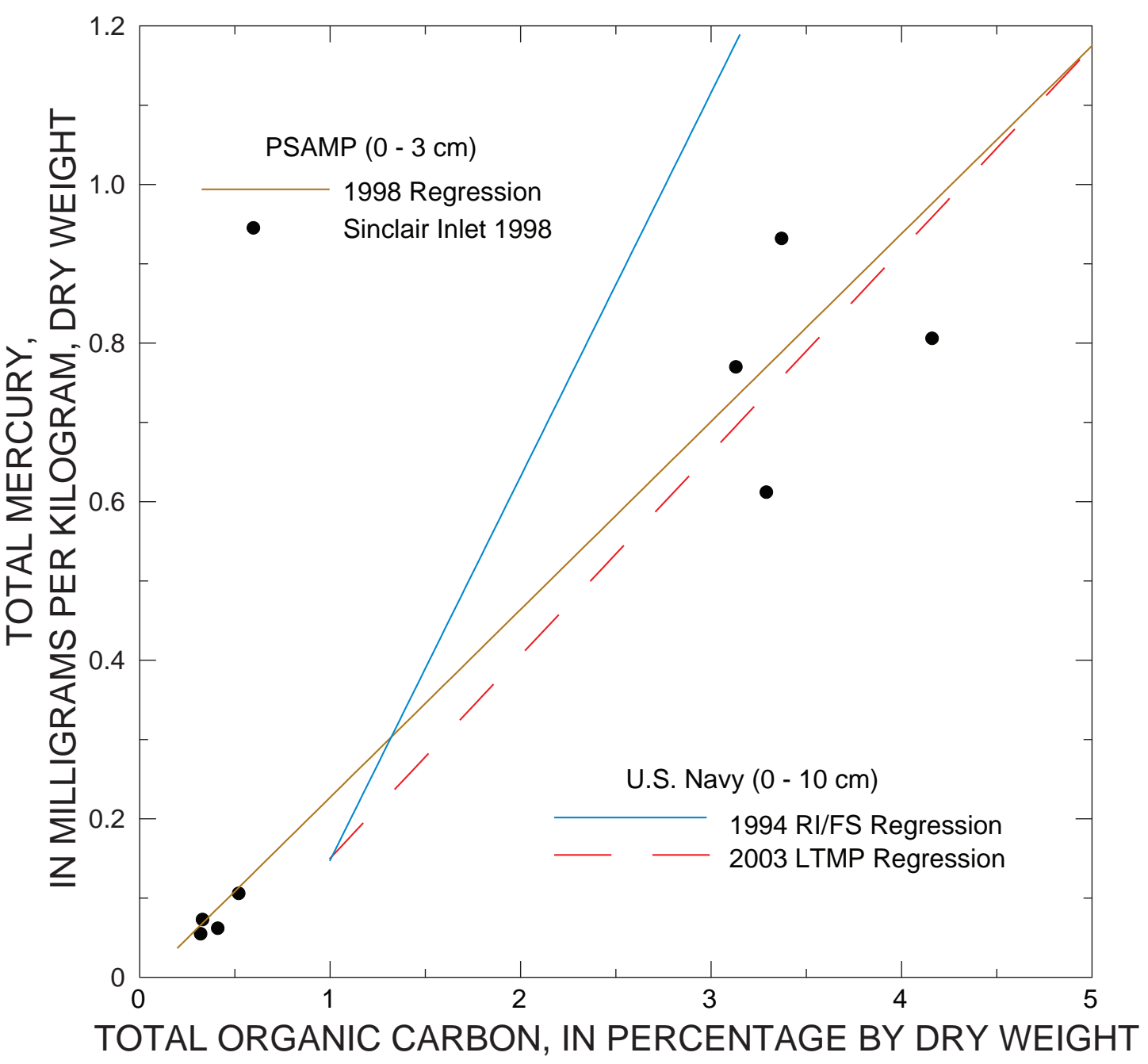

Figure 56. Total mercury concentrations compared to total organic carbon in the surface sediment $(0-3 \mathrm{~cm})$ collected by the Puget Sound Ambient Monitoring Program embayment study in 1998 (Long and others, 1999) and the regression line (table 1) for the 1994 Offshore Sinclair Inlet surface sediment $(0-10 \mathrm{~cm})$ from the Remedial Investigation/Feasibility Study (fig. 14) and the 2003 offshore surface sediment $(0-10 \mathrm{~cm})$ from the Long-Term Monitoring Program 1,500-ft grid sampling (fig. 32). 
THg sediment concentrations measured by PSAMP were highly correlated with sediment TOC within each urban embayment of Puget Sound (table 1). By comparing the relations of THg with TOC across geographical regions, one can normalize for the physical and biogeochemical processes that tend to enrich THg in marine surface sediment. THg sediment concentrations plotted against TOC (fig. 57) show that PSAMP samples from Bellingham Bay and Elliott Bay (fig. 1A) were below the regression line for PSAMP Sinclair Inlet samples. The sediment of Bellingham Bay was highly contaminated with mercury from wastewater discharges from a mercury-cell chlor-alkali plant (Crecelius and others, 1975) and Bellingham Bay is a State Cleanup site. Elliott Bay is an urban embayment off Seattle and receives wastewater from the Renton wastewater treatment facility, as well as non-point stormwater discharges from the industrial area of the Duwamish Waterway. Although THg has been identified as a chemical of concern for Elliott Bay, THg has not been a primary factor in Superfund designations within the Duwamish industrial area. Although samples from Elliott and Bellingham Bays are below the Sinclair Inlet regression line, the 95 percent confidence intervals of the slopes of $\mathrm{THg}$ sediment concentrations compared to sediment TOC for the three embayments are not significantly different.

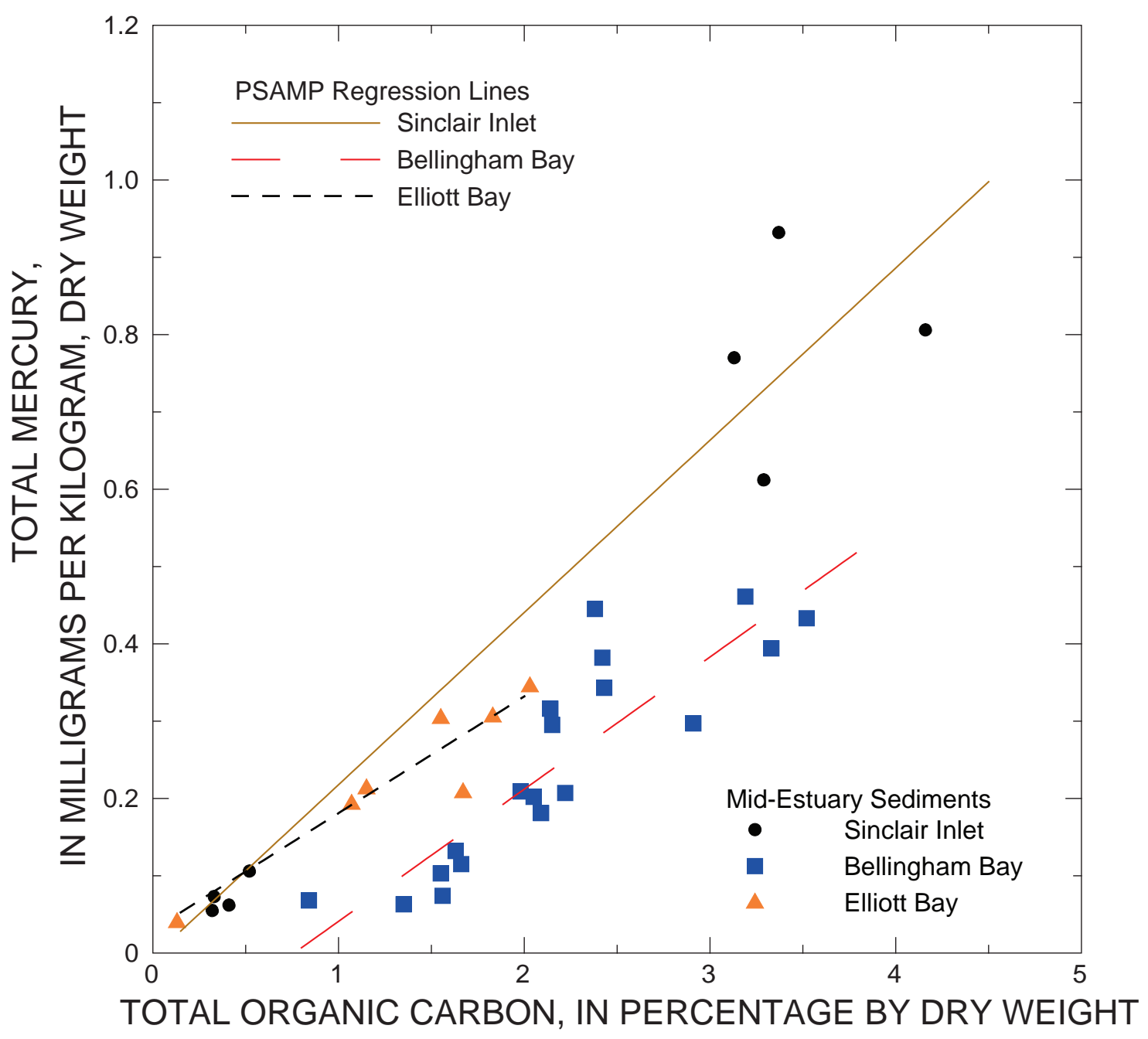

Figure 57. Total mercury concentrations compared to total organic carbon in the surface sediment $(0-3 \mathrm{~cm})$ collected by Puget Sound Ambient Monitoring Program embayment study in Washington State from Sinclair Inlet (1998), Elliott Bay off Seattle (1998), and Bellingham Bay (1997) (Long and others, 1999, 2000). The statistics for the regression lines are shown in table 1. 
The THg sediment concentrations of the other urban and non-urban embayments (fig. $1 A$ and $1 B$ ) were low compared to Sinclair Inlet when examined in relation to TOC (fig. 58). Offshore sediment of Commencement Bay (a Superfund site associated with Tacoma) and Port Gardner (located off the city of Everett) had TOC content of about 2 percent by dry weight and THg concentrations of about $0.1 \mathrm{mg} / \mathrm{kg}$. In contrast, Budd Inlet (adjacent to Olympia) and Liberty Bay (adjacent to the suburban town of Poulsbo) had TOC concentrations as high as those of Sinclair Inlet, but THg sediment concentrations were about one-quarter of those of Sinclair Inlet.

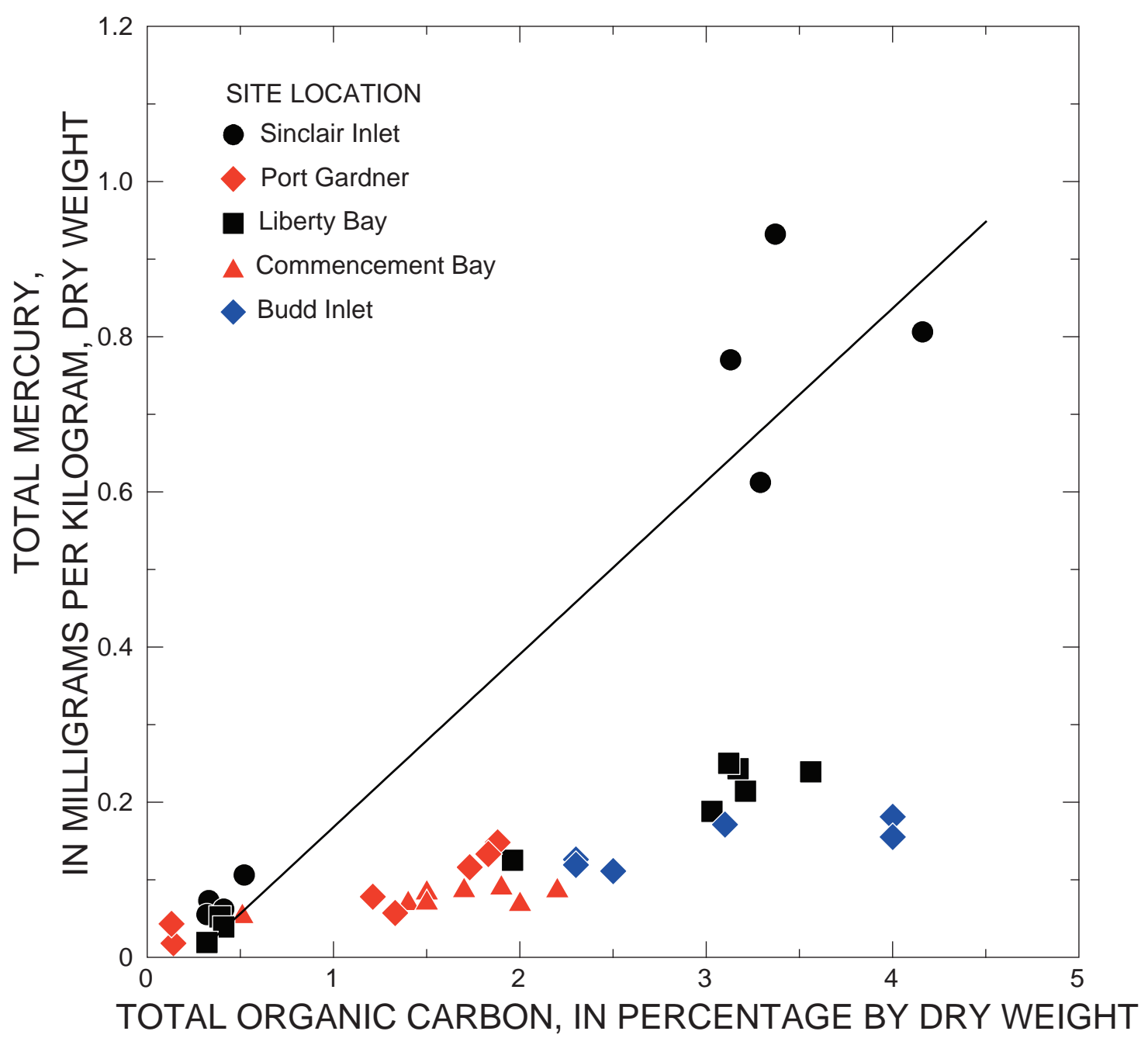

Figure 58. Total mercury concentrations compared to total organic carbon (Long and others, 1999, 2000, 2001) in the surface sediment (0-3 cm) from Sinclair Inlet (1998), Port Gardner off Everett (1997), Liberty Bay off Poulsbo (1998), Commencement Bay off Tacoma (1999), and Budd Inlet off Olympia (1999). The line is the regression of the 1998 Puget Sound (Washington) Ambient Monitoring Program Sinclair Inlet samples (fig. 56 and table 1). 
When THg sediment concentrations from Sinclair Inlet and other urban embayments are plotted against total fines, similar relations are apparent, but less striking. Most of the THg data for all embayments are below the 1998 PSAMP regression line for Sinclair Inlet (table 1), especially at higher total fines (fig. 59). However, a number of the embayments have weak correlations with total fines (table 1). For instance, all but two samples from Bellingham Bay had total fines greater than 90 percent, yet the THg concentrations varied from 0.08 to $0.46 \mathrm{mg} / \mathrm{kg}$. In contrast, the percentage of fines in Commencement Bay varies from 19 percent to 91 percent, yet $\mathrm{THg}$ concentrations only vary between 0.055 and $0.092 \mathrm{mg} / \mathrm{kg}$.

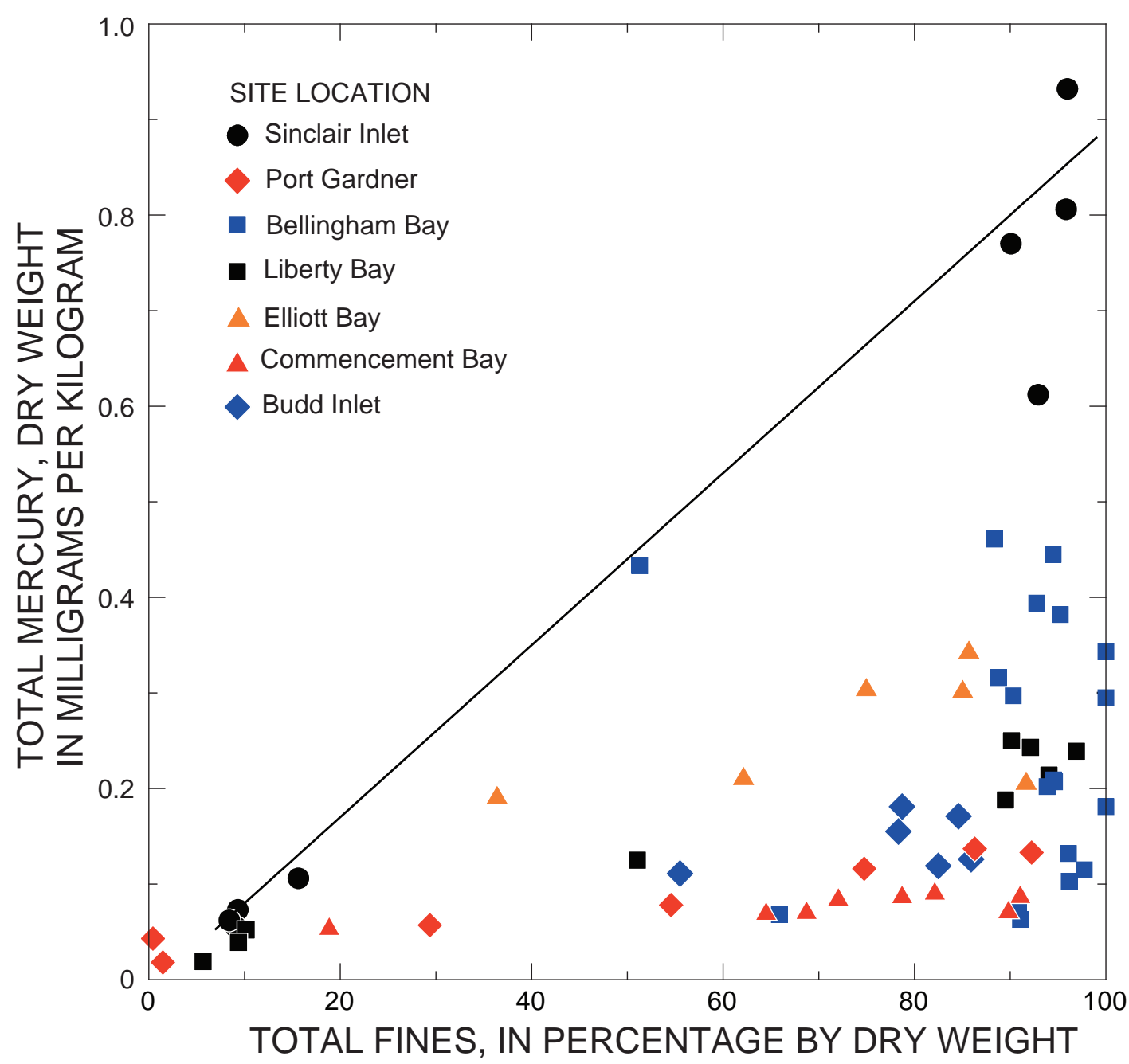

Figure 59. Total mercury concentrations compared to total fines (Long and others, 1999, $2000,2001)$ in the surface sediment $(0-3 \mathrm{~cm})$ from Sinclair Inlet (1998), Bellingham Bay (1997), Port Gardner off Everett (1997), Elliott Bay off Seattle (1998), Liberty Bay off Poulsbo (1998), Commencement Bay off Tacoma (1999), and Budd Inlet off Olympia (1999). The line is the regression of the 1998 Puget Sound (Washington) Ambient Monitoring Program Sinclair Inlet samples (fig. 56 and table 1). 


\section{Environment Investment (ENVVEST) Dated Cores and Sediment Traps}

The ENVVEST program (Crecelius and others, 2003) determined $\mathrm{THg}$ sediment concentrations at five locations along the center-line of Sinclair Inlet (fig. 1C) from the Gorst mudflats (S1) to the entrance of Sinclair Inlet (S5). Depth profiles were highly resolved with $2.5-\mathrm{cm}$ sections for the first $5 \mathrm{~cm}$ followed by $5-\mathrm{cm}$ sections to $60 \mathrm{~cm}$ (table B15). Sediment traps also were deployed near stations S1 and S5 to collect settling particles (Sediment_Trap_Data_plots.pdf available at http://www.ecy.wa.gov/programs/wq/tmdl/ sinclair-dyes_inlets/sinclair_cd/DATA/2002_Data/ BMSL/). The cores were dated by radionuclide analyses and sedimentation rates were calculated for each sediment core. Additional sediment traps were deployed along the northern shoreline, near the Port Orchard Marina and along the southern shoreline just outside of the study area (fig. 1C) and at one location within the BNC (fig. 2). Aluminum concentrations of sediment cores and sediment trap materials also were measured.

\section{Dated Cores}

The THg concentrations in the three sediment sections within the top $10 \mathrm{~cm}$ of the cores (Crecelius and others, 2003) were fairly constant (standard deviation of less than $0.08 \mathrm{mg} / \mathrm{kg}$, table 5), except for core S1 in inner Sinclair Inlet (fig. 1C) in which only the top $5 \mathrm{~cm}$ of sediment was uniform (figs. D20-D24). The THg concentrations of surface $(0-2.5 \mathrm{~cm})$ sediment of cores S2 to S5 (fig. 1C) were between 0.74 to $0.93 \mathrm{mg} / \mathrm{kg}$, and the surface sediment at S1 contained $0.51 \mathrm{mg} / \mathrm{kg}$. Below the surface mixed layer in cores S2 to S5, THg concentrations reached a maximum at depths between 10 and $30 \mathrm{~cm}$. These results are comparable to the RI/FS results of the one core (location 490 in fig. 1C, which is near S4) sectioned with high vertical resolution (table B4). THg concentrations in cores at locations S4 and 490 peaked at about $25 \mathrm{~cm}$ below the sediment-water interface (figs. 17 and D23). The maximum THg concentration at location S4 was $3.2 \mathrm{mg} / \mathrm{kg}$, whereas the maximum concentration at location 490 was $1.50 \pm 0.27 \mathrm{mg} / \mathrm{kg}$.

The approximate date at which sediment was deposited was determined for each section of the ENVVEST cores. The radionuclide data suggest that sediment with the maximum THg concentrations generally were deposited in cores S2, S3, and S5 between 1950 and 1965. Maximum concentrations in the Gorst mudflat occurred in the top $5 \mathrm{~cm}$, which represents deposition between 1985 and 2002. Disturbance of the sediment during dredging precluded the dating of core S4.

The maximum THg concentrations at depth in the sediment cores increased with distance from the Gorst mudflats (table 5). Maximum concentrations in the
Table 5. Variability of total mercury concentrations in the top $10-\mathrm{cm}$ of ENVironmental inVESTment cores, and the depth and the maximum total mercury concentration of total mercury peak in the sediment column of Sinclair Inlet, Washington.

[Data source: Crecelius and others, 2003; Locations are shown in figure 1C. Details for total mercury data listed in table B15. Abbreviations cm, centimeter; Std. dev., standard deviation; mg/kg, milligram per kilogram; wt., weight; , about; -, date could not be determined because top of core was disturbed]

\begin{tabular}{|c|c|c|c|c|c|}
\hline \multirow{3}{*}{$\begin{array}{c}\text { Core } \\
\text { Iocations }\end{array}$} & \multirow{2}{*}{\multicolumn{2}{|c|}{$\begin{array}{c}\text { Surface }(0-10 \mathrm{~cm}) \\
\text { Total mercury } \\
\text { (mg/kg, dry } \\
\text { weight) }\end{array}$}} & \multirow{3}{*}{$\begin{array}{l}\text { Depth at } \\
\text { maximum } \\
\text { (cm) }\end{array}$} & \multicolumn{2}{|l|}{ Maximum } \\
\hline & & & & \multirow{2}{*}{$\begin{array}{c}\text { Total } \\
\text { mercury } \\
\text { (mg/kg, } \\
\text { dry weight) }\end{array}$} & \multirow{2}{*}{$\begin{array}{c}\text { Approximate } \\
\text { date }\end{array}$} \\
\hline & Mean & $\begin{array}{l}\text { Std. } \\
\text { dev. }\end{array}$ & & & \\
\hline S1 & 0.51 & 0.01 & $0-2.5$ & 0.51 & 1985-2002 \\
\hline S2 & .92 & .01 & $10-20$ & 1.46 & $\sim 1950$ \\
\hline S3 & .93 & .08 & 20-30 & 1.72 & $\sim 1950$ \\
\hline $\mathrm{S} 4$ & .81 & .06 & $20-25$ & 3.21 & - \\
\hline S5 & .92 & .01 & 10-15 & 3.26 & 1965 \\
\hline
\end{tabular}

central part of Sinclair Inlet west of the BNC were 1.46 and $1.72 \mathrm{mg} / \mathrm{kg}$ for cores S2 and S3, respectively and concentrations off the shipyard and the entrance to Sinclair Inlet were 3.21 and $3.25 \mathrm{mg} / \mathrm{kg}$ for cores S4 and S5, respectively. The significant decreases in THg concentrations between sediment that was deposited around World War II at depth and recently deposited sediment at the surface confirms that THg discharges have decreased over the last 50 years.

\section{Particles Settling in Sediment Traps}

The particles settling into sediment traps could have entered Sinclair Inlet recently or could have been re-suspended from the sediment column (table 4). To determine the sources of particles, surface sediment and solids settling in sediment traps were analyzed at two locations: offshore of the Gorst mudflats (S1/T1; fig. 1C) and off the BNC (S4/T3; fig. 2). The composition of settling particles compared to surface sediment at the same location provides some insight into the relative importance of the accumulation of particles into traps (1) from particles recently entering Sinclair Inlet and (2) from particles that had been resuspended from the sediments. At Gorst (S1 and T1) and a northshore site (S4 and T3), the surface sediment and sediment trap material had similar THg and total aluminum concentrations (fig. 60), suggesting that sediment traps contain a substantial portion of resuspended sediments. Settling particles with the lowest THg concentrations in 
Sinclair Inlet were collected off the southern shoreline, either near the Port Orchard Marina (trap 4, $0.317 \mathrm{mg} / \mathrm{kg}$ ) or near the outfall of the Port Orchard wastewater treatment facility (trap 5, $0.248 \mathrm{mg} / \mathrm{kg}$ ). In contrast, the trap material collected in traps along the northern shore contained 0.615 and 0.705 $\mathrm{mg} / \mathrm{kg}$ near the outfall of the Bremerton wastewater treatment facility (trap 2) and off eastern PSNS \& IMF (trap 3), respectively.

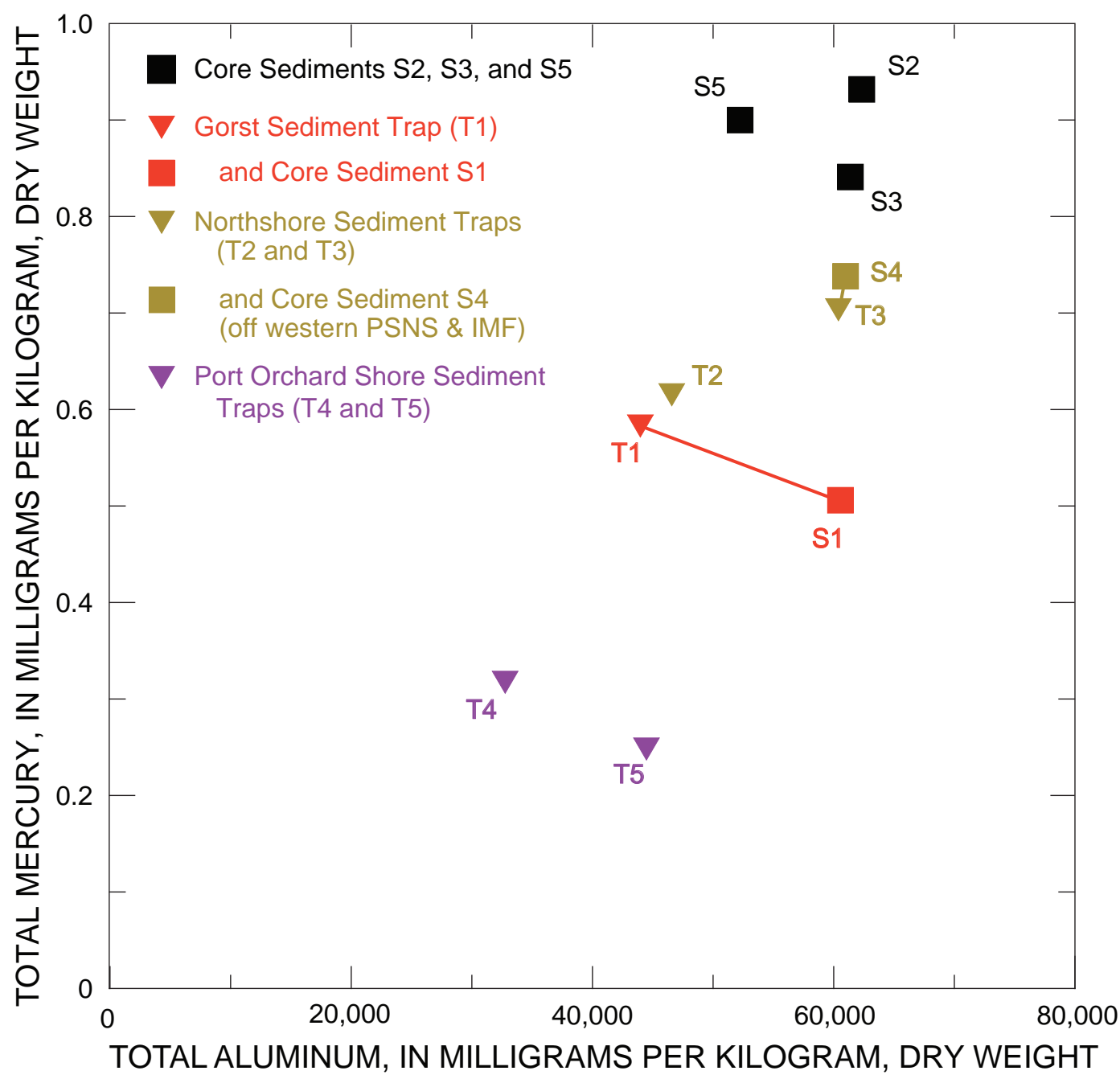

Figure 60. Total mercury concentrations compared to total aluminum concentrations for surface sediment $(0-2.5 \mathrm{~cm})$ in Sinclair Inlet, Washington (table B15) and material collected by sediment traps (table 4) by the ENVironmental InVESTment Project in 2002. The two lines connect surface sediment and settling particles collected at the same location (Gorst and Northshore). 


\section{Summary of Mercury in the Sediment of Sinclair Inlet}

In a large area of Sinclair Inlet offshore of the Bremerton naval complex, a peak in THg concentrations is observed in the sediment below the present sedimentwater interface. ENVVEST cores S2-S5 and U.S. Navy core 490 in central Sinclair Inlet (fig. 1C) all show subsurface maximums (table 5 and figs. D21-24; table B4 and fig. 17, respectively). Core S4 collected off PSNS had the largest sub-surface maximum with the THg concentration of $3.21 \mathrm{mg} / \mathrm{kg}$ in the $10-15 \mathrm{~cm}$ depth horizon. The ENVVEST cores were radiometrically dated and the historical record of sedimentation was consistent with the timing of PSNS activities in Sinclair Inlet (Crecelius and others, 2003). Similar to many lake cores in Western Washington (Paulson and Norton, 2008) in which THg concentrations began to increase in sediment with the beginning of the Industrial Revolution around 1900, THg concentrations in Sinclair Inlet began to increase with the opening of PSNS in 1896. In contrast to the timing of lake cores, the peak in sub-surface THg concentrations in Sinclair Inlet represents sedimentation occurring around the time of World War II, when PSNS activities were most intense. The sub-surface maximums of THg concentrations in cores S2-S5 and 490 range from 1.46 to $3.26 \mathrm{mg} / \mathrm{kg}$ compared to $0.3 \mathrm{mg} / \mathrm{kg}$ for core sections in the main basin of Puget Sound that represent World War II-era deposition (Bloom and Crecelius, 1987). Following World War II, better metallurgical management practices and environmental regulations were initiated and mercury sedimentation and THg sediment concentrations began to decrease from these sub-surface maximum concentrations to lower THg concentrations measured at the current sediment surface. However, the precise historical record of sedimentation of contaminants is blended because physical and biological processes continually mix sediment in about the top $4 \mathrm{~cm}$ of sediments (Brandenberger and others, 2007). The consequences of the historical contamination in Sinclair Inlet also are reflected in long-living organisms. For example, old rockfish (hatched between 1950 and 1970) collected from Sinclair Inlet contained the highest THg concentrations of any rockfish from Puget Sound (West and O'Neill, 1998).

Nearshore sites off OU A show even higher sub-surface maximums in Hg-TCLP concentrations. At station MS213, a nearshore location of OU A (location 213 in fig. 2), Hg-TCLP concentrations as high as $12.3 \mathrm{mg} / \mathrm{kg}$ were observed at depths between 5 and $20 \mathrm{~cm}$ station MS213 (table B3). The majority of locations with sub-surface concentrations maximums of THg and Hg-TCLP were capped during the 2000-2001 remedial activities. No core with a vertical resolution less than $60 \mathrm{~cm}$ was taken in the nearshore area off OU B that had not been dredged. In contrast, inner Sinclair Inlet seems to be less affected by PSNS activities. Both ENVVEST core S1 and RI/FS core ST-48 (location 228) showed maximum concentrations (0.51 and $1.1 \mathrm{mg} / \mathrm{kg}$ for THg and Hg-TCLP in tables 5 and B3, respectively) just below the sediment-water interface with concentrations decreasing with depth.

Two cells in the CAD pit apron (5CP and 6CP in fig. 20) had THg concentrations higher than the greater Sinclair Inlet trend (figs. 46 and 47) and higher than concentrations measured in the area shortly after the closure of the CAD pit. Because the area of apron cells 5CP and 6CP were not sampled before the development of the CAD pit, it is unknown if similar THg was present within these two cells before the CAD pit construction or if these elevated THg concentrations represent deposition of slowly settling fine-grained dredged material that was transported away from the pit (to the apron area) by tidal currents.

Strong relations of THg sediment concentrations with sediment TOC were observed for Sinclair Inlet, as well as many other Puget Sound embayments. The slope of the relation of THg sediment concentration to sediment TOC seems to be the best indicator of mercury enrichment and provides a valuable tool for comparisons of overall mercury contamination among the sediments of Puget Sound estuaries (table 1). Based on the PSAMP embayment studies (Long and others, 1998, 2000, 2001), the slope of the 1998 THg-to-TOC relation in Sinclair Inlet (table 1 and fig. 61) is comparable to the slope for sediment from Bellingham Bay (a mercury Superfund site) and Elliott Bay (adjacent to Superfund sites on the Duwamish Waterway). This indicates that Sinclair Inlet ranks in the top tier of urban estuaries contaminated with mercury.

When programs that used the same sampling depth interval $(0-10 \mathrm{~cm})$ for sediment collection in Sinclair Inlet are compared over time, it appears that there was a significant decrease in the slope of the regression between THg concentrations and TOC derived from sediment collected during 1994-95 compared to the slopes derived from samples collected between 2003 and 2007 (fig. 61). This suggests that the dredging around the pier (shown in the inset of figure 2) during 1994-95 and the larger CERCLA 2000-2001 activities (dredging and capping) significantly decreased mercury conditions throughout the greater Sinclair Inlet. This conclusion must be qualified because the RI/FS program (1994/1995) was not a randomly stratified sampling program and targeted sampling may have biased the slope. 


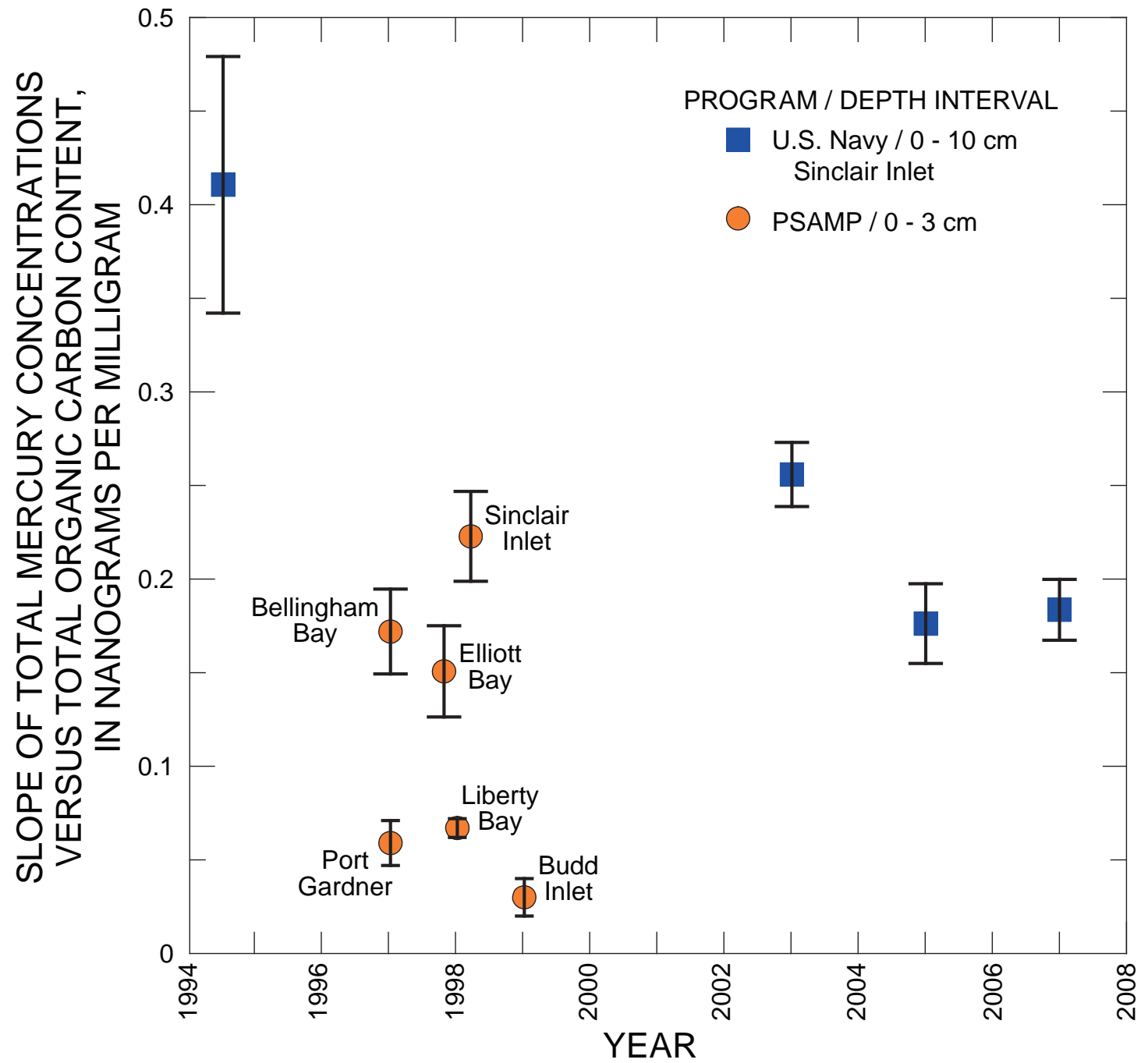

Figure 61. Slopes calculated from the linear relations between total mercury concentrations and total organic carbon content in sediments from Sinclair Inlet and other Puget Sound embayments in Washington 
Concentrations of THg measured in OU B Marine sediments were compared with the relation of THg with TOC and total fines collected from the greater Sinclair Inlet $1,500-\mathrm{ft}$ grid in 2003, 2005, and 2007. TOC and total fines from OU B Marine sediments were applied to the regression equation for the greater Sinclair Inlet 1,500-ft grid to calculate the predicted THg concentrations. Deviations of the actual values from the predicted values then were rank ordered (appendix E). Samples above the most significant break in the rank-order of deviations of THg for the TOC regression were identified as tier 1 samples. Tier 2 samples were identified as being above more subtle breaks in the rank-order for each data set, which ranged from $0.53 \mathrm{mg} / \mathrm{kg}$ in 2005 to $0.67 \mathrm{mg} / \mathrm{kg}$ in 2007. All tier 1 and tier 2 samples were greater than the 95 percent prediction intervals for the greater Sinclair Inlet regressions. These tier 1 and tier 2 samples indicate areas possibly affected by present terrestrial sources of mercury or recontamination resulting from either episodic events or from inputs of nearby contaminated sediment that had not been dredged. Areas of concern within BNC were identified by categorizing cells by the instances of tier 1 samples and the frequency of tier 2 samples (table 3). Three areas of particular concern are evident (fig. 62): (1) cell 39 off NBK Bremerton, (2) the area off central PSNS \& IMF, and (3) cell 71 off eastern PSNS \& IMF. Cell 39 includes location 110 (fig. 2), which contained a THg concentration of $2.9 \mathrm{mg} / \mathrm{kg}$ and which was not dredged. The area between also contained two sites that were not dredged and had high THg concentrations, including a $60-\mathrm{cm}$ vertical section with $6.6 \mathrm{mg} / \mathrm{kg}$ just to the east of the navigational dredged area off western PSNS \& IMF. In addition, the composite sample from cell 60 collected in 2004 contained a THg concentration of $18.8 \mathrm{mg} / \mathrm{kg}$ in 2005 . Cells 11 and 19 near the CAD pit also were categorized as tier 1 samples in 2003, but their THg concentrations were within the general Sinclair Inlet trend in 2005 and 2007. This temporary elevation of THg may be related to the closure of the CAD pit and to the elevated THg in CAD pit apron cells $5 \mathrm{CP}$ and 6CP.

The extent of sediment transport inferred from physical measurements seems to contradict measurements associated with sediments in the water and sediment column. During winter (February-March) and summer (July-August) of 1994 and summer (June-August) of 2005, 10 current meters were deployed for durations ranging between 6 and 8 weeks (Gartner and others, 1998; U.S. Navy, 2007b). Mean current speeds were weak $(3-10 \mathrm{~cm} / \mathrm{s})$ and maximum speeds ranged from 10.9 to $13.9 \mathrm{~cm} / \mathrm{s}$ for the summer 2005 deployments. The authors concluded that critical shear velocities for resuspension were achieved less than 1.5 hours per day (Gartner and others, 1998) and sediment transport "only occurs to a limited extent" (U.S. Navy, 2007b). In addition, the critical shear stress measured by Seaflume tests indicates that currents measured by current meters were not sufficient to achieve critical bed shear stresses for erosion.
In contrast, concentrations of total suspended solids samples collected within the water column during the velocity measurements indicate a considerable amount of suspended solids. The median total suspended solids concentrations in discrete water samples collected $0.5 \mathrm{~m}$ above the bottom in 1994 ranged between 27 to $45 \mathrm{mg} / \mathrm{L}$ for the three sites (Gartner and others, 1998). Spikes in the transmissivity measurements (as high as $10 \mathrm{NTU}$ ) were observed during limited measurements of optical backscatter during the 2005 current meter deployment.

The rate of mass settling into the sediment traps set in the summer of 2005 provides the strongest evidence that sediments were resuspended. The rate of dry settling mass ranged between 3.58 and $5.50 \mathrm{~g} / \mathrm{cm}^{2} / \mathrm{yr}$ at the two sites within OU B Marine and ranged between 3.38 and $3.77 \mathrm{~g} / \mathrm{cm}^{2} / \mathrm{yr}$ at the two sites in greater Sinclair Inlet (U.S. Navy, 2007a). In contrast, the range of net dry mass sedimentation within the sediment column ranged between 0.072 and $0.17 \mathrm{~g} / \mathrm{cm}^{2} / \mathrm{yr}$ for four sites in greater Sinclair Inlet (Brandenberger and others, 2008). Because the rate at which dry mass settled through the water column was higher than the rate at which sediments actually accumulated in the sediment column throughout Sinclair Inlet, solids are likely resuspended into the water column numerous times before being ultimately buried in the sediment column.

Sediment trap data from the ENVVEST study also confirm the observations of resuspension. Two sediment traps (T1 and T3) were co-located at the sites of the sediment core collection as part of the study. Similar to the U.S. Navy (2007b) observations, the rates of mass settling (5.78 and $7.45 \mathrm{~g} / \mathrm{cm}^{2} / \mathrm{yr}$, respectively) were more than an order of magnitude greater than the range of net mass sedimentation in Sinclair Inlet $\left(0.072\right.$ and $0.17 \mathrm{~g} / \mathrm{cm}^{2} / \mathrm{yr}$; Brandenberger and others, 2008). In addition, the similarity of the chemistry of solids settling into sediment traps to the chemistry of nearby sediments (figs. 50, 51, and 60) limits the possible source of the unknown dry mass settling through the water column into the traps. The source of this settling dry mass can be reevaluated when additional data on mercury concentrations from ongoing studies by the USGS and other agencies become available.

Temporal trends in Sinclair Inlet suggest that physical processes are changing the size distribution and chemistry of sediments more quickly than can be explained by sedimentation of new solids discharged to Sinclair Inlet. The radiometric data from sediment cores suggest that a $10-\mathrm{cm}$ core section represents about 20 years of net sedimentation. Between May 1998 and October 2003, the sediment grainsize distributions in surface sediment $(0-10 \mathrm{~cm})$ throughout Sinclair Inlet became coarser by one phi unit (from medium silt to coarse silt). Such a dramatic change in just 5 years (McLaren, 2004) is inconsistent with the rate of sedimentation of newly deposited solids obtained from dated sediment cores that were collected in 2002 (Crecelius and others, 2003). McLaren (2004) attributed this change in grain size 


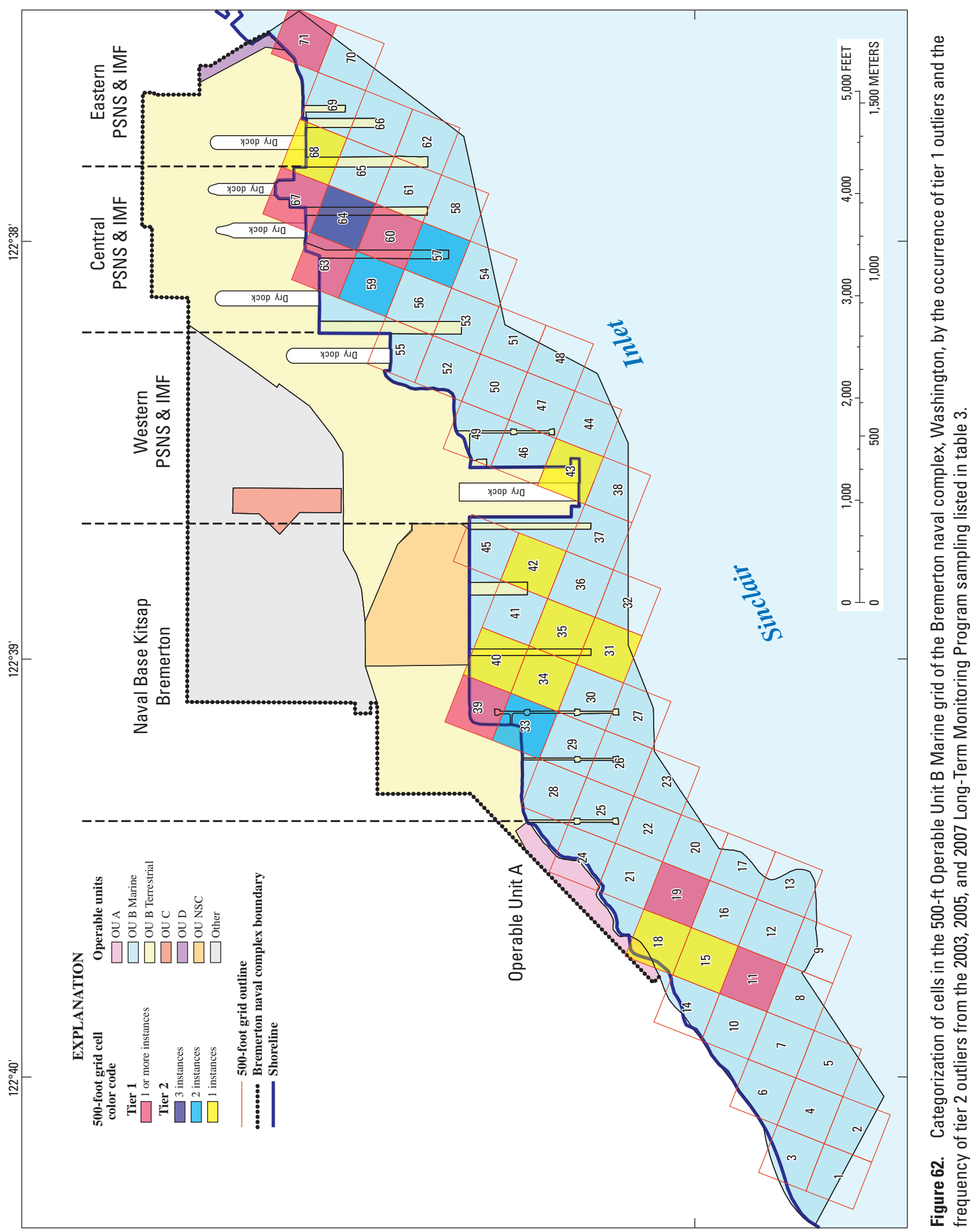


distribution to exposure of coarser glacial material during the 2001 dredging. Because the change in grain-size distribution occurred throughout Sinclair Inlet, the coarser glacial material from the exposed dredged areas must have been transported throughout Sinclair Inlet. In a more recent investigation of the grain-size distribution in 2007, McLaren determined that the grain-size distribution is changing to the finer material measured in 1998.

THg concentrations also are changing more rapidly than would be expected solely from deposition of newly discharged particles. Within the four year period of the LTMP (figs. 32, 34, and 36), the deviations of THg above the general Sinclair Inlet trend line decreased in the composite samples from cell 21 of the 1,500-ft grid (fig. 30). This would suggest that sediment from a nearby cell, which has the typical THg:TOC relation, is mixing with sediment from cell 21. In contrast, the hotspot at location D101 of the post-1995 monitoring around the pier (shown in inset of figure 2) also became indistinguishable with the general relation between THg and TOC within 3 years of dredging (fig. 18). Because the recontamination of areas recently dredged (fig. 2) was a concern, the U.S. Navy in a special study (U.S. Navy, 2007b) reassessed OU B 500-ft grid cell 35 and cell 56. Sub-surface sediment that would be exposed after dredging had low THg concentrations (for example, $0.177 \mathrm{mg} / \mathrm{kg}$ in $500-\mathrm{ft}$ grid cell 56, U.S. Navy, 1999). Within 7 years, the THg concentrations of sediment and settling particles from 500 -ft grid cell 35 that was dredged for navigational purposes plotted along the greater Sinclair Inlet trend line for the relations with THg concentrations compared to total fines (fig. 50). This observation indicates that sediment that has the general characteristics of greater Sinclair Inlet settled within this cell. In contrast, the THg concentrations in sediment from the 500$\mathrm{ft}$ cell grid 56 that had been dredged for remediation purposes were above the general trend line for greater Sinclair Inlet, and the THg concentrations of solids settling into traps fell on the general trend line. The recontamination of $500-\mathrm{ft}$ grid cell 56 with mercury above the general trend line could not have occurred from the deposition of settling particles under normal conditions and likely was a result of redistribution of nearby sediments that had not been dredged and contained historical THg buried in the sediment.

The strong relation among THg concentrations, TOC and total fines in Sinclair Inlet outside of the BNC suggests that the physical mixing processes of fine-grained, organicrich particles generally are controlling THg concentrations in sediment. Throughout greater Sinclair Inlet, coarse solids with low $\mathrm{THg}$ concentrations are mixing with finer solids with higher TOC and THg concentrations. The rapid changes in sediment grain-size and sediment chemistry and the large rate of mass settling through the water column into sediment traps are consistent with extensive long-term mixing of sediments within Sinclair Inlet.
However, current speeds measured in near-bottom waters do not support extensive erosion of Sinclair Inlet sediments. The discrepancy may be a matter of temporal and geographical scale. Perhaps the daily 1.5-hour resuspension events that increased total suspended solids near the bottom and caused spikes in turbidity are sufficient to cause the higher rates of mass settling into sediment traps and mix sediments geographically throughout Sinclair Inlet in 10-cm sediment samples that represent 20 years of deposition. Bottom sediment scour by conventional propellers and cycloidal thrusters used by the BNC can explain sediment transport within the BNC and from the BNC to greater Sinclair Inlet, as could dry dock docking and undocking operations, ship movements, ferry docking/undocking, and other harbor operations that are localized short term events. These episodic events may not be evident in the current meter records of limited temporal and spatial extent, but could be an important contributing factor for resuspension. This discrepancy among the observations must be resolved before the processes controlling mercury in Sinclair Inlet sediment can be fully understood.

\section{Mercury in Marine Waters of Sinclair Inlet}

The detection limit of the analytical technique used for the remedial investigations (cold vapor atomic absorption spectrometry) during the 1990 s was $200 \mathrm{ng} / \mathrm{L}$. No marine water sampled during these years contained THg levels above the detection limit.

In 2002, the ENVVEST program began looking at the presences and sources of THg in the marine waters of Sinclair Inlet to complement its study of $\mathrm{THg}$ from the watersheds of Sinclair and Dyes Inlets (fig. 1B). By the time that the ENVVEST project began, a newer, more-sensitive method of cold vapor atomic fluorescence spectrometry had been developed and was used by ENVVEST between 2002 and 2005 (Brandenberger and others, 2007). The quality assurance data from the ENVVEST project is extensive and well documented. In general, the quality of ENVVEST data is excellent even at concentrations less than $10 \mathrm{ng} / \mathrm{L}$.

On each of four days in 2002 (March 10, 12, and 13 and September 17), THg concentrations were measured in the near-surface waters at marine locations (figs. $1 B$ and $1 C$ ) in Rich Passage (M1), Port Orchard Passage (M2), central outer Sinclair Inlet (M3), and central inner Sinclair Inlet (M4). During two days during the wet season of 2004 (March 31 and May 27), marine water within the nearshore area of the PSNS and off Port Orchard were sampled and compared to various locations in central Sinclair Inlet (M3, M3.1, M3.2, M3.4, and M4 in fig. 1C). During 2005, nine samples were collected from central Sinclair Inlet (M3.1, M3.3, and M4). 
For all marine samples collected in 2005 for which THg was measured, discrete samples were collected for ancillary data (total aluminum, TOC, and total suspended solids).

To establish the fluxes of THg at the boundary of the ENVVEST study area, a more detailed study of water entering and leaving Sinclair Inlet began with sampling of both nearsurface and near-bottom water from Rich Passage (M1), Port Orchard Passage (M2), and central outer Sinclair Inlet (M3.3) on June 21, 2004. (figs. $1 B$ and 2) The boundary-condition study continued during September 2005 with sampling of near-surface water from M1, M2 and M3.3 and additional locations (figs. $1 B$ and $1 C$ ) in Port Orchard Passage (M9 and M10), at the entrance to Liberty Bay (M10.1), and in Port Madison (M11). Near-bottom water samples were collected at several sites. Only data from Dyes Inlet from September 2005 (M5-M8) are presented here because the availability of ancillary data allows for comparisons to Sinclair Inlet.

The THg concentrations in the water column of central Sinclair Inlet generally range between 0.7 and $1.3 \mathrm{ng} / \mathrm{L}$ (table 6 and fig. 63). For most sampling locations, the shortterm temporal variability was as large as the long-term temporal variability. For instance, the temporal variability at sampling locations M1-M4 during three days in March 2002 was almost as large as the temporal variability during the 4-year study. For sampling locations in central Sinclair Inlet (M3-M4), the highest THg water column concentrations at each location were observed during the storm events of May-June 2004 and the highest THg concentrations $(\sim 1.6 \mathrm{ng} / \mathrm{L})$ in central Sinclair Inlet were observed at locations M3.2 and M3.4 following the May 26-27, 2004 storm event that coincided with higher tides. THg concentrations in Sinclair Inlet are higher than the THg concentrations at $5 \mathrm{~m}$ in the water column throughout the main basin of Puget Sound ( 0.3 to $0.34 \mathrm{ng} / \mathrm{L}$ for Admiralty Inlet, Colvos Passage, and Jefferson Head in table 6) in 1999 and 2000 (King County Department of Natural Resources and Parks,2001). However, THg concentrations in the marine plume of the outfall of the West Point Sewage Treatment Facility (table 6) that is located across Puget Sound from Bainbridge Island were much higher (49.8 ng/L) and highly variable.

Following the May 26-27, 2004 storm event (3.4 cm of rain in Bremerton) that coincided with higher tides, near-surface water was collected at five PSNS nearshore locations and one location off Port Orchard. Although THg concentrations at four of the five nearshore locations were less than $2.2 \mathrm{ng} / \mathrm{L}$, a concentration of $10.71 \mathrm{ng} / \mathrm{L}$ was observed at PSNS location P2 in the 500-ft grid cell 39 (fig. 31) off NBK Bremerton.

Variations in THg concentrations in unfiltered marine waters are a function of independent variations associated with mercury on particles and in the dissolved phase. Particulate mercury varies primarily because of variations in the amount of solids suspended in the water column (total suspended solids (TSS) concentration), but it also can vary due to variable mercury content of the suspended solids. Because dissolved aluminum concentrations in marine waters are low, total aluminum concentrations reflect aluminum associated with particles (that is, the amount of aluminosilicate clays suspended in the water column). Thus, total aluminum concentrations can be used as a surrogate for suspended solids. Plots of THg concentrations compared to total aluminum concentrations (fig. 64) show that the high THg concentrations at locations M3.2 and M3.4 during May 2004 were not coincident with the highest total aluminum concentrations. This observation indicates that moderate suspended solids concentrations, as reflected by moderate total aluminum concentrations, were not entirely responsible for the high THg concentration at locations M3.2 and M3.4. Likewise, when all data from late May 2004 are plotted, the high THg concentration at location P2 is abnormally high for the slight elevation of total aluminum concentrations relative to location P1. The concentrations of copper, lead, zinc, and fecal coliform also were high at location P2 (http://www. ecy.wa.gov/programs/wq/tmdl/sinclair\%2Ddyes\%5Finlets/ sinclair\%5Fcd/DATA/2004\%5FSampling/2004_05_27_ Preliminary_Metals_Data_Plots.pdf). These observations indicate that the high concentration of THg at P2 was the result of discharge from storm drains, not mineral particles or resuspended sediment.

Seventeen unfiltered water samples collected September 13-14, 2005 (fig. 65) were examined to infer the effects of physical processes on THg concentrations (Brandenberger and others, 2006a). If freshwater was simply mixing with marine waters, the plot of THg compared to salinity would be represented by a straight line. The plot of THg compared to salinity in the complex system of Sinclair Inlet, Dyes Inlet, Port Orchard Passage, and Rick Passage indicates mixing is more complicated than the mixing of freshwater with one marine water mass.

These samples were examined more closely as subsets collected during each of the tidal cycles on September 13 and 14, 2005 (fig. 66). During the beginning of the flooding tide of September 13 when the vertical difference in salinity in Sinclair Inlet (M4) was 0.6 on the practical salinity scale (PSS) (fig. 67), the unfiltered deeper sample had higher THg concentration $(1.36 \mathrm{ng} / \mathrm{L})$ relative to the unfiltered two surface samples (0.97 ng/L) in Sinclair (M3.3 and M4). Likewise, the THg concentration in the deeper sample of Rich Passage (M2) had higher concentrations than the surface water sample; even the water column was well mixed. In contrast, the water column was well mixed in Port Orchard Passage (M1) during the later stages of flooding tidal cycle of September 13 and the higher salinity water of Port Orchard Passage had the lowest THg. 
Table 6. Concentrations of total mercury and ancillary data from unfiltered marine water-column samples collected from Sinclair Inlet and other Puget Sound locations in Washington.

[Data sources: $\mathrm{M}$ stations (figures 1B and 1C ); description for Sinclair Inlet nearshore samples are described relative to landmarks in figs. 1B and 2; Brandenberger and others, 2006a; 2007 (values in italics indicated replicate samples); Main Basin (figure 1), King County, 2001. Location: "D" after M locations indicates a near bottom sample. Abbreviations Std. dev., standard deviaiton; ng/L, nanogram per liter; $\mu$ g/L, microgram per liter; TOC, total organic carbon; mg/L, milligrams per liter; TSS, total suspended solids; PSS, Practical Salinity Scale; CTD, Conductivity-Temperature-Depth sensor; POTW, publically owned treatment works; -, no data]

\begin{tabular}{|c|c|c|c|c|c|c|c|c|}
\hline \multirow{2}{*}{ Location } & \multirow{2}{*}{$\begin{array}{l}\text { Collection } \\
\text { date }\end{array}$} & \multicolumn{2}{|c|}{ Total mercury (ng/L) } & \multirow{2}{*}{$\begin{array}{c}\text { Total } \\
\text { aluminum } \\
(\mu \mathrm{g} / \mathrm{L})\end{array}$} & \multirow{2}{*}{$\begin{array}{c}\text { TOC } \\
\text { (mg/L) }\end{array}$} & \multirow{2}{*}{$\begin{array}{c}\text { TSS } \\
\text { (mg/L) }\end{array}$} & \multicolumn{2}{|c|}{ Salinity (PSS) } \\
\hline & & Mean & Std. dev. & & & & Discrete & CTD \\
\hline \multicolumn{9}{|c|}{ Port Madison/Port Orchard Passage } \\
\hline M1 & 03-10-02 & 0.69 & - & 12.45 & - & - & - & - \\
\hline M1 & 03-12-02 & .96 & - & 50.9 & - & - & - & - \\
\hline M1 & 03-13-02 & .75 & - & 28.3 & - & - & - & - \\
\hline M1 & 09-17-02 & .83 & - & 25.5 & - & - & - & - \\
\hline M1 & $06-21-04$ & .62 & - & 6.1 & - & - & - & 27.6 \\
\hline M1 & 09-13-05 & .76 & - & 8.25 & 1.15 & 1 & 30.34 & - \\
\hline M1D & $06-21-04$ & .62 & - & 8.3 & - & - & - & 28.2 \\
\hline M1D & 09-13-05 & .73 & - & 10.1 & 1.2 & 2 & 30.35 & - \\
\hline M9 & 09-14-05 & 1.14 & - & 10.4 & 2 & 4 & 30.08 & - \\
\hline M9D & 09-14-05 & 1.79 & - & 48.7 & 1.2 & 5 & 30.23 & - \\
\hline M10 & 09-14-05 & 1.08 & - & 10.8 & 2.2 & 5 & 30.07 & - \\
\hline M10.1 & 09-14-05 & 1.12 & - & 22.2 & 2 & 5 & 30.07 & - \\
\hline M11 & 09-14-05 & 1.58 & - & 7.68 & 1.6 & 4 & 30.29 & - \\
\hline M11D & 09-14-05 & 1.82 & - & 35.2 & 0.6 & 3 & 30.54 & - \\
\hline \multicolumn{9}{|c|}{ Rich Passage } \\
\hline M2 & 03-10-02 & 1.33 & - & 13.2 & - & - & - & - \\
\hline M2 & 03-12-02 & .79 & - & 23.5 & - & - & - & - \\
\hline M2 & 03-13-02 & .88 & - & 34.2 & - & - & - & - \\
\hline M2 & 09-17-02 & .72 & - & 23.1 & - & - & - & - \\
\hline M2 & $06-21-04$ & 1.25 & - & 10.7 & - & - & - & 27.9 \\
\hline M2 & 09-13-05 & 1.19 & - & 7.48 & 2.1 & 3 & 30.08 & - \\
\hline M2D & 06-21-04 & .80 & - & 12.6 & - & - & - & 28.4 \\
\hline M2D & 09-13-05 & 1.69 & - & 16.4 & 1.3 & 2 & 30.17 & - \\
\hline \multicolumn{9}{|c|}{ Central Sinclair Inlet } \\
\hline${ }^{1} \mathrm{M} 3$ & 03-10-02 & 0.95 & - & 13.1 & - & - & - & - \\
\hline${ }^{1} \mathrm{M} 3$ & 03-12-02 & .70 & - & 34.3 & - & - & - & - \\
\hline${ }^{1} \mathrm{M} 3$ & 03-13-02 & .85 & - & 30.2 & - & - & - & - \\
\hline${ }^{1} \mathrm{M} 3$ & 09-17-02 & .86 & - & 28.2 & - & - & - & - \\
\hline${ }^{1} \mathrm{M} 3$ & $05-27-04$ & 1.13 & - & 22.1 & - & - & - & - \\
\hline M3.1 & 03-31-04 & 1.05 & - & 15.1 & - & - & - & - \\
\hline M3.1 & 02-09-05 & 1.01 & - & 19.65 & 1 & 0 & 28.76 & - \\
\hline M3.1 & 03-02-05 & .55 & - & 13.2 & 1.3 & 0 & 29.21 & - \\
\hline M3.1 & 03-19-05 & .70 & - & 11.9 & 1 & 2 & 29.26 & - \\
\hline M3.1 & 03-28-05 & .72 & - & 18.1 & 1.2 & 1 & 29.00 & - \\
\hline
\end{tabular}


Table 6. Concentrations of total mercury and ancillary data from unfiltered marine water-column samples collected from Sinclair Inlet and other Puget Sound locations.-Continued

[Data sources: $\mathrm{M}$ stations (figures 1B and 1C ); description for Sinclair Inlet nearshore samples are described relative to landmarks in figs. 1B and 2; Brandenberger and others, 2006a; 2007 (values in italics indicated replicate samples); Main Basin (figure 1), King County, 2001. Location: "D" after M locations indicates a near bottom sample. Abbreviations Std. dev., standard deviaiton; ng/L, nanogram per liter; $\mu$ g/L, microgram per liter; TOC, total organic carbon; mg/L, milligrams per liter; TSS, total suspended solids; PSS, Practical Salinity Scale; CTD, Conductivity-Temperature-Depth sensor; POTW, publically owned treatment works; -, no data]

\begin{tabular}{|c|c|c|c|c|c|c|c|c|}
\hline \multirow{2}{*}{ Location } & \multirow{2}{*}{$\begin{array}{l}\text { Collection } \\
\text { date }\end{array}$} & \multicolumn{2}{|c|}{ Total mercury (ng/L) } & \multirow{2}{*}{$\begin{array}{c}\text { Total } \\
\text { aluminum } \\
(\mu \mathrm{g} / \mathrm{L})\end{array}$} & \multirow{2}{*}{$\begin{array}{c}\text { TOC } \\
\text { (mg/L) }\end{array}$} & \multirow{2}{*}{$\begin{array}{c}\text { TSS } \\
(\mathrm{mg} / \mathrm{L})\end{array}$} & \multicolumn{2}{|c|}{ Salinity (PSS) } \\
\hline & & Mean & Std. dev. & & & & Discrete & CTD \\
\hline${ }^{2} \mathrm{M} 3.2$ & $05-27-04$ & 1.68 & - & 24.4 & - & - & - & - \\
\hline M3.3 & 06-21-04 & .95 & - & 17.0 & - & - & - & 28.35 \\
\hline M3.3 & 06-20-05 & .85 & - & 22.4 & 2.8 & 5 & 28.94 & - \\
\hline M3.3 & 09-13-05 & .97 & - & 8.44 & 1.7 & 3 & 29.59 & - \\
\hline M3.3D & 06-21-04 & .76 & - & 7.5 & - & - & - & 28.4 \\
\hline${ }^{3} \mathrm{M} 3.4$ & $05-27-04$ & 1.59 & - & 31.0 & - & - & - & - \\
\hline \multicolumn{9}{|c|}{ Central Sinclair Inlet-Continued } \\
\hline M4 & 03-10-02 & 0.82 & - & 10.7 & - & - & - & - \\
\hline M4 & 03-12-02 & .94 & - & 33.0 & - & - & - & - \\
\hline M4 & 03-13-02 & 1.06 & - & 33.6 & - & - & - & - \\
\hline M4 & 09-17-02 & 1.05 & - & 37.5 & - & - & - & - \\
\hline M4 & $05-27-04$ & 1.19 & - & 34.0 & - & - & - & - \\
\hline M4 & 02-09-05 & .94 & - & $1 \mathrm{U}$ & 1.1 & 0 & 28.06 & - \\
\hline M4 & 03-02-05 & .86 & - & 16.6 & 1.1 & 0 & 28.33 & - \\
\hline M4 & 03-19-05 & .97 & - & 18.1 & 1.1 & 0 & 29.22 & - \\
\hline M4 & 03-28-05 & .83 & - & 19.4 & 1.2 & 2 & 28.96 & - \\
\hline M4 & $9-13-2005$ & .97 & - & 12.8 & 1.5 & 4 & 29.30 & - \\
\hline M4D & 9-13-2005 & 1.36 & - & 6.73 & 2.3 & 3 & 29.86 & - \\
\hline \multicolumn{9}{|c|}{ Dyes Inlet } \\
\hline M5 & 09-14-05 & 1.76 & - & 25.3 & 1.5 & 4 & 30.05 & - \\
\hline M6 & 09-13-05 & 1.28 & - & 13.6 & 1.7 & - & 29.93 & - \\
\hline M7 & 09-14-05 & 1.89 & - & 19.2 & 1.5 & 3 & 30.04 & - \\
\hline M8 & 09-14-05 & 2.27 & - & 35.1 & 2.7 & 5 & 29.76 & - \\
\hline \multicolumn{9}{|c|}{ Nearshore Sinclair Inlet } \\
\hline $\mathrm{P} 1$ & $05-27-04$ & 2.02 & - & 91.1 & - & - & - & - \\
\hline P2 & $05-27-04$ & 10.71 & - & 116.0 & - & - & - & - \\
\hline P3 & 03-31-04 & 1.79 & - & 7.8 & - & - & - & - \\
\hline P4 & $05-27-04$ & 2.10 & - & 124 & - & - & - & - \\
\hline P5 & $05-27-04$ & 1.03 & - & 13.9 & - & - & - & - \\
\hline SN03 & $05-27-04$ & 2.16 & - & 64.0 & - & - & - & - \\
\hline \multicolumn{9}{|c|}{ Main Basin-Admiralty Inlet } \\
\hline ADMIRALC14-5m & June 1999 to & 0.34 & 0.13 & - & - & - & - & - \\
\hline ADMIRALC14-110m & June 2000 & .36 & 0.12 & - & - & - & - & - \\
\hline
\end{tabular}


Table 6. Concentrations of total mercury and ancillary data from unfiltered marine water-column samples collected from Sinclair Inlet and other Puget Sound locations.-Continued

[Data sources: $\mathrm{M}$ stations (figures 1B and 1C ); description for Sinclair Inlet nearshore samples are described relative to landmarks in figs. 1B and 2; Brandenberger and others, 2006a; 2007 (values in italics indicated replicate samples); Main Basin (figure 1), King County, 2001. Location: "D" after M locations indicates a near bottom sample. Abbreviations Std. dev., standard deviaiton; ng/L, nanogram per liter; $\mu \mathrm{g} / \mathrm{L}$, microgram per liter; TOC, total organic carbon; mg/L, milligrams per liter; TSS, total suspended solids; PSS, Practical Salinity Scale; CTD, Conductivity-Temperature-Depth sensor; POTW, publically owned treatment works; -, no data]

\begin{tabular}{|c|c|c|c|c|c|c|c|c|}
\hline \multirow{2}{*}{ Location } & \multirow{2}{*}{$\begin{array}{l}\text { Collection } \\
\text { date }\end{array}$} & \multicolumn{2}{|c|}{ Total mercury (ng/L) } & \multirow{2}{*}{$\begin{array}{c}\text { Total } \\
\text { aluminum } \\
(\mu \mathrm{g} / \mathrm{L})\end{array}$} & \multirow{2}{*}{$\begin{array}{c}\text { TOC } \\
\text { (mg/L) }\end{array}$} & \multirow{2}{*}{ TSS (mg/L) } & \multicolumn{2}{|c|}{ Salinity (PSS) } \\
\hline & & Mean & Std. dev. & & & & Discrete & CTD \\
\hline \multicolumn{9}{|c|}{ Main Basin-Colvos Passage } \\
\hline COLVOSPASS-5m & June 1999 to & 0.33 & 0.12 & - & - & - & - & - \\
\hline COLVOSPASS-85m & June 2000 & .39 & 0.13 & - & - & - & - & - \\
\hline \multicolumn{9}{|c|}{ Main Basin-Jefferson Head } \\
\hline KSBP01-5m & June 1999 to & 0.34 & 0.09 & - & - & - & - & - \\
\hline KSBP01-210m & June 2000 & .46 & 0.15 & - & - & - & - & - \\
\hline \multicolumn{9}{|c|}{ Main Basin-West Point POTW Outfall } \\
\hline KSSK02-5m & June 1999 to & 49.8 & 124.5 & - & - & - & - & - \\
\hline KSSK02-55m & June 2000 & 21.3 & 32.9 & - & - & - & - & - \\
\hline
\end{tabular}

${ }^{1}$ Location M3 is near location M3.1 on figure 2.

${ }^{2}$ Location M3.2 is located mid-channel between M3.1 and M3.3 in figure 2.

${ }^{3}$ Location M3.4 is located mid-channel between M3.3 and M4 in figure 2. 

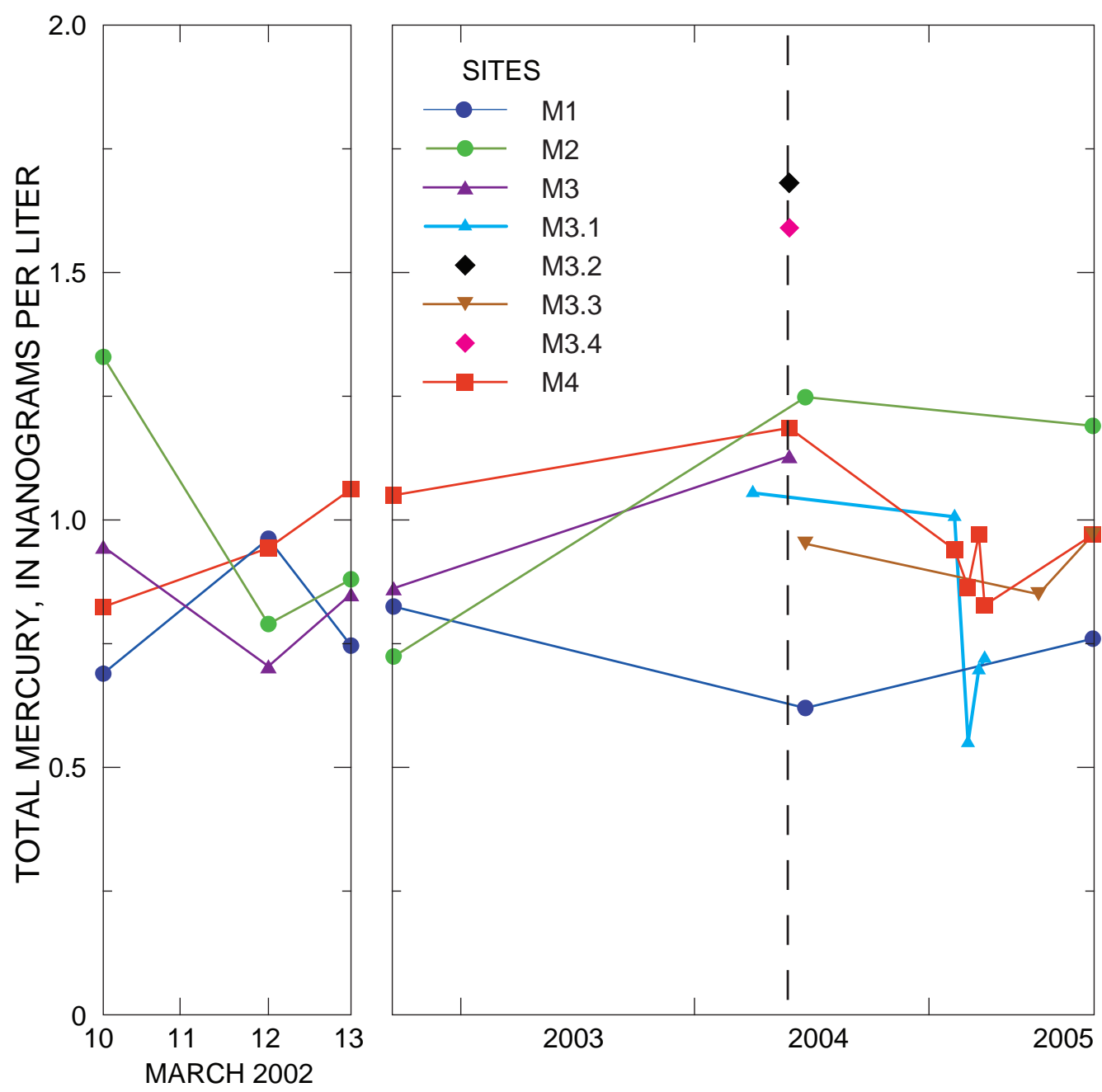

Figure 63. Total mercury concentrations in unfiltered near-surface waters of Sinclair Inlet, Port Orchard Passage, and Rich Passage (Washington) between 2002 and 2005 (table 6). Note the dashed line indicates the May 27, 2004 sampling after a storm event. 


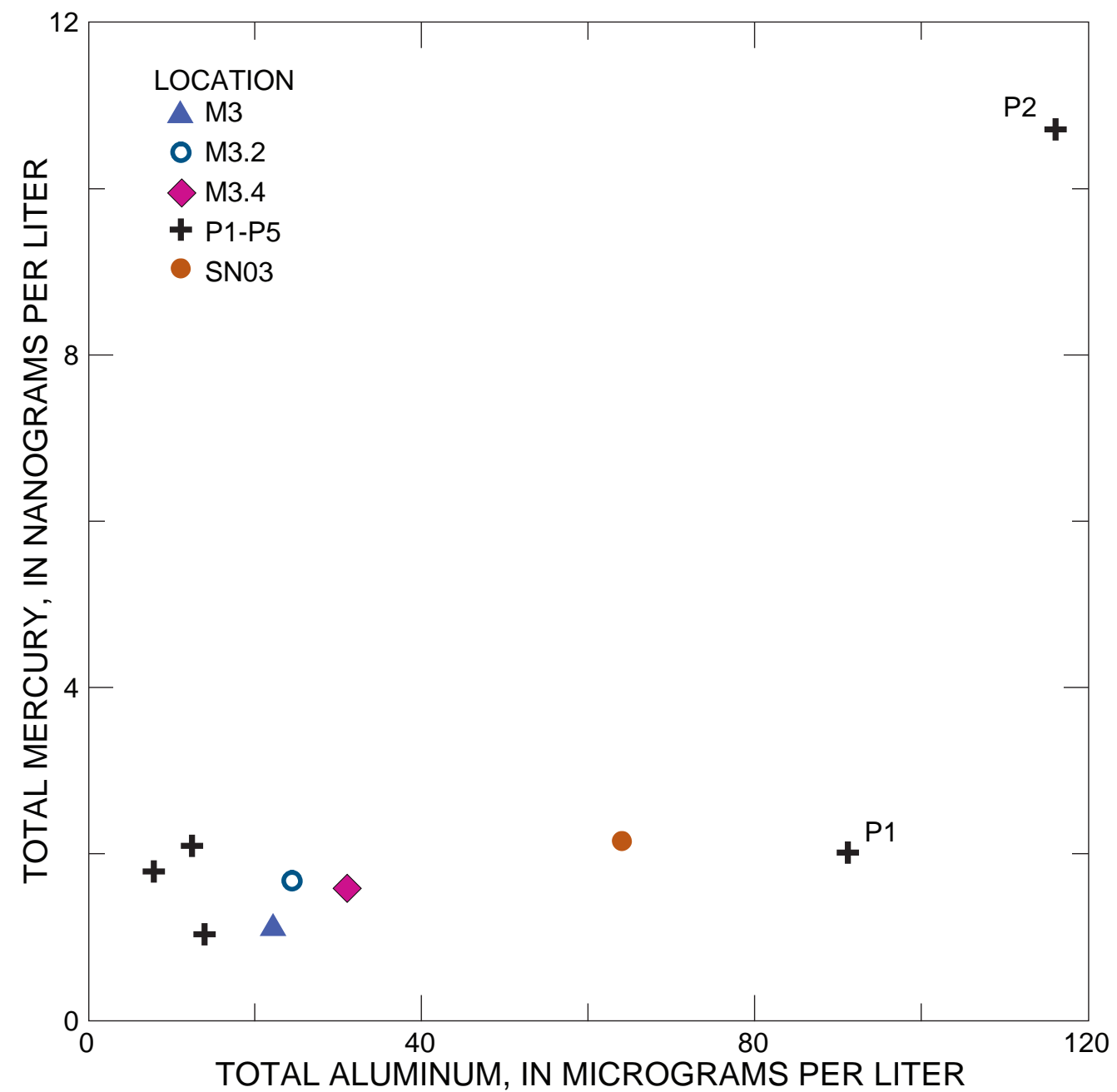

Figure 64. Total mercury compared to total aluminum concentrations in unfiltered marine water at nearshore stations within the Bremerton naval complex of Washington ( $P$ stations), a nearshore station off Port Orchard (SN03) and stations in central Sinclair Inlet (M stations) in the wet season of 2004 (table 6). 


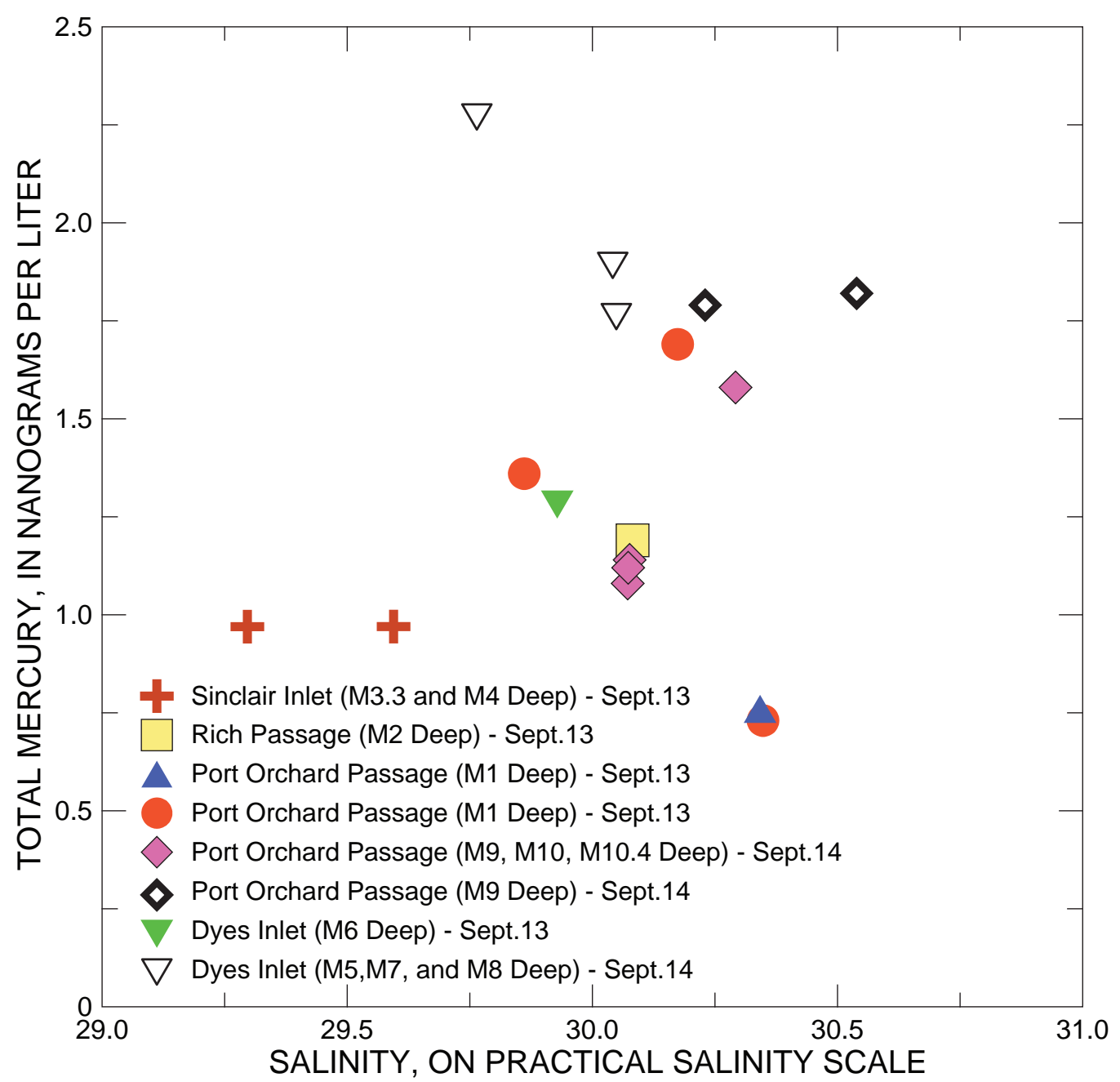

Figure 65. Total mercury concentrations compared to salinity for unfiltered marine water column samples collected in Puget Sound, Washington, September 13-14, 2005 (table 6) 
- Port Orchard Passage- M1

- Rich Passage- M2

$\checkmark$ Sinclair Inlet- M3.3

- Sinclair Inlet- M4

$\nabla$ Dyes Inlet- M6

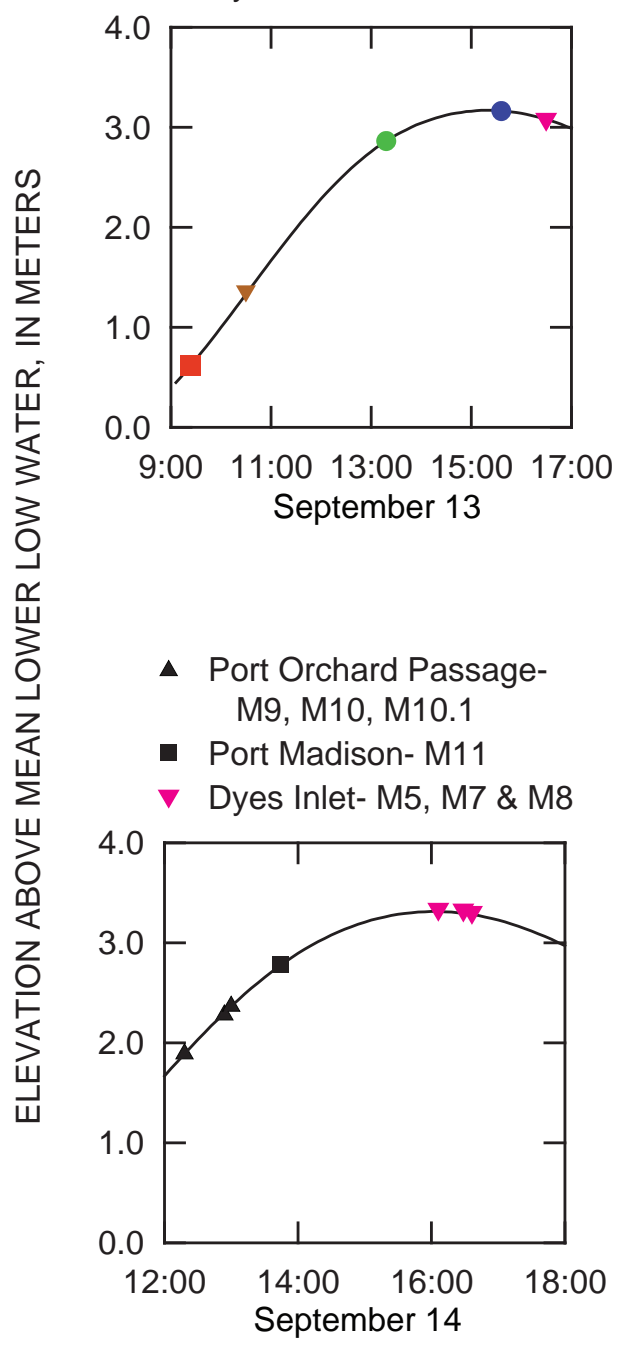

Figure 66. Water elevation in Puget Sound, Washington, compared to time and time of sampling at locations during the flooding tidal cycles of September 13 and 14, 2005.
- Port Orchard Passage- M1

- Rich Passage-M2

$\checkmark$ Sinclair Inlet- M 3.3

- Sinclair Inlet- M4

$\checkmark$ Dyes Inlet- M6

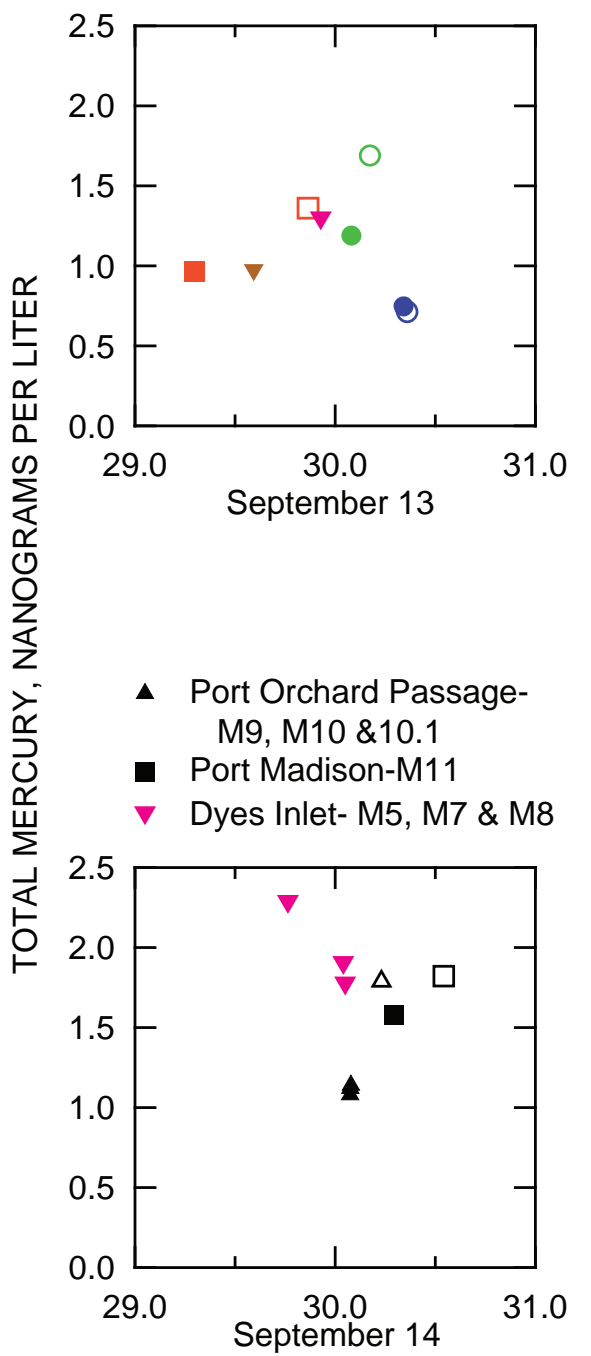

SALINITY, ON THE PRACTICAL SALINITY SCALE

Figure 67. Total mercury concentrations in waters of Puget Sound, Washington, compared to salinity for each of the subsets of unfiltered marine samples collected during the flooding tidal cycles of September 13 and 14, 2005 (table 6). Filled symbols represent samples collected near the surface while open symbols represent samples collected near the bottom sediment. 
Examination of TOC and total aluminum helps to explain the complex relation of $\mathrm{THg}$ during the flooding stage of September 13. During the flooding tidal cycle of September 13 , THg concentrations were correlated $\left(\mathrm{R}^{2}=0.90, p=0.005\right)$ to the TOC concentrations in the water column (fig. 68), with the exception of the higher THg concentration in the deeper water sample Rich Passage. The deeper water column sample in Rich Passage contained the highest concentrations of both THg and total aluminum (table 6 and fig. 69), probably indicating the resuspension of bottom sediments in this high energy channel. Thus, the complex relation of THg during the flooding tidal cycle of September 13 seems to be controlled by a complex mixing of multiple water masses with differing TOC concentrations and possibly affected by resuspension of sediments that increase THg and total aluminum concentrations in unfiltered water.

During initial stages of the flooding tidal cycle on September 14 (fig. 66), THg concentrations in Port Orchard Passage (M9, M10 and M10.1) and Port Madison (M11) increased $\left(\mathrm{R}^{2}=0.86, p=0.03\right)$ with increasing salinity (fig. 67). While the THg concentration of central Dyes Inlet (M5 and M7) collected at the later stages of the flooding tide (high slack water) plot on the relation above, the THg concentration in Ostrich Bay in Dyes Inlet (M8, table 6) was offset from this trend. In contrast to the samples collected on September 13, the THg concentrations collected in Port Orchard Passage and Port Madison on September 14 decreased $\left(\mathrm{R}^{2}=0.97, p=0.001\right)$ with increasing TOC concentrations (fig. 68). Similar to the relation of salinity, THg concentration of central Dyes Inlet (M5 and M7) plot on the TOC relation above while the THg concentration in Ostrich Bay in Dyes Inlet (M8, table 6) was offset from this trend. Unlike sampling on September 13, the sample with the highest THg (M8) was not the sample with the highest total aluminum concentration (deeper sample at M9 in Port Orchard Passage).

The varying THg on September 13 and 14, 2005 illustrates the need to understand the environmental context of the marine system from which samples are collected. Measures of the suspended solids concentrations, of tracers that differentiate water masses, and of organic carbon that facilitate the physical transport of mercury are necessary to understand mercury cycling in this complex system. Even with a full suite of ancillary data, the limitation of describing the mercury system from analysis of THg from 17 unfiltered samples collected over two days is evident.

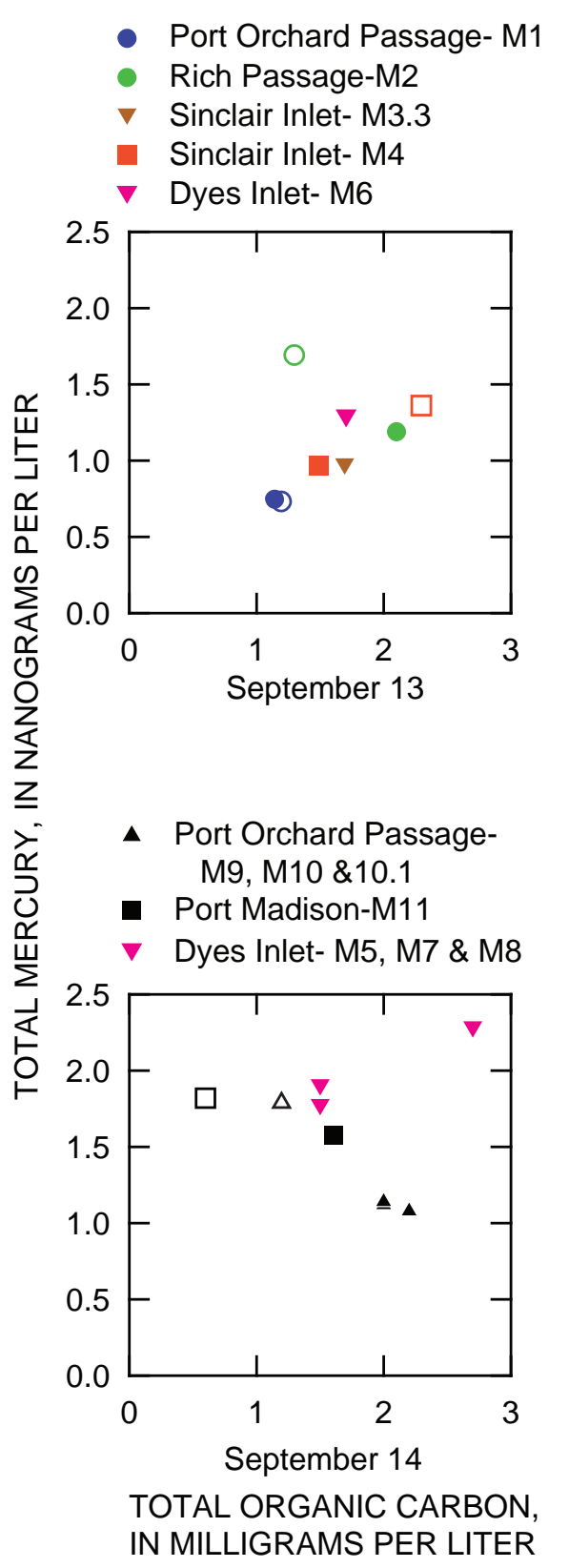

Figure 68. Concentrations of total mercury compared to total organic carbon concentrations for each of the unfiltered subsets of samples collected during the flooding tidal cycles of September 13 and 14, 2005 in Puget Sound, Washington (table 6). Filled symbols represent samples collected near the surface while open symbols represent samples collected near the bottom sediment. 
- Port Orchard Passage- M1

- Rich Passage-M2

$\checkmark$ Sinclair Inlet- M 3.3

- Sinclair Inlet- M4

$\checkmark$ Dyes Inlet- M6

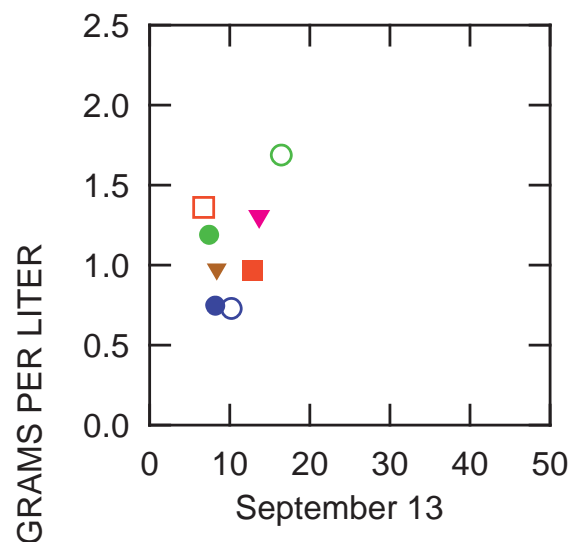

- Port Orchard Passage-

$\mathrm{M} 9, \mathrm{M} 10 \& 10.1$

Port Madison-M 11

$\checkmark$ Dyes Inlet- M5, M7 \& M8

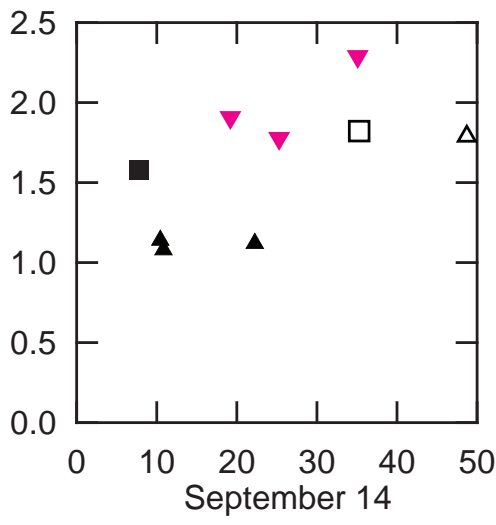

TOTAL ALUMINUM, IN

MICROGRAMS PER LITER

Figure 69. Total mercury concentrations in water from Puget Sound, Washington, compared to total aluminum concentrations for each of the subsets of unfiltered samples collected during the flooding tidal cycles of September 13 and 14, 2005 (table 6). Filled symbols represent samples collected near the surface while open symbols represent samples collected near the bottom sediment.

\section{Summary of Mercury in Marine Waters of Sinclair Inlet}

Total mercury (THg) concentrations in the marine water from central Sinclair Inlet generally ranged between 0.7 and $1.3 \mathrm{ng} / \mathrm{L}$ (fig. 63), except during the 2004 storm event sampling when THg concentrations were about $1.6 \mathrm{ng} / \mathrm{L}$. These concentrations were higher than those measured in central Puget Sound $(\sim 0.3 \mathrm{ng} / \mathrm{L})$. Water from one nearshore station near the OU B Marine 500-ft grid cell 39 had a THg concentration of $10.7 \mathrm{ng} / \mathrm{L}$ during a time of higher tides and storm events. Mixing of Sinclair Inlet water with adjacent water bodies was examined during two flooding tidal cycles during September 13 and 14. Ancillary data indicate that multiple water masses were observed during the study and the THg concentrations may have been affected by sediment resuspension. The spatial and temporal resolution of the sampling was not sufficient to develop a clear and precise understanding of the mixing of particulate and dissolved mercury into and out of Sinclair Inlet.

\section{Mercury in Biota of Sinclair Inlet}

Several past studies in Puget Sound have analyzed mercury in biological sampling, including the U.S. Navy as part of the RI/FS process (U.S. Navy, 2002, 2006a, 2008a) and the Washington State Department of Fish and Wildlife (WDFW) in cooperation with PSAMP (West and others, 2001; Brandenberger and others, 2006b, 2008). Recently, the ENVVEST project coordinated some aspects of the additional biological sampling among the interested agencies. The primary purpose of these studies was to evaluate risk to human health from the consumption of fish and invertebrate, with a secondary purpose of to compare bioaccumulation of toxic contaminants across Puget Sound regions.

Past analyses of mercury in biota in Puget Sound and Sinclair Inlet generally were performed on composite samples, including the PSAMP study that collected a number of species throughout Puget Sound between 1989 and 1999 (West and others, 2001). Analyses of composite samples were adequate for assessing human health risk and reduced the project costs relative to analyses of individual specimens. However, when attempting to compare bioaccumulation of toxic contaminants in fish across geographical regions, analyses of individual specimens provide a more accurate representation of the chemical conditions of fish at a specific location because differences in specimen sizes or between populations can be considered. In 2003, 2005, and 2007, PSAMP provided individual specimens of several fish and invertebrates species that were analyzed for THg by ENVVEST (Brandenberger and others, 2006b, 2008; Johnston and others, 2007). The WDFW also analyzed a number of individual specimens of English sole collected from Sinclair Inlet in 1996. 
The concentration of mercury in fish naturally increases as the age of the fish increases due to relatively low rates of physiological loss from tissues (West and O'Neill, 1998). It therefore is important to know the corresponding weight, length, and age data for each specimen used in a composite or as an individual sample to accurately determine the significance of $\mathrm{THg}$ concentration data. If the $\mathrm{THg}$ concentration in a fish species is significantly higher for a given region, then the weight, length, and age of the specimen can be used to determine how the observed mercury concentration is related to physiological parameters associated with that specimen or to environmental contamination. The analysis of individual whole-body staghorn sculpin specimens collected by PSAMP in 2005 (Brandenberger and others, 2006b) provides an example of the importance of considering physiological parameters. The mean THg concentration of individual specimens from Sinclair Inlet was higher than the mean THg concentration of individual specimens collected near Vendovi Island (fig. 1A). The higher mean THg concentration for Sinclair Inlet specimens may have been due to the fact that the mean length of staghorn sculpin from Sinclair Inlet (table F1) was greater than the mean length of specimens from Vendovi Island (fig. 70). There was no significant difference in $\mathrm{THg}$ concentration between the two locations when the samples were about $25 \mathrm{~cm}$ in length. All concentrations in this section are on wet weight basis, except for the 2005 caged mussel experiment for which concentrations are on a dry weight basis.

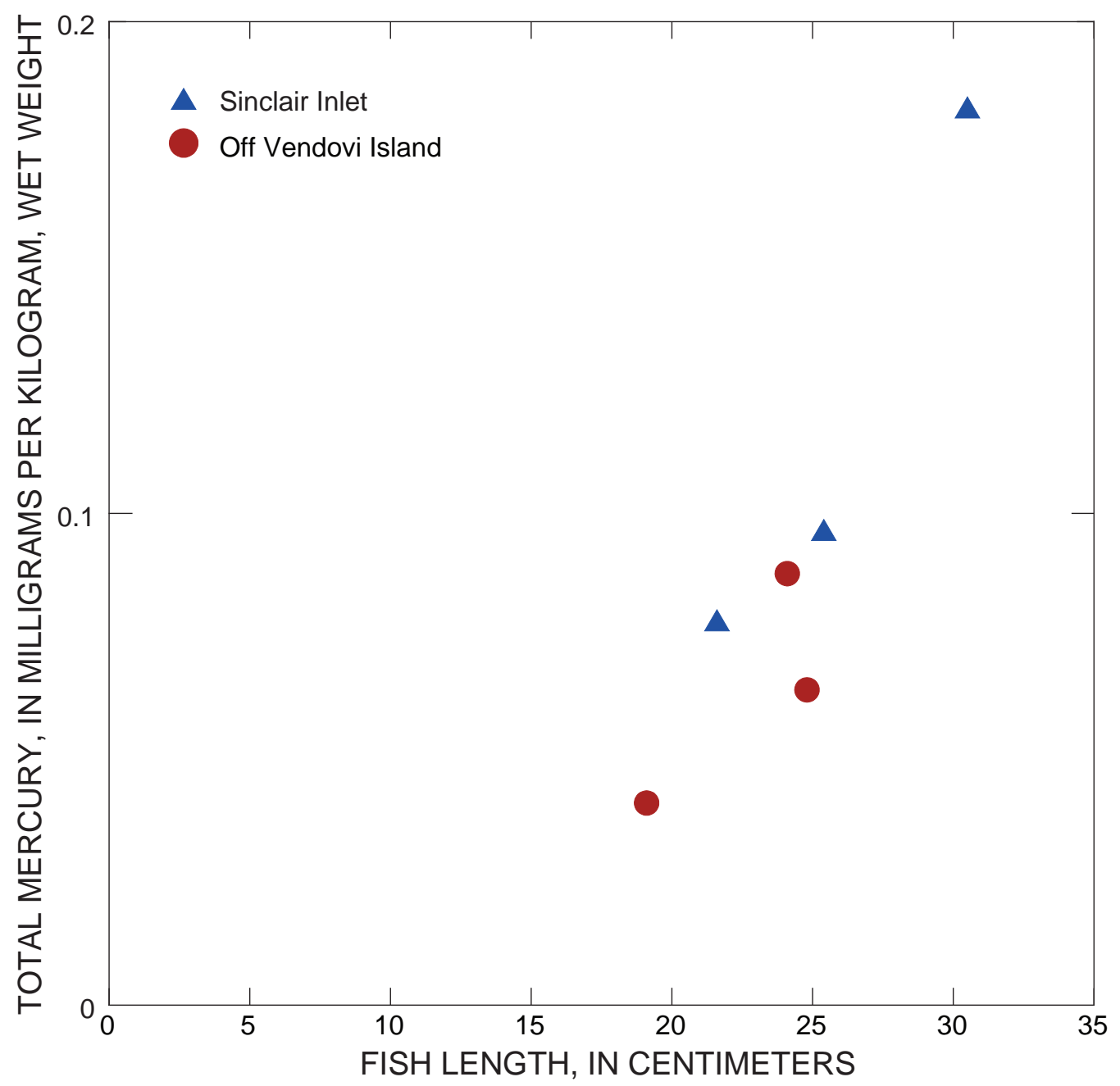

Figure 70. Total mercury concentration of whole- body staghorn sculpin compared to fish length for individual specimens collected in 2005 from Sinclair Inlet, Washington, and near Vendovi Island (table F1). 


\section{Composite Samples}

\section{English Sole}

The U.S. Navy studied toxic contamination in fish from Sinclair Inlet in 1994 (U.S. Navy, 2002) in which composite muscle samples of English sole (five individuals per composite) were prepared from five stations (fig. 71). English sole composites had a mean THg concentration of $0.036 \mathrm{mg} / \mathrm{kg}$ that ranged from 0.02 to 0.05 $\mathrm{mg} / \mathrm{kg}$ (wet weight) (table 7). In 2003, biota was sampled by PSAMP in May and analyzed by ENVVEST (Johnston and others, 2007) and sampled by the U.S. Navy in September (U.S. Navy, 2006a). Composites of muscle tissue from 20 English sole from Sinclair Inlet were collected and analyzed during both studies. THg concentrations in English sole muscle composites from the PSAMP study sampled in May ranged between 0.038 and $0.058 \mathrm{mg} / \mathrm{kg}$ for composites in which individual specimens averaged $33 \mathrm{~cm}$ long and 5.9 years old. THg concentrations of muscle composites of English sole collected by the U.S. Navy in September 2003 ranged from 0.027 to $0.041 \mathrm{mg} / \mathrm{kg}$ in which individual specimens had a mean length of $31 \mathrm{~cm}$ and a mean age of 5.1 years. In 2007, the U.S. Navy (2008a) analyzed another set of 10 muscle composites of English sole (20 individuals per composite with mean lengths from 27 to $32 \mathrm{~cm}$ ) that had THg concentrations ranging between 0.019 and $0.035 \mathrm{mg} / \mathrm{kg}$. Overall, the THg concentration of muscle from the three recent data sets (2003-07) ranged between 0.01 and $0.06 \mathrm{mg} / \mathrm{kg}$ and had similar ranges of fish lengths; the 2007 data set had the lowest mean THg concentrations.

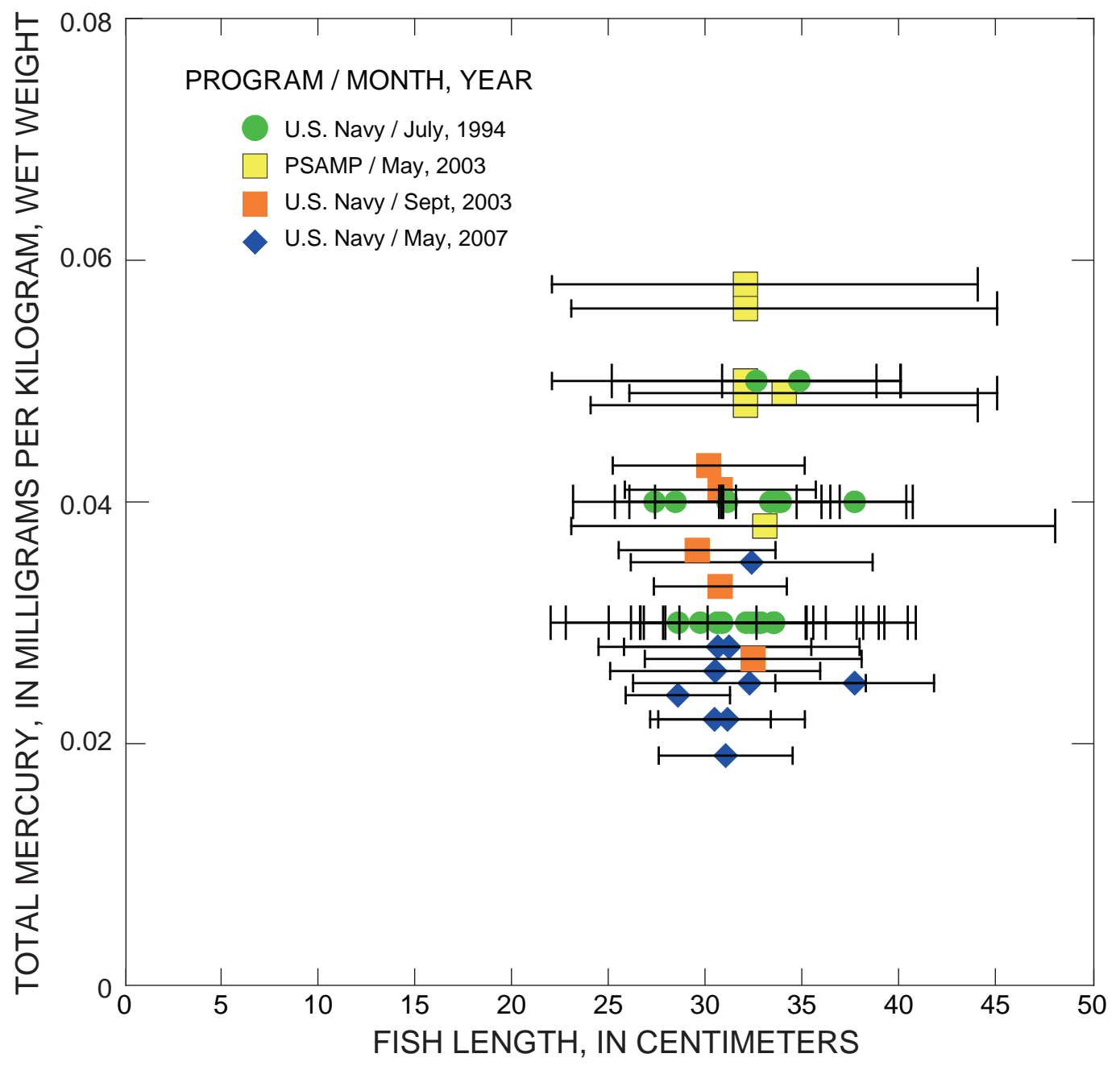

Figure 71. Mean total mercury concentrations in muscle tissue composites of English sole collected in Sinclair Inlet, Washington, by the U.S. Navy and the Puget Sound Ambient Monitoring Program between 1994 and 2007. The horizontal error bars represent the range of lengths of individual specimens represented by each composite (table 7). 
Table 7. Total mercury concentrations in muscle tissue composites of English sole collected from Sinclair Inlet, Washington.

[Data sources: 1994 RI/FS, U.S. Navy, 2006; 2003 U.S. Navy and PSAMP data, U.S. Navy 2006a; 2007 U.S. Navy data, U.S. Navy, 2008a. Abbreviations mg/kg, milligram per kilogram; cm, centimeter; RI/FS, Remedial Investigation/Feasibility Study; PSAMP, Puget Sound Ambient Monitoring Program; J, data qualified by quality assurance assessment]

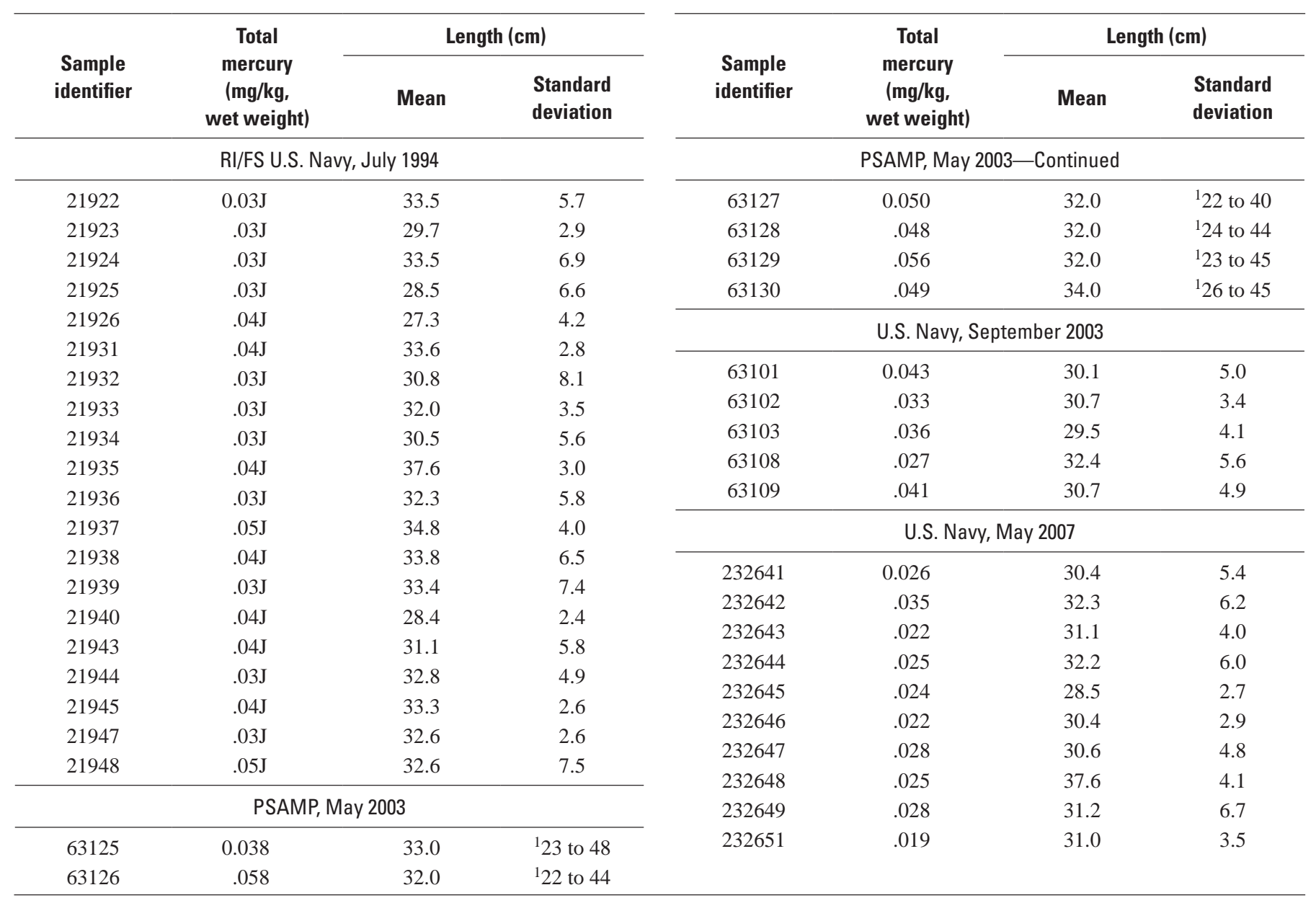

${ }^{1}$ Only ranges available.

From 1989-99 the WDFW collected and analyzed fish samples from several locations in Puget Sound (West and others, 2001). The main purpose of the study was to collect data regarding the bioaccumulation of toxic contaminants in biota (fish) in different Puget Sound regions. Ten fish species were collected and muscle tissue composites were analyzed for THg. At each location in Puget Sound, muscle fillets and livers from individual English sole were combined in composites (tables 8 and 9). The mean THg concentrations of English sole muscle in Puget Sound locations ranged from $0.02-0.11 \mathrm{mg} / \mathrm{kg}$. The mean THg concentration of English sole muscle in Sinclair Inlet $(0.08 \mathrm{mg} / \mathrm{kg})$ was in the top 20th percentile of Puget Sound locations. Locations with higher mean THg concentrations in muscle fillets included Eagle
Harbor and Harbor Island (fig. 1A). Data from other Sinclair Inlet studies are included in table 7 for comparison, but are not included in the rankings. Mean THg concentrations of English sole liver in Puget Sound locations ranged from $0.03-0.18 \mathrm{mg} / \mathrm{kg}$ and Sinclair Inlet ranked 25th highest of 33 locations in Puget Sound with a value of $0.12 \mathrm{mg} / \mathrm{kg}$.

To compare composite THg concentrations in English sole muscle analyzed by PSAMP, the U.S. Navy, and WDFW at various locations in Puget Sound, each location was grouped into specific Puget Sound Action Areas. The sample location in each Puget Sound Action Area with the highest mean THg concentration tended to be located near the most urban/industrial area (table 8). This trend also was observed for English sole liver (table 9). 
Table 8. Mean total mercury concentration in composites of English sole muscle collected throughout Puget Sound, Washington, between 1989 and 1999 .

[Values in milligrams per kilogram. Data sources: West and others, 2001; U.S. Navy, 2000, 2006a, and 2008a. Puget Sound ActionAreas(fig. 1A): C, Canada; SOJDF, Strait of Juan de Fuca; SJ/W, San Juan/Whatcom; HC, Hood Canal; W, Whidbey; NCPS, North Central Puget Sound; SCPS, South Central Puget Sound; SPS, South Puget Sound. Abbreviations mg/kg, milligrams per kilogram; No., number; WDFW, Washington State Department of Fish and Wildlife; PSAMP, Puget Sound Ambient Monitoring Program; Sinclair Inlet WDFW data in bold for emphasis]

\begin{tabular}{|c|c|c|c|c|c|c|c|}
\hline \multirow{2}{*}{$\begin{array}{l}\text { Puget Sound } \\
\text { Action Area }\end{array}$} & \multirow{2}{*}{ Location } & \multirow{2}{*}{$\begin{array}{c}\text { No. of } \\
\text { analyses }\end{array}$} & \multicolumn{3}{|c|}{ Total mercury (mg/kg, wet weight) } & \multirow{2}{*}{$\begin{array}{l}\text { Standard } \\
\text { deviation }\end{array}$} & \multirow{2}{*}{ References } \\
\hline & & & Mean & Minimum & Maximum & & \\
\hline $\mathrm{C}$ & Boulder Rock & 3 & 0.04 & 0.04 & 0.05 & 0.00 & WDFW 1989-1999 \\
\hline $\mathrm{C}$ & Iona Study Area & 3 & .04 & .04 & .05 & .01 & WDFW 1989-1999 \\
\hline SOJDF & Discovery Bay & 3 & .09 & .06 & .13 & .04 & WDFW 1989-1999 \\
\hline SOJDF & Strait of Juan de Fuca & 6 & .05 & .04 & .06 & .01 & WDFW 1989-1999 \\
\hline $\mathrm{SJ} / \mathrm{W}$ & Outer Birch & 3 & .05 & .03 & .06 & .02 & WDFW 1989-1999 \\
\hline $\mathrm{SJ} / \mathrm{W}$ & Strait of Georgia & 26 & .05 & .03 & .09 & .02 & WDFW 1989-1999 \\
\hline $\mathrm{SJ} / \mathrm{W}$ & Birch Point & 6 & .03 & .02 & .05 & .01 & WDFW 1989-1999 \\
\hline $\mathrm{SJ} / \mathrm{W}$ & Orcas Island & 3 & .03 & .02 & .03 & .01 & WDFW 1989-1999 \\
\hline $\mathrm{SJ} / \mathrm{W}$ & Outer Bellingham Bay & 9 & .03 & .02 & .04 & .01 & WDFW 1989-1999 \\
\hline $\mathrm{SJ} / \mathrm{W}$ & Point Roberts & 3 & .02 & .02 & .02 & .00 & WDFW 1989-1999 \\
\hline $\mathrm{SJ} / \mathrm{W}$ & Roberts Bank & 3 & .02 & .02 & .02 & .00 & WDFW 1989-1999 \\
\hline $\mathrm{HC}$ & Port Ludlow & 3 & .07 & .06 & .08 & .01 & WDFW 1989-1999 \\
\hline $\mathrm{HC}$ & North Hood Canal & 27 & .06 & .04 & .09 & .01 & WDFW 1989-1999 \\
\hline $\mathrm{HC}$ & Port Townsend & 12 & .05 & .03 & .08 & .01 & WDFW 1989-1999 \\
\hline $\mathrm{HC}$ & Mid Hood Canal & 6 & .04 & .03 & .05 & .01 & WDFW 1989-1999 \\
\hline $\mathrm{HC}$ & South Hood Canal & 6 & .03 & .02 & .04 & .01 & WDFW 1989-1999 \\
\hline W & Port Susan & 3 & .07 & .06 & .07 & .01 & WDFW 1989-1999 \\
\hline W & Saratoga Passage & 6 & .07 & .04 & .10 & .02 & WDFW 1989-1999 \\
\hline $\mathrm{W}$ & Possession Point & 6 & .06 & .04 & .07 & .01 & WDFW 1989-1999 \\
\hline W & Port Gardner & 25 & .05 & .02 & .09 & .01 & WDFW 1989-1999 \\
\hline W & Vendovi Island & 35 & .04 & .02 & .08 & .01 & WDFW 1989-1999 \\
\hline $\mathrm{W}$ & Mukilteo-Everett & 2 & .04 & .03 & .05 & .01 & WDFW 1989-1999 \\
\hline $\mathrm{W}$ & McAurthur Bank & 3 & .04 & .04 & .05 & .01 & WDFW 1989-1999 \\
\hline $\mathrm{W}$ & Holmes Habor & 5 & .02 & .01 & .03 & .01 & U.S. Navy 1994 \\
\hline NCPS & Eagle Harbor & 9 & .11 & .08 & .14 & .02 & WDFW 1989-1999 \\
\hline NCPS & Sindair Inlet & 49 & .08 & .03 & .14 & .02 & WDFW 1989-1999 \\
\hline NCPS & Outer Sinclair Inlet & 3 & .07 & .05 & .09 & .02 & WDFW 1989-1999 \\
\hline NCPS & Port Orchard & 9 & .07 & .05 & .07 & .01 & WDFW 1989-1999 \\
\hline NCPS & Sinclair Inlet & 1 & .0576 & .0504 & .0682 & .0094 & PSAMP 2003 \\
\hline NCPS & Sinclair Inlet & 6 & .050 & .038 & .058 & .007 & PSAMP 2003 \\
\hline NCPS & Liberty Bay & 6 & .05 & .04 & .06 & .01 & WDFW 1989-1999 \\
\hline NCPS & Dyes Inlet & 6 & .05 & .03 & .06 & .01 & WDFW 1989-1999 \\
\hline NCPS & Port Madison & 3 & .05 & .04 & .06 & .01 & WDFW 1989-1999 \\
\hline NCPS & Sinclair Inlet & 25 & .036 & .010 & .050 & .010 & U.S. Navy1994 \\
\hline NCPS & Sinclair Inlet & 5 & .036 & .027 & .043 & .006 & U.S. Navy 2003 \\
\hline NCPS & Sinclair Inlet & 8 & .025 & .019 & .035 & .004 & U.S. Navy 2007 \\
\hline SCPS & Harbor Island & 3 & .10 & .09 & .10 & .01 & WDFW 1989-1999 \\
\hline SCPS & Blake Island & 3 & .09 & .07 & .12 & .03 & WDFW 1989-1999 \\
\hline SCPS & Dash Point & 6 & .08 & .07 & .09 & .01 & WDFW 1989-1999 \\
\hline SCPS & Seattle Waterfront & 54 & .08 & .04 & .13 & .03 & WDFW 1989-1999 \\
\hline SCPS & Outer Commencement Bay & 6 & .08 & .05 & .09 & .02 & WDFW 1989-1999 \\
\hline
\end{tabular}


Table 8. Mean total mercury concentration in composites of English sole muscle collected throughout Puget Sound, Washington, between 1989 and 1999.-Continued

[Values in milligrams per kilogram. Data sources: West and others, 2001; U.S. Navy, 2000, 2006a, and 2008a. Puget Sound Action Areas(fig. 1A): C, Canada; SOJDF, Strait of Juan de Fuca; SJ/W, San Juan/Whatcom; HC, Hood Canal; W, Whidbey; NCPS, North Central Puget Sound; SCPS, South Central Puget Sound; SPS, South Puget Sound. Abbreviations mg/kg, milligrams per kilogram; No., number; WDFW, Washington State Department of Fish and Wildlife; PSAMP, Puget Sound Ambient Monitoring Program; Sinclair Inlet WDFW data in bold for emphasis]

\begin{tabular}{|c|c|c|c|c|c|c|c|}
\hline \multirow{2}{*}{$\begin{array}{l}\text { Puget Sound } \\
\text { Action Area }\end{array}$} & \multirow{2}{*}{ Location } & \multirow{2}{*}{$\begin{array}{c}\text { No. of } \\
\text { analyses }\end{array}$} & \multicolumn{3}{|c|}{ Total mercury (mg/kg, wet weight) } & \multirow{2}{*}{$\begin{array}{l}\text { Standard } \\
\text { deviation }\end{array}$} & \multirow{2}{*}{ References } \\
\hline & & & Mean & Minimum & Maximum & & \\
\hline SCPS & Myrtle Edwards & 3 & .08 & .06 & .09 & .02 & WDFW 1989-1999 \\
\hline SCPS & Alki & 3 & .07 & .07 & .07 & .00 & WDFW 1989-1999 \\
\hline SCPS & Thea Foss Waterway & 49 & .07 & .03 & .12 & .02 & WDFW 1989-1999 \\
\hline SCPS & Fern Cove & 3 & .07 & .07 & .08 & .01 & WDFW 1989-1999 \\
\hline SCPS & Apple Cove Point & 6 & .06 & .04 & .08 & .02 & WDFW 1989-1999 \\
\hline SCPS & Duwamish River & 9 & 0.06 & 0.04 & 0.08 & 0.01 & WDFW 1989-1999 \\
\hline SCPS & Shilshole & 6 & .06 & .03 & .08 & .02 & WDFW 1989-1999 \\
\hline SPS & Nisqually Reach & 15 & .07 & .04 & .09 & .02 & WDFW 1989-1999 \\
\hline SPS & Carr Inlet & 6 & .05 & .04 & .07 & .01 & WDFW 1989-1999 \\
\hline SPS & Wollochet & 6 & .05 & .05 & .06 & .01 & WDFW 1989-1999 \\
\hline SPS & South Case Inlet & 6 & .04 & .03 & .05 & .01 & WDFW 1989-1999 \\
\hline SPS & Dana Passage & 9 & .04 & .03 & .04 & .01 & WDFW 1989-1999 \\
\hline SPS & North Case Inlet & 3 & .04 & .04 & .04 & .00 & WDFW 1989-1999 \\
\hline SPS & Pickering Passage & 6 & .03 & .02 & .05 & .01 & WDFW 1989-1999 \\
\hline
\end{tabular}


Table 9. Mean total mercury concentration in composites of English sole liver collected throughout Puget Sound, Washington, between 1989 and 1999.

[Data sources: West and others, 2001. Puget Sound Action Aress(fig. 1): C, Canada; SOJDF, Strait of Juan de Fuca; SJ/W, San Juan/Whatcom; HC, Hood Canal; W, Whidbey; NCPS, North Central Puget Sound; SCPS, South Central Puget Sound; SPS, South Puget Sound; W, Whidbey. Abbreviation: mg/kg, milligrams per kilogram; No., number. Sinclair Inlet data in bold for emphasis]

\begin{tabular}{|c|c|c|c|c|c|c|}
\hline \multirow{2}{*}{$\begin{array}{l}\text { Puget Sound } \\
\text { Action Area }\end{array}$} & \multirow{2}{*}{ Location } & \multicolumn{4}{|c|}{ Total mercury (mg/kg, wet weight) } & \multirow{2}{*}{$\begin{array}{l}\text { Standard } \\
\text { deviation }\end{array}$} \\
\hline & & $\begin{array}{c}\text { No. of } \\
\text { analyses }\end{array}$ & Mean & Minimum & Maximum & \\
\hline $\mathrm{C}$ & Iona Study Area & 3 & 0.07 & 0.07 & 0.08 & 0.01 \\
\hline $\mathrm{C}$ & Boulder Rock & 1 & .05 & & & \\
\hline SOJDF & Strait of Juan de Fuca & 5 & .09 & .07 & .10 & .01 \\
\hline $\mathrm{SJ} / \mathrm{W}$ & Strait of Georgia & 12 & .07 & .05 & .12 & .02 \\
\hline $\mathrm{SJ} / \mathrm{W}$ & Birch Point & 2 & .06 & .04 & .09 & .04 \\
\hline $\mathrm{SJ} / \mathrm{W}$ & Roberts Bank & 2 & .05 & .04 & .05 & .01 \\
\hline $\mathrm{SJ} / \mathrm{W}$ & Outer Bellingham Bay & 4 & .05 & .04 & .06 & .01 \\
\hline $\mathrm{SJ} / \mathrm{W}$ & Point Roberts & 3 & .03 & .03 & .05 & .01 \\
\hline $\mathrm{HC}$ & Port Ludlow & 3 & .12 & .11 & .14 & .02 \\
\hline $\mathrm{HC}$ & North Hood Canal & 15 & .12 & .07 & .17 & .03 \\
\hline $\mathrm{HC}$ & Port Townsend & 6 & .06 & .04 & .09 & .02 \\
\hline $\mathrm{W}$ & Port Susan & 1 & .15 & & & \\
\hline W & Saratoga Passage & 1 & .13 & & & \\
\hline W & Mukilteo-Everett & 2 & .11 & .07 & .14 & .05 \\
\hline W & Port Gardner & 11 & .09 & .06 & .13 & .02 \\
\hline W & Possession Point & 3 & .08 & .08 & .09 & .01 \\
\hline W & Vendovi Island & 5 & .05 & .04 & .07 & .01 \\
\hline NCPS & Eagle Harbor & 3 & .14 & .12 & .15 & .02 \\
\hline NCPS & Sindair Inlet & 14 & .12 & .08 & .17 & .03 \\
\hline NCPS & Port Orchard & 3 & .11 & .09 & .12 & .02 \\
\hline NCPS & Dyes Inlet & 3 & .07 & .06 & .08 & .01 \\
\hline NCPS & Port Madison & 3 & .07 & .07 & .08 & .01 \\
\hline NCPS & Liberty Bay & 3 & .06 & .05 & .08 & .02 \\
\hline SCPS & Seattle Waterfront & 9 & .18 & .12 & .27 & .05 \\
\hline SCPS & Outer Commencement Bay & 3 & .13 & .13 & .14 & .01 \\
\hline SCPS & Thea Foss Waterway & 15 & .13 & .06 & .27 & .06 \\
\hline SCPS & Apple Cove Point & 6 & .12 & .07 & .19 & .05 \\
\hline SCPS & Dash Point & 3 & .12 & .11 & .13 & .00 \\
\hline SCPS & Duwamish River & 6 & .10 & .06 & .12 & .02 \\
\hline SPS & Wollochet & 1 & .11 & & & \\
\hline SPS & Nisqually Reach & 6 & .09 & .05 & .13 & .03 \\
\hline SPS & Carr Inlet & 1 & .08 & & & \\
\hline SPS & Dana Passage & 3 & .04 & .04 & .04 & .00 \\
\hline
\end{tabular}




\section{Rockfish}

The fish species with the highest overall mean $\mathrm{THg}$ concentrations in Puget Sound were yellow, brown, and quillback rockfish (West and others, 2001). Of these species, the largest were yellow rockfish with a mean length of $67.9 \mathrm{~cm}$ for the individuals that were composited, followed by quillback and brown rockfish with mean lengths of 31.6 and $25.8 \mathrm{~cm}$, respectively.

The mean THg concentration in quillback rockfish from Sinclair Inlet was $0.8177 \mathrm{mg} / \mathrm{kg}$ and the highest of sixteen locations in Puget Sound (table F2). The mean $\mathrm{THg}$ concentration of quillback rockfish from Sinclair Inlet was about nine times higher than the lowest concentration measured for quillback rockfish in South Puget Sound (fig. 1A). The mean THg concentration in brown rockfish from Sinclair Inlet (table F3) was $0.81 \mathrm{mg} / \mathrm{kg}$, which was about eight-fold higher than brown rockfish from the Thea Foss Waterway in Tacoma (fig. 1A)

\section{Salmon}

The mean THg concentration in Chinook salmon from Sinclair Inlet $(0.099 \mathrm{mg} / \mathrm{kg})$ was near the mean value for Puget Sound (table F4). The mean THg concentration of Coho salmon from Sinclair Inlet $(0.060 \mathrm{mg} / \mathrm{kg})$ was the eighth highest out of ten locations in Puget Sound (table F5).

\section{Sea Cucumber}

Of the 24 composite samples of sea cucumber collected from Sinclair Inlet during 1995 (U.S. Navy, 2002), only 2 acceptable THg concentrations values of 0.0120 and $0.0184 \mathrm{mg} / \mathrm{kg}$ and 1 qualified value of $0.0106 \mathrm{mg} / \mathrm{kg}$ (wet weight) were obtained (table F6). Of the three composites and eight individual specimens collected from Blake Passage and Rich Passage, six qualified concentrations ranging between 0.0107 and $0.0199 \mathrm{mg} / \mathrm{kg}$ were measured. Because of the quality of the data, a rigorous statistical analysis among locations was not performed. Three composite samples were collected in 2007 ranging from a value near the reporting level of $0.00256 \mathrm{mg} / \mathrm{kg}$ (wet weight) in the Strait of Georgia to $0.0137 \mathrm{mg} / \mathrm{kg}$ (wet weight) in Sinclair Inlet Brandenberger and others, 2008).

\section{Geographical Comparison of Mercury Concentrations in Biota Using Individual Specimens}

When comparing the THg concentrations in individual fish across locations, the physiological parameters of the individual fish must be considered. The discussion of the relations between THg and fish age in rockfish (1995-97) from Puget Sound locations (West and O'Neill, 1998) is an example of the statistical analysis required to make valid conclusion regarding THg concentrations across Puget Sound locations. In this USGS report, THg concentrations of individual fish or invertebrates (Brandenberger and others, 2006b; 2008; Johnston and others, 2007; Jim West, Washington State Department of Fisheries and Wildlife, written commun., 2008) were examined in relation to the length or weight of the individuals using Generalized Linear Models (SAS, 1990). Samples were analyzed for THg and corresponding weight/length data were list in tables F1 and F7. For all species examined from Sinclair Inlet, significant differences (probability that $\mathrm{THg}$ concentrations among collection years was less than 5 percent, or $p<0.05$ ) in THg, length or weight data were identified among the collection years (table 10). Since differences in THg might have been a result of differences in the size of individual fish analyzed, an analysis of covariance was performed on the regression of THg with size (length and weight) for Sinclair Inlet data by collection year for each species. If no significant difference of the THg relation by collection year $(p<0.05)$ was observed for Sinclair Inlet, data for all collection years for each location were grouped together, and analysis of covariance of $\mathrm{THg}$ compared to size was performed. A probability of less than 5 percent $(p<0.05)$ indicates that the relation between THg and size for at least one group is significantly different from the other groups. Analysis that is performed by grouping data with information that is independent of the data set is called post ad-hoc analysis. Post ad-hoc analysis of covariance included comparing the relation of $\mathrm{THg}$ concentrations compared to size in Sinclair Inlet individuals with the relation compared to size from individuals grouped by urban and nonurban estuaries.

\section{Rockfish}

Individual rockfish samples were collected from six locations in Puget Sound during 1995-1997 by WDFW/PSAMP (West and O’Neill, 1998), including north Puget Sound, central Puget Sound, Elliott Bay, and Sinclair Inlet (fig. 1A). THg concentrations in rockfish increased considerably with fish age. The seven individual rockfish collected from Sinclair Inlet had higher THg concentrations than rockfish from other locations in Puget Sound. Using methods similar to analysis of covariance, West and O'Neill (1998) concluded that the relation of THg compared to age Sinclair Inlet was different than other Puget Sound regions. However, rockfish from Sinclair Inlet were the oldest of all individuals collected and ranged between 20 and 35 years. The oldest rockfish from Sinclair Inlet at 35 years had the highest THg concentration at about $1.1 \mathrm{mg} / \mathrm{kg}$. 
Table 10. Statistics of analysis of variance and analysis of covariance of total mercury concentrations in fish and invertebrate from Puget Sound, Washington, 1996-2007.

Locations are shown in in figure 1A. Data source: Jim West, Washington State Department of Fish and Wildlife, written commun., 2008; Johnston and others, 2007; Brandenberger and others, 2006b; Johnston, U.S. Navy, written commun., 2009. Analysis of variance and covariance performed with Generalized Linear Models (SAS, 1990). Numbers in bold represent differences that are statistically different at the 0.05 level; >, greater than; blank, no data; -, no urban data]

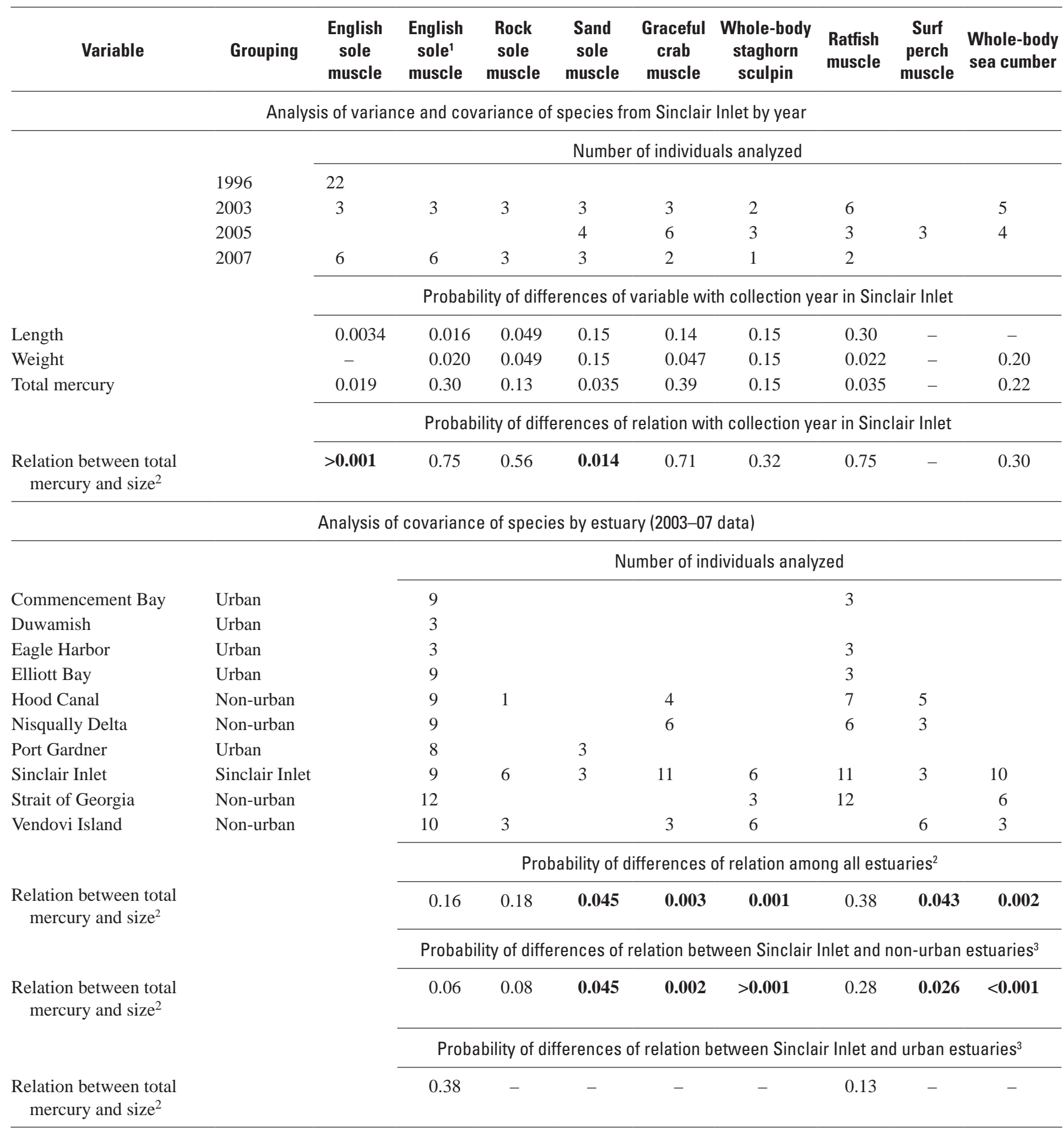

\footnotetext{
${ }^{1}$ Analysis includes only data collected in 2003 and after.

${ }^{2}$ Total mercury concentrations in wet weight and size as length and weight, except for weight for sea cucumber.

${ }^{3}$ Post ad-hoc analysis of covariance.
} 


\section{English, Rock, and Sand Sole}

Individual English sole samples were collected from Sinclair Inlet by PSAMP during 1996 (Jim West, Washington State Department of Fisheries and Wildlife, written commun., 2008) and were collected by PSAMP and analyzed by ENVVEST from various locations in Puget Sound during 2003 and 2007 (Johnston and others, 2007; Brandenberger and others, 2009; respectively). The 22 individual English sole from Sinclair Inlet collected during 1996 had THg in muscle that ranged from 0.0342 to $0.136 \mathrm{mg} / \mathrm{kg}$ (wet weight, table F7) and increased ( $p=0.003$ ) with increasing length, which ranged between $26.5 \mathrm{~cm}$ and $45.1 \mathrm{~cm}$. English sole collected in 1996 were longer and had higher THg concentrations ( $p=0.0034$ and 0.019 in table 10) than those caught in 2003 and 2007 (table 11 and fig. 72). The analyses of covariance indicated that there was a significant difference $(p>0.001)$ in the relation of THg compared to length of English sole (table 10) when grouped by collection years 1996, 2003, and 2007, but no difference $(p=0.75)$ was observed in this relation between 2003 and 2007. The mean THg was $0.0480 \mathrm{mg} / \mathrm{kg}$ (wet weight) for individuals collected from Sinclair Inlet in 2003 and 2007 that had a mean length of $31.4 \mathrm{~cm}$ (table 11). An analysis of covariance then was performed on the relation of THg compared to size (length and weight) for individuals collected in 2003, 2005, and 2007 in Sinclair Inlet compared to other Puget Sound estuaries..

Between 2003 and 2007, individual English sole (table F7 and fig. 73) also were collected from urban estuaries (Commencement Bay, Duwamish Waterway, Elliott Bay, and Port Gardner; fig. 1A) and non-urban estuaries (Hood Canal, the Nisqually Delta, Strait of Georgia, and off Vendovi Island) by PSAMP and analyzed by ENVVEST. Mean THg concentrations ranged from $0.0403 \mathrm{mg} / \mathrm{kg}$ (wet weight) for Duwamish Waterway English sole with a mean length of $21.8 \mathrm{~cm}$ to $0.0810 \mathrm{mg} / \mathrm{kg}$ (wet weight) for Elliott Bay English sole with a mean length of $26.1 \mathrm{~cm}$ (table 11). Analysis of covariance indicated no significant difference $(p=0.16)$ in the relation of THg compared to size among the estuaries (table 10). No significant difference in the Sinclair Inlet relation of THg compared to size was observed when compared to non-urban estuaries $(p=0.06)$ and urban estuaries $(p=0.38)$.

Rock sole (table F1) were collected from Sinclair Inlet in 2003 and 2007 (mean THg concentration of $0.0784 \mathrm{mg} / \mathrm{kg}$ (wet weight) and a mean fish length of $27.1 \mathrm{~cm}$ ) (fig. 74). Although there were significant differences in the weight and length between collection years, there was no significant difference $(p=0.56)$ in the relation of $\mathrm{THg}$ compared to size between years. The relation of THg compared to length of rock sole in Sinclair Inlet was not different $(p=0.08)$ from the relation of non-urban estuaries (Hood Canal and off Vendovi Island).

Sand sole individuals were collected in 2003, 2005, and 2007 and the THg concentrations in muscle tissue among years were statistically different $(p=0.035)$. Sand sole was the only species in which the relation of THg compared to fish length for Sinclair Inlet individuals was statistically different $(p=0.015)$ for collection year (table 10). Because Port Gardner was the only other location where THg concentrations in sand sole were available for individuals collected in 2003, the analysis of covariance was limited to the 2003 data set. The relation of THg compared to size for Sinclair Inlet (mean THg concentration of $0.0895 \mathrm{mg} / \mathrm{kg}$ (wet weight), and a mean fish length of $33.9 \mathrm{~cm})$ was significantly different $(p=0.045)$ than the relation for Port Gardner (mean THg concentration of $0.0490 \mathrm{mg} / \mathrm{kg}$ (wet weight), and mean fish length of $30.4 \mathrm{~cm}$ ).

\section{Graceful Crab}

THg concentrations in graceful crab (fig. 75) collected from Sinclair Inlet (mean THg concentration of $0.0714 \mathrm{mg} / \mathrm{kg}$ (wet weight) and a mean crab length of $9.1 \mathrm{~cm}$; table 11) were not significantly different $(p=0.39$; table 10$)$ by collection year (2003, 2005, and 2007), nor was the relation of THg compared to size grouped by year $(p=0.71)$. Therefore, the analysis of covariance was performed on data from each location for all collection years. When the size of individual specimens is taken into account, THg concentrations in graceful crab individuals (fig. 75) collected from Sinclair Inlet were higher $(p=0.002)$ than those collected from non-urban estuaries (Hood Canal, the Nisqually Delta, and off Vendovi Island; fig. 1A).

\section{Staghorn Sculpin}

Staghorn sculpin from Sinclair Inlet were collected in 2003, 2005 and 2007 (table F1) and no significant different was observed in Sinclair Inlet among collection years ( $p=0.32$, table 10$)$. The mean THg concentration of whole-body staghorn sculpin collected from Sinclair Inlet for all collection years was $0.0851 \mathrm{mg} / \mathrm{kg}$ (wet weight) for a mean fish length of $20.2 \mathrm{~cm}$ (table 11). The THg concentration relation with size of staghorn sculpin from Sinclair Inlet was significantly different from the relation among other non-urban estuaries (off Vendovi Island and the Strait of Georgia), both when other estuaries were considered separately $(p=0.001)$ or when other estuaries were considered together $(p<0.001)$. 
Table 11. Means and standard deviations of fish and invertebrate collected between 2003 and 2007 from Puget Sound, Washington, used in the analysis of covariance.

[Data source: Brandenberger and others, 2006b; Johnston and others, 2007; Johnston, U.S. Navy, written commun., 2009. Locations are shown in figure 1A. Abbreviations mg/kg, milligram per kilogram; cm, centimeter; kg, kilogram; Std. dev., standard deviation; No., number]

\begin{tabular}{|c|c|c|c|c|c|c|c|c|}
\hline \multirow{2}{*}{ Variable } & \multirow{2}{*}{ Grouping } & \multirow{2}{*}{$\begin{array}{c}\text { No. of } \\
\text { samples }\end{array}$} & \multicolumn{2}{|c|}{$\begin{array}{c}\text { Total mercury } \\
\text { (mg/kg, wet weight) }\end{array}$} & \multicolumn{2}{|c|}{$\begin{array}{l}\text { Length } \\
\text { (cm) }\end{array}$} & \multicolumn{2}{|c|}{$\begin{array}{l}\text { Weight } \\
\text { (kg) }\end{array}$} \\
\hline & & & Mean & Std. dev. & Mean & Std. dev. & Mean & Std. dev. \\
\hline \multicolumn{9}{|c|}{ English Sole Muscle } \\
\hline Sinclair Inlet & Sinclair Inlet & 9 & 0.0480 & 0.0211 & 31.4 & 6.7 & 0.360 & 0.204 \\
\hline Commencement Bay & Urban & 9 & .0554 & .0134 & 24.6 & 2.0 & .127 & .048 \\
\hline Duwamish Waterway & Urban & 3 & .0403 & .0050 & 21.8 & 4.1 & .109 & .042 \\
\hline Eagle Harbor & Urban & 3 & .0648 & .0211 & 28.4 & 6.8 & .236 & .169 \\
\hline Elliott Bay & Urban & 9 & .0810 & .0445 & 26.1 & 4.7 & .146 & .065 \\
\hline Hood Canal & Non-urban & 9 & .0550 & .0181 & 24.6 & 1.6 & .129 & .041 \\
\hline Nisqually Delta & Non-urban & 9 & .0716 & .0230 & 36.5 & 3.7 & .188 & .090 \\
\hline Port Gardner & Urban & 8 & .0507 & .0185 & 25.1 & 2.2 & .125 & .035 \\
\hline Strait of Georgia & Non-urban & 12 & .0577 & .0206 & 32.1 & 6.4 & .367 & .207 \\
\hline Vendovi Island & Non-urban & 10 & .0488 & .0216 & 27.0 & 4.1 & .208 & .071 \\
\hline \multicolumn{9}{|c|}{ Rock sole muscle } \\
\hline Sinclair Inlet & Sinclair Inlet & 6 & 0.0784 & 0.0512 & 27.1 & 9.0 & 0.322 & 0.189 \\
\hline Hood Canal & Non-urban & 1 & .0477 & - & 31.8 & - & .460 & - \\
\hline Vendovi Island & Non-urban & 3 & .0390 & .0138 & 24.1 & 6.0 & .257 & .219 \\
\hline \multicolumn{9}{|c|}{${ }^{1}$ Sand sole muscle (2003) } \\
\hline Sinclair Inlet & Sinclair Inlet & 3 & 0.0895 & 0.0399 & 33.9 & 6.9 & 0.464 & 0.240 \\
\hline Port Gardner & Urban & 3 & .0490 & .0150 & 30.4 & 5.1 & .409 & .202 \\
\hline \multicolumn{9}{|c|}{ Graceful crab muscle } \\
\hline Sinclair Inlet & Sinclair Inlet & 11 & 0.0714 & 0.0224 & 9.1 & 2.5 & 0.110 & 0.050 \\
\hline Hood Canal & Non-urban & 4 & .0219 & .0134 & 9.9 & 1.2 & .122 & .078 \\
\hline Nisqually Delta & Non-urban & 6 & .0441 & .0137 & 10.1 & 1.0 & .173 & .057 \\
\hline Vendovi Island & Non-urban & 3 & .0297 & .0187 & 9.8 & .8 & .110 & .020 \\
\hline \multicolumn{9}{|c|}{ Whole-body staghorn sculpin } \\
\hline Sinclair Inlet & Sinclair Inlet & 6 & 0.0851 & 0.0513 & 20.2 & 6.8 & 0.115 & 0.101 \\
\hline Strait of Georgia & Non-urban & 3 & .0422 & .0054 & 20.2 & 2.9 & .112 & .067 \\
\hline Vendovi Island & Non-urban & 6 & .0655 & .0155 & 22.8 & 3.4 & .204 & .099 \\
\hline \multicolumn{9}{|c|}{ Ratfish muscle } \\
\hline Sinclair Inlet & Sinclair Inlet & 11 & 0.1823 & 0.1099 & 42.7 & 5.3 & 0.612 & 0.166 \\
\hline Commencement Bay & Urban & 3 & .1014 & .0262 & 39.3 & 1.1 & .353 & .035 \\
\hline Eagle Harbor & Urban & 3 & .1522 & .0828 & 40.6 & 9.2 & .457 & .273 \\
\hline Elliott Bay & Urban & 3 & .1659 & .0630 & 45.3 & 7.0 & .510 & .260 \\
\hline Hood Canal & Non-urban & 7 & .1148 & .0320 & 38.4 & 2.1 & .393 & .061 \\
\hline Nisqually Delta & Non-urban & 6 & .1553 & .0646 & 39.4 & 5.0 & .507 & .080 \\
\hline$\underline{\text { Strait of Georgia }}$ & Non-urban & 12 & .2140 & .1616 & 40.3 & 6.3 & .555 & .278 \\
\hline \multicolumn{9}{|c|}{ Surf perch muscle } \\
\hline Sinclair Inlet & Sinclair Inlet & 3 & 0.0745 & 0.0166 & 11.8 & 0.8 & 0.017 & 0.006 \\
\hline Hood Canal & Non-urban & 5 & .0444 & .0048 & 11.3 & 1.7 & .023 & .010 \\
\hline Nisqually Delta & Non-urban & 3 & .0589 & .0205 & 11.0 & .7 & .020 & .000 \\
\hline Vendovi Island & Non-urban & 6 & .0514 & .0064 & 10.0 & 1.9 & .020 & .006 \\
\hline \multicolumn{9}{|c|}{ Whole-body sea cucumber } \\
\hline Sinclair Inlet & Sinclair Inlet & 10 & 0.0186 & 0.0078 & - & - & 0.636 & 0.189 \\
\hline Strait of Georgia & Non-urban & 6 & .0042 & .0004 & - & - & .365 & .122 \\
\hline Vendovi Island & Non-urban & 3 & .0030 & .0012 & - & - & .533 & .196 \\
\hline
\end{tabular}

${ }^{1}$ Significant difference in mercury concentration relation with size was detected for Sinclair Inlet sand sole (table 10). Therefore, the 2003 sand sole from Port Gardner was compared only to the 2003 sand sole from Sinclair Inlet. 


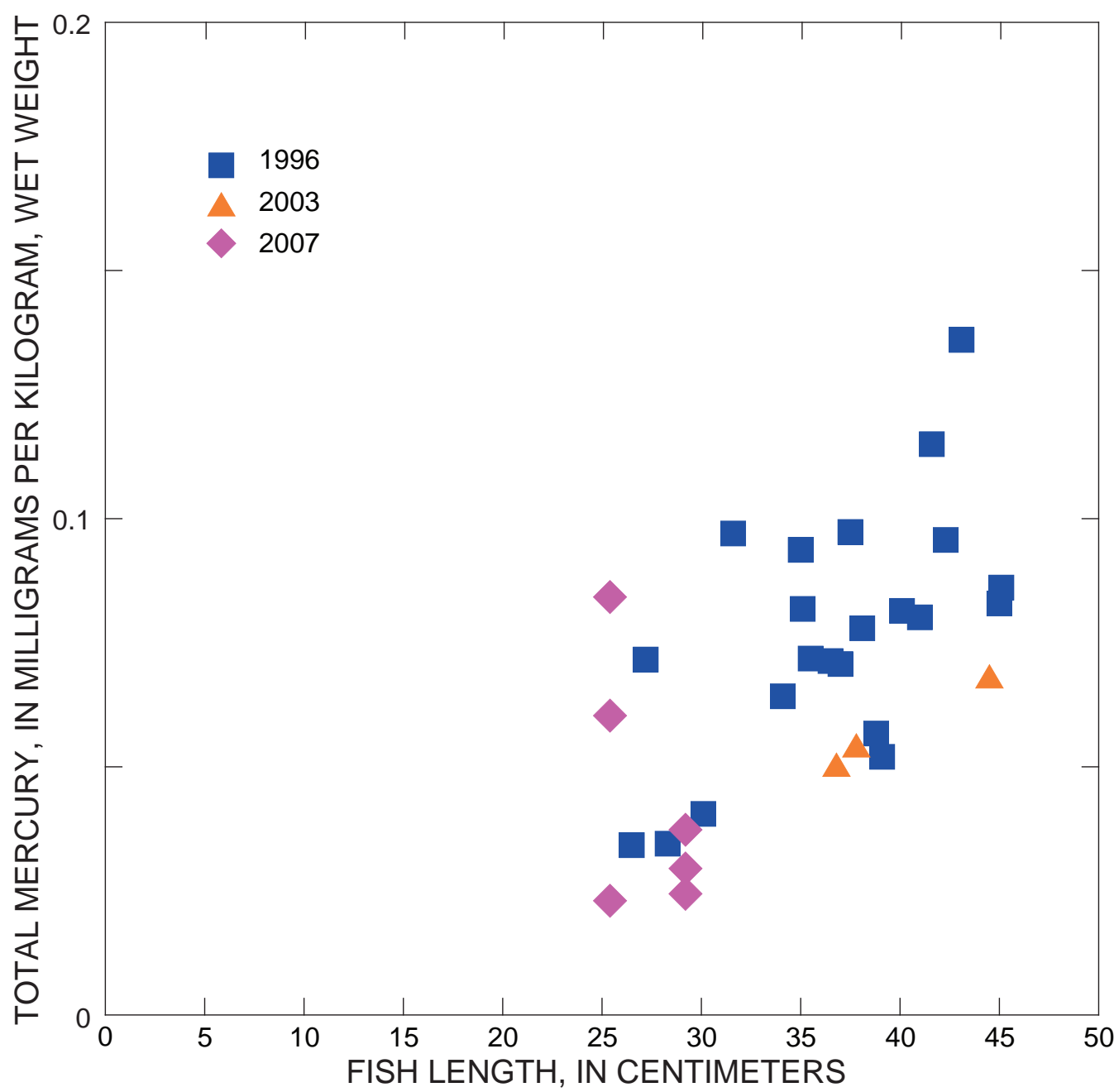

Figure 72. Total mercury concentrations in muscle of individual English sole specimens collected from Sinclair Inlet, Washington, during 1996, 2003, and 2007 compared to fish length (table F7). 


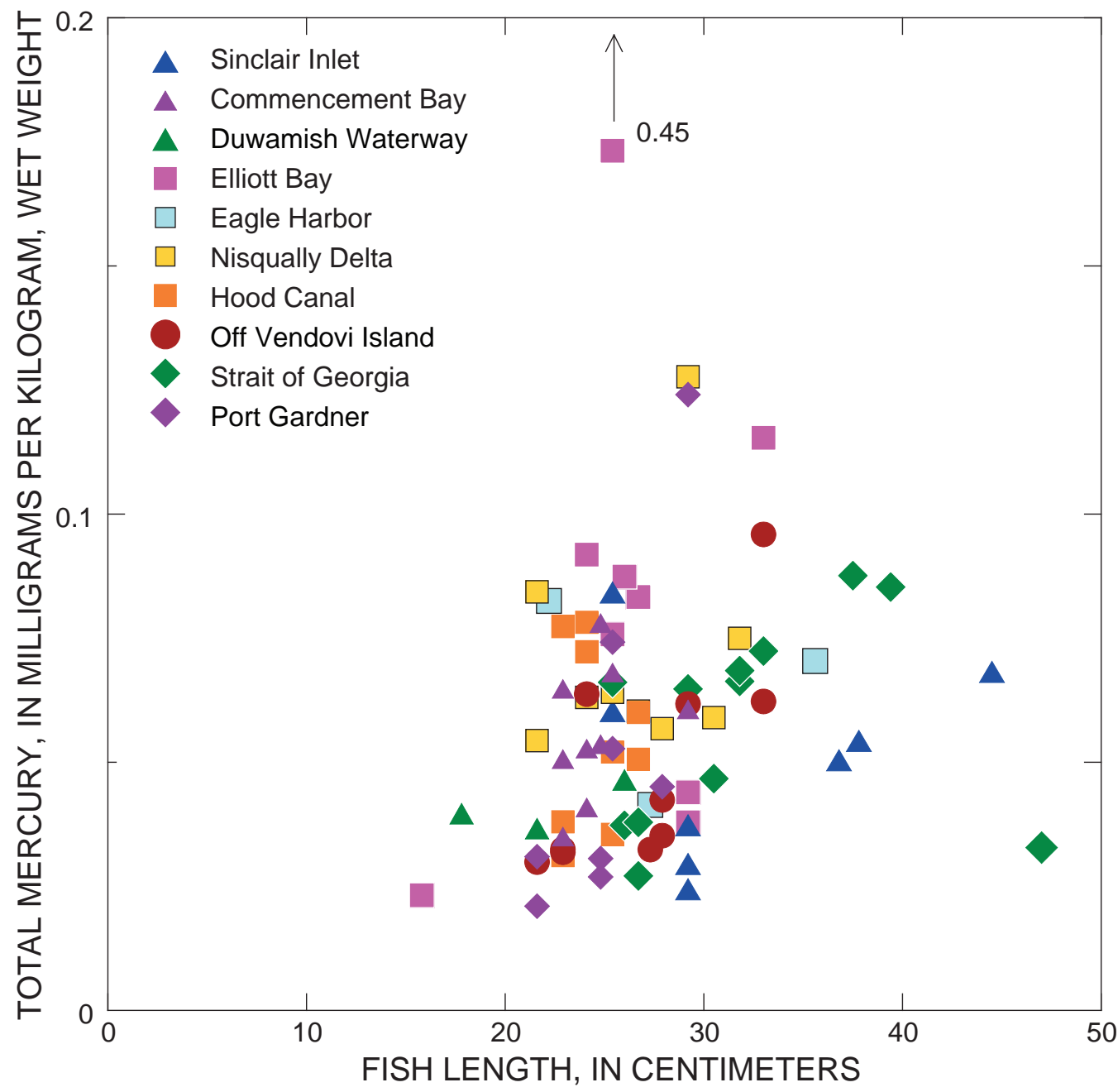

Figure 73. Total mercury concentrations in muscle of individual English sole specimens collected from Sinclair Inlet, Commencement Bay, Duwamish Waterway, Elliott Bay, Eagle Harbor, Nisqually Delta, Hood Canal, off Vendovi Island, the Strait of Georgia, and Port Gardner between 2003 and 2007 compared to fish length (table F7). Locations of Puget Sound estuaries in Washington are shown in figure $1 A$. 


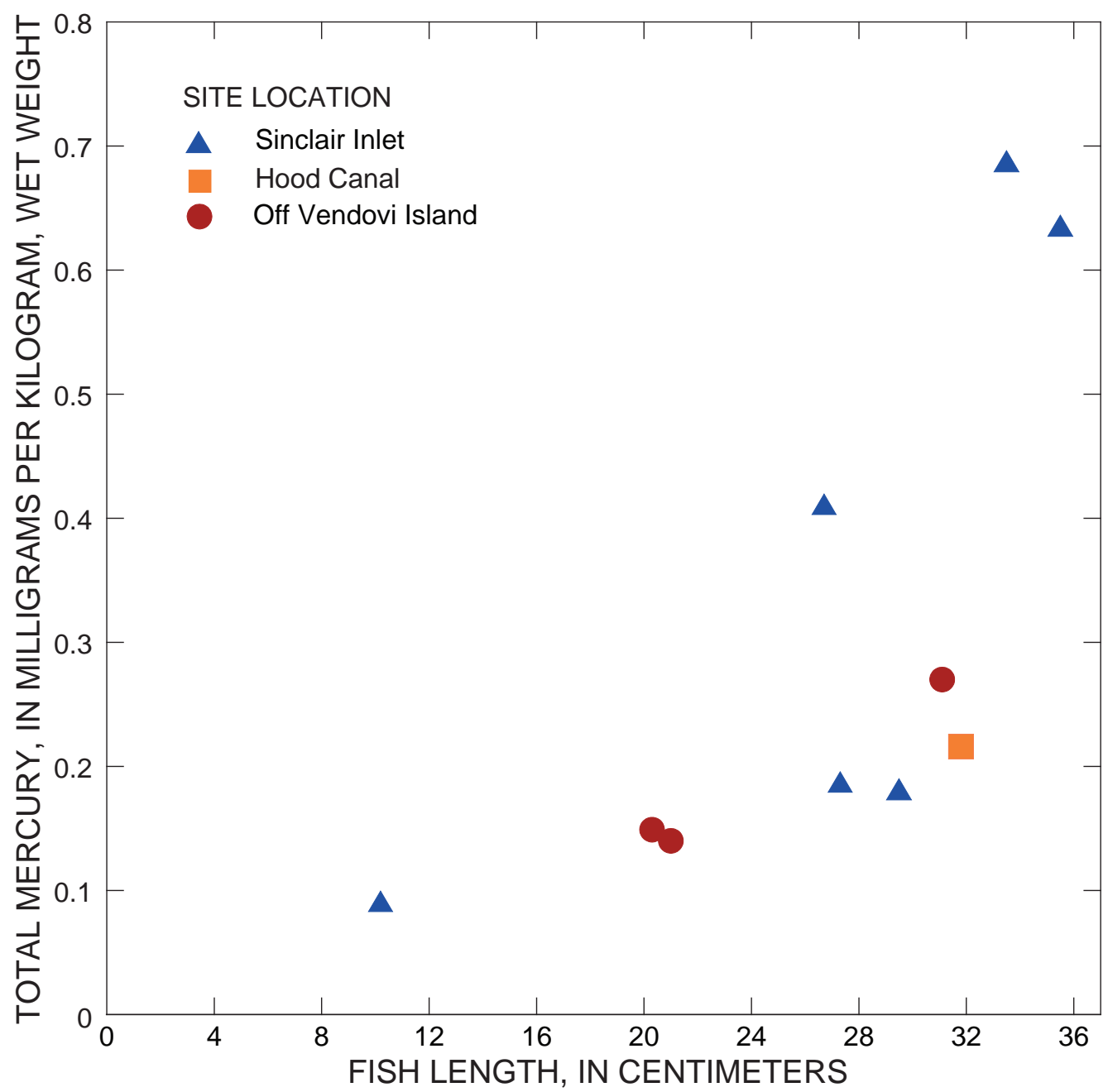

Figure 74. Total mercury concentrations in muscle of individual rock sole specimens individuals collected from Sinclair Inlet, Hood Canal, and off Vendovi Island between 2003 and 2007 compared to fish length (table F7). Locations of Puget Sound estuaries in Washington are shown in figure 1. 


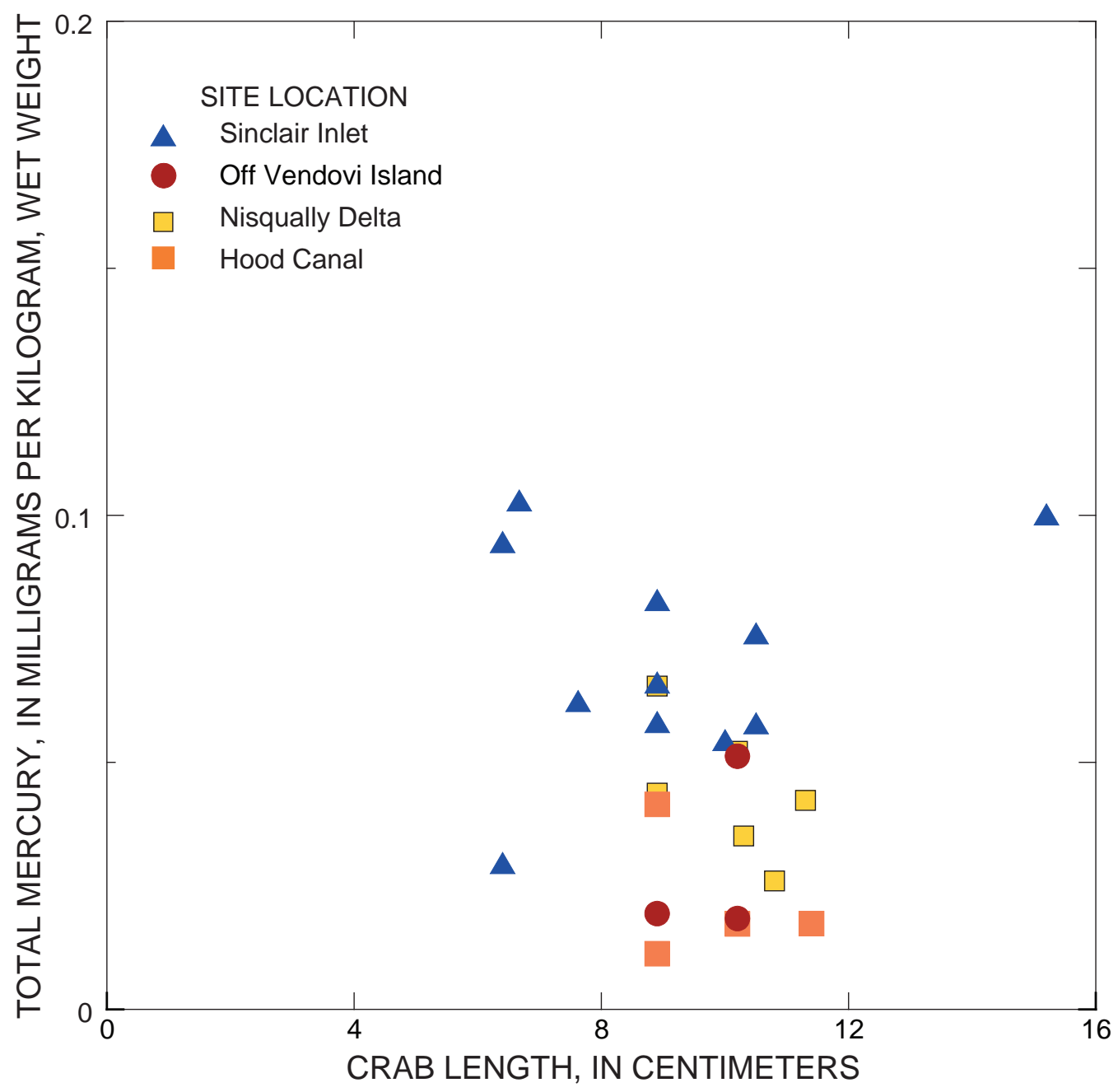

Figure 75. Total mercury concentrations in individual graceful crab specimen collected from Sinclair Inlet, off Vendovi Island, the Nisqually delta, and Hood Canal between 2002 and 2005 compared to crab length (table F7). Locations of Puget Sound estuaries in Washington are shown in figure $1 A$. 


\section{Ratfish}

The higher trophic level ratfish generally had higher THg concentrations than other species for a given estuary (table F1). THg concentrations in ratfish collected from Sinclair Inlet were significantly different $(p=0.035)$ by collection year (2003, 2005, and 2007), but the relation of THg concentration compared to size grouped by year was not significantly different $(p=0.75)$. The mean THg concentration of ratfish collected from Sinclair Inlet for all collection years was $0.1823 \mathrm{mg} / \mathrm{kg}$ (wet weight) for a mean length of $42.7 \mathrm{~cm}$ (table 11). When data from all collection years was combined by location (fig. 76), no difference in the relation between THg and size was observed among estuaries ( $p=0.38$ in table 10). Post ad-hoc analyses of covariance indicate no significant differences in the Sinclair Inlet relation of THg compared to size when compared to non-urban estuaries $(p=0.13)$ or to other urban estuaries $(p=0.28)$.

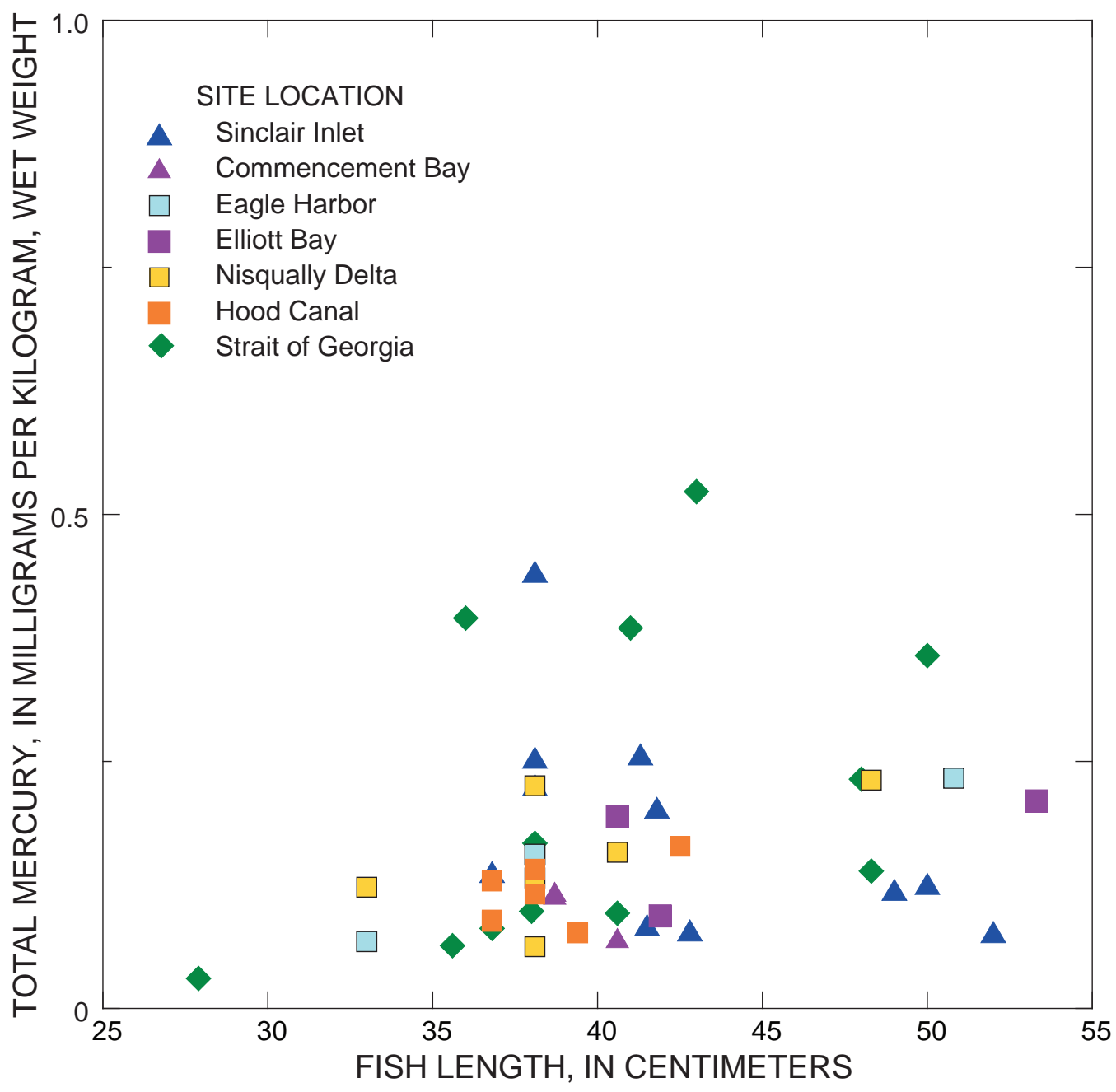

Figure 76. Total mercury concentrations in muscle of individual ratfish specimens collected from Sinclair Inlet, Commencement Bay, Eagle Harbor, Elliott Bay, the Nisqually Delta, Hood Canal, and the Strait of Georgia between 2003 and 2005 compared to fish length (table F7). Locations of Puget Sound estuaries in Washington are shown in figure $1 A$. 


\section{Surf Perch}

Surf perch were collected in Sinclair Inlet only during 2005 (fig. 77) and had a mean THg concentration of $0.0745 \mathrm{mg} / \mathrm{kg}$ (wet weight) and a mean length of $11.8 \mathrm{~cm}$ (table 11). The relation of THg concentration compared to fish size for Sinclair Inlet was significantly different (table 10) than those relations of non-urban estuaries (Hood Canal, the Nisqually Delta, and off Vendovi Island, table F1), whether estuaries were considered individually $(p=0.043)$ or when data from non-urban estuaries were combined during the post ad-hoc analysis $(p=0.026)$.

\section{Sea Cucumber}

Sea cucumber were not significantly different in THg concentrations ( $p=0.22)$ and weight $(p=0.20)$ by collection year (2003 and 2005), nor was the relation of THg concentration compared to weight significantly different by collection year $(p=0.30)$. THg concentrations in individual sea cucumber specimens collected from Sinclair Inlet in 2003 and 2005 (0.0186 mg/kg (wet weight) and a mean wet weight of $0.636 \mathrm{~kg}$; table 11) were significantly higher than in those collected from non-urban estuaries (the Strait of Georgia and off Vendovi Island) when weight was considered ( $p<0.001$ in table 10).

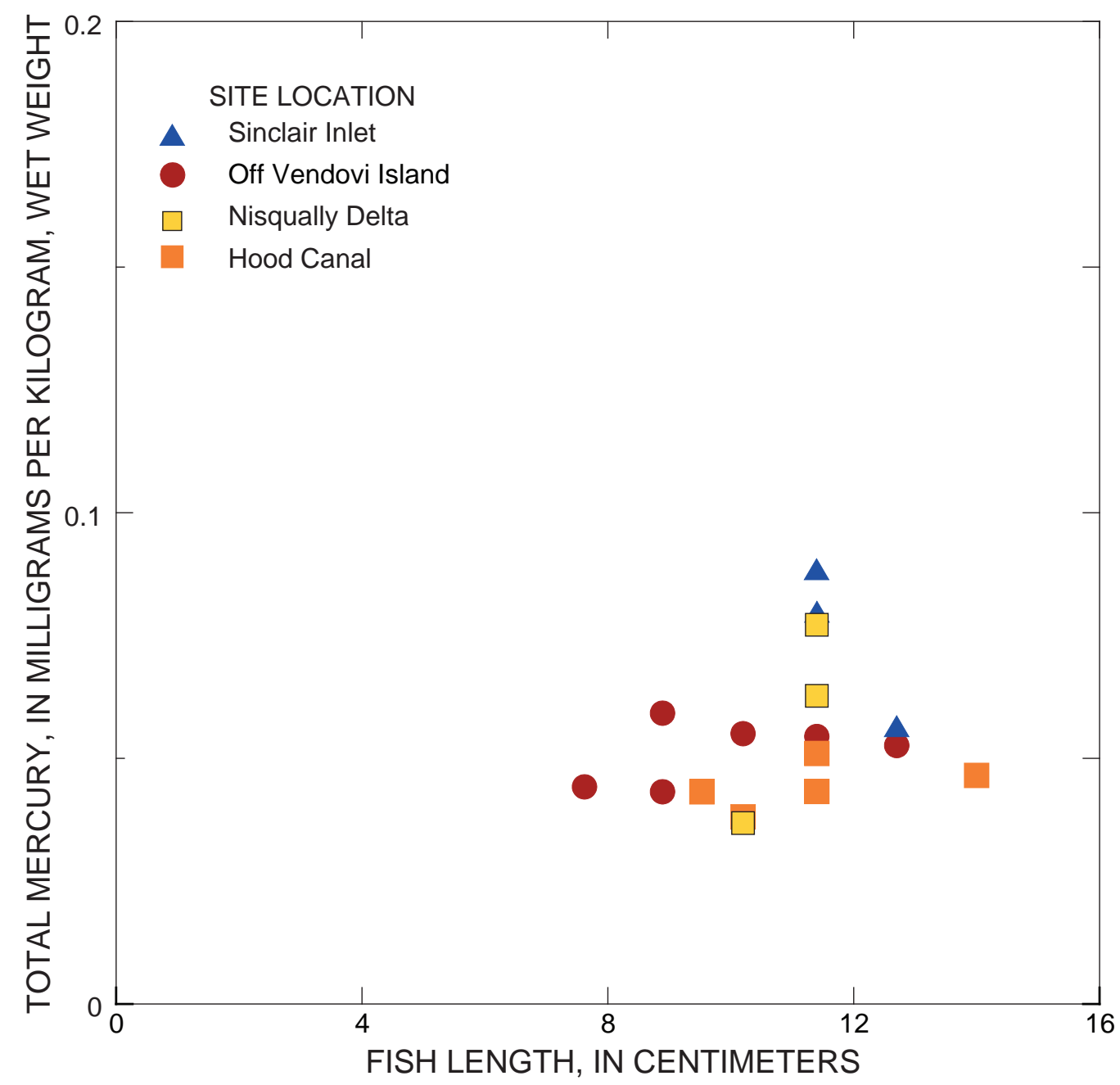

Figure 77. Total mercury concentrations of individual specimens and composites of two surf perch of comparable size from Sinclair Inlet, off Vendovi Island, the Nisqually Delta, and Hood Canal compared to fish length collected in 2005 and 2007 (table F7). Locations of Puget Sound estuaries in Washington are shown in figure $1 A$. 


\section{Caged Mussel}

Caged mussels were studied in Sinclair Inlet in 1994 and 2005. For the caged mussel test in 1994 (U.S. Navy, 2002), three replicate cages, each consisting of 100 mussels, were deployed for 121 days at four stations in Sinclair Inlet and one reference station in Holmes Harbor, an inlet of Whidbey Island (fig. 1A). THg concentrations in composites of mussels prior to deployment were less than the reporting level of $0.01 \mathrm{mg} / \mathrm{kg}$ wet weight (table 12). The THg concentrations in composites of mussels deployed in Holmes Harbor were at or below the reporting level of $0.01 \mathrm{mg} / \mathrm{kg}$ wet weight. Four composites of recovered mussels deployed in Sinclair Inlet for 121 days had concentration sat the reporting level of $0.01 \mathrm{mg} / \mathrm{kg}$ (wet weight) and eight had concentration of $0.02 \mathrm{mg} / \mathrm{kg}$. Although THg concentrations from Sinclair Inlet were at the reporting level or one significant unit above the reporting level, a Wilcoxon rank-sum test indicates that THg concentrations in mussels deployed in Sinclair Inlet were significantly ( $p=0.028$ ) higher than those deployed in Holmes Harbor. However, because All THg concentrations were within one significant unit of the reporting level, the significance of this conclusion is limited.

In 2005, ENVVEST (Applied Biomonitoring, 2009) deployed 56 mussels in each of 3 cages vertically stacked on top of each other at six sites site for 82 days. Mussels were deployed at two sites located at the BNC (NAVSTA and CIA in fig. 2), two sites located in heavy boat traffic areas of the Port Orchard Marina and Sinclair Inlet Ross Point (POM and SIRP in fig. $1 C$, respectively), and sites in Ostrich Bay, Dyes Inlet (OBDI is near M8, fig. 1B) and Port Orchard Passage (POP, fig. 1B); the latter two were considered reference sites. In addition, indigenous mussels were collected from Waterman Point (IWP in fig. 1B), Naval Station Kitsap Bremerton and the Port Orchard Marina at the time the caged mussels were recovered. Mussel tissue was analyzed as composites and the reporting and quality of the THg analysis was good (Brandenberger and others, 2006c). A paired Dunnett’s

Table 12. Total mercury concentration of composites of mussels deployed in cages in Sinclair Inlet and Holmes Harbor, Puget Sound, Washington, 1994.

[Data source: U.S. Navy, 2002. Abbreviations No.,number; mg/kg, milligram per kilogram; mm, millimeter; g, gram; U, below reporting level]

\begin{tabular}{|c|c|c|c|c|c|c|c|c|c|c|}
\hline \multirow[b]{2}{*}{ Location } & \multirow{2}{*}{$\begin{array}{l}\text { Sample } \\
\text { date }\end{array}$} & \multirow{2}{*}{$\begin{array}{l}\text { Sample } \\
\text { number }\end{array}$} & \multirow{2}{*}{$\begin{array}{c}\text { No. of } \\
\text { individual } \\
\text { samples in } \\
\text { composite }\end{array}$} & \multirow{2}{*}{$\begin{array}{c}\text { Total } \\
\text { mercury } \\
\text { (mg/kg, } \\
\text { wet weight) }\end{array}$} & \multicolumn{2}{|c|}{ Length (mm) } & \multicolumn{2}{|c|}{ Weight (g) } & \multicolumn{2}{|c|}{ Gain } \\
\hline & & & & & Initial & Final & Initial & Final & $\begin{array}{l}\text { Length } \\
(\mathrm{mm})\end{array}$ & $\begin{array}{c}\text { Weight } \\
\text { (g) }\end{array}$ \\
\hline \multicolumn{11}{|c|}{ Sinclair Inlet } \\
\hline \multirow[t]{3}{*}{488} & $06-15-94$ & 20091 & 2 & 0.02 & 34.59 & 39.45 & 3.63 & 6.46 & 4.89 & 2.83 \\
\hline & & 20092 & 4 & .01 & 34.50 & 39.20 & 3.70 & 6.57 & 4.62 & 2.84 \\
\hline & & 20093 & 11 & .01 & 34.60 & 40.50 & 3.60 & 6.88 & 6.01 & 3.31 \\
\hline \multirow[t]{3}{*}{489} & $06-15-94$ & 20085 & 7 & .02 & 34.56 & 39.90 & 3.67 & 6.52 & 5.42 & 2.88 \\
\hline & & 20086 & 6 & .02 & 34.56 & 39.80 & 3.64 & 6.63 & 5.04 & 3.00 \\
\hline & & 20087 & 13 & .01 & 34.50 & 40.00 & 3.61 & 6.70 & 5.45 & 3.09 \\
\hline \multirow[t]{3}{*}{490} & $06-15-94$ & 20088 & 14 & .02 & 34.58 & 40.40 & 3.57 & 6.73 & 5.82 & 3.16 \\
\hline & & 20089 & 10 & .02 & 34.60 & 40.10 & 3.62 & 6.74 & 5.48 & 3.12 \\
\hline & & 20090 & 9 & .02 & 34.50 & 39.40 & 3.67 & 6.30 & 4.88 & 2.63 \\
\hline \multirow[t]{3}{*}{491} & $06-15-94$ & 20094 & 15 & .02 & 34.58 & 40.24 & 3.63 & 6.84 & 5.66 & 3.21 \\
\hline & & 20095 & 12 & .02 & 34.50 & 40.20 & 3.59 & 6.58 & 5.69 & 2.99 \\
\hline & & 20096 & 1 & .01 & 34.50 & 39.10 & 3.63 & 6.23 & 4.50 & 2.58 \\
\hline \multicolumn{11}{|c|}{ Holmes Harbor } \\
\hline \multirow[t]{3}{*}{492} & 06-16-94 & 20099 & 8 & $0.01 \mathrm{U}$ & 34.55 & 39.46 & 3.62 & 6.18 & 4.93 & 2.57 \\
\hline & & 20100 & 3 & .01 & 34.50 & 39.40 & 3.64 & 6.17 & 4.90 & 2.53 \\
\hline & & 21551 & 5 & .01 & 34.50 & 40.10 & 3.68 & 6.29 & 5.58 & 2.61 \\
\hline \multicolumn{11}{|c|}{ Pre-deployment } \\
\hline & 03-16-94 & 20031 & & $0.01 \mathrm{U}$ & & & & & & \\
\hline & & 20032 & & $.01 \mathrm{U}$ & & & & & & \\
\hline & & 20033 & & $.01 \mathrm{U}$ & & & & & & \\
\hline
\end{tabular}


multiple comparison test was used to evaluate differences of mussel growth metrics from the combined data from the three cages among sites (table F8). Mussel growth was higher at reference sites (Ostrich Bay, Dyes Inlet and Port Orchard Passage), whereas a group of sites with lower growth included Port Orchard Marina, Sinclair Inlet Ross Point, and Controlled Industrial Area, Puget Sound Naval Shipyard sites. Growth in the Naval Station Kitsap Bremerton site was intermediate between the groups with lower and higher growth (Applied Biomonitoring, 2009). The cause of the variance of the THg in mussel tissue of the three stacked cages at each site could not be evaluated because statistics on the weight and length of mussels from individual cages were not readily available (fig. A1).

For both caged and indigenous mussels, THg concentrations in mussel tissue (table F8) at all locations were higher than the THg concentration of pre-deployment mussels ( $0.0283 \mathrm{mg} / \mathrm{kg}$ dry weight) (fig. 78). Turkey-The Kramer multiple comparisons (Applied Biomonitoring, 2009) indicated that caged mussels at the two BNC stations (mean concentration of $0.108 \pm 0.002$ and $0.0850 \pm 0.002 \mathrm{mg} / \mathrm{kg}$, dry weight for sites CIA and NAVSTA, respectively) and the reference stations (mean concentrations of $0.071 \pm 0.0076$ and $0.0819 \pm 0.0073 \mathrm{mg} / \mathrm{kg}$, dry weight for POP and OBDI, respectively) were ranked as one group. Caged Port Orchard Marina mussels ( $0.216 \pm 0.006 \mathrm{mg} / \mathrm{kg}$ dry weight) and caged Sinclair Inlet Ross Point mussels (0.212 $\pm 0.043 \mathrm{mg} / \mathrm{kg}$ dry weight) were ranked as a second group with significantly higher THg concentrations than the first group that contained the reference sites. The Sinclair Inlet Ross Point site had the greatest differences in THg concentrations among the three replicate cages.

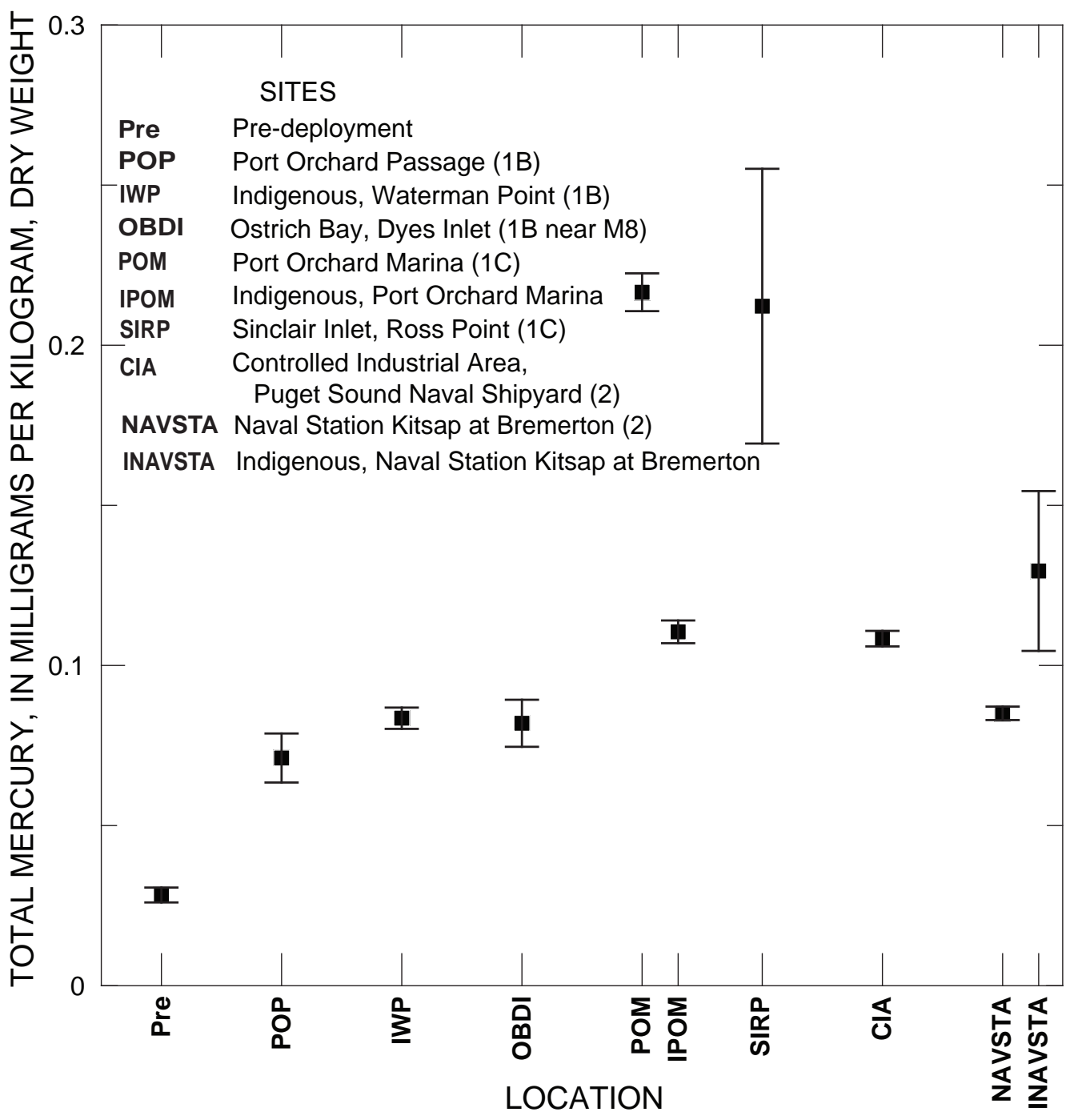

Figure 78. Mean mercury concentrations of tissue from indigenous mussels and caged mussels deployed in Sinclair Inlet, Puget Sound, Washington, and nearby water bodies for 84 days during 2005. The error bars represent \pm one standard deviation (table F8). 
Mean THg concentration of tissue from indigenous mussels ranged from 0.0835 to $0.130 \mathrm{mg} / \mathrm{kg}$, dry weight (Brandenberger and others, 2006c). Indigenous mussels from Waterman Point (IWP in fig. 1C) had a slightly lower mean concentration of THg $(0.0835 \mathrm{mg} / \mathrm{kg}$, dry weight $)$ than the indigenous mussels collected at the Naval Station Kitsap Bremerton (0.130 mg/kg, dry weight) and Port Orchard Marina stations $(0.110 \mathrm{mg} / \mathrm{kg}$, dry weight $)$. At the Port Orchard Marina site, the mean THg concentration of indigenous mussels $(0.110 \mathrm{mg} / \mathrm{kg}$, dry weight) was much lower than the concentration of caged test mussels $(0.216 \pm 0.006 \mathrm{mg} / \mathrm{kg}$, dry weight $)$ at the same location by the end of the caging period. In contrast, the mean THg concentration of tissue of indigenous BNC mussels collected from the Naval Station Kitsap Bremerton site $(0.130 \pm 0.025$ $\mathrm{mg} / \mathrm{kg}$, dry weight) was higher than the concentration of caged test mussels $(0.085 \pm 0.002 \mathrm{mg} / \mathrm{kg}$, dry weight).

\section{Summary of Mercury in the Biota of Sinclair Inlet}

$\mathrm{THg}$ concentrations in fish generally are dependent on age, length, and weight of individual specimens. In order to detect differences among populations, the analyses of numerous samples over a wide range of ages, lengths, and weights are needed for each population of interest. Alternatively, sampling at all locations could target a narrow size and age range. Past analyses of mercury in biota in Puget Sound and Sinclair Inlet generally were performed on composite samples for human health-risk assessments (table 13). In the absence of data on age, size, and length for individual specimens in composites collected between 1989 and 1999, THg concentrations in composites of tissue of quillback rockfish from Sinclair Inlet were determined to be the highest of 16 sites examined throughout Puget Sound and concentrations in English sole and Coho salmon from Sinclair Inlet were in the top 20th percentile.

Table 13. Summary of mercury in composites and individual specimens of various species and results of caged mussel experiments in Puget Sound, Washington.

[Abbreviations RI/FS, Remedial Investigation/Feasibility Study; PSAMP, Puget Sound Ambient Monitoring Program; WDFW, Washington State Department of Fish and Wildlife; BNC, Bremerton naval complex; mg/kg, milligram per kilogram; cm, centimeter]

\begin{tabular}{|c|c|c|}
\hline Programs & Species & Summary results \\
\hline & & Composites \\
\hline $\begin{array}{l}\text { RI/FS } \\
\text { U.S. Navy }\end{array}$ & English sole & $\begin{array}{l}\text { In Sinclair Inlet THg were relatively low ranging from } 0.02 \text { to } 0.05 \mathrm{mg} / \mathrm{kg} \\
\text { wet weight with corresponding lengths ranging from } 28 \text { to } 38 \mathrm{~cm} \text {. }\end{array}$ \\
\hline PSAMP & English sole & $\begin{array}{l}\text { In Sinclair Inlet total mercury concentrations were relatively low ranging } \\
\text { from } 0.04 \text { to } 0.06 \mathrm{mg} / \mathrm{kg} \text { wet weight with corresponding lengths ranging } \\
\text { from } 32 \text { to } 34 \mathrm{~cm} \text {. }\end{array}$ \\
\hline WDFW & $\begin{array}{l}\text { English sole - } \\
\text { muscle }\end{array}$ & $\begin{array}{l}\text { Sinclair Inlet ( } 0.08 \mathrm{mg} / \mathrm{kg} \text { wet weight }) \text { ranked } 41 \text { out of } 51 \text { locations } \\
\text { ranked lowest to highest THg. Locations with the highest mean THg } \\
\text { tended to be located near urban/industrial areas in Puget Sound. }\end{array}$ \\
\hline WDFW & $\begin{array}{l}\text { English sole - } \\
\quad \text { liver }\end{array}$ & $\begin{array}{l}\text { Sinclair Inlet was ranked 22nd out of } 32 \text { locations with a value of } \\
0.12 \mathrm{mg} / \mathrm{kg} \text {. Locations with the highest mean mercury concentration } \\
\text { tended to be located near urban/industrial areas in Puget Sound. }\end{array}$ \\
\hline $\begin{array}{l}\text { RI/FS } \\
\text { U.S. Navy }\end{array}$ & Sea cucumber & $\begin{array}{l}\text { There was no significant difference between } \mathrm{THg} \text { at Sinclair Inlet } \\
\text { compared to the reference stations of Blake Island and Rich Passage. }\end{array}$ \\
\hline WDFW & Rockfish & $\begin{array}{l}\text { Yellow, brown and quillback rockfish had the highest mean THg of } \\
\text { species sampled in Puget Sound. Quillback rockfish from Sinclair Inlet } \\
\text { had the highest THg concentrations ( } 0.8177 \mathrm{mg} / \mathrm{kg} \text { wet weight ) out of } \\
16 \text { locations. The THg concentration of brown rockfish in Sinclair Inlet } \\
\text { (0.81 mg/kg wet weight ) was about } 8 \text { times higher than the only other } \\
\text { observaton (Thea Foss Waterway in Tacoma). }\end{array}$ \\
\hline WDFW & Salmon & $\begin{array}{l}\text { The mean THg concentration in Chinook salmon in Sinclair Inlet (0.099 } \\
\mathrm{mg} / \mathrm{kg} \text { wet weight ) was near the mean for Puget Sound. The mean } \\
\mathrm{THg} \text { for Coho salmon from Sinclair Inlet was } 0.060 \mathrm{mg} / \mathrm{kg} \text { wet weight, } \\
\text { which was the eighth highest of } 10 \text { locations in Puget Sound. }\end{array}$ \\
\hline
\end{tabular}

U.S. Navy, 2002

U.S. Navy, 2006a

West and others, 2001

West and others, 2001

U.S. Navy, 2002

West and others, 2001

West and others, 2001 
Table 13. Summary of mercury in composites and individual specimens of various species and results of caged mussel experiments in Puget Sound, Washington.-Continued

[Abbreviations RI/FS, Remedial Investigation/Feasibility Study; PSAMP, Puget Sound Ambient Monitoring Program; WDFW, Washington State Department of Fish and Wildlife; BNC, Bremerton Naval Complex; THg, total mercury; mg/kg, milligram per kilogram; cm, centimeter]

\begin{tabular}{cccc}
\hline Programs & Species & Summary results & References \\
\hline & Individual specimens
\end{tabular}

\begin{tabular}{lll}
\hline PSAMP & Rockfish & THg concentrations in long-lived rockfish are highly correlated with \\
& age. THg concentrations in rockfish from Sinclair Inlet are highest of \\
& all Puget Sound regions. The rockfish from Sinclair Inlet were up to \\
& 50 years old and hatched at the time that mercury concentrations in \\
& Sinclair Inlet were at their highest.
\end{tabular}

PSAMP/ Sand sole

ENVVEST

\begin{tabular}{|c|c|}
\hline $\begin{array}{l}\text { PSAMP/ } \\
\text { ENVVEST }\end{array}$ & Rock sole \\
\hline $\begin{array}{l}\text { PSAMP/ } \\
\text { ENVVEST }\end{array}$ & $\begin{array}{l}\text { Graceful crab } \\
\text { and staghorn } \\
\text { sculpin }\end{array}$ \\
\hline $\begin{array}{l}\text { PSAMP/ } \\
\text { ENVVEST }\end{array}$ & Ratfish \\
\hline
\end{tabular}

PSAMP/ Surf perch

ENVVEST

PSAMP/ Sea cucumber
Sand sole was the only species for which the relation of THg and size differed by the year individuals were caught from Sinclair Inlet. The relation of THg concentrations versus size of sand sole caught from Sinclair Inlet in 2003 was significantly different from the relation of individuals caught from Port Gardner in 2003.

When individual size was considered, THg concentrations of rock sole collected from Sinclair Inlet $(2003,2007)$ were not significantly different from rock sole non-urban estuaries.

Individual specimens from Sinclair Inlet had higher THg concentrations compared to other non-urban locations in Puget Sound when individual size was considered.

In estuaries where they were caught, ratfish had the highest total mercury concentrations of any species. When individual size was considered, total mercury concentrations of ratfish collected from Sinclair Inlet $(2003,2005,2007)$ were not significantly different from ratfish caught from urban or non-urban estuaries.

Total mercury concentrations in Sinclair Inlet were significantly higher than non-urban estuaries.

Total THg in sea cucumbers collected from Sinclair Inlet were higher than those collected off Vendovi Island and from the Strait of Georgia.
West and O’Neill, 1998

Brandenberger and others, 2006b, 2008; Johnston and others, 2007; Jim West, Washington State Department of Fish and Wildlife, written commun. 2008.

Brandenberger and others, 2006b, 2008; Johnston and others, 2007.

Johnston and others, 2007; Brandenberger and others, 2008.

Brandenberger and others, 2006b, 2008, Johnston and others, 2007.

Brandenberger and others, 2006b, 2008; Johnston and others, 2007.

Johnston and others, 2007; Brandenberger and others, 2008.

Brandenberger and others, 2006b; Johnston and others, 2007,

Caged mussel experiments

RI/FS U.S. Navy

ENVVEST
$\mathrm{THg}$ concentrations in mussels in Sinclair Inlet were significantly higher than in mussels at the reference station. All THg concentrations were within one significant unit of the reporting level which limited the significance of the results.

THg concentrations at all locations were higher than those for caged and indigenous mussels. Mean THg concentrations at the two BNC stations and the two reference stations had similar values. Mussels deployed in Port Orchard Marina and off Ross Point in Sinclair Inlet had significantly higher concentrations than the BNC and reference stations. Indigenous mussels from Port Orchard Marina and the BNC were not significantly different than indigenous mussels outside of Sinclair Inlet.
U.S. Navy, 2002

Brandenberger and others, $2006 \mathrm{c}$ 
In contrast, THg concentrations of composites of Chinook salmon were near the mean concentrations of 10 locations throughout Puget Sound. THg concentrations near the reporting level in caged mussels from Sinclair Inlet were statistically higher than those from the reference site in Holmes Harbor. THg concentrations in composites of tissue of caged mussels within OU B Marine were higher than those in caged mussels in Port Orchard Passage, but the highest THg concentrations were measured in composites of mussels caged off Port Orchard Marina and in inner Sinclair Inlet. THg concentrations of sea cucumber composites collected in 1994 were below the reporting level for most samples.

The study of long-lived rockfish (West and O'Neill, 1998) is an example of a study in which sufficient individual specimens from Sinclair Inlet were analyzed to show significantly higher $\mathrm{THg}$ concentrations relative to $\mathrm{THg}$ concentrations in individuals collected from other Puget Sound locations. When the size of individual English sole were taken into consideration, English sole collected between 2003 and 2007 had lower THg concentrations than those collected in 1996, before the remedial dredging occurred in 2000-2001. For a given size, sand sole, graceful crab, staghorn sculpin, surf perch and sea cucumber collected from Sinclair Inlet had higher THg concentrations than individuals collected from non-urban estuaries. For the two species in which individuals from urban bays were collected (English sole and ratfish), $\mathrm{THg}$ concentrations in individuals collected from Sinclair Inlet did not differ from the THg concentrations of individuals from either urban or non-urban estuaries when the size of the individuals was taken into consideration.

\section{Observations to be Considered for Future Sampling Efforts}

This report describes mercury concentrations data from a variety of sources and from multiple studies with differing purposes. Because mercury concentrations in most media are controlled by a variety of biological, geochemical and physical processes, the mercury data need to be examined in the context of these environmental processes. This examination requires the collection of a consistent set of ancillary data. Below are observations concerning collection of ancillary data associated with the collection of mercury data for sediment, biota, and water to assist in interpreting mercury data within the broader context of the entire Sinclair Inlet watershed. It is recognized that the collection of additional data that might be suggested by observations listed below often are beyond the data requirements required for regulatory programs such as total daily maximum loadings calculations or human health risk assessments.

\section{Sediment, Settling Particles, and Suspended Solids}

1. Sediment samples were collected for mercury analyses over a variety of depth intervals, with a variety of ancillary data, and by multiple agencies often with differing program objectives. In Sinclair Inlet, both grainsize and TOC data seem to be equally useful as variables for normalizing mercury concentrations. Consistent sets of sediment aluminum concentrations were only collected in the Sinclair Inlet during the 1994-95 OU B Remedial Investigation and during the ENVVEST coring program. For these two data sets, THg concentrations seemed to be less related to aluminum than to grain size and TOC. Data from the PSAMP program suggest that TOC content is a more universal normalizing parameter for the embayments of Puget Sound.

- Observation: Collection of TOC data in conjunction with mercury analyses of sediment, settling particles, and suspended solids would provide the environmental context to interpret the mercury data.

2. Surface sediment was collected to a variety of depth intervals (0-2 to 0-60 cm) in Sinclair Inlet for a variety of purposes. As a surface sediment sampling interval increases, the time period of deposition that it represents becomes longer. For instance, a 5-cm surface section at ENVVEST core S3 (fig. 1C) represents deposition over about 11 years and a 10 -cm surface section represents deposition over about 24 years. Surface sediment often was collected to a depth of $0-10 \mathrm{~cm}$ because $10 \mathrm{~cm}$ is considered to be the maximum depth of the biologically active zone. In Sinclair Inlet, radiometric data suggest that the mixing zone extends down to about $4 \mathrm{~cm}$ (Crecelius and others, 2003). Scientists planning sediment collection in Sinclair Inlet should recognize that collection of surface sediment below the mixing zone will result in mercury data that represent longer periods of deposition. Mercury concentrations data from sediment depth intervals representing longer periods of deposition are less useful for investigating recent sources of mercury.

- Observation: The depth interval to which surface sediment is collected affects the ability to measure changes in concentrations of contaminants in recently deposited sediment in the surface mixed layer. In Sinclair Inlet, this layer is about $4 \mathrm{~cm}$.

3. The PSAMP Long-Term Temporal Monitoring site was established before the contamination in nearby OU A was known and before the nearby CAD pit was constructed, filled, and covered. The area near the Sinclair Inlet 
PSAMP Long-Term Temporal Monitoring site is subject to significant horizontal gradients in the total fines and TOC content, both of which affect mercury concentrations (fig. 53). In addition, the relations of mercury between both total fines and TOC content do not follow the corresponding strong correlations observed in greater Sinclair Inlet (table 1).

- Observation: The present PSAMP Long-Term Temporal Monitoring site in Sinclair Inlet does not represents the general environmental conditions of greater Sinclair Inlet.

4. Mercury in sediment was extracted by a variety of methods before the mercury in the liquid extractant was analyzed by either cold vapor atomic absorption spectrometry, cold vapor atomic fluorescence spectrometry, or graphite furnace atomic absorption spectrometry. Extractants included weak acid (TCLP), 10 percent hydrochloric acid (AVS-SEM), strong acid (for example, aqua-regia), or total digestion, which includes hydrofluoric acid. Because the majority of the mercury seemed to be associated with organic carbon bound to the surfaces of the particles, total digestion could be avoided with little effect on the recovery of mercury without comprising the measurement of biologically available mercury. Analytical methods that completely oxidize organic matter are suitable if sufficient sediment is available for digestion and appropriate laboratory qualitycontrol procedures are implemented and reported.

- Observation: When sample mass for ancillary analyses is limited, such as in the collection of sediment-trap materials or suspended solids, evaluation of analytical methods that provide completeness of organic matter oxidation may limit sample mass needed for mercury analyses and provide mass for ancillary analyses.

\section{Water}

1. It is recognized that only $\mathrm{THg}$ concentration data in source waters and the marine waters of Sinclair Inlet are required to manage using the Total Daily Maximum Loading approach. However, information regarding partitioning of mercury between particulate and dissolved phases is extremely helpful in assessing the effects of different sources, especially on bioavailability. For instance, the measurement of the particulate/dissolved partitioning of mercury nearshore in marine water sample P2 and central Sinclair Inlet samples M3.2 and 3.4 (fig. 1C) would have provided a better understanding of the impact of stormwater on Sinclair Inlet.
- Observation: Analyses of filtrate and particles of unfiltered water samples for $\mathrm{THg}$ provide useful information of biogeochemical processes affecting mercury in environmental systems.

2. Knowledge of amount of particulate mercury in a sample of source water or marine water also is useful in assessing whether the mercury is likely to settle in Sinclair Inlet or to be advected to Puget Sound through Rich or Port Orchard Passages. In order to assess what effect the particles in a water sample may have on increasing or decreasing the sediment THg concentrations, the concentration of total suspended solids (TSS) in the water column must also be known. Because the ultra-trace sampling method with quartz fiber filters precludes simultaneously obtaining the accurate mass of the particles on the filter and concurrent accurate measurement of TSS, other methods are required. To allow accurate determination of mercury concentrations on the particulates using small volumes ( 1 liter), the reporting level for TSS should be less than $0.1 \mathrm{mg} / \mathrm{L}$. To assure that the sample population of particles being measured by the mercury and TSS method are the same, sub-sampling from the same larger bottle ( 2-L bottle) for both mercury and TSS is suggested.

- Observation: Measurements of total suspended solids concentrations in the water column concurrent with measurement of mercury concentrations associated with suspended solids allow calculations of the mercury concentrations on the particles, which can be compared to sediment mercury concentrations.

3. Methylmercury is the species of mercury most responsible for bioaccumulation of mercury in biota. But, no measurements of methylmercury have been reported by the major monitoring programs described in this report. As part of this study, USGS will report on the concentrations of methylmercury in groundwater, waste water treatment plant effluents, dry dock discharges, stormwater, surface water, marine water, and the interstitial waters of marine sediments. The relative concentrations of methylmercury in these various effluents and natural waters should provide the background information to begin monitoring methylmercury in a manner that relates to mercury bioaccumulation in biota.

- Observation: Measurements of methylmercury in monitoring programs, especially those programs related to bioaccumulation of mercury in marine biota, provide valuable information on biogeochemical processes. 
4. Field parameters, especially electrical conductivity (from which salinity is calculated) should be collected for all water samples. In addition, dissolved organic carbon is a useful tracer of aqueous phase mercury. Analysis of particulate organic carbon also is suggested as a routine ancillary measurement when sampling for particulate mercury.

- Observation: Field parameters, particulate organic carbon, and dissolved organic carbon provide the environmental context in which to interpret mercury concentrations.

\section{Biota}

1. It is recognized that the majority of biota samples collected for mercury analyses are performed on composites of varying sizes for human health-risk assessments.

- Observation: Data on key physical characteristics (that is, weight, length, and age) of the individual specimens that compose each composite sample should be measured and be accessible.

2. Although the process of sample compositing is a cost effective approach for human-health risk assessment programs, this approach limits the usefulness of the biota mercury data for other purposes. Because mercury concentrations in most living aquatic resources have been shown to be highly correlated with a number of key physical characteristics, detecting significant differences among populations, either geographically or temporally, requires an analysis of covariance using a correlating factor. For programs measuring mercury in living aquatic resources that wish their mercury data to be used for detecting differences among populations, the analyses of a number of individual specimens over a range of recorded sizes should be considered. As an alternative, compositing individual specimens within a specific and consistent size bracket(s) would allow direct comparisons across sites.

- Observation: Measurement of mercury in individual specimens over specific and consistent size ranges in a subset of measurements would allow data collected for human health risk assessment to be used for geographical comparisons.

\section{Summary}

Data from dated sediment cores indicate that mercury concentrations in Sinclair Inlet began to increase above pre-Industrial Revolution concentrations during the 1890s with the construction of the Puget Sound Naval Shipyard of the Bremerton naval complex (BNC) and reached maximum concentrations around the time of World War II. Total mercury concentrations in sediment deposited in Sinclair Inlet in the 1950s were 5- to 10-fold larger than in sediment deposited in central Puget Sound during the same period. The peak in total mercury concentrations in sediment deposited around the 1950s probably is partially responsible for the highest body burden of mercury in long-lived rockfish among Puget Sound locations. Although total mercury concentrations in sediments have been decreasing since the 1960s due to the implementation of environmental regulations, the decrease has been slow. The slow rate of sedimentation relative to vertical mixing of sediment in Sinclair Inlet limits the decrease of mercury in sediment in the top $10 \mathrm{~cm}$.

Monitoring after two dredging projects in and off the BNC illustrates that sediment texture and chemistry do change with time. Three years after dredging both sides of the pier off NBK Bremerton, total mercury concentrations in the dredged area were along the trend of mercury concentration with total organic carbon observed for greater Sinclair Inlet. After navigational and CERCLA dredging in 2000-01, mercury concentrations in sediment just outside the BNC collected in 2003 deviated from the greater Sinclair Inlet correlation of mercury concentrations with total organic carbon content. By 2007, the deviation was less noticeable. Within the BNC, higher than mean mercury concentrations in two areas adjacent to the Confined Aquatic Disposal pit were observed in 2003, but resampling of these areas in 2005 and 2007 revealed total mercury concentrations consistent with the greater Sinclair Inlet trend. In addition, the 2000-2001 dredging also caused a shift in the grain-size distribution throughout Sinclair Inlet. In contrast, the recontamination of areas dredged down to clean sediment prompted a special study of sediment adjacent to two piers within the Bremerton naval complex. In the eastern portion of NBK Bremerton and western PSNS \& IMF, total mercury concentrations in sediment followed the greater Sinclair Inlet trend, suggesting recontamination by resuspension and settling of normal Sinclair Inlet particles. The total mercury concentrations in a cell off central PSNS \& IMF were above the greater Sinclair Inlet trend, suggesting transport of a localized source of high total mercury sediments. Bottom sediment scour from propellers and thrusters operating during normal operations 
can explain the resuspension of bottom sediment and transport of suspended solids within the BNC. However, the mechanism of sediment transport within greater Sinclair Inlet is unknown because a number of physical oceanographic studies indicate that the maximum velocity of tidal currents of Sinclair Inlet is insufficiently strong to resuspend and erode sediments. This discrepancy among the observations must to be resolved before the processes controlling total mercury in Sinclair Inlet sediment can be understood fully.

The slope of the line relating total mercury concentrations to total organic content in mid-estuary sediment of Puget Sound urban estuaries seems to be the best indicator of the baseline mercury contamination above pre-industrial levels. An extensive sampling of estuarine sediment by the National Oceanic and Atmospheric Administration and Washington State Department of Ecology in Puget Sound allows for direct comparisons among urban estuaries. The slopes of the linear regression between total mercury concentrations and total organic carbon across Puget Sound (mid-estuary sediment from urban estuaries) distinguishes Sinclair Inlet within the top tier of estuaries contaminated with mercury, along with Bellingham Bay and Elliott Bay off Seattle. The slope of this linear regression in Sinclair Inlet between 2003 and 2007 is lower than the slope of the pre-remediation 1994 correlation, suggesting that the remediation dredging had significant positive effect on Sinclair Inlet as a whole.

Total mercury sediment concentrations inside the boundary of the BNC in 2003, 2005, and 2007 were compared to the greater Sinclair Inlet trend to identify areas of localized contamination. About 80 percent of BNC sediment had total mercury concentrations that are within about $0.6 \mathrm{mg} / \mathrm{kg}$ of the greater Sinclair Inlet trend. Three areas adjacent to the waterfront of the BNC have total mercury concentrations above this range and indicate a possible terrestrial source from waterfront areas of the BNC or continuing effects of World War II era contamination. Sources of mercury will be examined in the final phase of this study.

The ENVVEST program measured THg concentrations in a limited number of unfiltered marine water samples from Sinclair Inlet and connecting water bodies, including Dyes Inlet, Port Orchard Passage, and Rich Passage between 2002 and 2005. THg concentrations in unfiltered Sinclair Inlet water are about $1 \mathrm{ng} / \mathrm{L}$, which is three-fold higher than concentrations observed in central Puget Sound during 2000. The tidal mixing of numerous distinct water masses in this complex estuarine system coupled with sediment resuspension effects in the Passages makes it difficult to discern the geographical distribution of total mercury within Sinclair Inlet and among adjacent water bodies. One notable observation is the high concentration of $\mathrm{THg}(10.7 \mathrm{ng} / \mathrm{L})$ in unfiltered nearshore waters off the BNC during the May 24, 2004 storm event coincident with higher than normal tides, where higherthan-average total mercury sediment concentrations also were observed.
Total mercury concentrations in biota were compared among geographical locations using data from composite samples, individual specimens, and caged mussels. Total mercury concentrations from composite samples containing specimens over a range of sizes and ages are more useful for human health risk assessments than geographical comparisons. Total mercury concentrations in muscle and liver of English sole from Sinclair Inlet ranked in the upper quarter or third of all Puget Sound locations sampled. For other species, there were no differences among locations (sea cucumber) or concentrations from Sinclair Inlet were within the mid-range of locations (Chinook salmon). Mercury concentrations of the long-lived and higher trophic-level rockfish in both composites and individual specimens from Sinclair Inlet tended to be the highest of locations sampled in Puget Sound.

For a given size, sand sole, graceful crab, staghorn sculpin, surf perch, and sea cucumber individuals collected from Sinclair Inlet had higher THg concentrations than individuals collected from non-urban estuaries. Mercury concentrations in English sole and ratfish were not significantly different from concentrations in individuals of various sizes collected from either urban or non-urban estuaries in Puget Sound. Mercury concentrations in English sole collected from Sinclair Inlet in 2003 and 2005 after the 2000-2001 dredging appear to have lower mercury concentrations those collected in 1996 before the dredging project. In a 1994 study, mercury concentrations in caged mussels deployed throughout Sinclair Inlet were higher than that of a reference site (Holmes Harbor, Whidbey Island). In contrast, the highest mercury concentrations of mussels caged in 2002 were measured not in the Bremerton naval complex, but in the Port Orchard Marina and the inner Sinclair Inlet off Ross Point.

\section{Acknowledgments}

The authors wish to thank Grady May, Suzanna M. Jefferis, and Dwight Leisle, U.S. Navy, Engineering Command Northwest Naval Base Kitsap; Robert K. Johnston, U.S. Navy, Marine Environmental Support Office; Margaret Dutch, Washington State Department of Ecology; Jim West, Washington State Department of Fisheries and Wildlife; Jill M. Brandenberger, Battelle Marine Science Laboratory of the Pacific Northwest National Laboratories; and Paul Johanson, URS Corporation, for access to mercury data not previously available. Robert Crist and Theresa Olsen, USGS, provided graphical and GIS support, respectively, for production of the figures. Mark Marvin-DiPasquale, Robin Stewart, Richard J. Wagner, and Marijke van Heeswijk, USGS, and Dwight Leisle and Robert K. Johnston, U.S. Navy, provided a technical review of an earlier manuscript and Debra Grillo, Johanna Fabian-Marks and Eavon Mobley provided an editorial review. 


\section{References Cited}

Applied Biomonitoring, 2009, Using caged mussels to characterize exposure and effects over small spatial scales in Sinclair Inlet-A risk assessment based approach-A caged mussel study for Puget Sound Naval Shipyard \& Intermediate Maintenance Facility Project: ENVVEST. Final Report prepared for SPAWAR Systems Center, Pacific, San Diego, Calif.

Bloom, N.S., and Crecelius, E.A., 1987, Distribution of silver, mercury, lead, copper, and cadmium in central Puget Sound sediment: Marine Chemistry, v. 21, p. 377-390.

Brandenberger, J.M, Suslick, C.R., and Johnston, R.K., 2006a, Metals and conventional water chemistry data for the 2005 ambient marine and model boundary events in support of stormwater studies in Sinclair and Dyes Inlets, Washington: Pacific Northwest National Laboratory Data Report.

Brandenberger, J.M., Suslick, C.R., and Johnston, R.K., 2006b, Biological sampling and analysis in Sinclair and Dyes Inlets, Washington-Chemical analyses for 2005 Puget Sound biota study: Pacific Northwest National Laboratory, PNNL 15834, 125 p., accessed online July 13, 2009, at http://www.ecy.wa.gov/programs/wq/tmdl/sinclairdyes_inlets/sinclair_cd/DATA/2005_Data/BIOTA/.

Brandenberger, J.M., Suslick, C.R., and Johnston, R.K., 2006c, Biological sampling and analysis in Sinclair and Dyes Inlets, Washington-Chemical analyses for the caged mussel study: Richland, Wash., Pacific Northwest National Laboratory, PNNL-15835, 122 p., accessed online July 13, 2009, at http://www.ecy.wa.gov/programs/wq/tmdl/sinclairdyes_inlets/sinclair_cd/DATA/2005_Data/BIOTA/.

Brandenberger, J.M., May, C.W., Cullinan, V.I., and Johnston, R.K., 2007, Surface and stormwater quality assessment for Sinclair and Dyes Inlet, Washington: Pacific Northwest National Laboratory.

Brandenberger J.M., Suslick, C.R., and Johnston, R.K., 2008, Biological Sampling and Analysis in Sinclair and Dyes Inlets, Washington-Chemical Analyses for 2007 Puget Sound Biota Study: Pacific Northwest National Laboratory Report, PNNL-17948, 207 p., accessed online November 10, 2009, at http://www.pnl.gov/main/ publications/external/technical_reports/PNNL-17948.pdf.

Crecelius, E.A., Bothner, M.H., and Carpenter, R., 1975, Geochemistries of arsenic, antimony, mercury and related elements in sediment of Puget Sound: Environmental Science and Technology, v. 9, p. 325-333.
Crecelius, E.A., Robert, K., Johnston, R.K., Leather, J., Guerrero, J., Mille, M., and Brandenberger, J., 2003, Contaminant mass balance for Sinclair and Dyes Inlets, Puget Sound, WA, in Georgia Basin Puget Sound Research Conference, Vancouver, B.C., Canada, April 2, 2003, Proceedings: Olympia, Wash., Puget Sound Partnership, paper 6e_crece.

Cullinan,Valerie I., May, C.W., Brandenberger, J.M., Judd, Chaeli, and Johnston, R.K., 2007, Development of an Empirical Water Quality Model for Stormwater Based on Watershed Land-Use in Puget Sound, in Georgia Basin Puget Sound Research Conference, Vancouver, B.C., Canada, 2007, Proceedings: Olympia, Wash., Puget Sound Partnership, and Vancouver, B.C., Environment Canada, accessed online November 10, 2009, at http://www.engr. washington.edu/epp/psgb/2007psgb/2007proceedings/ papers/5e_culli.pdf.

Dutch, M., Partridge, V., Aasen, S., and Welch, K., 2005, Changes and Trends in Puget Sound Sediment-Results of the Puget Sound Ambient Monitoring Program, 1989-2000: Puget Sound Ambient Monitoring Program, Washington State Department of Ecology, accessed online November 10, 2009, at http://www.ecy.wa.gov/ biblio/0503024.html.

Evans-Hamilton, Inc., and D.R. Systems, Inc., 1987, Puget Sound Environmental Atlas: Prepared for U.S. Environmental Protection Agency, Puget Sound Water Quality Authority, and U.S. Army Corps of Engineers; Seattle, Wash., Evans-Hamilton, Inc., 2 v.

Gartner, J.W., Prych, E.A., Tate, G.B., Cacchione, D.A., Cheng, R.T, Bidlake, W.R., and Ferreria, J.T., 1998, Water velocities and the potential for the movement of bed sediment in Sinclair Inlet of Puget Sound, Washington: U.S. Geological Survey Open-File Report 98-572, 140 p.

Johnston, R.K., Leisle, D.E., Brandenberger, J.M., Steinert, S.A., Salazar, Michael, and Salazar, Sandra, 2007, Contaminant residues in demersal fish, invetebrates, and deployed mussels in selected areas of the Puget Sound, WA, in Georgia Basin Puget Sound Research Conference, Vancouver, B.C., Canada, March 26-29, 2007, Proceedings: Olympia, Wash., Puget Sound Partnership, and Vancouver, B.C., Environment Canada, accessed online July 13, 2003, at http://www.engr.washington.edu/epp/ psgb/2007psgb/2007proceedings/papers/13e_johns.pdf.

King County Department of Natural Resources, 2001, Water quality status report for marine waters, 1999 and 2000: Seattle, Wash., King County Department of Natural Resources, $558 \mathrm{p}$. 
Long, E.D., Hameedi, J., Robertson, A., Dutch, M., Aasen, S., Ricci, C., Welch, K., Magoon, S., Carr, R.S., Johnson, T., Biedenbach, J., Scott, K.J., Mueller, C., and Anderson, J.A., 1999, Sediment quality in Puget Sound, Year 1Northern Puget Sound: Olympia, Wash., Washington State Department of Ecology, 221 p. and appendixes.

Long, E.D., Dutch, M., Aasen, S.,Welch, K., Magoon, S., Carr, R.S., Johnson, T., Biedenbach, J., Scott, K.J., Mueller, C., and Anderson, J.A., 2000, Sediment quality in Puget Sound, Year 2-Central Puget Sound: Olympia, Wash., Washington State Department of Ecology, 343 p.

Long, E.D., Dutch, M., Aasen, S., Welch, K., Hameedi, J., Magoon, S., Carr, R.S., Johnson, T., Biedenbach, J., Scott, K.J., Mueller, C., and Anderson, J.A., 2002, Sediment quality in Puget Sound, Year 3-Southern Puget Sound: Olympia, Wash., Washington State Department of Ecology, 295 p. and appendixes.

Malins, D.C., McCain, B.B., Brown, D.W., Sparks, A.K., and Hodgins, H., 1982, Chemical contaminants and abnormalities in fish and invertebrates from Puget Sound: Boulder, Colo., National Oceanic and Atmospheric Administration Technical Memorandum OMPA-19, 168 p.

McLaren, P., 2004, The Sediments of Sinclair Inlet-An assessment of progressive change from 1997-8 to 2003: Bremerton, Wash., Puget Sound Naval Shipyard and Intermediate Maintenance Facility.

McLaren, P., 2008, The sediments of Sinclair Inlet-An assessment of progressive change from 1998 to 2008: Bremerton, Wash., Puget Sound Naval Shipyard and Intermediate Maintenance Facility.

Paulson, A.J., and Norton, D., 2008, Mercury sedimentation in lakes in western Whatcom County, Washington, U.S.A. and its relation to local industrial and municipal atmospheric sources: Water, Air, and Soil Pollution, v. 189, p. 5-19

SAS, 1990, SAS/STAT User's Guide (4th ed.): Cary, N.C., SAS Institute.

Tetra Tech, Inc., 1990, Puget Sound ambient monitoring program 1989-Marine sediment monitoring program: Olympia, Wash., Washington State Department of Ecology.

URS Consultants, Inc., 1991, Time critical removal action at initial assessment study site 2, Remedial Action ReportNovember 8, 1991.

U.S. Environmental Protection Agency, 1990, Test methods for evaluating solid waste, physical/chemical methods (3d ed.): Washington, D.C., U.S. Environmental Protections Agency, accessed online July 13, 2009, at http://www.epa. gov/waste/hazard/testmethods/sw846/index.htm.
U.S. Environmental Protection Agency, 2000, EPA Superfund Record of Decision-Puget Sound Naval Shipyard Complex, Bremerton, Washington: Washington, D.C., U.S. Environmental Protections Agency, accessed July 13, 2009, at http://www.epa.gov/superfund/sites/rods/fulltext/ r1000516.pdf.

U.S. Navy, 1992, Site inspection report, v. 1: Seattle, Wash., URS Consultants, 2063 p.

U.S. Navy, 1994a, Data quality assessment historical data, Operable Unit B, Puget Sound Naval Shipyard, Bremerton, Washington: Seattle, Wash., URS Consultants 331 p.

U.S. Navy, 1994b, Phase 1 technical memorandum for the remedial investigation and feasibility study (RI/FS) at Operable Unit B, Puget Sound Naval Shipyard, Bremerton, Washington: Seattle, Wash., URS Consultants,243 p.

U.S. Navy, 1995a, Final remedial investigation report Operable Unit A-Puget Sound Naval Shipyard, Bremerton, Washington, v. 1: Seattle, Wash., URS Consultants, 2433 p.

U.S. Navy, 1995b, Final remedial investigation report, Operable Unit NSC Fleet and Industrial Supply Center Bremerton, Washington, v. 1: Seattle, Wash., URS Consultants, 1956 p.

U.S. Navy, 1998, Final 1997 sampling and analysis report, Pier D long-term sediment monitoring program, Puget Sound Naval Shipyard, Bremerton, Washington: Seattle, Wash., URS Greiner, Inc., 254 p.

U.S. Navy, 1999, Sediment characterization at Puget Sound Naval Shipyard, Bremerton, Washington-Phase 1: Bothell, Wash., Science Applications International Corporation, 110 p.

U.S. Navy, 2000, Sediment characterization at Puget Sound Naval Shipyard, Bremerton, Washington-Phase 2: Bothell, Wash., Science Applications International Corporation, 77 p.

U.S. Navy, 2002, Final remedial investigation report, Operable Unit B, Bremerton naval complex, Bremerton, Washington, v. 1: Seattle, Wash., URS Greiner, 1402 p.

U.S. Navy, 2004, Closure report-Enhanced natural recovery for Operable Unit B Marine, Confined Aquatic Disposal (CAD) Pit BNC Bremerton, Washington: Pasadena, Calif., Tetra Tech, Inc., 35 p.

U.S. Navy, 2006a, 2003 Marine monitoring report, OU B Marine, BNC Bremerton, Washington: Seattle, Wash., URS Group., Inc., 295 p.

U.S. Navy, 2006b, 2005 Marine monitoring report, OU B Marine, BNC Bremerton, Washington: Seattle, Wash., URS Group., Inc., 272 p. 
U.S. Navy, 2007a, Second five-year review, BNC, Bremerton, Washington: Silverdale, Wash., U.S. Navy Naval Facilities Engineering Command Northwest, 258 p.

U.S. Navy, 2007b, Sediment transport study and natural recovery model report, BNC Bremerton, Washington: Seattle, Wash., URS Group., Inc., 224 p.

U.S. Navy, 2008a, 2007 Marine monitoring report OU B Marine, BNC Bremerton, Washington: Seattle, Wash., URS Group., Inc., 284 p.

U.S. Navy, 2008b, Cycloidal thruster scour analysis memorandum, Bremerton naval complex, Bremerton, Washington: Pasadena, Calif., Tetra Tech., Inc., 39 p.
Wang, P.F., and Richter, K., 1999, A hydrodynamic modeling study using CH3D for Sinclair Inlet: San Diego, Calif., SPAWAR Systems Center, 50 p.

West, J., and O’Neill, S., 1998, Persistent pollutants and factors affecting their accumulation in rockfishes (Sebastes spp.) from Puget Sound, Washington: Olympia, Wash. Puget Sound Research Conference, Puget Sound Partnership.

West, J., O’Neill, S., Lippert, G., and Quinnell, S., 2001, Toxic contaminants in marine and anadromous fishes from Puget Sound, Washington-Results from the Puget Sound Ambient Monitoring Program Fish Component, 19891999: Olympia, Wash., Washington Department of Fish and Wildlife Technical Report FTP01-14. 
122 Mercury in Sediment, Water, and Biota of Sinclair Inlet, Puget Sound, Washington, 1989-2007

This page intentionally left blank. 


\section{Appendix A. Evaluation of the Quality of Available Data for Marine Sediment, Marine Water, and Biota}

\section{Quality of Sediment Data}

The quality assurance data reported as part of the Site Investigation and Remedial Investigation/Feasibility Study (RI/FS) were of limited usefulness because only the laboratory data that were outside of the data quality objectives were reported. The numerical values of spike recoveries and outside quality control samples were not reported. In most cases, the values of field replicates were reported, which allowed for calculation of relative percent difference or relative standard deviations.

\section{Site Investigation (1990)}

As part of the Site Investigation in 1990, the surface sediment $(0-4 \mathrm{~cm})$ from 7 sites in Operable Unit (OU) A, 47 sites in OU B Marine and 7 sites outside of the PSNS (fig. 2 and tables B1-B5) were sampled and analyzed for THg and total aluminum. The reporting level for THg was about $0.12 \mathrm{mg} / \mathrm{kg}$ (U.S. Navy, 1994a). The spike recoveries of mercury for samples PS06-SD17 and PS06-SD41 were less than 25 percent. The relative percent difference (RPD) of the THg analyses of samples PS06-SD17 (mean $1.3 \mathrm{mg} / \mathrm{kg}$ ) and PS06-SD46 (mean $0.32 \mathrm{mg} / \mathrm{kg}$ ) were 24 and 22 percent, respectively. Four of the seven samples outside of the BNC were less than the reporting level and all mercury results for OU A were qualified for holding time exceedances. The RPDs for the total aluminum analyses of samples PS06-SD17 and PS06-SD46 were 6 and 2 percent, respectively. TOC content was determined for 14 samples, and total fines were determined for 13 of the 14 sites for which TOC was determined. Although no field replicates for TOC were performed on the 14 marine sediment samples, the overall assessment of analysis of TOC was deemed acceptable. In summary, RPDs of two field duplicates for THg averaged 23 percent and THg analyses of OU A samples were qualified for holding time exceedances.

\section{Remedial Investigation/Feasibility Study}

In 1993, mercury was extracted from 46 marine sediment samples from OU A by Laucks Laboratory using the TCLP6010 protocol (U.S. Environmental Protection Agency, 1990) and the leachate was analyzed by cold-vapor atomic absorption spectrometry. No analysis of standard reference materials was performed because TCLP extraction does not dissolve the entire solid matrix. Four of five matrix spikes of TCLP leachates were outside of the quality control limits (page H-76 of Appendix H of U.S. Navy, 1995, which is p. 1882 in the electronic PDF file of the document) and sediment samples were qualified accordingly. Even though only 29 percent of the mercury analyses were deemed acceptable due to low matrix spike recoveries and values below the reporting level, the RPDs of three laboratory duplicates and one field duplicate of this weak acid digestion were less than 4 percent.

In 1994, marine sediment samples were collected from 38 locations in Phase 1 of the RI/FS OU B and analyzed for mercury by Southwest Research Institute (SWRI). The reporting level was about $0.23 \mathrm{mg} / \mathrm{kg}$, and 18 of the samples had unqualified positive results. The reason for the qualified data could not be determined in interim reports (U.S. Navy, 1994b) or the final report (U.S. Navy, 2002). The RPD of one sample with a mean mercury concentration of $0.58 \mathrm{mg} / \mathrm{kg}$ was 26 percent. The analytical method of samples shown in Section 70.8-70.15 in volume 3 of the RI/FS Report (p. 903-910 of volume 3 of the electronic PDF file) seems to be mislabeled, and this error is carried over into the Navy Database. In Section 70.8 (p. 903 in volume 3 of electronic PDF file), the report switches from the 1993 TCLP-6010 procedure used by Laucks Laboratory to the 1994 analyses of SWRI. The TCLP extraction is a selective extraction and does not attack the clay matrix of sediment. Therefore, the amounts of aluminum yielded by the TCLP extraction performed by Laucks Laboratory were low (tens of $\mathrm{mg} / \mathrm{kg}$ ). All of the 1994-95 analyses performed by SWRI yielded aluminum concentrations that ranged between 7,000 and $23,000 \mathrm{mg} / \mathrm{kg}$, indicating a strong acid digestion. As part of the RI/FS study, metals simultaneously extracted for acid-volatile sulfur (SEM-AVS) were measured in four samples listed in table A1. In the SEM-AVS procedure, the sediment is digested in 10 percent (volume/volume) hydrochloric acid. The mercury concentrations released by 10 percent hydrochloric acid in the SEM-AVS method were very similar to the results of the method shown in Section 70.8-70.15 in volume 3 of the RI/FS (table A1), thereby strongly indicating that the method used by SWRI was a strong acid digestion yielding THg values rather than the TCLP values for the weaker extraction. Marine sediment samples with aluminum concentrations greater than 5,000 mg/kg listed in Section 70.8-70.15 will be assumed to have been digested by a strong acid. 
Table A1. Comparison of mercury concentrations in different samples at four stations from the routine total mercury analysis and mercury extracted by strong acid during a special study on acid volatile sulfur.

[Mercury is in milligrams per kilogram. Data Source: U.S. Navy, 2000.

Abbreviations: AVS, acid volatile sulfur; J, qualified data]

\begin{tabular}{lccc}
\hline \multirow{2}{*}{ Station name } & Date & \multicolumn{2}{c}{ Mercury (mg/kg) } \\
\cline { 3 - 4 } & & Total analysis & $\begin{array}{c}\text { AVS } \\
\text { special study }\end{array}$ \\
\hline 451-6W BIASED & $05-10-94$ & $0.9 \mathrm{~J}$ & $1.1 \mathrm{~J}$ \\
453-6W REP & $05-09-94$ & $1.3 \mathrm{~J}$ & $1.4 \mathrm{~J}$ \\
454-6W REP & $05-09-94$ & $1.6 \mathrm{~J}$ & $1.4 \mathrm{~J}$ \\
455-6W REP & $05-09-94$ & $1.6 \mathrm{~J}$ & $1.5 \mathrm{~J}$ \\
\hline
\end{tabular}

Phase 2 of the RI/FS of OU B (after May 30, 1995) included sediment sampling for the core at station 490, the surface sediment offshore of OUs A and B (locations 811 to 816 ), and three cores between piers (locations 826-828 in fig. 2). The RPD of one sample with an estimated THg concentration of $6.5 \mathrm{mg} / \mathrm{kg}$ was 2 percent, and the RPD of the second replicate at an estimated THg concentration of about $2 \mathrm{mg} / \mathrm{kg}$ was 87 percent. The six samples for the cores between the piers were qualified because holding times were exceeded (appendix R (PDF p. 202) of U.S. Navy, 2002).

\section{Monitoring of Dredging off NBK Bremeton (1994-97)}

The quality assurance of the chemical analysis of the annual monitoring after the pier navigational dredging included blanks and field replicates (U.S. Navy, 1998). The two blanks for the 1996 pier monitoring were less than the total mercury reporting level of $0.2 \mathrm{mg} / \mathrm{kg}$. The RPD of one field duplicate with a mean $\mathrm{THg}$ concentration of $0.73 \mathrm{mg} / \mathrm{kg}$ was 6.9 percent, and the RPD of field replicates for TOC and total fines were 1.8 and 0.8 percent, respectively. The relative standard deviation of triplicate laboratory replicates was 2 percent at a total fines value of 25 percent. One 1997 processing blank THg was less than the reporting level of $0.1 \mathrm{mg} / \mathrm{kg}$. Duplicate analyses of one sample at a $\mathrm{THg}$ concentration of $0.8 \mathrm{mg} / \mathrm{kg}$ were identical within the reporting precision of $0.1 \mathrm{mg} / \mathrm{kg}$. The RPDs of measurements of TOC and total fines of field duplicates were 3 and 13 percent, respectively, and the RPD for replicate laboratory analyses for one total fine sample was 27 percent.

\section{Sediment Characterization for Dredging}

For sediment in proposed Dredged Material Management Units sampled in January 1999 (U.S. Navy, 1999), all 1.2-m surface core sections had THg concentrations were above the reporting level of about $0.025 \mathrm{mg} / \mathrm{kg}$. One-half of the six sub-surface cores were at or below the reporting level. The RPD for three field duplicates of THg in surface cores ranged between 36 and 51 percent (table A2). One set of the subsurface cores collected for field duplicates was below the THg reporting level, and the RPD for the second set of field duplicate THg measurements for subsurface cores was 46 percent. For both studies, the authors conclude (U.S. Navy, 2000), "Overall, the sediment chemistry data results are acceptable and useable as qualified." Horizontal variability over the 1.2-m length core probably was the cause of the high RPDs.

Table A2. Results of field replicates of total mercury during sediment characterization of Dredged Material Management Units in 1999.

[Data sourceand locations: U.S. Navy, 1999. Abbrevations RPD, relative percent difference; U, below reporting level, NA, not applicable; mg/kg, milligrams per kilogram]

\begin{tabular}{|c|c|c|c|c|}
\hline $\begin{array}{c}\text { Sample } \\
\text { identification } \\
\text { number }\end{array}$ & $\begin{array}{c}\text { Total } \\
\text { mercury } \\
\text { (mg/kg) }\end{array}$ & $\begin{array}{c}\text { Sample } \\
\text { identification } \\
\text { number }\end{array}$ & $\begin{array}{c}\text { Total } \\
\text { mercury } \\
\text { (mg/kg) }\end{array}$ & RPD \\
\hline \multicolumn{5}{|c|}{ January 1999 field replicates } \\
\hline S39 & 0.121 & S79 & 0.084 & 36 \\
\hline S48 & .262 & S81 & .379 & 37 \\
\hline S71 & .166 & S82 & .281 & 51 \\
\hline D1 & .83 & D9 & .517 & 46 \\
\hline D4 & $.025 \mathrm{U}$ & D10 & $.026 \mathrm{U}$ & NA \\
\hline \multicolumn{5}{|c|}{ October 1999 field replicates } \\
\hline 73 & 0.068 & 173 & 0.138 & 68 \\
\hline DD4-PB-64 & .0244 & $\begin{array}{l}\text { DD4- } \\
\text { PB-164 }\end{array}$ & .0299 & 20 \\
\hline SS101 & .302 & SS201 & .464 & 42 \\
\hline
\end{tabular}

\section{Confined Aquatic Disposal Closure and Explanation of Significant Difference}

No report was written and no quality control samples were obtained for the samples collected in June 2000 before the CAD pit was filled, the two samples in front of the smallest dry dock in central PSNS \& IMF collected in January 2001, and the samples collected around the CAD pit after it was covered in August 2001. The U.S. Navy database (Grady May, U.S. Navy, written commun., 2007) indicated that the two samples collected in front of this dry dock with $\mathrm{THg}$ concentrations of 1.39 and $7.54 \mathrm{mg} / \mathrm{kg}$ were qualified.

No report was written and no quality control samples were obtained for the samples collected in the State Owned Aquatic Lands (fig. 2) in June 2003 (Grady May, U.S. Navy, written commun., 2007). Unlabeled locations and PCB concentrations for these samples are in figure 2-1 of U.S. Navy (2004). 


\section{Long-Term Monitoring Program}

Assessment of the quality of sediment data presented in reports of the Long-Term Monitoring Program is limited to evaluating RPDs of field replicates. In 2003, replicate field composites were taken from two 1,500-ft grid cells (table A3), six 500-ft grid cells (table A3), one surface CP cell (table A4), and one surface section from a CAD pit core (table A4). The RPD for mercury of field composites from the $1,500-\mathrm{ft}$ grid cells was 6 percent, and the RPDs for the six field composites from 500-ft grid cells ranged from 1 to 50 percent with a median RPD of 9 percent. The composite sample with a RPD of 50 percent was located in the apron of the CAD pit. The RPDs for TOC of field replicates from the 1,500-ft grid cells were 1 percent or less, and the RPDs for the six field replicates from 500 -ft grid cells ranged from 1 to 10 percent with a median RPD of 3 percent. The RPDs for total fines of field replicates from the 1,500-ft grid cells were 1 percent, and the RPDs for the six field replicates from 500-ft grid cells ranged from 0.3 to 14 percent with a median RPD of 4 percent. The field duplicates with a RPD of 14 percent for total fines was collected from 500-ft grid cell 52, which adjacent to the shoreline stabilization project. The RPD for THg of duplicates from a cell in the apron of the CAD pit (CP10) was 80 percent and the RPD of a surface section of the core from the PIT-01 location was 29 percent. The RPDs for TOC for the CAD pit apron and the pit core were also higher (15 and 55 percent, respectively) than the composite samples. The field replicate for the CAD pit apron was disregarded in the discussion of the results.

In 2005, replicate field composites were taken from one 1,500-ft grid cells, four 500-ft grid cells (table A3), two surface $\mathrm{CP}$ cells, and one surface section from a CAD pit core (table A4). The RPDs for the one field composite from the 1,500-ft grid cell were 33, 4, and 1 percent for $\mathrm{THg}$, TOC, and total fines, respectively. The RPD of the mercury concentration for the $0-30 \mathrm{~cm}$ section of core PIT-04 was 55 percent for a mean qualified value of $0.4 \mathrm{mg} / \mathrm{kg}$. The RPD for TOC and total fines was less than 0.1 and 2 percent, respectively. The asterisk for the $0-1 \mathrm{ft}$ core section of PIT-04 of table 3-1 (U.S. Navy, 2006b) is missing to indicate an average of field duplicates.

In 2007, replicate field composites were taken from two 1,500-ft grid cells, four gird 500-ft cells (table A3), and one subsurface section from a CAD pit core (table A4). The RPDs for THg of field composites from the 1,500-ft grid cells were 1 and 22 percent, and the RPD for the four field composites from 500 -ft grid cells ranged from 1 to 16 percent with a median RPD of 3 percent. The RPDs for TOC of field replicates from the 1,500-ft grid cells were 1 and 2 percent and the RPD for the six field replicates from 500-ft grid cells ranged from 1 to 10 percent with a median RPD of 3 percent. The RPDs for total fines of field replicates were generally less than 1 percent. The RPD of the THg concentration for the 30-61 cm section of core PIT-02 was 2 percent for a mean qualified value of $0.4 \mathrm{mg} / \mathrm{kg}$. The RPD of total fines was 70 percent, mainly as a result of a three-fold difference in the clay fraction. This difference in the clay fraction probably also caused a 35 percent RPD for TOC. The RPD of total solids was less than 4 percent.

In general, the RPDs of THg, TOC and total fines from the LTMP were acceptable. High RPD differences were measured in samples from grid cells with a significant gradient in sediment characteristics, such as in cells where the total fines were low.

\section{Puget Sound Ambient Monitoring Program}

Quality control measures for analysis of sediment for THg during 1989-2005 for the Long-Term Temporal Monitoring program consisted of matrix spikes, field duplicates, and an occasional analysis of standard reference material (SRM). In most instances, case narratives provided by Margaret Dutch (Washington State Department of Ecology, written commun., 2008) only reported results that were outside the data quality objectives, which was \pm 25 percent for recovery of mercury matrix spikes and \pm 35 percent RPD for field duplicates. In 1989 and 1993, one of five matrix spikes for THg was outside the acceptable range, and in 1992 mercury was qualified because THg analyses were outside the acceptable range. The actual spike recoveries were reported for mercury in 1995 and they were 99 percent \pm 4 percent. In 1990 , recovery of SRM was reported to be \pm 30 percent of the certified value. Throughout most estuaries sampled, THg concentrations in 1996 were systematically low, suggesting an analytical basis. As a result, the 1996 data were disregarded in this study.

Quality control measures for TOC included matrix spikes, replicated analyses, blind replicate field analyses, and laboratory control standards. In 1989, 20 percent of the analyses were outside of the \pm 25 percent acceptable range for matrix spikes and at least one of the four samples in 1990 was outside the \pm 25 percent acceptable range. All matrix spikes from 1991 and thereafter were acceptable. The maximum coefficients of variance for triplicate analyses in 1991 and 1992 were 13.3 and 11.2 percent, respectively, and less than 20 percent thereafter. Reported recoveries of laboratory control samples for TOC in 1994 was 99 percent \pm 1 percent. The RPD of field duplicates in some cases approached 50 percent and was attributed to natural variability. For grain size measurements, recovery of solids was generally within \pm 5 percent. In 1990, analyses from some stations were qualified. RPD of field blanks was reported to be less than 35 percent between 1989 and 1993, and less than 20 percent thereafter. In 1989, three samples were revalidated and two of the three initial values were deemed incorrect. 


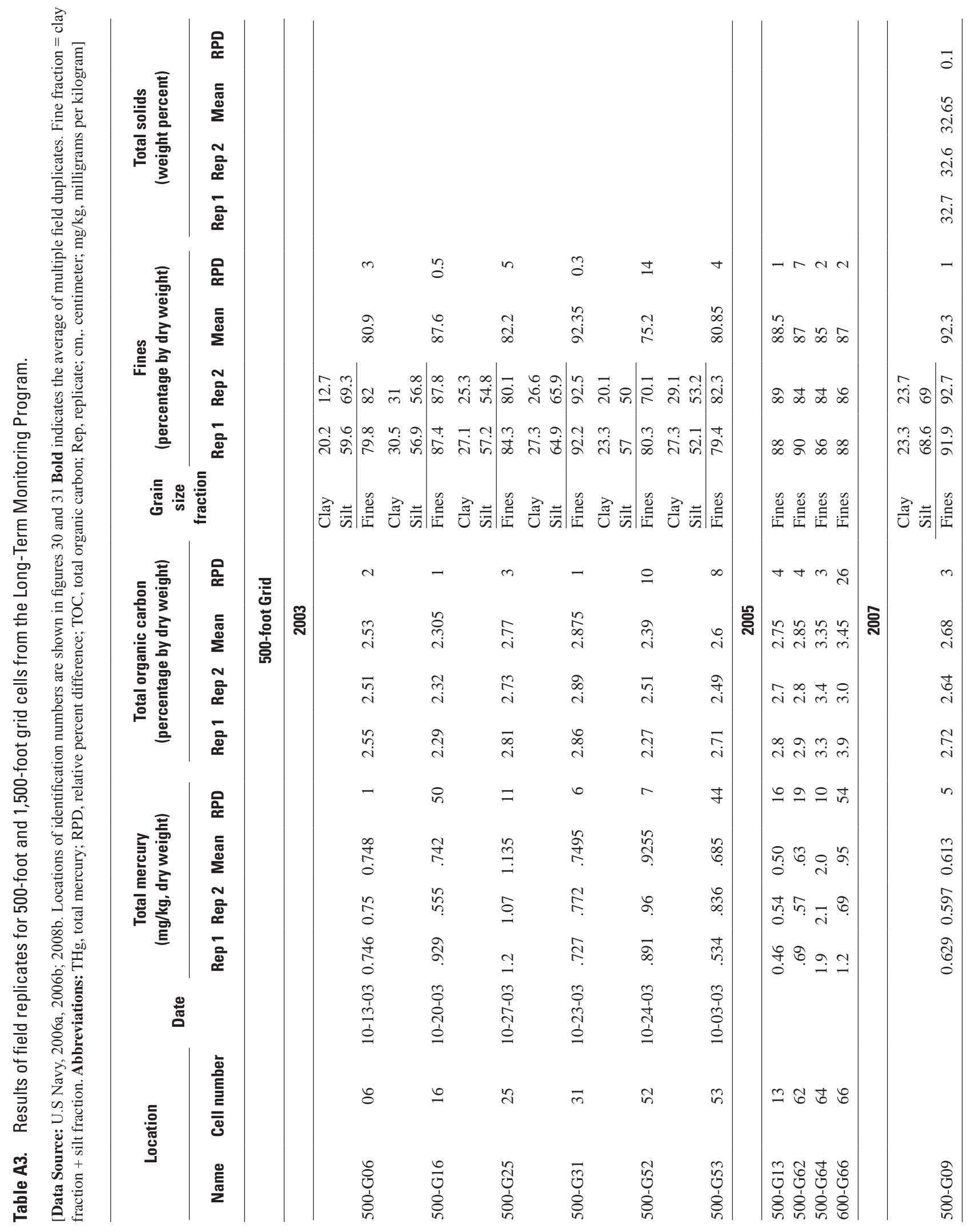




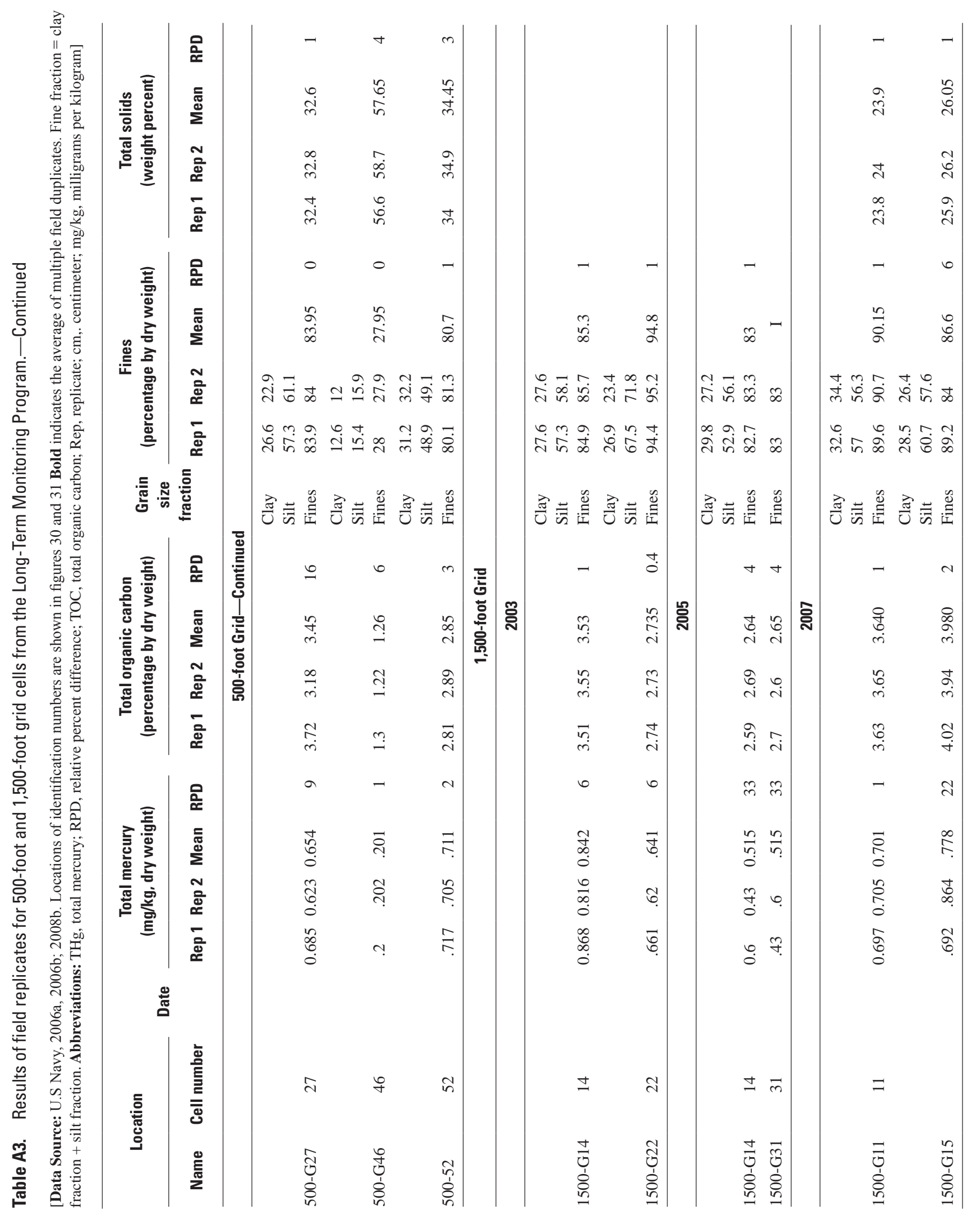




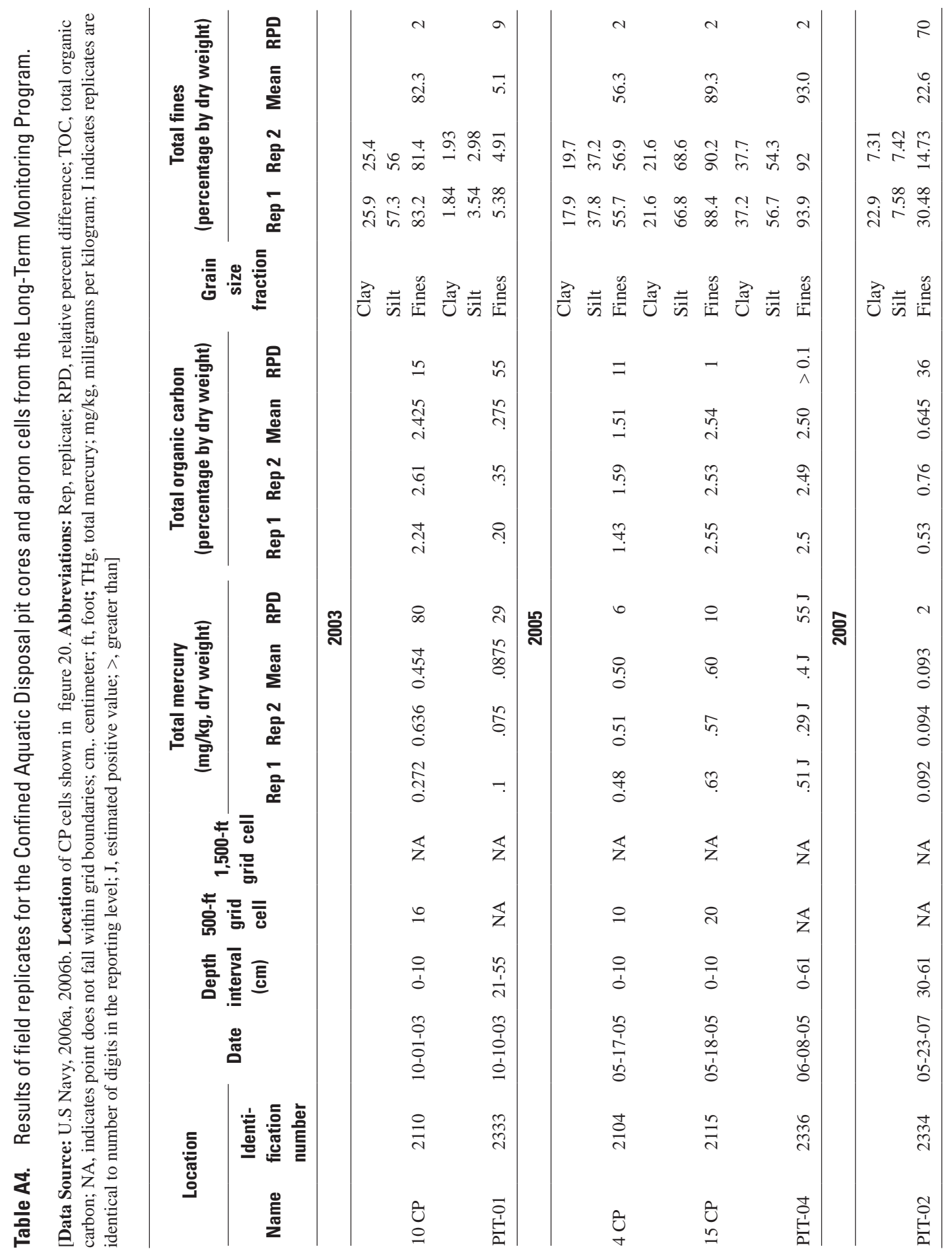




\section{ENVironmental InVESTment (ENVVEST) Cores and Settling Particles}

Assessment of the quality of mercury analysis of sediment cores taken by ENVVEST in 2002 was based on laboratory blanks, laboratory control samples, analyses of standard reference materials, matrix spikes, and laboratory replicates (Battelle Marine Sciences Laboratory, QA/QC narrative for MVS Sediment Confirmatory Analyses Project, written commun., 2004). The values from seven procedural blanks resulted in a THg reporting level of $0.006 \mathrm{mg} / \mathrm{kg}$. Six of the seven laboratory control samples spiked at a THg concentration of $1 \mathrm{mg} / \mathrm{kg}$ ranged between 94 and 102 percent recovery, but the THg recovery of one laboratory control sample was only 60 percent. The relative percent difference from the analysis of seven samples of the standard reference material MESS-3 (certified THg value of $0.091 \mathrm{mg} / \mathrm{kg}$ ) ranged between 1 and 10 percent, and had a median relative percentage difference from the certified value of 3 percent. The relative percent difference from the certified value of seven analyses of the higher concentration PACS-3 (certified THg value of $3.04 \mathrm{mg} / \mathrm{kg}$ ) ranged between 1 and 4 percent, and had a median of 2 percent. The recovery of THg spikes (spiked with about $0.95 \mathrm{mg} / \mathrm{kg}$ ) added to four Sinclair Inlet samples that ranged in concentration between 0.045 and $1.46 \mathrm{mg} / \mathrm{kg}$ ranged between 94 and 116 percent, and had a median RPD of duplicate spike recoveries of 8 percent. The RPDs of the four laboratory replicate spikes samples were between 1 and 7 percent. Except for the samples associated with the 60 percent recovery of the laboratory control sample, the accuracy and precision of the analyses were less than 15 percent.

\section{Quality of Water Data}

The quality control data for the THg analyses by the cold vapor-atomic fluorescence spectrometry analysis from four stations (KSS02, ADMIRALC14, KSBP01, and COLVOSPASS)in seawater from four stations (KSS02, ADMIRALC14, KSBP01, and COLVOSPASS) performed by Frontier Geosciences, Inc. (Seattle, Wash.) between June 1999 and June 2000 (King County Department of Natural Resources, 2001) included reagent, filter and method blanks, duplicate matrix spikes and analysis of standard reference materials (Colin Elliott, King County Department of Natural Resources, written commun., 2008). For each of the 13 months of sampling, the minimum detection limit was estimated by three standard deviations of the replicate reagent blanks, with the number of analyses ranging from 3 to 15 . The median minimum detection limit was $0.075 \mathrm{ng} / \mathrm{L}$; however, the analyses from November 1999 to January 2000 seemed to suffer from random contamination resulting in the minimum detection limits exceeding $0.1 \mathrm{ng} / \mathrm{L}$. The amounts of THg gained when filtering blank water were generally less than $0.1 \mathrm{ng} / \mathrm{L}$ for filtering blanks performed from June 1999 to November 1999. For the sampling between December 1999 and June 2000, the THg concentration of the distilled blank water that was filtered was greater than $0.12 \mathrm{ng} / \mathrm{L}$, which resulted in a change in total THg concentrations ranging from a loss of $0.412 \mathrm{ng} / \mathrm{L}$ during filtration to a gain of $0.082 \mathrm{ng} / \mathrm{L}$. For the other four filtering blanks between December 1999 and June 2000, for which the THg concentration of the distilled blank water was less than $0.12 \mathrm{ng} / \mathrm{L}$, the change in THg concentration ranged from a loss of $0.05 \mathrm{ng} / \mathrm{L}$ to a gain of $0.14 \mathrm{ng} / \mathrm{L}$. The method blank for THg ranged from 0.01 to $0.17 \mathrm{ng} / \mathrm{L}$ in 10 out of the 13 sampling periods, and was used to correct laboratory values. For August and September 1999 and April 2000, the mean THg method blanks ranged from 0.27 to $0.33 \mathrm{ng} / \mathrm{L}$, which were comparable to the THg concentrations reported for Puget Sound water. The August data was not blank corrected because it was determined that the high THg method blank was limited to distilled blank water used in the method blank. For September 1999 and April 2000, quality control documents do not mention any corrective action concerning the method blanks and the reported concentrations are similar to concentrations from other months. For the four stations listed in table 6, the median recovery of 47 duplicate analyses of Puget Sound Seawater samples spiked with THg at a concentration of about $2 \mathrm{ng} / \mathrm{L}$ (matrix spike) was 97 percent (range from 75 to 117 percent). The mean RPD of the duplicate matrix spikes was 4.5 percent (ranged from 0 percent (identical values to $0.01 \mathrm{ng} / \mathrm{L}$ ) to 24 percent). From June 1999 to February 2000, a digest of the Dogfish muscle SRM DORM-2 (National Research Council of Canada, Ottawa, Ontario, Canada) was analyzed 33 times for THg resulting in a median recovery of 92 percent ( \pm 3.8 percent) and a range between 85 and 101 percent. From March to June 2000, the SRM 1641d (mercury in water, National Institute of Science and Technology, Gaithersburg, MD) diluted to 4,640 ng/L (March 2000) and 1,590 ng/L (April to June 2000) was analyzed 16 times with a median THg recovery of 101 percent ( \pm 7.9 percent) and recoveries ranging from 86 to 118 percent.

The quality of the cold vapor-atomic fluorescence spectrometry analysis of THg in seawater in Sinclair Inlet and outside its boundary by the ENVironmental inVEStment (ENVVEST) program collected between 2002 and 2005 was good. The laboratory blank was $0.17 \mathrm{ng} / \mathrm{L}$ for THg, and three methods blanks were below this THg reporting level. The mean recoveries of a THg spike at about a concentration of $5 \mathrm{ng} / \mathrm{L}$ to a $0.4 \mathrm{ng} / \mathrm{L}$ blank was 97 percent, and had a range between 81 and 111 percent. For the analyses outside the boundary of the Sinclair Inlet Study area, the THg recovery of a $10 \mathrm{ng} / \mathrm{L}$ spike to the $1.22 \mathrm{ng} / \mathrm{L}$ seawater matrix was 102 percent, and had a RPD of 1 percent. For the analyses of samples in Sinclair Inlet, the recovery of a $19 \mathrm{ng} / \mathrm{L}$ spike to the $1.3 \mathrm{ng} / \mathrm{L}$ seawater matrix was 114 percent and had a RPD of 8 percent. The THg recovery of a 1,590,000 ng/L ( \pm 18 percent) standard reference material SRM 1641 ranged between 88 and 111 percent. 


\section{Quality of Biota Data}

\section{English Sole}

English sole specimens were collected between July 11 and 14, 1994 during Phase 2 of the RI/FS and analyzed for mercury by the normal level Inductively-coupled Plasma spectrometric method. All values were qualified in the final report (U.S. Navy, 2002).

\section{Sea Cucumber}

Of the 35 individual and composite samples analyzed for mercury in the RI/FS (U.S. Navy, 2002), 26 samples were below the reporting level, 7 results were qualified and 2 samples were acceptable.

\section{Individual Specimens, 2003, 2005, 2007}

The quality control samples for individual specimens collected by the Puget Sound Ambient Monitoring Program and analyzed by ENVVEST (Brandenberger and others, 2006a) included procedural blanks, laboratory control samples, matrix spikes and matrix spike duplicates, laboratory replicates, and analyses of standard reference materials. In 2003, four blank samples had THg concentrations below the reporting level of $0.005 \mathrm{mg} / \mathrm{kg}$. Recoveries of two blank samples spiked with THg corresponding to a concentration of $2 \mathrm{mg} / \mathrm{kg}$ were near 100 percent and two others at 76 and 56 percent. The recoveries of four matrix samples spiked at a THg corresponding to a concentration of $2 \mathrm{mg} / \mathrm{kg}$ were within 10 percent of the expected values. The RPD of the duplicates of matrix spikes were less than 5 percent and the RPD of four laboratory duplicates ranged between 7 and 12 percent. The recovery of four aliquots of Dogfish Muscle SRM DORM2 (certified THg value of $4.64 \pm 0.26 \mathrm{mg} / \mathrm{kg}$ ) ranged between 96 to 97 percent.

Analyses of five procedural blanks in 2007 resulted in a THg reporting level of $0.002 \mathrm{mg} / \mathrm{kg}$ dry weight. The recovery of five laboratory control samples ranged between 100 and 109 percent, and had a median recovery of 106 percent. Five matrix spikes at THg concentrations of about $5 \mathrm{mg} / \mathrm{kg}$ dry weight ranged between 99 and 103 percent and had a median value of 99 percent. The RPD for the five matrix spikes were 1 percent or less. The RPD of five laboratory duplicate analyses ranged between 2 and 15 percent and had a median RPD of 4 percent. The recoveries of five analyses of the Dogfish Muscle SRM DORM2 ranged between 101 and 103 percent.
In 2007, the THg concentrations of five of six blanks were within $0.001 \mathrm{mg} / \mathrm{kg}$ of the reporting level of $0.005 \mathrm{mg} / \mathrm{kg}$ and the sixth blank had a THg concentration of $0.0161 \mathrm{mg} / \mathrm{kg}$. Blank recoveries ranged from 78 to 103 percent and the recoveries of four matrix samples spiked at a $\mathrm{THg}$ concentration of about $2 \mathrm{mg} / \mathrm{kg}$ ranged from 94 to 106 percent. RPDs of matrix spikes were 3 percent or less. The RPDs of 16 laboratory duplicates ranged between 1 and 7 percent with the highest RPD of 20 percent from a Hood Canal ratfish (mean THg concentration of $0.331 \mathrm{mg} / \mathrm{kg}$ ). Recoveries of six samples of Dogfish Muscle SRM DORM2 ranged between 86 and 94 percent.

\section{Caged Mussel Studies}

All mercury concentrations of mussels for the $1994 \mathrm{RI} /$ FS study were within one significant unit of the reporting level of $0.01 \mathrm{mg} / \mathrm{kg}$ (U.S. Navy, 2002).

The THg concentration of procedural blank for the 2005 ENVVEST caged mussel study ranged between 0.002 and $0.004 \mathrm{mg} / \mathrm{kg}$ dry weight. Laboratory controls with THg concentrations of about $5 \mathrm{mg} / \mathrm{kg}$ dry weight were within 5 percent of expected values, and recoveries of matrix spikes at THg concentrations corresponding to $5 \mathrm{mg} / \mathrm{kg}$ dry weight were within 3 percent of expected values. The RPDs of two samples with mean THg concentrations of 0.043 and $0.106 \mathrm{mg} / \mathrm{kg}$ dry weight were 1 percent. The recoveries of two analyses of oyster tissue (SRM1566b with certified THg value of $0.0371 \mathrm{mg} / \mathrm{kg}$ dry weight) were 107 and 114 percent (Brandenberger and others, 2006b).

The differences in mercury concentrations among the replicates at some of the sites seem to trend with the relative vertical position of each cage (fig. A1). For instance, the THg concentration of the composite of the mussels caged in the bottom cage at the Sinclair Inlet Ross Point site (SIRP in fig. 1C) was 26 percent higher than that mussels deployed in the top cage. THg concentrations often are correlated with biological metrics. A possible reason for the differences in THg concentration could be that the bottom cage is closer to the bottom sediment and the mussels in the bottom cage grew faster and larger. Unlike the caged mussel experiment from the $\mathrm{RI} / \mathrm{FS}$, the corresponding weight/length data for the mussels recovered by ENVVEST that made up each composite are not available to test this hypothesis. 


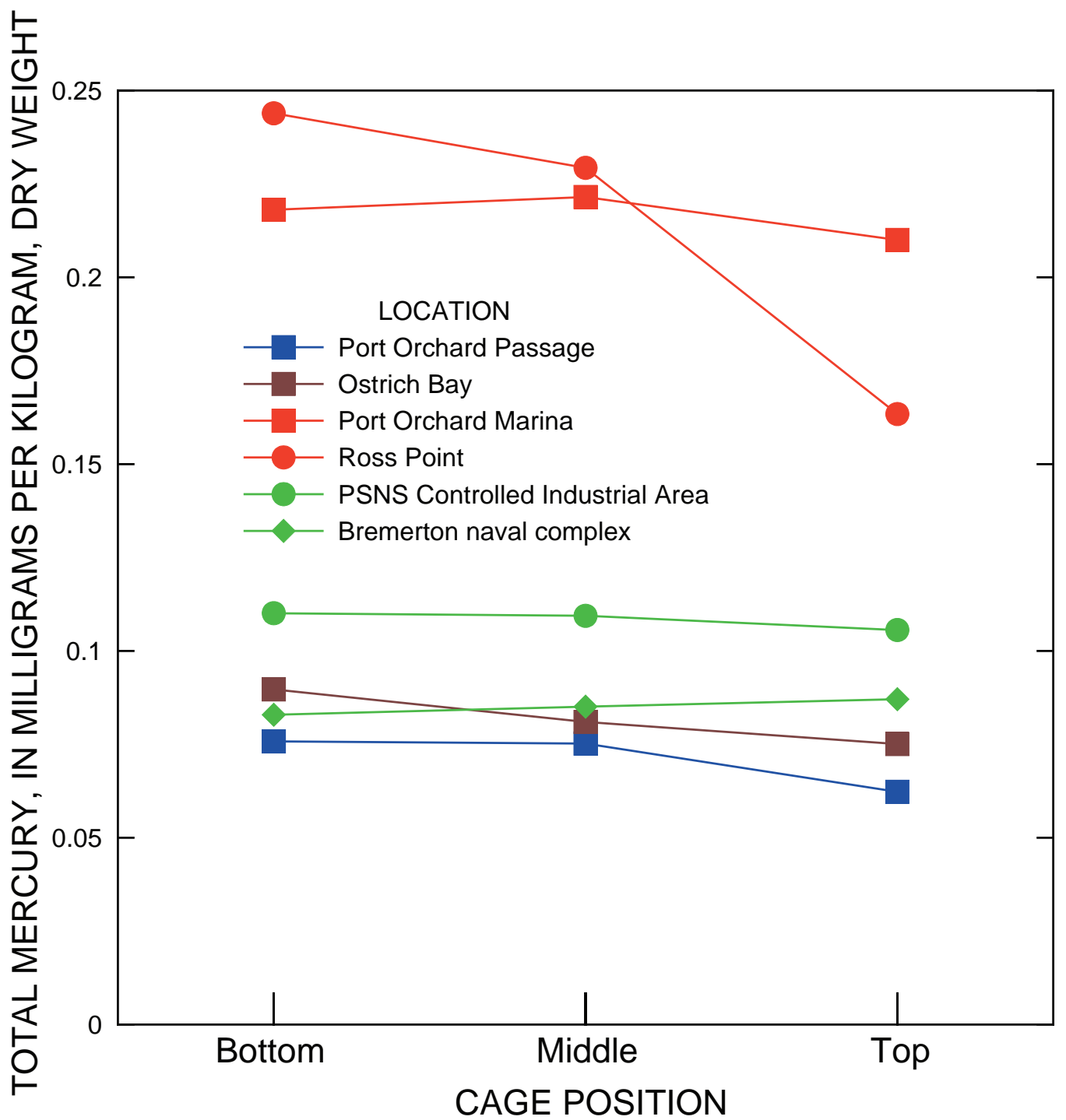

Figure A1. Mercury concentrations in mussels caged in 2002 as a function of vertical position. 


\section{Appendix A: References Cited}

Brandenberger, J.M., Suslick, C.R., and Johnston, R.K., 2006a, Biological sampling and analysis in Sinclair and Dyes Inlets, Washington-Chemical analyses for 2005 Puget Sound biota study: Pacific Northwest National Laboratory, PNNL 15834, 125 p., accessed online July 13, 2009, at http://www.ecy.wa.gov/programs/wq/tmdl/sinclairdyes_inlets/sinclair_cd/DATA/2005_Data/BIOTA/

Brandenberger, J.M., Suslick, C.R., and Johnston, R.K., 2006b, Biological sampling and analysis in Sinclair and Dyes Inlets, Washington-Chemical analyses for the caged mussel study: Richland, Wash., Pacific Northwest National Laboratory, PNNL-15835, 122 p., accessed online July 13, 2009, at http://www.ecy.wa.gov/programs/wq/tmdl/sinclairdyes_inlets/sinclair_cd/DATA/2005_Data/BIOTA/

King County Department of Natural Resources, 2001, Water quality status report for marine waters, 1999 and 2000: Seattle, Wash., King County Department of Natural Resources, 558 p.

U.S. Environmental Protection Agency, 1990, Test Methods for Evaluating Solid Waste, Physical/Chemical Methods (3d ed.): U.S. Environmental Protection Agency Report SW-846.

U.S. Navy, 1994a, Data Quality Assessment Historical Data, Operable Unit B, Puget Sound Naval Shipyard Bremerton, Washington: Seattle, Wash., URS Team 331 p.

U.S. Navy, 1994b, Phase 1 Technical Memorandum for the Remedial Investigation and Feasibility Study (RI/FS) at Operable Unit B, Puget Sound Naval Shipyard, Bremerton, Washington: Seattle, Wash., URS Consultants, 243 p.

U.S. Navy, 1995, Final Remedial Investigation Report, Operable Unit A. Puget Sound Naval Shipyard, Bremerton, Washington, v. 1: Seattle, Wash., URS Team, 2433 p.
U.S. Navy, 1998, Final 1997 Sampling and Analysis Report, Pier D Long-Term Sediment Monitoring Program, Puget Sound Naval Shipyard, Bremerton, Washington: Seattle, Wash., URS Greiner, Inc., 254 p.

U.S. Navy,1999, Sediment Characterization at Puget Sound Naval Shipyard, Bremerton, Washington- Phase 1: Bothell, Wash., Science Applications International Corporation, $110 \mathrm{p}$.

U.S. Navy, 2000, Sediment Characterization at Puget Sound Naval Shipyard, Bremerton, Washington-Phase 2: Bothell, Wash., Science Applications International Corporation, $77 \mathrm{p}$.

U.S. Navy, 2002, Final Remedial Investigation Report, Operable Unit B, BNC, Bremerton, Washington, v. 1: Seattle, Wash., URS Grier 1402 p.

U.S. Navy, 2004, Closure report-Enhanced natural recovery for Operable Unit B Marine, Confined Aquatic Disposal (CAD) Pit BNC Bremerton, Washington: Pasadena, Calif., Tetra Tech, Inc., 35 p.

U.S. Navy, 2006a, 2003 Marine Monitoring Report, OU B Marine, BNC Bremerton, Washington: Seattle, Wash., URS Group., Inc., 295 p.

U.S. Navy, 2006b, 2005 Marine Monitoring Report, OU B Marine, BNC Bremerton, Washington: Seattle, Wash., URS Group, Inc., 272 p.

U.S. Navy, 2008, 2007 Marine Monitoring Report, OU B Marine, BNC Bremerton, Washington, Seattle, Wash., URS Group. 


\section{Appendix B. Listings of Sediment Data Examined}

Table B1. Concentrations of total mercury and total aluminum and percentage of total organic carbon and total fines from marine surface sediment $(0-4 \mathrm{~cm})$ outside of Operable Unit B Marine of the Bremerton naval complex, Washington, from the 1990 Site Investigation.

[Data Source U.S. Navy, 1992. Location number in figures 1B and 1C. Mercury qualifier: A, acceptable; U, Not detected. Abbreviations: NA, indicates point does not fall within grid boundaries; -, data not available; cm, centimeter; mg/kg, milligrams per kilogram; no., number]

\begin{tabular}{|c|c|c|c|c|c|c|c|c|}
\hline \multicolumn{2}{|c|}{ Location } & \multirow{2}{*}{ Date } & \multirow{2}{*}{$\begin{array}{l}\text { Depth } \\
\text { interval } \\
\text { (cm) }\end{array}$} & \multirow{2}{*}{$\begin{array}{c}\text { 1,500- } \\
\text { foot grid } \\
\text { cell no. }\end{array}$} & \multirow{2}{*}{$\begin{array}{c}\text { Total } \\
\text { mercury } \\
\text { (mg/kg, dry } \\
\text { weight) }\end{array}$} & \multirow{2}{*}{$\begin{array}{l}\text { Mercury } \\
\text { qualifier }\end{array}$} & \multirow{2}{*}{$\begin{array}{c}\text { Total } \\
\text { aluminum } \\
\text { (mg/kg, dry } \\
\text { weight) }\end{array}$} & \multirow{2}{*}{$\begin{array}{l}\text { Total organic } \\
\text { carbon } \\
\text { (percentage by } \\
\text { dry weight) }\end{array}$} \\
\hline Name & Number & & & & & & & \\
\hline PS06-SD48 & 148 & $11-29-90$ & $0-4$ & 10 & 1.4 & A & 22,000 & 4.00 \\
\hline PS06-SD49 & 149 & $11-29-90$ & $0-4$ & 6 & 1 & A & 22,500 & - \\
\hline PS06-SD50 & 150 & $11-29-90$ & $0-4$ & 3 & .12 & $\mathrm{U}$ & 10,200 & - \\
\hline PS06-SD51 & 151 & $12-07-90$ & $0-4$ & NA & .13 & $\mathrm{U}$ & 7,730 & 1.00 \\
\hline PS06-SD52 & 152 & $12-07-90$ & $0-4$ & NA & .14 & $\mathrm{U}$ & 7,600 & - \\
\hline PS06-SD53 & 153 & $12-07-90$ & $0-4$ & NA & .13 & $\mathrm{U}$ & 7,130 & - \\
\hline
\end{tabular}




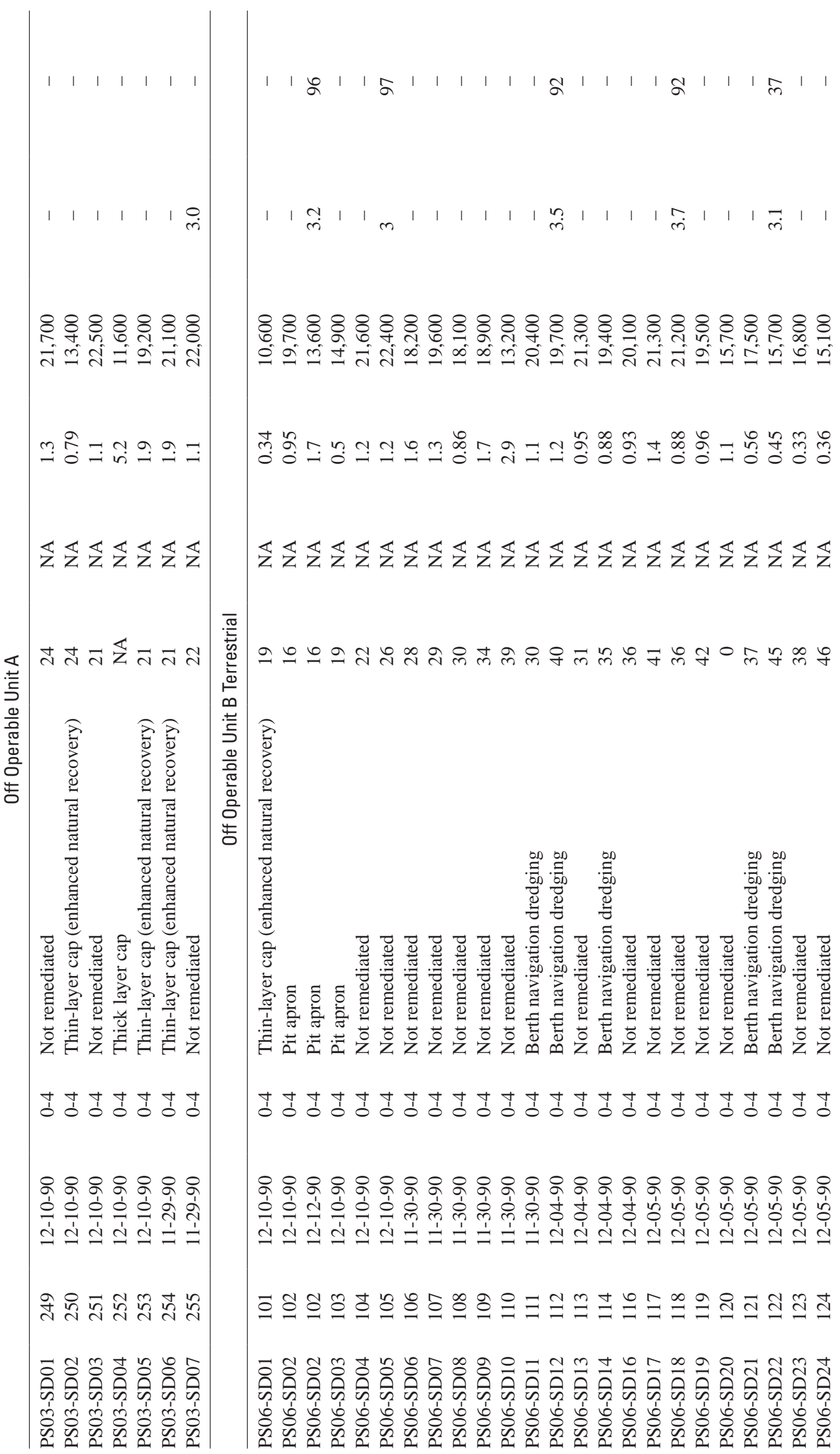




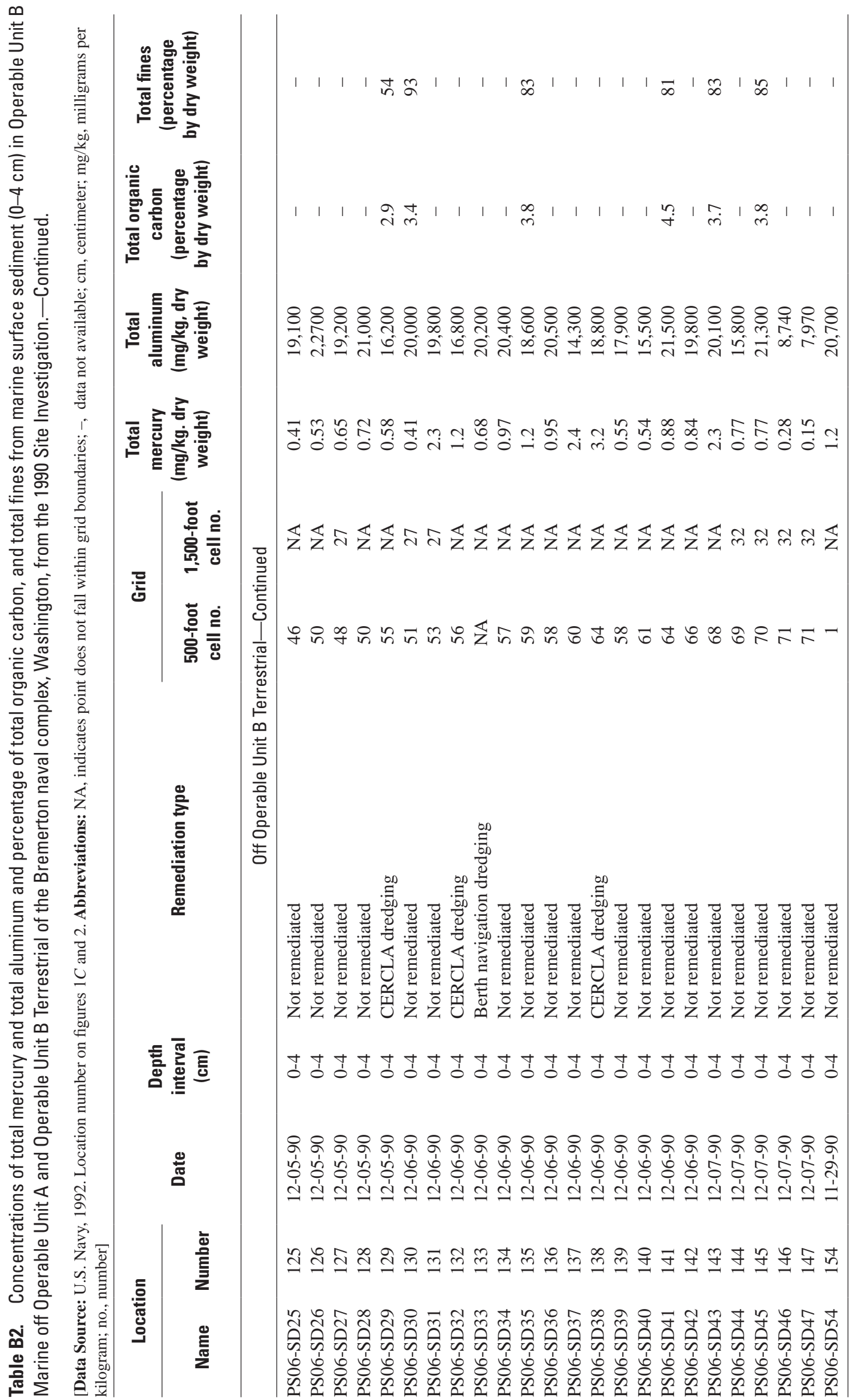




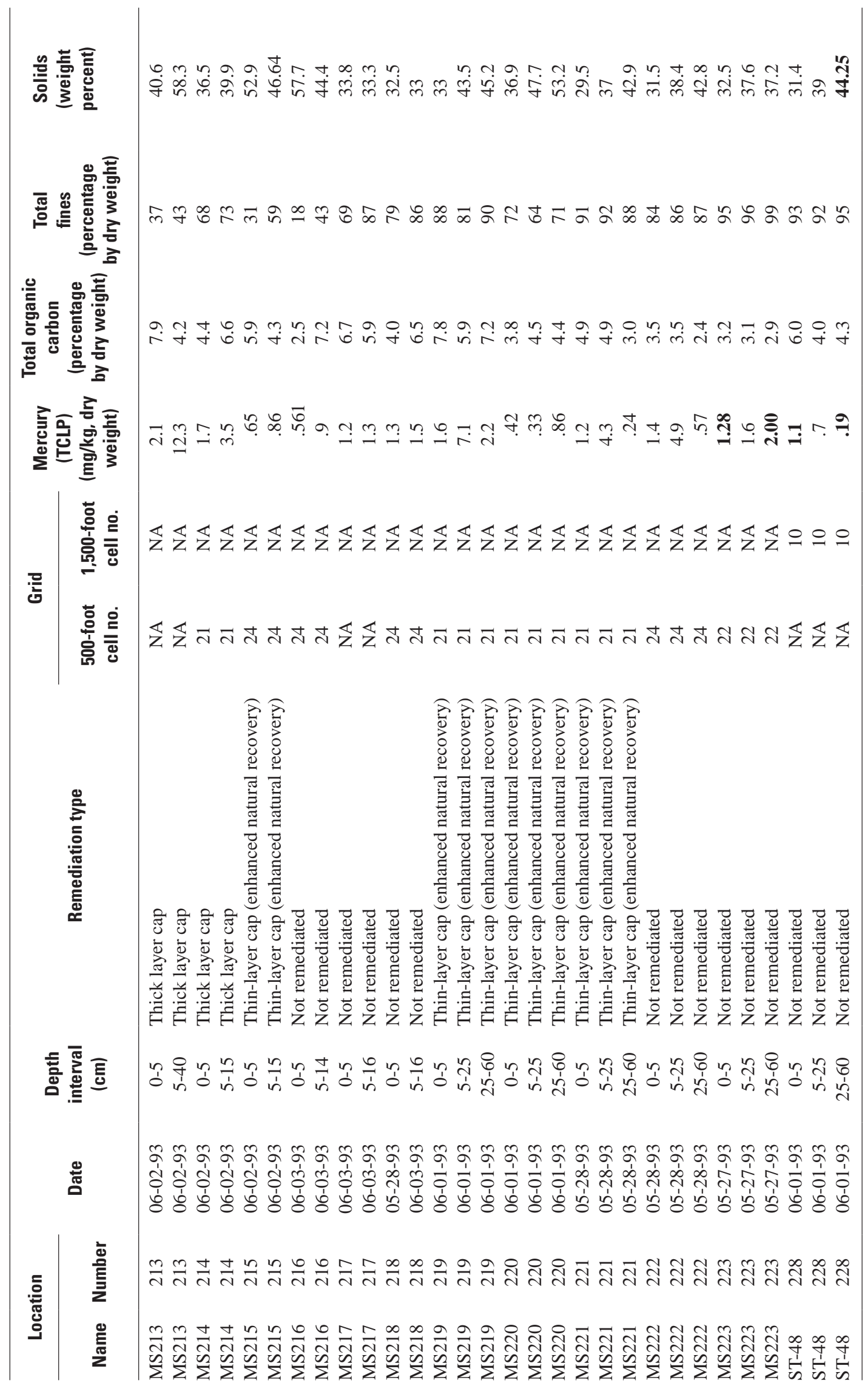


횽 뜰 흘

$\subseteq$ ฮ

횽요

迆

등

䒕希

Е

岁 $\frac{0}{\pi}$

हิ व

음든

高

ब

苋㐫

空

它

후용

항

ธิ

낭뭉

言.

핌 둬

응

등 중

象

은 웡

荡 苂

흘

要 壱

प항

空

刃

응 \&

흥을오

高 空

톤

的家

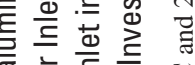

흘

정 흔

क्ष

它的㐫

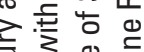

氜 势

迹

元

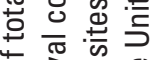

웓

을 둔 흉

릴 동ㅁㅇ

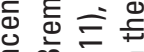

ठำ

ن

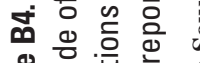

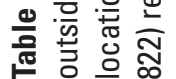

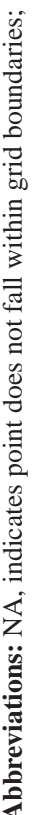

造

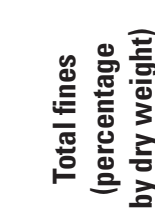

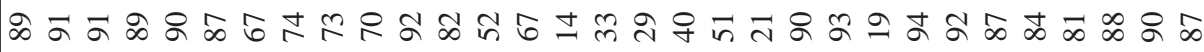

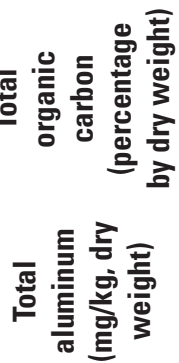

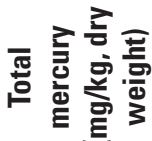

蒙

믑

范

客 $\overline{\mathrm{d}}$

言票

๓ัँ

离

ฮั

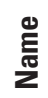

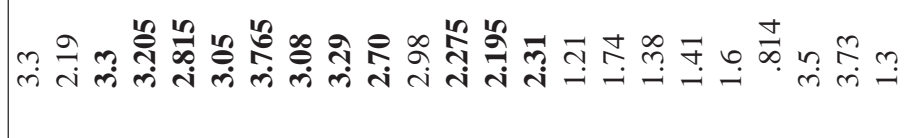

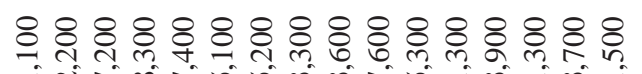

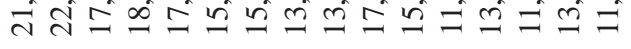

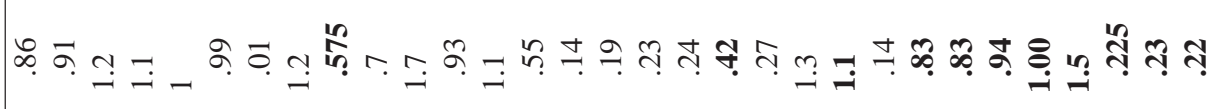

๓

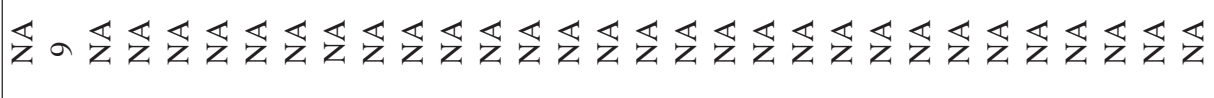

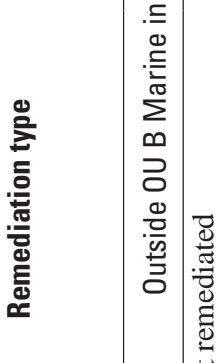

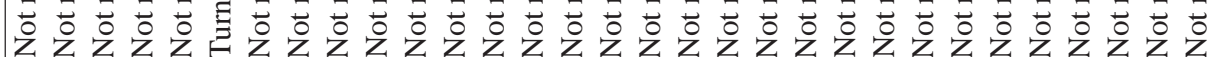

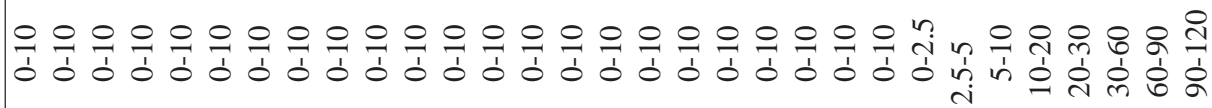

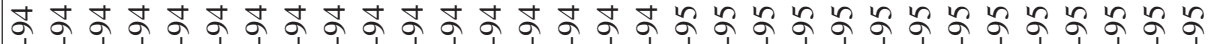
ت خ

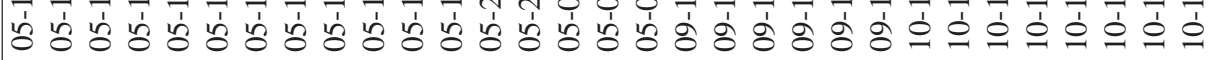

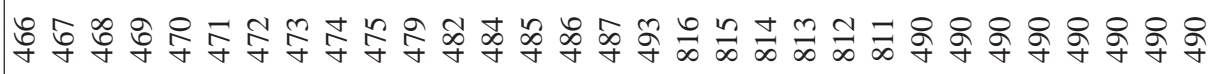

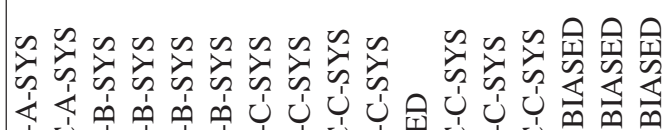

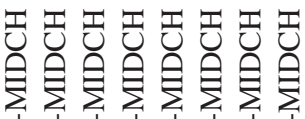

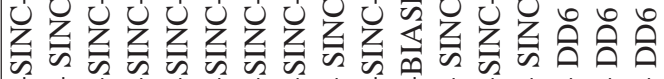

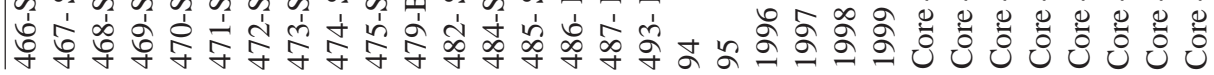



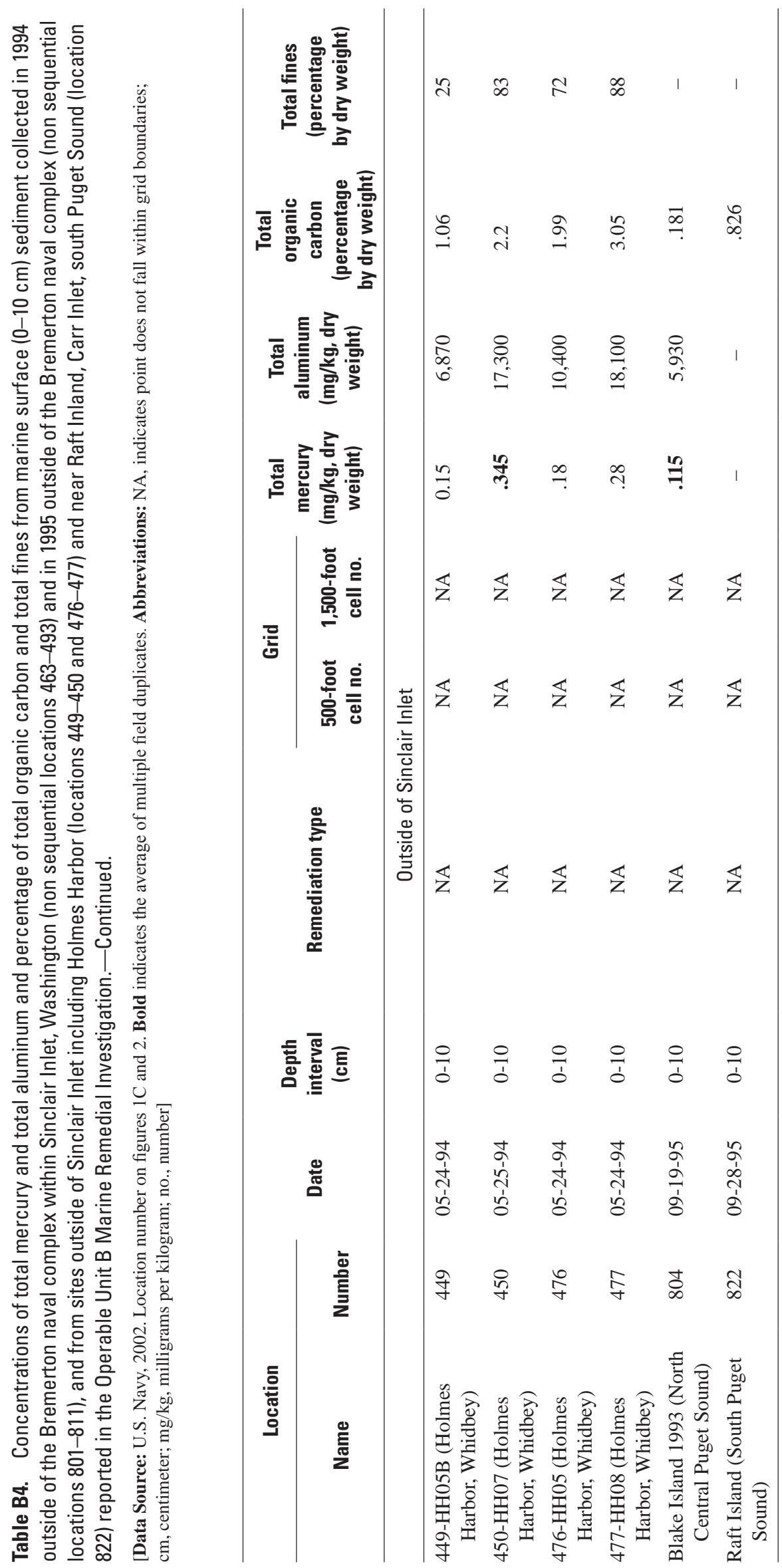


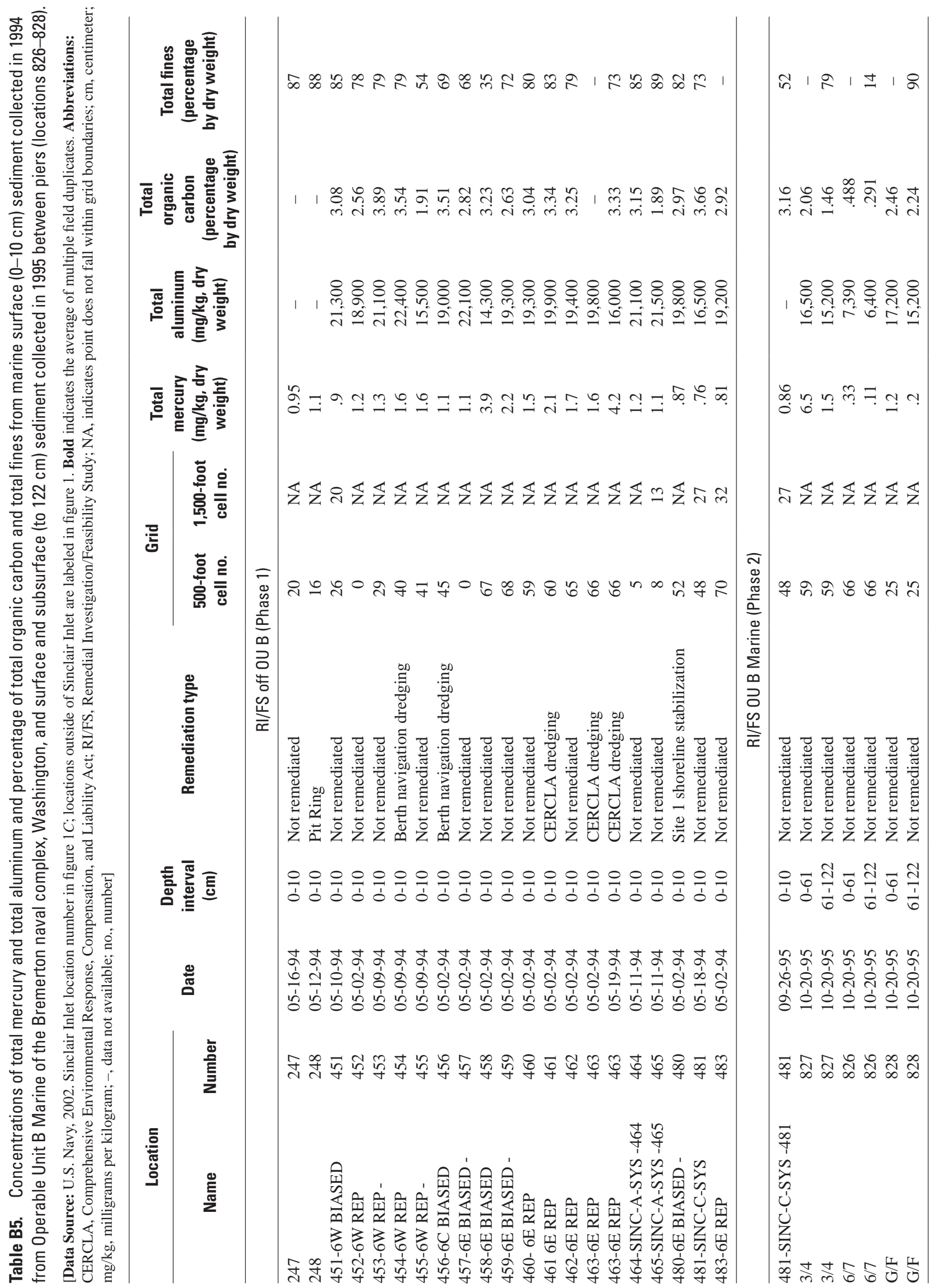




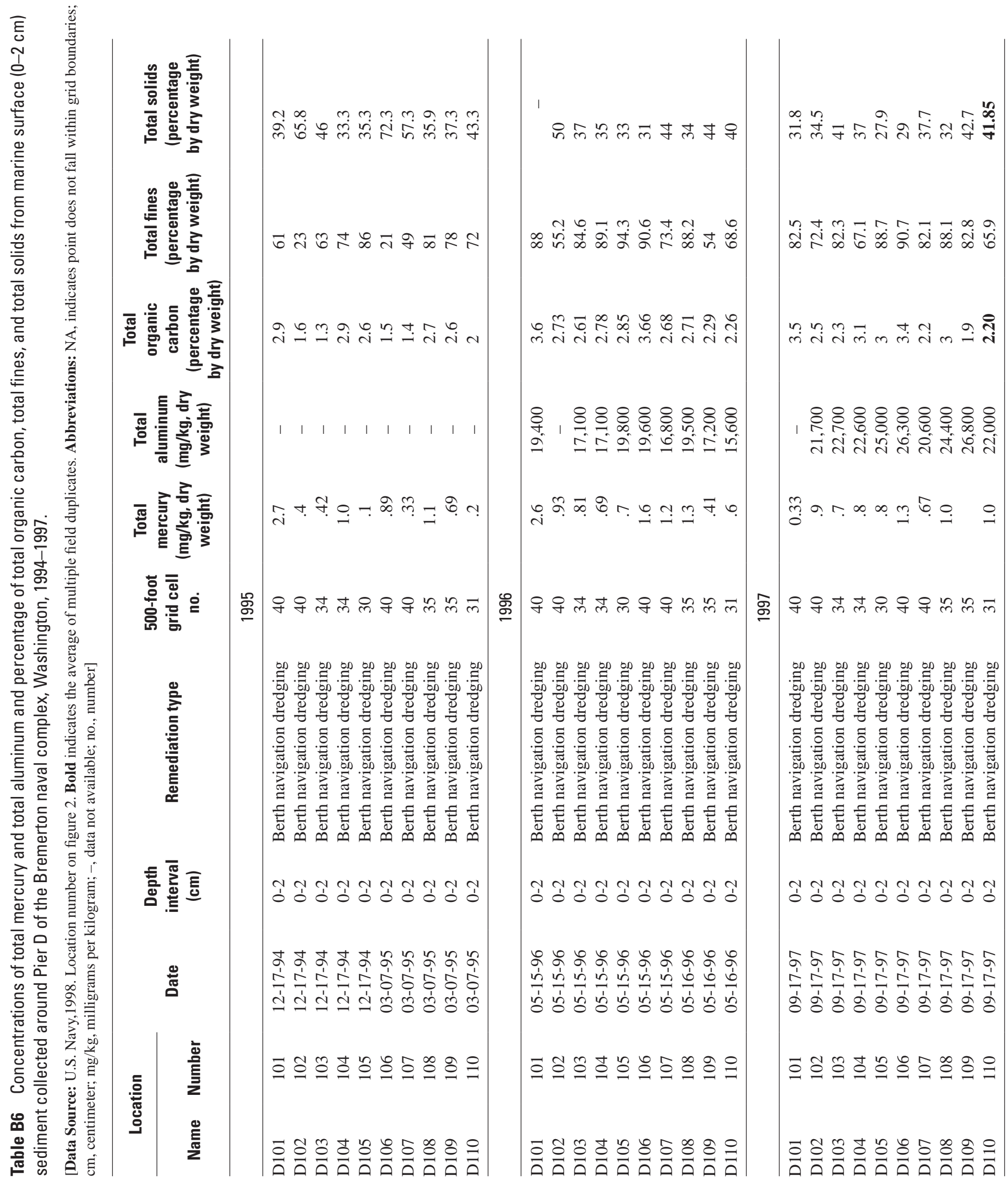


ம்

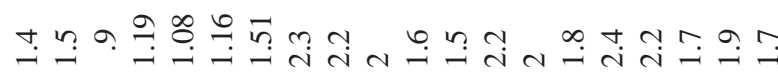

ت્ન

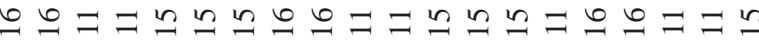

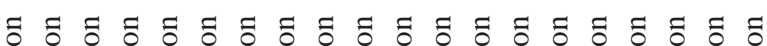

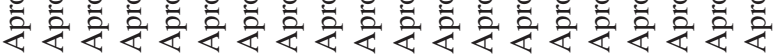

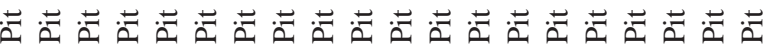

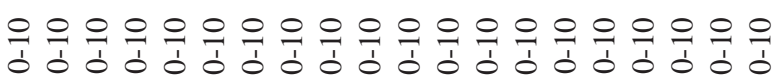

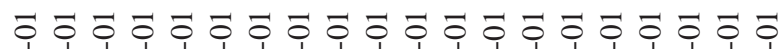

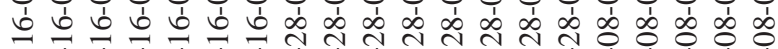

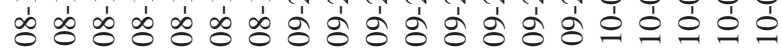
도ํ m

때 m

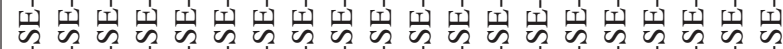

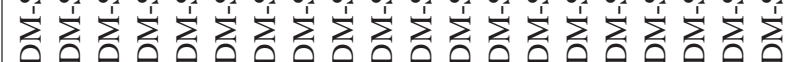


น

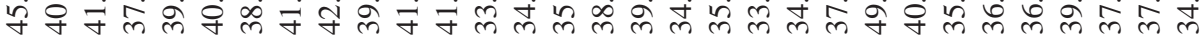

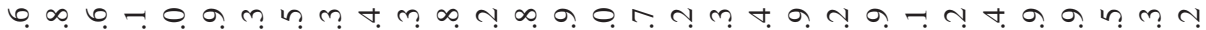
ல்ஸ் ळ

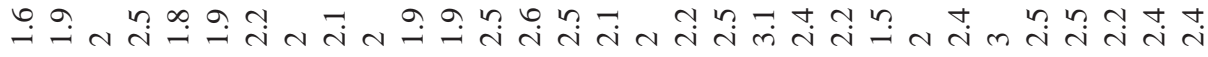
芒

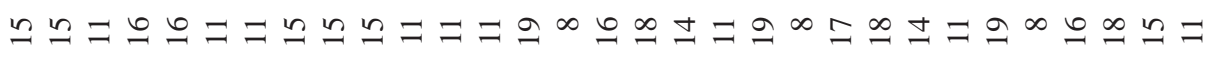

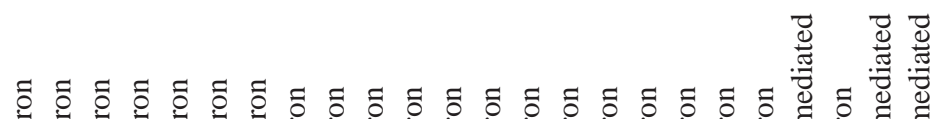

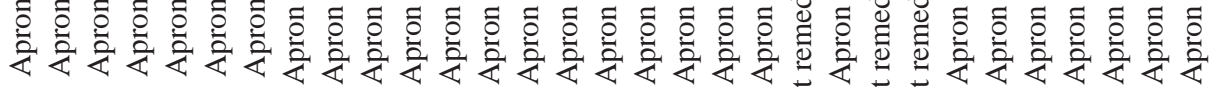

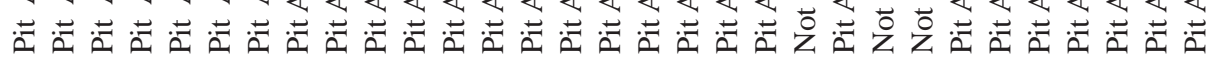

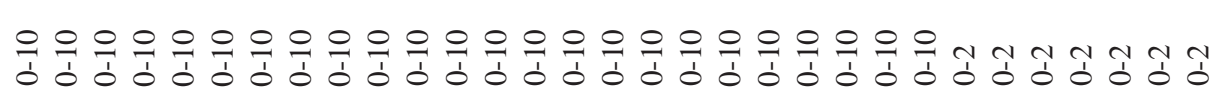

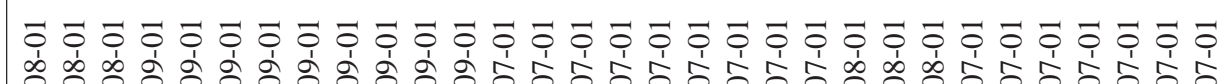

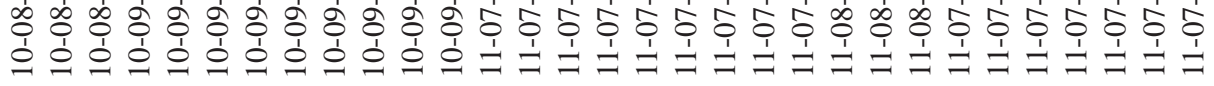

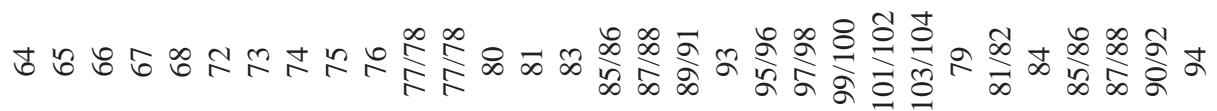

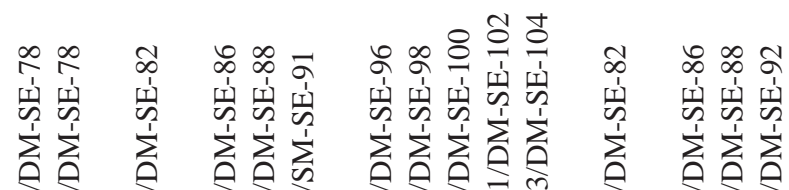

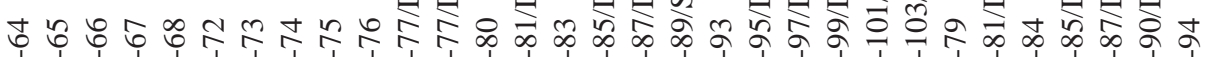

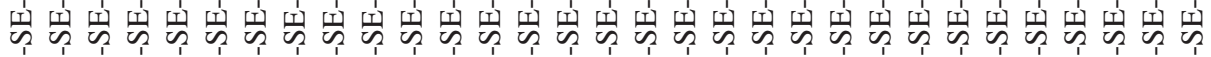

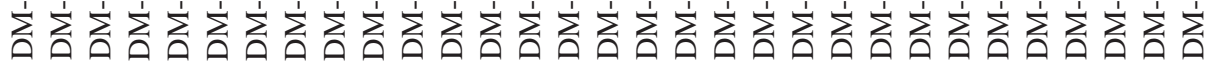



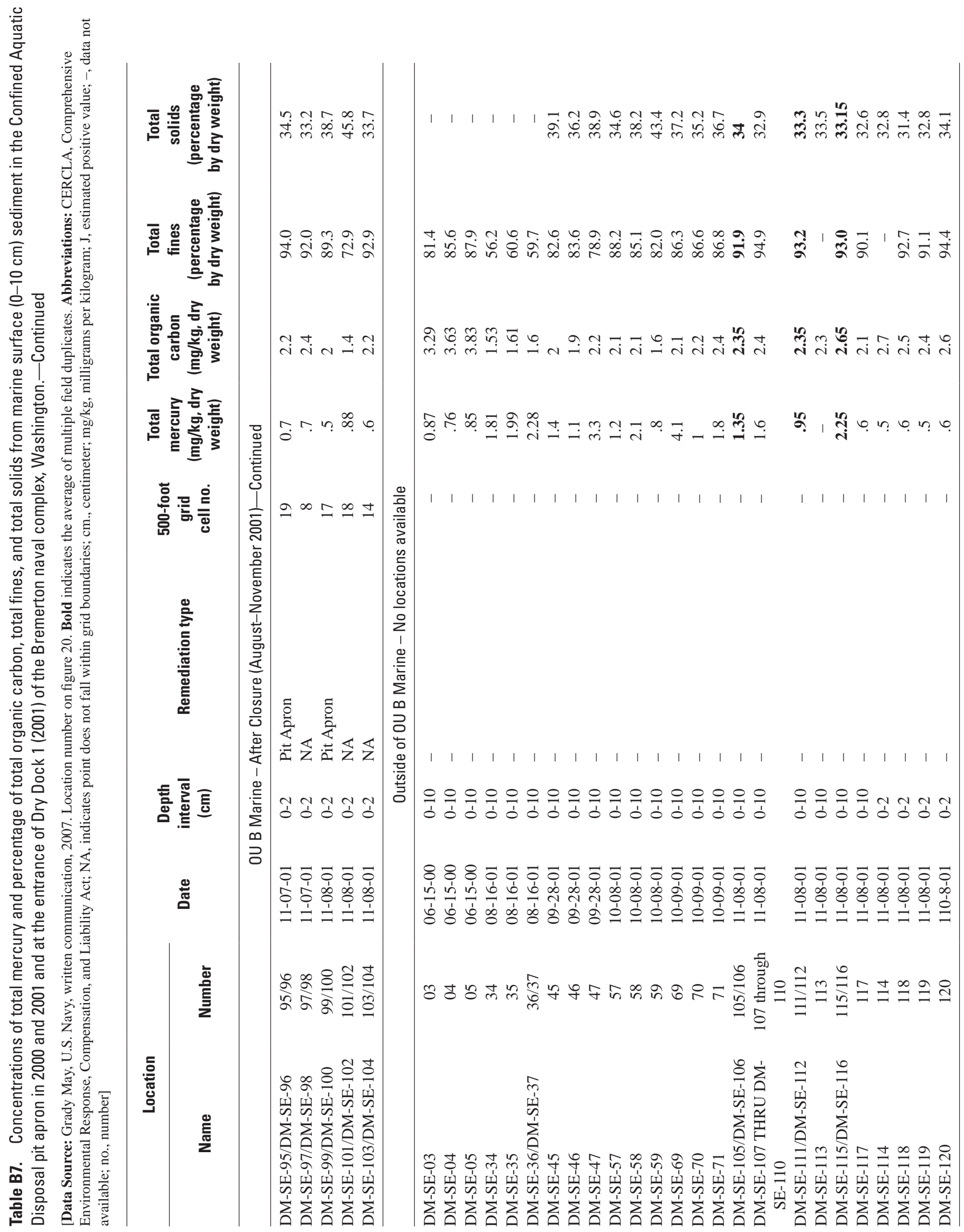
Table B8. Concentrations of total mercury and percentage of total organic carbon and total fines from marine sediment collected from State-owned aquatic lands to the southeast of the Confined Aquatic Disposal pit of the Bremerton naval complex, Washington, 2003.

[Data Source: Grady May, U.S. Navy, written commun., 2007. Location of State-owned aquatic lands shown in figure 20 and location of samples are shown in figure 2-1 of U.S. Navy, 2004. Abbreviations: $\mathrm{cm}$, centimeter; $\mathrm{mg} / \mathrm{kg}$, milligrams per kilogram; -, no data]

\begin{tabular}{|c|c|c|c|c|c|c|}
\hline \multicolumn{2}{|c|}{ Location } & \multirow{2}{*}{ Date } & \multirow{2}{*}{$\begin{array}{l}\text { Depth } \\
\text { interval } \\
\text { (cm) }\end{array}$} & \multirow{2}{*}{$\begin{array}{c}\text { Total } \\
\text { mercury } \\
\text { (mg/kg, dry } \\
\text { weight) }\end{array}$} & \multirow{2}{*}{$\begin{array}{c}\text { Total organic } \\
\text { carbon } \\
\text { (percentage } \\
\text { by dry weight) }\end{array}$} & \multirow{2}{*}{$\begin{array}{c}\text { Total } \\
\text { fines } \\
\text { (percentage } \\
\text { by dry weight) }\end{array}$} \\
\hline Name & Number & & & & & \\
\hline DNR-SE-1 & 1 & 09-26-03 & $0-10$ & 1.36 & 2.4 & 35.7 \\
\hline DNR-SE-2 & 2 & 09-26-03 & $0-10$ & 1.18 & 2.3 & 38.3 \\
\hline DNR-SE-3 & 3 & 09-26-03 & $0-16$ & .59 & 2.2 & 38.6 \\
\hline DNR-SE-4 & 4 & 09-26-03 & $0-12$ & .44 & 2.2 & 37.5 \\
\hline DNR-SE-5 & 5 & $09-26-03$ & $0-12$ & .29 & 2.2 & 37.9 \\
\hline DNR-SE-6 & 6 & $09-26-03$ & $0-14$ & .56 & 2.4 & 38.2 \\
\hline DNR-SE-7 & 7 & 09-26-03 & $0-12$ & .46 & 2.3 & 36.7 \\
\hline DNR-SE-8 & 8 & $09-26-03$ & $0-10$ & .73 & 2.4 & 37.9 \\
\hline DNR-SE-9 & 9 & 09-26-03 & $0-10$ & .62 & 2.2 & 38.2 \\
\hline DNR-SE-10 & 10 & 09-26-03 & $0-10$ & .63 & 2.4 & 39 \\
\hline DNR-SE-11 & 11 & 09-26-03 & $0-10$ & .6 & 2.2 & 37.6 \\
\hline DNR-SE-12 & 12 & 09-26-03 & $0-10$ & .65 & 2.4 & 35.6 \\
\hline DNR-SE-13 & 13 & $09-25-03$ & $0-10$ & .76 & 2.3 & 36.3 \\
\hline DNR-SE-14 & 14 & $09-25-03$ & $0-10$ & .98 & 2.3 & 35.9 \\
\hline DNR-SE-15 & 15 & 09-25-03 & $0-10$ & .85 & 2.5 & 36.2 \\
\hline DNR-SE-16 & 16 & $09-25-03$ & $0-10$ & .67 & 2.3 & 35.7 \\
\hline DNR-SE-17 & 17 & $09-25-03$ & $0-10$ & - & 2.3 & 35.4 \\
\hline DNR-SE-18 & 18 & $09-25-03$ & $0-12$ & .66 & 2.3 & 36.6 \\
\hline DNR-SE-19 & 19 & $09-25-03$ & $0-10$ & 1.05 & 2.4 & 36.5 \\
\hline DNR-SE-20 & 20 & $09-25-03$ & $0-10$ & 1.33 & 2.3 & 36.3 \\
\hline DNR-SE-21 & 21 & $09-25-03$ & $0-10$ & 1.53 & 2.5 & 33.8 \\
\hline DNR-SE-22 & 22 & 09-25-03 & $0-10$ & 1.7 & 2.3 & 38.1 \\
\hline DNR-SE-23 & 23 & 09-25-03 & $0-10$ & 2.2 & 2.2 & 39.1 \\
\hline DNR-SE-24 & 24 & 09-25-03 & $0-10$ & 1.14 & 2.4 & 33.9 \\
\hline DNR-SE-25 & 25 & 09-25-03 & $0-10$ & 1.46 & 2.7 & 32.9 \\
\hline DNR-SE-26 & 26 & 09-24-03 & $0-10$ & 1.04 & 2.4 & 35.3 \\
\hline DNR-SE-27 & 27 & 09-24-03 & $0-10$ & .92 & 2.7 & 33.6 \\
\hline DNR-SE-28 & 28 & 09-24-03 & $0-10$ & .92 & 2.6 & 33.8 \\
\hline DNR-SE-29 & 29 & $09-24-03$ & $0-10$ & 1.17 & 2.4 & 33.2 \\
\hline DNR-SE-30 & 30 & 09-24-03 & $0-10$ & .96 & 2.6 & 33.3 \\
\hline DNR-SE-31 & 31 & 09-24-03 & $0-10$ & .86 & 3.1 & 29.9 \\
\hline
\end{tabular}




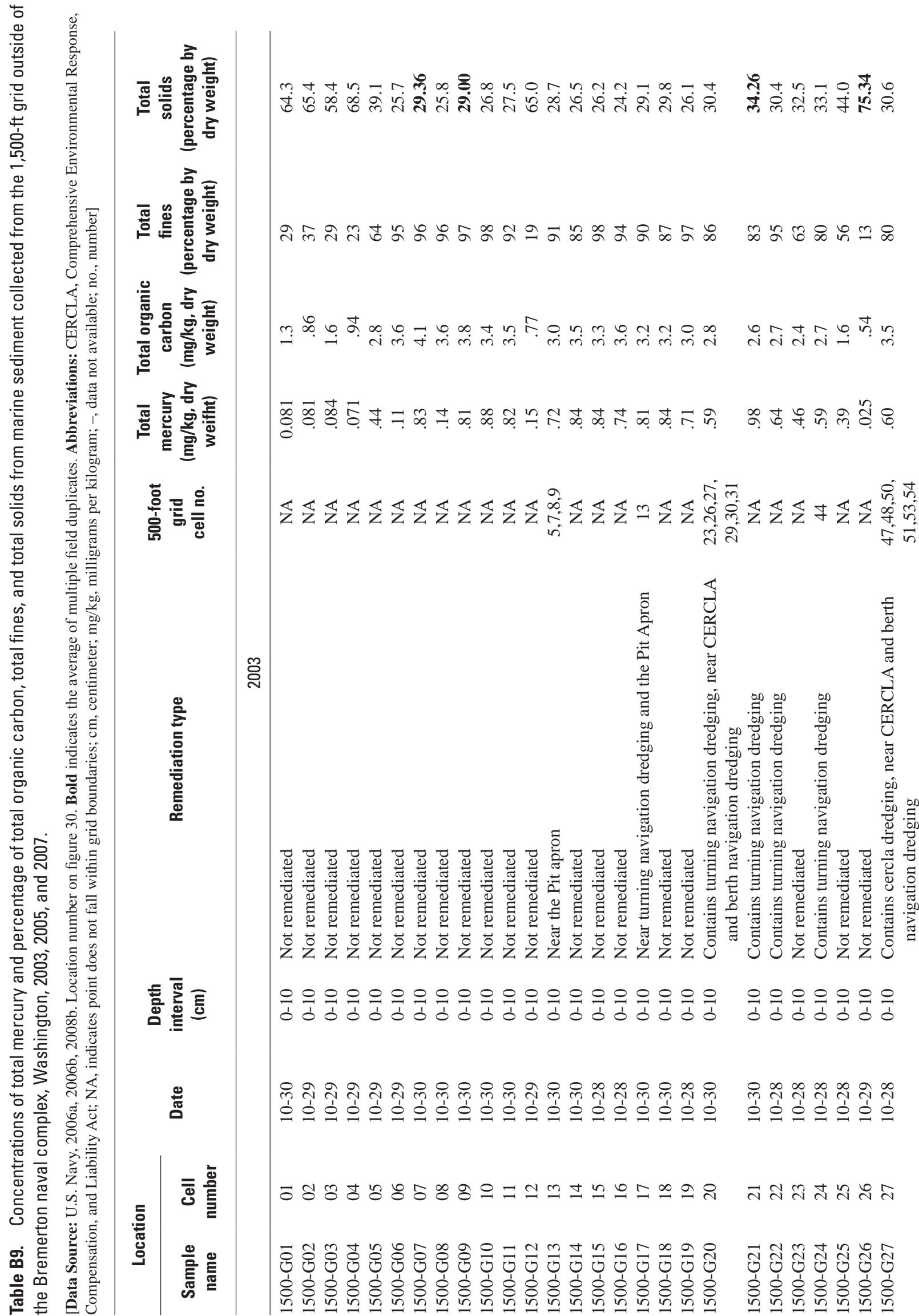




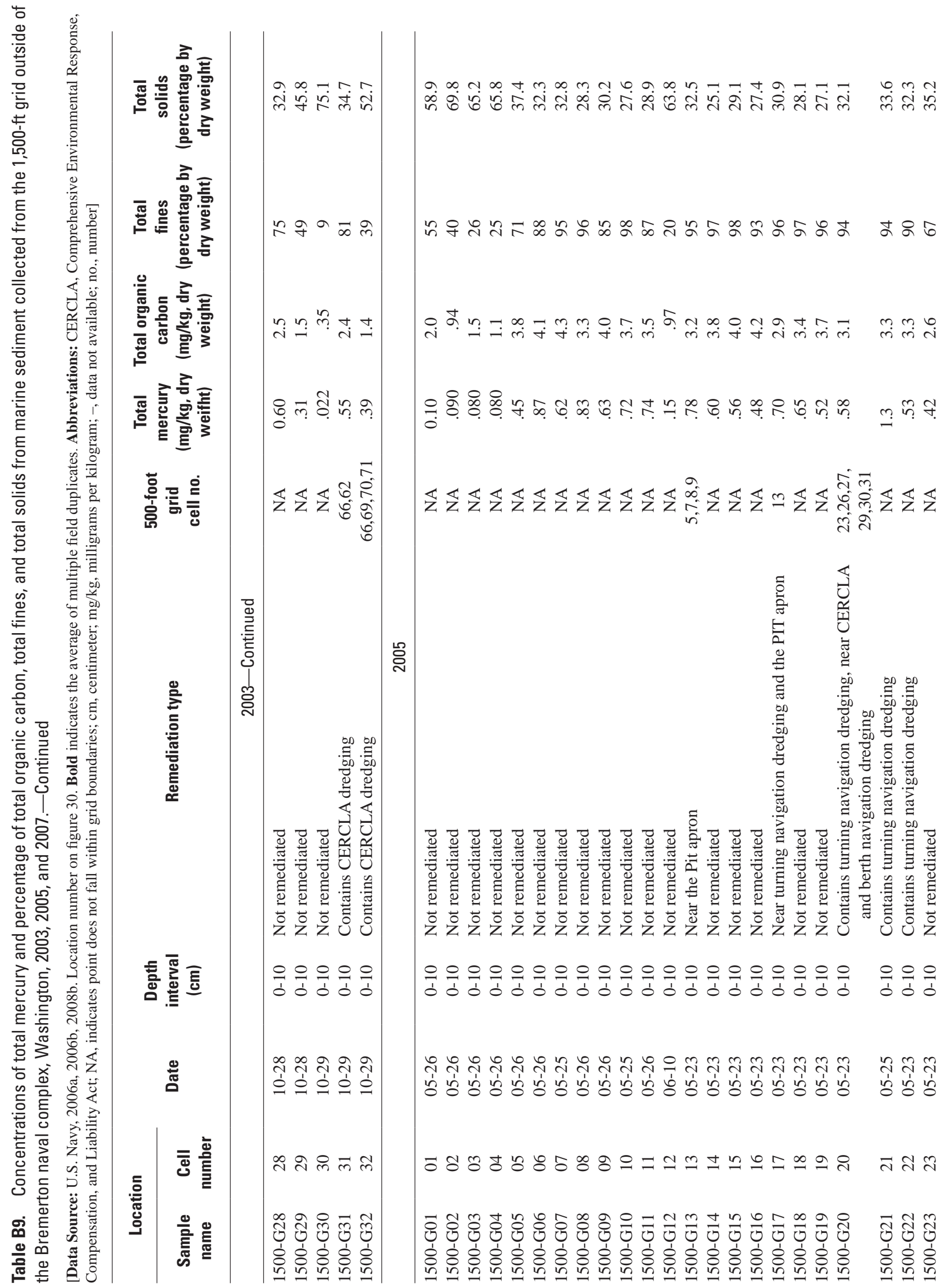




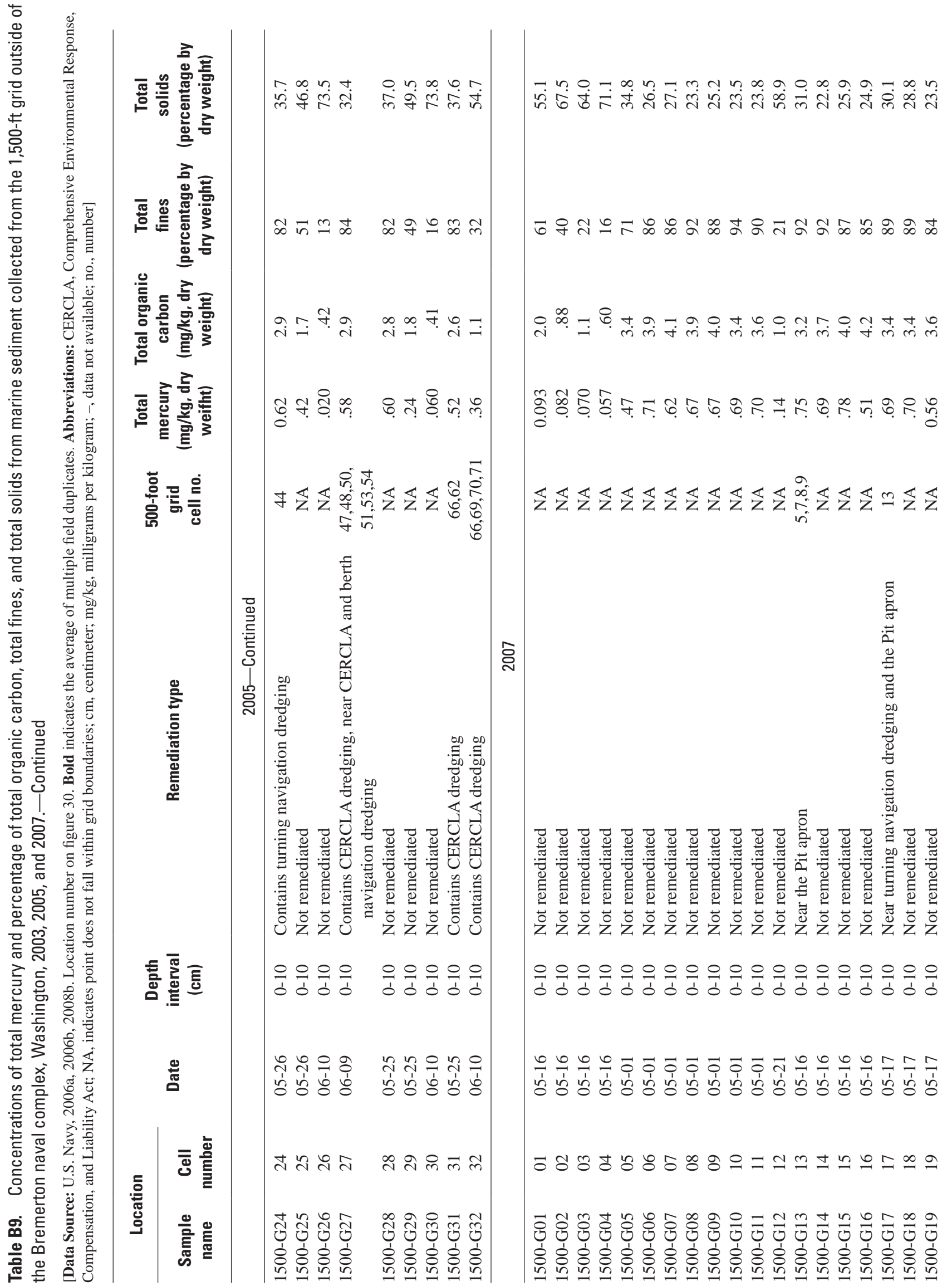




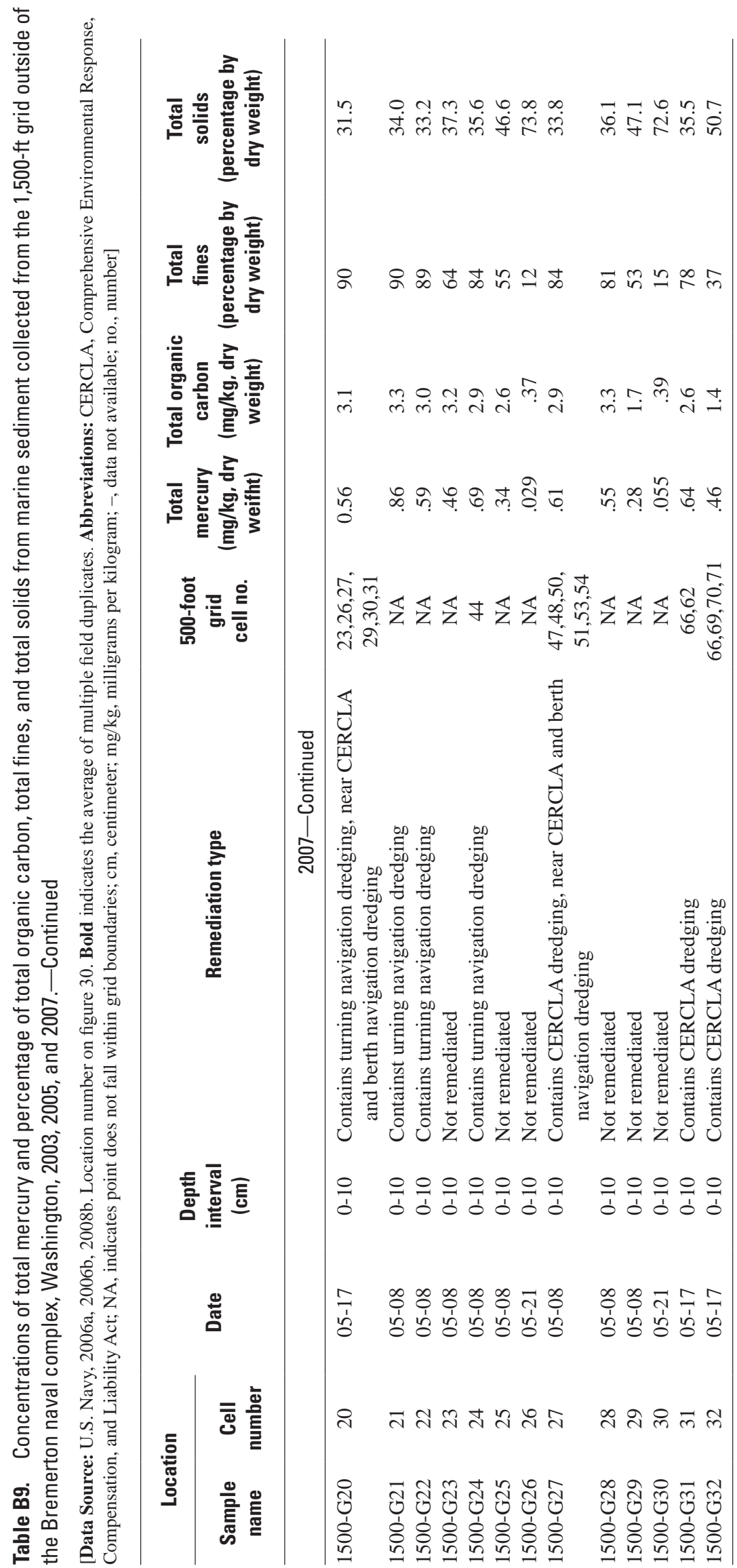




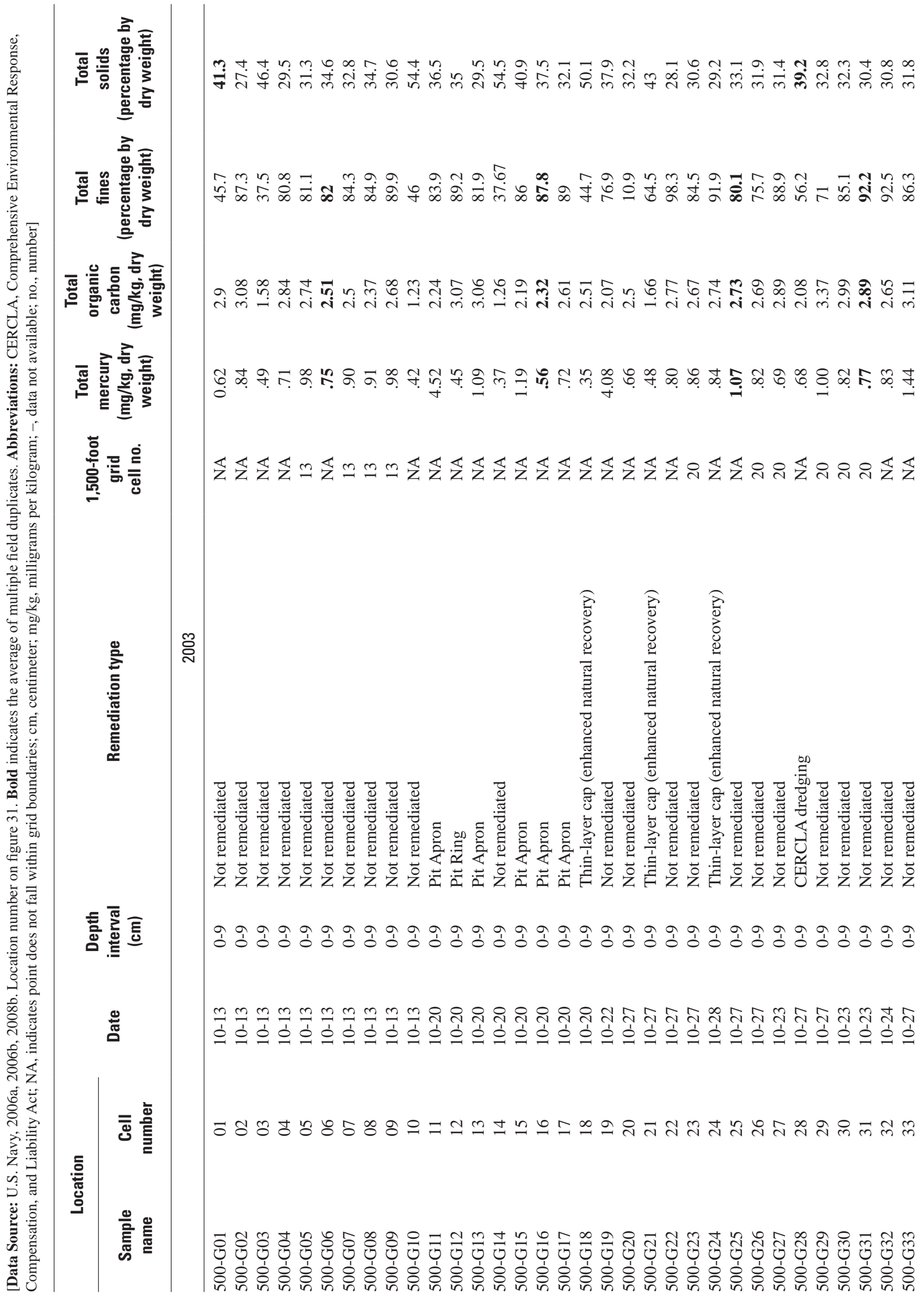




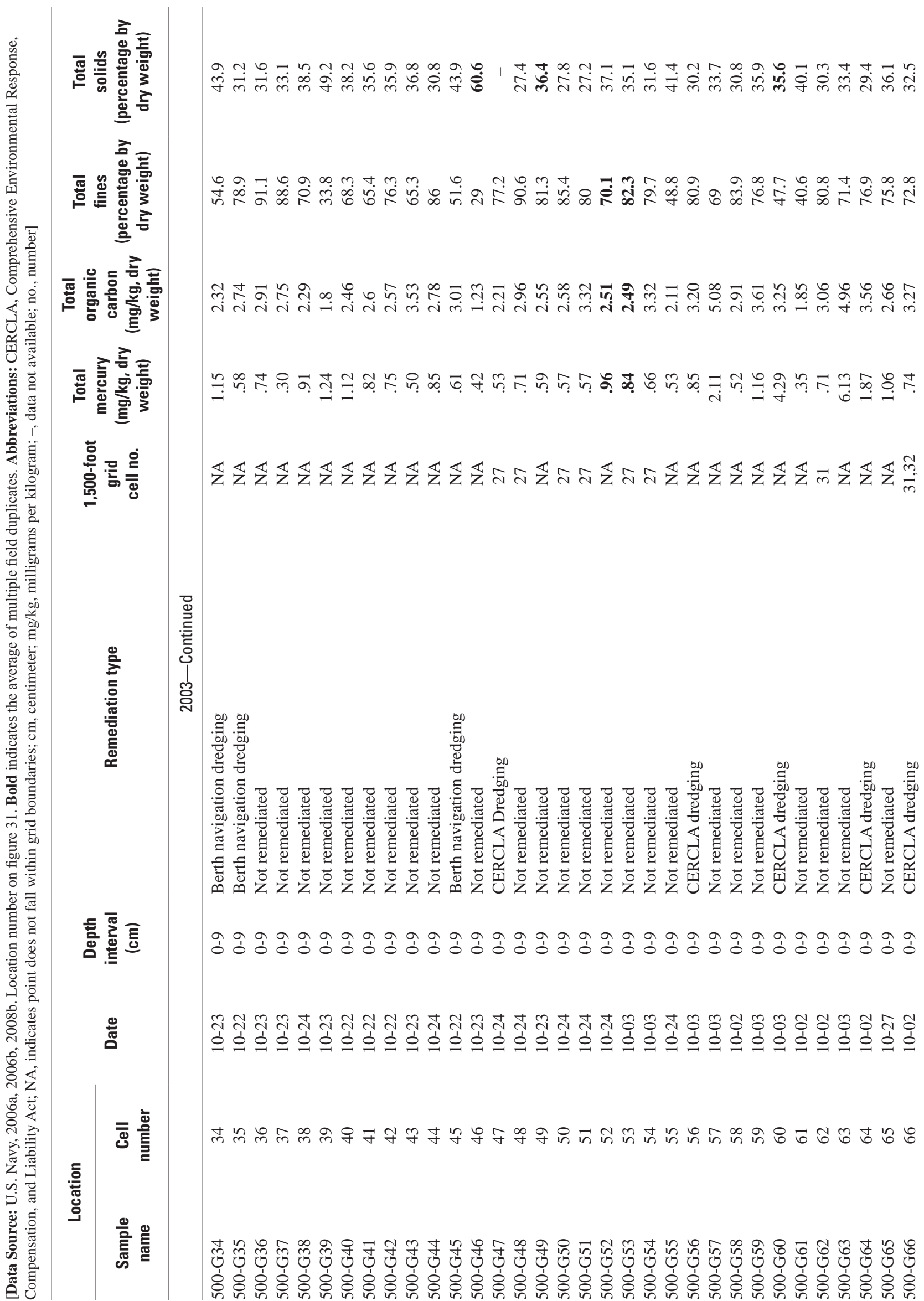




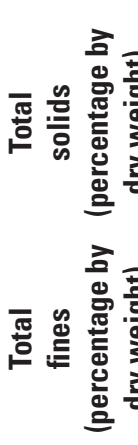

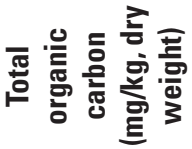

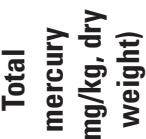

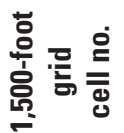

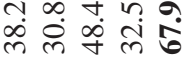

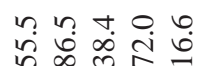

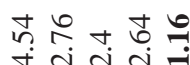

ஓ 우 눈 눈 $\checkmark$

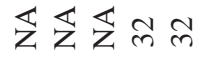

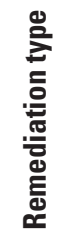

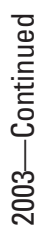

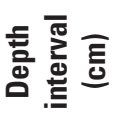

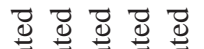

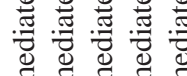

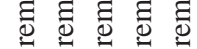

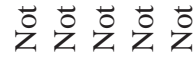

농

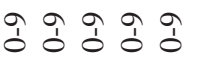

苋

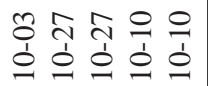

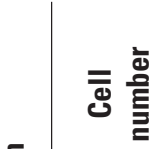

흘

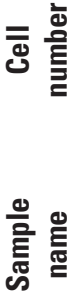

승ㅇㅇㅇㅈㅈㅈㅏ

엉엉유 至

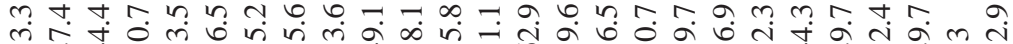

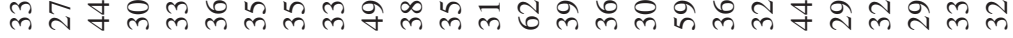

F m்

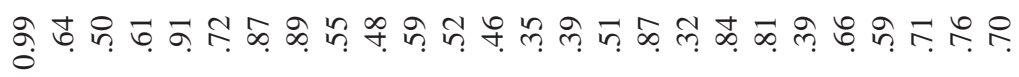

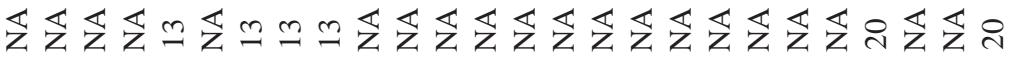

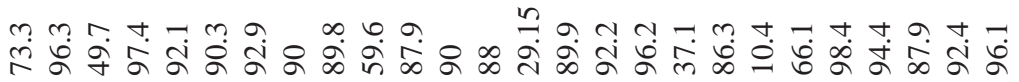
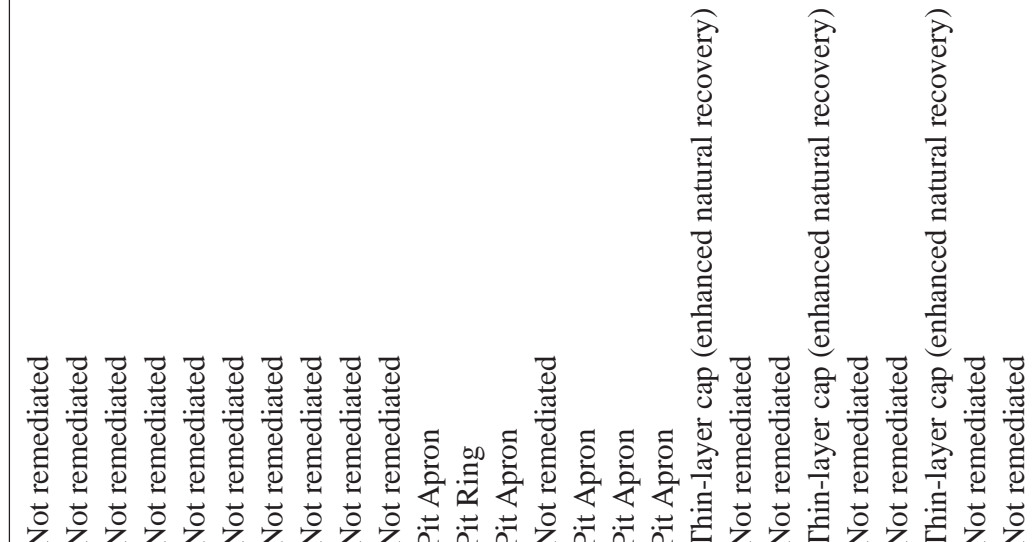

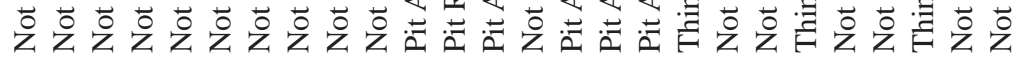

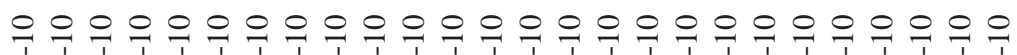

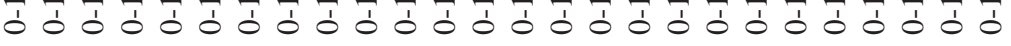

뉴

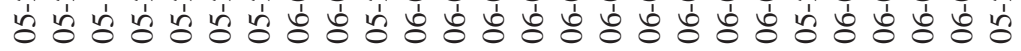

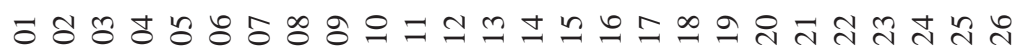

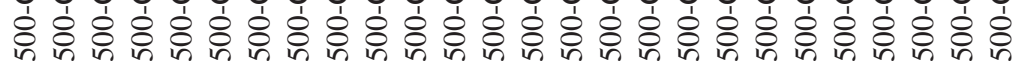




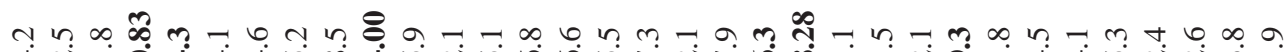

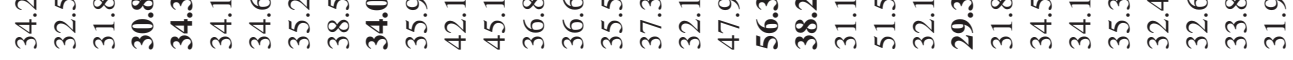

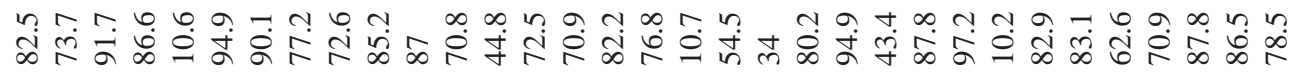

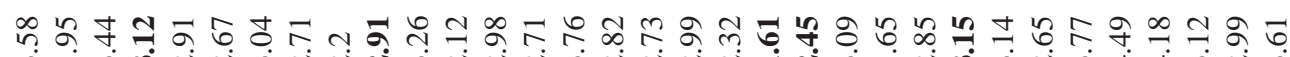

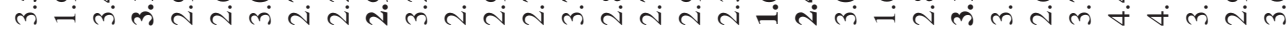

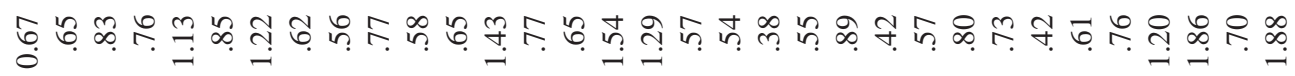

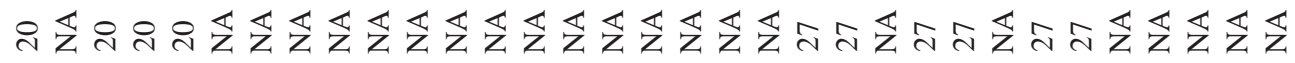

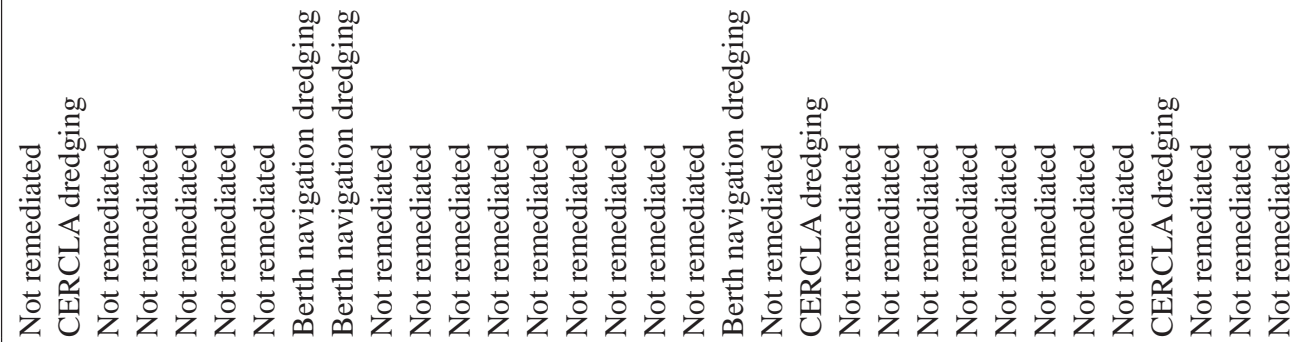

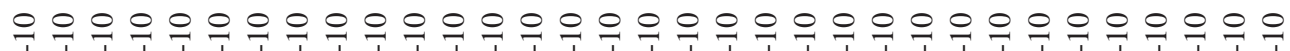

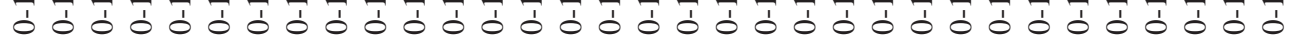

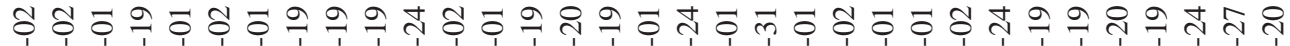

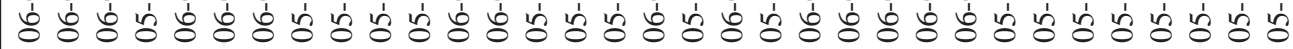

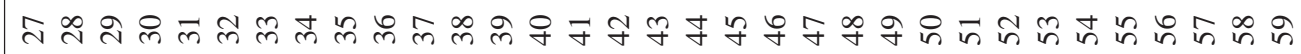




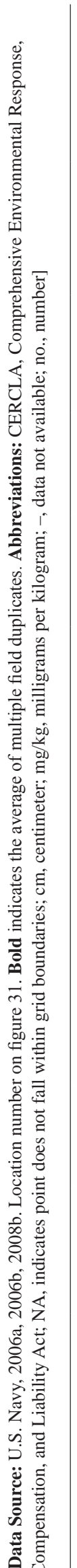
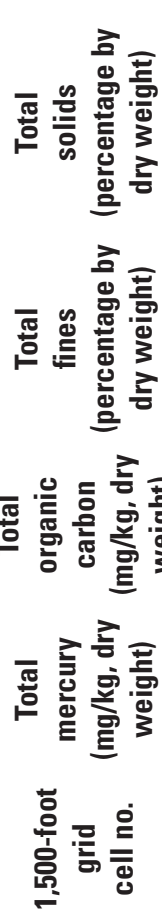

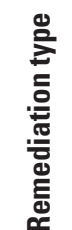

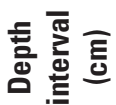

逭

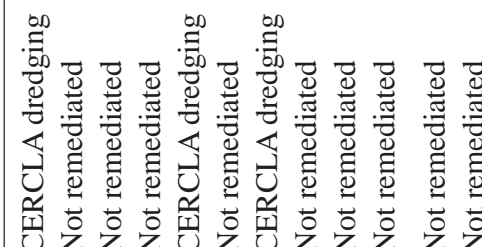

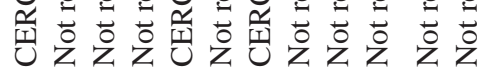

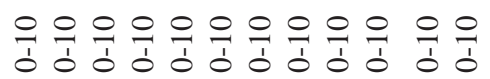

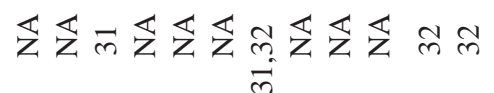

.

苋

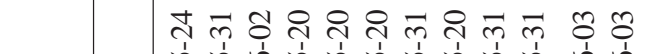

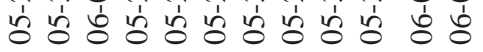

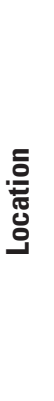

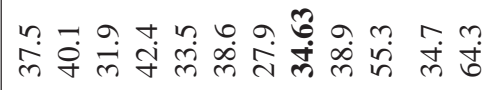

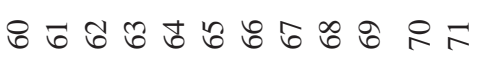

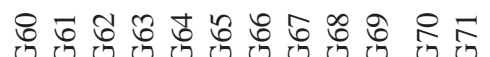

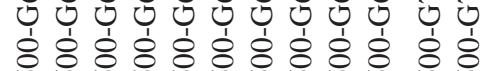

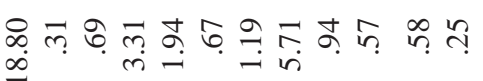

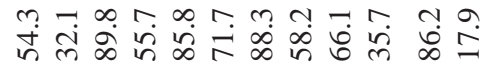

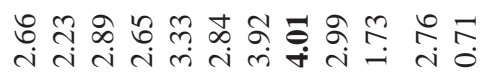

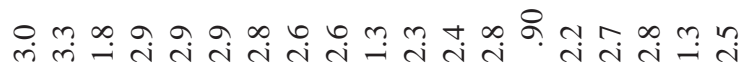

옹

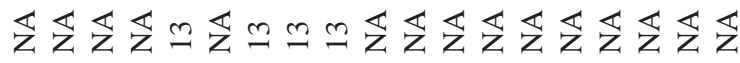

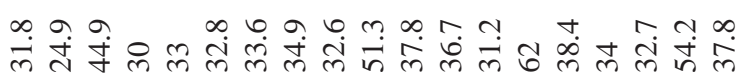

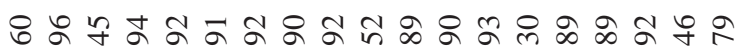

호․

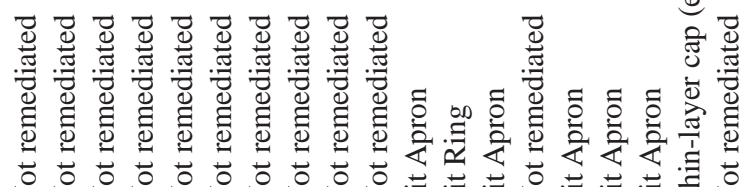

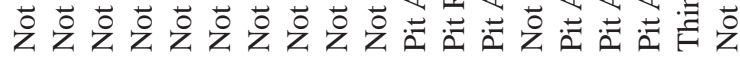

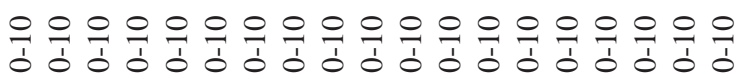

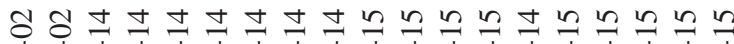

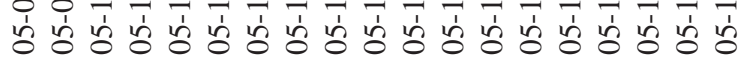

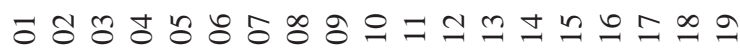

둥 ชิ U్ 安 
L

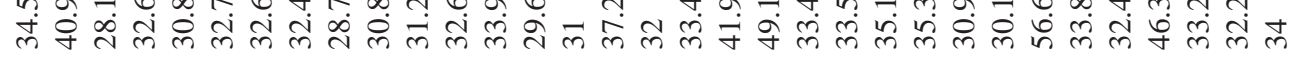

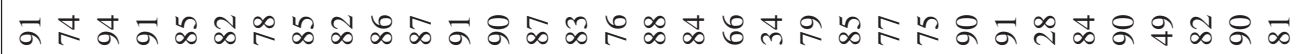

舟

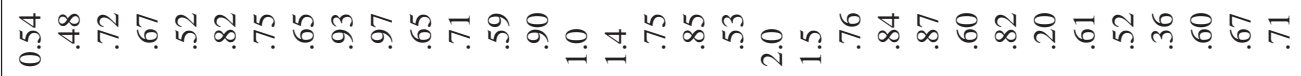

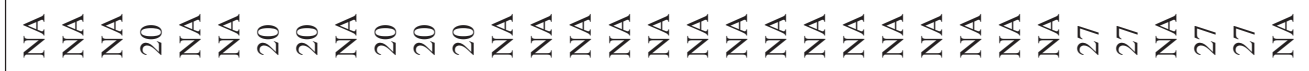

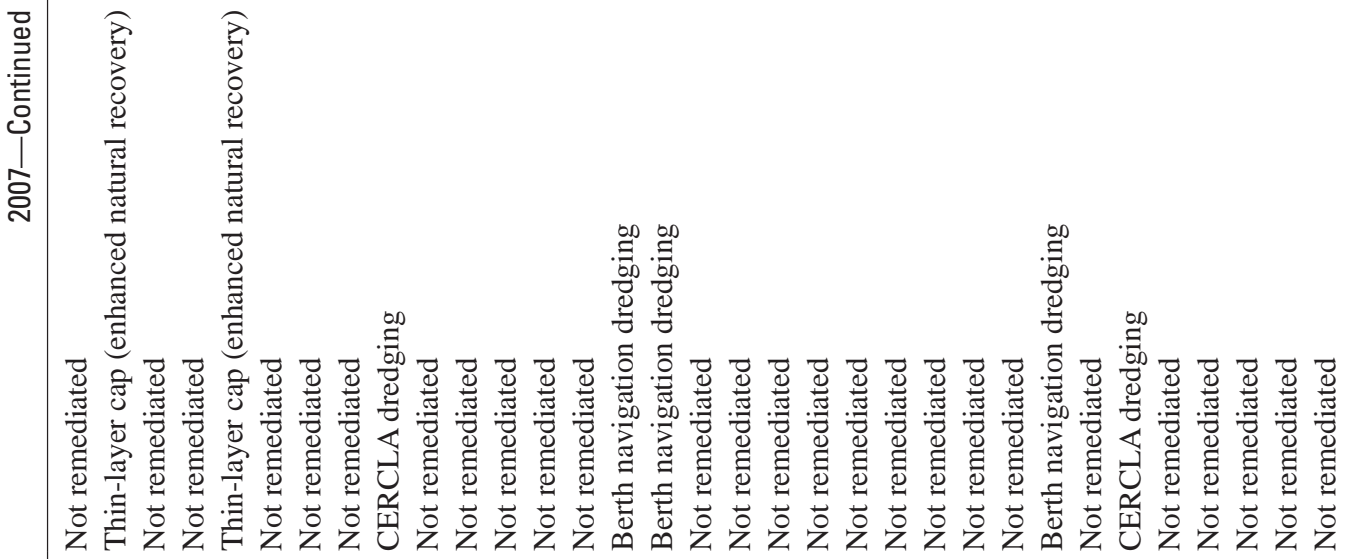

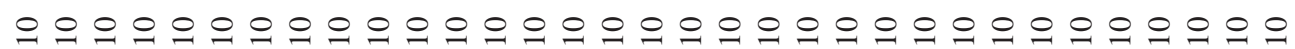

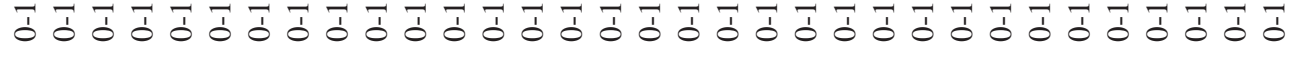

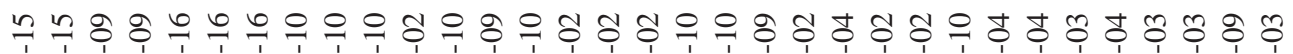

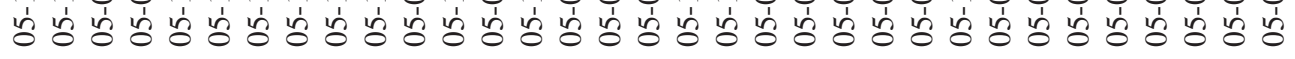

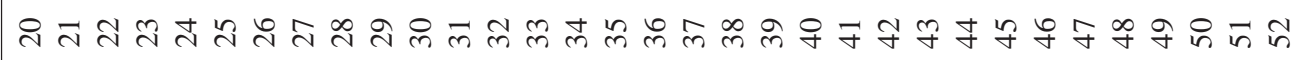

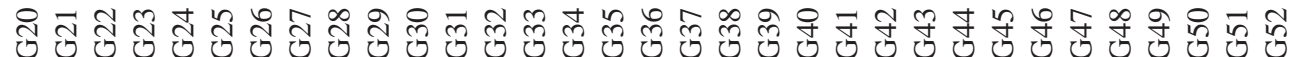

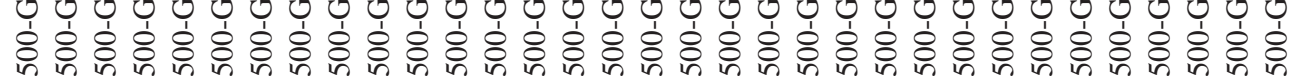




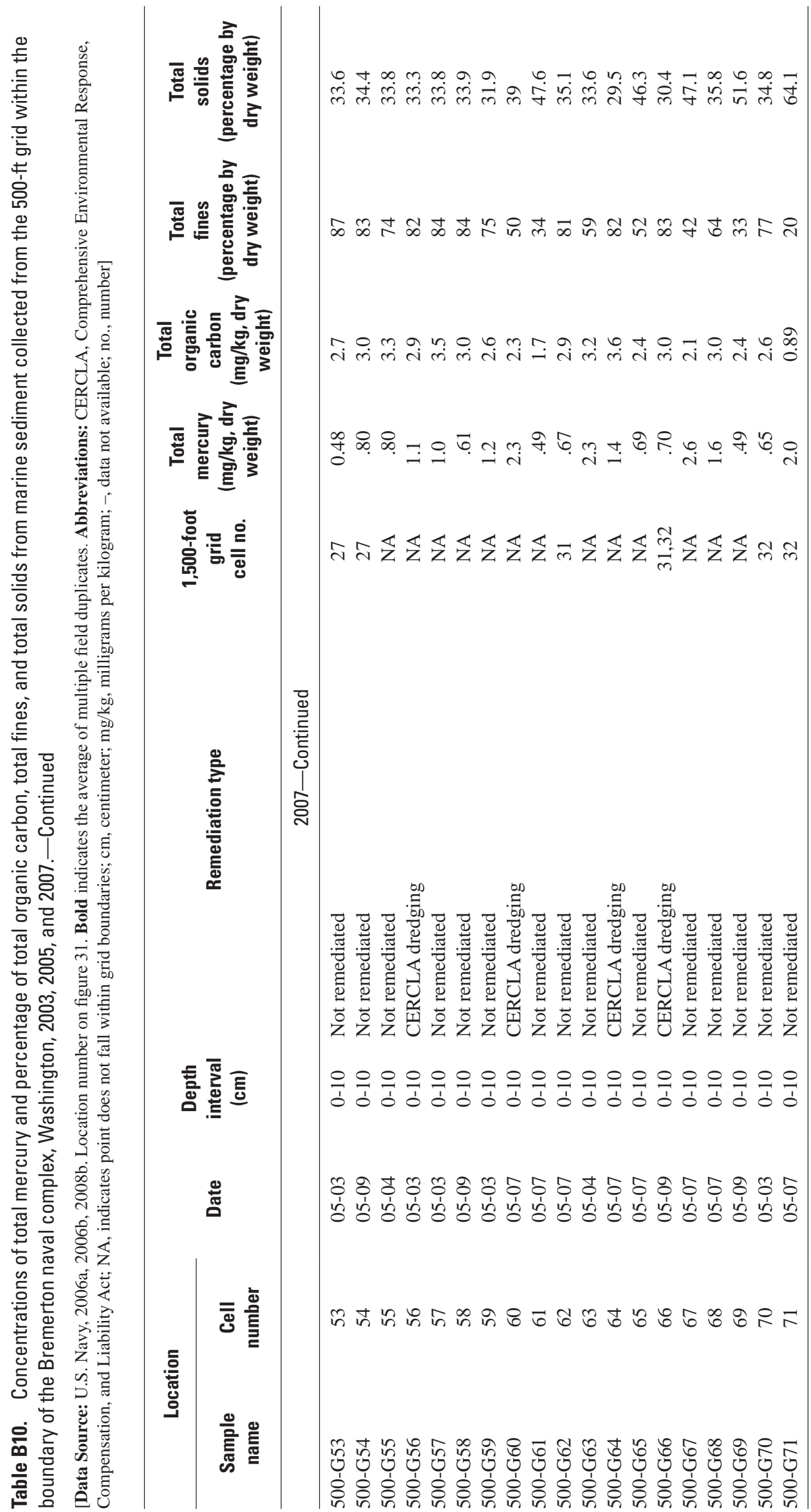


Table B11. Concentrations of total mercury and percentage of total organic carbon, total fines, and total solids from marine sediment collected from the Confined Aquatic Disposal pit cores, Bremerton naval complex, Washington, 2003, 2005, and 2007.

[Data Source U.S Navy, 2006a,2006b, 2008a. Bold indicates the average of multiple field duplicates. Abbreviations cm, centimeter; mg/kg, milligrams per kilogram; -, no data]

\begin{tabular}{|c|c|c|c|c|c|c|c|}
\hline \multicolumn{2}{|c|}{ Location } & \multirow[b]{2}{*}{ Date } & \multirow{2}{*}{$\begin{array}{l}\text { Depth } \\
\text { interval } \\
\text { (cm) }\end{array}$} & \multirow{2}{*}{$\begin{array}{c}\text { Total } \\
\text { mercury } \\
\text { (mg/kg, dry } \\
\text { weight) }\end{array}$} & \multirow{2}{*}{$\begin{array}{l}\text { Total organic } \\
\text { carbon } \\
\text { (percentage by } \\
\text { dry weight) }\end{array}$} & \multirow{2}{*}{$\begin{array}{c}\text { Total } \\
\text { fines } \\
\text { (percentage by } \\
\text { dry weight) }\end{array}$} & \multirow{2}{*}{$\begin{array}{c}\text { Total } \\
\text { solids } \\
\text { (percentage by } \\
\text { weight) }\end{array}$} \\
\hline $\begin{array}{l}\text { Sample } \\
\text { name }\end{array}$ & $\begin{array}{l}\text { Sample } \\
\text { number }\end{array}$ & & & & & & \\
\hline \multicolumn{8}{|c|}{2003} \\
\hline PIT-01 & 2333 & $10-10-03$ & $0-21$ & 0.143 & 1.97 & 65.9 & 58.1 \\
\hline PIT-01 & 2333 & & $21-55$ & .09 & .20 & 5.38 & 88.1 \\
\hline PIT-02 & 2334 & & $0-27$ & .17 & 2.31 & 90.6 & 38.8 \\
\hline PIT-02 & 2334 & & $27-49$ & - & .44 & 4.79 & 82.2 \\
\hline PIT-03 & 2335 & & $0-30$ & .40 & 2.25 & 90.5 & 41.5 \\
\hline PIT-04 & 2336 & & $0-30$ & .61 & 2.71 & 76.3 & 39.5 \\
\hline PIT-04 & 2336 & & $30-46$ & .10 & - & - & - \\
\hline \multicolumn{8}{|c|}{2005} \\
\hline PIT-01 & 2333 & 06-07-05 & $0-30$ & .13 & 2.15 & 93.9 & 41.6 \\
\hline PIT-01 & 2333 & & $30-61$ & .10 & 2.30 & 94.1 & 43.3 \\
\hline PIT-01 & 2333 & & $61-91$ & .26 & 2.35 & 92.4 & 44.5 \\
\hline PIT-02 & 2334 & 06-08-05 & $0-30$ & .19 & 2.47 & 92.4 & 40 \\
\hline PIT-02 & 2334 & & $30-61$ & .27 & 6.70 & 83 & 42.1 \\
\hline PIT-02 & 2334 & & 61-91 & .05 & .68 & 20.56 & 73.9 \\
\hline PIT-03 & 2335 & & $0-30$ & .23 & 2.27 & 91.9 & 43 \\
\hline PIT-03 & 2335 & & $30-61$ & .11 & 2.39 & 93.8 & 43.2 \\
\hline PIT-03 & 2335 & & $61-91$ & .06 & .91 & 27.7 & 67.1 \\
\hline PIT-04 & 2336 & & $0-30$ & .40 & 2.50 & 93 & 37.4 \\
\hline PIT-04 & 2336 & & $30-61$ & .55 & 248 & 924 & 40.6 \\
\hline PIT-04 & 2336 & & 61-91 & .53 & 3.25 & 88.9 & 43.2 \\
\hline \multicolumn{8}{|c|}{2007} \\
\hline PIT-01 & 2333 & 05-23-07 & $0-30$ & 0.253 & 2.29 & 90.4 & 38.2 \\
\hline PIT-01 & 2333 & & $30-61$ & .212 & 2.67 & 93 & 39.8 \\
\hline PIT-01 & 2333 & & $61-91$ & .31 & 2.3 & 88.4 & 44.2 \\
\hline PIT-02 & 2334 & & $0-30$ & .179 & 2.37 & 92.3 & 39.2 \\
\hline PIT-02 & 2334 & & $30-61$ & .093 & .645 & 14.85 & 74.3 \\
\hline PIT-02 & 2334 & & 61-91 & .223 & 1.7 & 70 & 49.8 \\
\hline PIT-03 & 2335 & & $0-30$ & .304 & 1.97 & 83.6 & 44.5 \\
\hline PIT-03 & 2335 & & $30-61$ & .121 & 2.11 & 78.7 & 46.3 \\
\hline PIT-03 & 2335 & & $61-91$ & .029 & .34 & 7.76 & 78.2 \\
\hline PIT-04 & 2336 & & $0-30$ & .615 & 2.58 & 91.8 & 39.8 \\
\hline PIT-04 & 2336 & & $30-61$ & .289 & 2.47 & 90.7 & 42.6 \\
\hline PIT-04 & 2336 & & $61-91$ & .157 & 5.57 & 86.9 & 44.9 \\
\hline
\end{tabular}


Table B12. Concentrations of total mercury and percentage of total organic carbon, total fines, and total solids from marine sediment collected from the apron (CP Cells) of the Confined Aquatic Disposal pit, Bremerton naval complex, Washington, 2003 and 2005.

[Data Source U.S Navy, 2006a, 2006b. Location number on figure 20. Bold indicates the average of multiple field duplicates. Abbreviations: cm, centimeter; mg/kg, milligrams per kilogram; -, no data; no., number]

\begin{tabular}{|c|c|c|c|c|c|c|c|c|}
\hline \multicolumn{2}{|c|}{ Location } & \multirow[b]{2}{*}{ Date } & \multirow{2}{*}{$\begin{array}{l}\text { Depth } \\
\text { interval } \\
\text { (cm) }\end{array}$} & \multirow{2}{*}{$\begin{array}{l}\text { 500-foot } \\
\text { grid } \\
\text { cell no. }\end{array}$} & \multirow{2}{*}{$\begin{array}{c}\text { Total } \\
\text { mercury } \\
\text { (mg/kg, dry } \\
\text { weight) }\end{array}$} & \multirow{2}{*}{$\begin{array}{l}\text { Total organic } \\
\text { carbon } \\
\text { (percentage by } \\
\text { dry weight) }\end{array}$} & \multirow{2}{*}{$\begin{array}{c}\text { Total } \\
\text { fines } \\
\text { (percentage by } \\
\text { dry weight) }\end{array}$} & \multirow{2}{*}{$\begin{array}{c}\text { Total } \\
\text { solids } \\
\text { (percentage by } \\
\text { weight) }\end{array}$} \\
\hline $\begin{array}{c}\text { Sample } \\
\text { name }\end{array}$ & $\begin{array}{l}\text { Sample } \\
\text { number }\end{array}$ & & & & & & & \\
\hline \multicolumn{9}{|c|}{2003} \\
\hline $1 \mathrm{CP}$ & 2101 & 09-30-03 & $0-10$ & 8 & 0.798 & 2.19 & 87.7 & 36.1 \\
\hline $2 \mathrm{CP}$ & 2102 & & $0-10$ & 11 & .479 & 2.18 & 87.4 & 38.6 \\
\hline 3 CP & 2103 & & $0-10$ & 11 & .807 & 2.72 & 83.4 & 36.5 \\
\hline $4 \mathrm{CP}$ & 2104 & & $0-10$ & 10 & .706 & 1.51 & 52.5 & 46.6 \\
\hline $5 \mathrm{CP}$ & 2105 & $10-01-03$ & $0-10$ & 15 & .958 & 2.14 & 81.9 & 39.7 \\
\hline $6 \mathrm{CP}$ & 2106 & & $0-10$ & 15 & 1.17 & 1.65 & 68.8 & 37.3 \\
\hline 7 CP & 2107 & & $0-10$ & 18 & .681 & 2.15 & 84.3 & 37.7 \\
\hline $8 \mathrm{CP}$ & 2108 & & $0-10$ & 19 & .761 & 2.34 & 84.2 & 36.7 \\
\hline $9 \mathrm{CP}$ & 2109 & & $0-10$ & 19 & .698 & 2.28 & 84 & 36.3 \\
\hline $10 \mathrm{CP}$ & 2110 & & $0-10$ & 16 & .636 & 2.61 & 81.4 & 36.6 \\
\hline $11 \mathrm{CP}$ & 2111 & & $0-10$ & 19 & .489 & 2.18 & 83.2 & 35.2 \\
\hline $12 \mathrm{CP}$ & 2112 & & $0-10$ & 20 & .575 & 3.2 & 89.6 & 38.7 \\
\hline $13 \mathrm{CP}$ & 2113 & & $0-10$ & 17 & .642 & 2.2 & 81.4 & 35.3 \\
\hline $14 \mathrm{CP}$ & 2114 & & $0-10$ & 17 & .544 & 2.2 & 85.5 & 38 \\
\hline $15 \mathrm{CP}$ & 2115 & & $0-10$ & 20 & .654 & 2.34 & 85.1 & 34.6 \\
\hline \multicolumn{9}{|c|}{2005} \\
\hline $1 \mathrm{CP}$ & 2101 & 05-17-05 & $0-10$ & 8 & - & 2.65 & 89.3 & 37.9 \\
\hline $2 \mathrm{CP}$ & 2102 & & $0-10$ & 11 & 0.59 & 2.35 & 87.7 & 39.2 \\
\hline 3 CP & 2103 & & $0-10$ & 11 & .84 & 2.45 & 90.7 & 36.7 \\
\hline $4 \mathrm{CP}$ & 2104 & & $0-10$ & 10 & .5 & 1.51 & 56.3 & 50.3 \\
\hline $5 \mathrm{CP}$ & 2105 & & $0-10$ & 15 & 1.29 & 2.22 & 83.0 & 41.7 \\
\hline $6 \mathrm{CP}$ & 2106 & & $0-10$ & 15 & 1.6 & 1.88 & 78.0 & 44.7 \\
\hline 7 CP & 2107 & & $0-10$ & 18 & .75 & 2.36 & 87.5 & 40 \\
\hline $8 \mathrm{CP}$ & 2108 & & $0-10$ & 19 & .8 & 2.33 & 86.3 & 38.2 \\
\hline $9 \mathrm{CP}$ & 2109 & & $0-10$ & 19 & .8 & 2.44 & 87.2 & 35.3 \\
\hline $10 \mathrm{CP}$ & 2110 & 05-18-05 & $0-10$ & 16 & .61 & 2.32 & 87.3 & 36.8 \\
\hline $11 \mathrm{CP}$ & 2111 & & $0-10$ & 19 & .37 & 2.52 & 89.3 & 34 \\
\hline $12 \mathrm{CP}$ & 2112 & & $0-10$ & 20 & .38 & 2.44 & 92.2 & 34.5 \\
\hline $13 \mathrm{CP}$ & 2113 & & $0-10$ & 17 & .62 & 2.49 & 90.8 & 34.4 \\
\hline $14 \mathrm{CP}$ & 2114 & & $0-10$ & 17 & .60 & 2.45 & 90.2 & 35.3 \\
\hline $15 \mathrm{CP}$ & 2115 & & $0-10$ & 20 & .60 & 2.54 & 93.0 & 34.5 \\
\hline
\end{tabular}




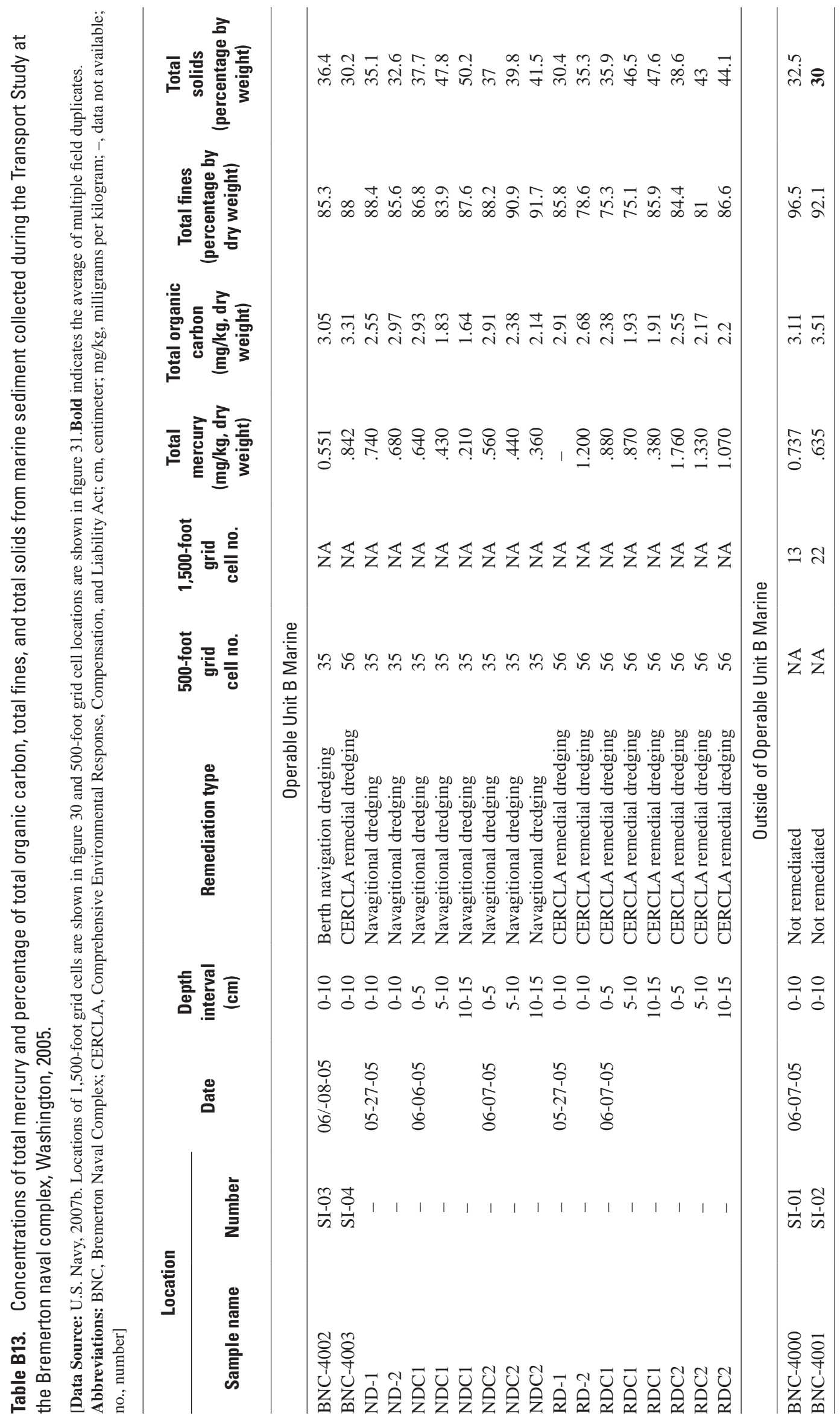


Table B14. Station locations from the Puget Sound Ambient Monitoring Program of Washington used in the regressions listed in table 1.

[Data is from Long and others, 1999, 2000, 2002 and in the sediment database PSAMPSedComponentdatabase.zip accessed at http://www.ecy.wa.gov/programs/ eap/psamp/index.html]

\begin{tabular}{|c|c|c|c|c|}
\hline Embayment & Station numbers used in the regression & $\begin{array}{c}\text { Figure no. } \\
\text { and PDF page } \\
\text { of online } \\
\text { document }\end{array}$ & Reference & URL of online PDF \\
\hline Bellingham Bay & $\begin{array}{l}\text { 20,21,22,23,24,25,26,27,28,29,30,31,32,33, } \\
4,37,59,60,61\end{array}$ & 3c, 45 & Long and others, 1999 & $\begin{array}{l}\text { http://www.ecy.wa.gov/ } \\
\text { biblio/99347.html }\end{array}$ \\
\hline Port Gardner & $85,95,96,97,98,99,100$ & 3h, 50 & Long and others, 1999 & $\begin{array}{l}\text { http://www.ecy.wa.gov/ } \\
\text { biblio/99347.html }\end{array}$ \\
\hline Elliott Bay & $172,173,174,185,187$ & 3f, 104 & Long and others, 2000 & $\begin{array}{l}\text { http://www.ecy.wa.gov/ } \\
\text { biblio/0003055.html }\end{array}$ \\
\hline Liberty Bay & $142,143,144,145,146$ & 3c, 101 & Long and others, 2000 & $\begin{array}{l}\text { http://www.ecy.wa.gov/ } \\
\text { biblio/0003055.html }\end{array}$ \\
\hline Sinclair Inlet & $156,157,158,159,160$ & 3e, 103 & Long and others, 2000 & $\begin{array}{l}\text { http://www.ecy.wa.gov/ } \\
\text { biblio/0003055.html }\end{array}$ \\
\hline
\end{tabular}


Table B15. Concentrations of total mercury and total aluminum, and total solids for five ENVnvironment InVESTvestment (ENVVEST) cores collected in Sinclair Inlet, Washington.

[Data Source: Crecelius and others, 2003. Bold values are average of replicate samples. Abbreviations cm, centimeter; mg/kg, milligrams per kilogram]

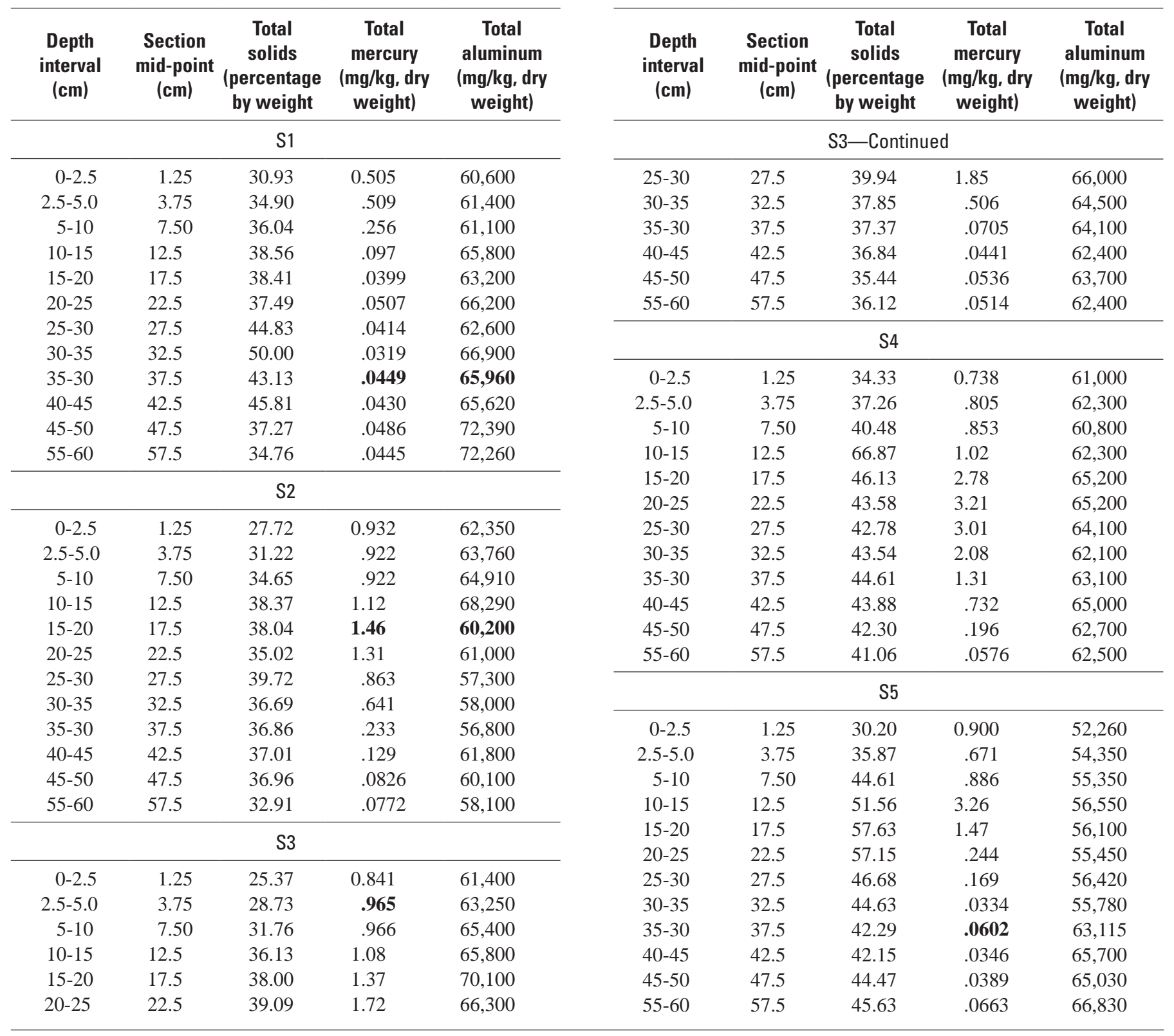




\section{Appendix C. Relations Between Ancillary Sediment Parameters}

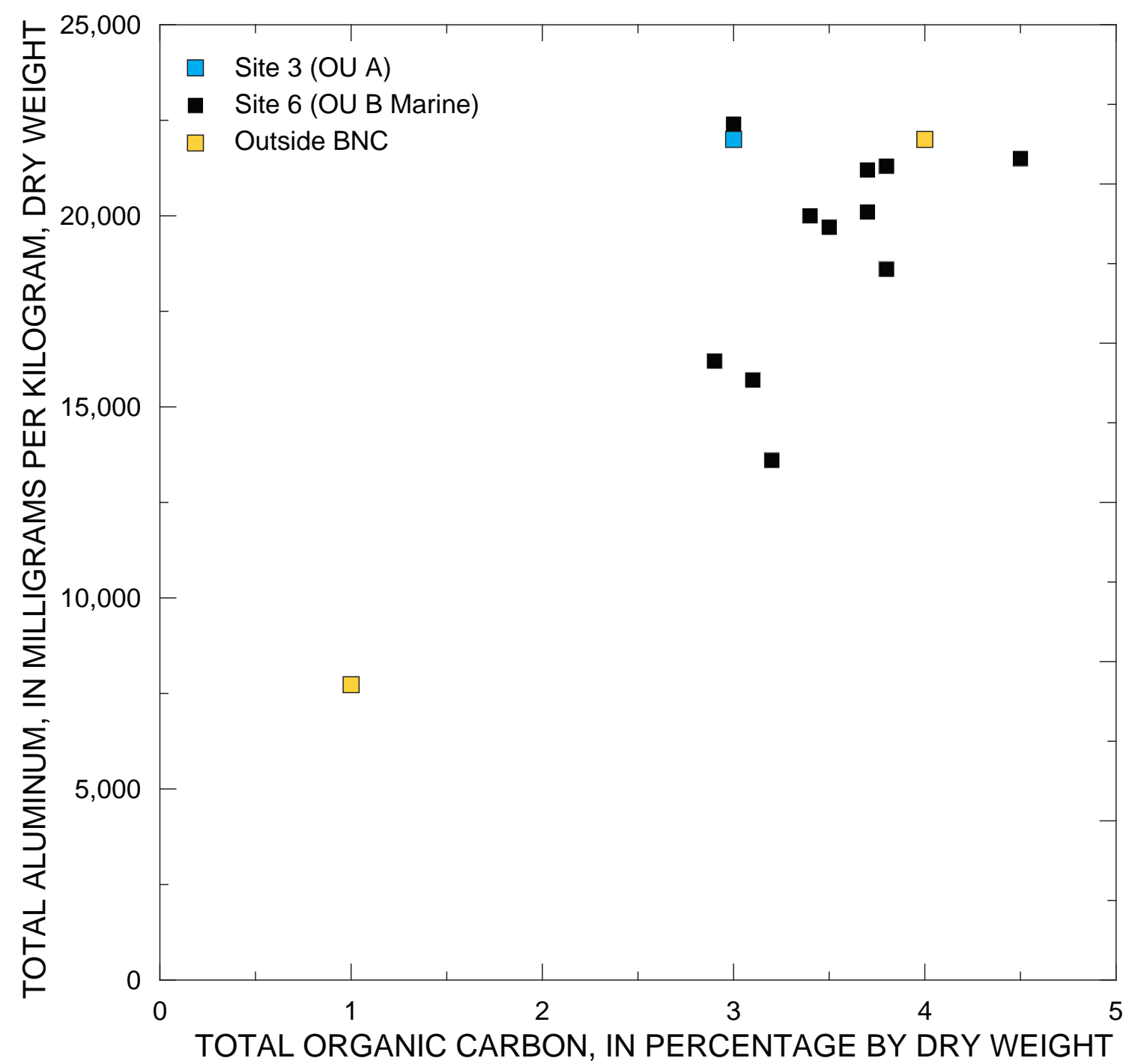

Figure C1. Total aluminum concentrations compared to total organic carbon in surface sediment $(0-4 \mathrm{~cm})$ off Operable Unit A and Operable Unit B Terrestrial and outside of Bremerton naval complex, Washington, from the 1990 site investigation (U.S. Navy, 1992). 


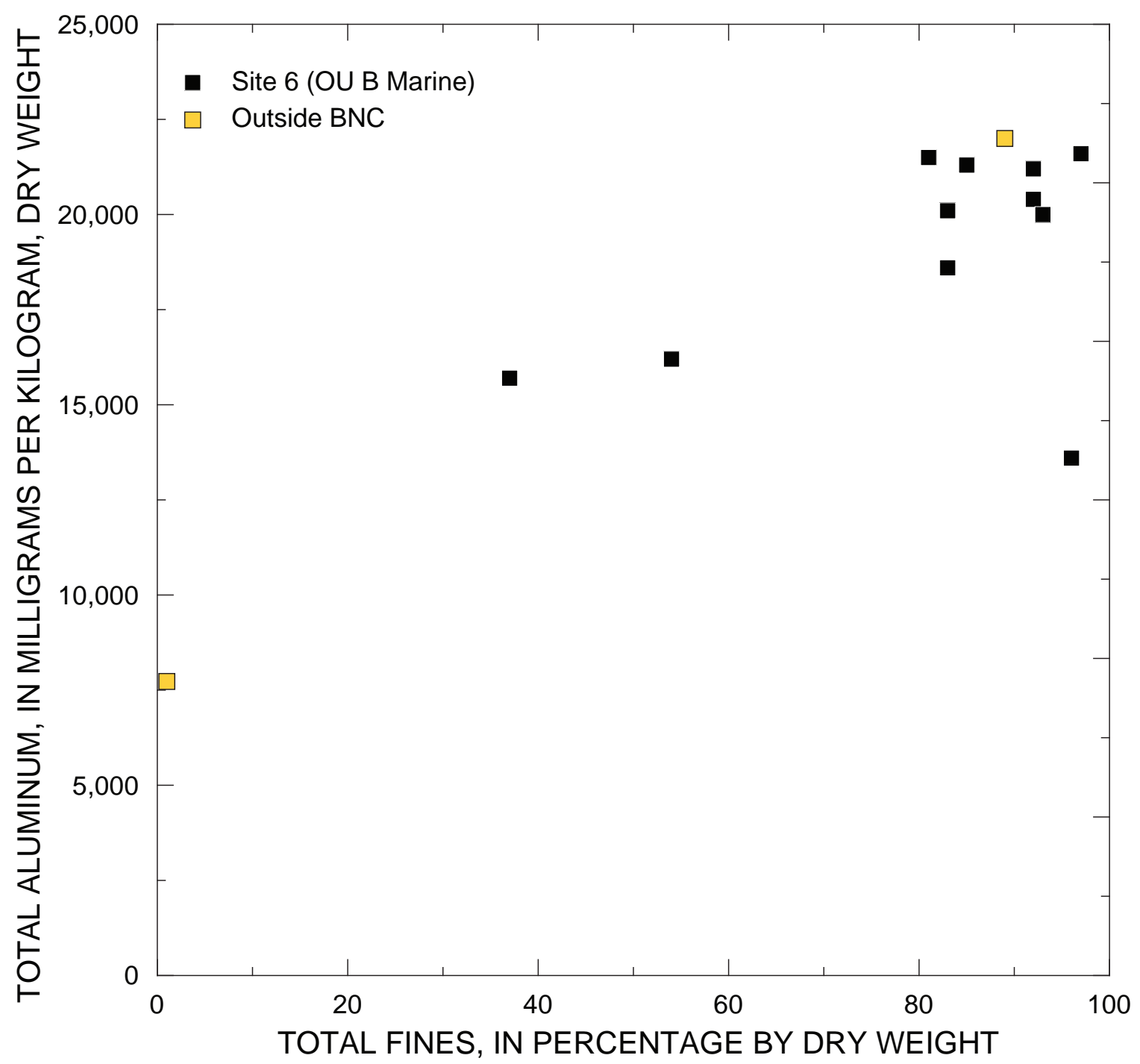

Figure C2. Total aluminum concentrations compared to total fines compared to in surface sediment $(0-4 \mathrm{~cm})$ off Operable Unit A and Operable Unit B Terrestrial and outside of the Bremerton naval complex, Washington, from the 1990 site investigation (U.S. Navy, 1992). 


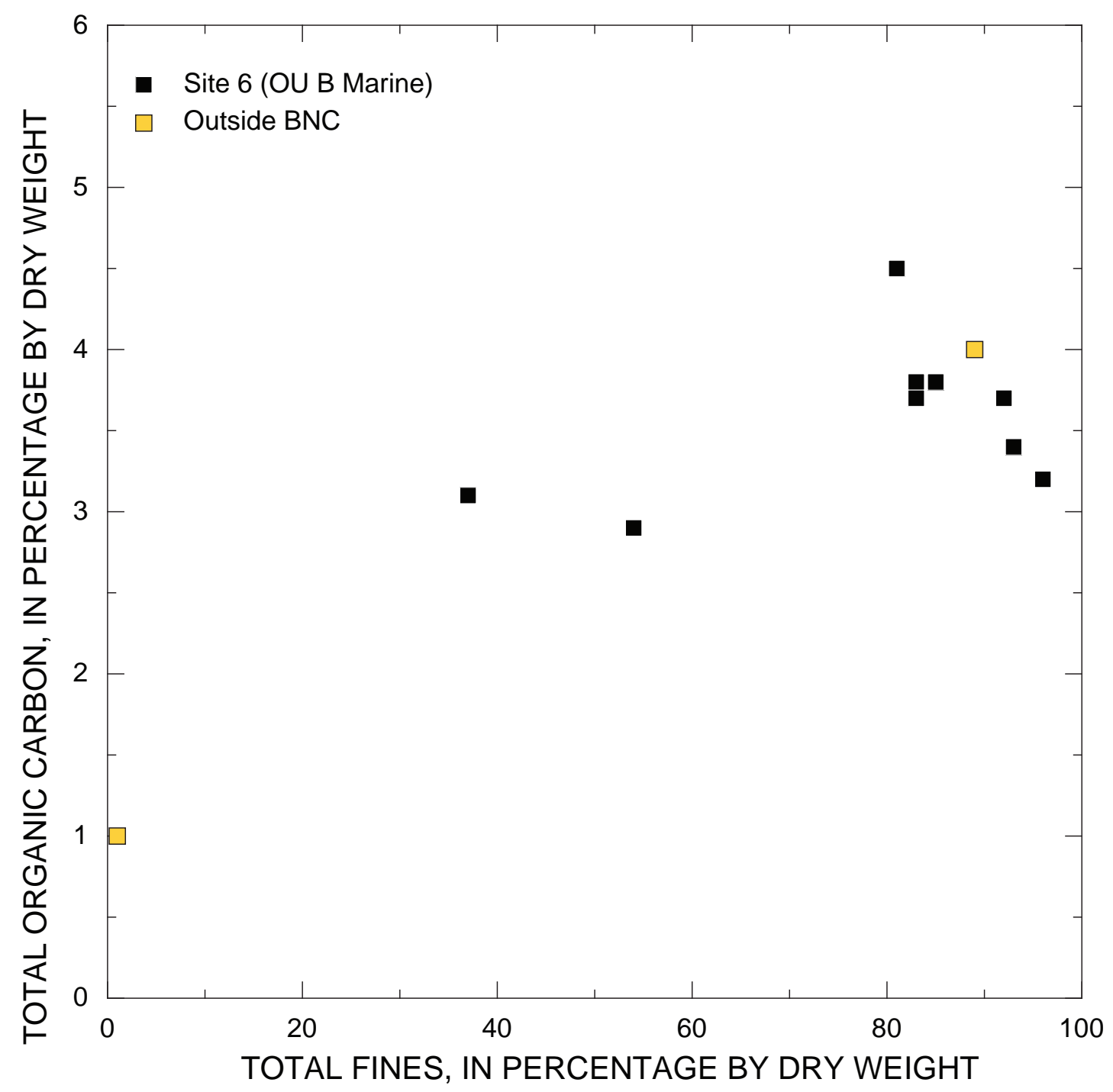

Figure C3. Total organic carbon compared to total fines in surface sediment $(0-4 \mathrm{~cm})$ off Operable Unit A and Operable Unit B Terrestrial and outside of the Bremerton naval complex, Washington, from the $1990 \mathrm{~s}$ ite investigation (U.S. Navy, 1992). 


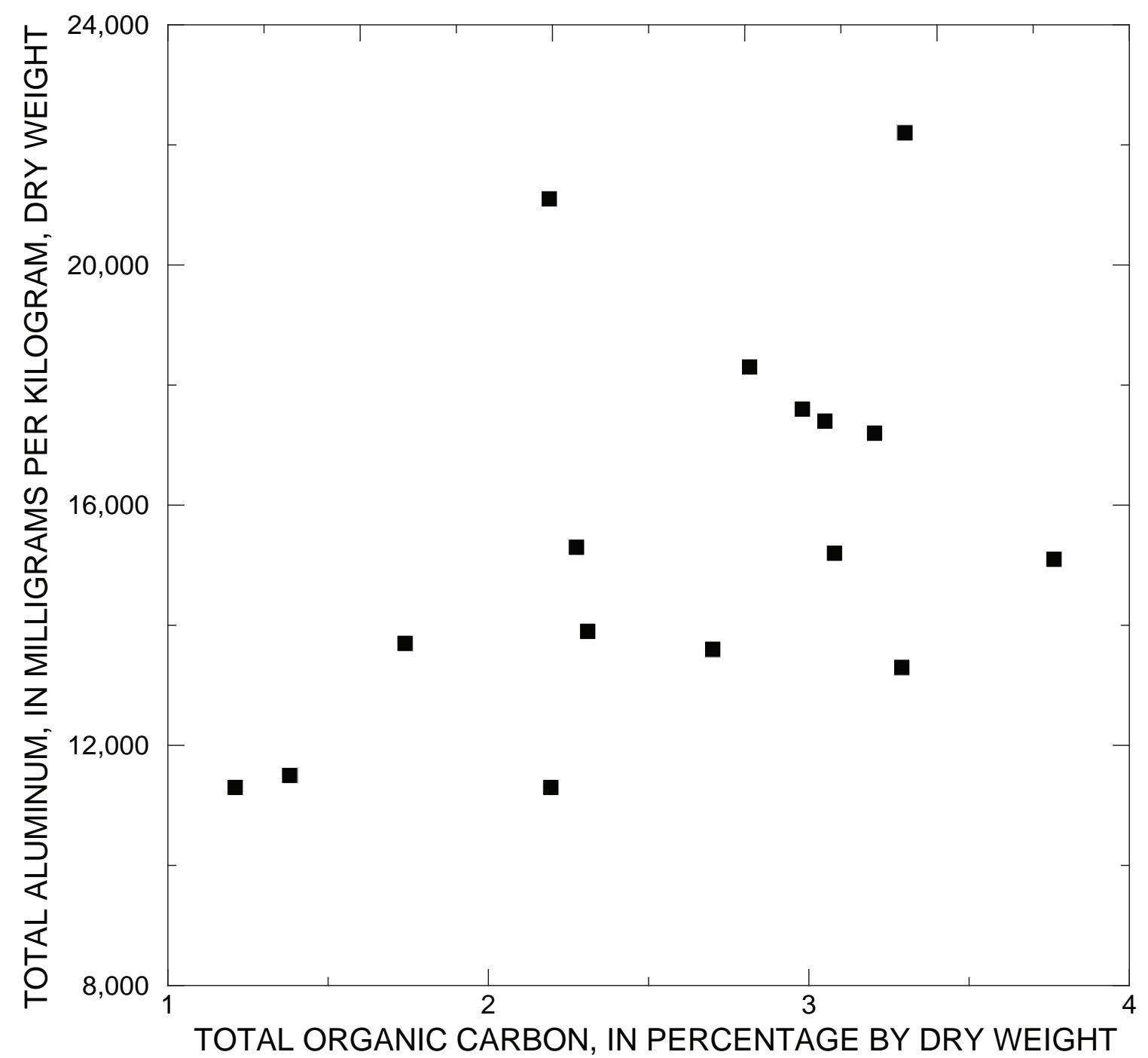

Figure C4. Total aluminum concentrations compared to total organic carbon concentrations in surface sediment $(0-10 \mathrm{~cm})$ outside of the Bremerton naval complex, Washington, from the 1993-1994 Remedial Investigation/Feasibility Study (U.S. Navy, 2000). 


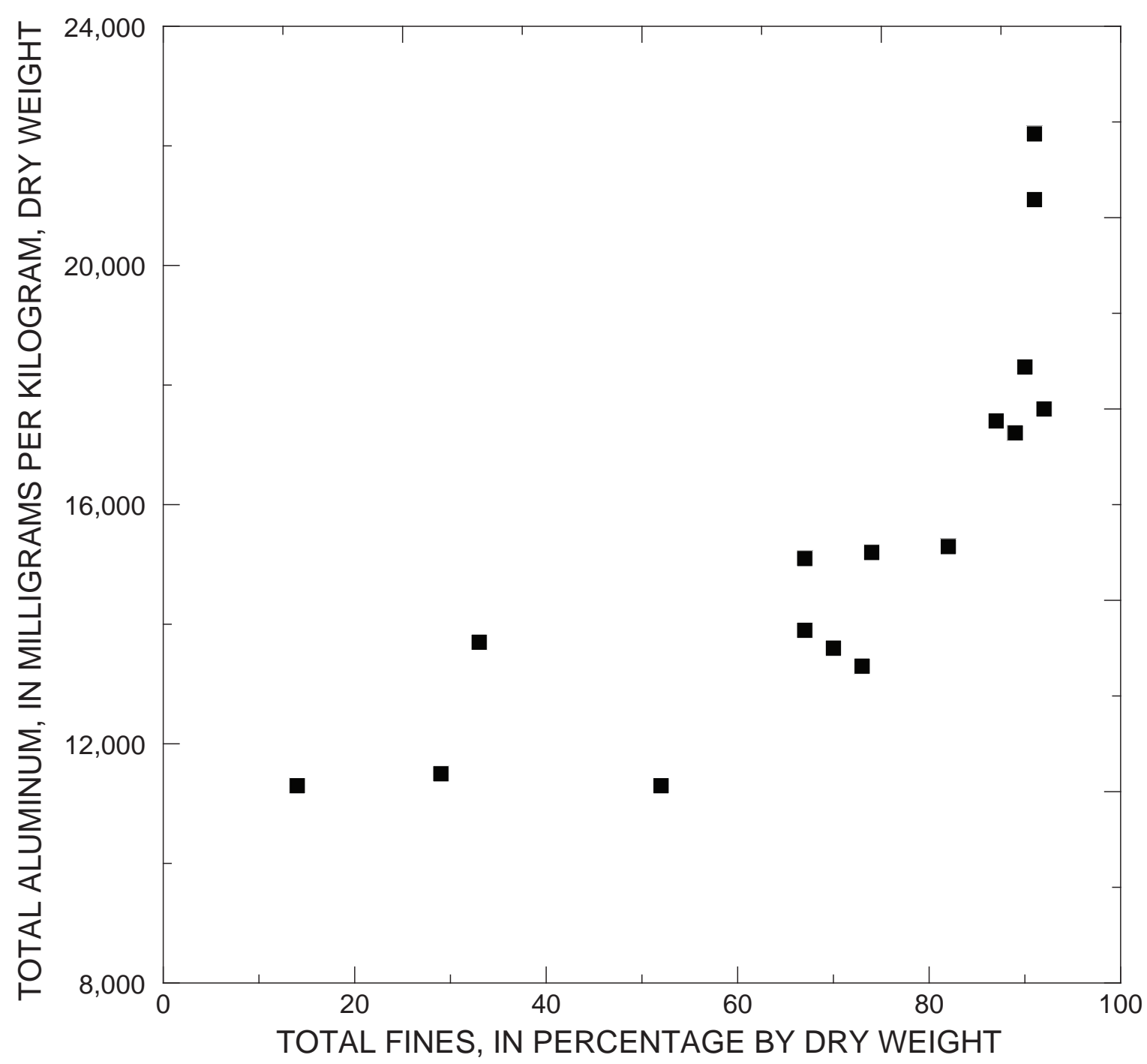

Figure C5. Total aluminum concentrations compared to fines total fines compared to in surface sediment $(0-10 \mathrm{~cm})$ outside of the Bremerton naval complex, Washington, from the 1993-1994 Remedial Investigation/Feasibility Study (U.S. Navy, 2000). 


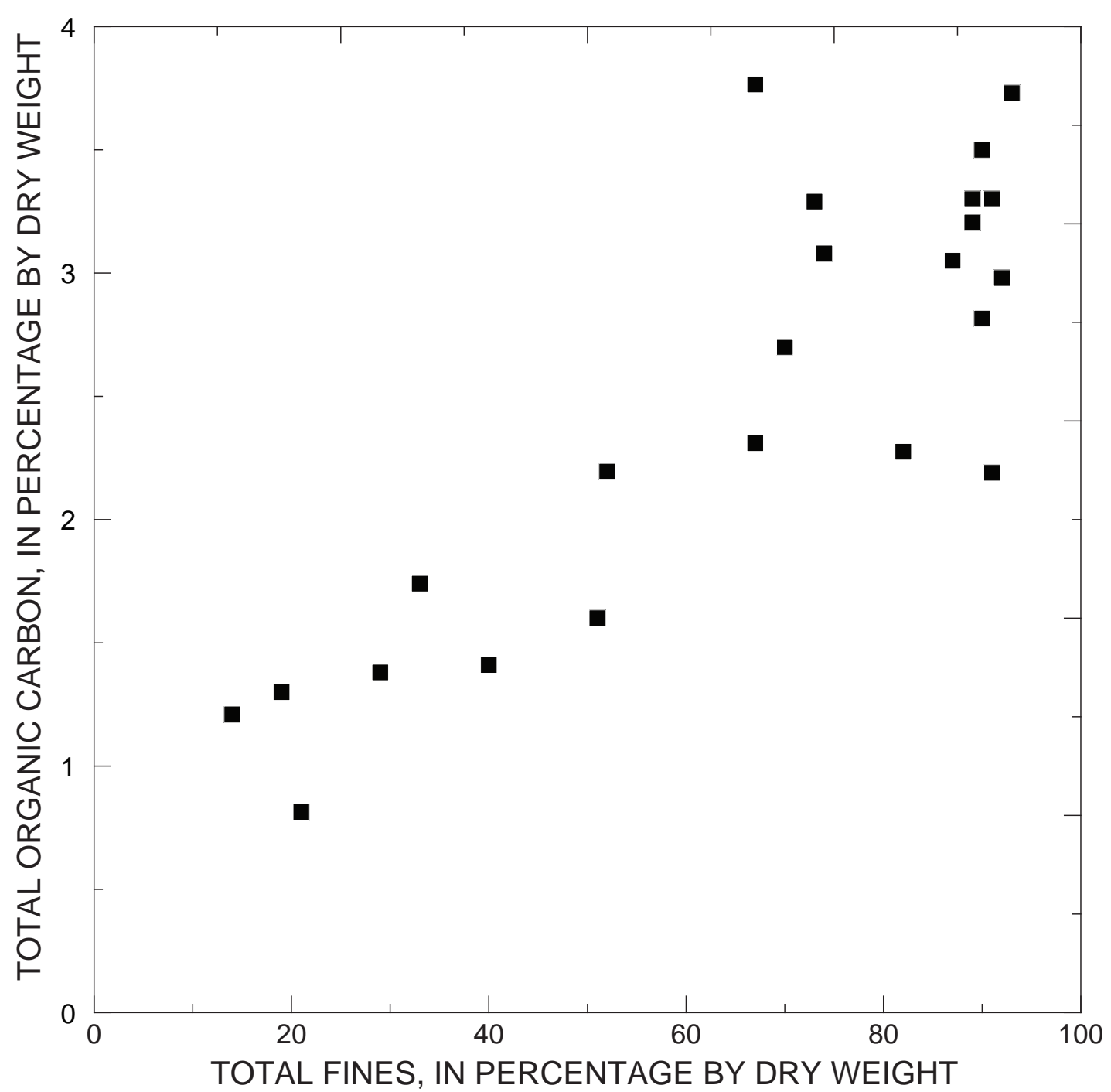

Figure C6. Total organic carbon compared to total fines in surface sediment $(0-10 \mathrm{~cm})$ outside of the Bremerton naval complex, Washington, from the 1993-1994 Remedial Investigation/ Feasibility Study (U.S. Navy, 2000) 


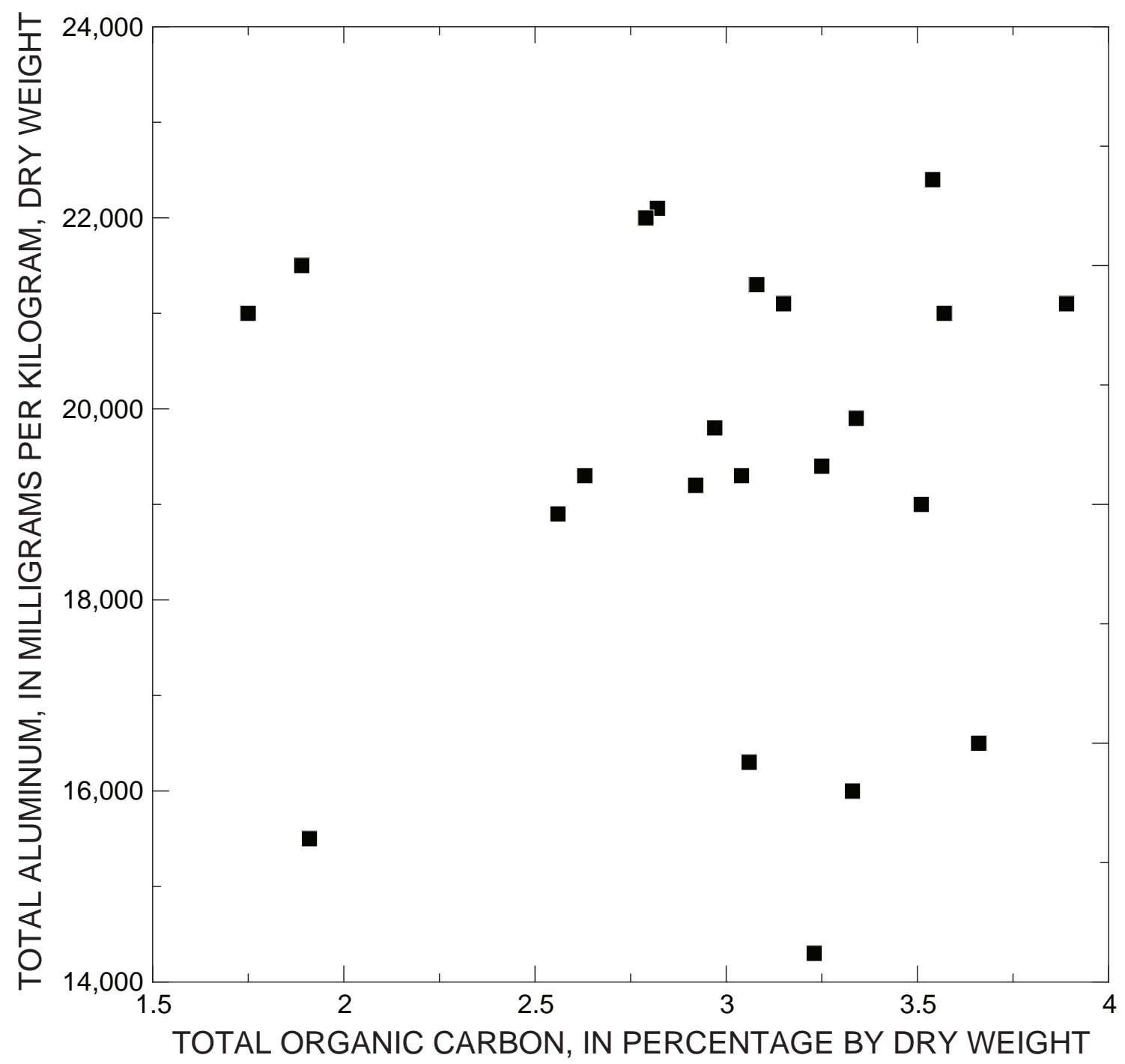

Figure C7. Total aluminum concentrations compared to total organic carbon concentrations in surface sediment $(0-10 \mathrm{~cm})$ from Operable Unit B Marine from the 1993-1994 Remedial Investigation/Feasibility Study (U.S. Navy, 2000). 


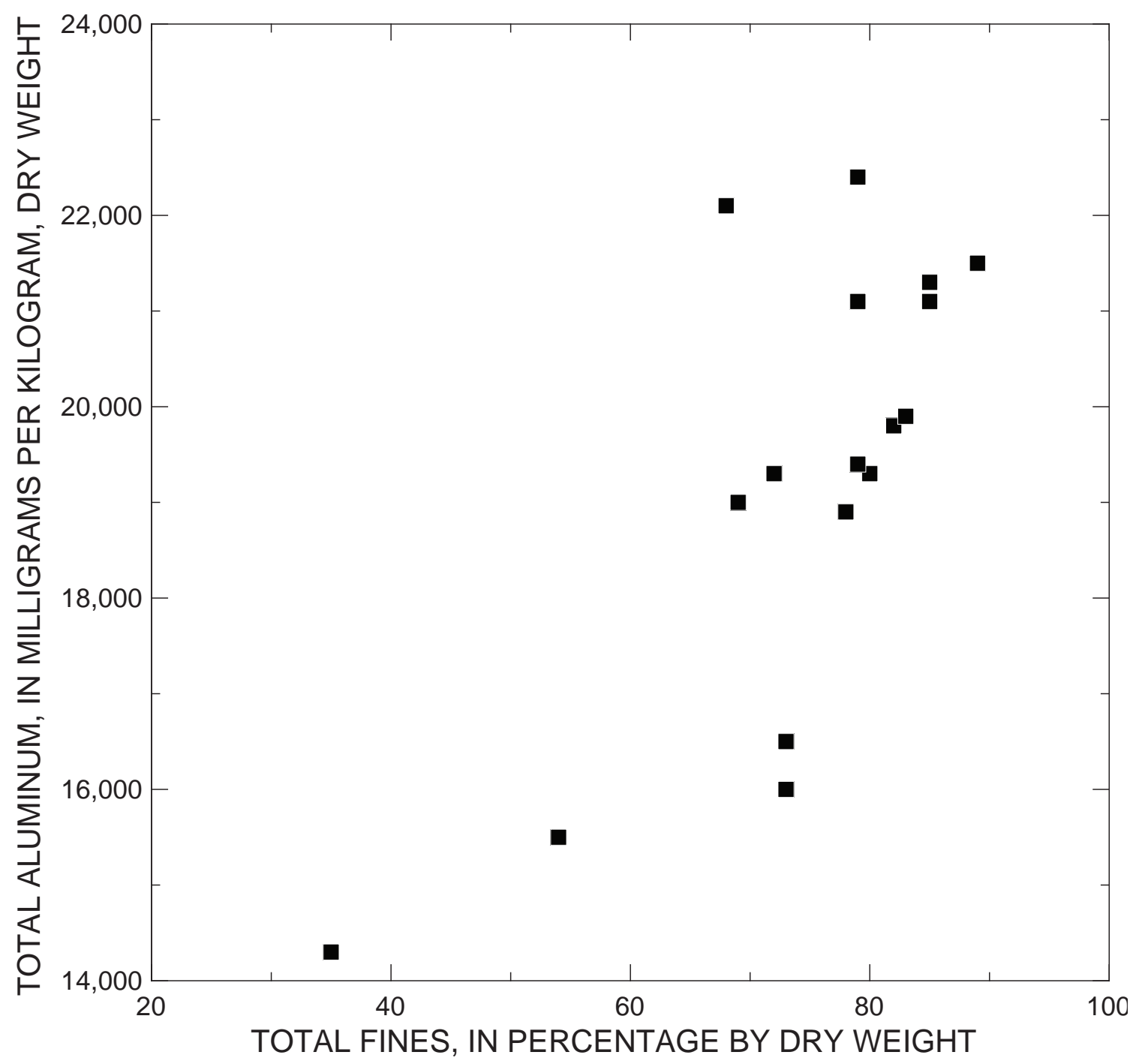

Figure C8. Total aluminum concentrations compared to fines total fines compared to in surface sediment $(0-10 \mathrm{~cm})$ from Operable Unit B Marine of the Bremerton naval complex, Washington, from the 1993-1994 Remedial Investigation/Feasibility Study (U.S. Navy, 2000). 


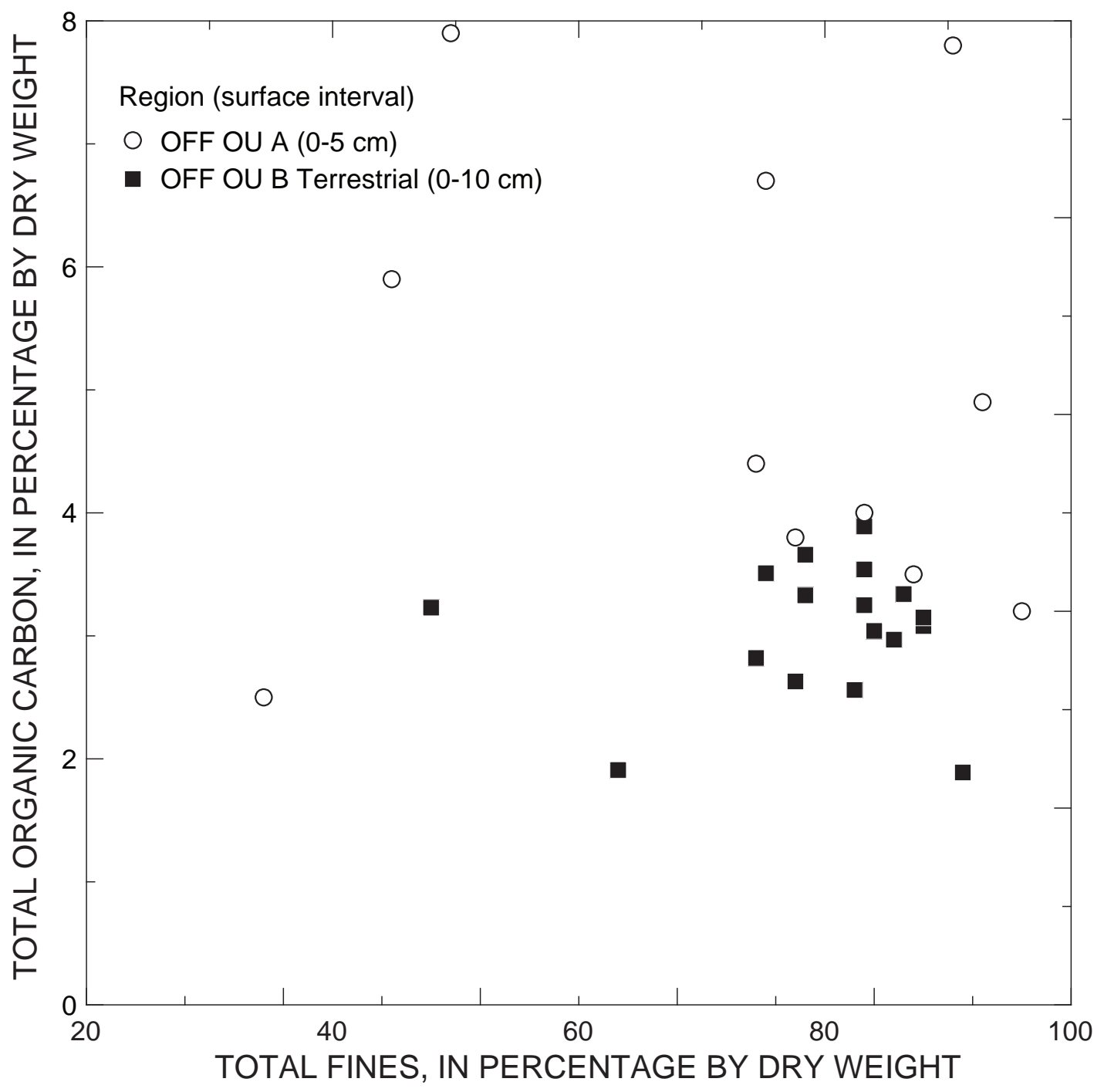

Figure C9. Total organic carbon compared to total fines in surface sediment $(0-5 \mathrm{~cm}$ and $0-10$ $\mathrm{cm}$ ) from Operable Unit B Marine of the Bremerton naval complex, Washington, from the 19931994 Remedial Investigation/Feasibility Study (U.S. Navy, 2000). 


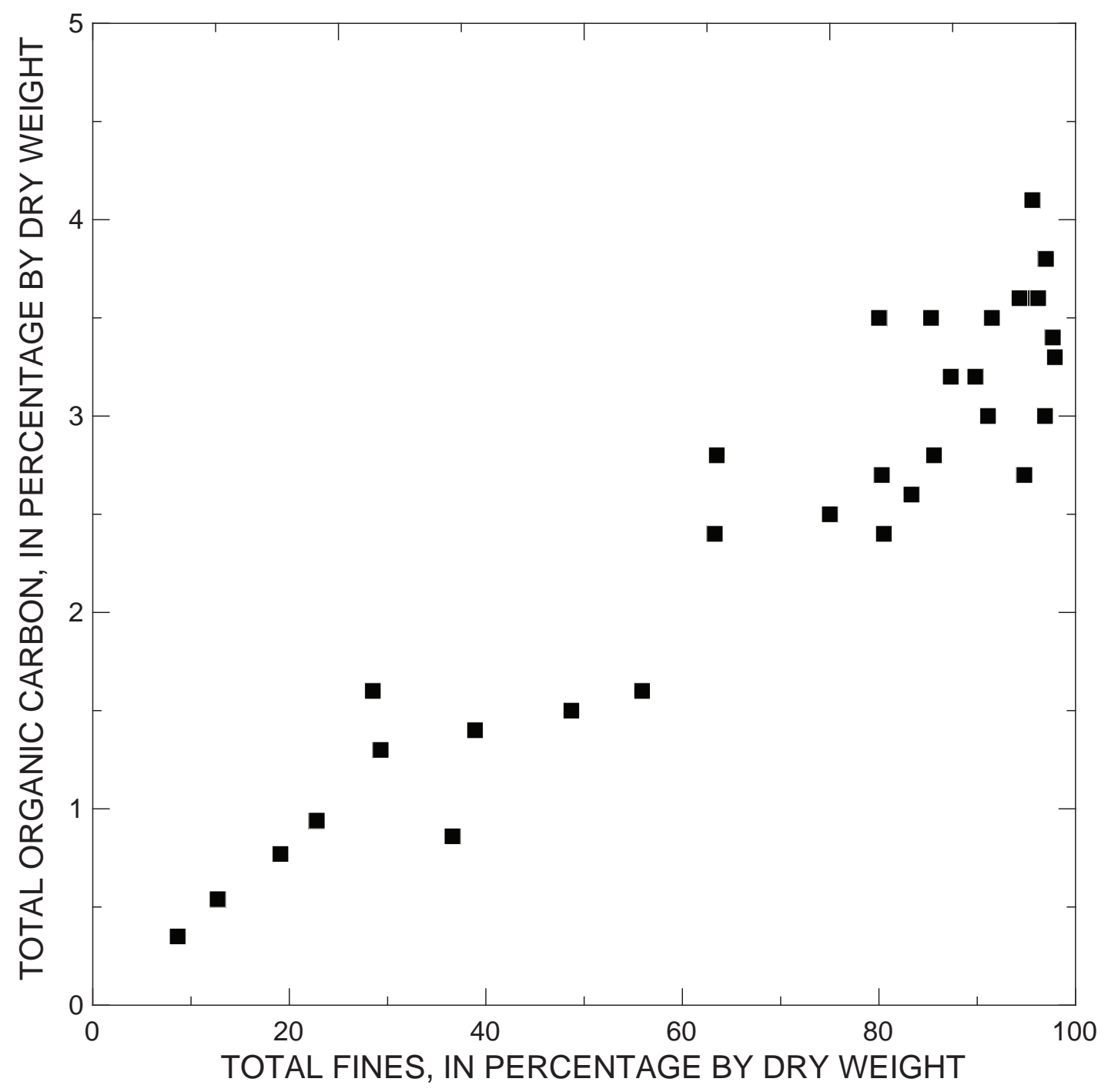

Figure C10. Total organic carbon compared to total fines in surface sediment $(0-10 \mathrm{~cm})$ outside of the of the Bremerton naval complex, Washington, from the 2003 1,500-ft Long-Term Monitoring Program grid (U.S. Navy, 2006a). 


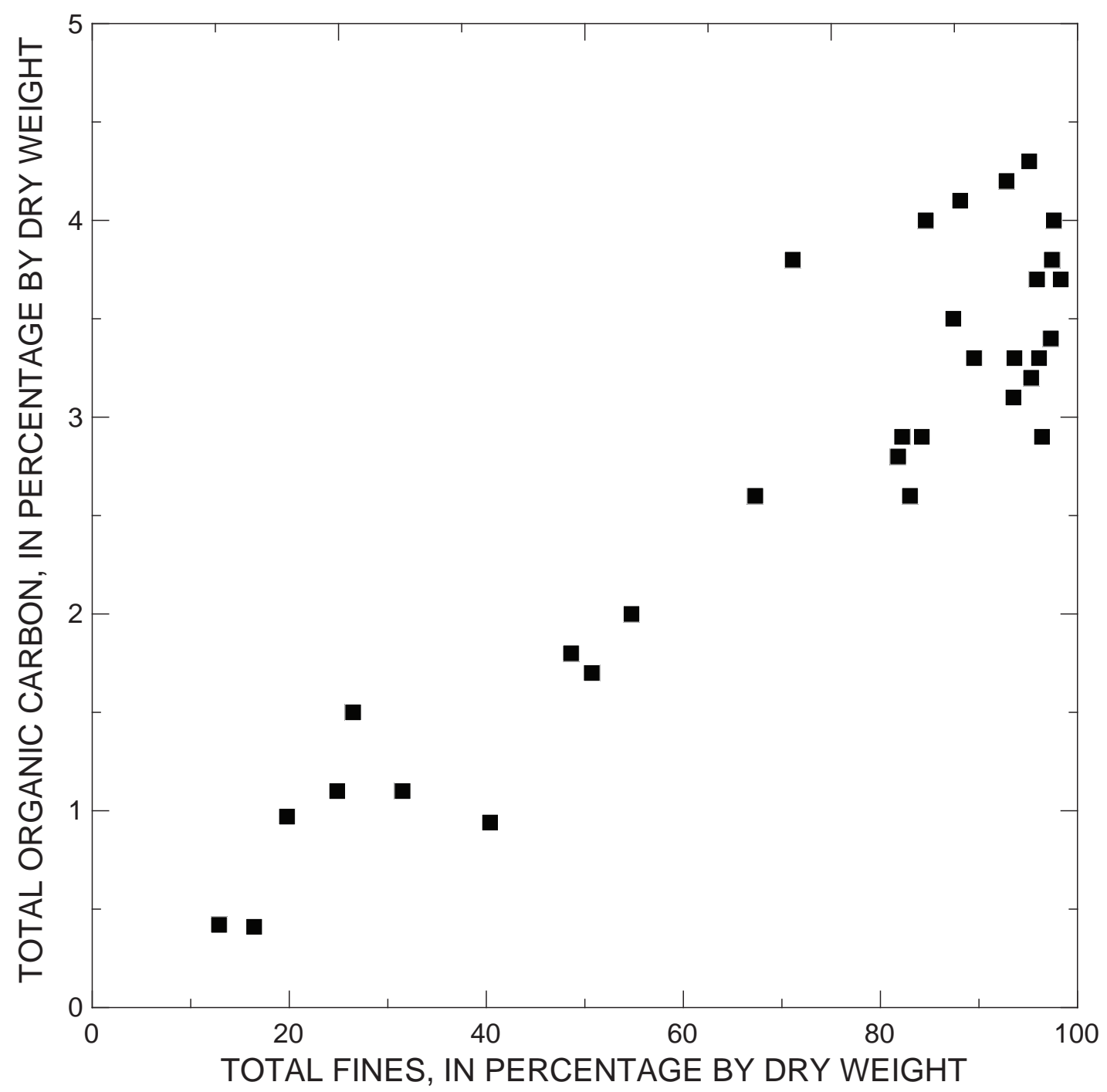

Figure C11. Total organic carbon compared to total fines in surface sediment $(0-10 \mathrm{~cm})$ outside of the Bremerton naval complex Washington, from the 2005 1,500-ft Long-Term Monitoring Program grid (U.S. Navy, 2006b). 


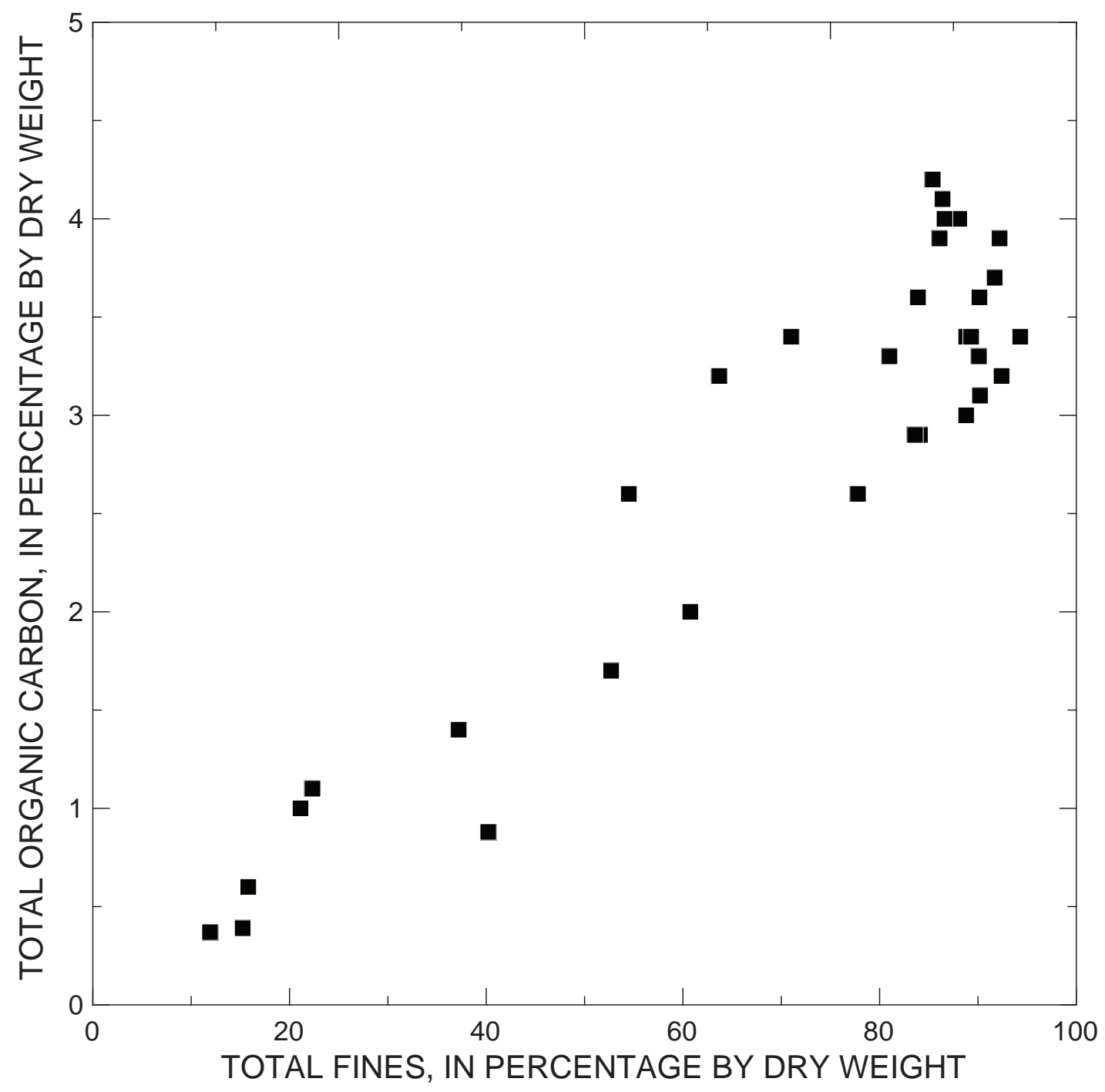

Figure C12. Total organic carbon compared to total fines in surface sediment $(0-10 \mathrm{~cm})$ outside of the Bremerton naval complex, Washington, from the 2007 1,500-ft Long-Term Monitoring Program grid (U.S. Navy, 2008b). 


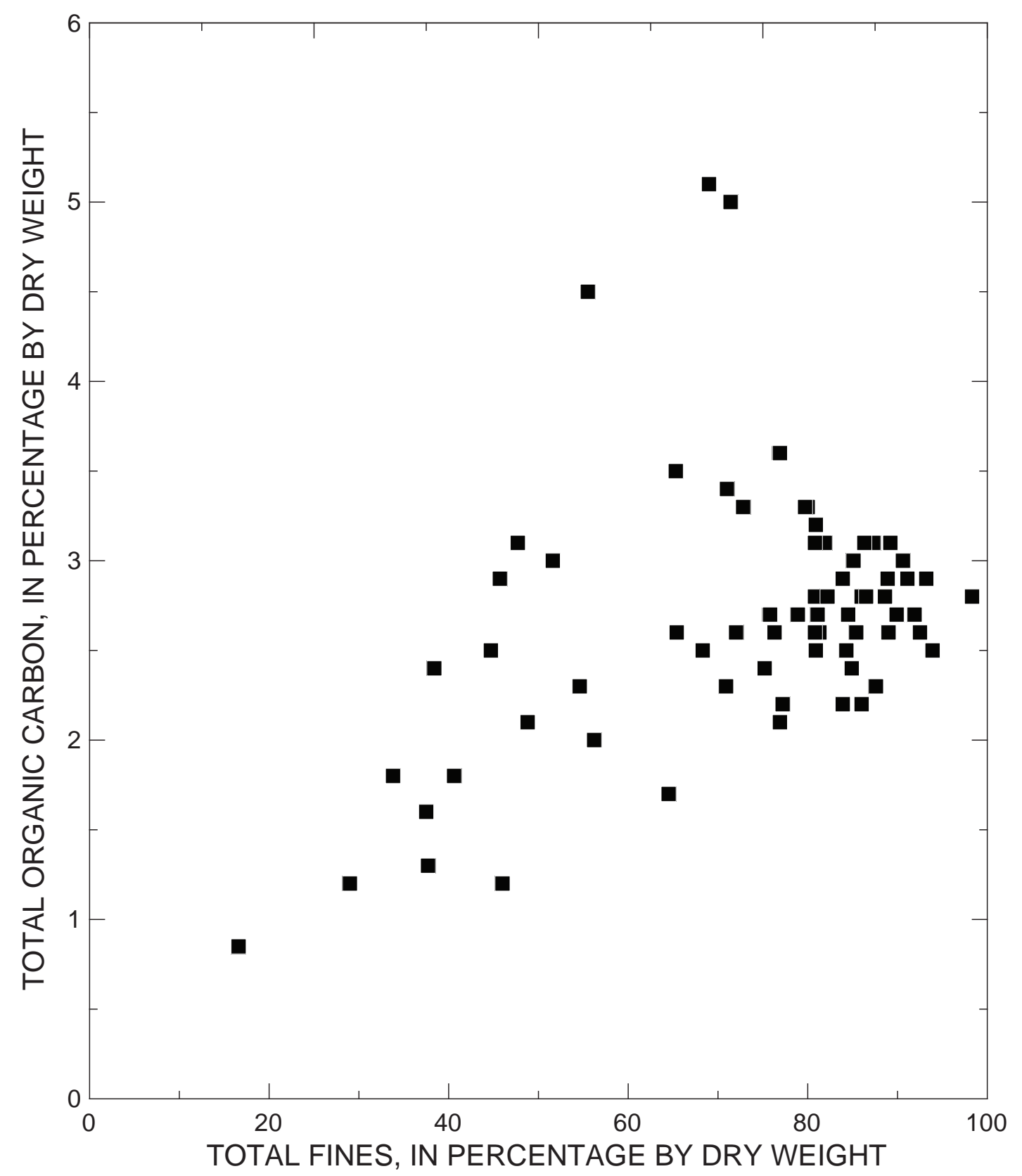

Figure C13. Total organic carbon compared to total fines in surface sediment $(0-10 \mathrm{~cm})$ from Operable Unit B Marine of the Bremerton naval complex, Washington, from the $2003500-\mathrm{ft}$ LongTerm Monitoring Program grid (U.S. Navy, 2006a). 


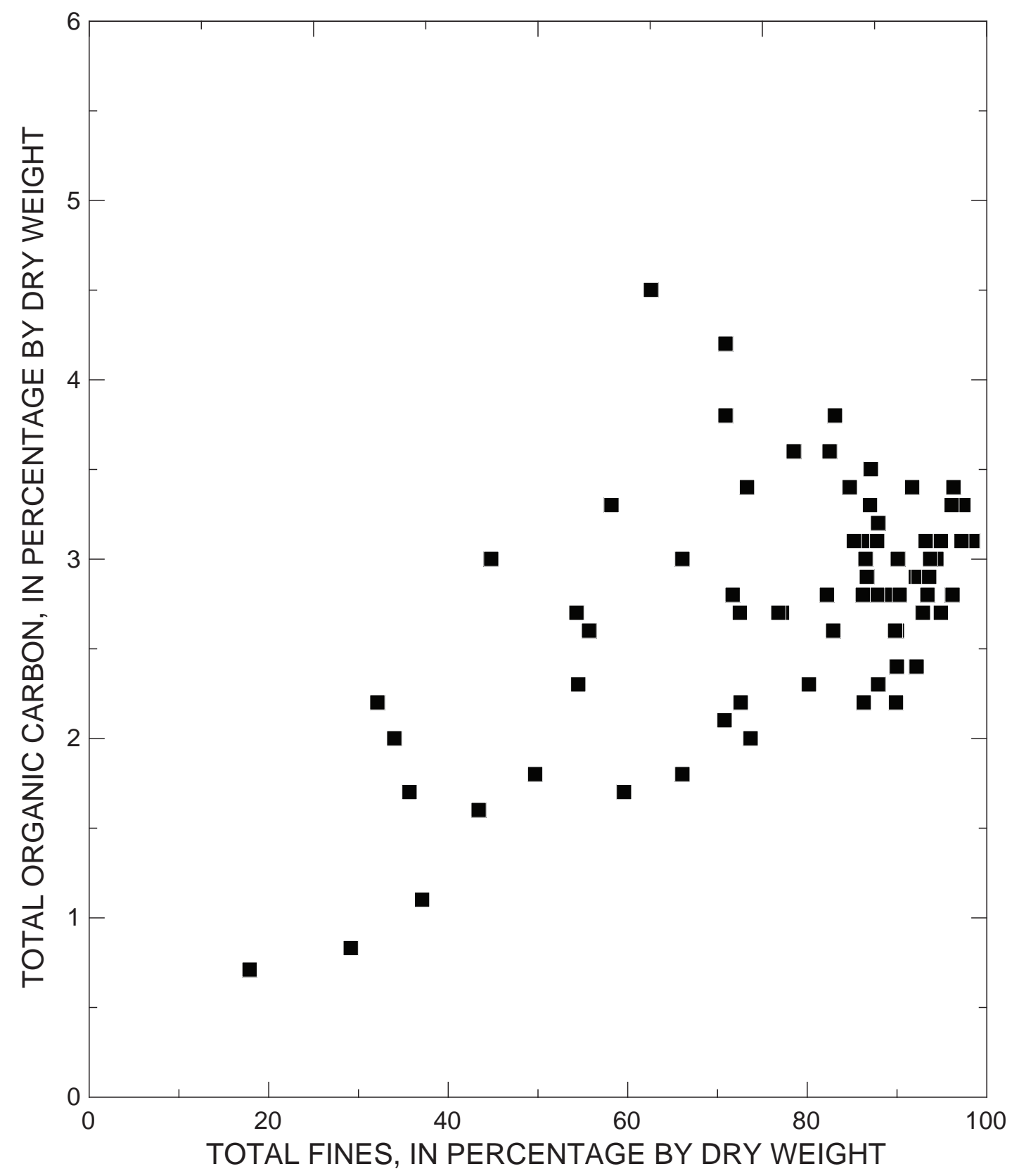

Figure C14. Total organic carbon compared to total fines in surface sediment $(0-10 \mathrm{~cm})$ from Operable Unit B Marine of the Bremerton naval complex, Washington, from the 2005500 - $f$ LongTerm Monitoring Program grid (U.S. Navy, 2006b). 


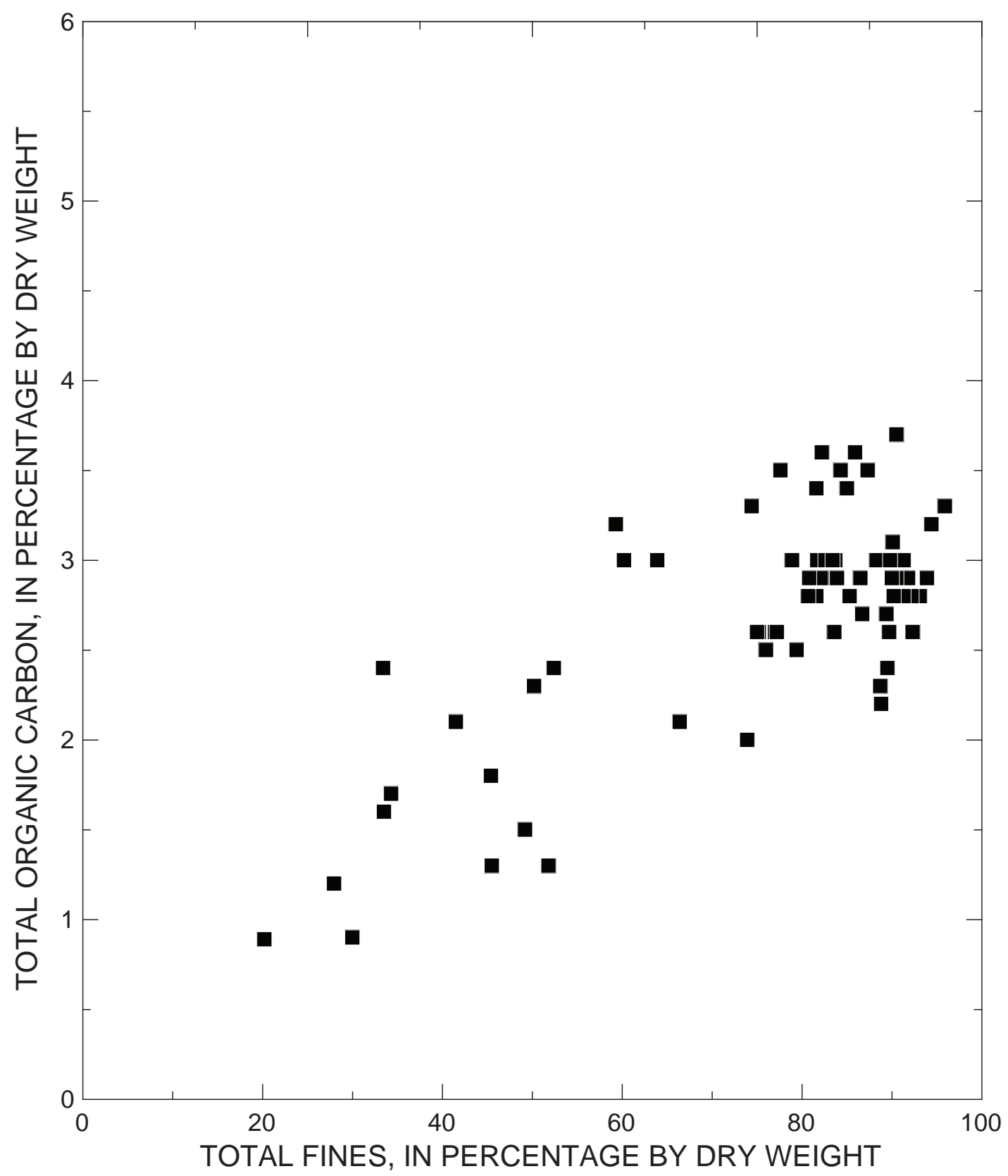

Figure C15. Total organic carbon compared to total fines in surface sediment $(0-10 \mathrm{~cm})$ from Operable Unit B Marine of the Bremerton naval complex, Washington, from the $2007500-\mathrm{ft}$ LongTerm Monitoring Program grid (U.S. Navy, 2008b). 
176 Mercury in Sediment, Water, and Biota of Sinclair Inlet, Puget Sound, Washington, 1989-2007

This page intentionally left blank. 


\section{Appendix D. Core Profiles from the Operable Units A and B Remedial Investigation/Feasibility Studies from the Confined Aquatic Disposal Pit for the Long-Term Monitoring Program, from the Special Transport Study, and from the Environment Investment (Envvest) Project}

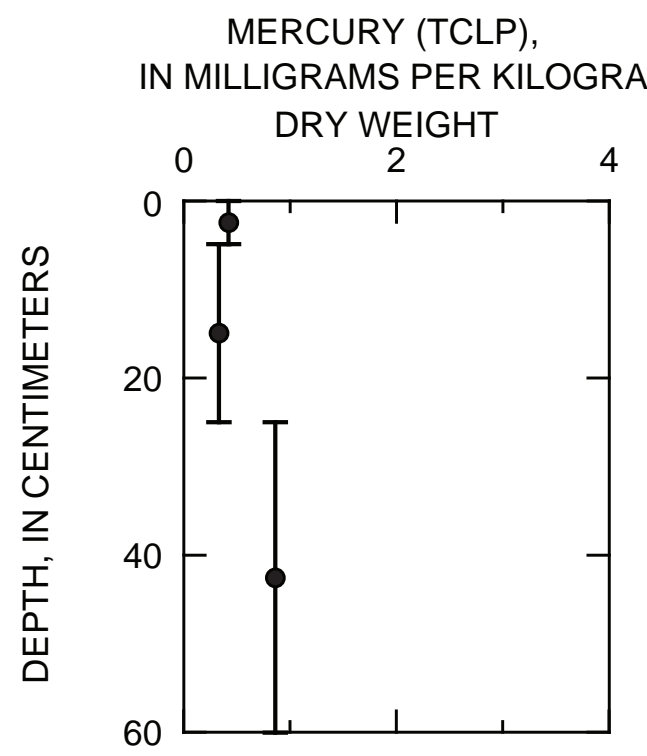

TOTAL ORGANIC CARBON,

PERCENTAGE BY DRY WEIGHT
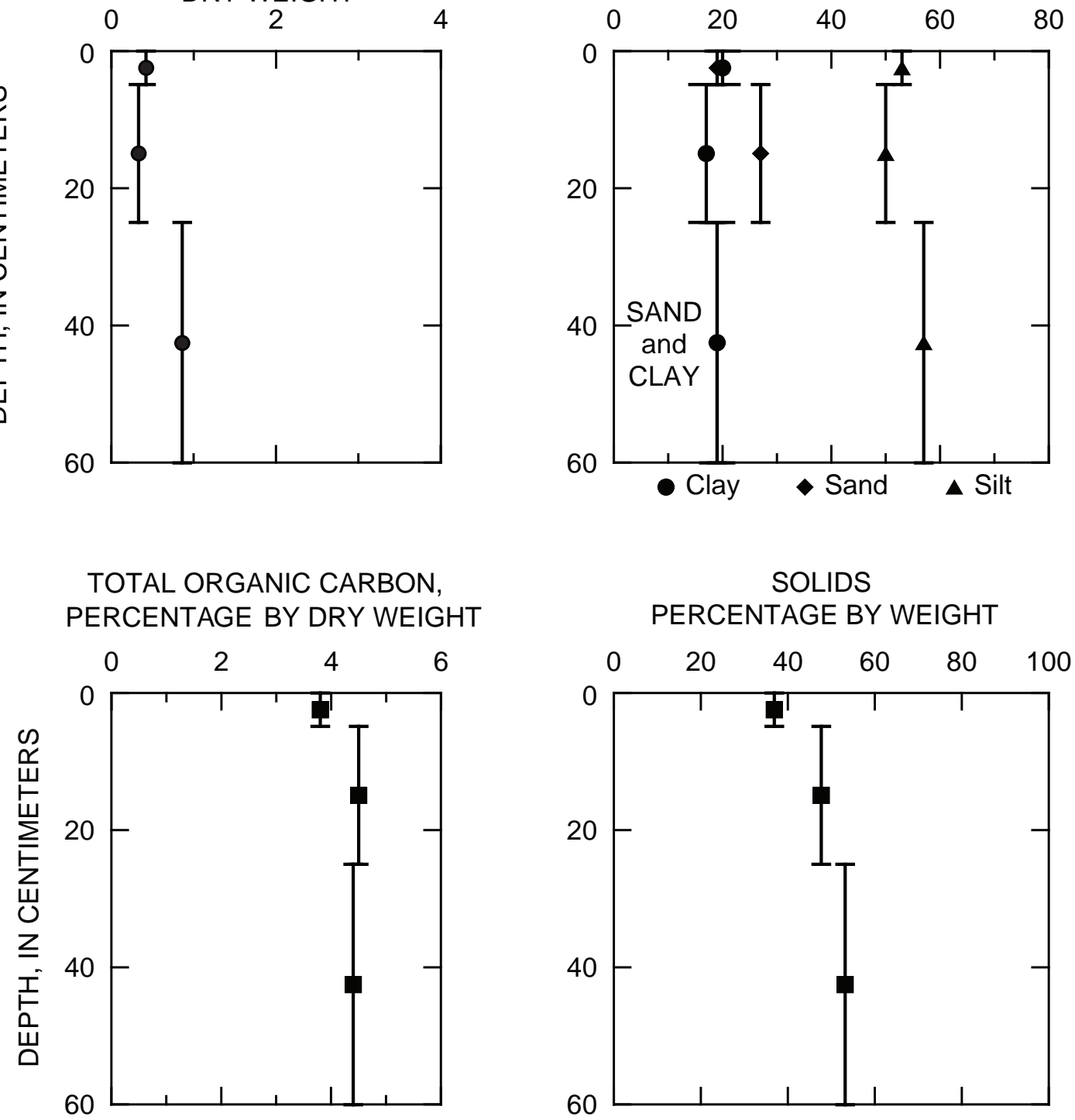

Figure D1. Vertical profiles of mercury concentrations by toxicity characteristic leaching procedure (TCLP) extraction, percentages of sand, silt and clay, total organic carbon, and percentage of solids at MS220 (location 220) of Operable Unit A of the Bremerton naval complex Washington. 

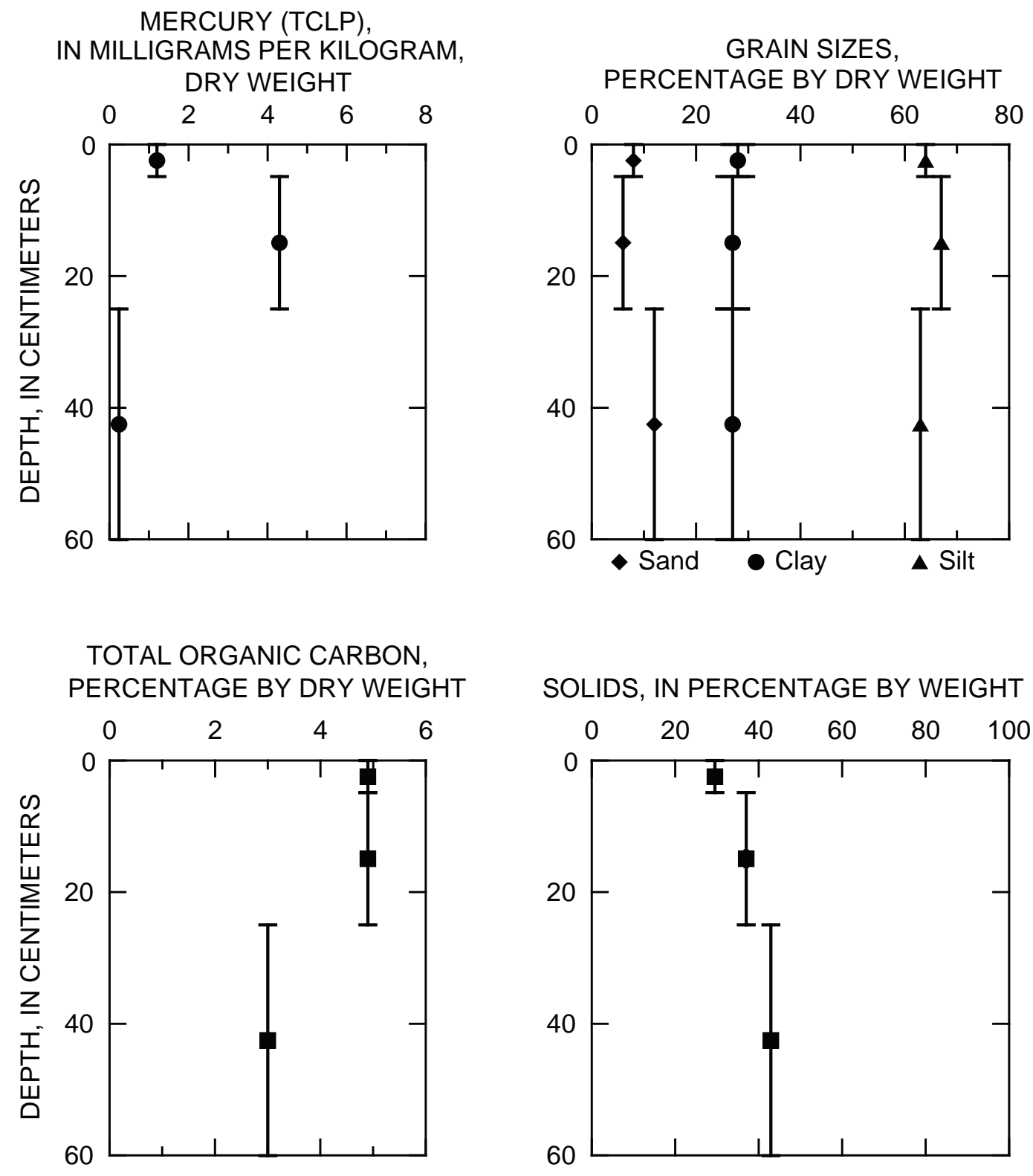

SOLIDS, IN PERCENTAGE BY WEIGHT

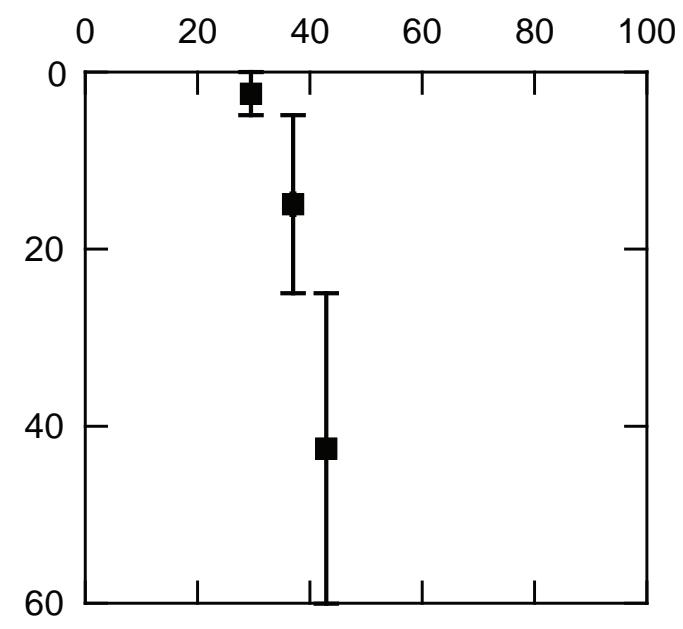

Figure D2. Vertical profiles of mercury concentrations by toxicity characteristic leaching procedure (TCLP) extraction, percentages of sand, silt and clay, total organic carbon, and percentage of solids at MS221 (location 221) of Operable Unit A of the Bremerton naval complex, Washington (U.S. Navy, 1995a). 

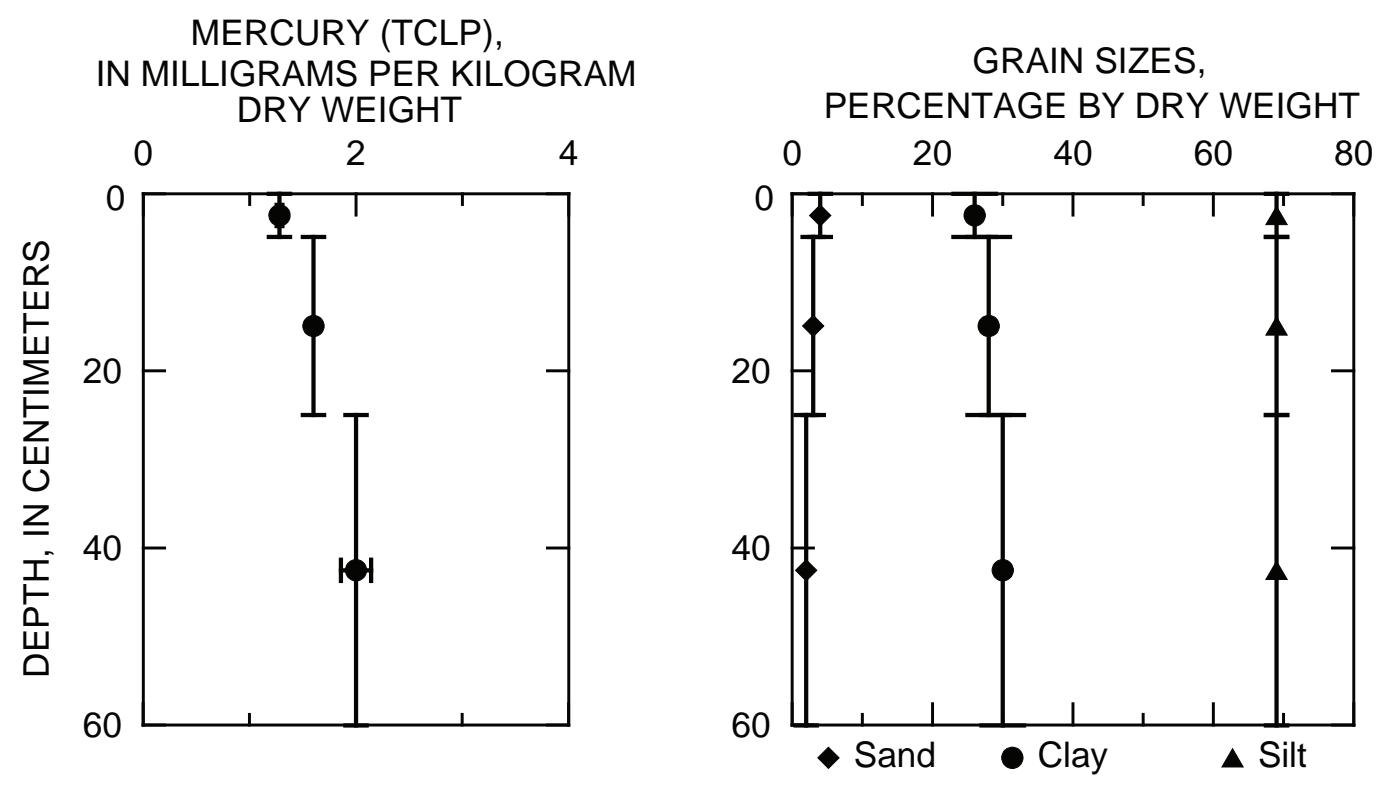

TOTAL ORGANIC CARBON, PERCENTAGE BY DRY WEIGHT

SOLIDS, IN PERCENTAGE BY WEIGHT
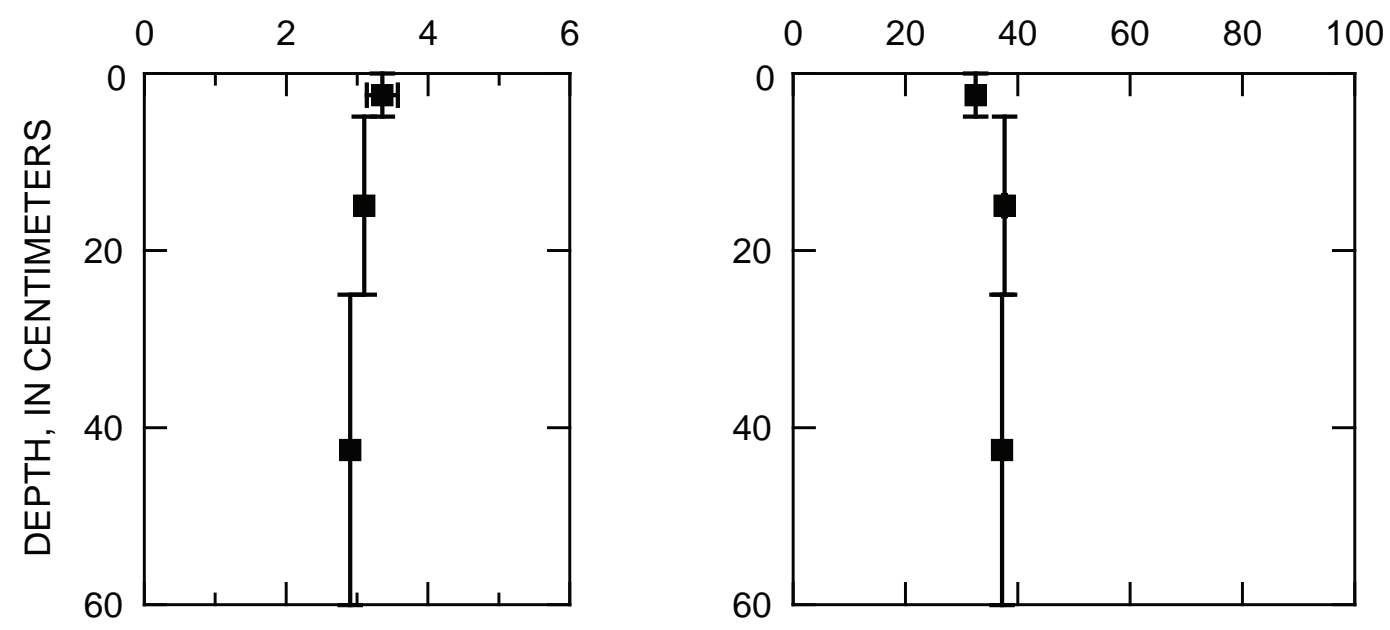

Figure D3. Vertical profiles of mercury concentrations by toxicity characteristic leaching procedure extraction, percentages of sand, silt and clay, total organic carbon, and percentage of solids at MS223 (location 223) of Operable Unit A of the Bremerton naval complex, Washington (U.S. Navy, 1995a). 

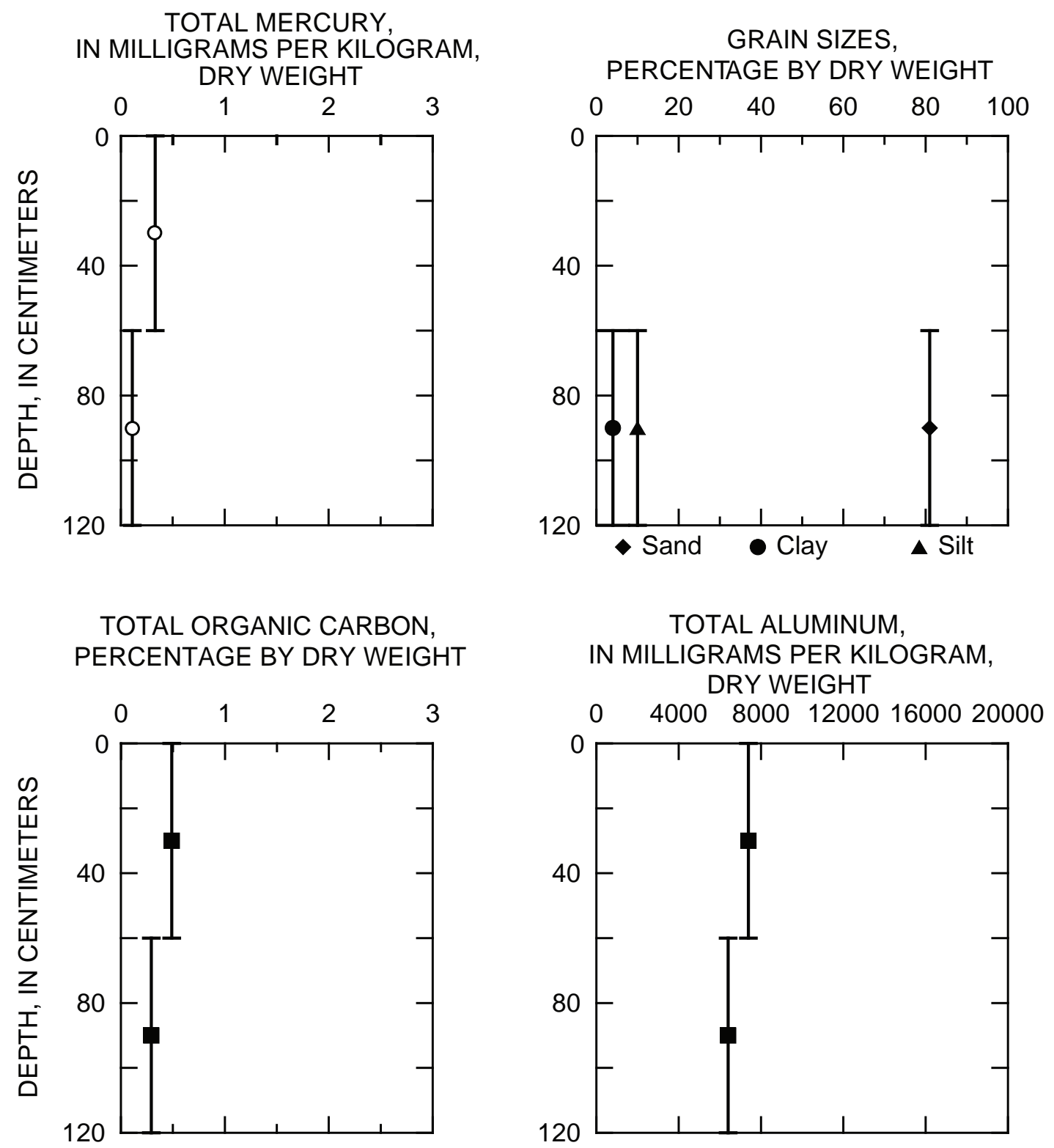

Figure D4. Vertical profiles of total mercury concentrations, percentages of sand, silt and clay, total organic carbon, and total aluminum concentrations of location core 826 of Operable Unit B of the Bremerton naval complex, Washington. 
TOTAL MERCURY,

IN MILLIGRAMS PER KILOGRAM, DRY WEIGHT

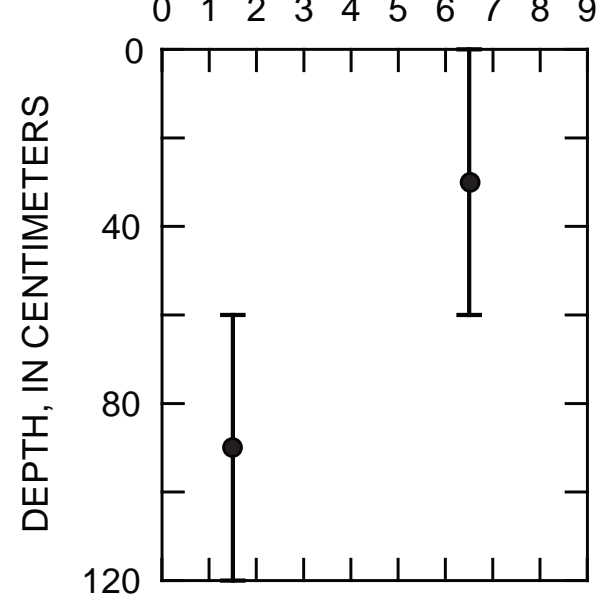

TOTAL ORGANIC CARBON, IN PERCENTAGE BY DRY WEIGHT

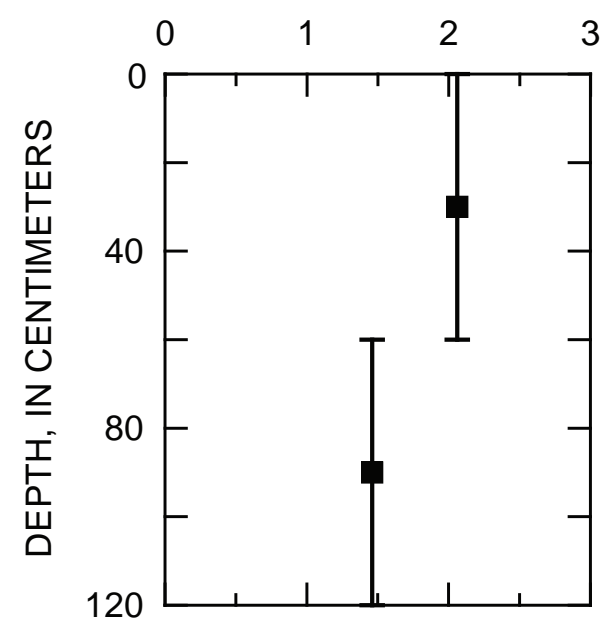

GRAIN SIZES, IN PERCENTAGE BY DRY WEIGHT

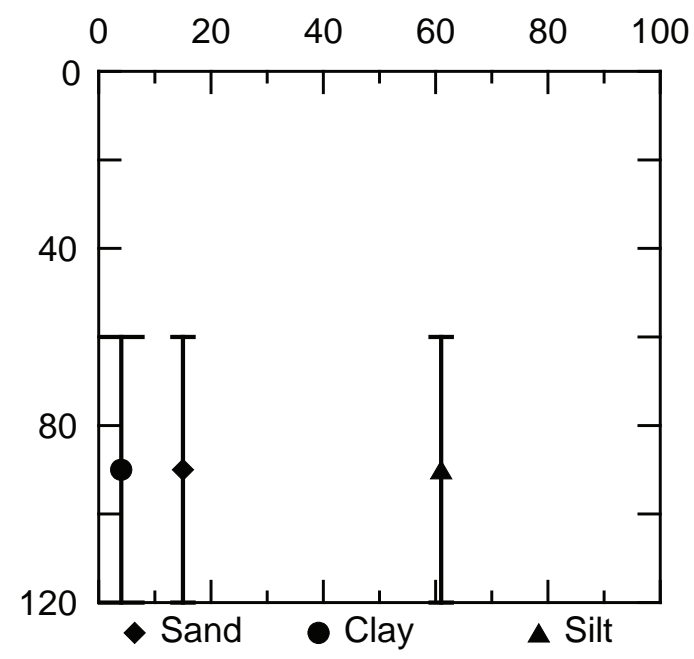

TOTAL ALUMINUM, IN MILLIGRAMS PER KILOGRAM, DRY WEIGHT

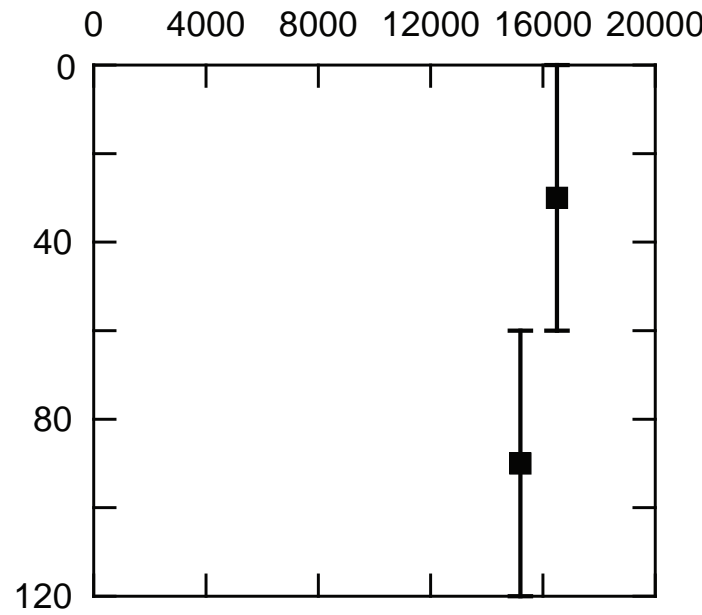

Figure D5. Vertical profiles of total mercury concentrations, percentages of sand, silt and clay, total organic carbon, and total aluminum concentrations of location core 827 of Operable Unit B of the Bremerton naval complex, Washington. 

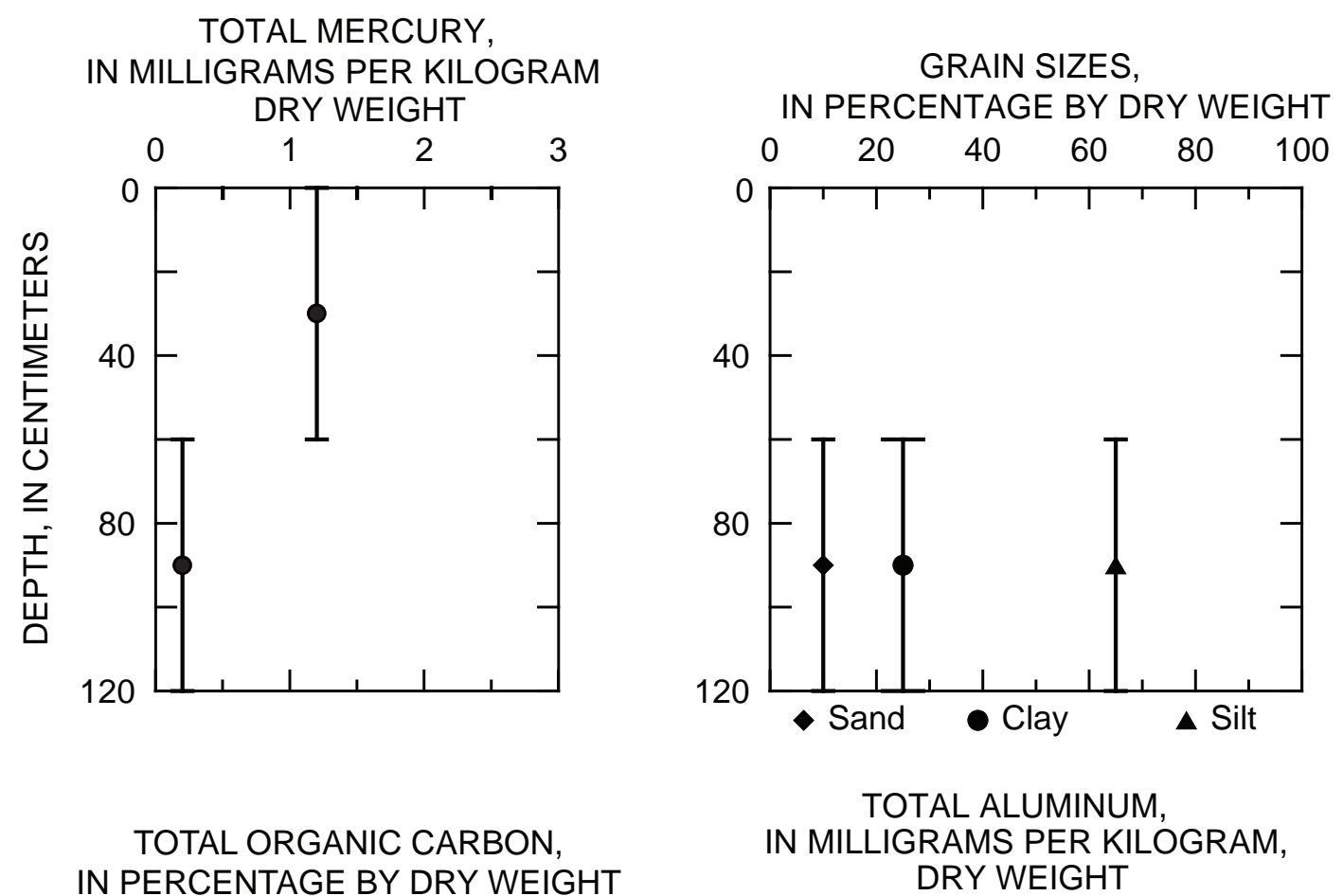

TOTAL ORGANIC CARBON, IN PERCENTAGE BY DRY WEIGHT DRY WEIGHT
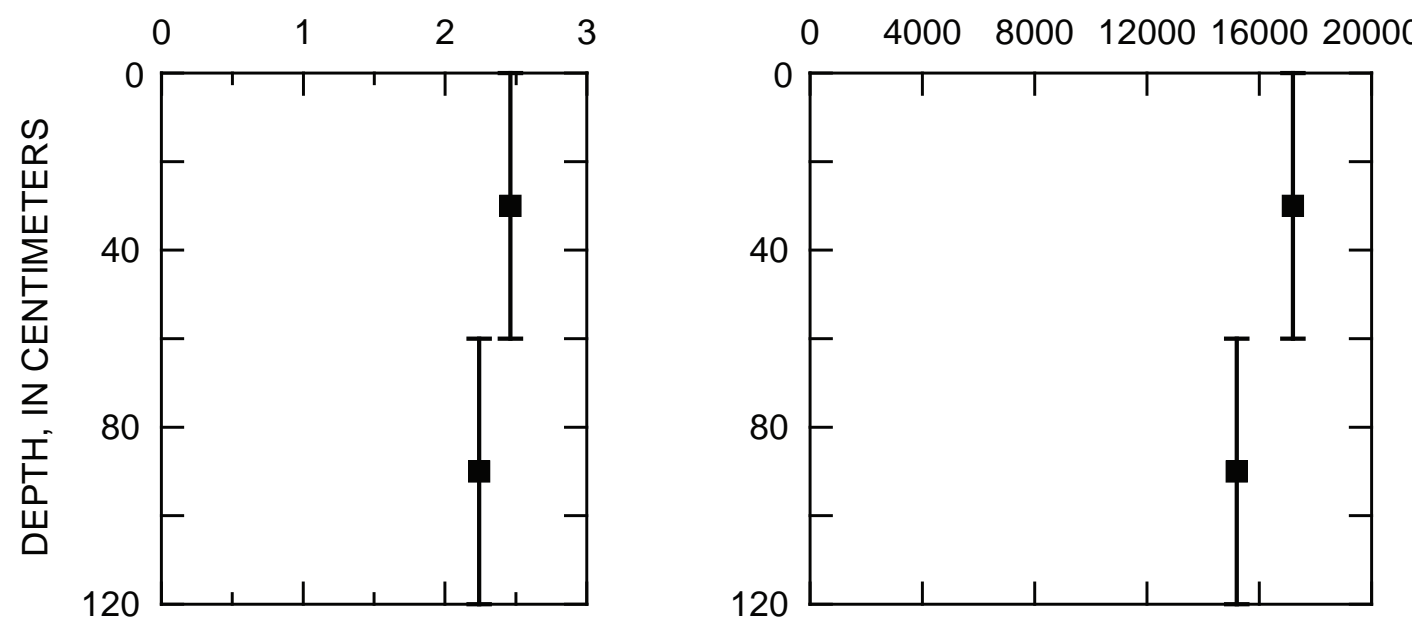

Figure D6. Vertical profiles of total mercury concentrations, percentages of sand, silt and clay, total organic carbon, and total aluminum concentrations of solids at location 828 of Operable Unit B of the Bremerton naval complex, Washington. Open symbols (presently red squares) are qualified (U.S. Navy, 2000). 
TOTAL MERCURY,

IN MILLIGRAMS PER KILOGRAM, DRY WEIGHT

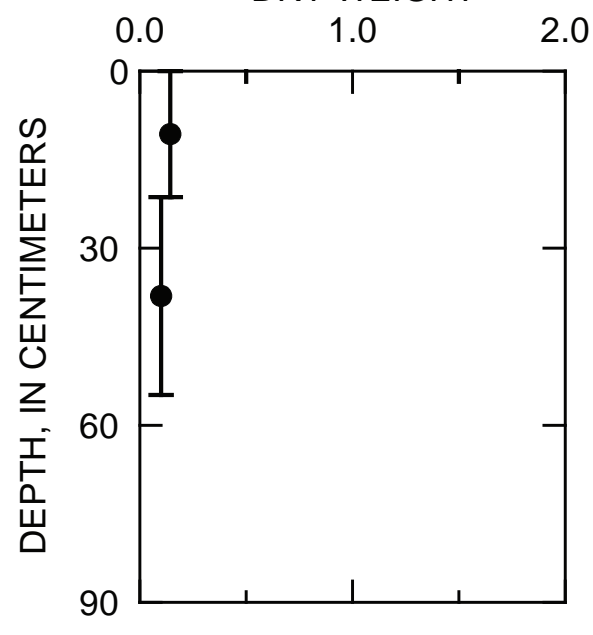

GRAIN SIZES, IN PERCENTAGE BY DRY WEIGHT

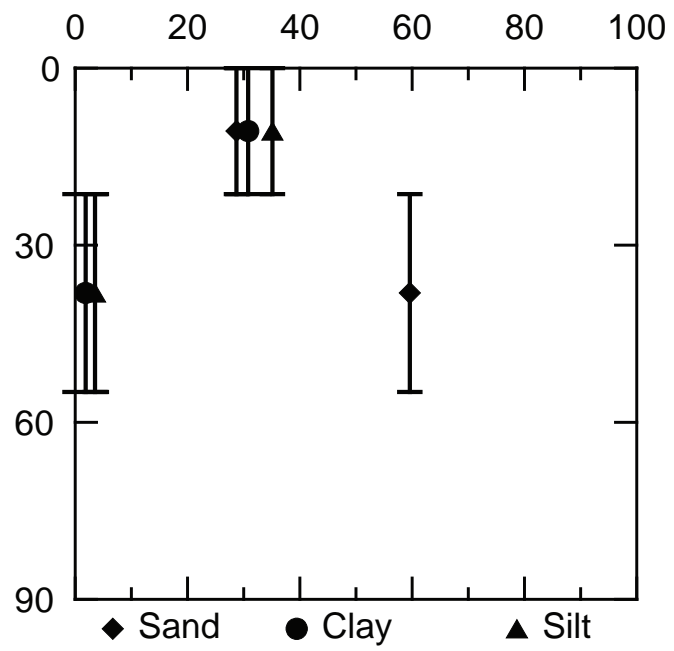

TOTAL ORGANIC CARBON, IN PERCENTAGE BY DRY WEIGHT

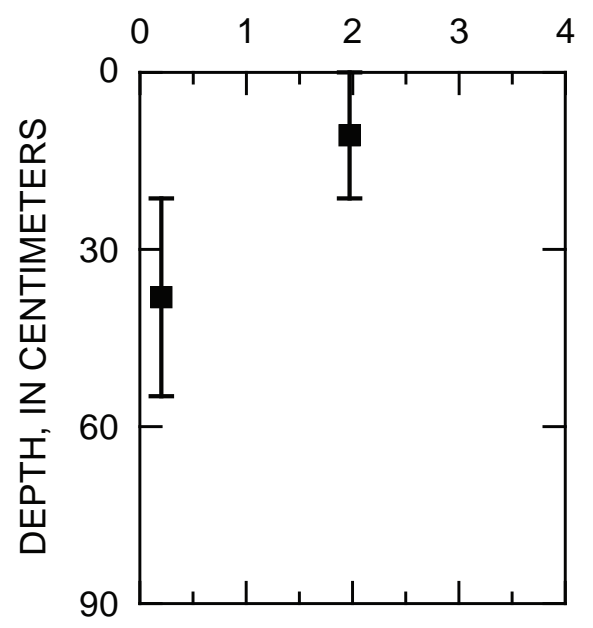

Figure D7. Vertical profiles of total mercury concentrations, percentages of sand, silt and clay, and total organic carbon at confined aquatic disposal pit core PIT-01 of Operable Unit B Marine of the Bremerton naval complex, Washington, 2003 (U.S. Navy, 2006a). 
TOTAL MERCURY,

IN MILLIGRAMS PER KILOGRAM

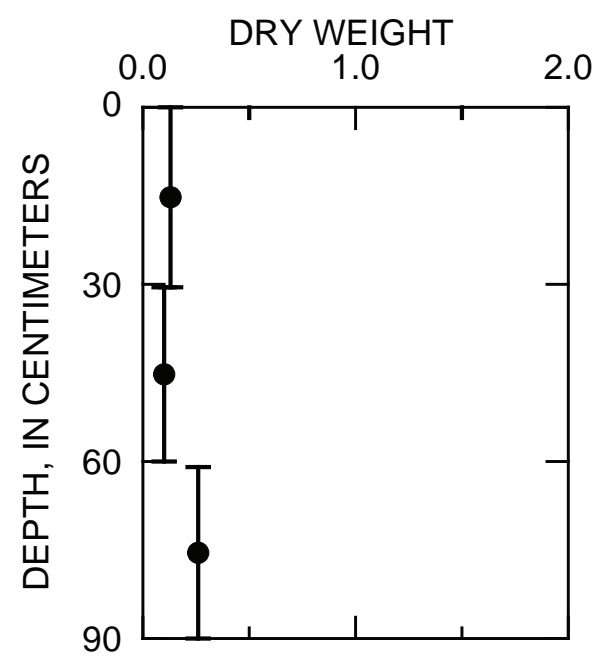

GRAIN SIZES, IN PERCENTAGE BY DRY WEIGHT

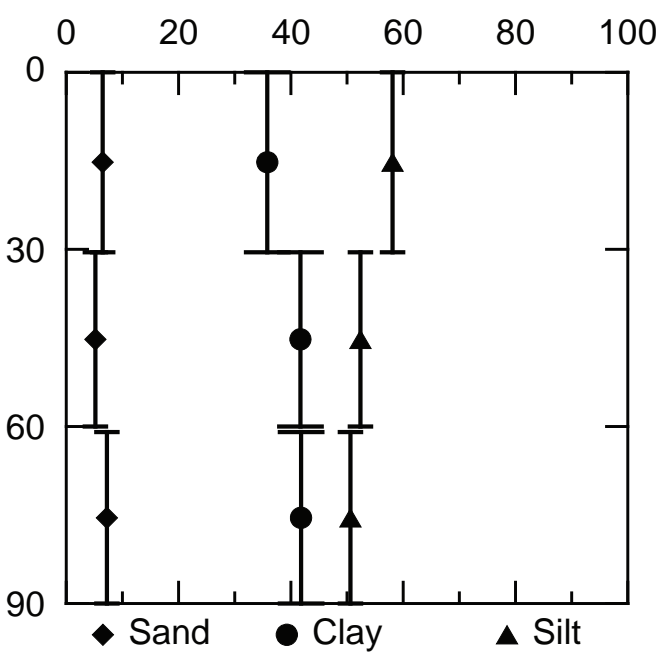

TOTAL ORGANIC CARBON,

IN PERCENTAGE BY DRY WEIGHT

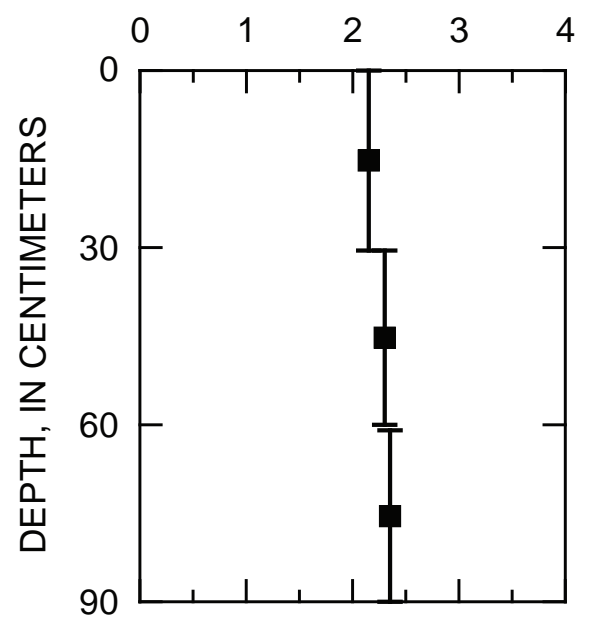

Figure D8. Vertical profiles of total mercury concentrations, percentages of sand, silt and clay, and total organic carbon at confined aquatic disposal pit core PIT-01 of Operable Unit B Marine of the Bremerton naval complex, Washington, 2005 (U.S. Navy, 2006b). 
TOTAL MERCURY,

IN MILLIGRAMS PER KILOGRAM, DRY WEIGHT

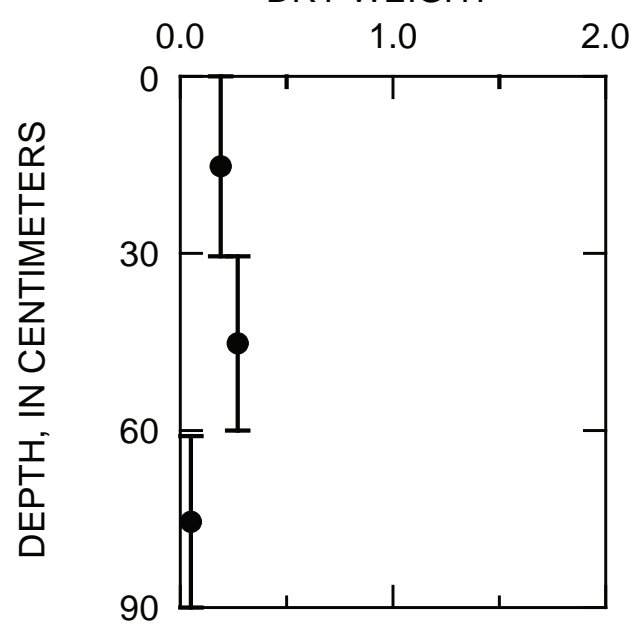

TOTAL ORGANIC CARBON, IN PERCENTAGE BY DRY WEIGHT

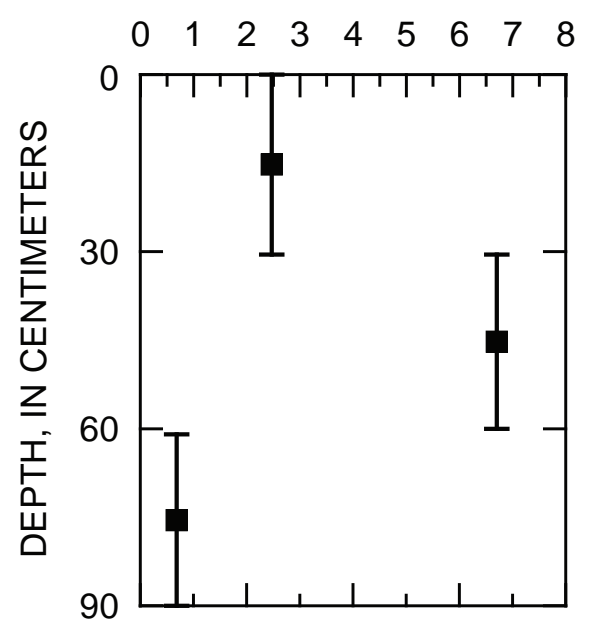

GRAIN SIZES,
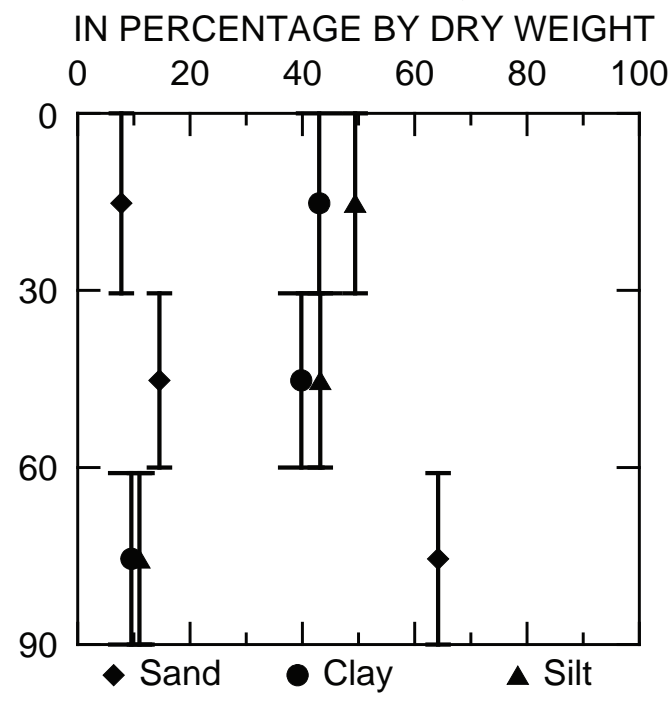

Figure D9. Vertical profiles of mercury concentrations, percentages of sand, silt and clay, and total organic carbon at confined aquatic disposal pit core PIT-02 of Operable Unit B Marine of the Bremerton naval complex, Washington, 2005 (U.S. Navy, 2006b). 
TOTAL MERCURY,
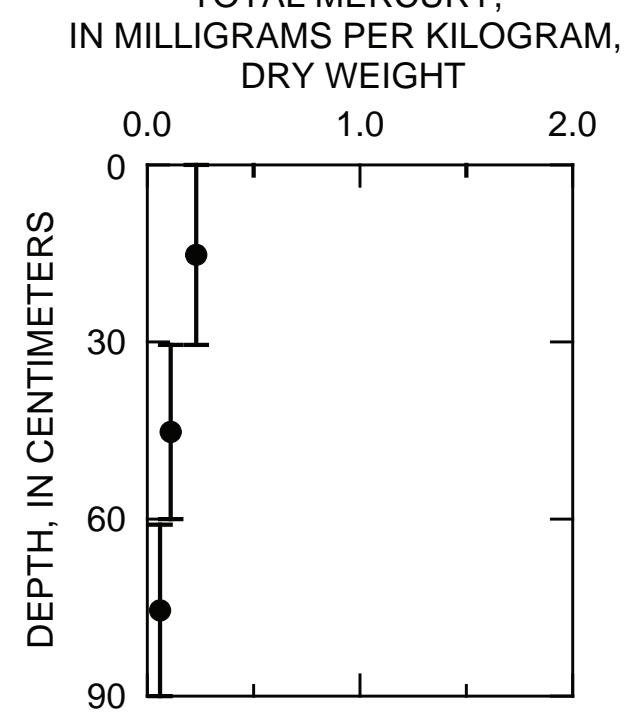

TOTAL ORGANIC CARBON, IN PERCENTAGE BY DRY WEIGHT

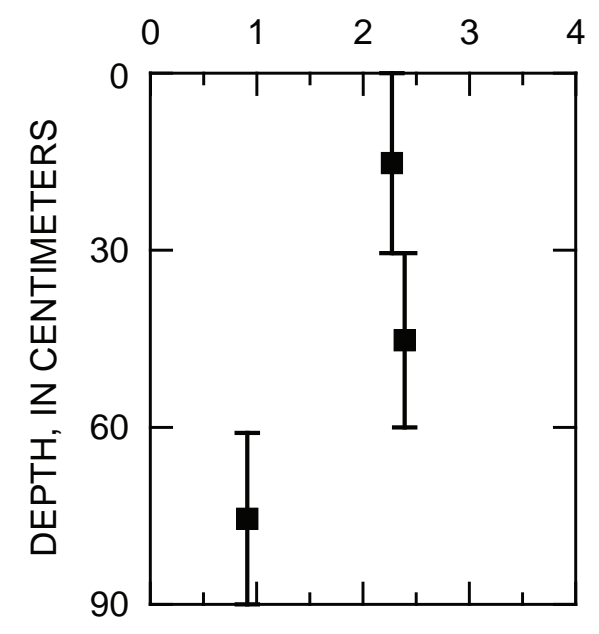

Figure D10. Vertical profiles of total mercury concentrations, percentages of sand, silt and clay, and total organic carbon at confined aquatic disposal pit core PIT-03 of Operable Unit B Marine of the Bremerton naval complex, Washington, 2005 (U.S. Navy, 2006b). 
TOTAL MERCURY

IN MILLIGRAMS PER KILOGRAM,

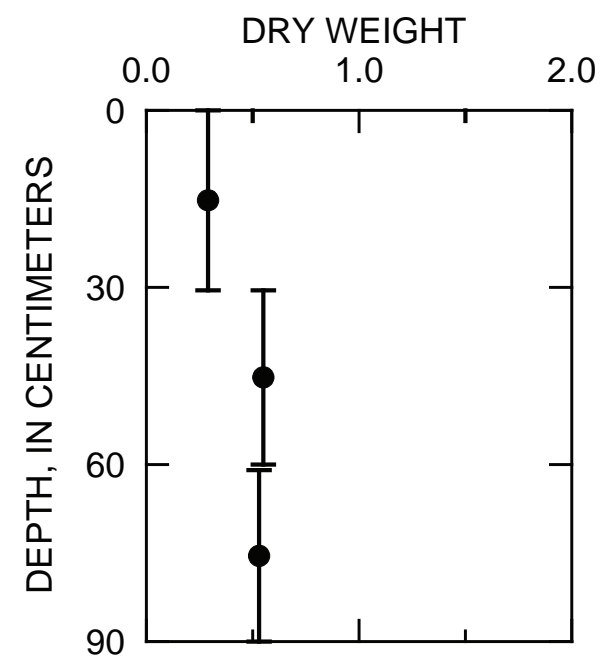

TOTAL ORGANIC CARBON, IN PERCENTAGE BY DRY WEIGHT

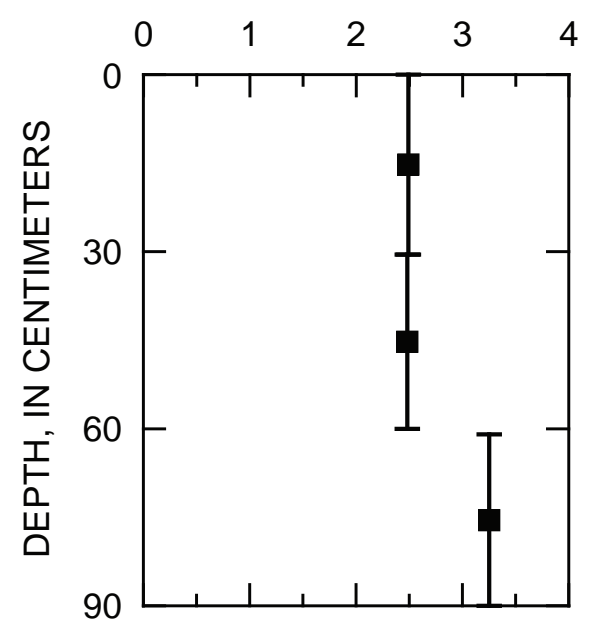

Figure D11. Vertical profiles of total mercury concentrations, percentages of sand, silt and clay), and total organic carbon at confined aquatic disposal pit core PIT-04 of Operable Unit B Marine of the Bremerton naval complex, Washington, 2005 (U.S. Navy, 2006b). 
TOTAL MERCURY,

IN MILLIGRAMS PER KILOGRAM, DRY WEIGHT,

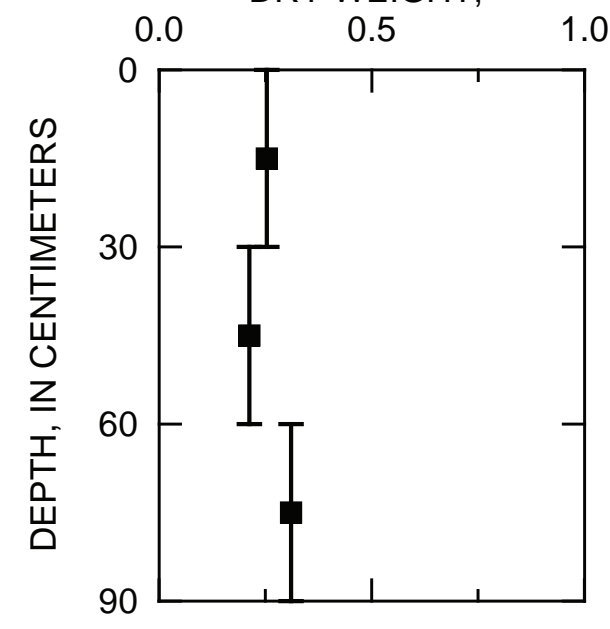

TOTAL ORGANIC CARBON, IN PERCENTAGE BY DRY WEIGHT

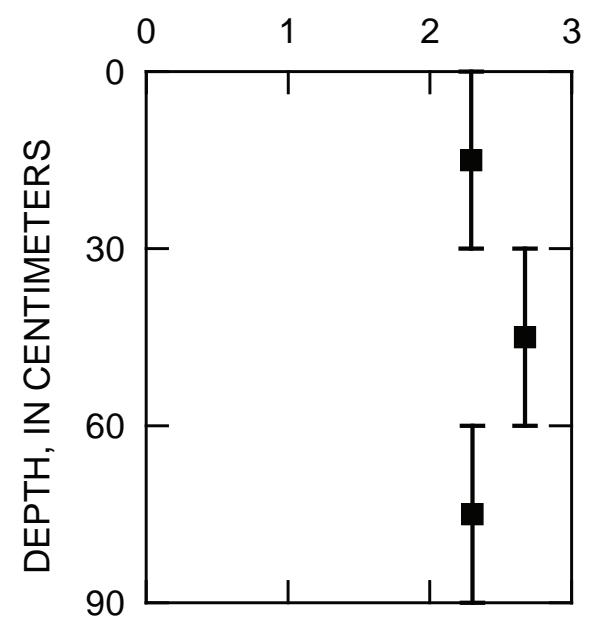

GRAIN SIZES, IN PERCENTAGE BY DRY WEIGHT
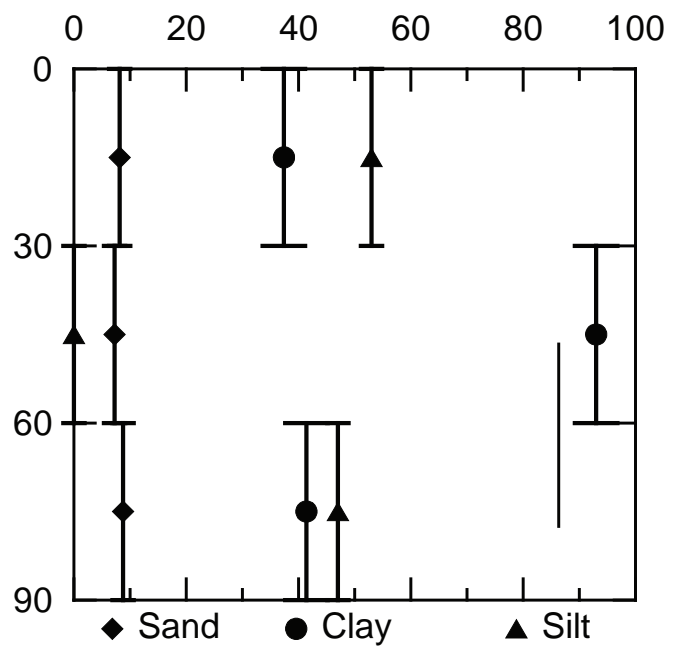

Figure D12. Vertical profiles of total mercury concentrations, percentages of sand, silt and clay, and total organic carbon, and percentage of solids at confined aquatic disposal pit core PIT-01 of Operable Unit B Marine of the Bremerton naval complex, Washington, 2007 (U.S. Navy, 2008b). 
TOTAL MERCURY,

IN MILLIGR AMS PER KILOGRAM, DRY WEIGHT

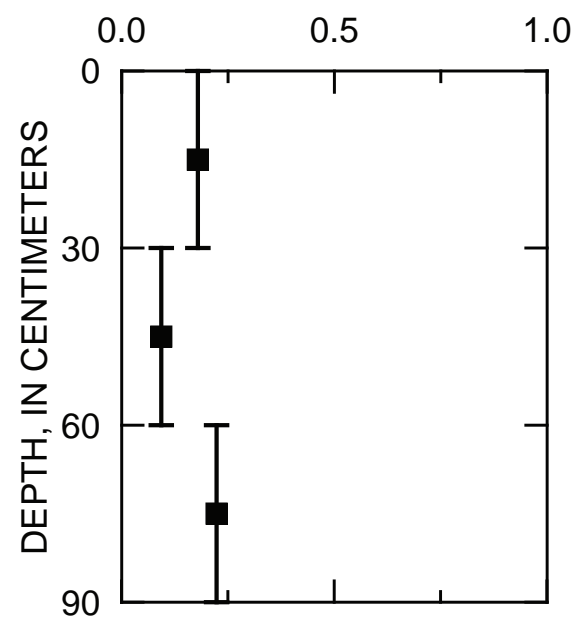

GRAIN SIZES,

IN PERCENTAGE BY DRY WEIGHT

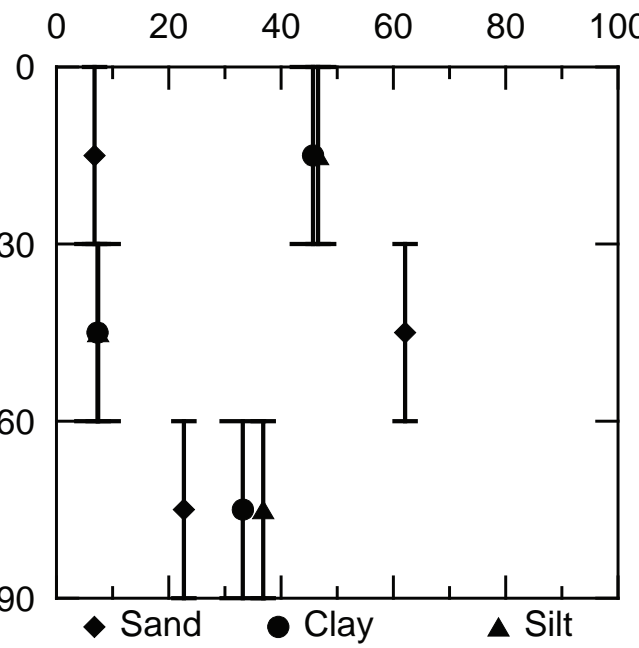

TOTAL ORGANIC CARBON, IN PERCENTAGE BY DRY WEIGHT

SOLIDS, PERCENTAGE BY WEIGHT
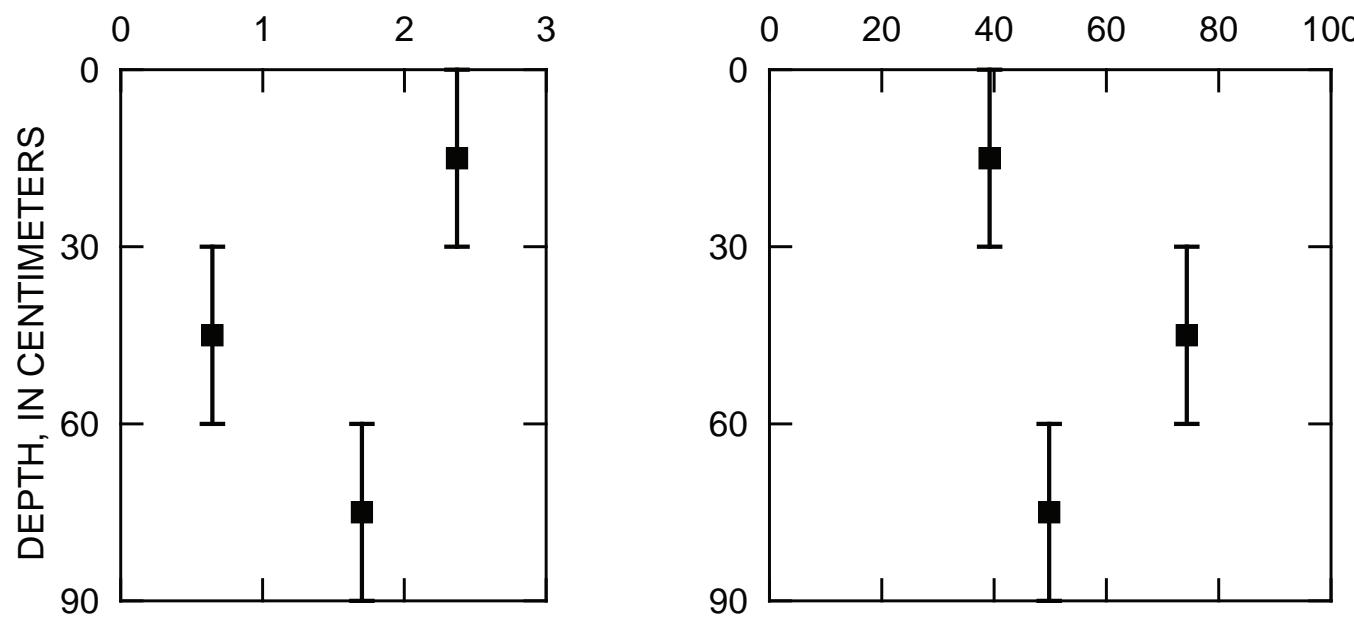

Figure D13. Vertical profiles of total mercury concentrations, percentages of sand, silt and clay, and total organic carbon, and percentage of solids at confined aquatic disposal pit core PIT-02 of Operable Unit B Marine of the Bremerton naval complex, Washington, 2007 (U.S. Navy, 2008b). 
TOTAL MERCURY,

IN MILLIGRAMS PER KILOGRAM, DRY WEIGHT

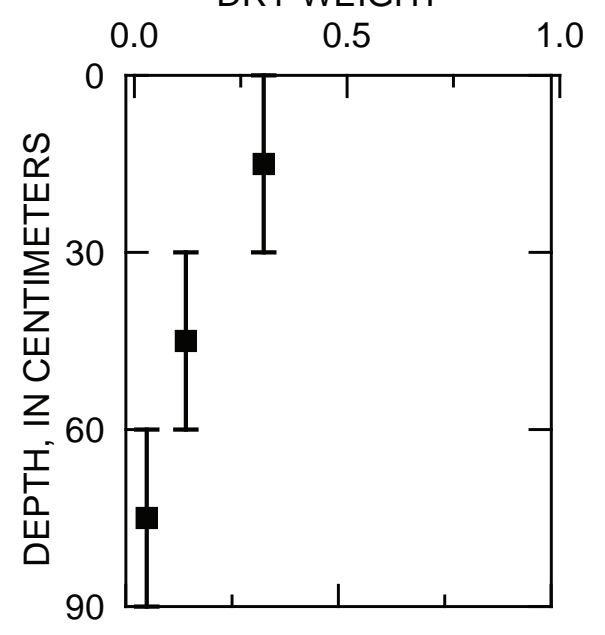

TOTAL ORGANIC CARBON, IN PERCENTAGE BY DRY WEIGHT

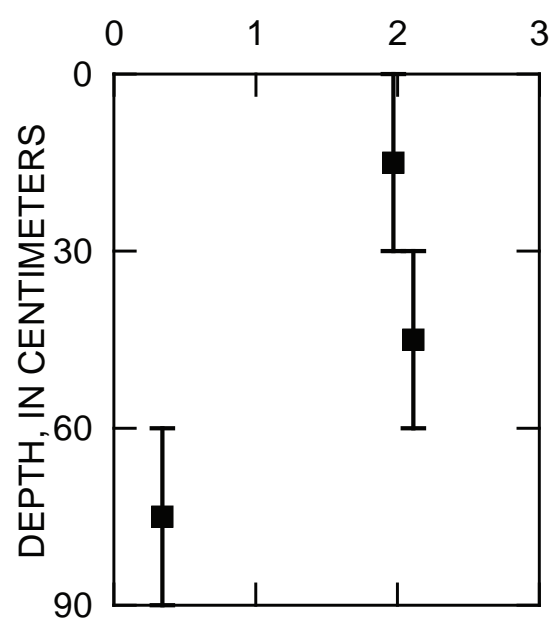

GRAIN SIZES, IN PERCENTAGE BY DRY WEIGHT

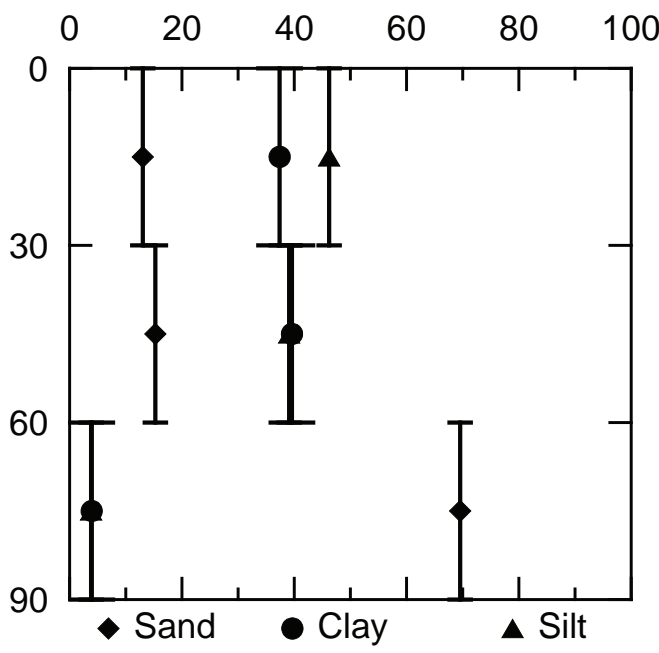

Figure D14. Vertical profiles of total mercury concentrations, percentages of sand, silt and clay, and total organic carbon, and percentage of solids at confined aquatic disposal pit corePIT-03 of Operable Unit B Marine of the Bremerton naval complex, Washington, 2007 (U.S. Navy, 2008b). 
TOTAL MERCURY,

IN MILLIGRAMS PER KILOGRAM, DRY WEIGHT

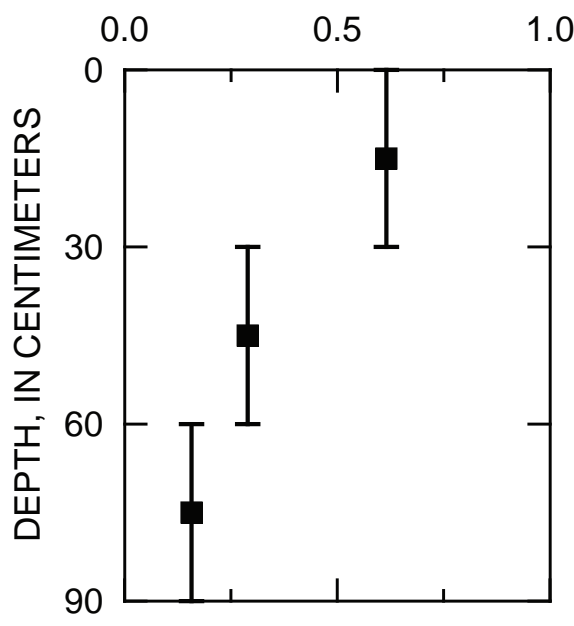

TOTAL ORGANIC CARBON, IN PERCENTAGE BY DRY WEIGHT

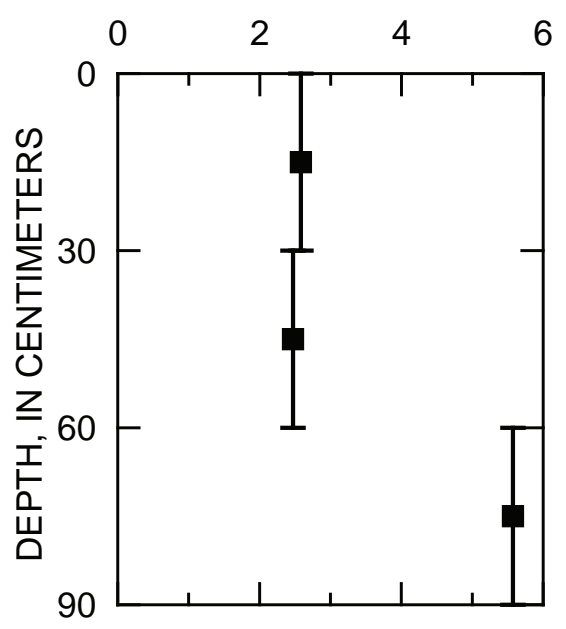

GRAIN SIZES, IN PERCENTAGE BY DRY WEIGHT

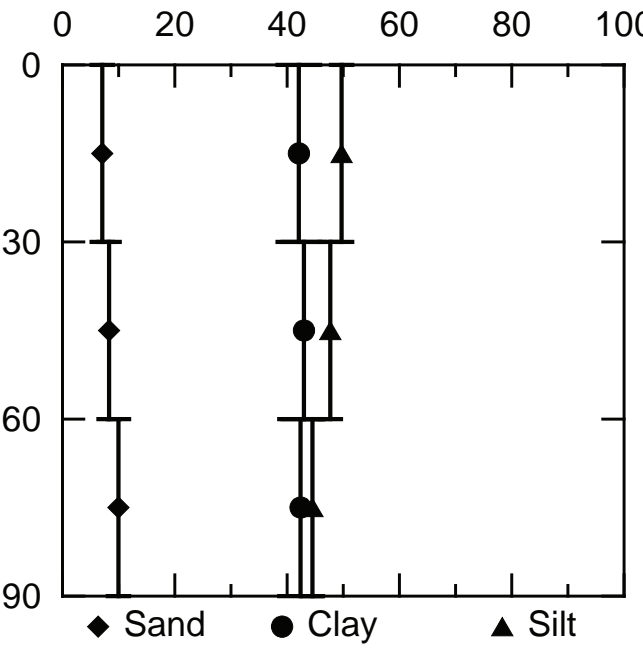

Figure D15. Vertical profiles of total mercury concentrations, percentages of sand, silt and clay, and total organic carbon, and percentage of solids at confined aquatic disposal pit core PIT-04 of Operable Unit B Marine of the Bremerton naval complex, Washington, 2007 (U.S. Navy, 2008b). 
TOTAL MERCURY,

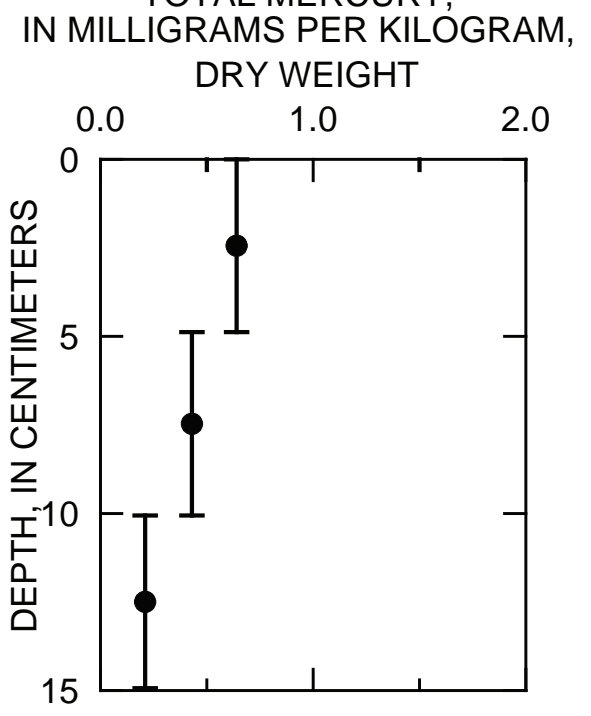

GRAIN SIZES, IN PERCENTAGE BY DRY WEIGHT

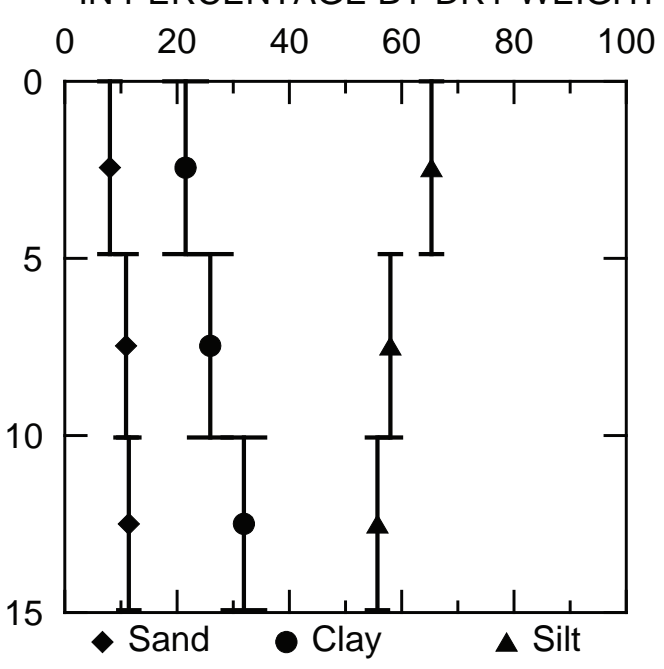

TOTAL ORGANIC CARBON, IN PERCENTAGE BY DRY WEIGHT

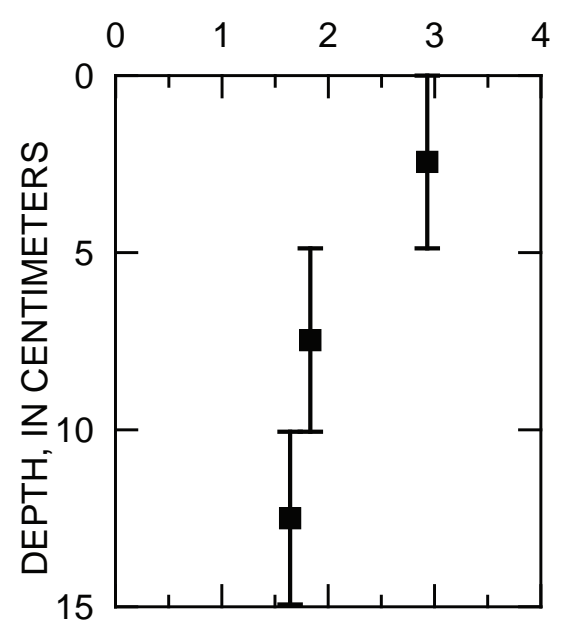

Figure D16. Vertical profiles of total mercury concentrations, percentages of sand, silt and clay, and total organic carbon in Transport Study Core NDC1 of Operable Unit B Marine of the Bremerton naval complex, Washington (U.S. Navy, 2007). 
TOTAL MERCURY,

IN MILLIGRAMS PER KILOGRAM,

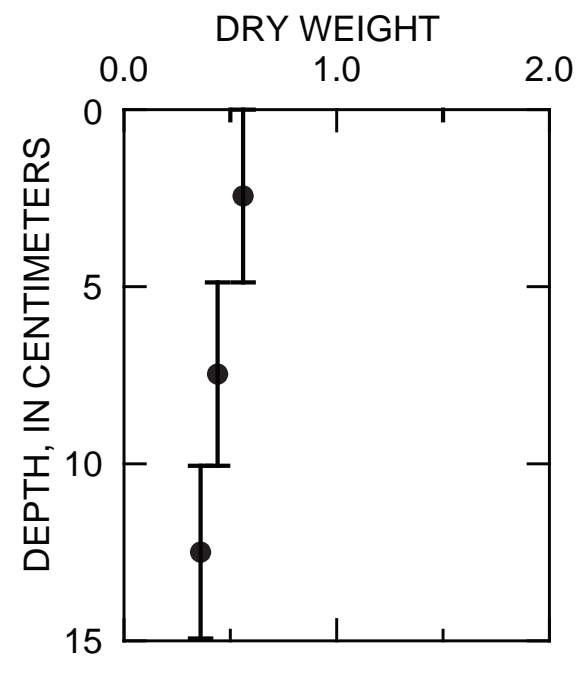

GRAIN SIZES, IN PERCENTAGE BY DRY WEIGHT

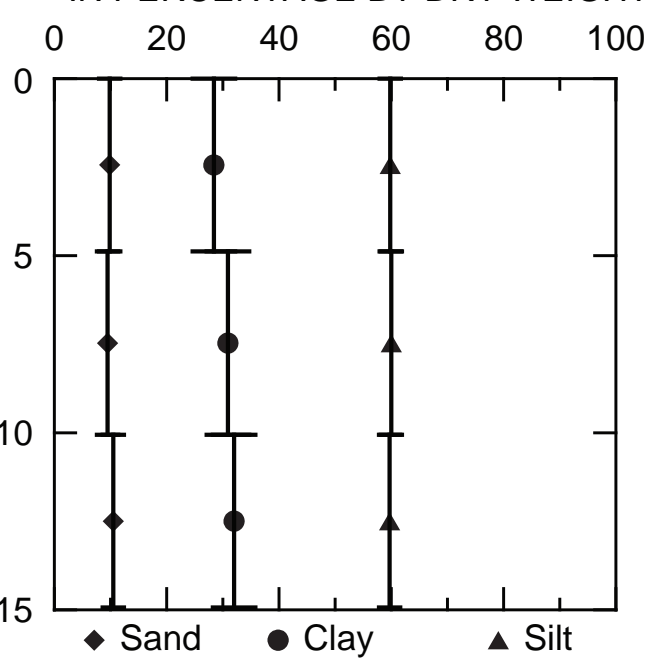

TOTAL ORGANIC CARBON,

IN PERCENTAGE BY DRY WEIGHT

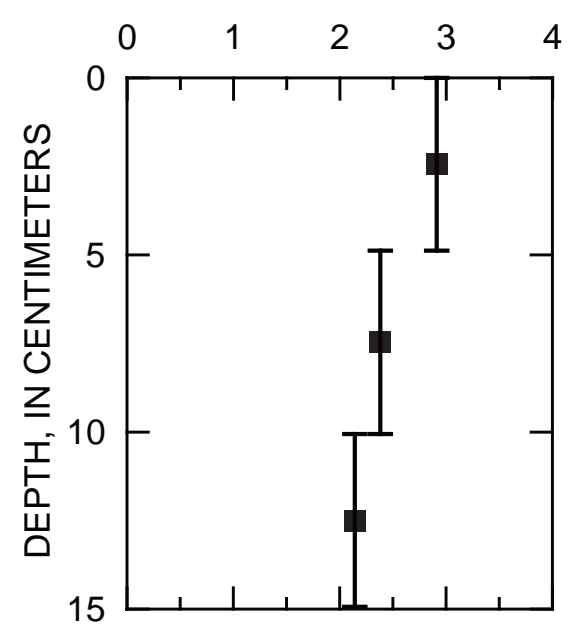

Figure D17. Vertical profiles of total mercury concentrations, percentages of sand, silt and clay, and total organic carbon in Transport Study Core NDC2 of Operable Unit B Marine of the Bremerton naval complex, Washington (U.S. Navy, 2007). 

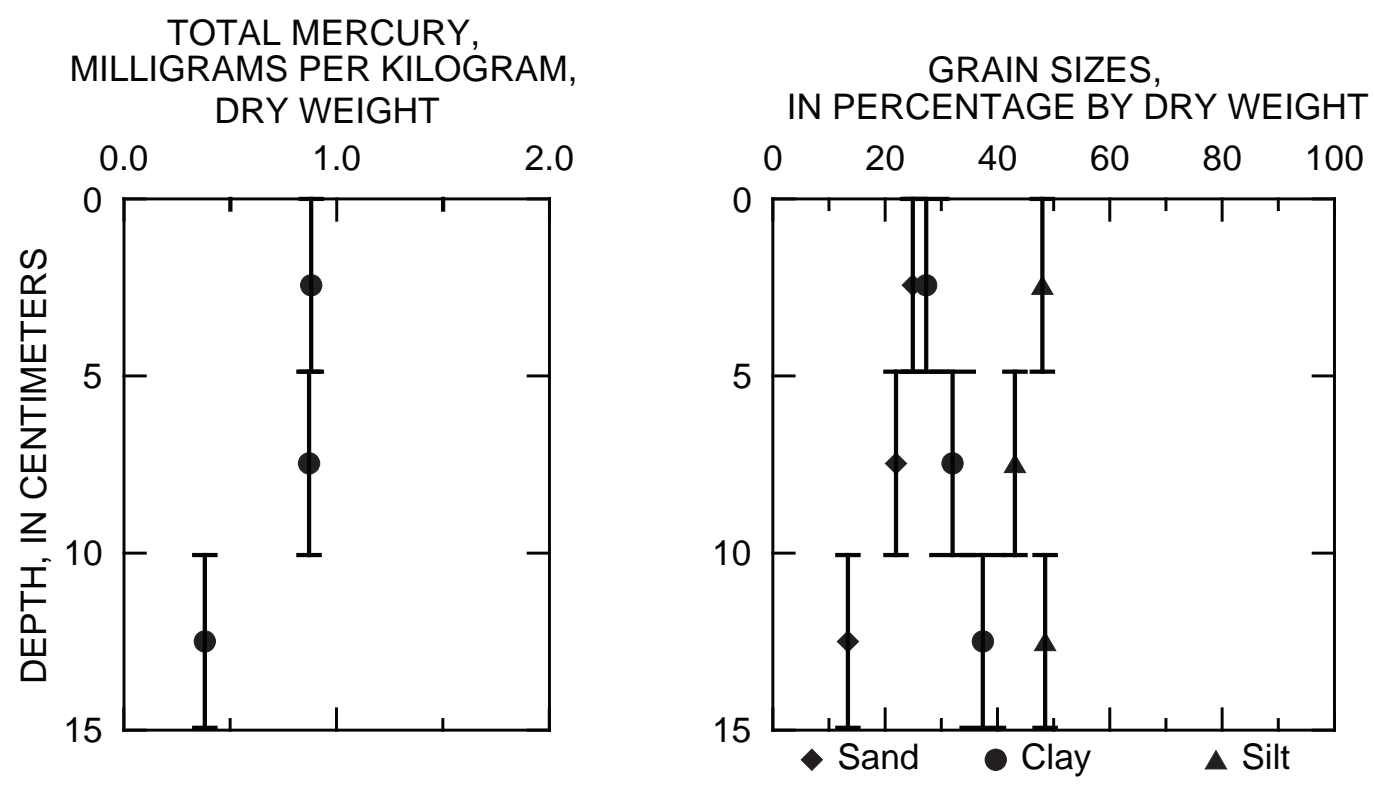

TOTAL ORGANIC CARBON,

IN PERCENTAGE BY DRY WEIGHT

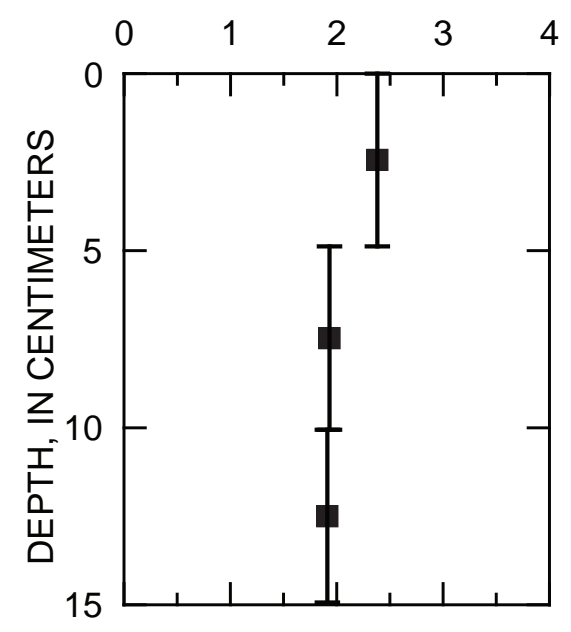

Figure D18. Vertical profiles of total mercury concentrations, percentages of sand, silt and clay, and total organic carbon in Transport Study Core RDC1 of Operable Unit B Marine of the Bremerton naval complex, Washington (U.S. Navy, 2007). 
TOTAL MERCURY

IN MILLIGRAMS PER KILOGRAM, DRY WEIGHT

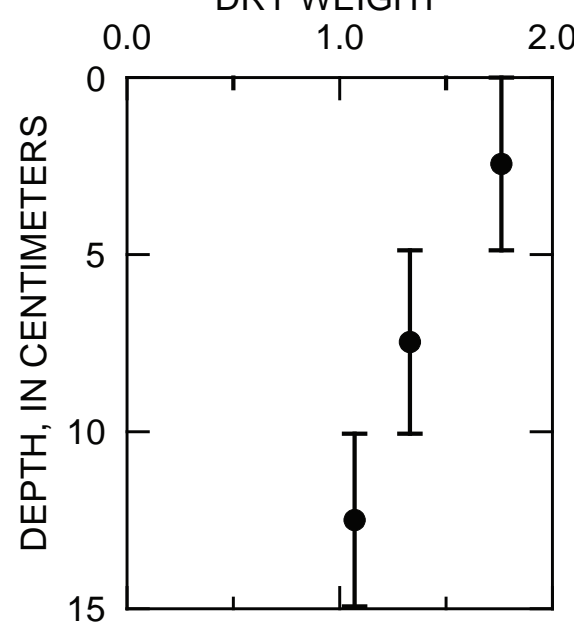

GRAIN SIZES, IN PERCENTAGE BY DRY WEIGHT

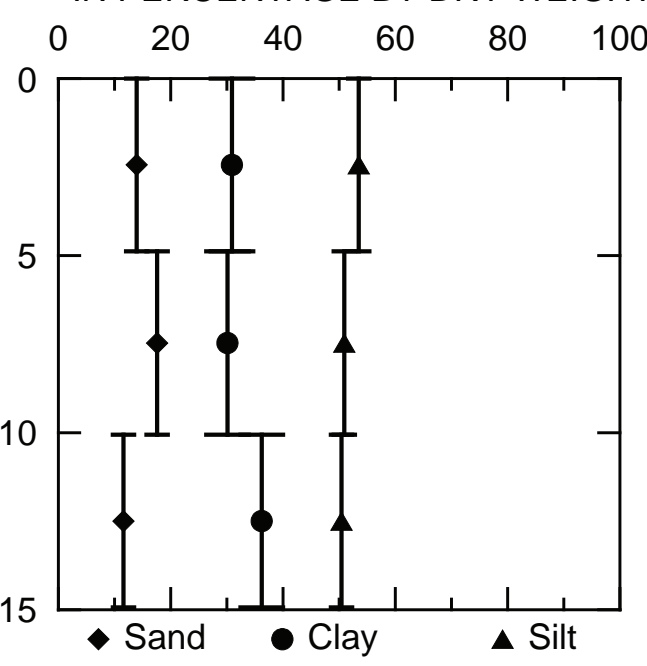

TOTAL ORGANIC CARBON, IN PERCENTAGE BY DRY WEIGHT

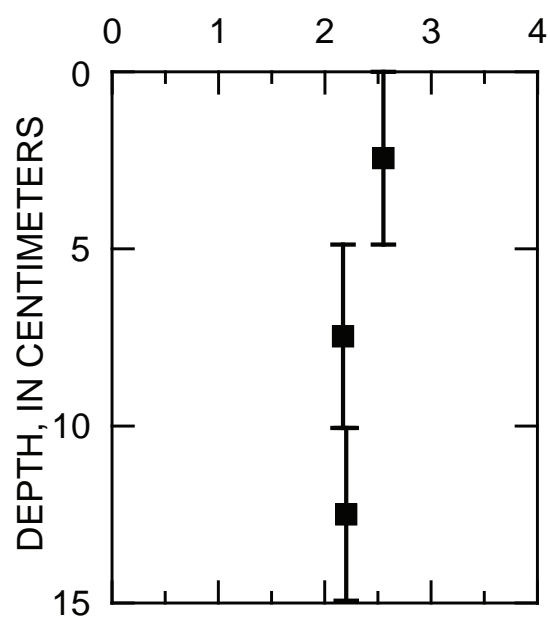

Figure D19. Vertical profiles of total mercury concentrations, percentages of sand, silt and clay, and total organic carbon in Transport Study Core RDC2 of Operable Unit B Marine of the Bremerton naval complex, Washington (U.S. Navy, 2007). 
TOTAL MERCURY, IN MILLIGRAMS PER KILOGRAM, DRY WEIGHT

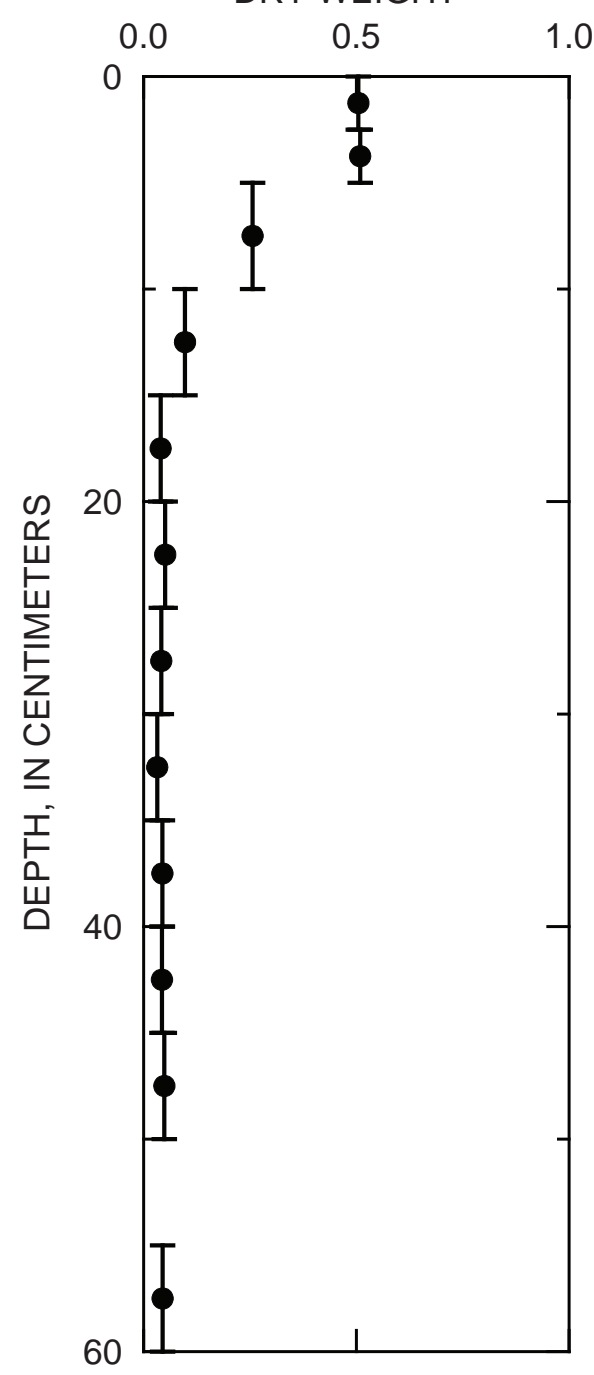

TOTAL ALUMINUM, IN MILLIGRAMS PER KILOGRAM, DRY WEIGHT

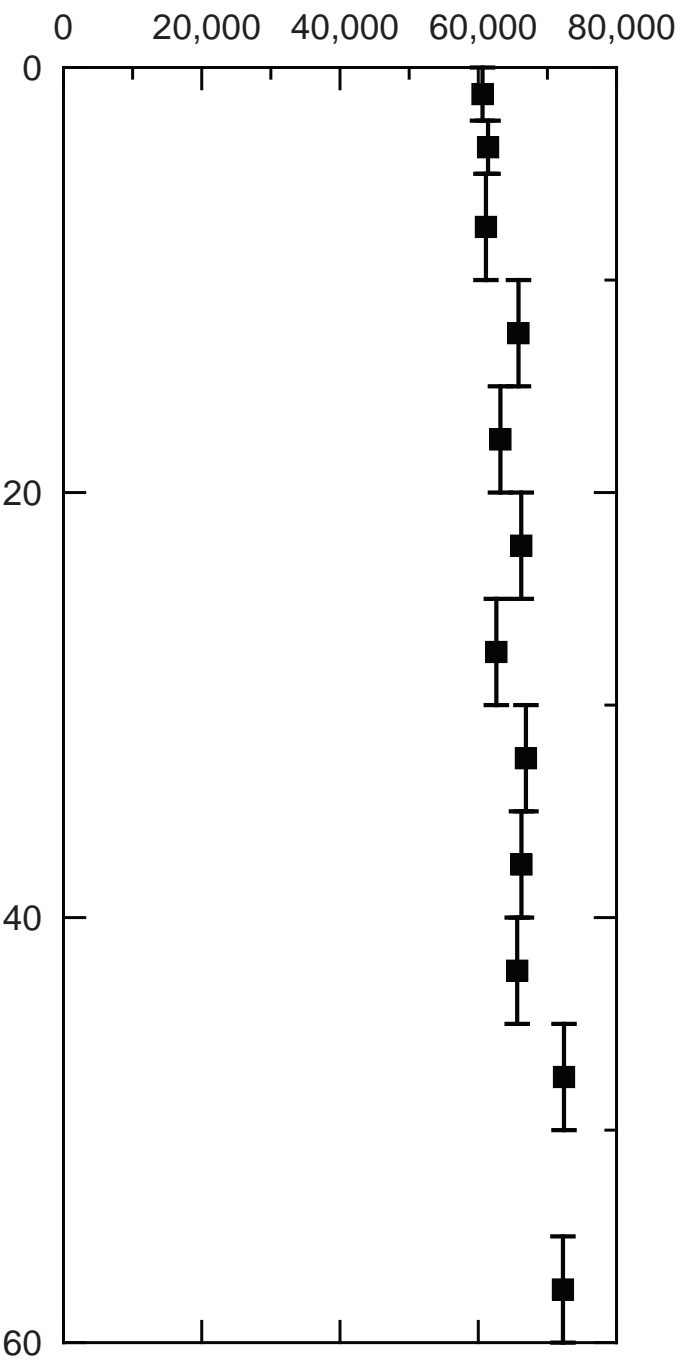

Figure D20. Vertical profiles of the total concentrations of total mercury and total aluminum from the ENVironment InVESTment core S1 in Sinclair Inlet, Washington, collected in 2002 (Crecelius and others, 2003). 
TOTAL MERCURY,

IN MILLIGRAMS PER KILOGRAM, DRY WEIGHT

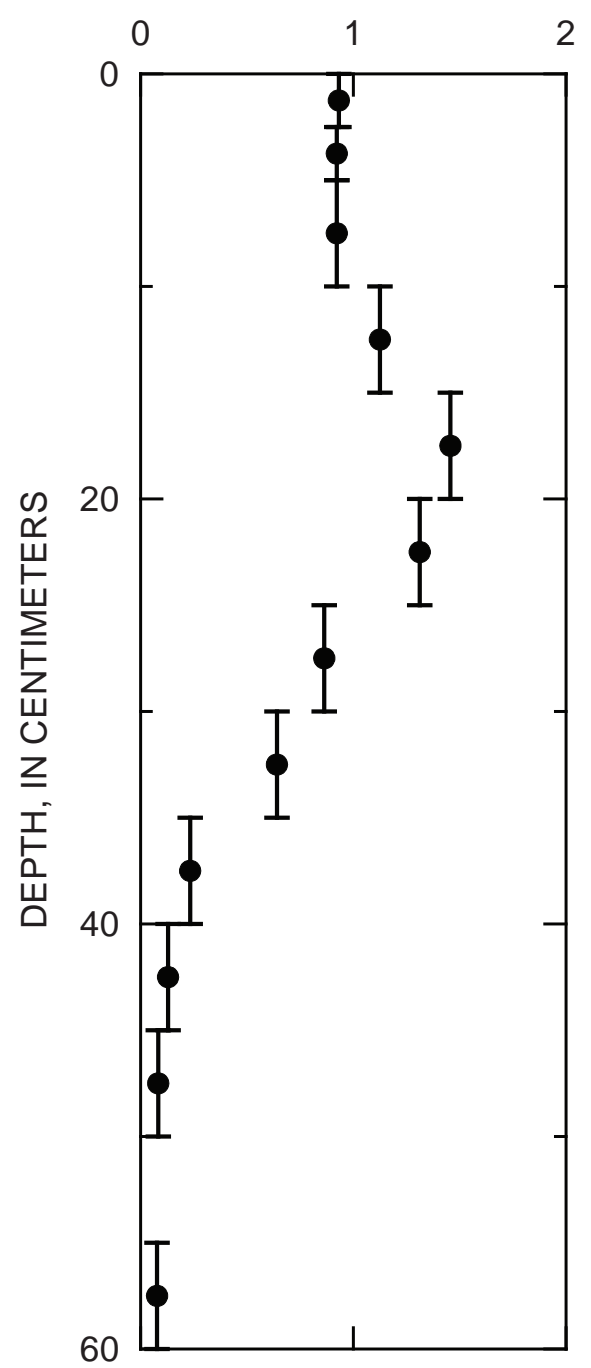

TOTAL ALUMINUM, IN MILLIGRAMS PER KILOGRAM, DRY WEIGHT

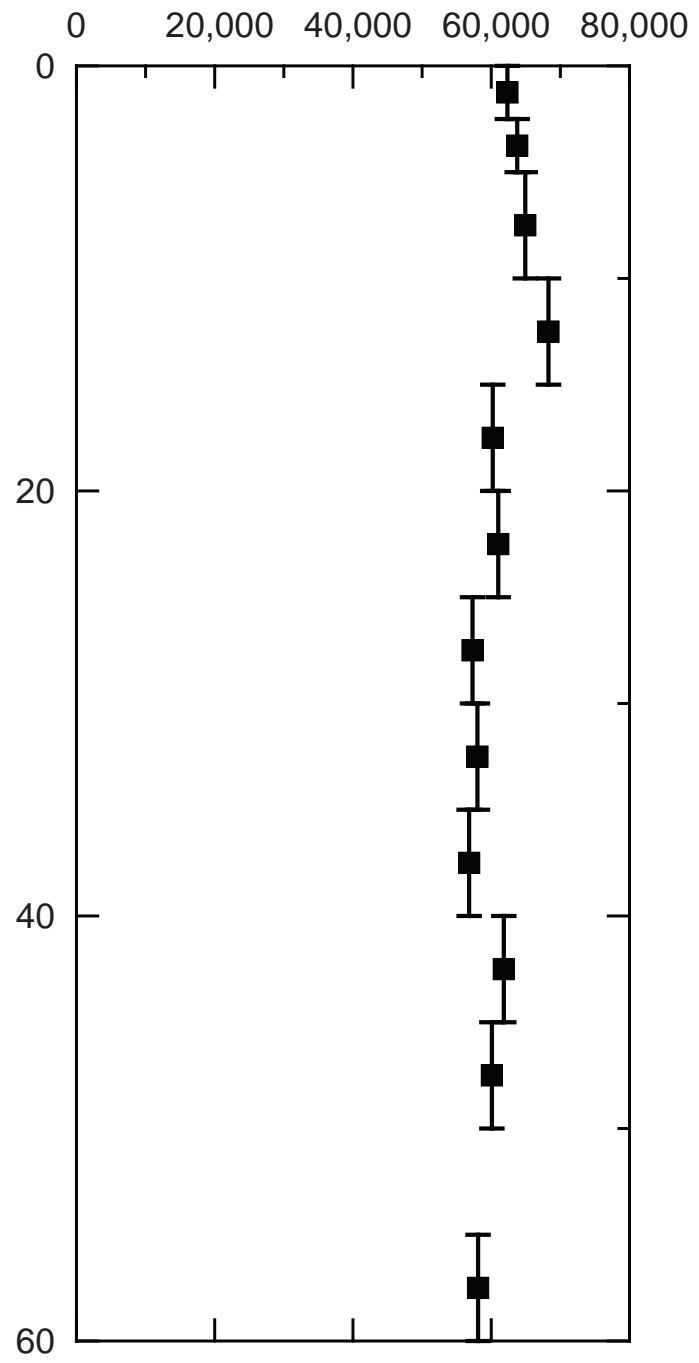

Figure D21. Vertical profiles of the total concentrations of total mercury and total aluminum from the ENVironment InVESTment core S2 in Sinclair Inlet, Washington, collected in 2002 (Crecelius and others, 2003). 

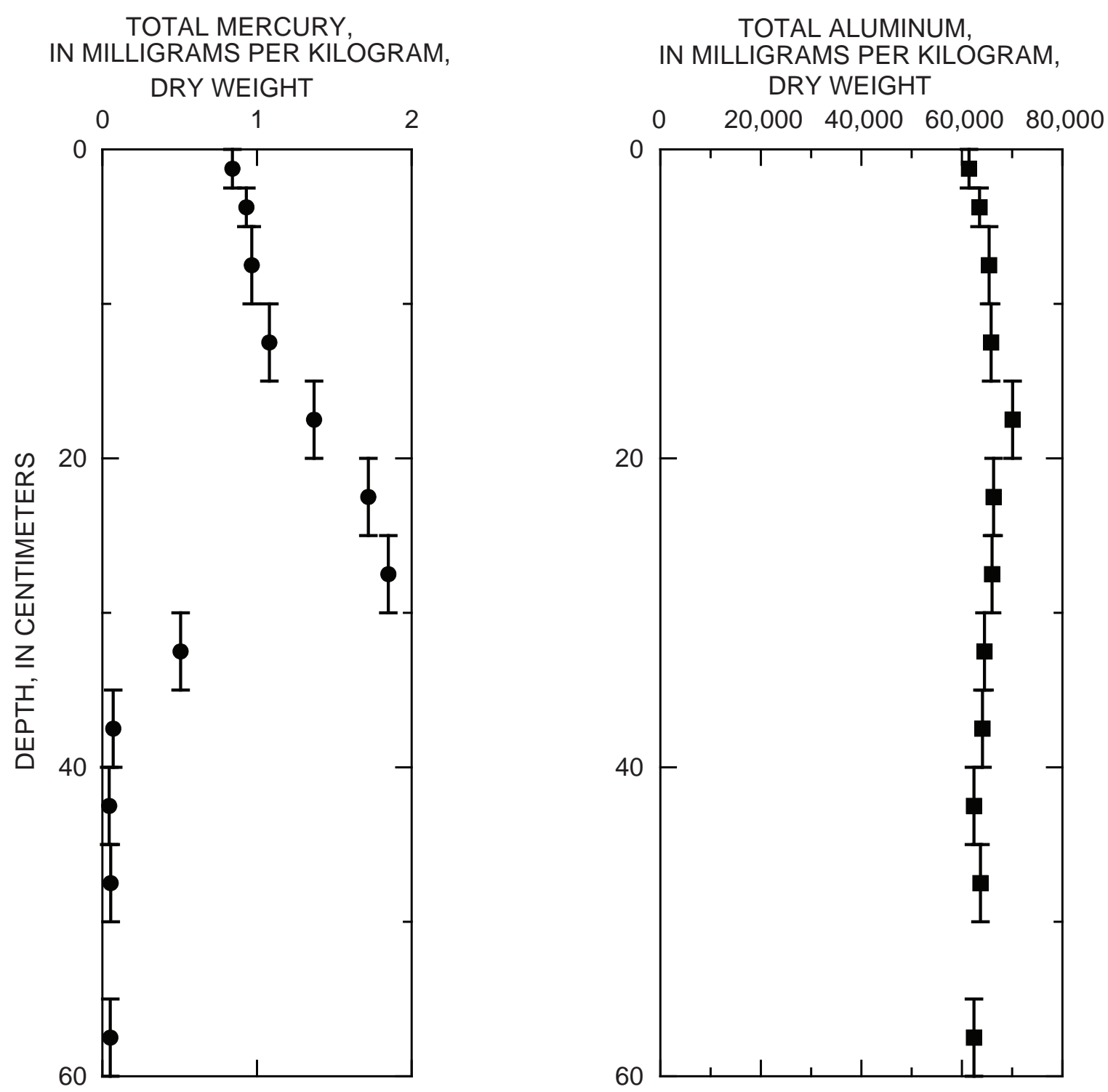

Figure D22. Vertical profiles of the concentrations of total mercury and total aluminum from the ENVironment InVESTment core S3 in Sinclair Inlet, Washington, collected in 2002 (Crecelius and others, 2003). 
TOTAL MERCURY,

IN MILLIGRAMS PER KILOGRAM, DRY WEIGHT

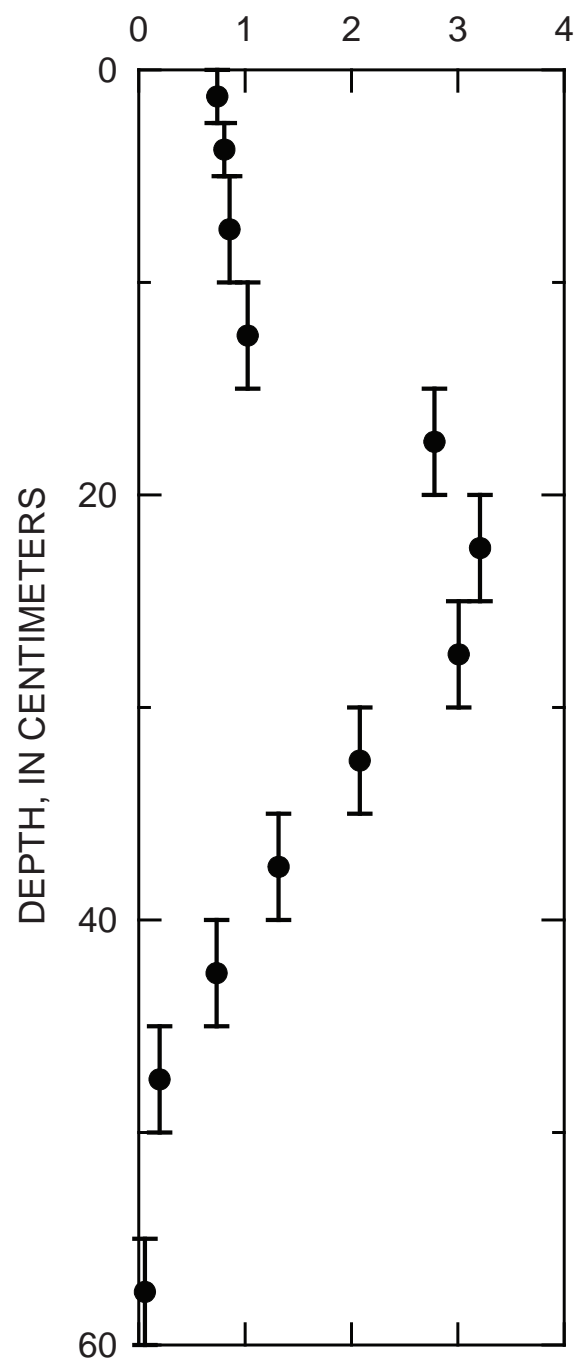

TOTAL ALUMINUM, IN MILLIGRAMS PER KILOGRAM, DRY WEIGHT

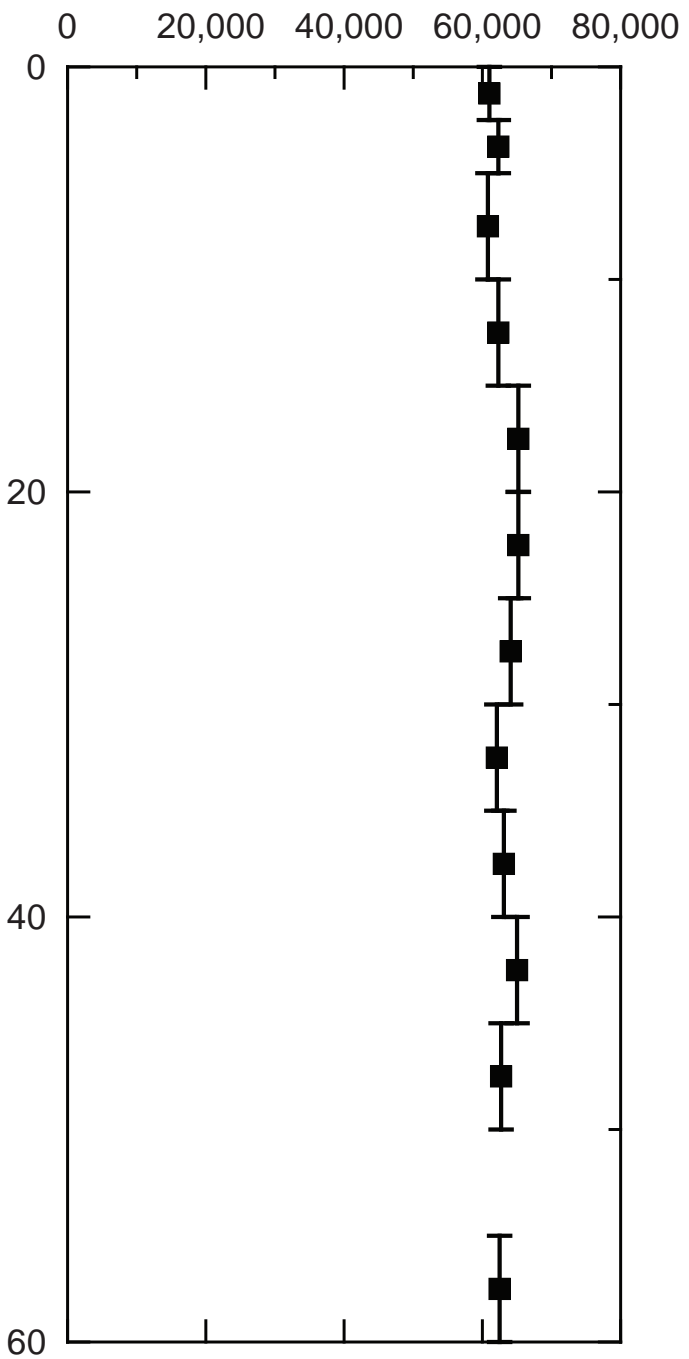

Figure D23. Vertical profiles of the concentrations of total mercury and total aluminum from the ENVironment InVESTment core S4 in Sinclair Inlet, Washington, collected in 2002 (Crecelius and others, 2003). 
TOTAL MERCURY, IN MILLIGRAMS PER KILOGRAM, DRY WEIGHT

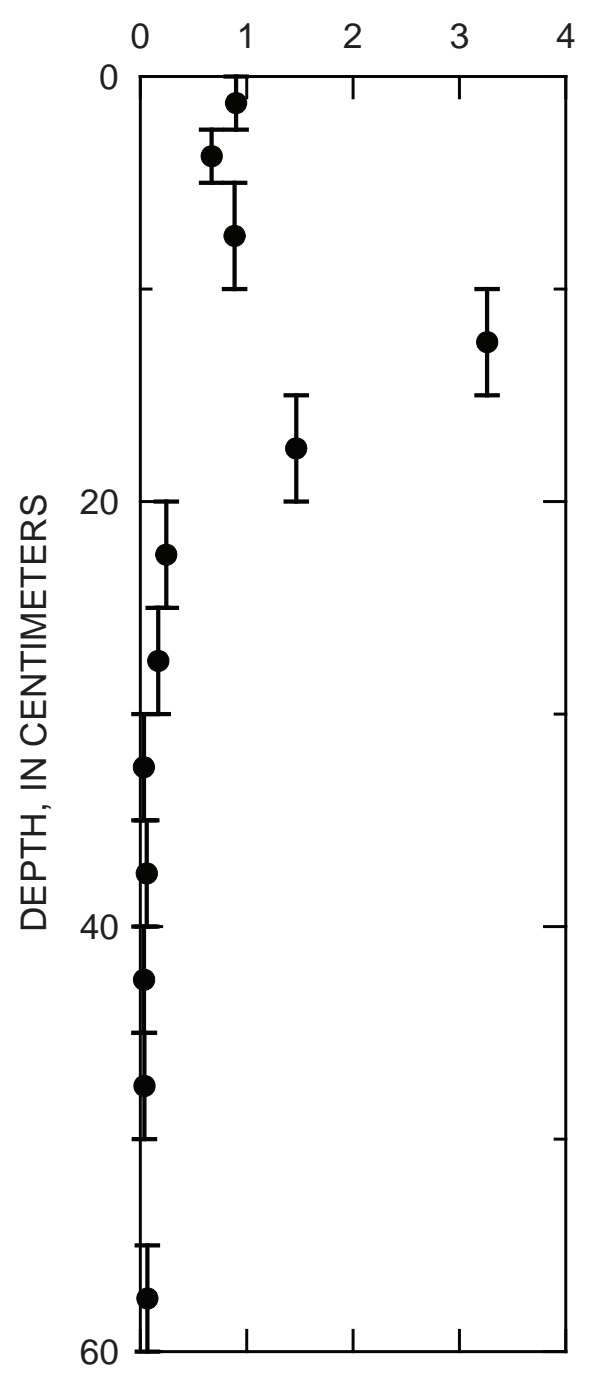

TOTAL ALUMINUM, IN MILLIGRAMS PER KILOGRAM, DRY WEIGHT

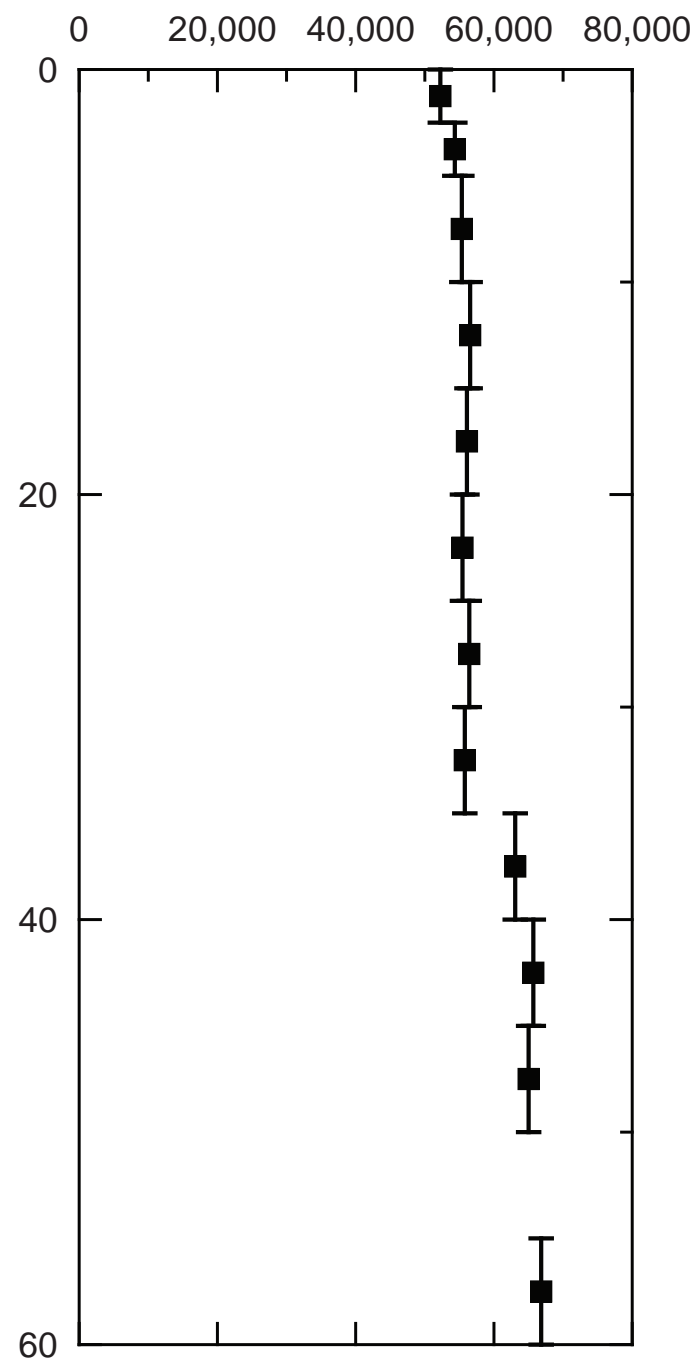

Figure D24. Vertical profiles of the concentrations of total mercury and total aluminum from the ENVironment InVESTment core S5 in Sinclair Inlet, Washington, collected in 2002 (Crecelius and others, 2003). 


\section{Appendix E. Residuals for Long-Term Monitoring Program}

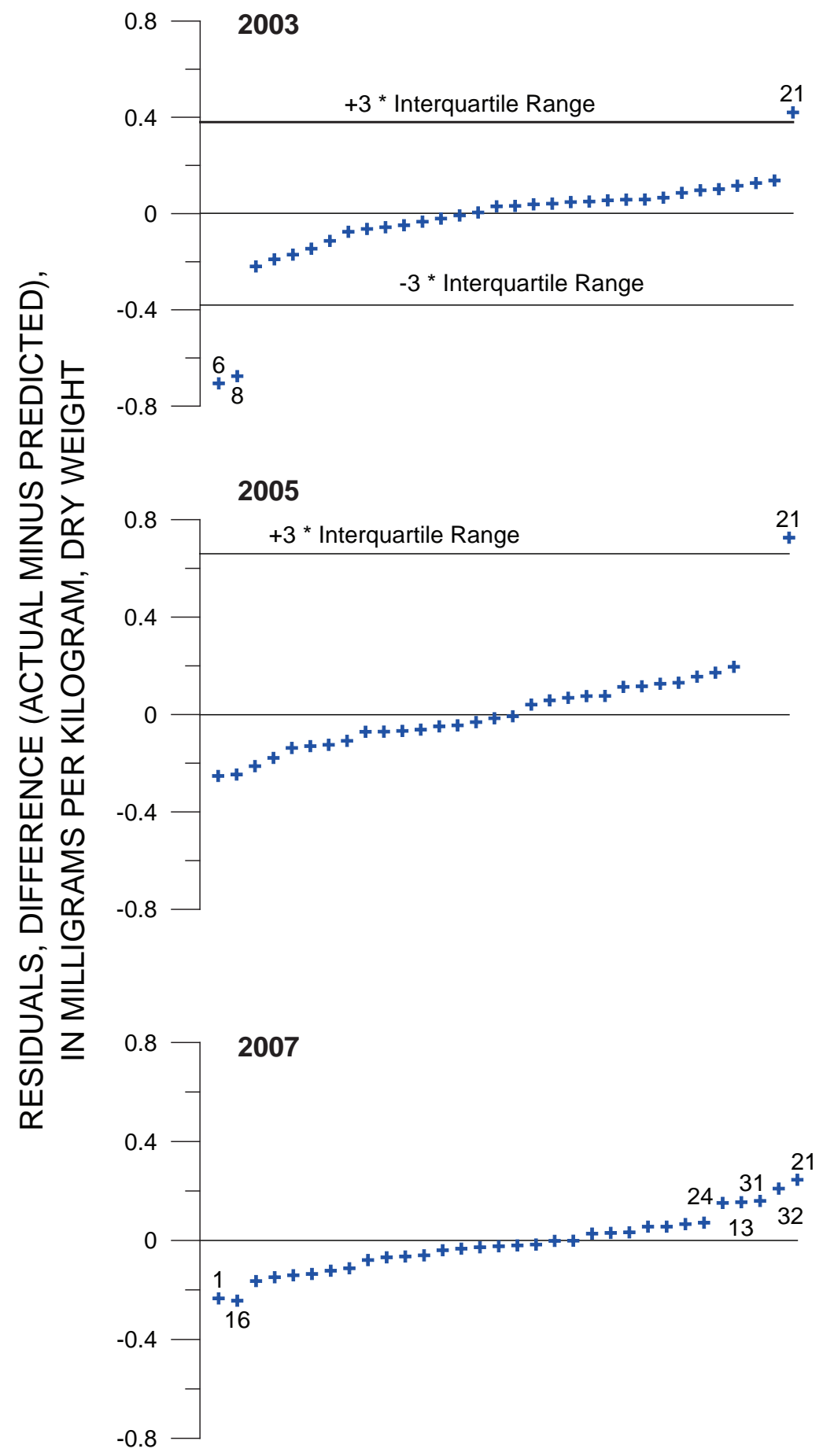

Figure E1. Rank ordered residuals of total mercury compared to total organic carbon in the surface sediment $(0-10 \mathrm{~cm})$ from outside of Operable Unit B Marine of the Bremerton naval complex, Washington, collected in 2003, 2005 and 2007 with low and high outliers labeled with 1,500-ft grid cell numbers. The samples were composites of three grab samples collected within each 1,500-ft grid cell (Data from U.S. Navy, 2006a, 2006b, 2008a). 


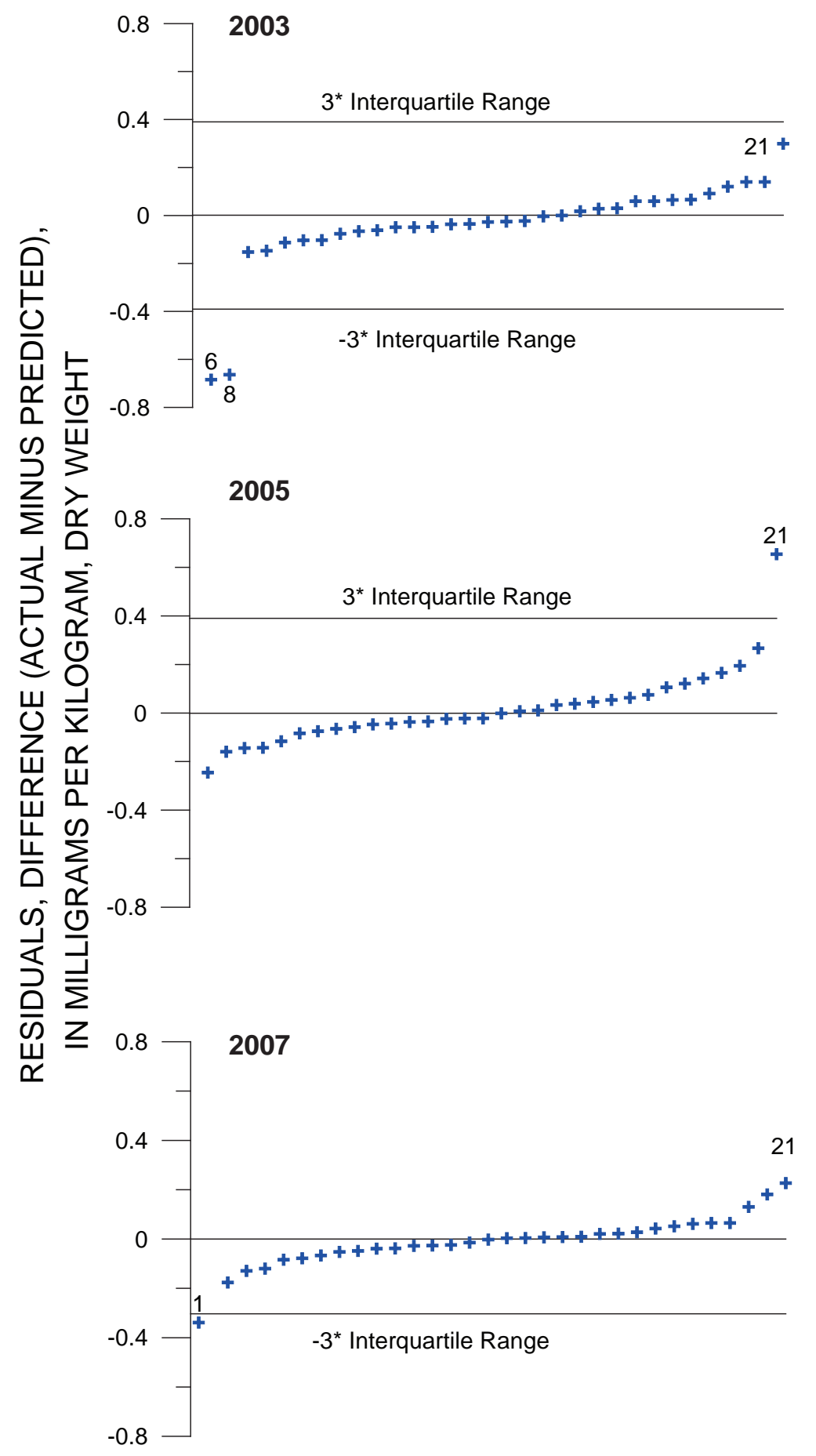

Figure E2. Rank ordered residuals of total mercury compared to total fines in the surface sediment $(0-10 \mathrm{~cm})$ from outside of Operable Unit B Marine of the Bremerton naval complex, Washington, collected in 2003, 2005 and 2007 with low and high outliers labeled with 1500 -ft grid cell numbers. The samples were composites of three grab samples collected within each 1,500-ft grid cell (Data from U.S. Navy, 2006a, 2006b, 2008a). 


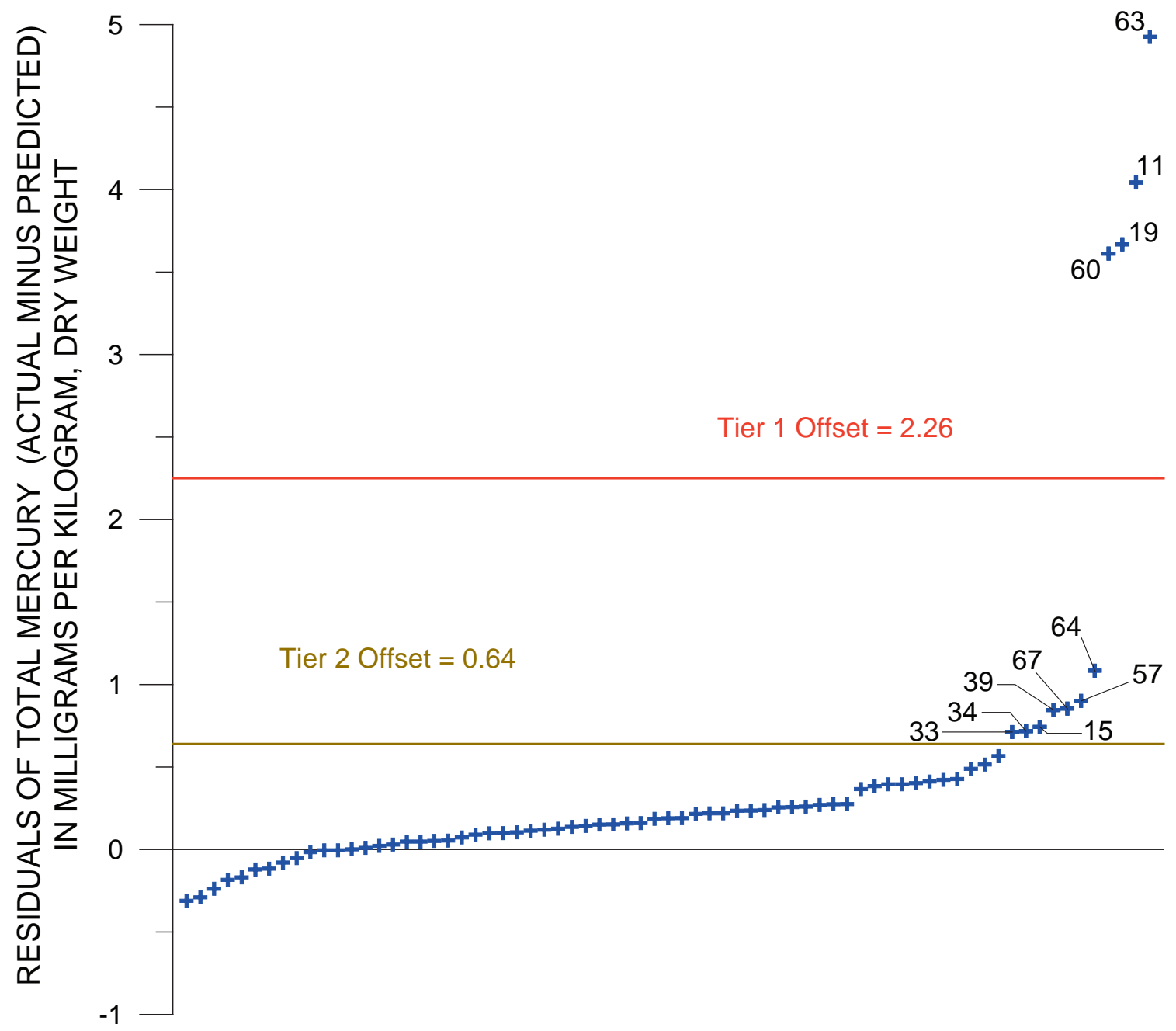

Figure E3. Rank ordered residuals of total mercury compared to total organic carbon in the surface sediment $(0-10 \mathrm{~cm})$ within the Operable Unit B Marine of the Bremerton naval complex, Washington, collected in 2003 with tier 1 and tier offsets and 500 -ft grid cell numbers of tier 1 and tier 2 samples labeled. The samples were composites of three grab samples collected within each 500-ft grid cell (Data from U.S. Navy, 2006a). 


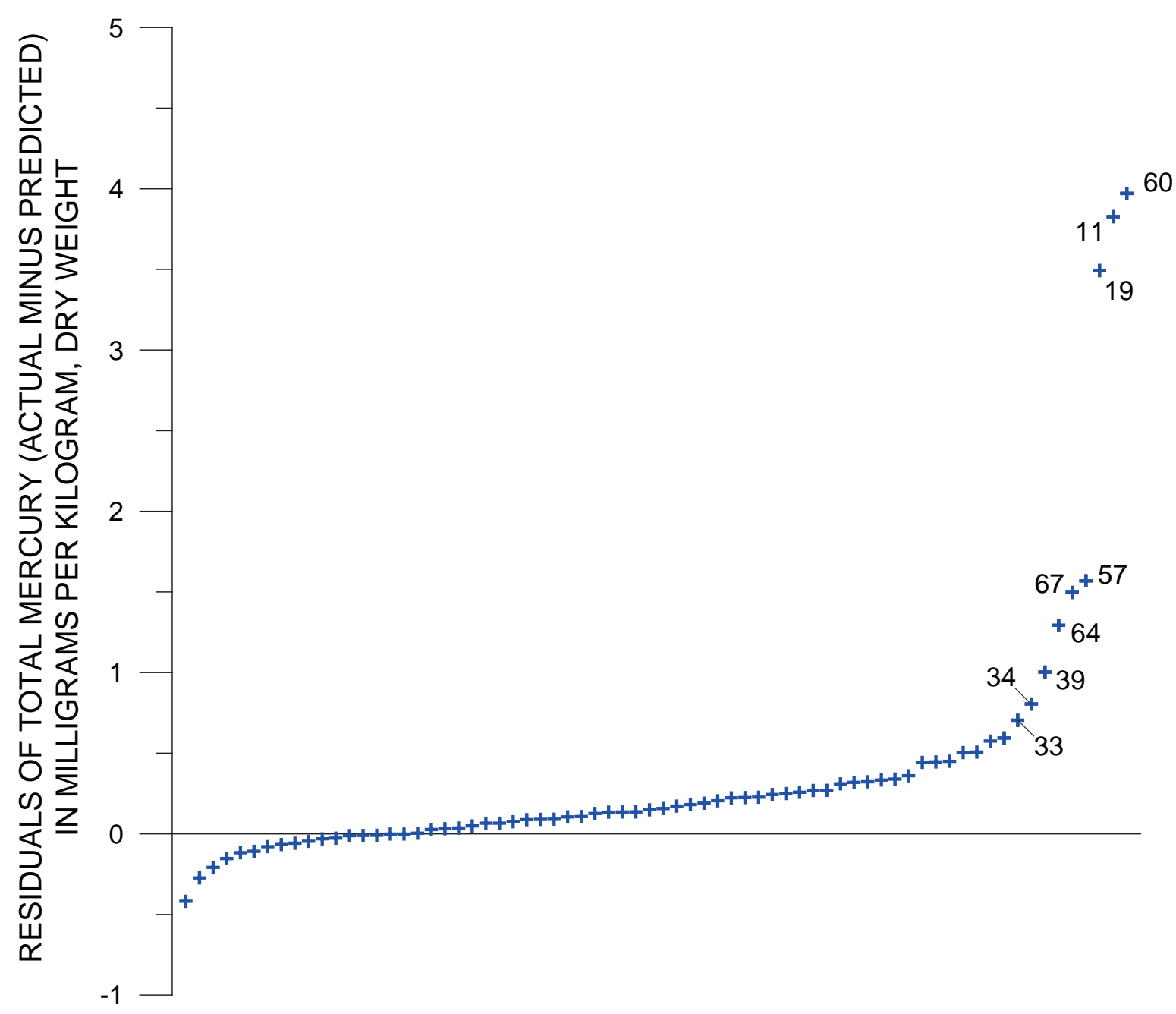

Figure E4. Rank ordered residuals of total mercury compared to fines in the surface sediment $(0-10 \mathrm{~cm})$ within the Operable Unit B Marine of the Bremerton naval complex, Washington, collected in 2003. The samples were composites of three grab samples collected within each 500 -ft grid cell (Data from U.S. Navy, 2006a). Samples of interest are labeled with their respective cell numbers of the $500-\mathrm{ft}$ grid. 
Grid 60, $y=19^{\wedge}$

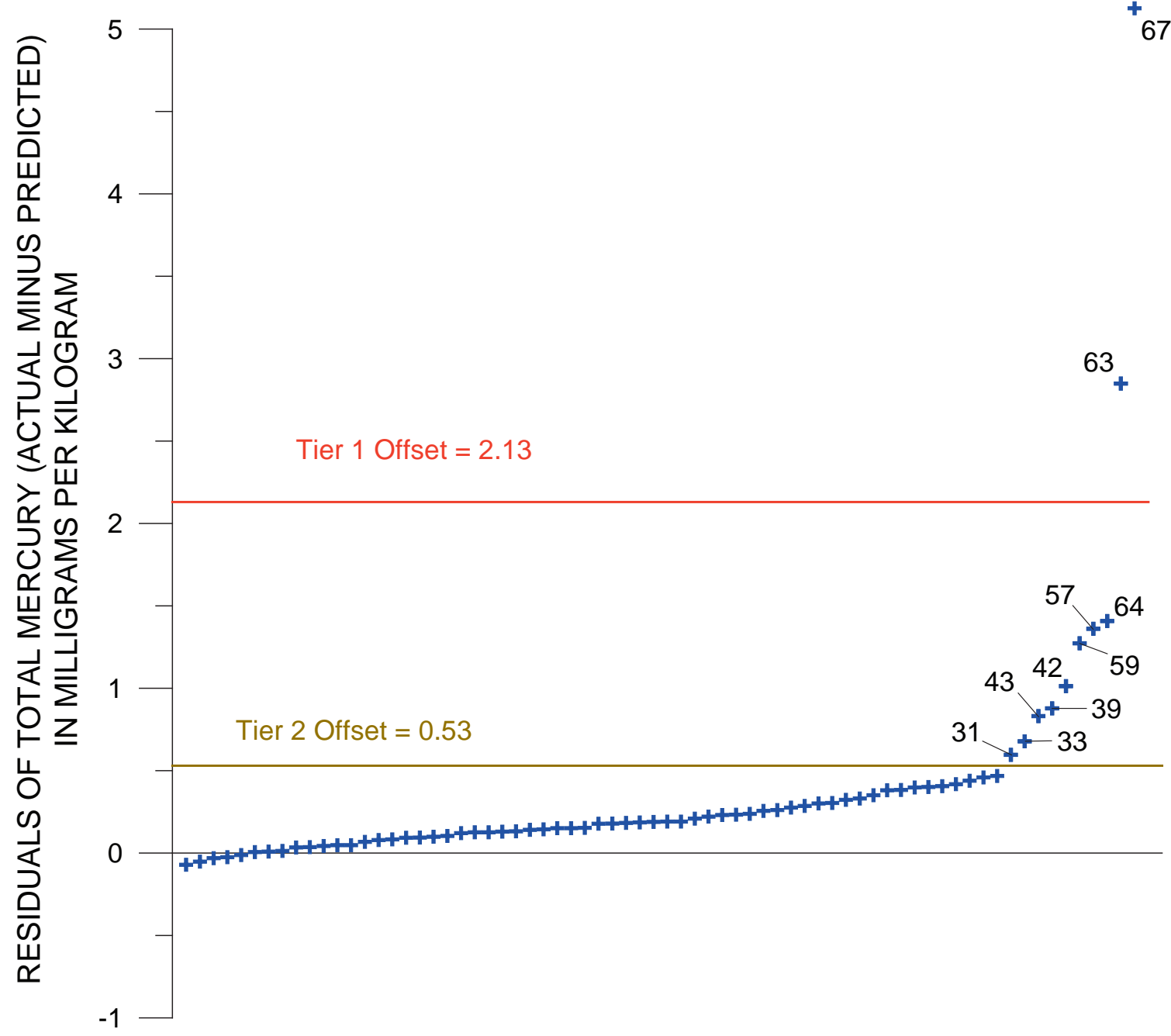

Figure E5. Rank ordered residuals of total mercury compared to total organic carbon in the surface sediment $(0-10 \mathrm{~cm})$ within the Operable Unit B Marine of the Bremerton naval complex, Washington, collected in 2005 with tier 1 and tier offsets and 500-ft grid cell numbers of tier 1 and tier 2 samples labeled. The samples were composites of three grab samples collected within each 500-ft grid cell (Data from U.S. Navy, 2006b). 
Cell 60, $y=-18.6^{\wedge}$

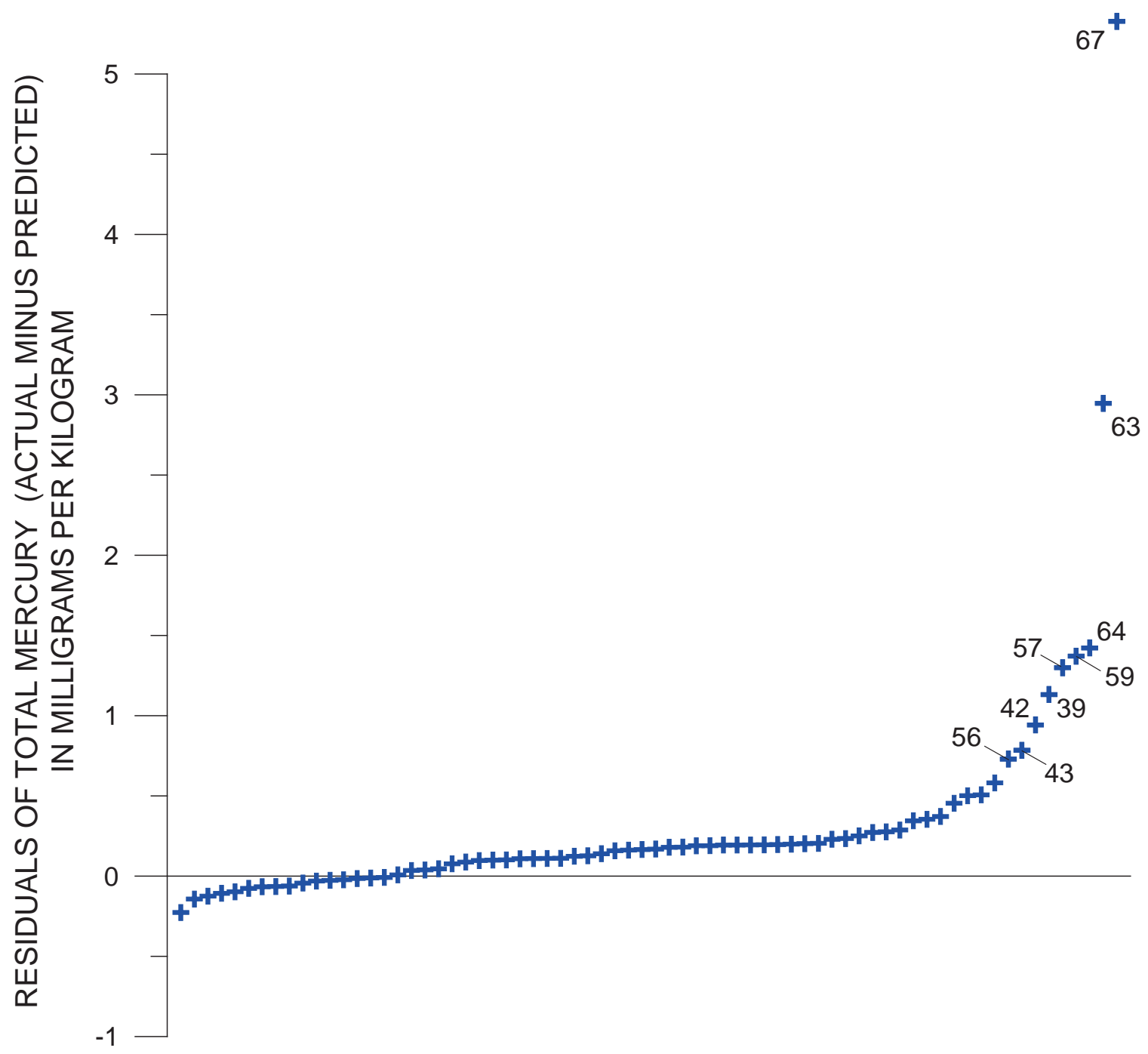

Figure E6. Rank ordered residuals of total mercury compared to total fines in the surface sediment $(0-10 \mathrm{~cm})$ within the Operable Unit B Marine of the Bremerton naval complex, Washington, collected in 2005. The samples were composites of three grab samples collected within each 500-ft grid cell (Data from U.S. Navy, 2006b). Samples of interest are labeled with their respective cell numbers of the $500-\mathrm{ft}$ grid. 


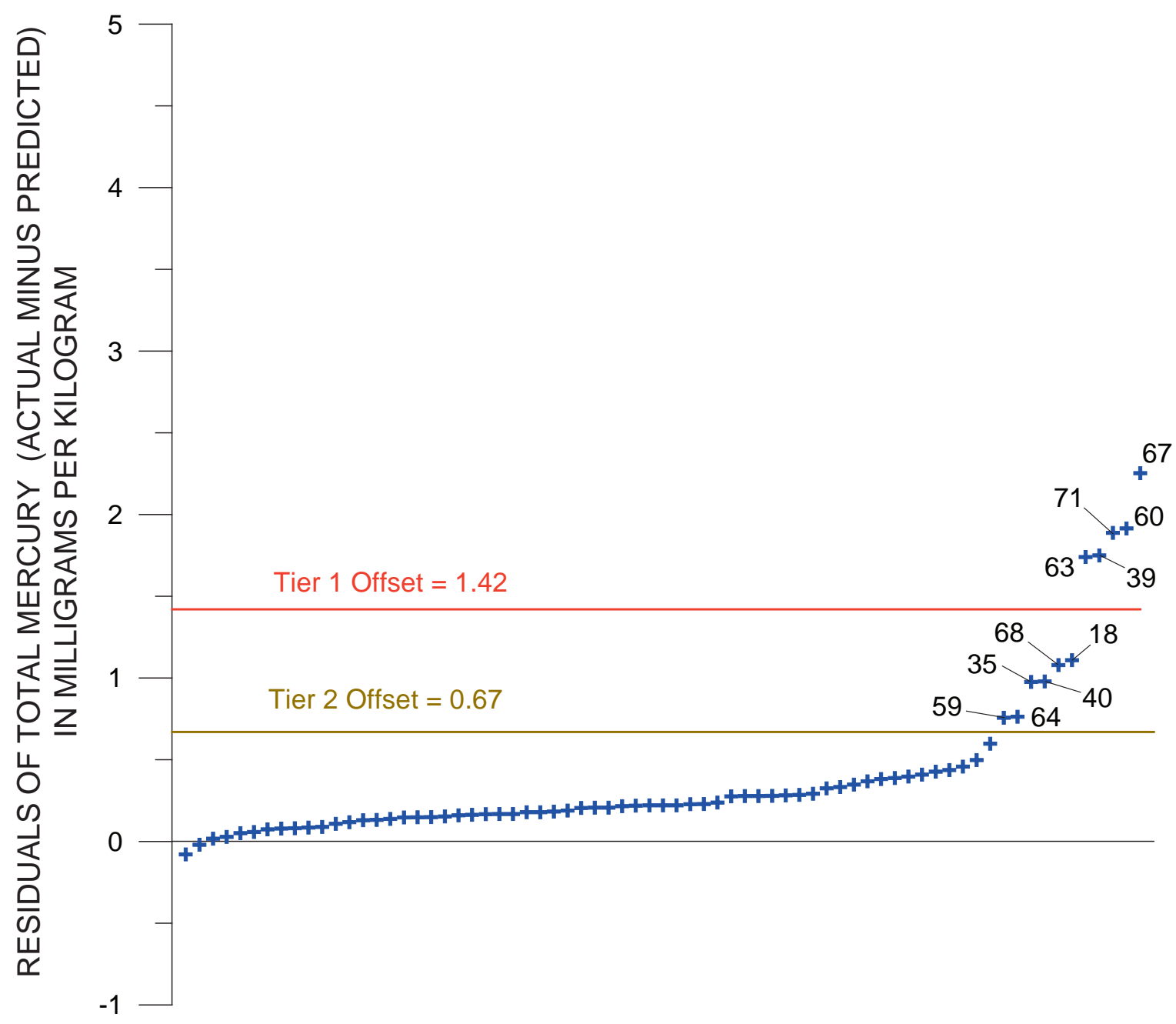

Figure E7. Rank ordered residuals of total mercury compared to total organic carbon in the surface sediment $(0-10 \mathrm{~cm})$ within the Operable Unit B Marine of the Bremerton naval complex, Washington, collected in 2007 with tier 1 and tier offsets and 500-ft grid cell numbers of tier 1 and tier 2 samples labeled. The samples were composites of three grab samples collected within each 500-ft grid cell (Data from U.S. Navy, 2008a). 


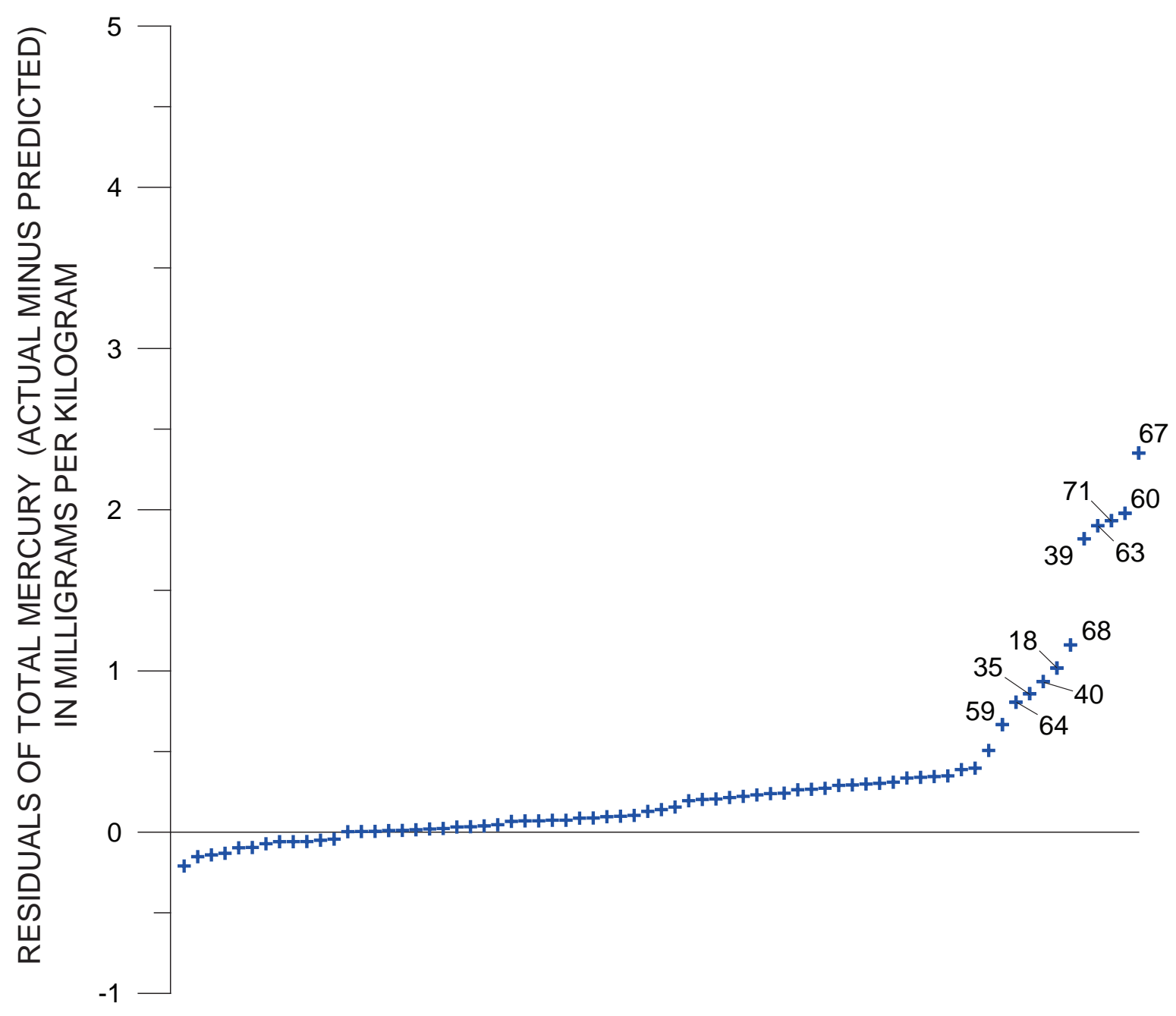

Figure E8. Rank ordered residuals of total mercury compared to total fines in the surface sediment $(0-10 \mathrm{~cm})$ within the Operable Unit B Marine of the Bremerton naval complex, Washington, collected in 2007. The samples were composites of three grab samples collected within each 500 -ft grid cell (Data from U.S. Navy, 2008a). Samples of interest are labeled with their respective cell numbers of the $500-\mathrm{ft}$ grid. 


\section{Appendix F. Listings of Biological Data Examined}

Table F1. Total mercury concentrations in whole specimens of staghorn sculpin, graceful crab, ratfish, surf perch, sand sole, rock sole, and sea cucumber collected from Puget Sound, Washington, and Strait of Georgia, British Columbia, Canada, 2003, 2005 , and 2007.

[Data Source: Brandenberger and others, 2006b, 2008; Johnston and others, 2007. Locations shown in figure 1A. Mercury: J, estimated positive value; U, not detected. Abbreviations: PSAMP, Puget Sound Ambient Monitoring Program; mg/kg, milligrams per kilogram; kg, kilogram; cm, centimeter; -, length not applicable]

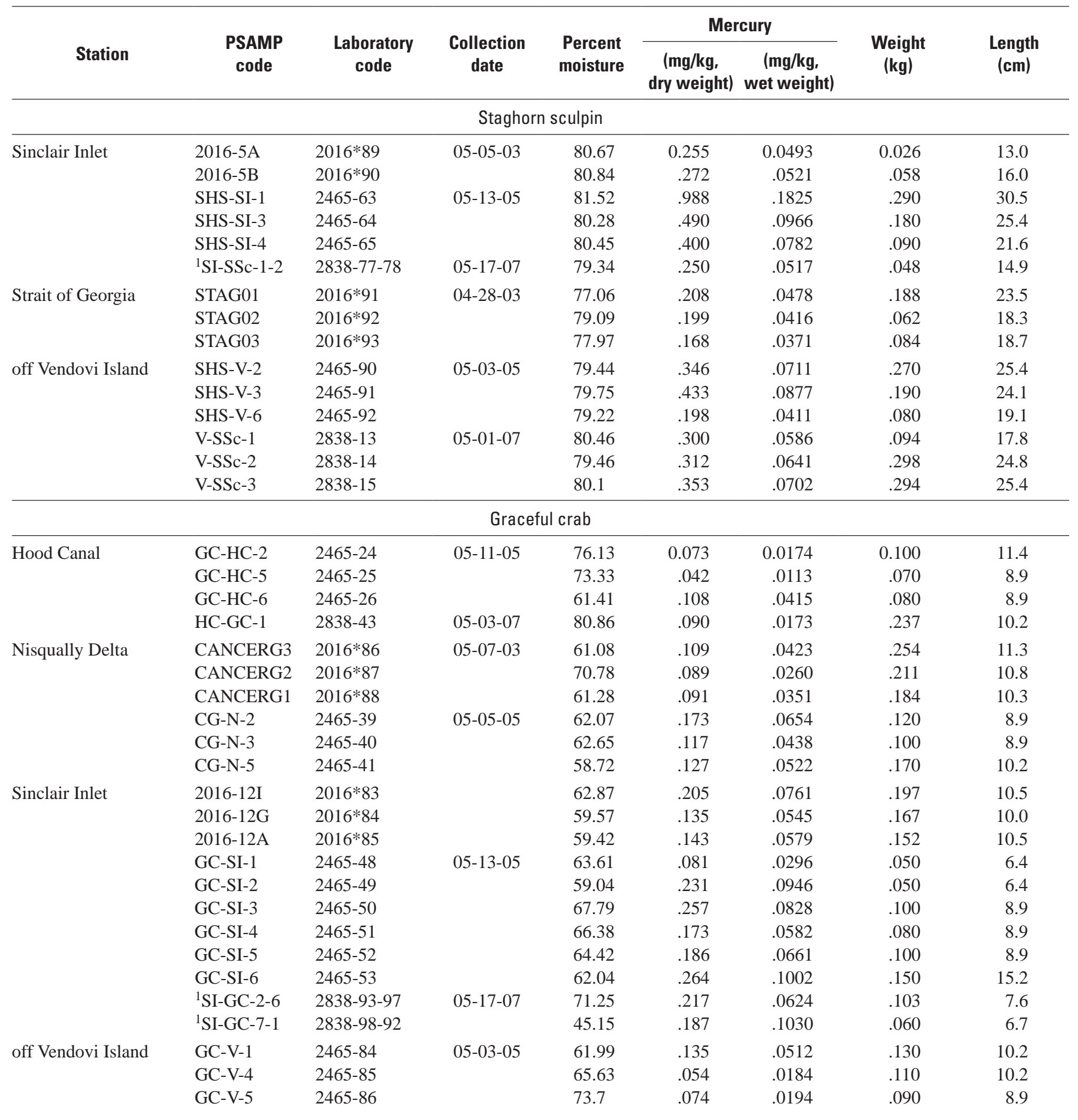


Table F1. Total mercury concentrations in whole specimens of staghorn sculpin, graceful crab, ratfish, surf perch, sand sole, rock sole, and sea cucumber collected from Puget Sound, Washington, and Strait of Georgia, British Columbia, Canada, 2003, 2005, and 2007.Continued.

[Data Source: Brandenberger and others, 2006b, 2008; Johnston and others, 2007. Locations shown in figure 1A. Mercury: J, estimated positive value; U, not detected. Abbreviations PSAMP, Puget Sound Ambient Monitoring Program; mg/kg, milligrams per kilogram; kg, kilogram; cm, centimeter; -, length not applicable]

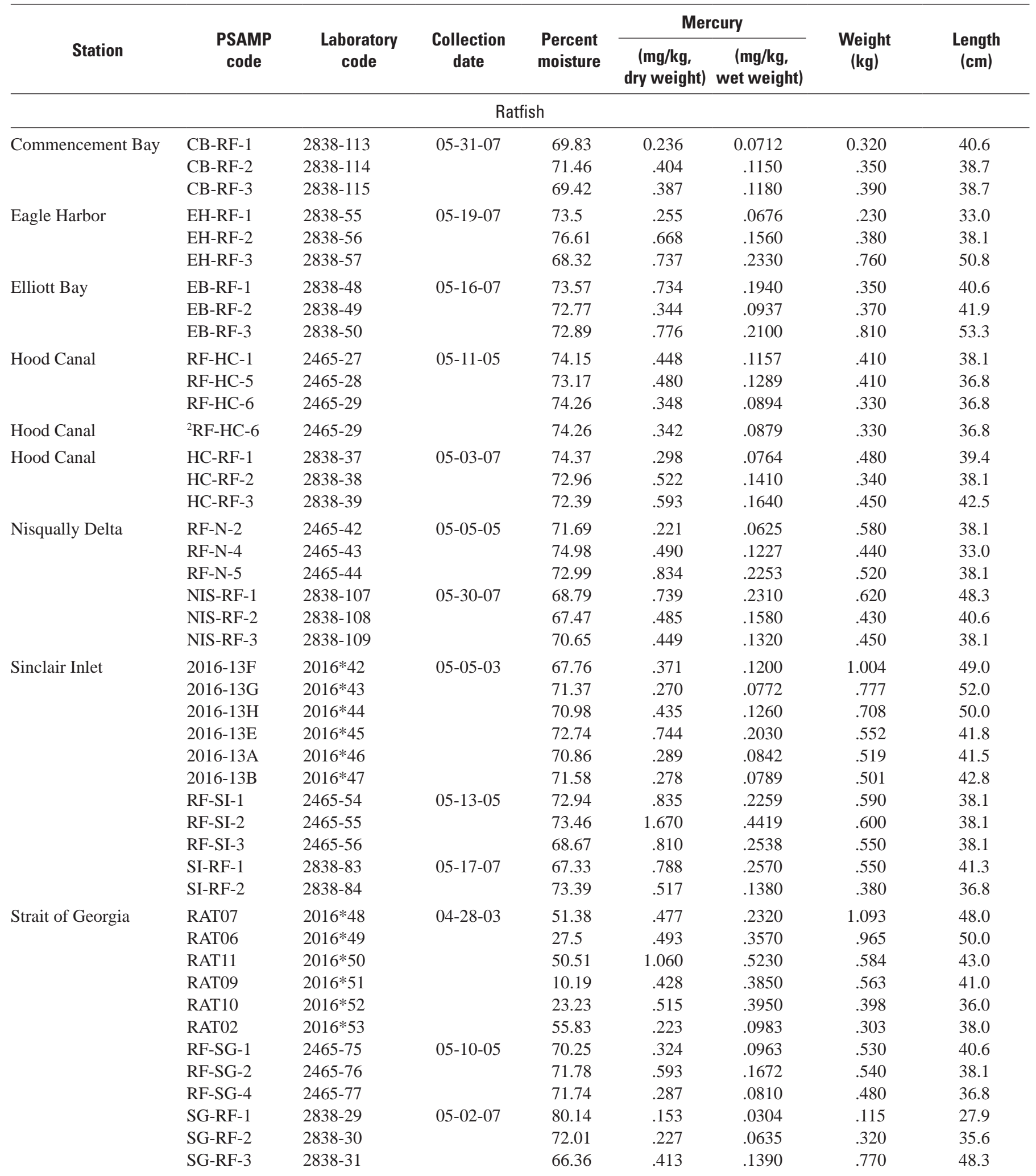


Table F1. Total mercury concentrations in whole specimens of staghorn sculpin, graceful crab, ratfish, surf perch, sand sole, rock sole, and sea cucumber collected from Puget Sound, Washington, and Strait of Georgia, British Columbia, Canada, 2003, 2005, and 2007.Continued.

[Data Source: Brandenberger and others, 2006b, 2008; Johnston and others, 2007. Locations shown in figure 1A. Mercury: J, estimated positive value; U, not detected. Abbreviations PSAMP, Puget Sound Ambient Monitoring Program; mg/kg, milligrams per kilogram; kg, kilogram; cm, centimeter; -, length not applicable]

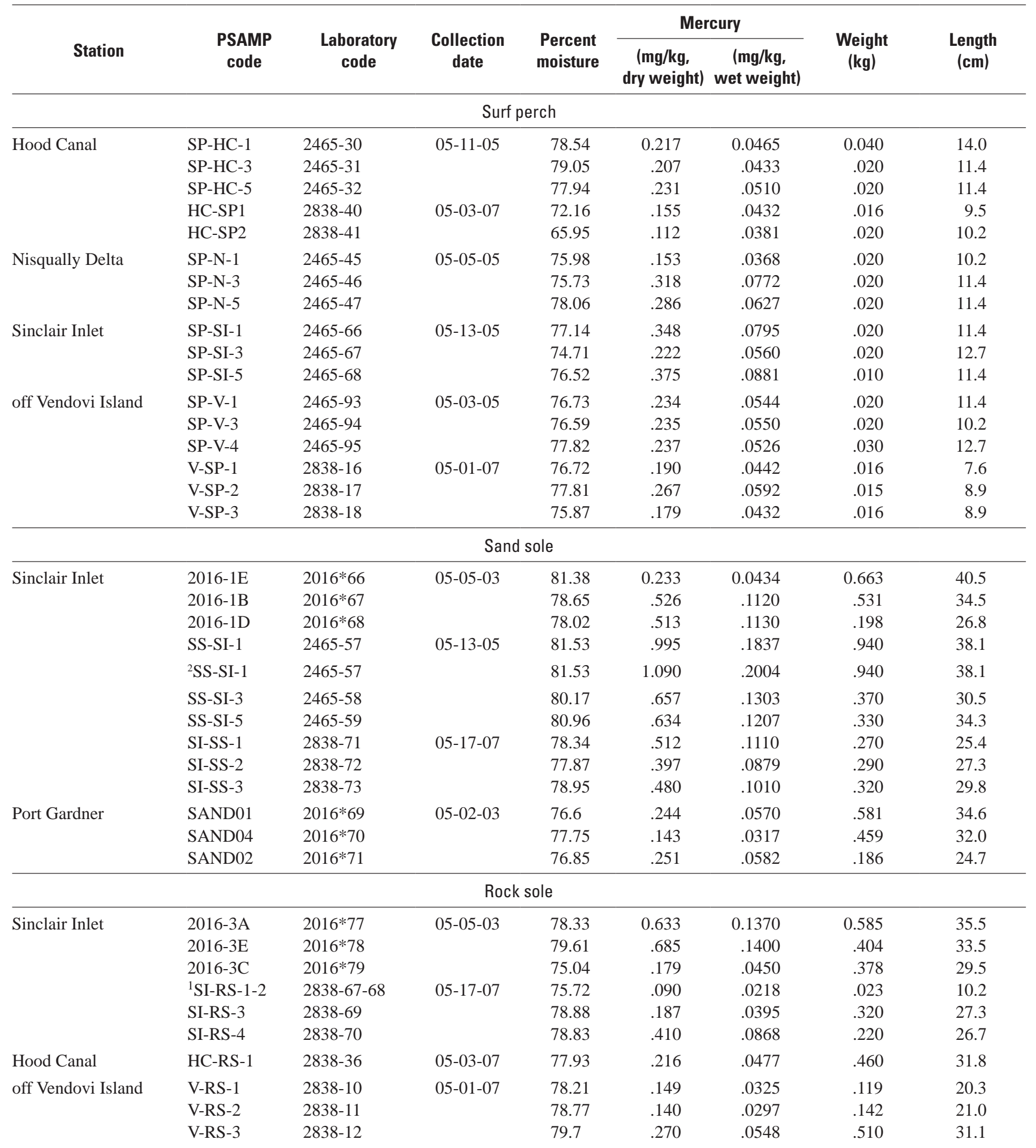


Table F1. Total mercury concentrations in whole specimens of staghorn sculpin, graceful crab, ratfish, surf perch, sand sole, rock sole, and sea cucumber collected from Puget Sound, Washington, and Strait of Georgia, British Columbia, Canada, 2003, 2005, and 2007.Continued.

[Data Source Brandenberger and others, 2006b, 2008; Johnston and others, 2007. Locations shown in figure 1A. Mercury: J, estimated positive value; U, not detected. Abbreviations PSAMP, Puget Sound Ambient Monitoring Program; mg/kg, milligrams per kilogram; kg, kilogram; cm, centimeter; -, length not applicable]

\begin{tabular}{|c|c|c|c|c|c|c|c|c|}
\hline \multirow[b]{2}{*}{ Station } & \multirow[b]{2}{*}{$\begin{array}{l}\text { PSAMP } \\
\text { code }\end{array}$} & \multirow[b]{2}{*}{$\begin{array}{l}\text { Laboratory } \\
\text { code }\end{array}$} & \multirow[b]{2}{*}{$\begin{array}{c}\text { Collection } \\
\text { date }\end{array}$} & \multirow[b]{2}{*}{$\begin{array}{l}\text { Percent } \\
\text { moisture }\end{array}$} & \multicolumn{2}{|c|}{ Mercury } & \multirow[b]{2}{*}{$\begin{array}{l}\text { Weight } \\
\text { (kg) }\end{array}$} & \multirow[b]{2}{*}{$\begin{array}{l}\text { Length } \\
(\mathrm{cm})\end{array}$} \\
\hline & & & & & $\begin{array}{c}\text { (mg/kg, } \\
\text { dry weight) }\end{array}$ & $\begin{array}{c}\text { (mg/kg, } \\
\text { wet weight) }\end{array}$ & & \\
\hline \multirow[t]{7}{*}{ Sinclair Inlet } & 2016-4B & $2016 * 54$ & 05-05-03 & 90.45 & 0.155 & 0.0148 & 0.881 & - \\
\hline & $2016-4 F$ & $2016 * 55$ & & 91.85 & .089 & .0073 & .859 & - \\
\hline & 2016-4D & $2016 * 58$ & & 92.07 & .022 & $.00171 \mathrm{~J}$ & .585 & - \\
\hline & 2016-4C & $2016 * 59$ & & 89.34 & .329 & .0351 & .454 & - \\
\hline & SC-SI-2 & $2465-60$ & 05-13-05 & 88.34 & .211 & .0245 & .440 & - \\
\hline & SC-SI-3 & 2465-61 & & 89.14 & .191 & .0208 & .330 & - \\
\hline & SC-SI-4 & 2465-62 & & 88.88 & .151 & .0168 & .710 & - \\
\hline \multirow{3}{*}{ Strait of Georgia } & CUC03 & $2016 * 63$ & & 91.52 & .003 & $.00338 \mathrm{~J}$ & .310 & - \\
\hline & CUC04 & $2016 * 64$ & & 93.02 & .001 & $.0012 \mathrm{U}$ & .306 & - \\
\hline & CUC02 & $2016 * 65$ & & 91.48 & .004 & $.00350 \mathrm{~J}$ & .190 & - \\
\hline \multirow[t]{3}{*}{ off Vendovi Island } & SC-V-2 & 2465-87 & 05-03-05 & 91.13 & .040 & .0036 & .480 & - \\
\hline & SC-V-4 & 2465-88 & & 90.18 & .039 & .0038 & .750 & - \\
\hline & SC-V-5 & 2465-89 & & 90.15 & .016 & .0016 & .370 & - \\
\hline
\end{tabular}

${ }^{1}$ Designates a composite of two individuals of comparable size.

${ }^{2}$ Laboratory replicate. 
Table F2. Total mercury concentrations in quillback rockfish collected between 1989 and 1999 from Puget Sound, Washington.

[Total mercury concentrations in milligrams per kilogram wet weight from West and others, 2001. See figure $1 A$ for location of Puget Sound action areas. Abbreviations HC, Hood Canal; NCPS, North Central Puget Sound; SCPS, South Central Puget Sound; SJ/W, San Juan/Whatcom; SPS, South Puget Sound; W, Whidbey. Sinclair Inlet bolded for emphasis.]

\begin{tabular}{|c|c|c|c|c|c|c|}
\hline $\begin{array}{l}\text { Puget Sound } \\
\text { Action Area }\end{array}$ & Location & $\begin{array}{l}\text { Number of } \\
\text { samples } \\
\text { analyzed }\end{array}$ & Mean & Minimum & Maximum & $\begin{array}{l}\text { Standard } \\
\text { deviation }\end{array}$ \\
\hline \multirow[t]{2}{*}{$\mathrm{SJ} / \mathrm{W}$} & San Juan Islands & 36 & 0.2423 & 0.0818 & 0.806 & 0.1564 \\
\hline & Orcas Island & 5 & .4012 & .1350 & .770 & .3232 \\
\hline \multirow[t]{2}{*}{$\mathrm{HC}$} & Triton Head & 8 & .1825 & .1000 & .400 & .1070 \\
\hline & Foulweather Bluff & 14 & .2909 & .1370 & .751 & .1613 \\
\hline \multirow[t]{2}{*}{ W } & Double Bluff & 36 & .2305 & .0987 & .410 & .0780 \\
\hline & Mukilteo-Everett & 6 & .3238 & .2290 & .490 & .0883 \\
\hline \multirow[t]{2}{*}{ NCPS } & Blakely Rocks & 35 & .2500 & .0800 & .470 & .1000 \\
\hline & Sindair Inlet & 3 & .8177 & .5120 & 1.060 & .2794 \\
\hline \multirow[t]{7}{*}{ SCPS } & Gig Harbor & 5 & .2214 & .0040 & .394 & .1504 \\
\hline & Brown's Point & 2 & .2700 & .1800 & .360 & .1300 \\
\hline & Lakota & 4 & .2948 & .0963 & .409 & .1409 \\
\hline & Fuller Wreck & 21 & .3558 & .0922 & .631 & .1500 \\
\hline & Seattle Waterfront & 35 & .3979 & .0761 & .832 & .1982 \\
\hline & Harbor Island & 8 & .4076 & .2250 & .567 & .1245 \\
\hline & Dalco Passage & 2 & .4960 & .3720 & .620 & .1754 \\
\hline SPS & Day Island & 6 & .0983 & .0600 & .130 & .0264 \\
\hline
\end{tabular}

Table F3. Total mercury concentrations in brown rockfish collected between 1989 and 1999 from Puget Sound, Washington.

[Total mercury concentrations in milligrams per kilogram wet weight from West and others, 2001. See figure 1A for location of Puget Sound action areas. Abbreviations NCPS, North Central Puget Sound; SCPS, South Central Puget Sound. Sinclair Inlet bolded for emphasis.]

\begin{tabular}{llccccc}
\hline $\begin{array}{c}\text { Puget Sound } \\
\text { action area }\end{array}$ & Location & $\begin{array}{c}\text { Number of } \\
\text { samples } \\
\text { analyzed }\end{array}$ & Mean & Minimum & Maximum & $\begin{array}{c}\text { Standard } \\
\text { deviation }\end{array}$ \\
\hline NCPS & Sindair Inlet & $\mathbf{1 1}$ & $\mathbf{0 . 8 1}$ & $\mathbf{0 . 3 3}$ & $\mathbf{1 . 1 5 0}$ & $\mathbf{0 . 2 8}$ \\
SCPS & Thea Foss Waterway & 1 & .11 & & \\
\hline
\end{tabular}


Table F4. Total mercury concentrations in Chinook salmon collected between 1989 and 1999 from Puget Sound, Washington.

[Total mercury concentrations in milligrams per kilogram wet weight from West and others, 2001. See figure $1 \mathrm{~A}$ for location of Puget Sound action areas. Abbreviations NCPS, North Central Puget Sound; SCPS, South Central Puget Sound; SJ/W, San Juan/Whatcom; SPS, South Puget Sound; W, Whidbey. Sinclair Inlet bolded for emphasis.]

\begin{tabular}{llcrrrr}
\hline $\begin{array}{c}\text { Puget Sound } \\
\text { action area }\end{array}$ & \multicolumn{1}{c}{ Location } & $\begin{array}{c}\text { Number of } \\
\text { samples } \\
\text { analyzed }\end{array}$ & Mean & Minimum & Maximum & $\begin{array}{c}\text { Standard } \\
\text { deviation }\end{array}$ \\
\hline SJ/W & Nooksack River & 18 & 0.087 & 0.062 & 0.110 & 0.015 \\
W & Skagit River & 18 & .100 & .058 & .160 & .030 \\
NCPS & Sinclair Inlet & $\mathbf{6}$ &. $\mathbf{0 9 9}$ & $\mathbf{. 0 7 4}$ & $\mathbf{. 1 2 0}$ & $\mathbf{. 0 1 8}$ \\
SCPS & Apple Cove Point. & 12 & .062 & .051 & .074 & .007 \\
& Central Sound & 4 & .070 & .070 & .070 & .000 \\
SPS & Duwamish River & 18 & .102 & .059 & .150 & .027 \\
& Nisqually River & 12 & .085 & .065 & .105 & .014 \\
& Deschutes River & 12 & .108 & .077 & .160 & .028 \\
\hline
\end{tabular}

Table F5. Total mercury concentrations in Coho salmon collected between 1989 and 1999 from Puget Sound, Washington.

[Total mercury concentrations in milligrams per kilogram wet weight from West and others, 2001. See figure $1 A$ for location of Puget Sound action areas. Abbreviations: NCPS, North Central Puget Sound; SCPS, South Central Puget Sound; SJ/W, San Juan/ Whatcom; SPS, South Puget Sound; W, Whidbey. Sinclair Inlet bolded for emphasis.]

\begin{tabular}{llccccc}
\hline $\begin{array}{c}\text { Puget Sound } \\
\text { action area }\end{array}$ & \multicolumn{1}{c}{ Location } & $\begin{array}{c}\text { Number of } \\
\text { samples } \\
\text { analyzed }\end{array}$ & Mean & Minimum & Maximum & $\begin{array}{c}\text { Standard } \\
\text { deviation }\end{array}$ \\
\hline SJ/W & Nooksack River & 18 & 0.041 & 0.027 & 0.056 & 0.010 \\
W & Skagit River & 18 & .049 & .028 & .075 & .014 \\
NCPS & Sindair Inlet & $\mathbf{2}$ & $\mathbf{. 0 6 0}$ & $\mathbf{. 0 5 9}$ & $\mathbf{. 0 6 1}$ & $\mathbf{. 0 0 1}$ \\
& Colvos Passage & 6 & .062 & .051 & .069 & .006 \\
SCPS & Apple Cove Point & 12 & .040 & .028 & .054 & .008 \\
& Duwamish River & 18 & .041 & .025 & .053 & .008 \\
SPS & Central Sound & 6 & .052 & .050 & .060 & .004 \\
& Deschutes River & 10 & .049 & .026 & .073 & .017 \\
& South Sound & 6 & .057 & .045 & .071 & .009 \\
\hline
\end{tabular}




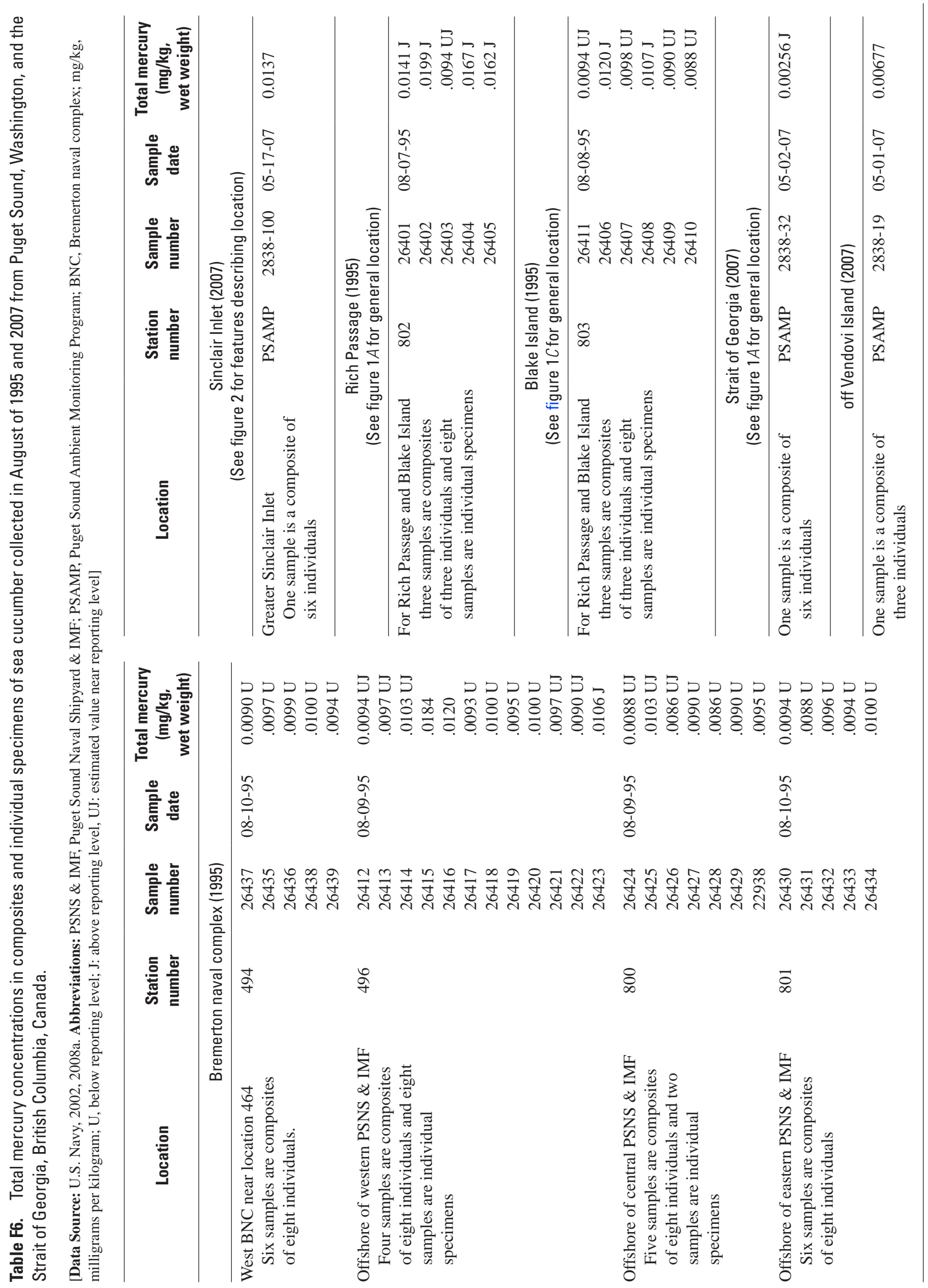


Table F7. Total mercury concentrations in the muscle of English sole from individual specimens collected from Puget Sound, Washington, and the Strait of Georgia, British Columbia, Canada, 1996, 2003, 2005, and 2007.

[Data Source PSAMP, 1996; Jim West, Washington Department of Fish and Wildlife, written commun., 2008; Puget Sound Ambient Monitoring Program/ENVironmental inVESTment, Brandenberger and others, 2006b, 2008; Johnston and others, 2007; Abbreviations PSAMP, Puget Sound Ambient Monitoring System; PSAMP/ENVEST, Puget Sound Ambient Monitoring Program/ENVironmental inVESTment; mg/kg, milligrams per kilogram; kg, kilogram, cm, centimeter; - , not available]

\begin{tabular}{|c|c|c|c|c|c|}
\hline \multirow[b]{2}{*}{ Sample No. } & \multirow[b]{2}{*}{ Location } & \multicolumn{2}{|c|}{ Total mercury } & \multirow[b]{2}{*}{$\begin{array}{l}\text { Length } \\
(\mathrm{cm})\end{array}$} & \multirow{2}{*}{$\begin{array}{l}\text { Weight } \\
\text { (kg) }\end{array}$} \\
\hline & & $\begin{array}{c}\text { (mg/kg, } \\
\text { dry weight) }\end{array}$ & $\begin{array}{c}\text { (mg/kg, } \\
\text { wet weight) }\end{array}$ & & \\
\hline \multicolumn{6}{|c|}{ PSAMP 1996} \\
\hline F1442 & Sinclair Inlet & - & 0.0718 & 35.5 & - \\
\hline F1450 & & - & .0818 & 35.1 & - \\
\hline F1451 & & - & .0973 & 37.5 & - \\
\hline F1453 & & - & .0779 & 38.1 & - \\
\hline F1457 & & - & .0829 & 45.0 & - \\
\hline F1458 & & - & .0567 & 38.8 & - \\
\hline F1462 & & - & .0957 & 42.3 & - \\
\hline F1463 & & - & .0342 & 26.5 & - \\
\hline F1465 & & - & .1360 & 43.1 & - \\
\hline F1467 & & - & .0937 & 35.0 & - \\
\hline F1470 & & - & .0345 & 28.3 & - \\
\hline F1472 & & - & .0520 & 39.1 & - \\
\hline F1474 & & - & .0861 & 45.1 & - \\
\hline F1475 & & - & .0801 & 41.0 & - \\
\hline F1480 & & - & .0716 & 27.2 & - \\
\hline F1481 & & - & .0707 & 37.0 & - \\
\hline F1482 & & - & .0814 & 40.1 & - \\
\hline F1487 & & - & .0713 & 36.5 & - \\
\hline F1490 & & - & .0405 & 30.1 & - \\
\hline F1491 & & - & .0642 & 34.1 & - \\
\hline F1497 & & - & .1150 & 41.6 & - \\
\hline F1498 & & - & .0970 & 31.6 & - \\
\hline \multicolumn{6}{|c|}{ PSAMP/ENVVEST 2003} \\
\hline $2016 * 31$ & Sinclair Inlet & 0.299 & 0.0682 & 44.5 & 0.7933 \\
\hline $2016 * 32$ & & .262 & .0543 & 37.8 & .5529 \\
\hline $2016 * 33$ & & .255 & .0504 & 36.8 & .4198 \\
\hline $2016 * 34$ & Strait of Georgia & .186 & .0328 & 47.0 & .8782 \\
\hline $2016 * 35$ & & .436 & .0853 & 39.4 & .5486 \\
\hline $2016 * 36$ & & .436 & .0876 & 37.5 & .5279 \\
\hline \multicolumn{6}{|c|}{ PSAMP/ENVVEST 2005} \\
\hline 5241 & Commencement Bay & 0.254 & 0.0600 & 29.2 & 0.19 \\
\hline 5242 & & .187 & .0403 & 24.1 & .11 \\
\hline 5243 & & .244 & .0521 & 24.1 & .11 \\
\hline 5244 & & .191 & .0500 & 22.9 & .12 \\
\hline 5245 & & .263 & .0641 & 22.9 & .02 \\
\hline 5246 & & .334 & .0674 & 25.4 & .13 \\
\hline 5721 & Elliott Bay & .364 & .0918 & 24.1 & .11 \\
\hline 5722 & & .324 & .0758 & 25.4 & .12 \\
\hline 5723 & & .176 & .0378 & 29.2 & .18 \\
\hline${ }^{1} 5723$ & & .204 & .0439 & 29.2 & .18 \\
\hline 5724 & & 2.210 & .4543 & 25.4 & .11 \\
\hline 5725 & & .503 & .1154 & 33.0 & .28 \\
\hline 5726 & & .368 & .0833 & 26.7 & .13 \\
\hline
\end{tabular}


Table F7. Total mercury concentrations in the muscle of English sole from individual specimens collected from Puget Sound, Washington, and the Strait of Georgia, British Columbia, Canada, 1996, 2003, 2005, and 2007.-Continued.

[Data Source PSAMP, 1996; Jim West, Washington Department of Fish and Wildlife, written commun., 2008; Puget Sound Ambient Monitoring Program/ENVironmental inVESTment, Brandenberger and others, 2006b, 2008; Johnston and others, 2007; Abbreviations: PSAMP, Puget Sound Ambient Monitoring System; PSAMP/ENVEST, Puget Sound Ambient Monitoring Program/ENVironmental inVESTment; mg/kg, milligrams per kilogram; kg, kilogram, cm, centimeter; - , not available]

\begin{tabular}{|c|c|c|c|c|c|}
\hline \multirow[b]{2}{*}{ Sample No. } & \multirow[b]{2}{*}{ Location } & \multicolumn{2}{|c|}{ Total mercury } & \multirow[b]{2}{*}{$\begin{array}{l}\text { Length } \\
\text { (cm) }\end{array}$} & \multirow[b]{2}{*}{$\begin{array}{l}\text { Weight } \\
\text { (kg) }\end{array}$} \\
\hline & & $\begin{array}{c}\text { (mg/kg, } \\
\text { dry weight) }\end{array}$ & $\begin{array}{c}\text { (mg/kg, } \\
\text { wet weight) }\end{array}$ & & \\
\hline \multicolumn{6}{|c|}{ PSAMP/ENVVEST 2005-Continued } \\
\hline 5141 & Everett (Port Gardner) & 0.337 & 0.0742 & 25.4 & 0.13 \\
\hline 5142 & & .216 & .0451 & 27.9 & .15 \\
\hline 5143 & & .245 & .0527 & 25.4 & .09 \\
\hline 5144 & & .143 & .0310 & 21.6 & .06 \\
\hline 5145 & & .601 & .1241 & 29.2 & .18 \\
\hline 5601 & Hood Canal & .376 & .0782 & 24.1 & .12 \\
\hline 5602 & & .273 & .0600 & 26.7 & .12 \\
\hline 5603 & & .374 & .0773 & 22.9 & .09 \\
\hline 5604 & & .244 & .0521 & 25.4 & .09 \\
\hline 5605 & & .165 & .0355 & 25.4 & .16 \\
\hline 5606 & & .351 & .0723 & 24.1 & .10 \\
\hline 5361 & Nisqually Delta & .247 & .0544 & 21.6 & .09 \\
\hline 5362 & & .275 & .0631 & 24.1 & .10 \\
\hline 5363 & & .254 & .0568 & 27.9 & .19 \\
\hline 5364 & & .404 & .0843 & 21.6 & .08 \\
\hline 5365 & & .643 & .1277 & 29.2 & .22 \\
\hline 5366 & & .347 & .0750 & 31.8 & .34 \\
\hline 5481 & Strait of Georgia & .180 & .0467 & 30.5 & .35 \\
\hline 5482 & & .296 & .0685 & 31.8 & .35 \\
\hline 5483 & & .240 & .0648 & 29.2 & .31 \\
\hline 5484 & & .288 & .0724 & 33.0 & .41 \\
\hline 5485 & & .302 & .0663 & 31.8 & .31 \\
\hline 5486 & & .233 & .0661 & 25.4 & .15 \\
\hline 5001 & off Vendovi Island & .302 & .0622 & 33.0 & .28 \\
\hline 5002 & & .443 & .0959 & 33.0 & .30 \\
\hline 5003 & & .272 & .0617 & 29.2 & .27 \\
\hline 5004 & & .128 & .0299 & 21.6 & .09 \\
\hline 5005 & & .144 & .0325 & 22.9 & .13 \\
\hline${ }^{1} 5005$ & & .141 & .0319 & 22.9 & .13 \\
\hline 5006 & & .294 & .0637 & 24.1 & .21 \\
\hline \multicolumn{6}{|c|}{ PSAMP/ENVVEST 2007} \\
\hline 2838-110 & Commencement Bay & 0.160 & 0.0344 & 22.9 & 0.145 \\
\hline 2838-111 & & .327 & .0774 & 24.8 & .157 \\
\hline 2838-112 & & .229 & .0530 & 24.8 & .162 \\
\hline 2838-116 & Duwamish Waterway & .170 & .0390 & 17.8 & .075 \\
\hline 2838-117 & & .177 & .0360 & 21.6 & .096 \\
\hline 2838-118 & & .199 & .0458 & 26.0 & .156 \\
\hline 2838-52 & Eagle Harbor & .406 & .0704 & 35.6 & .420 \\
\hline $2838-53$ & & .353 & .0825 & 22.2 & .089 \\
\hline $2838-54$ & & .191 & .0414 & 27.3 & .199 \\
\hline $2838-45-46$ & Elliott Bay & .108 & .0232 & 15.8 & .044 \\
\hline 2838-47 & & .443 & .0874 & 26.0 & .157 \\
\hline
\end{tabular}


Table F7. Total mercury concentrations in the muscle of English sole from individual specimens collected from Puget Sound, Washington, and the Strait of Georgia, British Columbia, Canada, 1996, 2003, 2005, and 2007.-Continued.

[Data Source: PSAMP, 1996; Jim West, Washington Department of Fish and Wildlife, written commun., 2008; Puget Sound Ambient Monitoring Program/ENVironmental inVESTment, Brandenberger and others, 2006b, 2008; Johnston and others, 2007; Abbreviations: PSAMP, Puget Sound Ambient Monitoring System; PSAMP/ENVEST, Puget Sound Ambient Monitoring Program/ENVironmental inVESTment; mg/kg, milligrams per kilogram; kg, kilogram, cm, centimeter; - , not available]

\begin{tabular}{|c|c|c|c|c|c|}
\hline \multirow[b]{2}{*}{ Sample No. } & \multirow[b]{2}{*}{ Location } & \multicolumn{2}{|c|}{ Total mercury } & \multirow{2}{*}{$\begin{array}{l}\text { Length } \\
\text { (cm) }\end{array}$} & \multirow{2}{*}{$\begin{array}{c}\text { Weigh } \\
\text { (kg) }\end{array}$} \\
\hline & & $\begin{array}{c}\text { (mg/kg, } \\
\text { dry weight) }\end{array}$ & $\begin{array}{c}\text { (mg/kg, } \\
\text { wet weight) }\end{array}$ & & \\
\hline \multicolumn{6}{|c|}{ PSAMP/ENVVEST 2007—Continued } \\
\hline 2838-101 & Everett (Port Gardner) & 0.159 & 0.0306 & 24.8 & 0.158 \\
\hline 2838-102 & & .101 & .0210 & 21.6 & .101 \\
\hline 2838-103 & & .135 & .0269 & 24.8 & .128 \\
\hline 2838-33 & Hood Canal & .212 & .0380 & 22.9 & .131 \\
\hline 2838-34 & & .154 & .0312 & 22.9 & .133 \\
\hline 2838-35 & & .239 & .0506 & 26.7 & .220 \\
\hline 2838-104 & Nisqually Delta & .310 & .0641 & 25.4 & .166 \\
\hline 2838-105 & & .280 & .0603 & 26.7 & .214 \\
\hline 2838-106 & & .273 & .0590 & 30.5 & .290 \\
\hline 2838-58 & Sinclair Inlet & .133 & .0295 & 29.2 & .330 \\
\hline 2838-59 & & .126 & .0244 & 29.2 & .330 \\
\hline 2838-61 & & .207 & .0842 & 25.4 & .192 \\
\hline 2838-63 & & .113 & .0230 & 25.4 & .178 \\
\hline 2838-64 & & .294 & .0603 & 25.4 & .179 \\
\hline 2838-65 & & .180 & .0373 & 29.2 & .261 \\
\hline 2838-22 & Strait of Georgia & .132 & .0271 & 26.7 & .184 \\
\hline $2838-23$ & & .178 & .0373 & 26.0 & .189 \\
\hline 2838-24 & & .177 & .0379 & 26.7 & .192 \\
\hline $2838-5$ & off Vendovi Island & .228 & .0424 & 27.9 & .224 \\
\hline $2838-6$ & & .198 & .0352 & 27.9 & .250 \\
\hline $2838-8$ & & .143 & .0324 & 27.3 & .197 \\
\hline
\end{tabular}

${ }^{1}$ Laboratory replicate. 
Table F8. Concentration of total mercury in tissue of caged and indigenous mussels collected from Puget Sound, Washington, 2005.

[Data source: Total mercury concentrations rounded to three significant figures, Brandenberger and others, 2006c; Gain data, Applied Biomonitoring, 2009. Abbreviations mg/wk, milligram per week; mg/kg, milligram per kilogram; Std. Dev., standard deviation; mm, millimeters]

\begin{tabular}{|c|c|c|c|c|c|c|}
\hline \multirow{2}{*}{$\begin{array}{l}\text { Sample type and } \\
\text { identifier }\end{array}$} & \multirow{2}{*}{$\begin{array}{c}\text { Cage } \\
\text { position }\end{array}$} & \multicolumn{3}{|c|}{$\begin{array}{c}\text { Total mercury } \\
\text { (mg/kg, dry weight) }\end{array}$} & \multicolumn{2}{|c|}{$\begin{array}{c}\text { Gain } \\
\text { (mg/wk) }\end{array}$} \\
\hline & & Cage value & Mean & Std. Dev. & Weight & Length \\
\hline \multicolumn{7}{|c|}{ Pre-deployment } \\
\hline \multirow[t]{3}{*}{ Pre-deployment } & Top & 0.0269 & 0.0283 & 0.0023 & & \\
\hline & Middle & .0271 & & & & \\
\hline & Bottom & .0310 & & & & \\
\hline \multicolumn{7}{|c|}{ Port Orchard Passage (fig. 1B) } \\
\hline \multirow[t]{3}{*}{ Caged (POP) } & Top & 0.0623 & 0.0711 & 0.0076 & 671 & 0.64 \\
\hline & Middle & .0752 & & & & \\
\hline & Bottom & .0758 & & & & \\
\hline \multicolumn{7}{|c|}{ Waterman Point (fig. 1B) } \\
\hline \multirow[t]{3}{*}{ Indigenous (IWP) } & Top & 0.0797 & 0.0835 & 0.0033 & & \\
\hline & Middle & .0851 & & & & \\
\hline & Bottom & .0858 & & & & \\
\hline \multicolumn{7}{|c|}{ Ostrich Bay, Dyes Inlet (near M8 in fig. 1B) } \\
\hline \multirow[t]{3}{*}{ Caged (OBDI) } & Top & 0.0751 & 0.0819 & 0.0073 & 836 & 0.76 \\
\hline & Middle & .0810 & & & & \\
\hline & Bottom & .0897 & & & & \\
\hline \multicolumn{7}{|c|}{ Port Orchard Marina (fig. 1C) } \\
\hline \multirow[t]{3}{*}{ Caged (POM) } & Top & 0.210 & 0.216 & 0.006 & 597 & 0.58 \\
\hline & Middle & .222 & & & & \\
\hline & Bottom & .218 & & & & \\
\hline \multirow[t]{3}{*}{ Indigenous (IPOM) } & Top & .1064 & 0.111 & 0.004 & & \\
\hline & Middle & .1123 & & & & \\
\hline & Bottom & .1128 & & & & \\
\hline \multicolumn{7}{|c|}{ Sinclair Inlet, Ross Point (fig. 1C) } \\
\hline \multirow[t]{3}{*}{ Caged (SIRP) } & Top & 0.1634 & 0.212 & 0.043 & 603 & 0.59 \\
\hline & Middle & .2293 & & & & \\
\hline & Bottom & .2439 & & & & \\
\hline \multicolumn{7}{|c|}{ Controlled Industrial Area, Puget Sound Naval Shipyard (fig. 2) } \\
\hline \multirow[t]{3}{*}{ Caged (CIA) } & Top & 0.106 & 0.108 & 0.002 & 648 & 0.57 \\
\hline & Middle & .109 & & & & \\
\hline & Bottom & .110 & & & & \\
\hline \multicolumn{7}{|c|}{ Naval Station Kitsap at Bremerton (fig. 2) } \\
\hline \multirow[t]{3}{*}{ Caged (NAVSTA) } & Top & 0.0871 & 0.0850 & 0.002 & 668 & 0.70 \\
\hline & Middle & .0851 & & & & \\
\hline & Bottom & .0829 & & & & \\
\hline \multirow[t]{3}{*}{ Indigenous (INAVSTA) } & Top & .103 & 0.130 & 0.025 & & \\
\hline & Middle & .133 & & & & \\
\hline & Bottom & .153 & & & & \\
\hline
\end{tabular}


220 Mercury in Sediment, Water, and Biota of Sinclair Inlet, Puget Sound, Washington, 1989-200

This page intentionally left blank. 
Publishing support provided by the U.S. Geological Survey Publishing Network, Tacoma Publishing Service Center

Director, Washington Water Science Center

U.S. Geological Survey

934 Broadway - Suite 300

Tacoma, Washington 98402

http://wa.water.usgs.gov 

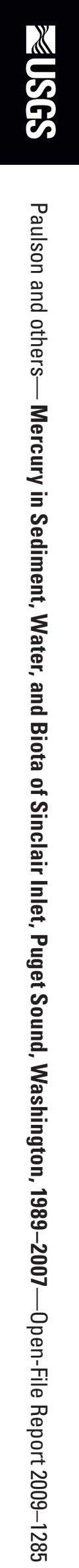